Prepared in cooperation with the Yellowstone River Conservation District Council and the U.S. Army Corps of Engineers

\title{
Streamflow Statistics for Unregulated and Regulated Conditions for Selected Locations on the Yellowstone, Tongue, and Powder Rivers, Montana, 1928-2002
}

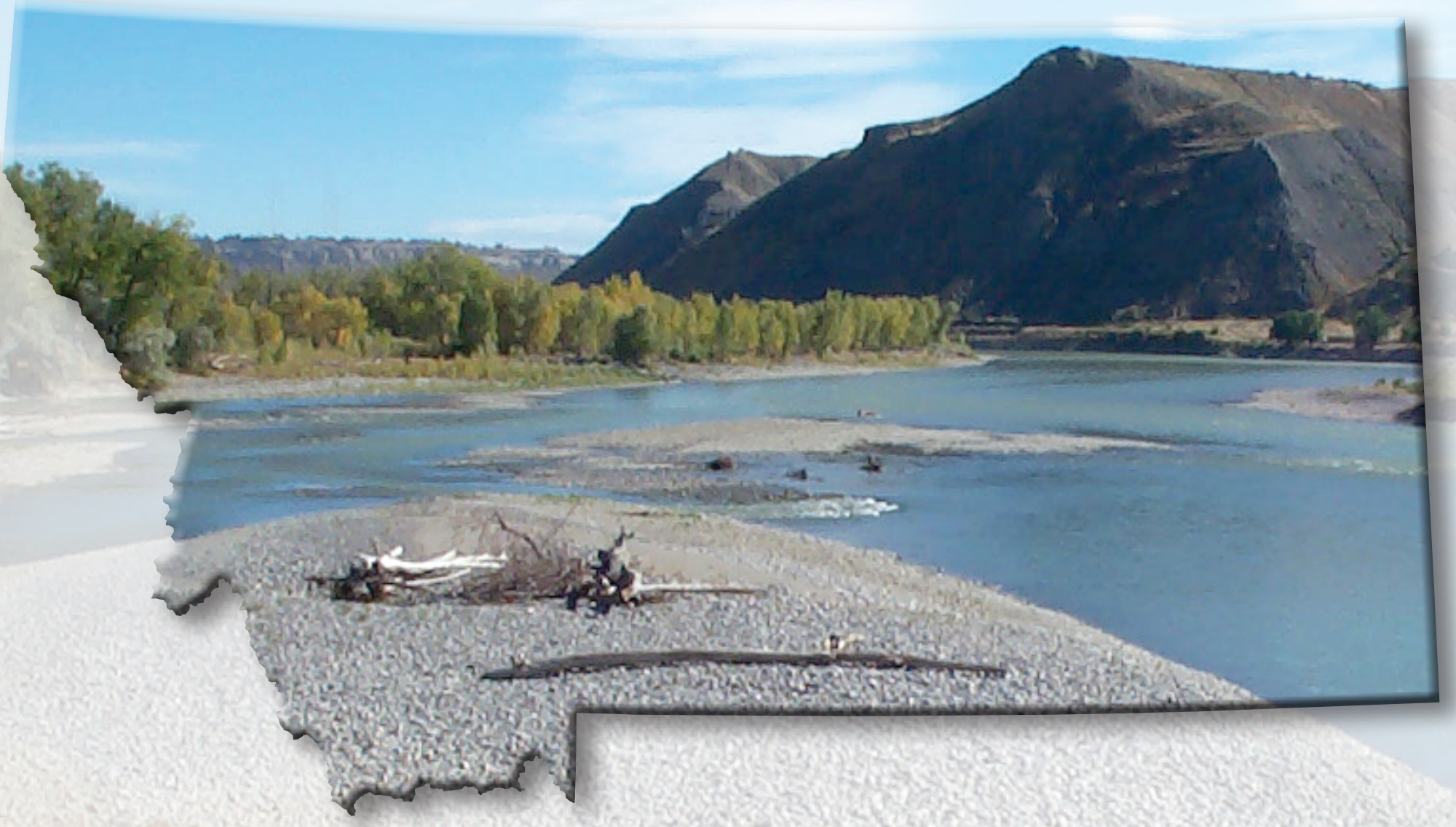

Scientific Investigations Report 2013-5173

Version 1.1, June 2014 
Cover photograph: Yellowstone River south of Billings, Montana, looking downstream from South Billings Boulevard (photograph by the U.S. Geological Survey, September 29, 2005). 


\section{Streamflow Statistics for Unregulated and Regulated Conditions for Selected Locations on the Yellowstone, Tongue, and Powder Rivers, Montana, 1928-2002}

By Katherine J. Chase

Prepared in cooperation with the Yellowstone River Conservation District Council and the U.S. Army Corps of Engineers

Scientific Investigations Report 2013-5173

Version 1.1, June 2014 


\title{
U.S. Department of the Interior SALLY JEWELL, Secretary
}

\section{U.S. Geological Survey Suzette M. Kimball, Acting Director}

\author{
U.S. Geological Survey, Reston, Virginia: 2013 \\ Revised: June 2014
}

For more information on the USGS - the Federal source for science about the Earth, its natural and living resources, natural hazards, and the environment, visit http://www.usgs.gov or call 1-888-ASK-USGS.

For an overview of USGS information products, including maps, imagery, and publications, visit http://WwW.usgs.gov/pubprod

To order this and other USGS information products, visit http://store.usgs.gov

Any use of trade, product, or firm names is for descriptive purposes only and does not imply endorsement by the U.S. Government.

Although this information product, for the most part, is in the public domain, it also may contain copyrighted materials as noted in the text. Permission to reproduce copyrighted items must be secured from the copyright owner.

Suggested citation:

Chase, K.J., 2013, Streamflow statistics for unregulated and regulated conditions for selected locations on the Yellowstone, Tongue, and Powder Rivers, Montana, 1928-2002 (ver. 1.1, June 23, 2014): U.S. Geological Survey Scientific Investigations Report 2013-5173, 183 p., http://dx.doi.org/10.3133/sir20135173. 


\section{Contents}

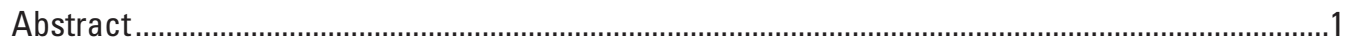

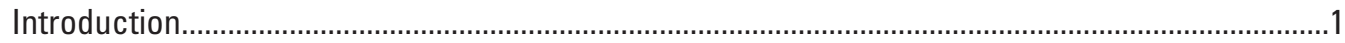

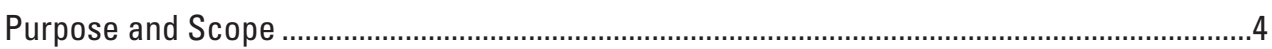

Description of the Study Area .........................................................................................

Methods for Calculating Streamflow Statistics for Unregulated and Regulated Conditions ...........5

Synthesis of Missing Streamflow Records .......................................................................

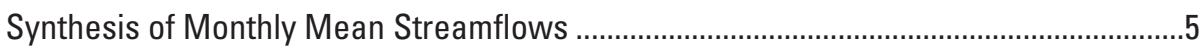

Yellowstone River Streamflow-Gaging Stations ......................................................5

Tongue and Powder River Streamflow-Gaging Stations............................................

Synthesis of Daily Mean Streamflows ........................................................................

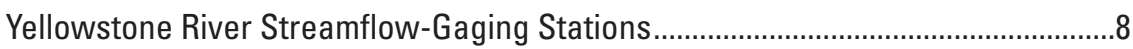

Tongue and Powder River Streamflow-Gaging Stations.........................................8

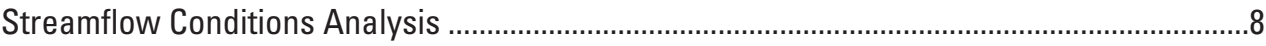

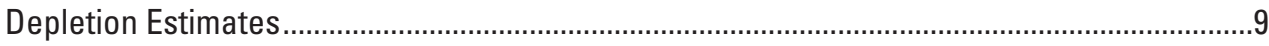

Lower Yellowstone River Subbasin Depletion Estimates....................................................

Tongue and Powder River Subbasin Depletion Estimates.............................................11

Tongue River Reservoir Depletion Estimates .............................................................11

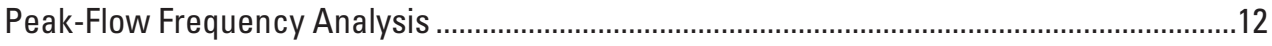

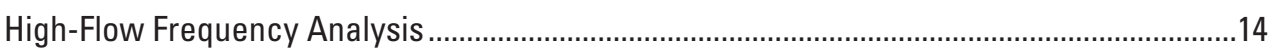

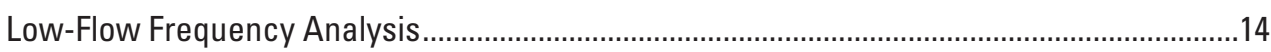

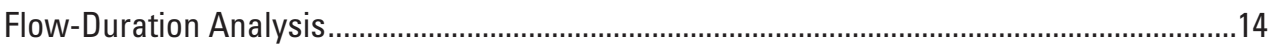

Monthly and Annual Streamflow Characteristics ................................................................14

Interpolation of Streamflow Statistics for Selected Study Reaches ....................................14

Streamflow Statistics for Unregulated and Regulated Conditions for Selected Locations on the Yellowstone, Tongue, and Powder Rivers ..................................................................16

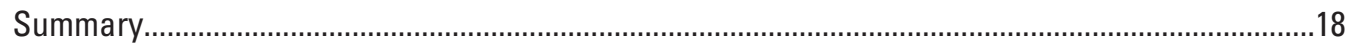

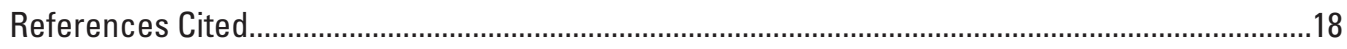

Appendix 1. Depletion Data for the Yellowstone River Basin, Mont., and Wyo., 1928-2002.......22

Appendix 2. Statistics for Selected Streamflow-Gaging Stations on the Yellowstone, Tongue, and Powder Rivers, Mont., for Unregulated and Regulated Streamflow

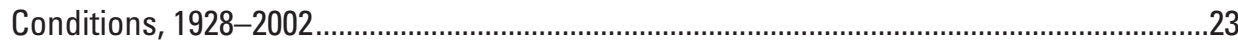

Appendix 2-1. Statistics for Streamflow-Gaging Station 06295000 (Yellowstone River

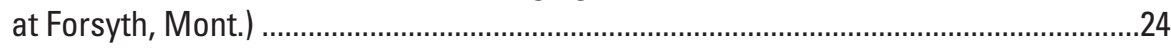

Appendix 2-2. Statistics for Streamflow-Gaging Station 06309000 (Yellowstone River at Miles City, Mont.) ...............................................................................................50

Appendix 2-3. Statistics for Streamflow-Gaging Station 06327500 (Yellowstone River at Glendive, Mont.) .............................................................................................

Appendix 2-4. Statistics for streamflow-Gaging station 06329500 (Yellowstone River at Sidney, Mont.) .................................................................................................102

Appendix 2-5. Statistics for Streamflow-Gaging Station 06308500 (Tongue River at Miles City, Mont.)

Appendix 2-6. Statistics for Streamflow-Gaging Station 06326500 (Powder River near Locate, Mont.) 
Appendix 3. Annual Instantaneous Peak-Flow Data at Selected Locations on the Yellowstone River, Mont., for Unregulated and Regulated Streamflow Conditions, 1928-2002.

Appendix 4. Annual $n$-day High-Flow Frequency Data at Selected Locations on the Yellowstone River, Mont., for Unregulated and Regulated Streamflow Conditions, 1928-2002...

Appendix 5. Annual $n$-day Low-Flow Frequency Data at Selected Locations on the Yellowstone River, Mont., for Unregulated and Regulated Streamflow Conditions, 1928-2002.

Appendix 6. Annual and Seasonal Flow-Duration Data at Selected Locations on the Yellowstone River, Mont., for Unregulated and Regulated Streamflow Conditions, 1928-2002.

\section{Figures}

1. Yellowstone River Basin in Montana, Wyoming, and North Dakota

2. Showing study area subbasins in Montana, Wyoming, and North

Dakota, and Bureau of Reclamation node basins and streamflow-gaging stations in Montana and Wyoming

3. Mean monthly observed streamflow at Tongue River at Miles City, Mont. (streamflow-gaging station 06308500) and mean monthly depletion estimates, 1960-2002.

4. Mean monthly unregulated streamflows at Tongue River at Miles City, Mont. (streamflow-gaging station 06308500), 1960-2002 .

5. Selected reaches along the Yellowstone River, Mont....................................................15

Appendix 2-1 Figures, 06295000 Yellowstone River at Forsyth, Mont................................24

Appendix 2-2 Figures, 06309000 Yellowstone River at Miles City, Mont ..........................50

Appendix 2-3 Figures, 06327500 Yellowstone River at Glendive, Mont ............................76

Appendix 2-4 Figures, 06329500 Yellowstone River at Sidney, Mont.............................102

Appendix 2-5 Figures, 06308500 Tongue River at Miles City, Mont.................................128

Appendix 2-6 Figures, 06326500 Powder River near Locate, Mont................................154 


\section{Tables}

1. Information for selected streamflow-gaging stations in the Yellowstone River Basin, Montana and Wyoming .4

2. Selected information about Maintenance of Variance Extension, Type 1 (MOVE.1) analyses for synthesizing monthly mean streamflows at selected Yellowstone River Basin streamflow-gaging stations, Montana, during the study period January 1928 through December 2002.

3. Selected information about daily mean streamflow to monthly mean streamflow ratio (daily/monthly ratio) analyses for synthesizing daily mean streamflows at selected Yellowstone River Basin streamflow-gaging stations, Montana, during the study period, January 1928 through December 2002.

4. Annual instantaneous peak-flow data for selected streamflow-gaging stations on the Yellowstone, Tongue, and Powder Rivers, Montana, for unregulated and regulated streamflow conditions, 1928-2002.

Appendix 2-1 Tables, 06295000 Yellowstone River at Forsyth, Mont ...............................24

Appendix 2-2 Tables, 06309000 Yellowstone River at Miles City, Mont...........................50

Appendix 2-3 Tables, 06327500 Yellowstone River at Glendive, Mont..............................78

Appendix 2-4 Tables, 06329500 Yellowstone River at Sidney, Mont ...............................102

Appendix 2-5 Tables, 06308500 Tongue River at Miles City, Mont..................................128

Appendix 2-6 Tables, 06326500 Powder River near Locate, Mont ..................................154 


\section{Conversion Factors, Datum, Abbreviations, and Definitions for Streamflow Terminology}

\begin{tabular}{|c|c|c|}
\hline Multiply & By & To obtain \\
\hline \multicolumn{3}{|c|}{ Length } \\
\hline inch (in.) & 2.54 & centimeter $(\mathrm{cm})$ \\
\hline inch (in.) & 25.4 & millimeter (mm) \\
\hline foot (ft) & 0.3048 & meter (m) \\
\hline mile (mi) & 1.609 & kilometer (km) \\
\hline \multicolumn{3}{|c|}{ Area } \\
\hline acre & 4,047 & square meter $\left(\mathrm{m}^{2}\right)$ \\
\hline acre & 0.4047 & hectare (ha) \\
\hline acre & 0.4047 & square hectometer $\left(\mathrm{hm}^{2}\right)$ \\
\hline acre & 0.004047 & square kilometer $\left(\mathrm{km}^{2}\right)$ \\
\hline square mile $\left(\mathrm{mi}^{2}\right)$ & 259.0 & hectare (ha) \\
\hline square mile $\left(\mathrm{mi}^{2}\right)$ & 2.590 & square kilometer $\left(\mathrm{km}^{2}\right)$ \\
\hline acre-foot (acre-ft) & 1,233 & cubic meter $\left(\mathrm{m}^{3}\right)$ \\
\hline kilo acre-foot (KAF) & $1,233,000$ & cubic meter $\left(\mathrm{m}^{3}\right)$ \\
\hline \multicolumn{3}{|c|}{ Flow rate } \\
\hline cubic foot per second $\left(\mathrm{ft}^{3} / \mathrm{s}\right)$ & 0.02832 & cubic meter per second $\left(\mathrm{m}^{3} / \mathrm{s}\right)$ \\
\hline
\end{tabular}

Temperature in degrees Fahrenheit $\left({ }^{\circ} \mathrm{F}\right)$ may be converted to degrees Celsius $\left({ }^{\circ} \mathrm{C}\right)$ as follows:

${ }^{\circ} \mathrm{C}=\left({ }^{\circ} \mathrm{F}-32\right) / 1.8$

Vertical coordinate information is referenced to the North American Vertical Datum of 1988 (NAVD 88).

Horizontal coordinate information is referenced to the North American Datum of 1983 (NAD 83).

\section{Abbreviations}

CES

Cumulative-effects study

MOVE.1

Maintenance of Variance Extension, Type 1, curve-fitting procedure

OLS ordinary least-squares

Reclamation U.S. Department of the Interior, Bureau of Reclamation

USACE U.S. Army Corps of Engineers

USGS U.S. Geological Survey

YRCDC

Yellowstone River Conservation District Council 


\section{Definitions for Streamflow Terminology}

\begin{tabular}{|c|c|}
\hline Annual mean streamflow & $\begin{array}{l}\text { arithmetic mean of all daily mean streamflows for a single } \\
\text { specified year }\end{array}$ \\
\hline Annual instantaneous peak flow & $\begin{array}{l}\text { maximum instantaneous streamflow that occurred during a } \\
\text { single specified year }\end{array}$ \\
\hline Daily mean streamflow & arithmetic mean streamflow for a single specified day \\
\hline Mean annual streamflow & $\begin{array}{l}\text { arithmetic mean of all annual mean streamflows for the } \\
\text { period of record or a specific period of multiple years }\end{array}$ \\
\hline Mean daily streamflow & $\begin{array}{l}\text { arithmetic mean of all daily mean streamflows for a } \\
\text { specified day for the period of record or for a specific } \\
\text { period of multiple years }\end{array}$ \\
\hline Mean monthly streamflow & $\begin{array}{l}\text { arithmetic mean of all monthly mean streamflows for a } \\
\text { specified month for the period of record or for a specific } \\
\text { period of multiple years }\end{array}$ \\
\hline Monthly mean streamflow & $\begin{array}{l}\text { arithmetic mean of all daily mean streamflows for a single } \\
\text { specified month in a single specified year }\end{array}$ \\
\hline
\end{tabular}

\section{Acknowledgments}

Special thanks are given to Steven K. Sando (U.S. Geological Survey Montana Water Science Center) and Daniel D. Driscoll (U.S. Geological Survey South Dakota Water Science Center) for helpful peer reviews. The assistance of Peter M. McCarthy (U.S. Geological Survey Montana Water Science Center) also is gratefully acknowledged.

The author also appreciates the assistance of Douglas J. Clemetson and Roger L. Kay (U.S. Army Corps of Engineers). 



\title{
Streamflow Statistics for Unregulated and Regulated Conditions for Selected Locations on the Yellowstone, Tongue, and Powder Rivers, Montana, 1928-2002
}

\author{
By Katherine J. Chase
}

\section{Abstract}

Major floods in 1996 and 1997 on the Yellowstone River in Montana intensified public debate over the effects of human activities on the Yellowstone River. In 1999, the Yellowstone River Conservation District Council was formed to address conservation issues on the river. The Yellowstone River Conservation District Council partnered with the U.S. Army Corps of Engineers to conduct a cumulative-effects study on the main stem of the Yellowstone River. The cumulative-effects study is intended to provide a basis for future management decisions in the watershed. Streamflow statistics, such as flow-frequency and flow-duration data calculated for unregulated and regulated streamflow conditions, are a necessary component of the cumulative effects study.

The U.S. Geological Survey, in cooperation with the Yellowstone River Conservation District Council and the U.S. Army Corps of Engineers, calculated streamflow statistics for unregulated and regulated conditions for the Yellowstone, Tongue, and Powder Rivers for the 1928-2002 study period. Unregulated streamflow represents flow conditions that might have occurred during the 1928-2002 study period if there had been no water-resources development in the Yellowstone River Basin. Regulated streamflow represents estimates of flow conditions during the 1928-2002 study period if the level of water-resources development existing in 2002 was in place during the entire study period. Peak-flow frequency estimates for regulated and unregulated streamflow were developed using methods described in Bulletin 17B. High-flow frequency and low-flow frequency data were developed for regulated and unregulated streamflows from the annual series of highest and lowest (respectively) mean flows for specified $n$-day consecutive periods within the calendar year. Flow-duration data, and monthly and annual streamflow characteristics, also were calculated for the unregulated and regulated streamflows.

\section{Introduction}

The Yellowstone River is one of the longest free-flowing rivers in the lower 48 States, draining about 70,000 square miles $\left(\mathrm{mi}^{2}\right)$ as it flows more than 600 miles (mi) from its origin east of Yellowstone National Park, Wyoming, through Montana to the confluence with the Missouri River in North Dakota (Jean and Crispin, 2001; U.S. Geological Survey, 2010; fig. 1). The Yellowstone River supports a wide variety of agricultural, domestic, industrial, and recreational uses, and in some areas of Montana, is a blue-ribbon trout stream.

Major floods in 1996 and 1997 intensified public debate over the effects of human activities on the Yellowstone River and led to multidisciplinary efforts to understand the river's response to flood control, channel stabilization, and construction along the Yellowstone River corridor. In 1999 the Yellowstone River Conservation District Council (YRCDC) was formed to address conservation issues on the river. The YRCDC partnered with the U.S. Army Corps of Engineers (USACE) to conduct a cumulative-effects study (CES) on the Yellowstone River main stem. The CES is intended to provide a basis for future management decisions in the watershed. Streamflow statistics for unregulated and regulated conditions along the Yellowstone River main stem are a necessary component of the CES.

In a previous study, the USACE calculated streamflow statistics for unregulated and regulated streamflow conditions for the Yellowstone River main stem in the Upper Yellowstone River Subbasin and for the Bighorn River (fig. 2; U.S. Army Corps of Engineers, 2011a, b). To supplement that work, the U.S. Geological Survey (USGS), in cooperation with the YRCDC and the USACE, began a study that would calculate streamflow statistics for unregulated and regulated streamflow conditions for the Yellowstone River main stem in the Lower Yellowstone River Subbasin (fig. 2). At the request of the USACE and the YRCDC's Technical Advisory Committee, streamflow statistics for unregulated and regulated streamflow conditions for the Tongue and Powder Rivers also were included, although those Yellowstone River tributaries are not specifically part of the CES of the Yellowstone River main stem. 


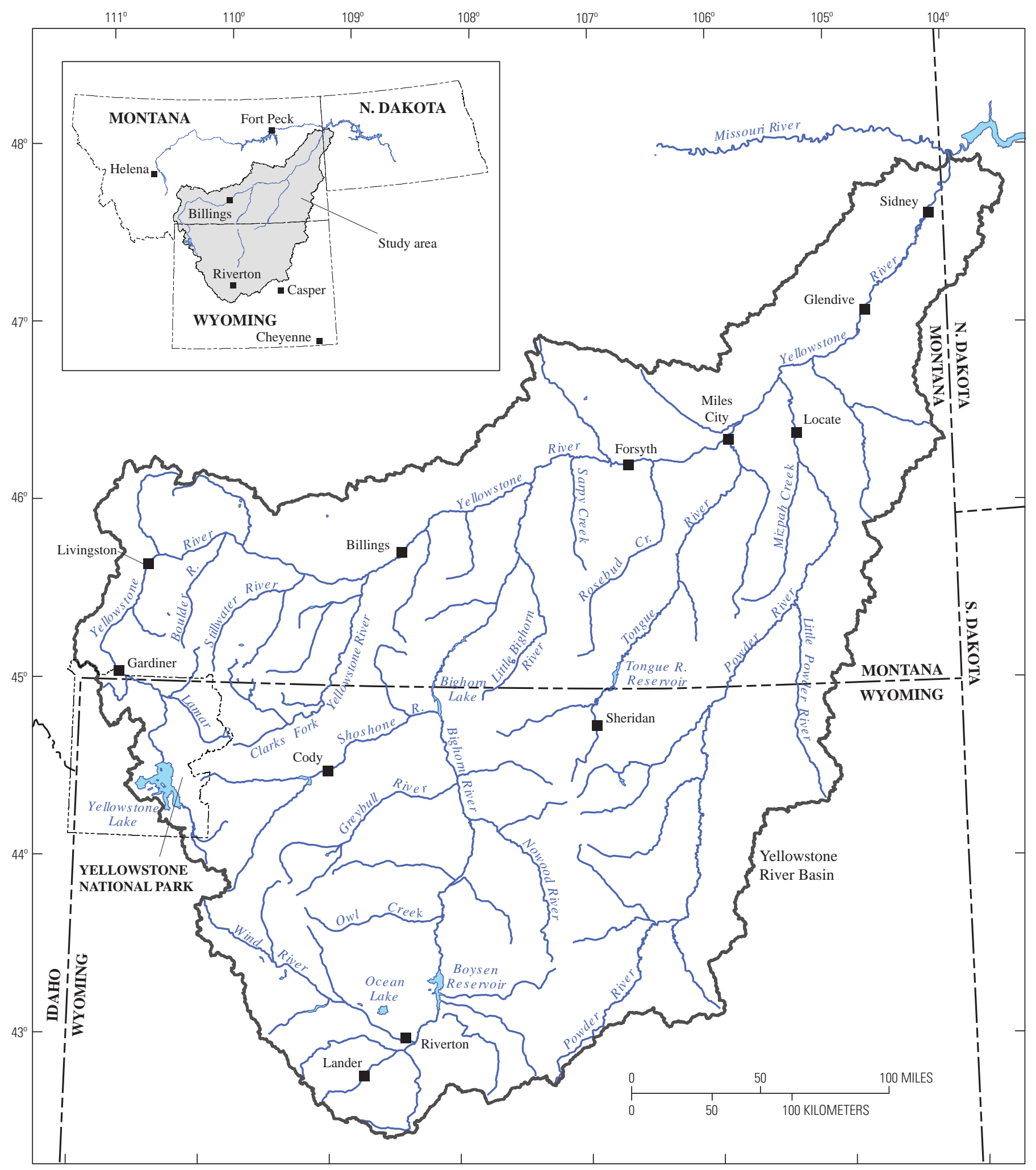

Base modified from U.S. Geological Survey Digital Line Graph

(DLG), 1:2,000,000, 1973, Lambert Conformal Conic Projection

Standard parallels $45^{\circ} 00^{\prime}$ and $49^{\circ} 00^{\prime}$ central meridian $-109^{\circ} 30^{\prime}$

North American Datum of 1983 (NAD 83).

Figure 1. Yellowstone River Basin in Montana, Wyoming, and North Dakota. 


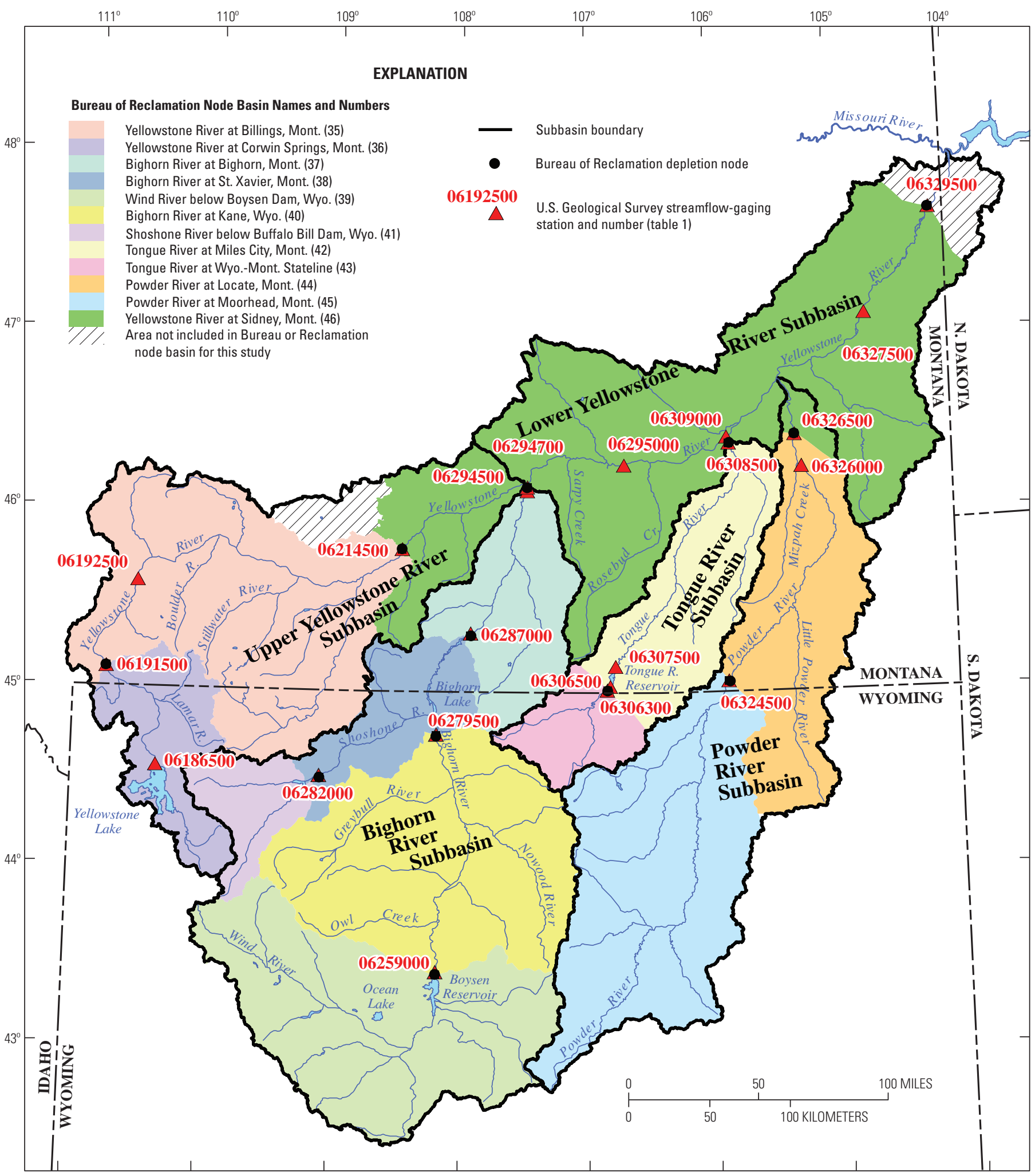

Base modified from U.S. Geological Survey Digital Line Graph

(DLG), 1:2,000,000, 1973, Lambert Conformal Conic Projection

Standard parallels $45^{\circ} 00^{\prime}$ and $49^{\circ} 00^{\prime}$ central meridian $-109^{\circ} 30^{\prime}$ North American Datum of 1983 (NAD 83).

Figure 2. Study area subbasins in Montana, Wyoming, and North Dakota, and Bureau of Reclamation node basins and streamflowgaging stations in Montana and Wyoming. 


\section{Purpose and Scope}

The purpose of this report is to present streamflow statistics for selected locations on the Yellowstone, Tongue, and Powder Rivers for the 1928-2002 (calendar year) study period. These statistics include basic summary statistics and flow-frequency data, and flow-duration data for two streamflow conditions: "unregulated," where effects of streamflow regulation and water use have been removed, and "regulated," where streamflows are adjusted to represent near-present-day (based on 2002 data) levels of development. Streamflow data, from these regulated and unregulated conditions, are intended for use in management and development of main-stem Yellowstone River resources. Information for selected streamflow-gaging stations on the Yellowstone, Bighorn, Tongue, and Powder Rivers is summarized in table 1; locations of selected streamflow-gaging stations in the Yellowstone River Basin are shown on figure 2. To facilitate the data analyses, the Yellowstone River Basin was divided into five subbasins (fig. 2): (1) Upper Yellowstone River Subbasin, (2) Bighorn River Subbasin, (3) Lower Yellowstone River Subbasin, (4) Tongue River Subbasin, and (5) Powder River Subbasin. Though the Yellowstone River Basin extends into Wyoming and North Dakota, streamflow statistics only were calculated for locations in Montana.

Table 1. Information for selected streamflow-gaging stations in the Yellowstone River Basin, Montana and Wyoming1.

\begin{tabular}{|c|c|c|c|c|}
\hline $\begin{array}{l}\text { Station } \\
\text { number }\end{array}$ & Station name & $\begin{array}{l}\text { Drainage area } \\
\text { (square miles) }\end{array}$ & $\begin{array}{c}\text { Contributing } \\
\text { drainage area } \\
\text { (square miles) }\end{array}$ & $\begin{array}{l}\text { Period of record } \\
\text { (through 2010) }\end{array}$ \\
\hline 06191500 & Yellowstone River at Corwin Springs, Mont. & 2,619 & & $1889-93,1910-2010$ \\
\hline 06214500 & Yellowstone River at Billings, Mont. & 11,805 & 11,408 & $1904-05,1928-2010$ \\
\hline 06294500 & Bighorn River above Tullock Creek near Bighorn, Mont. & 22,414 & & $1945-55,1956-2010$ \\
\hline 06295000 & Yellowstone River at Forsyth, Mont. & 40,146 & 39,455 & $1921-23,1977-2010$ \\
\hline 06309000 & Yellowstone River at Miles City, Mont. & 48,253 & & $1922-23,1928-2010$ \\
\hline 06306300 & Tongue River at State Line near Decker, Mont. & 1,453 & & $1960-2010$ \\
\hline 06306500 & Tongue River near Decker, Mont. & 1,585 & & $1928-1938$ \\
\hline 06307500 & Tongue River at Tongue River Dam, near Decker, Mont. & 1,770 & & 1939-2010 \\
\hline 06308500 & Tongue River at Miles City, Mont. & 5,397 & & $1938-42,1946-2010$ \\
\hline 06324500 & Powder River at Moorhead, Mont. & 8,086 & & $1929-72,1974-2010$ \\
\hline 06326000 & Powder River at Mizpah, Mont. & 12,132 & & $1928-1933$ \\
\hline 06326500 & Powder River near Locate, Mont. & 13,068 & & $1938-2010$ \\
\hline
\end{tabular}

${ }^{1}$ U.S. Geological Survey (2010).

${ }^{2}$ Contributing area only specified for selected streamflow-gaging stations in U.S. Geological Survey (2010).

\section{Description of the Study Area}

The headwaters of the Yellowstone River are in northern Wyoming, east of Yellowstone National Park. The river enters Montana near the town of Gardiner and flows north and east across $500 \mathrm{mi}$ of Montana to its confluence with the Missouri River in North Dakota (fig. 1). Elevations in the drainage basin range from about 13,780 feet (ft; above NAVD 88) in the mountains south of Yellowstone National Park to $1,850 \mathrm{ft}$ at the mouth of the Yellowstone River (Zelt and others, 1999). Major tributaries to the Yellowstone River include the Bighorn, Tongue, and Powder Rivers (table 1, fig. 1).

Generally, the climate is semiarid with cold winters and warm summers. Based on climatic data for 1971-2000, monthly mean temperatures at Yellowstone Lake, Wyo. (fig. 1; elevation $7,870 \mathrm{ft}$ ), ranged from $-3.1^{\circ} \mathrm{F}$ in January to $70.4{ }^{\circ} \mathrm{F}$ in July, and monthy mean temperatures at Sidney, Mont. (in the eastern part of the basin, elevation 1,920 ft), ranged 
from $2.7^{\circ} \mathrm{F}$ in January to $86.3^{\circ} \mathrm{F}$ in July (National Oceanic and Atmospheric Administration, 2002). The mean annual precipitation of 20.40 inches (in.) at Yellowstone Lake, Wyo. was distributed fairly evenly throughout the year, whereas about 58 percent of the mean annual precipitation (14.31 in.) at Sidney, Mont., fell from May to August.

The typical annual flow pattern for the Yellowstone River downstream from Billings, Mont., consists of a lowland snowmelt peak during the late winter/early spring followed by a peak from the mountain snowmelt during the late spring/early summer (Zelt and others, 1999). Several short- to moderateduration rainstorm peaks typically augment the spring/summer snowmelt peaks and the summer base flows.

\section{Methods for Calculating Streamflow Statistics for Unregulated and Regulated Conditions}

Observed daily streamflow records from USGS streamflow-gaging stations served as the basis for calculating the streamflow statistics. Daily mean streamflows (referred to herein as daily streamflows) were retrieved and analyzed using methods developed by the USACE and the USGS. The USACE retrieved daily streamflows for selected USGS streamflow-gaging stations (U.S. Geological Survey, 2010) and organized the data into a USACE Hydrologic Engineering Center Data Storage System database using the computer program HEC-DSSvue (U.S. Army Corps of Engineers, 2009a; Douglas J. Clemetson, P.E., Chief, Hydrology Section, U.S. Army Corps of Engineers, written commun., November 2009). Missing daily streamflows for ungaged periods were synthesized to develop a complete set of daily streamflows for the selected streamflow-gaging stations for the 1928-2002 study period. This study period was chosen because the USACE desired a 75-year study period and U.S. Department of the Interior Bureau of Reclamation (Reclamation) depletion data (necessary to estimate unregulated and regulated streamflows) were only available for 1929-2002. The daily streamflows were modified to represent unregulated and regulated streamflow conditions, respectively. Statistical summaries were calculated for each set of conditions.

\section{Synthesis of Missing Streamflow Records}

In order to develop a complete set of daily streamflows for the 1928-2002 study period, monthly mean streamflows (referred to herein as monthly streamflows) for periods of missing records were synthesized using the Maintenance of Variance Extension, Type 1 (MOVE.1) curve-fitting procedure described by Hirsch (1982) and Alley and Burns (1983) and discussed below in the section "Synthesis of Monthly Mean Streamflows." The synthesized monthly streamflows were used to synthesize daily streamflows.

\section{Synthesis of Monthly Mean Streamflows}

Monthly streamflows for the Lower Yellowstone River (or the part of the Yellowstone River in the Lower Yellowstone River Subbasin; fig. 2), Tongue River, and Powder River were synthesized using MOVE.1. The MOVE. 1 procedure is based on correlation of streamflow records for a target station (that is, a streamflow-gaging station needing estimation of missing records) with concurrent streamflow records for one or more index stations. The MOVE. 1 procedure is analogous to ordinary leastsquares (OLS) regression, except that MOVE.1 results in a synthesized flow record with a variance comparable to that of the observed flow record (Cary and Parrett, 1996). This mixed-station procedure can be applied to cases for which an appropriate index station has a shorter record length than the target station (Sando and others, 2008). Selected information about MOVE.1 analyses for synthesizing monthly streamflows at streamflow-gaging stations for this study is presented in table 2 .

\section{Yellowstone River Streamflow-Gaging Stations}

For the streamflow-gaging stations on the Yellowstone River, monthly streamflows were synthesized for less than 1.0 percent (06309000, Yellowstone River at Miles City) to 96 percent (06327500, Yellowstone River at Glendive) of the study period (table 2). Pearson correlation coefficients calculated for the concurrent data for the target and index stations ranged from 0.87 to 1.0, indicating a strong positive correlation (Hirsch and others, 1993). Values of the standard error of prediction in percent (SEP; as discussed in Alley and Burns, 1983) ranged from 5.2-9.3 percent; these relatively small (less than 10 percent) values of SEP indicate that the results from the MOVE.1 analyses are reliable.

\section{Tongue and Powder River Streamflow-Gaging Stations}

For the Tongue and Powder Rivers, monthly streamflows were synthesized for 19 and 14 percent of the study period, respectively (table 2). Pearson correlation coefficients calculated for concurrent data for the target and index stations generally were lower than coefficients associated with synthesized Yellowstone streamflows, ranging from 0.25 to 0.98 . The SEPs were 55 and 56 percent for the Tongue and Powder River streamflow-gaging stations, respectively. The monthly streamflows synthesized for the Tongue and Powder Rivers are, therefore, less reliable than monthly streamflows synthesized for the Yellowstone River. Given that less than 20 percent of the monthly streamflows for the study period were synthesized, however, and that the Tongue and Powder Rivers are not specifically part of the cumulative effects study, the synthesized monthly streamflows are sufficient for purposes of this study. 
Table 2. Selected information about Maintenance of Variance Extension, Type 1 (MOVE.1) analyses for synthesizing monthly mean streamflows at selected Yellowstone River Basin streamflow-gaging stations, Montana, during the study period January 1928 through December 2002.

[All stations located in Montana except for Lamar River near Tower Falls Range Station, YNP, Wyoming. Abbreviations: SEP, standard error of prediction, in percent; YNP, Yellowstone National Park; R, River; bl, below; Cr, Creek]

\begin{tabular}{|c|c|c|c|c|c|c|c|c|c|c|c|}
\hline \multicolumn{6}{|c|}{ Target station for which monthly mean streamflows were synthesized } & \multicolumn{6}{|c|}{ Index station(s) used in synthesis of monthly mean streamflows } \\
\hline Station name & $\begin{array}{l}\text { Station } \\
\text { number }\end{array}$ & $\begin{array}{l}\text { Drainage } \\
\text { area', in } \\
\text { square } \\
\text { miles }\end{array}$ & $\begin{array}{l}\text { Period of } \\
\text { systematic monthly } \\
\text { recordin thestudy } \\
\text { period }\end{array}$ & $\begin{array}{l}\text { Ungaged period } \\
\text { requiring synthesis } \\
\text { of monthly mean } \\
\text { streamflows }\end{array}$ & $\begin{array}{l}\text { Percent } \\
\text { missing } \\
\text { monthly } \\
\text { mean } \\
\text { stream- } \\
\text { flows }\end{array}$ & Station name & $\begin{array}{l}\text { Station } \\
\text { number }\end{array}$ & $\begin{array}{l}\text { Drainage } \\
\text { area', in } \\
\text { square } \\
\text { miles }\end{array}$ & $\begin{array}{c}\text { Number of } \\
\text { monthly } \\
\text { mean } \\
\text { streamflows } \\
\text { synthesized } \\
\text { based on } \\
\text { this station }\end{array}$ & $\begin{array}{c}\text { Pearson } \\
\text { correlation } \\
\text { coefficient } \\
\text { for } \\
\text { concurrent } \\
\text { data for target } \\
\text { and index } \\
\text { station } \\
\end{array}$ & $\begin{array}{l}\text { SEP of } \\
\text { MOVE.1 } \\
\text { analysis }\end{array}$ \\
\hline \multirow[t]{3}{*}{$\begin{array}{l}\text { Yellowstone } \\
\text { River at Forsyth }\end{array}$} & 06295000 & 40,146 & $\begin{array}{c}\text { 10/1977-12/2002 } \\
\text { (303 months) }\end{array}$ & $\begin{array}{l}\text { 1/1928-9/1977 } \\
\quad(597 \text { months) }\end{array}$ & 66 & $\begin{array}{l}\text { Yellowstone River } \\
\text { at Miles City }\end{array}$ & 06309000 & 48,253 & 565 & $0.97-0.99$ & 5.2 \\
\hline & & & & & & $\begin{array}{l}\text { Yellowstone River } \\
\text { near Sidney }\end{array}$ & 06329500 & 69,083 & 8 & $0.90-0.99$ & \\
\hline & & & & & & $\begin{array}{c}\text { Yellowstone River } \\
\text { near Miles City }\end{array}$ & 06296120 & 42,847 & 24 & 1.00 & \\
\hline $\begin{array}{l}\text { Yellowstone } \\
\text { River at Miles } \\
\text { City }\end{array}$ & 06309000 & 48,253 & $\begin{array}{c}9 / 1928-12 / 2002 \\
\quad(892 \text { months })\end{array}$ & $\begin{array}{l}1 / 1928-8 / 1928 \\
\quad(8 \text { months })\end{array}$ & 0.89 & $\begin{array}{l}\text { Yellowstone River } \\
\text { near Sidney }\end{array}$ & 06329500 & 69,083 & 8 & $0.91-0.99$ & 8.1 \\
\hline \multirow[t]{3}{*}{$\begin{array}{l}\text { Yellowstone } \\
\text { River at } \\
\text { Glendive }\end{array}$} & 06327500 & 66,739 & $\begin{array}{l}\text { 10/1931-9/1934; } \\
\text { 10/2002-12/2002 } \\
\text { (39 months) }\end{array}$ & $\begin{array}{l}\text { 1/1928-9/1931; } \\
\text { 10/1934-9/2002 } \\
\text { (861 months) }\end{array}$ & 96 & $\begin{array}{l}\text { Yellowstone River } \\
\text { near Sidney }\end{array}$ & 06329500 & 69,083 & 8 & $0.97-0.98$ & 7.0 \\
\hline & & & & & & $\begin{array}{l}\text { Yellowstone River } \\
\text { at Miles City }\end{array}$ & 06309000 & 48,253 & 811 & $0.87-1.00$ & \\
\hline & & & & & & $\begin{array}{l}\text { Yellowstone River } \\
\text { at Billings }\end{array}$ & 06214500 & 11,805 & 42 & 0.93 & \\
\hline \multirow[t]{2}{*}{$\begin{array}{l}\text { Yellowstone } \\
\text { River near } \\
\text { Sidney }\end{array}$} & 06329500 & 69,083 & $\begin{array}{l}\text { 1/1928-12/1931; } \\
\text { 10/1933-12/2002 } \\
\text { (879 months) }\end{array}$ & $\begin{array}{l}1 / 1932-9 / 1933 \\
\text { (21 months) }\end{array}$ & 2.3 & $\begin{array}{l}\text { Yellowstone River } \\
\text { at Miles City }\end{array}$ & 6309000 & 48,253 & 13 & $0.95-0.99$ & 9.3 \\
\hline & & & & & & $\begin{array}{l}\text { Yellowstone River } \\
\text { at Glendive }\end{array}$ & 06327500 & 66,739 & 8 & $0.97-0.98$ & \\
\hline
\end{tabular}


Table 2. Selected information about Maintenance of Variance Extension, Type 1 (MOVE.1) analyses for synthesizing monthly mean streamflows at selected Yellowstone River Basin streamflow-gaging stations, Montana, during the study period January 1928 through December 2002.-Continued

[All stations located in Montana except for Lamar River near Tower Falls Range Station, YNP, Wyoming. Abbreviations: SEP, standard error of prediction, in percent; YNP, Yellowstone National Park; R, River; bl, below; Cr, Creek]

\begin{tabular}{|c|c|c|c|c|c|c|c|c|c|c|c|}
\hline \multicolumn{6}{|c|}{ Target station for which monthly mean streamflows were synthesized } & \multicolumn{6}{|c|}{ Index station(s) used in synthesis of monthly mean streamflows } \\
\hline Station name & $\begin{array}{l}\text { Station } \\
\text { number }\end{array}$ & $\begin{array}{c}\text { Drainage } \\
\text { area', in } \\
\text { square } \\
\text { miles }\end{array}$ & $\begin{array}{l}\text { Period of systematic } \\
\text { monthly record in the } \\
\text { study period }\end{array}$ & $\begin{array}{l}\text { Ungaged period } \\
\text { requiring synthesis } \\
\text { of monthly mean } \\
\text { streamflows }\end{array}$ & $\begin{array}{l}\text { Percent } \\
\text { missing } \\
\text { monthly } \\
\text { mean } \\
\text { stream- } \\
\text { flows }\end{array}$ & Station name & $\begin{array}{l}\text { Station } \\
\text { number }\end{array}$ & $\begin{array}{l}\text { Drainage } \\
\text { area', in } \\
\text { square } \\
\text { miles }\end{array}$ & $\begin{array}{c}\text { Number of } \\
\text { monthly } \\
\text { mean } \\
\text { streamflows } \\
\text { synthesized } \\
\text { based on } \\
\text { this station }\end{array}$ & $\begin{array}{c}\text { Pearson } \\
\text { correlation } \\
\text { coefficient } \\
\text { for } \\
\text { concurrent } \\
\text { data for target } \\
\text { and index } \\
\text { station }\end{array}$ & $\begin{array}{c}\text { SEP of } \\
\text { MOVE.1 } \\
\text { analysis }\end{array}$ \\
\hline \multirow[t]{8}{*}{$\begin{array}{l}\text { Tongue River at } \\
\text { Miles City }\end{array}$} & 06308500 & 5,397 & $\begin{array}{l}4 / 1938-4 / 1942 ; \\
4 / 1946-12 / 2002 \\
\text { (730 months) }\end{array}$ & $\begin{array}{c}\text { 1/1928-3/1938; } \\
5 / 1942-3 / 1946 \\
\text { (170 months) }\end{array}$ & 19 & $\begin{array}{l}\text { Clarks Fork } \\
\text { Yellowstone } \\
\text { near Belfry }\end{array}$ & 06207500 & 1,154 & 14 & $0.25-0.53$ & 55 \\
\hline & & & & & & $\begin{array}{l}\text { Lamar River near } \\
\text { Tower Falls Ranger } \\
\text { Station, YNP, Wyo. }\end{array}$ & 06188000 & 660 & 8 & $0.31-0.67$ & \\
\hline & & & & & & $\begin{array}{l}\text { Shields River at } \\
\text { Clyde Park }\end{array}$ & 06193500 & 543 & 21 & $0.55-0.74$ & \\
\hline & & & & & & $\begin{array}{l}\text { Powder River at } \\
\text { Moorhead }\end{array}$ & 06324500 & 8,086 & 81 & $0.27-0.88$ & \\
\hline & & & & & & $\begin{array}{l}\text { Tongue River at } \\
\text { Tongue River } \\
\text { Dam, near Decker }\end{array}$ & 06307500 & 1,770 & 30 & $0.79-0.96$ & \\
\hline & & & & & & $\begin{array}{l}\text { Little Bighorn R bl } \\
\text { Pass Cr near Wyola }\end{array}$ & 06290500 & 428 & 8 & $0.81-0.88$ & \\
\hline & & & & & & $\begin{array}{l}\text { Powder River near } \\
\text { Locate }\end{array}$ & 06326500 & 13,068 & 4 & 0.81 & \\
\hline & & & & & & $\begin{array}{l}\text { Bighorn River near } \\
\text { St. Xavier }\end{array}$ & 06287000 & 19,667 & 4 & 0.45 & \\
\hline \multirow[t]{2}{*}{$\begin{array}{r}\text { Powder River } \\
\text { near Locate }\end{array}$} & 06326500 & 13,068 & $\begin{array}{r}4 / 1938-12 / 2002 \\
(777 \text { months })\end{array}$ & $\begin{array}{l}\text { 1/1928-3/1938 } \\
\quad(123 \text { months })\end{array}$ & 14 & $\begin{array}{l}\text { Clarks Fork } \\
\text { Yellowstone } \\
\text { near Belfry }\end{array}$ & 06207500 & 1,154 & 16 & $0.26-0.56$ & 56 \\
\hline & & & & & & $\begin{array}{l}\text { Powder River at } \\
\text { Moorhead }\end{array}$ & 06324500 & 8,086 & 107 & $0.70-0.98$ & \\
\hline
\end{tabular}




\section{Synthesis of Daily Mean Streamflows}

Daily streamflows were synthesized by distributing the synthesized monthly streamflows to daily streamflows by using ratios of daily to monthly streamflows (referred to herein as daily/monthly ratios) developed from appropriate index stations. Selected information about daily/monthly ratio analyses for synthesizing daily mean streamflows is presented in table 3. Errors associated with the synthesized daily streamflows include the errors associated with the monthly streamflows and additional errors resulting from the monthly-to-daily distribution. Therefore, the errors associated with synthesis of daily streamflows likely are higher than errors associated with synthesis of monthly streamflow values.

\section{Yellowstone River Streamflow-Gaging Stations}

Daily streamflows for each of the four Yellowstone River streamflow-gaging stations were synthesized using daily/ monthly ratios from the Yellowstone River near Sydney and/ or the Yellowstone River at Miles City streamflow-gaging stations (table 3). Daily/monthly ratios from the Yellowstone River at Forsyth and Yellowstone River at Glendive were not used because those streamflow-gaging stations had much shorter periods of record during the study period (table 1).

Daily streamflows were synthesized for the entire study period (1928-2002). Initially, the synthesized daily streamflows were compared with observed daily streamflows to determine the effect of travel-time between the target and index streamflow-gaging stations. For three of the target/ index streamflow-gaging station pairs, the series of daily/ monthly ratios was shifted backward (when the index station was downstream from the target station) or forward (when the index station was upstream from the target station) in order to achieve better agreement between synthesized and observed daily streamflows (table 3 ).

\section{Tongue and Powder River Streamflow-Gaging Stations}

Missing daily streamflows for the Tongue River at Miles City for the 1920s and 1930s were synthesized using two types of data (table 3). Long-term mean daily/monthly ratios from the Tongue River at Miles City (calculated from the observed streamflows for the streamflow-gaging station period of record concurrent with the study period) were used for the period from January 1, 1928, to April 19, 1928, because no data were available from appropriate index stations for that period. Daily/monthly ratios from the Tongue River near Decker were used for the period from April 20, 1928, to April 1, 1938.

Daily streamflows for the Tongue River at Miles City for the period from May 1, 1943 to March 31, 1946 were synthesized by using weighted averages of daily/monthly ratios for the Tongue River at Tongue River Dam, near Decker (weighting of 33 percent) and the Powder River near Locate (weighting of 67 percent). Weighted averages of data from the two streamflow gages were used (instead of data exclusively from either streamflow gage) to account for regulation effects that the Tongue River Dam may have on the synthesized daily streamflows. Daily streamflow data were not available for this same period for the Tongue River at State line, near Decker, Mont., which is upstream from the Tongue River Reservoir and, therefore, is unaffected by reservoir regulation. Using data exclusively from the Tongue River at Tongue River Dam (which drains about 33 percent of the Tongue River at Miles City drainage area) for estimating daily/monthly ratios might result in synthesized daily streamflows that are overly affected by stream regulation. Even though the Powder River Subbasin is adjacent to the Tongue River Subbasin (fig. 2), and the topography, vegetation, and climate for both Subbasins are similar, using data exclusively from the Powder River near Locate as an index station might result in synthesized daily streamflows with no representation of the regulation effects of the Tongue River Dam. The streamflows synthesized for the Tongue River at Miles City are less reliable than the daily streamflows synthesized for the Yellowstone and Powder Rivers because of the uncertainties associated with the weightedaverage analyses. Less than 7 percent of the record, however, was synthesized in this manner; therefore, the synthesized daily streamflows are acceptable for the purposes of this study.

Synthesized streamflows for the Tongue River at Miles City include a daily streamflow of 12,320 cubic feet per second $\left(\mathrm{ft}^{3} / \mathrm{s}\right)$ for June 20, 1944, which is larger than any observed daily streamflow for that streamflow-gaging station and is smaller than the largest known annual instantaneous peak streamflow of 13,300 ft 3 (Parrett and Johnson, 2004), which occurred June 15, 1962 (U.S. Geological Survey, 2010). That large synthesized daily streamflow $\left(12,320 \mathrm{ft}^{3} / \mathrm{s}\right)$ appears to be reasonable, because the second largest observed daily streamflow on the Powder River at Locate $\left(23,500 \mathrm{ft}^{3} / \mathrm{s}\right)$ also occurred on the same date, and climate stations in the vicinity received extremely large amounts of precipitation on and just before June 20, 1944 (Robb, 1944).

Missing daily streamflows for the Powder River near Locate mostly were synthesized using daily/monthly ratios from two index stations; the Powder River near Mizpah and the Powder River at Moorhead (table 3). Similar to the synthesis for the Tongue River at Miles City, long-term mean daily/monthly ratios from the Powder River near Locate (calculated from the observed streamflows for the streamflowgaging station period of record concurrent with the study period) were used from January 1, 1928, to August 28, 1928, because no data were available from appropriate index stations for that period.

\section{Streamflow Conditions Analysis}

Streamflow datasets were synthesized for two hypothetical streamflow conditions: unregulated and regulated. These datasets are more homogenous than the observed streamflow datasets because effects of changing water use practices were removed (for the unregulated dataset) or modified to be uniform through the study period (for the regulated dataset). Data homogeneity is an important assumption for the procedures 
used in the statistical analyses (U.S. Interagency Advisory Council on Water Data, 1982).

Unregulated conditions represent estimates of streamflows during the 1928-2002 study period assuming there was no water-resources development in the Yellowstone River Basin. Water-resources development includes irrigation operations, reservoir operations, and other human-caused changes to the amount and timing of streamflow. Historical depletions estimated by Reclamation (U.S. Department of the Interior Bureau of Reclamation, 1999 and 2005) and described in the section "Depletion Estimates", account for changes to streamflow caused by water-resources development throughout the Yellowstone River Basin. Unregulated streamflows were estimated by adding the historical depletions estimated by Reclamation to the observed streamflows.

Regulated streamflows represent estimates of streamflows that might have occurred during the 1928-2002 study period assuming a uniform level of water-resources development existing in 2002 and applied throughout the entire study period. Regulated streamflows were estimated by subtracting the "2002-level depletions" (described in the section "Depletion Estimates") from the respective unregulated streamflows.

\section{Depletion Estimates}

The Bureau of Reclamation developed estimates of historical and 2002-level depletions for the entire Missouri River Basin (U.S. Department of the Interior Bureau of Reclamation, 2005) for water years 1929-2002. Depletion estimates were developed for 118 node basins in the Missouri River Basin, which included 12 node basins (fig. 2) in the Yellowstone River Basin. The node basin boundaries do not necessarily correspond with the subbasin boundaries (fig. 2). For example, the lower part of the Powder River Subbasin is included in the Yellowstone River at Sidney, Mont. node basin. Also a small part (approximately $690 \mathrm{mi}^{2}$ ) of the Upper Yellowstone River Subbasin northwest of the Yellowstone River at Billings, Mont. streamflow-gaging station (06214500) was not included in any node basins within the Yellowstone River Basin; this area corresponds with the non-contributing drainage area of $691 \mathrm{mi}^{2}$ at the Yellowstone River at Forsyth, Mont. streamflow gaging station (06295000; table 1; difference between drainage area and non-contributing drainage area). In addition, the part of the Lower Yellowstone River Subbasin downstream from the Yellowstone River near Sidney, Mont. streamflowgaging station (0629500) is not included in any node basin considered for this study.

The term "depletion" refers to changes to natural streamflows that result from water-resources development. In almost all cases, water-resources development results in net decreases in streamflow over periods of one to multiple years. Some water-resources development (for example, reservoir and irrigation operations), however, can result in decreases in streamflow (relative to natural conditions) during specific times of the year and increases in streamflow during other times of the year. In unusual cases, such as construction of a reservoir and the associated increase in water surface area in a region where precipitation exceeds evaporation, water-resources development can result in net increases in streamflow over relatively long periods. Thus, the term "depletion" as used by Reclamation (U.S. Department of the Interior, Bureau of Reclamation, 2005) and in this report does not imply a decrease in streamflow, especially on a seasonal basis. Positive depletions indicate decreases in streamflow relative to natural conditions, and conversely, negative depletions indicate increases in streamflow relative to natural conditions.

The historical depletions determined by Reclamation (U.S. Department of the Interior, Bureau of Reclamation, 2005) included estimates of irrigation operations, reservoir operations, and other water uses that existed each year during 1929-2002. Those estimates were based on climatological records, the irrigation methods in use and number of irrigated acres, and municipal and industrial water uses for each year. The 2002-level depletions determined by Reclamation were based upon estimates of irrigation operations, reservoir operations, and municipal and industrial water uses that existed in 2002, which then were applied to each year during 1929-2002. Applying the 2002-level depletions to each year accounts for effects of interannual climatic variability on water demand and consumptive use. Because Reclamation did not develop depletion estimates for 1928, monthly depletions for 1928 (this study) were estimated from the monthly averages for the years 1929 to 1933 for the historical and 2002-level depletions. The Reclamation 1929-2002 depletion data and 1928 estimates from this study are presented in Appendix 1 of this report.

\section{Lower Yellowstone River Subbasin Depletion Estimates}

Monthly historical and 2002-level depletions at each gage along the Yellowstone River main stem in the Lower Yellowstone River Subbasin were apportioned according to the number of irrigated acres upstream from the gage relative to the total irrigated acres in each Reclamation node basin. The U.S. Army Corps of Engineers (2011b) modified the monthly depletions calculated by Reclamation for the Bighorn River Subbasin. Those modified monthly depletions for the Bighorn River Subbasin and the monthly depletions for the Upper Yellowstone River Subbasin were added to the monthly depletions calculated for each streamflow-gaging station in the Lower Yellowstone River Subbasin. The monthly depletions were distributed to daily depletions assuming a constant value for each day of each month. To be consistent with the USACE approach for the Bighorn Subbasin and the Upper Yellowstone River Basin (Douglas J. Clemetson, Hydrology Section, U.S. Army Corps of Engineers, written commun., 2010), when subtraction of daily depletions from observed daily streamflows resulted in negative unregulated daily streamflows, those negative streamflows were set to zero. 
Table 3. Selected information about daily mean streamflow to monthly mean streamflow ratio (daily/monthly ratio) analyses for synthesizing daily mean streamflows at selected Yellowstone River Basin streamflow-gaging stations, Montana, during the study period, January 1928 through December 2002.

[All stations located in Montana. Abbreviations: NA, not applicable]

\begin{tabular}{|c|c|c|c|c|c|c|c|c|c|c|c|c|c|}
\hline \multicolumn{8}{|c|}{ Information about target stations for which daily mean streamflows were synthesized } & \multicolumn{6}{|c|}{$\begin{array}{l}\text { Information about index station(s) used in devleoping daily/monthly ratios for synthesis } \\
\text { of daily mean streamflows }\end{array}$} \\
\hline $\begin{array}{c}\text { Station } \\
\text { name }\end{array}$ & $\begin{array}{l}\text { Station } \\
\text { number }\end{array}$ & $\begin{array}{l}\text { Drain- } \\
\text { age } \\
\text { area, in } \\
\text { square } \\
\text { miles }\end{array}$ & $\begin{array}{l}\text { Period of } \\
\text { systematic } \\
\text { record in } \\
\text { study period }\end{array}$ & $\begin{array}{l}\text { Ungaged } \\
\text { period } \\
\text { requiring } \\
\text { synthesis } \\
\text { of daily } \\
\text { mean } \\
\text { streamflows }\end{array}$ & $\begin{array}{c}\text { Percent of } \\
\text { missing daily } \\
\text { mean } \\
\text { streamflows }\end{array}$ & $\begin{array}{r}\text { Station } \\
\text { an } \\
\text { supplemen } \\
\text { inform }\end{array}$ & $\begin{array}{l}\text { n name } \\
\text { nd } \\
\text { tal analysis } \\
\text { mation }\end{array}$ & $\begin{array}{l}\text { Station } \\
\text { number }\end{array}$ & $\begin{array}{l}\text { Drainage } \\
\text { area, in } \\
\text { square } \\
\text { miles }\end{array}$ & $\begin{array}{l}\text { Period of } \\
\text { synthesized } \\
\text { daily mean } \\
\text { streamflows } \\
\text { based on } \\
\text { this station }\end{array}$ & $\begin{array}{l}\text { Percent of } \\
\text { study period } \\
\text { represented } \\
\text { by } \\
\text { synthesized } \\
\text { daily mean } \\
\text { streamflows }\end{array}$ & $\begin{array}{l}\text { Length of } \\
\text { intervening } \\
\text { reach } \\
\text { between } \\
\text { target } \\
\text { and index } \\
\text { station } \\
\text { (miles) }\end{array}$ & $\begin{array}{c}\text { Shift' }^{1} \\
\text { (in days) } \\
\text { applied to } \\
\text { approximately } \\
\text { account for } \\
\text { travel time } \\
\text { between the } \\
\text { target and } \\
\text { index station } \\
\end{array}$ \\
\hline Yellowstone & 06295000 & 40,146 & $10 / 1 / 1977-$ & $1 / 1 / 1928-9 / 30 / 1977$ & 66 & \multicolumn{2}{|c|}{ Yellowstone River near Sidney } & 06329500 & 69,083 & $1 / 1 / 1928-8 / 27 / 1928$ & 0.87 & 209 & -2 \\
\hline $\begin{array}{l}\text { River at } \\
\text { Forsyth }\end{array}$ & & & $12 / 31 / 2002$ & & & \multicolumn{2}{|c|}{ Yellowstone River at Miles City } & 06309000 & 48,253 & 8/28/1928-9/30/1977 & 65 & 54 & 0 \\
\hline $\begin{array}{l}\text { Yellowstone } \\
\text { River at } \\
\text { Miles City }\end{array}$ & 06309000 & 48,253 & $\begin{array}{l}8 / 28 / 1928- \\
12 / 31 / 2002\end{array}$ & $1 / 1 / 1928-8 / 27 / 1928$ & 0.89 & \multicolumn{2}{|c|}{ Yellowstone River near Sidney } & 06329500 & 69,083 & $1 / 1 / 1928-8 / 27 / 1928$ & 0.89 & 155 & -1 \\
\hline $\begin{array}{l}\text { Yellowstone } \\
\text { River at } \\
\text { Glendive }\end{array}$ & 06327500 & 66,739 & $\begin{array}{l}10 / 1 / 1931- \\
9 / 30 / 1934\end{array}$ & $\begin{array}{l}\text { 1/1/1928- } \\
\text { 9/30/1931; } \\
\text { 10/1/1934- } \\
\text { 12/31/2002 }\end{array}$ & 96 & \multicolumn{2}{|c|}{ Yellowstone River near Sidney } & 06329500 & 69,083 & $\begin{array}{l}\text { 1/1/1928-9/30/1931; } \\
\text { 10/1/1934- } \\
\text { 9/30/2002 }\end{array}$ & 96.0 & 63.2 & 0 \\
\hline $\begin{array}{l}\text { Yellowstone } \\
\text { River near } \\
\text { Sidney }\end{array}$ & 06329500 & 69,083 & $\begin{array}{l}\text { 1/1/1928- } \\
\text { 12/31/1931; } \\
\text { 10/1/1933- } \\
\text { 12/31/2002 }\end{array}$ & 1/1/1932-9/30/1933 & 2.3 & \multicolumn{2}{|c|}{ Yellowstone River at Miles City } & 06309000 & 48,253 & 1/1/1932-9/30/1933 & 2.3 & 155 & +1 \\
\hline \multirow[t]{4}{*}{$\begin{array}{l}\text { Tongue River } \\
\text { at Miles City }\end{array}$} & 06308500 & 5,397 & $\begin{array}{l}\text { 4/2/1938-4/30/1942; } \\
\text { 4/1/1946- } \\
12 / 31 / 2002\end{array}$ & $\begin{array}{l}\text { 1/1/1928-4/1/1938; } \\
5 / 1 / 1942- \\
3 / 31 / 1946\end{array}$ & 19 & \multicolumn{2}{|c|}{$\begin{array}{l}\text { Tongue River at Miles City } \\
\text { (long-term mean daily/ } \\
\text { monthly ratioº }\end{array}$} & 06308500 & 5,397 & $1 / 1 / 1928-4 / 19 / 1928$ & 0.40 & NA & NA \\
\hline & & & & & & \multicolumn{2}{|c|}{ Tongue River near Decker } & 06306500 & 1,585 & $4 / 20 / 1928-4 / 1 / 1938$ & 13 & 189.2 & +1 \\
\hline & & & & & & \multirow{2}{*}{$\begin{array}{l}\text { Tongue River } \\
\text { at Tongue } \\
\text { River Dam } \\
\text { combined } \\
\text { with Powder } \\
\text { River near } \\
\text { Locate } \\
\text { (weighted } \\
\text { average) }\end{array}$} & $\begin{array}{l}\text { Tongue River } \\
\text { at Tongue } \\
\text { River Dam } \\
\text { (weighing } \\
\text { of } 33 \text { percent) }\end{array}$ & 06307500 & 1,770 & $5 / 1 / 1942-3 / 31 / 1946$ & 5 & 180 & +1 \\
\hline & & & & & & & $\begin{array}{l}\text { Powder River } \\
\text { near Locate } \\
\text { (weighting of } \\
67 \text { percent) }\end{array}$ & 06326500 & 13,068 & & & NA & NA \\
\hline \multirow[t]{3}{*}{$\begin{array}{l}\text { Powder River } \\
\text { near Locate }\end{array}$} & 06326500 & 13,068 & $\begin{array}{l}3 / 26 / 1938- \\
12 / 31 / 2002\end{array}$ & $1 / 1 / 1928-3 / 25 / 1938$ & 14 & \multicolumn{2}{|c|}{$\begin{array}{l}\text { Powder River near Locate } \\
\text { (long-term mean daily/ } \\
\text { monthly ratio }{ }^{2} \text { ) }\end{array}$} & 06326500 & 13,068 & $1 / 1 / 1928-8 / 28 / 1928$ & 0.88 & NA & 0 \\
\hline & & & & & & \multicolumn{2}{|c|}{ Powder River near Mizpah } & 06326200 & 12,132 & 8/29/1928-3/31/1933 & 6.1 & 19 & 0 \\
\hline & & & & & & \multicolumn{2}{|c|}{ Powder River at Moorhead } & 06324500 & 8,086 & 4/1/1933-3/25/1938 & 6.6 & 181.3 & +2 \\
\hline
\end{tabular}

${ }^{1}$ After applying the daily/monthly ratios, the synthesized daily mean streamflows were shifted backward (negative values) or forward (positive values) to approximately account for travel time between the target and index station.

${ }^{2}$ For periods when appropriate index stations were not available, the long-term mean daily/monthy ratio for the given month was used to synthesize daily mean streamflows.

${ }^{3}$ Weighted averages of daily/monthly rates from the two streamflow gaging stations were used to account for effects of the Tongue River Reservoir on daily streamflow estimates. 


\section{Tongue and Powder River Subbasin Depletion Estimates}

Monthly depletions estimated by Reclamation for the Tongue River Subbasin (fig. 2) were totaled to estimate the depletions at the streamflow-gaging station at the Tongue River at Miles City (06308500). Likewise, monthly depletions for the Powder River Subbasin were totaled to estimate the depletions at Powder River near Locate (06326500). Initially, the monthly depletions were distributed to daily depletions assuming a constant value for each day of each month. When subtraction of daily depletions from observed streamflows resulted in negative unregulated daily streamflows for a given month, the daily depletions for that given month were recalculated assuming a pattern similar to the daily streamflow hydrograph. After that recalculation, unregulated daily streamflows for a few days in October remained negative for some years; in those cases, all negative unregulated streamflows were set to zero. The intermediate step of redistributing depletions based on the daily streamflow hydrograph to decrease the number of negative unregulated streamflow values was applied to the Tongue and Powder streamflows because (1) negative streamflows occurred for more days for the Tongue and Powder Rivers than for the Yellowstone River, and (2) consistency with the USACE approach was not as critical for the Tongue and Powder Rivers because the USACE did not calculate streamflow statistics for the Tongue and Powder Rivers.

\section{Tongue River Reservoir Depletion Estimates}

The Tongue River just below the Tongue River Dam has a drainage area of $1,770 \mathrm{mi}^{2}$, which is about 33 percent of the Tongue River Subbasin as measured at the Tongue River at Miles City, Mont. streamflow-gaging station (06308500; U.S. Geological Survey, 2010). The Tongue River Dam was constructed in 1940 and has an active storage capacity at the spillway crest of 79,071 acre-ft (Montana Department of Natural Resources and Conservation, 2004). Most of the stored water is released into the Tongue River for irrigation downstream to the confluence of the Tongue and Yellowstone Rivers at Miles City (Montana Department of Natural Resources and Conservation, 2004). Overall effects of the Tongue River reservoir and other small (less than 200,000 acre-ft) reservoirs were included in the "Other Depletions" category in the Reclamation depletion estimates (U.S. Department of the Interior Bureau of Reclamation, 1999) in a general manner that, according to Reclamation (U.S. Department of the Interior Bureau of Reclamation, 1999), likely accounted only for reservoir evaporation. The "Other Depletions" category also included conservation tillage practices, farm ponds, and livestock, municipal, energy, industrial, and ruraldomestic uses. "Other Depletions" for node basins in a large part of the Missouri River Basin (that is, the approximately 280,000 $\mathrm{mi}^{2}$ upstream from Gavins Point Dam on the South Dakota-Nebraska border and including the Tongue River Subbasin) were roughly estimated to be 7 percent of the annual irrigation depletions in the respective node basins. Because of the general manner used to estimate overall small-reservoir depletions, Reclamation "Other Depletions" estimates were examined closely to determine whether such estimates accounted adequately for Tongue River Reservoir depletions to meet the objectives of this study.

Depletions for the Tongue River Reservoir were calculated by the USGS by subtracting reservoir outflows, as measured at the streamflow-gaging station at the Tongue River at Tongue River Dam, near Decker, Mont., (06307500), from reservoir inflows (as measured at the streamflow-gaging station at the Tongue River at State line, near Decker, Mont. 06306300) for the period 1960-2002, when data from both gages were available (table 1 ). The mean annual calculated reservoir depletion for 1960-2002 was 30 acre-ft, which is substantially smaller than the mean annual total depletions for the Tongue River Subbasin (5,500 acre-ft) and the mean annual total depletions for the Yellowstone River Basin upstream from Miles City (7,482,000 acre-ft) that were estimated by Reclamation for the same period (U.S. Department of the Interior Bureau of Reclamation, 1999). Also, the calculated mean monthly depletions for the Tongue River Reservoir (this study) are small compared to the mean monthly total depletions for the Yellowstone River Basin at Miles City that were estimated by Reclamation. The ratio of the mean monthly depletions for the Tongue River Reservoir (this study) to the mean monthly total depletions for the Yellowstone River Basin at Miles City that were estimated by Reclamation is 5 percent or less for every month except March (which was 14 percent).

Calculated reservoir depletions were compared to Reclamation "Other Depletions" estimates (U.S. Department of the Interior, Bureau of Reclamation, 1999), and differences were apparent (fig. 3). In May and June, the calculated mean monthly reservoir depletions were 82 and 75 percent (respectively) greater than the Reclamation "Other Depletions" estimates. In July, August, and September, the calculated mean monthly reservoir depletions were negative (indicating reservoir outflows were greater than reservoir inflows) and 130, 110 , and 110 percent (respectively) less than the Reclamation "Other Depletions" estimates, which were slightly positive.

The effect of such differences between the calculated reservoir depletions and Reclamation "Other Depletions" estimates on determinations of the unregulated streamflows for the Tongue River at Miles City was examined. Mean monthly unregulated streamflows for Tongue River at Miles City were determined by two methods: (1) adding the calculated reservoir depletions to Reclamation "Other Depletions" estimates; and (2) using the Reclamation "Other Depletions" estimates alone. Differences between unregulated streamflows for Tongue River at Miles City determined using methods 1 and 2 generally were small (fig. 4). Generally the largest differences occur in May and August. In May, the Reclamation estimates (method 2) result in higher mean monthly streamflows for a difference between the two methods of $+214 \mathrm{ft}^{3} / \mathrm{s}$, or 17 percent. In August, Reclamation estimates (method 2) result in lower mean monthly streamflow for a difference 


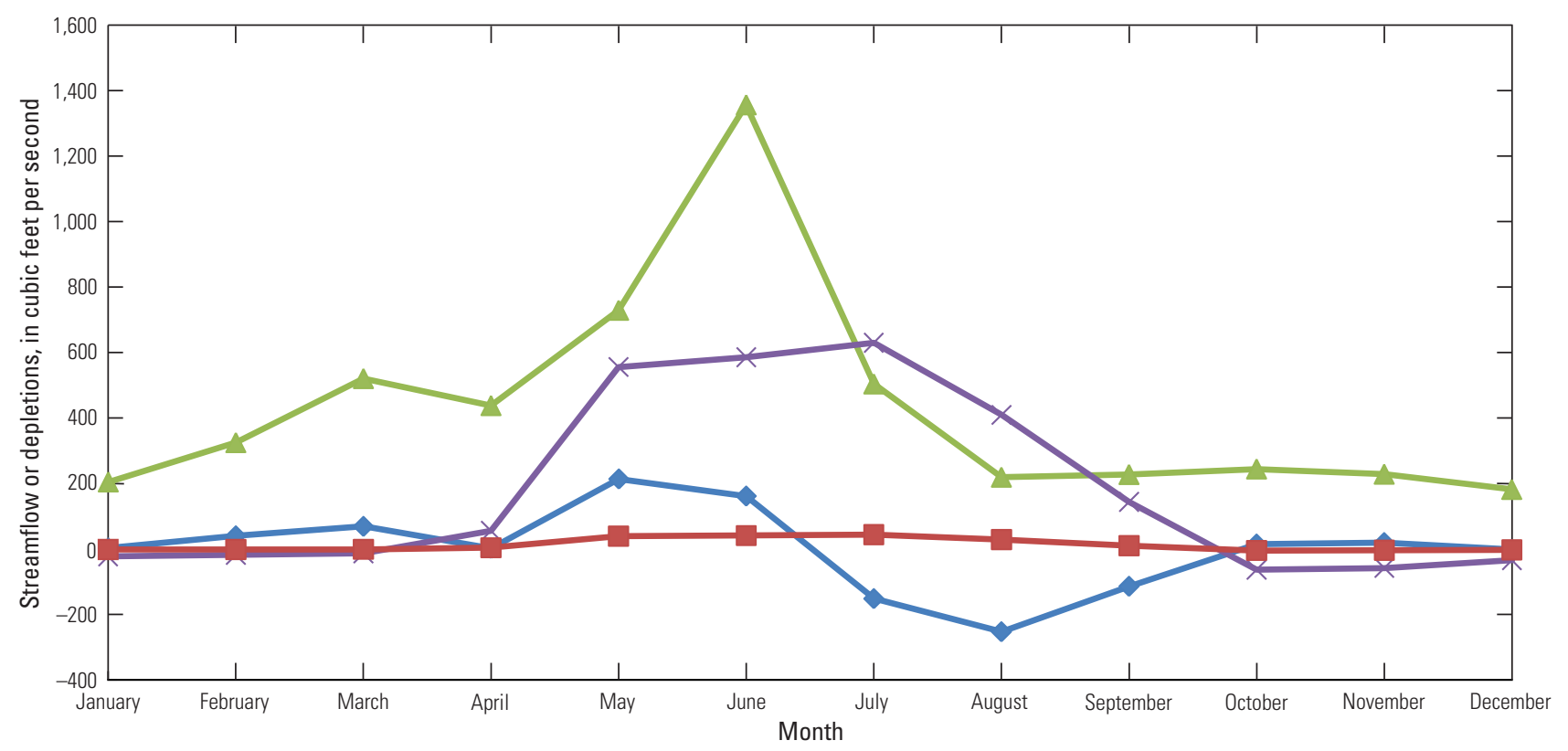

EXPLANATION

Observed mean monthly streamflow at Tongue River at Miles City,
Mont. (06308500)
Mean monthly depletions for the Tongue River Reservoir, calculated
as reservoir inflow (Tongue River at State line, near Decker, Mont.
(06306300)) minus reservoir outflow (Tongue River at Tongue River
Dam near Decker, Mont. (06307500))

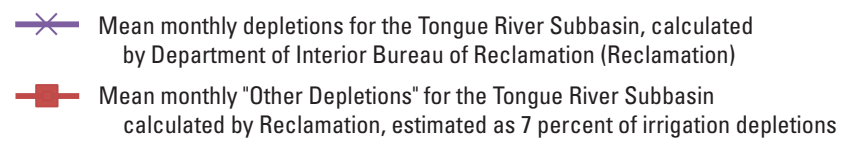

Figure 3. Mean monthly observed streamflow at Tongue River at Miles City, Mont. (streamflow-gaging station 06308500) and mean monthly depletion estimates, 1960-2002.

between the two methods of $-253 \mathrm{ft}^{3} / \mathrm{s}$, or -40 percent. To provide a perspective on the effect of these differences on Yellowstone River main-stem streamflows (the primary focus of the CES), $214 \mathrm{ft}^{3} / \mathrm{s}$ is about 1 percent of the May mean monthly streamflow $\left(17,200 \mathrm{ft}^{3} / \mathrm{s}\right)$, and $253 \mathrm{ft}^{3} / \mathrm{s}$ is about 3 percent of the August mean monthly streamflow $\left(7,970 \mathrm{ft}^{3} / \mathrm{s}\right)$ for the Yellowstone River at Miles City, based on observed streamflow records from 1922 to 2010 (U.S. Geological Survey, 2010).

The Reclamation "Other Depletions" estimates (with no additional accounting for Tongue River Reservoir depletions) were determined the most suitable for estimating unregulated and regulated streamflows at Tongue River at Miles City based on the following factors: (1) adding the calculated Tongue River Reservoir depletions to the Reclamation "Other Depletions" estimates for the period 1960-2002 did not have a substantial effect on estimated unregulated streamflows at Tongue River at Miles City (fig. 4) for most months; (2) because reservoir inflow data for 1939-59 are not available, reservoir depletions for that period would have to be estimated by using reservoir models, reservoir storage data, and/or other procedures; (3) incorporating the reservoir depletions into the regulated streamflow calculations would entail using 2002level depletions by assuming 2002 reservoir operating procedures and historical-climatic data; (4) calculated mean annual reservoir depletions for 1960-2002 were very small compared to Reclamation total depletions estimates for the Tongue River Subbasin and the Yellowstone River Basin upstream from Miles City; and (5) the Tongue River Subbasin is not specifically part of the CES.

\section{Peak-Flow Frequency Analysis}

Procedures described in Bulletin 17B, "Guidelines for Determining Flood Flow Frequency" (U.S. Interagency Advisory Council on Water Data, 1982; hereinafter referred to as Bulletin 17B), were used for developing peak-flow frequency data for unregulated and regulated flows. Annual instantaneous peak flows for the unregulated and regulated datasets were estimated for each year by multiplying the estimated annual maximum daily streamflows for both streamflow conditions by the ratios of annual instantaneous peak flow to annual maximum daily streamflow computed from observed records. For periods of missing records for a given streamflow-gaging station, the annual maximum daily streamflows were multiplied by the ratios of annual instantaneous peak flow to annual maximum daily streamflow for nearby streamflow-gaging stations that were hydrologically similar. The computer program HEC-SSP (U.S. Army Corps of Engineers, 2009b) was used to calculate the frequency analysis by using standard Bulletin 17B default procedures for fitting the log-Pearson III 


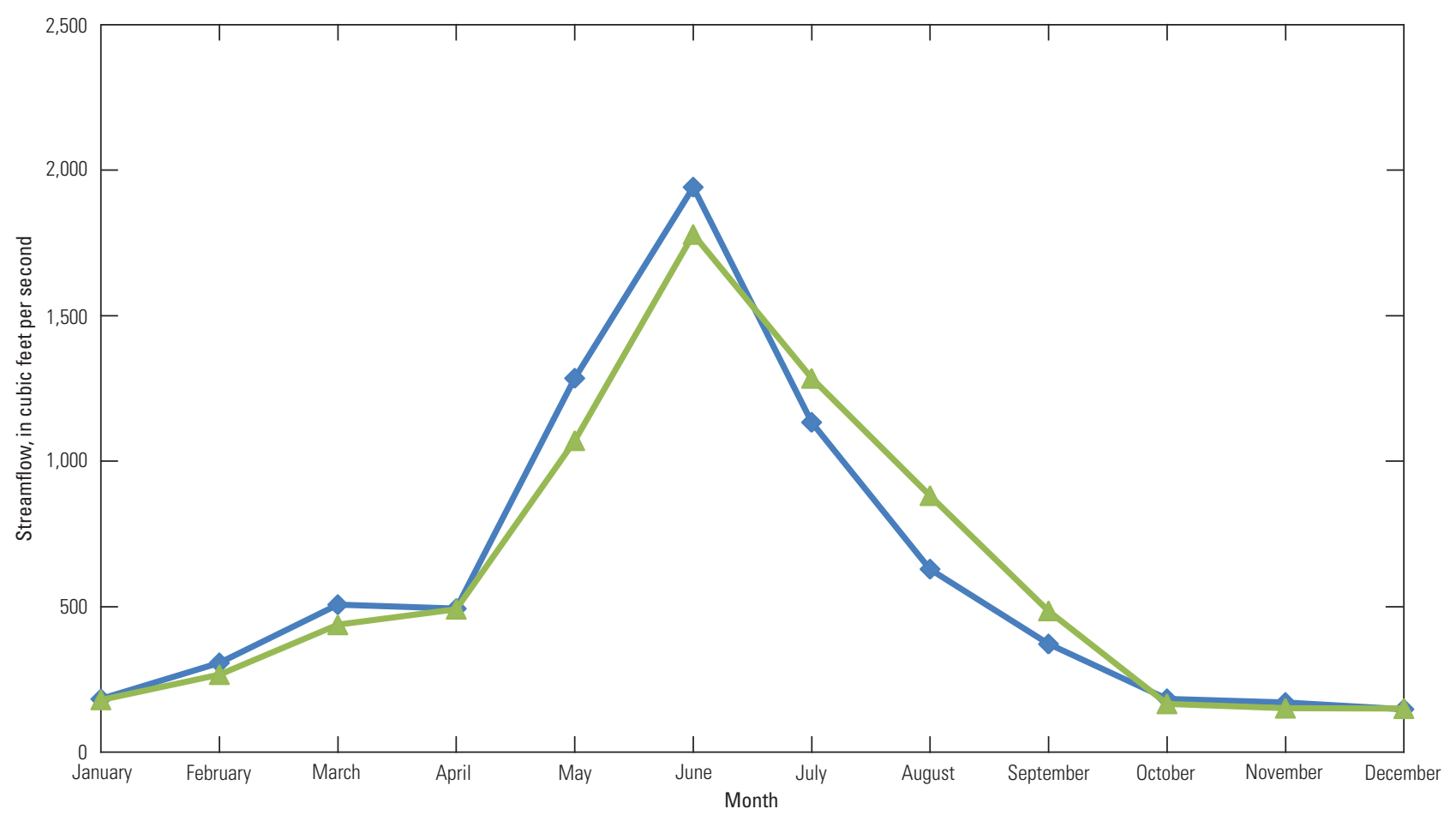

EXPLANATION
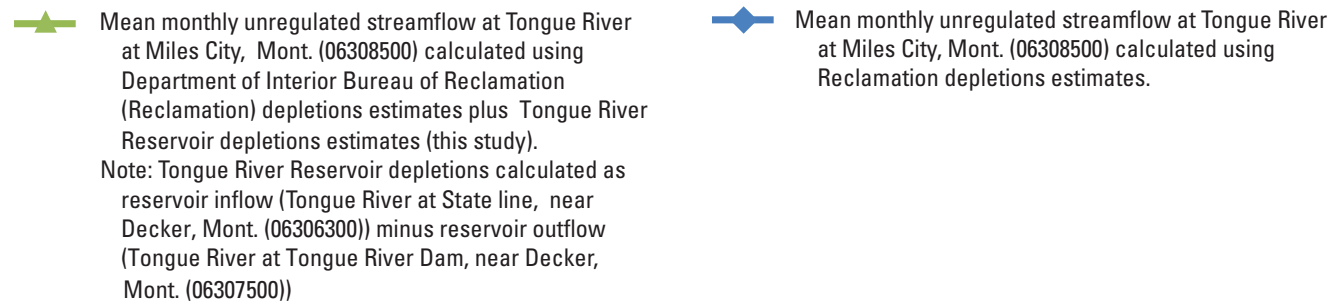
Reclamation depletions estimates.

(Reclamation) depletions estimates plus Tongue River

reservoir inflow (Tongue River at State line, near

(06306300) minus reservoir outflow

Mont. (06307500)

Figure 4. Mean monthly unregulated streamflows at Tongue River at Miles City, Mont. (streamflow-gaging station 06308500), 1960-2002.

distribution to the estimated unregulated and regulated annual instantaneous peak flows. Peak-flow frequency data were developed for recurrence intervals of 1.5, 2, 5, 10, 25, 50, 100, 200, and 500 years. Peak-flow data for the 200- and 500-year recurrence intervals are included in this study, as is done in many other peak-flow frequency studies (for example, Sando and others, 2008; Parrett and Johnson, 2004), because they are necessary for flood-plain mapping.

As recommended in Bulletin 17B (U.S. Interagency Advisory Council on Water Data, 1982), procedures for calculating the skew coefficient and for accounting for low outliers were applied for this study. A weighted skew coefficient was calculated by using the skew of the log series of the systematic record (commonly termed the "station skew") and a generalized skew coefficient. The generalized skew coefficient was determined by using the nationwide generalized skew map (presented in Bulletin 17B, plate 1) as discussed in Parrett and Johnson (2004). The station skew coefficient was weighted based on systematic record length, and the generalized skew coefficient was weighted based on a mean-square error of 0.64 when applying the nationwide generalized skew map in Montana (Parrett and Johnson, 2004). Procedures from Bulletin $17 \mathrm{~B}$ were used for determining low-outlier thresholds based on the mean and standard deviation of the log series of peak flows as described by Grubbs and Beck (1972).

Effects of ice-jam releases were not accounted for in the peak-flow frequency analysis. This approach is consistent with recommendations in a hydrology study for the Yellowstone and Tongue Rivers at Miles City by the U.S. Army Corps of Engineers (2007). The USACE estimated peak-flow frequencies for an "ice-affected season" (January 1-April 15) and for an "open-water-affected season" (April 16-January 1) and then combined the two curves in a "combined dischargefrequency analysis." Next, the combined discharge-frequency analyses were compared with the "all-seasons" dischargefrequency analyses. Finally, the all-seasons discharge frequency analyses were recommended because the resulting flood-frequency data most closely matched observed historical streamflow data. In addition, the flood-frequency data from the combined analyses were similar to the flood-frequency 
data from the all-seasons analyses. For this study, the USGS conducted a similar analysis for the Yellowstone River at Sidney. A single frequency curve adequately represented all of the peak flows; therefore separate analyses for ice-affected seasons were not necessary.

\section{High-Flow Frequency Analysis}

Annual $n$-day high-flow frequency data were developed from annual series of the highest daily streamflows for specified $n$-day consecutive periods within the calendar year. For example, an annual series of 3-day high flows consists of the highest mean flow that occurs over any 3-day consecutive period during each year of record (McCarthy, 2004).

The computer program HEC-SSP (U.S. Army Corps of Engineers, 2009b) was used to calculate high-flow frequency relationships for the $n$-day datasets for the unregulated and regulated streamflow conditions. The log-Pearson III distribution along with the station skew was used to estimate highflow frequency data for consecutive periods of $1,3,7,15$, $30,60,90,120$, and 183 days for recurrence intervals of 2,5 , $10,25,50$, and 100 years. The 200- and 500-year high-flow frequency data were not estimated because the study period includes only 75 years of data, and USGS guidelines recommend limiting analyses to twice the period of record (Parrett, 1997; Walter Hofmann, U.S. Geological Survey, written commun., 1973), except where peak-flow data are necessary for flood insurance studies, as noted in the "Peak-Flow Frequency Analysis" section.

\section{Low-Flow Frequency Analysis}

Annual $n$-day low-flow frequency data were developed from an annual series of the lowest daily streamflows for $n$-day consecutive periods within each climatic year, from April 1-March 31 (Riggs, 1972, reprinted 1982). For example, an annual series of 7-day low flows consists of the lowest mean flow that occurred over any 7-day consecutive period during each year of record. In addition, seasonal low-flow frequency data were developed from the annual series of the lowest daily streamflows for 7-day and 30-day consecutive periods for the winter (January-March), spring (April-June), summer (July-September), and fall (October-December) seasons, and monthly low-flow frequency data were developed from the annual series of the lowest daily streamflows for 7-day consecutive periods for each month.

The computer program HEC-SSP (U.S. Army Corps of Engineers, 2009b) was used to calculate the low-flow frequency relationships for $n$-day datasets for unregulated and regulated streamflow conditions. The log-Pearson III distribution was applied (in a manner similar to the analysis described in the "High-Flow Frequency Analysis" section) to estimate low-flow frequency data for consecutive periods of 7 and 30 days for recurrence intervals of 2, 5, 10, 25, 50, and 100 years. Non-exceedance probabilities were calculated using only non-zero flows, and then a conditional adjustment probability was used to refine the non-exceedance probability for the zero flows in the record. If the log-Pearson III distribution did not fit the data, then a Pearson III distribution was applied. If neither the log-Pearson III nor the Pearson III distribution fit the data, then a graphical curve was fit through the data.

\section{Flow-Duration Analysis}

Annual and seasonal flow-duration data were developed for unregulated and regulated streamflow conditions using the computer program HEC-DSSvue (U.S. Army Corps of Engineers, 2009a) for the Tongue River. As the analyses progressed, version 2.0 of HEC-SSP was released, which included the capability to calculate flow-duration data, so the computer program HEC-SSP, version 2.0, (U.S. Army Corps of Engineers, 2010) was used to calculate flow-duration data for the Yellowstone and Powder Rivers. The flow-duration calculation routines in HEC-DSSvue and HEC-SSP produce identical results. The flow-duration characteristic is defined as a daily streamflow that has been equaled or exceeded a specific percentage of days during the period of record. Flowduration data were developed from daily streamflows over the entire period of record; those data, however, are not related to the sequence of flow events. For example, the streamflow value on a flow-duration table that corresponds to a 10-percent exceedance is the value that was exceeded by 10 percent of the flow record without regard to when those days of exceedance occurred. The days of exceedance might not have been consecutive and might have occurred either in a single year or during several years (McCarthy, 2004; Ludwig, 1992).

\section{Monthly and Annual Streamflow Characteristics}

Maxima, minima, and mean monthly and annual streamflows were calculated using HEC-DSSvue (U.S. Army Corps of Engineers, 2009a). The standard deviation of both the mean monthly streamflows and the mean annual streamflows also were calculated.

\section{Interpolation of Streamflow Statistics for Selected Study Reaches}

The Yellowstone River was divided into several study reaches for the cumulative-effects study (fig. 5). For study reaches $\mathrm{C} 10, \mathrm{C} 17, \mathrm{D} 6$, and $\mathrm{D} 13$, the statistics calculated at the streamflow-gaging stations that are located within each reach represent the study-reach statistics. For the rest of the selected study reaches downstream from the Yellowstone River/ Bighorn River confluence, peak-flow frequency, high-flow frequency, low-flow frequency, and flow-duration statistics were interpolated linearly between streamflow-gaging stations (fig. 5). Monthly and annual streamflow characteristics are not reported for the selected study reaches because some of these statistics (including maximum and minimum values with associated months of occurrence) cannot be determined accurately by interpolation. 


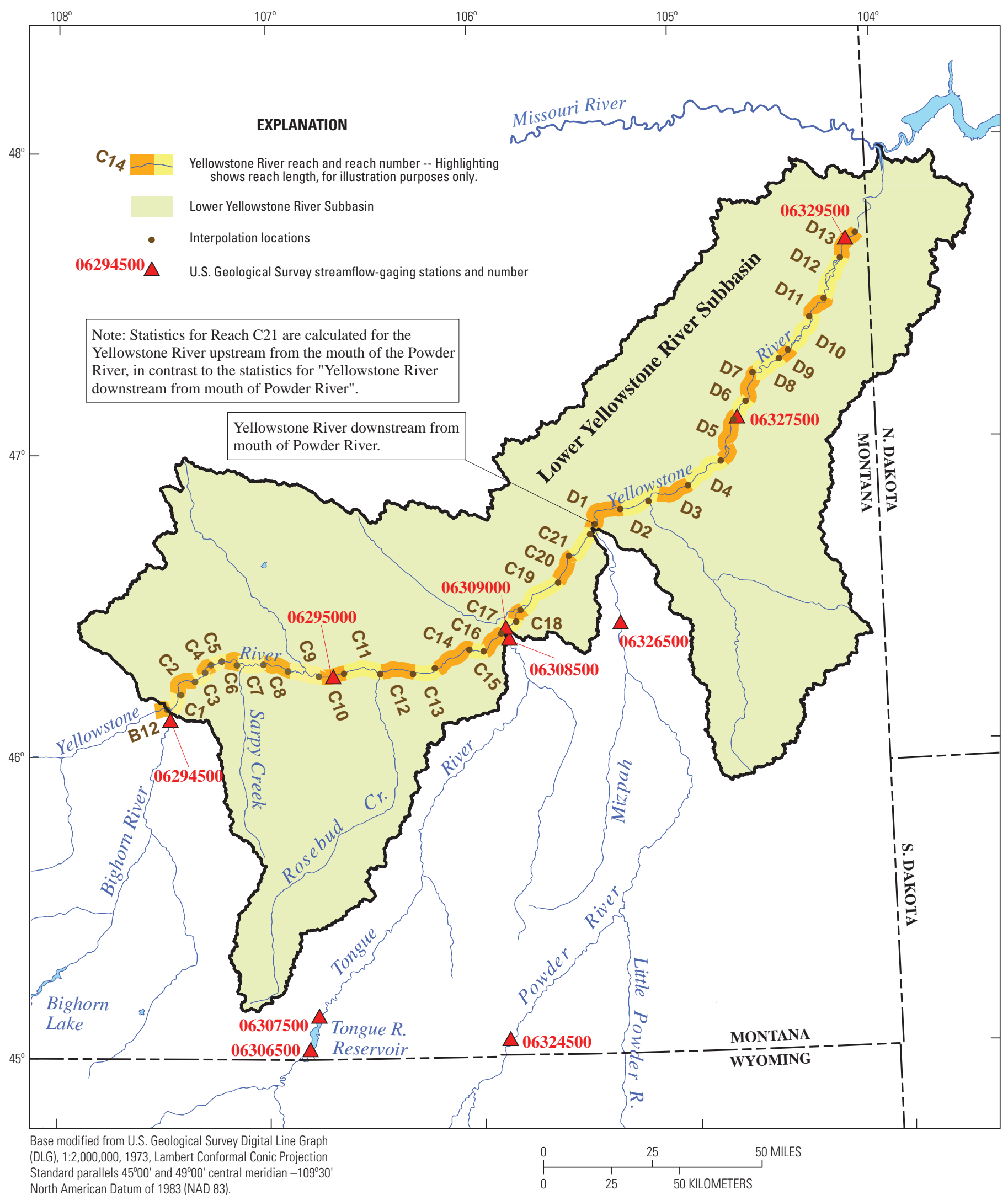

Figure 5. Selected reaches along the Yellowstone River, Mont. (modified from Bryan Swindell, DTM Consulting, Inc., written commun., 2011). 
Streamflow statistics for selected study reaches downstream from the Yellowstone River at Forsyth, Mont. streamflow-gaging station (06295000) were interpolated linearly on the basis of approximate drainage area at the downstream end of each study reach relative to the drainage areas of the bracketing streamflow-gaging stations. In many cases, changes in streamflow statistics between different locations on a river channel do not vary linearly with proportional changes in drainage area. In fact, at some locations a given streamflow statistic decreased between one streamflow-gaging station and the next downstream streamflow gaging station. In those locations, interpolation on the basis of drainage areas resulted in unrealistically large decreases in the streamflow statistic in reaches containing a large tributary (such as the Powder River). Because this study was largely focused on calculation of streamflow statistics at gaging stations, and because streamflow data to improve interpolation are unavailable, the interpolated data are presented with those unrealistic decreases.

Drainage areas were estimated using digital elevation models (cell size 689 square meters) provided by the USACE (Douglas J. Clemetson, Hydrology Section, U.S. Army Corps of Engineers, written commun., 2009). In some instances, the drainage areas estimated for the streamflow-gaging stations using the digital elevation models were different (by up to 1 percent of total contributing drainage area) than the drainage areas reported in U.S. Geological Survey (2010), probably due to differences in the resolution of the elevation data and methods used to delineate the drainage area boundaries.

Because study reach C21 includes the confluence of the Yellowstone and Powder Rivers, and because a streamflowgaging station does not exist on the Yellowstone River just downstream from the Yellowstone/Powder River confluence, streamflow statistics also were interpolated for the additional location "Yellowstone River downstream from the mouth of the Powder River." In addition to the statistics for the gaging stations included in this report, peak-flow data and the drainage area for reach B12, upstream from the Yellow-stone River/ Bighorn River confluence, were included in U.S. Army Corps of Engineers (2011b). These data were used to interpolate streamflow statistics for study reaches C1-C9. High-flow frequency, low-flow frequency, and flow-duration statistics were not included in U.S. Army Corps of Engineers (2011b), therefore those statistics were not interpolated for reaches C1-C9.

\section{Streamflow Statistics for Unregulated and Regulated Conditions for Selected Locations on the Yellowstone, Tongue, and Powder Rivers}

Streamflow statistics for the period 1928-2002 were calculated for unregulated and regulated conditions using methods described in the preceding sections "Peak-Flow Frequency Analysis," "High-Flow Frequency Analysis," "Low-Flow Frequency Analysis," "Flow-Duration Analysis," and "Monthly and Annual Streamflow Characteristics" for four streamflow-gaging stations on the Yellowstone River, one streamflow gaging station on the Tongue River, and one streamflow-gaging station on the Powder River. In addition, peak-flow frequency data were interpolated for 31 locations between streamflow-gaging stations; and annual $n$-day highflow frequency data, annual $n$-day low-flow frequency data, and annual and seasonal flow-duration data were interpolated for 22 locations on the Yellowstone River between streamflow gaging stations.

Streamflow statistics for the six streamflow-gaging stations are presented in tables and figures contained in appendix 2 . The tables and graphs summarize annual $n$-day high-flow frequency data; annual, seasonal and monthly $n$-day low-flow frequency data; annual and seasonal flow-duration data; and maxima, minima, and mean monthly and annual streamflow data. Instantaneous peak-flow data for each of these stations also are presented in table 4 .

Interpolated streamflow statistics for the Yellowstone River are presented in Excel spreadsheets (appendixes 3-6). Interpolated annual instantaneous peak-flow data for 31 locations between streamflow-gaging stations, as well as for reach B12, upstream from the Yellowstone River/Bighorn River confluence (fig. 5; calculated by the U.S. Army Corps of Engineers, 2011b) and the four streamflow-gaging stations on the Yellowstone River, are presented in appendix 3. Interpolated annual $n$-day high-flow frequency data for 22 locations between streamflow-gaging stations, as well as calculated data for the four streamflow-gaging stations, are presented in appendix 4. Interpolated annual $n$-day low-flow frequency data for 22 locations between streamflow-gaging stations, as well as calculated data for the four streamflowgaging stations, are presented in appendix 5. Interpolated annual and seasonal flow-duration data for 22 locations between streamflow-gaging stations, as well as calculated data for the four streamflow-gaging stations, are presented in appendix 6. 
Table 4. Annual instantaneous peak-flow data for selected streamflow-gaging stations on the Yellowstone, Tongue, and Powder Rivers, Montana, for unregulated and regulated streamflow conditions, 1928-2002.

[Abbreviations: $\mathrm{ft}^{3} / \mathrm{s}$, cubic feet per second. Symbol: \%, percent]

\begin{tabular}{|c|c|c|c|c|c|c|c|c|c|c|c|}
\hline \multirow{2}{*}{$\begin{array}{l}\text { Station } \\
\text { number }\end{array}$} & \multirow[b]{2}{*}{ Station name } & \multirow{2}{*}{$\begin{array}{l}\text { Streamflow } \\
\text { condition }\end{array}$} & \multicolumn{9}{|c|}{ Annual instantaneous peak flow, in $\mathrm{ft}^{3} / \mathrm{s}$, for: recurrence interval, in years , and annual exceedance probability, in percent } \\
\hline & & & $\begin{array}{c}1.5 \\
67 \%\end{array}$ & $\begin{array}{c}2 \\
50 \%\end{array}$ & $\begin{array}{c}5 \\
20 \%\end{array}$ & $\begin{array}{c}10 \\
10 \%\end{array}$ & $\begin{array}{l}25 \\
4 \%\end{array}$ & $\begin{array}{l}50 \\
2 \%\end{array}$ & $\begin{array}{l}100 \\
1 \%\end{array}$ & $\begin{array}{c}200 \\
0.5 \%\end{array}$ & $\begin{array}{c}500 \\
0.2 \%\end{array}$ \\
\hline \multirow[t]{2}{*}{06295000} & \multirow{2}{*}{$\begin{array}{l}\text { Yellowstone River at } \\
\text { Forsyth, Mont. }{ }^{1}\end{array}$} & Unregulated & 54,700 & 61,300 & 77,300 & 87,900 & 101,000 & 111,000 & 121,000 & 131,000 & 145,000 \\
\hline & & Regulated & 41,100 & 46,900 & 61,300 & 70,700 & 82,700 & 91,600 & 101,000 & 110,000 & 122,000 \\
\hline \multirow[t]{2}{*}{06309000} & \multirow{2}{*}{$\begin{array}{l}\text { Yellowstone River at } \\
\text { Miles City, Mont. }{ }^{1}\end{array}$} & Unregulated & 56,700 & 63,400 & 78,900 & 88,600 & 100,000 & 109,000 & 117,000 & 125,000 & 136,000 \\
\hline & & Regulated & 41,700 & 48,200 & 62,700 & 71,300 & 81,200 & 88,000 & 94,400 & 100,000 & 108,000 \\
\hline \multirow[t]{2}{*}{06327500} & \multirow{2}{*}{$\begin{array}{l}\text { Yellowstone River at } \\
\text { Glendive, Mont. }\end{array}$} & Unregulated & 61,300 & 69,400 & 89,400 & 103,000 & 120,000 & 133,000 & 146,000 & 159,000 & 177,000 \\
\hline & & Regulated & 46,000 & 54,200 & 74,000 & 86,800 & 103,000 & 114,000 & 125,000 & 136,000 & 151,000 \\
\hline \multirow[t]{2}{*}{06329500} & \multirow{2}{*}{$\begin{array}{l}\text { Yellowstone River near } \\
\text { Sidney, Mont. }{ }^{1}\end{array}$} & Unregulated & 61,400 & 69,900 & 90,500 & 104,000 & 120,000 & 132,000 & 143,000 & 155,000 & 170,000 \\
\hline & & Regulated & 46,000 & 54,300 & 75,100 & 89,100 & 107,000 & 120,000 & 134,000 & 147,000 & 166,000 \\
\hline \multirow[t]{2}{*}{06308500} & \multirow{2}{*}{$\begin{array}{l}\text { Tongue River at Miles } \\
\text { City, Mont. }\end{array}$} & Unregulated & 3,260 & 4,140 & 6,740 & 8,790 & 11,800 & 14,200 & 17,000 & 20,000 & 24,400 \\
\hline & & Regulated & 2,860 & 3,760 & 6,410 & 8,480 & 11,400 & 13,900 & 16,500 & 19,400 & 23,500 \\
\hline \multirow[t]{2}{*}{06326500} & \multirow{2}{*}{$\begin{array}{l}\text { Powder River near } \\
\text { Locate, Mont. }\end{array}$} & Unregulated & 5,030 & 7,390 & 14,600 & 20,200 & 27,900 & 33,800 & 39,900 & 46,100 & 54,400 \\
\hline & & Regulated & 4,650 & 6,990 & 14,300 & 20,100 & 27,900 & 34,000 & 40,300 & 46,700 & 55,200 \\
\hline
\end{tabular}

${ }^{1}$ Peak flows decrease in the downstream direction between stations 06295000 and 06309000 and between stations 06327500 and 06329500 for lower annual exceedance-probability flows. The decrease is relatively small and probably is within the error of the frequency analysis. A decrease in peak flows in the downstream direction could be due to attenuation of these larger peak flows. A similar decrease in peak flows between station numbers 06295000 and 06309000 is reported in Parrett and Johnson (2004, table 2).

${ }^{2}$ In general, regulated streamflows should not be higher than unregulated streamflows for the 0.2-, 0.5-, 1-, and 2-percent annual exceedance-probability flows. The regulated flows for the Powder River near Locate, Mont., are less than about 1 percent higher than unregulated streamflows for these exceedance probability flows; this discrepancy is well within the error of the statistical analyses. 


\section{Summary}

The Yellowstone River is one of the longest free-flowing rivers in the lower 48 States. The river supports a wide variety of agricultural, domestic, industrial, and recreational uses, and in some areas of Montana, is a blue-ribbon trout stream. Major floods in 1996 and 1997 intensified public debate over the effects of human activities on the Yellowstone River. In 1999, the Yellowstone River Conservation District Council (YRCDC) was formed to address conservation issues on the river. The YRCDC partnered with the U.S. Army Corps of Engineers (USACE) to conduct a cumulative-effects study (CES) on the main stem of the Yellowstone River. The CES is intended to provide a basis for future management decisions in the watershed. Streamflow statistics, such as flow-frequency and flow-duration data calculated for unregulated and regulated streamflow conditions, are necessary for many aspects of that cumulative-effects study.

The U.S. Geological Survey, in cooperation with the YRCDC and the USACE, calculated streamflow statistics for unregulated and regulated streamflow conditions for the Yellowstone, Tongue and Powder Rivers for the 1928-2002 study period (calendar year). These statistics include basic summary statistics and flow-frequency data, and flow-duration data for two streamflow conditions: "unregulated," where effects of streamflow regulation and water use have been removed, and "regulated," where streamflows are adjusted to represent nearpresent-day (based on 2002 data) levels of development.

Missing daily streamflows for ungaged periods were synthesized to develop a complete set of daily streamflow data for all of the streamflow-gaging stations for the 1928-2002 study period. Monthly mean streamflows for periods of missing records were synthesized using the Maintenance of Variance Extension, Type 1 (MOVE.1) curve-fitting procedure. Daily mean streamflows were synthesized by distributing monthly mean streamflows to daily mean streamflows by using ratios of daily mean to monthly mean streamflows developed from appropriate index stations.

Unregulated and regulated daily streamflows were estimated from the observed and synthesized daily streamflows and Bureau of Reclamation depletions data, and then statistical summaries were calculated for the unregulated and regulated daily streamflow datasets. Unregulated streamflows were estimated by adding historical depletions to the observed streamflows (or to synthesized streamflows for periods of missing records). Regulated streamflows were estimated by subtracting the 2002level depletions from the unregulated streamflows. Peak-flow frequency estimates for unregulated and regulated streamflow conditions were developed using methods described in the U.S. Interagency Advisory Council on Water Data Bulletin 17B. High-flow frequency and low-flow frequency data were developed from the respective annual series of highest and lowest mean flows for specified $n$-day consecutive periods within the calendar year, for unregulated and regulated conditions. Flowduration data and monthly and annual streamflow characteristics also were calculated for unregulated and regulated streamflows and are presented in tabular and graphic form in this report.

\section{References Cited}

Alley, W.M., and Burns, A.W., 1983, Mixed station extension of monthly streamflow records: Journal of Hydraulic Engineering, American Society of Civil Engineers, v. 109, no. 10, p. 1,272-1,284.

Cary, L.E., and Parrett, Charles, 1996, Synthesis of natural flows at selected sites in the upper Missouri River basin, Montana, 1928-89: U.S. Geological Survey WaterResources Investigations Report 95-1461, 109 p.

Grubbs, F.E., and Beck, Glenn, 1972, Extension of sample sizes and percentage points for significance tests of outlying observations: Technometrics, v. 14, no. 4, p. 847-854.

Helsel, D.R., and Hirsch, R.M., 2002, Statistical methods in water resources: Techniques of Water-Resources Investigations of the U.S. Geological Survey, book 4, chapter A3, 522 pages.

Hirsch, R.M., 1982, A comparison of four streamflow record extension techniques: Water Resources Research, v. 18, no. 4 , p. 1,081-1,088.

Hirsch, R.M., Helsel, D.R., Cohn, T.A., and Gilroy, E.J., 1993, Statistical analysis of hydrologic data, in Maidment, D. R., Handbook of Hydrology: San Francisco, Calif., McGraw Hill, Inc., p. 17.1-17.55.

Jean, C., and Crispin, S., 2001, Inventory of important biological resources in the Upper Yellowstone River Watershed: Report to the Environmental Protection Agency, Montana Natural Heritage Program, Helena Montana, 26 p., plus appendixes.

Ludwig, A.H., 1992, Flow duration and low-flow characteristics of selected Arkansas streams: U.S. Geological Survey Water-Resources Investigations Report 92-4026, 57 p.

McCarthy, P.M., 2004, Statistical summaries of streamflow in Montana and adjacent areas, water years 1900 through 2002: U.S. Geological Survey Scientific Investigations Report 2004-5266, 317 p.

Montana Department of Natural Resources and Conservation, 2004, Tongue River dam manual for operation and maintenance: Helena, Mont., State Water Projects Bureau, Water Resources Division, Montana Department of Natural Resources and Conservation, P.O. Box 210601, Helena, MT 59620, variously paginated.

National Oceanic and Atmospheric Administration, 2002, Monthly station normals of temperature, precipitation, and heating and cooling degree days 1971-2000, Montana: Asheville, N.C., National Environmental Satellite, Data, and Information Service, National Climatic Data Center, Climatography of the United States, no. 81, 51 p., accessed May 10, 2011, at http://hurricane.ncdc.noaa.gov/climatenormals/ clim81/MTnorm.pdf. 
Parrett, Charles, 1997, Regional analyses of annual precipitation maxima in Montana: U.S. Geological Survey WaterResources Investigations Report 97-4004, 51 p.

Parrett, Charles, and Johnson, D.R., 2004, Methods for estimating flood frequency in Montana based on data through water year 1998: U.S. Geological Survey Water-Resources Investigations Report 03-4308, 101 p.

Riggs, H.C., 1972 [reprinted 1982], Low-flow investigations: Techniques of Water-Resources Investigations of the United States Geological Survey, book 4, chap. B1, 18 p.

Robb, A.D., 1944, Climatological data, Montana section, year 1944: Helena, Mont., U.S. Department of Commerce, Weather Bureau, v. XLVII, 8 p.

Sando, S.K., Driscoll, D.G., and Parrett, Charles, 2008, Peak-flow frequency estimates based on data through water year 2011 for selected streamflow-gaging stations in South Dakota: U.S. Geological Survey Scientific Investigations Report 2008-5104, 42 p. [with online only appendixes and tables]. Also available online at http://pubs.usgs.gov/ sir/2008/5104/.

U.S. Army Corps of Engineers, 2007, Miles City, Mont., hydrologic analysis: Omaha, Neb., U.S. Army Corps of Engineers Omaha District, 28 p., [revised 2007].

U.S. Army Corps of Engineers, 2009a, Hydrologic Engineering Center data storage system HEC-DSSVue visual utility engine user's manual: Davis, Calif., U.S. Army Corps of Engineers Hydrologic Engineering Center, 490 p.

U.S. Army Corps of Engineers, 2009b, Hydrologic Engineering Center statistical software package HEC-SSP, version 1.1: Davis, Calif., U.S. Army Corps of Engineers Hydrologic Engineering Center, 214 p.

U.S. Army Corps of Engineers, 2010, Hydrologic Engineering Center statistical software package HEC-SSP, version 2.0: Davis, Calif., U.S. Army Corps of Engineers Hydrologic Engineering Center, $313 \mathrm{p}$.

U.S. Army Corps of Engineers, 2011a, Yellowstone River corridor study, Lower Bighorn River hydrology: Omaha, Nebraska, U.S. Army Corps of Engineers Engineering Division, Hydrologic Engineering Branch, Hydrology Section, Final Report, 22 p.

U.S. Army Corps of Engineers, 2011b, Yellowstone River corridor study, Upper Yellowstone River hydrology: Omaha, Nebraska, U.S. Army Corps of Engineers Engineering Division, Hydrologic Engineering Branch, Hydrology Section, Final Report, 63 p.

U.S. Department of the Interior, Bureau of Reclamation, 1999, A study to determine the historic and present-level streamflow depletions in the Missouri River basin above Hermann, Missouri,-Appendix F-C of Upper Mississippi
River system flow frequency study: Billings, Mont., U.S. Department of the Interior, Bureau of Reclamation, Water Resources Service Group, Great Plains Regional Office, variously paged.

U.S. Department of the Interior, Bureau of Reclamation, 2005, A study to determine the historic and present-level streamflow depletions in the Missouri River basin for the period 1929 to 2002: Billings, Mont., U.S. Department of the Interior, Bureau of Reclamation, Water Resources Service Group, Great Plains Regional Office, variously paged.

U.S. Geological Survey, 2010, Water data for the Nation, surface water: U.S. Geological Survey database, accessed November 4, 2010, at http://waterdata.usgs.gov.

U.S. Interagency Advisory Council on Water Data, 1982, Guidelines for determining flood flow frequency-Bulletin 17B of the Hydrology Subcommittee: U.S. Geological Survey, Office of Water Data Coordination, 183 p.

Zelt, R.B., Boughton, G.K, Miller, K.A., Mason, J.P., and Gianakos, L.M., 1999, Environmental setting of the Yellowstone River basin, Montana, North Dakota, and Wyoming: U.S. Geological Survey Water-Resources Investigations Report 98-4269, 112 p.

Publishing support provided by:

Denver Publishing Service Center

For more information concerning this publication, contact:

Center Director, USGS Wyoming-Montana Water Science Center 3162 Bozeman Ave.

Helena, MT 59601

(406) 457-5900

Or visit the Montana Water Science Center Web site at: http://mt.water.usgs.gov/ 



\section{Appendixes}

The Bureau of Reclamation depletions data (appendix 1), annual instantaneous peak-flow data at and between streamflow-gaging stations (appendix 3 ), annual $n$-day high-flow frequency data at and between streamflow-gaging stations (appendix 4), annual $n$-day low-flow frequency data at and between streamflow-gaging stations (appendix 5) and annual and seasonal flowduration data at and between streamflow-gaging stations (appendix 6) are presented in Excel spreadsheets. Additionally, the streamflow statistics for selected streamflow-gaging stations (appendix 2) are included as part of this report. 


\section{Appendix 1. Depletion Data for the Yellowstone River Basin, Mont., and Wyo., 1928-2002}

Appendix 1 contains historical and 2002-level depletion data from the Bureau of Reclamation (2005) for selected Bureau of Reclamation node basins. The excel file is named sir2013-5173_APP_1_depletion.xlsx. Locations of node basins are shown on figure 2 (main report). 


\section{Appendix 2. Statistics for Selected Streamflow-Gaging Stations on the Yellowstone, Tongue, and Powder Rivers, Mont., for Unregulated and Regulated Streamflow Conditions, 1928-2002}

Appendix 2 contains tables and figures showing statistics for six selected streamflow-gaging stations. Locations of the streamflow-gaging stations are shown in figure 2 (main report). 


\section{Appendix 2-1. Statistics for Streamflow-Gaging Station 06295000 (Yellowstone River at Forsyth, Mont.)}

Table 2-1-1. Annual $n$-day high-flow frequency data for streamflow-gaging station 06295000 (Yellowstone River at Forsyth, Mont.) for unregulated and regulated streamflow conditions, 1928-2002.

[Abbreviations: $\mathrm{ft}^{3} / \mathrm{s}$, cubic feet per second. Symbol: \%, percent]

\begin{tabular}{|c|c|c|c|c|c|c|c|}
\hline \multicolumn{8}{|c|}{ Unregulated } \\
\hline \multirow{2}{*}{$\begin{array}{l}n, \text { period of } \\
\text { consecutive } \\
\text { days }\end{array}$} & \multicolumn{7}{|c|}{ Streamflow, in $\mathrm{ft}^{3} / \mathrm{s}$, for indicated recurrence interval, in years, and exceedance probability, in percent } \\
\hline & $\begin{array}{c}2 \\
50 \%\end{array}$ & $\begin{array}{c}5 \\
20 \%\end{array}$ & $\begin{array}{c}10 \\
10 \%\end{array}$ & $\begin{array}{l}20 \\
5 \%\end{array}$ & $\begin{array}{l}25 \\
4 \%\end{array}$ & $\begin{array}{c}50 \\
2 \%\end{array}$ & $\begin{array}{l}100 \\
1 \%\end{array}$ \\
\hline 1 & 59,900 & 75,100 & 84,600 & 93,400 & 96,100 & 104,000 & 113,000 \\
\hline 3 & 58,100 & 72,430 & 81,100 & 88,900 & 91,300 & 98,500 & 105,000 \\
\hline 7 & 54,700 & 68,300 & 76,500 & 83,900 & 86,200 & 92,900 & 99,400 \\
\hline 15 & 50,400 & 62,700 & 70,200 & 76,900 & 79,000 & 85,200 & 91,200 \\
\hline 30 & 45,600 & 56,400 & 62,800 & 68,500 & 70,200 & 75,400 & 80,400 \\
\hline 60 & 38,500 & 46,800 & 51,600 & 55,900 & 57,200 & 61,000 & 64,500 \\
\hline 90 & 32,700 & 39,100 & 42,700 & 45,800 & 46,800 & 49,500 & 52,100 \\
\hline 120 & 28,000 & 33,200 & 36,100 & 38,600 & 39,400 & 41,600 & 43,600 \\
\hline 183 & 21,600 & 25,400 & 27,500 & 29,300 & 29,900 & 31,400 & 32,900 \\
\hline \multicolumn{8}{|c|}{ Regulated } \\
\hline \multirow{2}{*}{$\begin{array}{c}n, \text { period of } \\
\text { consecutive } \\
\text { days }\end{array}$} & \multicolumn{7}{|c|}{ Streamflow, in $\mathrm{ft}^{3} / \mathrm{s}$, for indicated recurrence interval, in years, and exceedance probability, in percent } \\
\hline & $\begin{array}{c}2 \\
50 \%\end{array}$ & $\begin{array}{c}5 \\
20 \%\end{array}$ & $\begin{array}{c}10 \\
10 \% \\
\end{array}$ & $\begin{array}{r}20 \\
5 \% \\
\end{array}$ & $\begin{array}{l}25 \\
4 \% \\
\end{array}$ & $\begin{array}{c}50 \\
2 \% \\
\end{array}$ & $\begin{array}{l}100 \\
1 \% \\
\end{array}$ \\
\hline 1 & 45,900 & 60,100 & 68,600 & 76,200 & 78,500 & 85,500 & 92,000 \\
\hline 3 & 44,000 & 57,400 & 65,200 & 72,100 & 74,200 & 80,200 & 85,900 \\
\hline 7 & 41,000 & 53,800 & 61,300 & 67,700 & 69,700 & 75,400 & 80,600 \\
\hline 15 & 37,600 & 49,200 & 55,900 & 61,800 & 63,500 & 68,600 & 73,300 \\
\hline 30 & 33,500 & 43,800 & 49,700 & 54,800 & 56,300 & 60,600 & 64,600 \\
\hline 60 & 27,300 & 35,900 & 40,800 & 45,100 & 46,400 & 50,200 & 53,600 \\
\hline 90 & 22,500 & 29,300 & 33,200 & 36,600 & 37,600 & 40,500 & 43,200 \\
\hline 120 & 19,000 & 24,500 & 27,700 & 30,400 & 31,200 & 33,500 & 35,700 \\
\hline 183 & 15,324 & 19,300 & 21,500 & 23,500 & 24,100 & 25,800 & 27,400 \\
\hline
\end{tabular}


Table 2-1-2. Annual, seasonal, and monthly $n$-day low-flow frequency data for streamflow-gaging station 06295000 (Yellowstone River at Forsyth, Mont.) for unregulated and regulated streamflow conditions, 1928-2002.

[Abbreviations: $\mathrm{ft}^{3} / \mathrm{s}$, cubic feet per second. Symbol: \% percent]

Unregulated

\begin{tabular}{|c|c|c|c|c|c|c|c|}
\hline \multirow{2}{*}{$\begin{array}{l}\text { n, period of consecutive } \\
\text { days (month, for monthly } \\
\text { frequency data) }\end{array}$} & \multicolumn{7}{|c|}{ Streamflow, in $\mathrm{ft}^{3} / \mathrm{s}$, for indicated recurrence interval, in years, and exceedance probability, in percent } \\
\hline & $\begin{array}{c}2 \\
50 \%\end{array}$ & $\begin{array}{c}5 \\
20 \%\end{array}$ & $\begin{array}{c}10 \\
10 \%\end{array}$ & $\begin{array}{c}20 \\
5 \%\end{array}$ & $\begin{array}{l}25 \\
4 \%\end{array}$ & $\begin{array}{r}50 \\
2 \%\end{array}$ & $\begin{array}{l}100 \\
1 \%\end{array}$ \\
\hline 7 & 1,920 & 1,210 & 927 & 732 & 681 & 551 & 452 \\
\hline 30 & 3,410 & 2,620 & 2,250 & 1,960 & 1,880 & 1,660 & 1,480 \\
\hline \multicolumn{8}{|c|}{ Winter (January-March) } \\
\hline 7 & 2,560 & 1,690 & 1,320 & 1,060 & 994 & 815 & 676 \\
\hline 30 & 3,820 & 2,840 & 2,380 & 2,040 & 1,950 & 1,700 & 1,490 \\
\hline \multicolumn{8}{|c|}{ Spring (April-June) } \\
\hline 7 & 7,280 & 5,510 & 4,700 & 4,100 & 3,940 & 3,500 & 3,130 \\
\hline 30 & 8,620 & 6,610 & 5,720 & 5,060 & 4,880 & 4,400 & 3,990 \\
\hline 30 & 8,750 & 7,010 & 6,140 & 5,450 & 5,260 & 4,720 & 4,260 \\
\hline \multicolumn{8}{|c|}{ Fall (October-December) } \\
\hline 7 & 2,490 & 1,470 & 1,080 & 826 & 760 & 596 & 474 \\
\hline 30 & 4,190 & 3,260 & 2,830 & 2,500 & 2,400 & 2,150 & 1,940 \\
\hline \multicolumn{8}{|c|}{ Monthly } \\
\hline 7 (January) & 2,840 & 1,830 & 1,400 & 1,100 & 1,020 & 820 & 664 \\
\hline 7 (February) & 3,650 & 2,570 & 2,100 & 1,760 & 1,670 & 1,430 & 1,240 \\
\hline 7 (March) & 4,770 & 3,520 & 2,990 & 2,600 & 2,490 & 2,210 & 1,980 \\
\hline 7 (April) & 7,280 & 5,510 & 4,700 & 4,100 & 3,940 & 3,500 & 3,130 \\
\hline 7 (October) & 5,700 & 4,230 & 3,550 & 3,040 & 2,900 & 2,530 & 2,220 \\
\hline 7 (November) & 4,820 & 3,110 & 2,270 & 1,670 & 1,520 & 1,120 & 835 \\
\hline 7 (December) & 2,750 & 1,650 & 1,210 & 914 & 838 & 648 & 508 \\
\hline
\end{tabular}


Table 2-1-2. Annual, seasonal, and monthly n-day low-flow frequency data for streamflow-gaging station 06295000 (Yellowstone River at Forsyth, Mont.) for unregulated and regulated streamflow conditions, 1928-2002.—Continued

[Abbreviations: $\mathrm{ft}^{3} / \mathrm{s}$, cubic feet per second. Symbol: \% percent]

\section{Regulated}

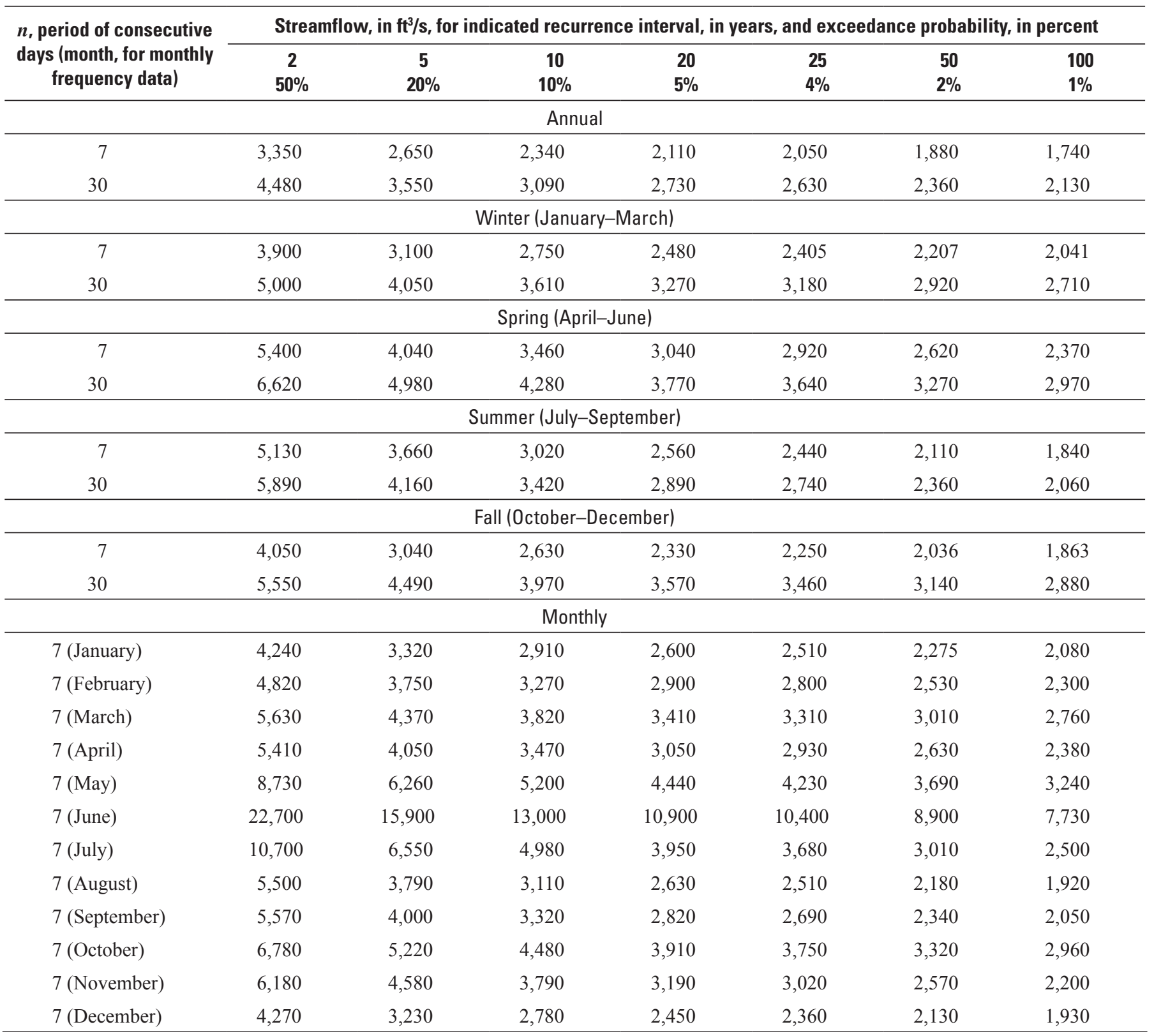


Table 2-1-3. Annual and seasonal flow-duration data for streamflow-gaging station 06295000 (Yellowstone River at Forsyth, Mont.) for unregulated and regulated streamflow conditions, 1928-2002.

[Abbreviations: $\mathrm{ft}^{3} / \mathrm{s}$, cubic feet per second. Symbol: \%, percent]

\begin{tabular}{|c|c|c|c|c|c|c|c|c|c|c|c|c|c|c|c|c|c|c|c|}
\hline \multicolumn{20}{|c|}{ Streamflow, in $\mathrm{ft}^{3} / \mathrm{s}$, which was equaled or exceeded for indicated percent of time } \\
\hline $\begin{array}{c}\text { Streamflow } \\
\text { condition }\end{array}$ & $1 \%$ & $2 \%$ & $5 \%$ & $10 \%$ & $15 \%$ & $20 \%$ & $25 \%$ & $30 \%$ & $40 \%$ & $50 \%$ & $60 \%$ & $70 \%$ & $75 \%$ & $80 \%$ & $85 \%$ & $90 \%$ & $95 \%$ & $98 \%$ & $99 \%$ \\
\hline \multicolumn{20}{|c|}{ Annual } \\
\hline Unregulated & 64,000 & 56,600 & 44,900 & 33,600 & 26,100 & 20,600 & 16,400 & 13,400 & 9,890 & 7,770 & 6,470 & 5,530 & 5,110 & 4,650 & 4,130 & 3,550 & 2,760 & 1,910 & 1,490 \\
\hline Regulated & 50,100 & 43,800 & 33,800 & 24,200 & 17,300 & 13,200 & 11,000 & 9,770 & 8,220 & 7,280 & 6,520 & 5,820 & 5,430 & 5,040 & 4,630 & 4,200 & 3,580 & 2,900 & 2,540 \\
\hline \multicolumn{20}{|c|}{ Winter (January-March) } \\
\hline Unregulated & 19,000 & 15,100 & 11,400 & 8,700 & 7,680 & 7,040 & 6,490 & 6,100 & 5,370 & 4,850 & 4,410 & 3,930 & 3,660 & 3,360 & 3,010 & 2,620 & 1,990 & 1,540 & 1,250 \\
\hline Regulated & 19,800 & 15,700 & 12,000 & 9,660 & 8,650 & 7,860 & 7,430 & 7,030 & 6,430 & 5,940 & 5,470 & 5,020 & 4,770 & 4,510 & 4,200 & 3,830 & 3,230 & 2,770 & 2,520 \\
\hline \multicolumn{20}{|c|}{ Spring (April-June) } \\
\hline Unregulated & 75,700 & 68,900 & 60,000 & 52,000 & 45,800 & 41,300 & 37,200 & 33,600 & 27,500 & 22,400 & 17,600 & 12,700 & 10,600 & 9,440 & 7,780 & 6,840 & 5,930 & 5,100 & 4,580 \\
\hline Regulated & 61,100 & 54,500 & 46,500 & 39,600 & 34,300 & 30,200 & 26,700 & 23,400 & 17,600 & 13,600 & 10,800 & 8,180 & 7,310 & 6,430 & 5,810 & 5,080 & 4,330 & 3,760 & 3,430 \\
\hline \multicolumn{20}{|c|}{ Summer (July-September) } \\
\hline Unregulated & 60,200 & 52,100 & 42,100 & 33,600 & 28,000 & 24,100 & 20,900 & 18,500 & 15,200 & 13,200 & 11,500 & 10,100 & 9,490 & 8,910 & 8,320 & 7,530 & 6,150 & 5,230 & 4,510 \\
\hline Regulated & 46,600 & 40,100 & 32,200 & 25,000 & 19,700 & 15,900 & 13,200 & 11,500 & 9,530 & 8,230 & 7,170 & 6,090 & 5,610 & 5,120 & 4,580 & 4,090 & 3,320 & 2,660 & 2,350 \\
\hline \multicolumn{20}{|c|}{ Fall (October-December) } \\
\hline Unregulated & 11,200 & 10,300 & 9,030 & 8,070 & 7,410 & 6,970 & 6,650 & 6,360 & 5,850 & 5,460 & 5,060 & 4,510 & 4,160 & 3,790 & 3,450 & 2,990 & 2,280 & 1,400 & 1,110 \\
\hline Regulated & 12,100 & 11,400 & 10,400 & 9,400 & 8,910 & 8,450 & 8,040 & 7,720 & 7,240 & 6,800 & 6,340 & 5,790 & 5,420 & 5,030 & 4,650 & 4,200 & 3,590 & 2,830 & 2,520 \\
\hline
\end{tabular}


Table 2-1-4. Monthly and annual streamflow characteristics for streamflow-gaging station 06295000 (Yellowstone River at Forsyth, Mont.) for unregulated and regulated streamflow conditions, 1928-2002.

[Abbreviations: $\mathrm{ft}^{3} / \mathrm{s}$, cubic feet per second]

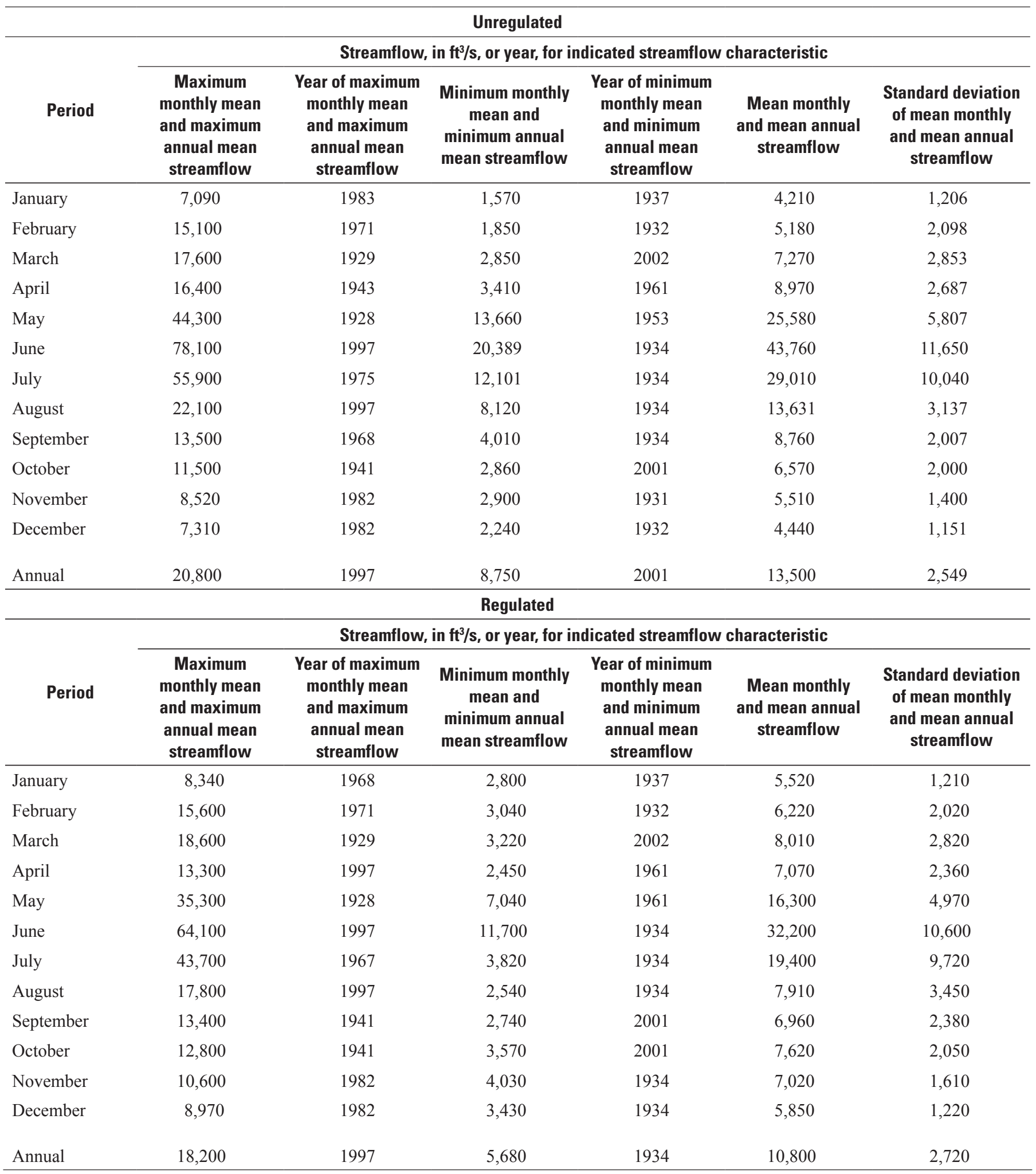




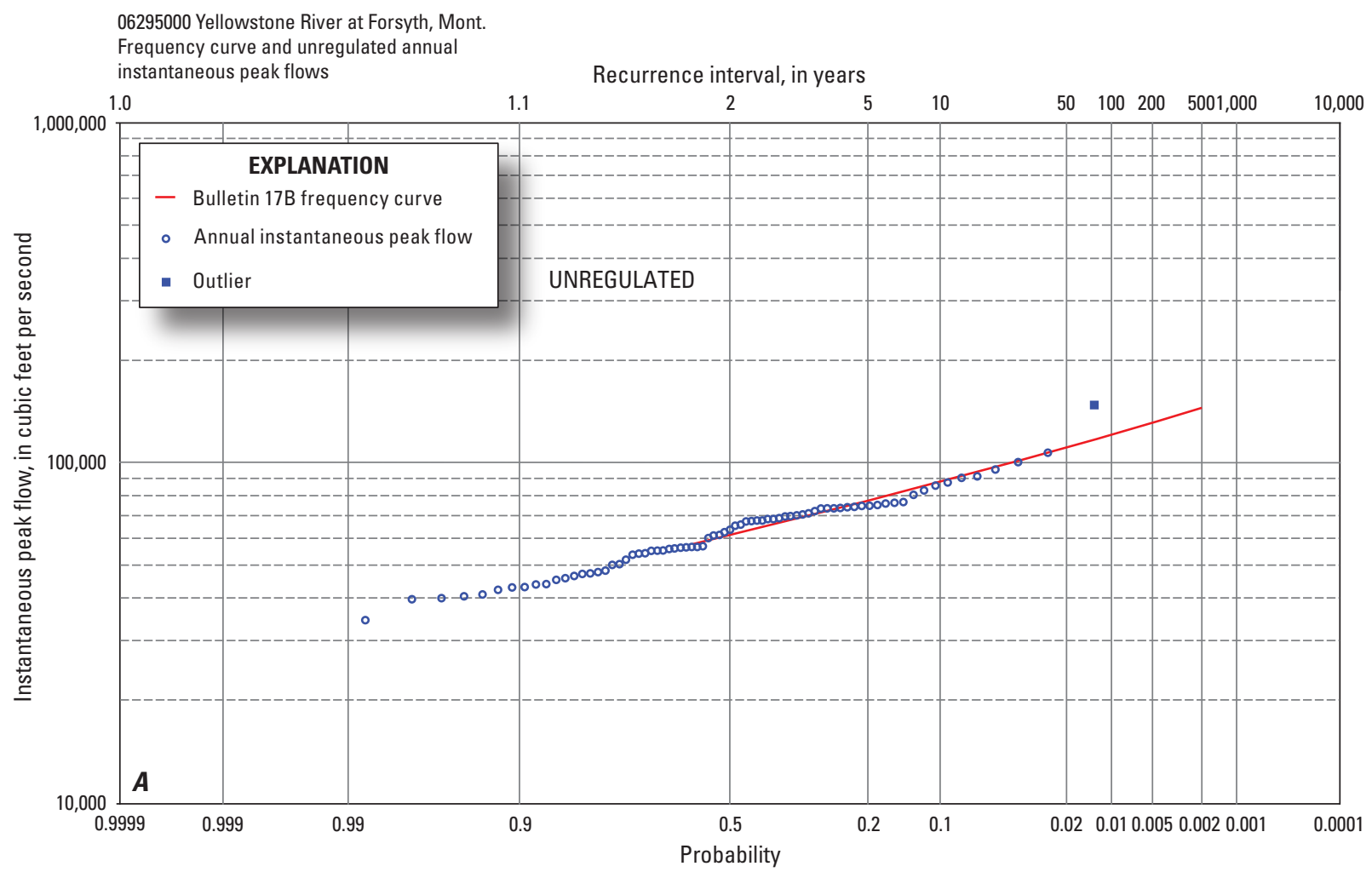

06295000 Yellowstone River at Forsyth, Mont.

Time series of unregulated annual instantaneous peak flows

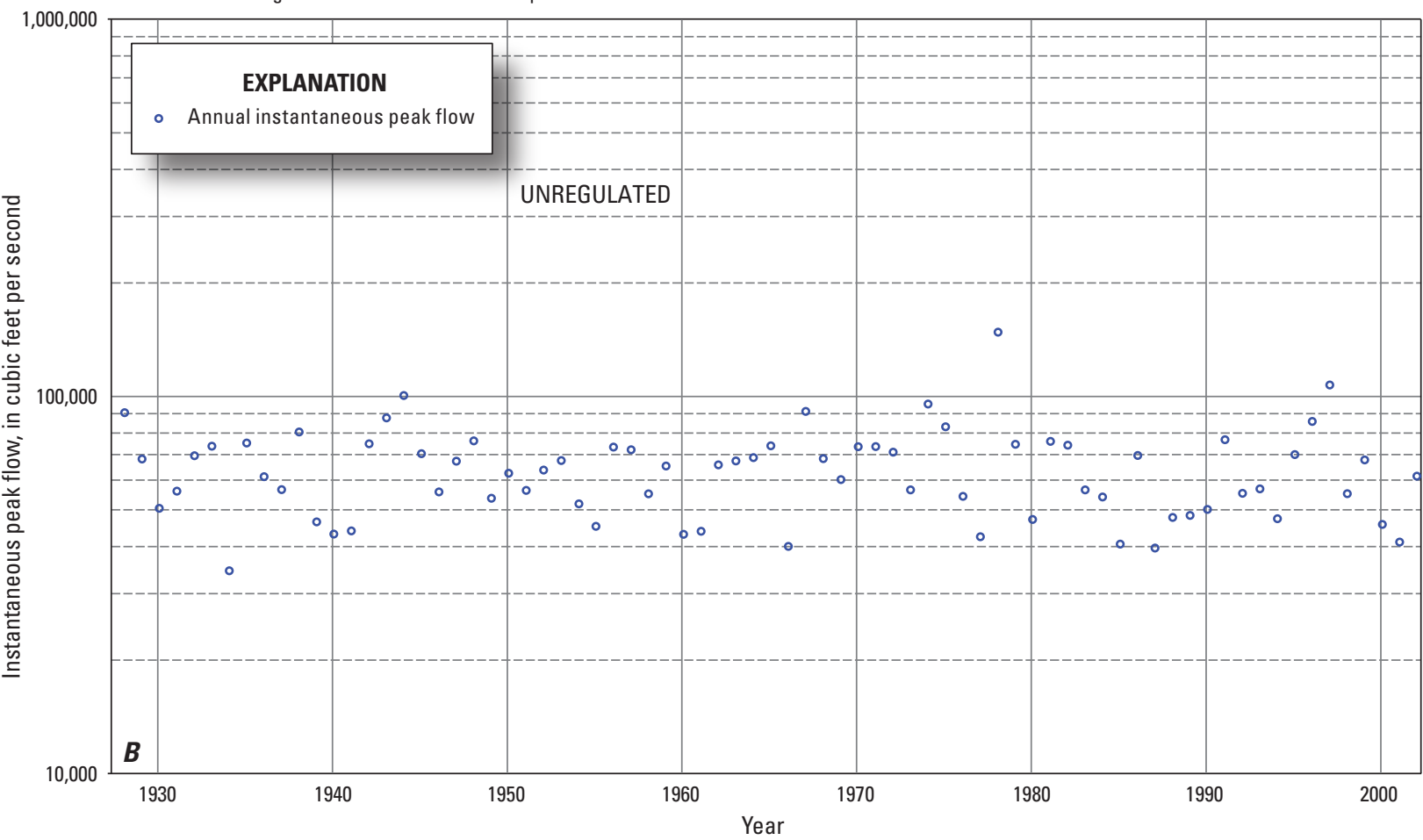

Figure 2-1-1. Annual instantaneous peak-flow data for streamflow-gaging station 06295000 (Yellowstone River at Forsyth, Mont.) for unregulated streamflow conditions, 1928-2002. A, Frequency curve and unregulated annual instantaneous peak flows. $B$, Time series of unregulated annual instantaneous peak flows. [Bulletin 17B: U.S. Interagency Advisory Council on Water Data, 1982] 

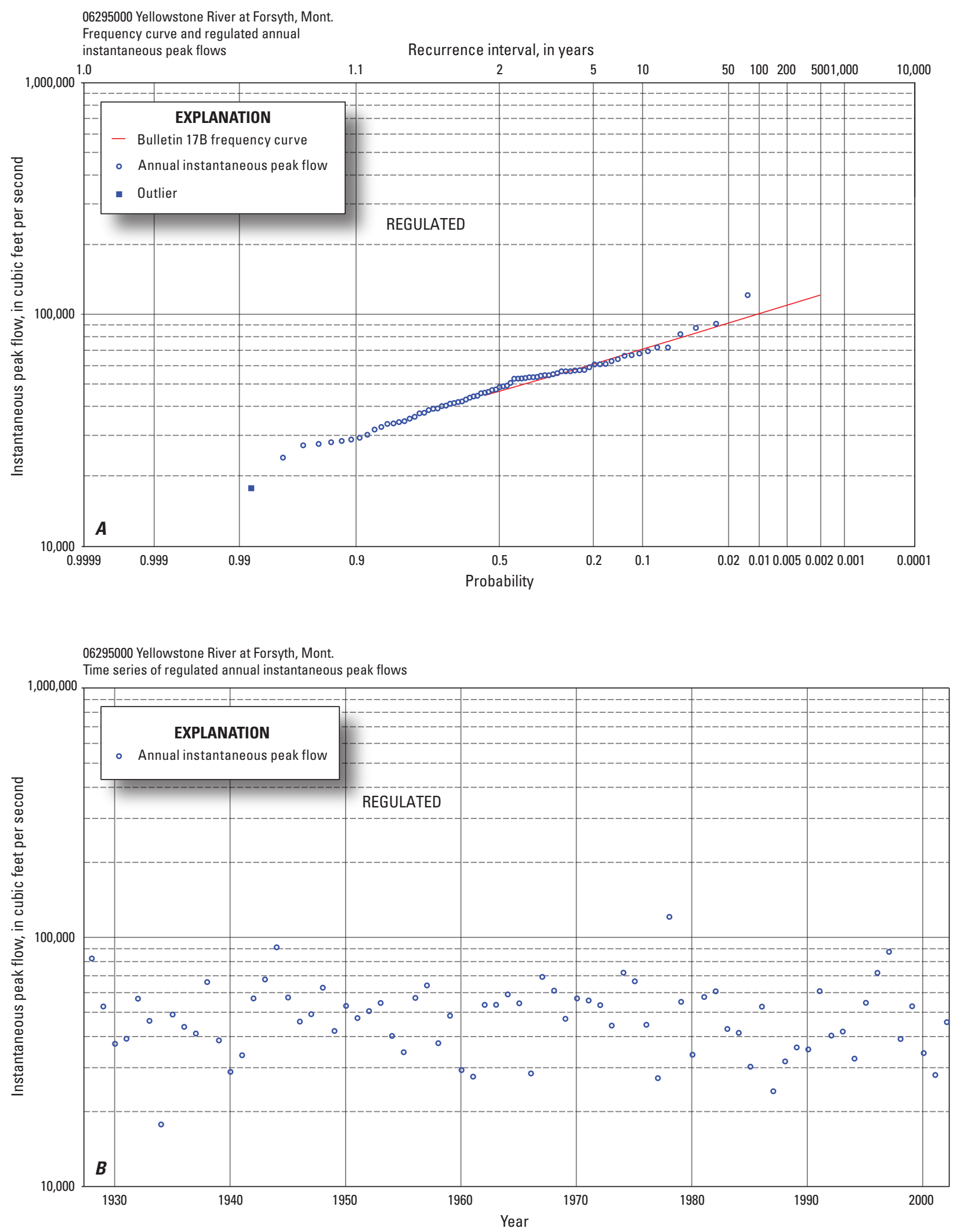

Figure 2-1-2. Annual instantaneous peak-flow data for streamflow-gaging station 06295000 (Yellowstone River at Forsyth, Mont.) for regulated streamflow conditions, 1928-2002. A, Frequency curve and regulated annual instantaneous peak flows. $B$, Time series of regulated annual instantaneous peak flows. [Bulletin 17B: U.S. Interagency Advisory Council on Water Data, 1982] 


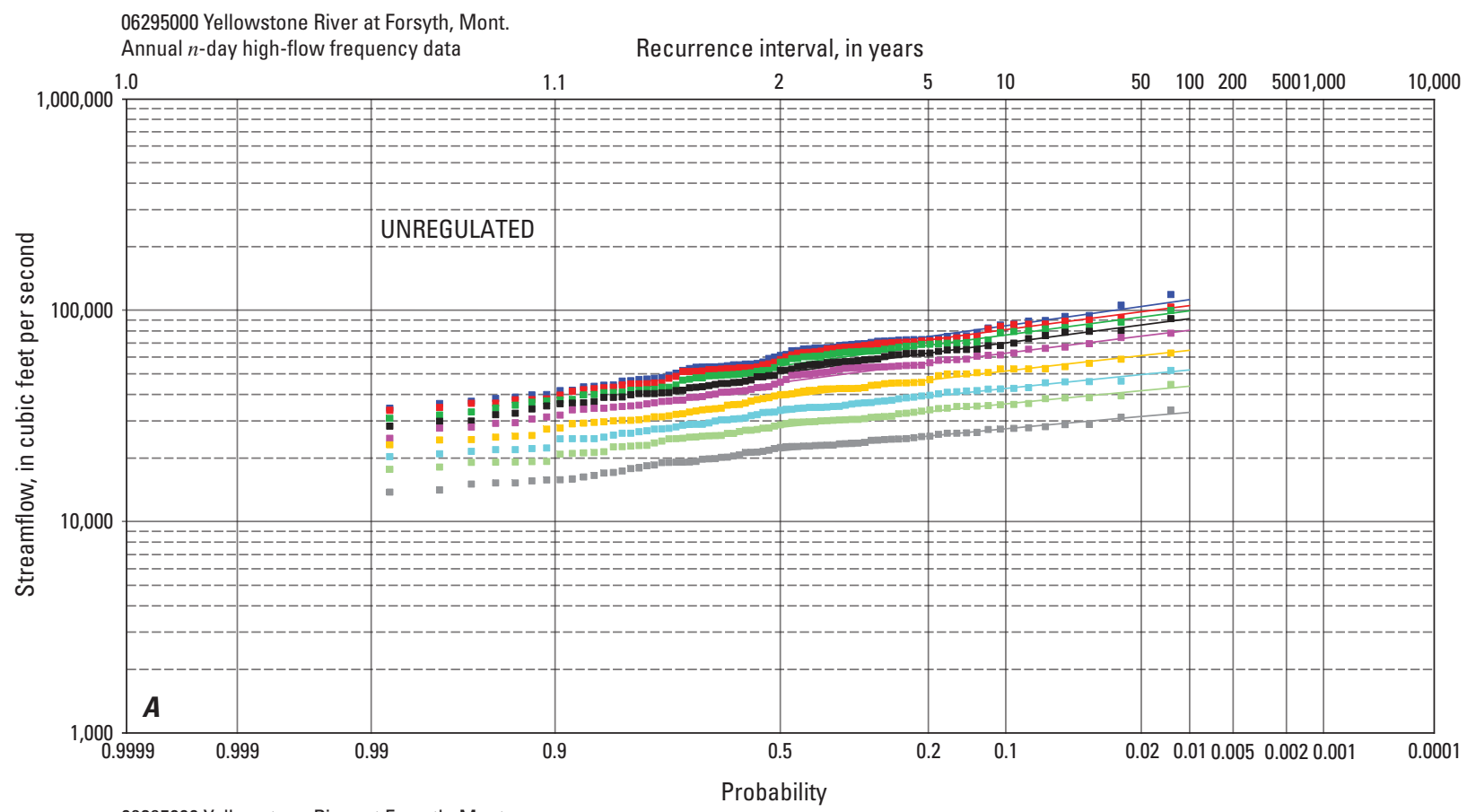

06295000 Yellowstone River at Forsyth, Mont Annual $n$-day high-flow frequency data

Recurrence interval, in years

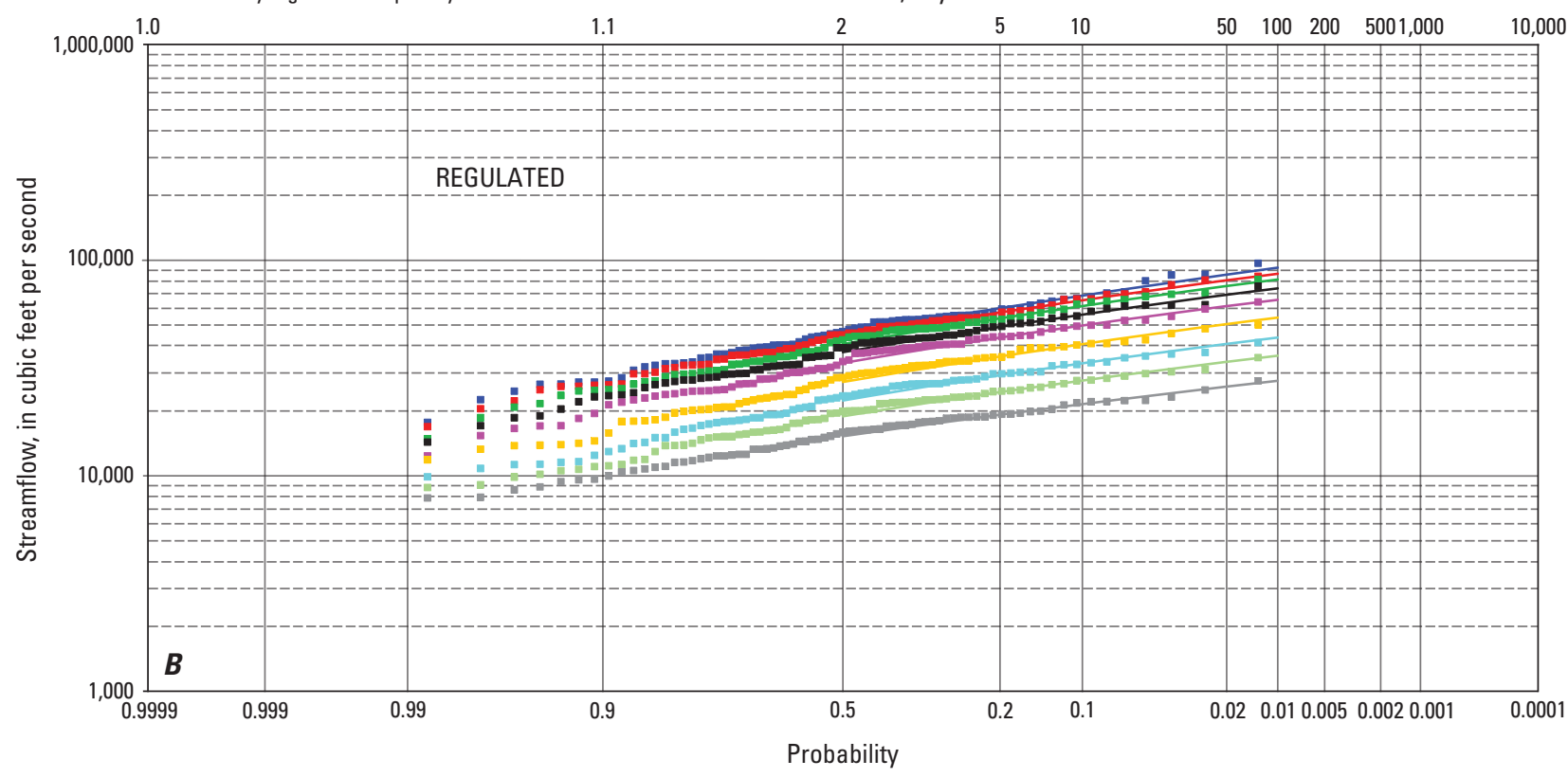

EXPLANATION

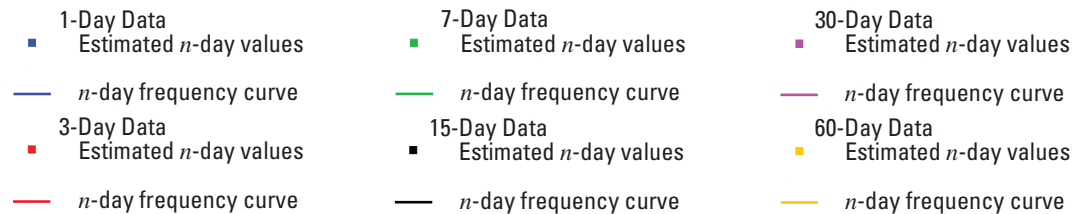

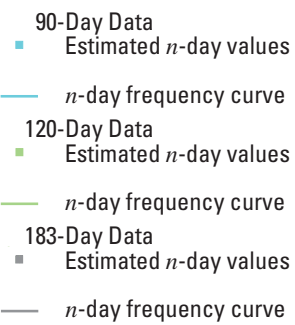

Figure 2-1-3. Annual $n$-day high-flow frequency data for streamflow-gaging station 06295000 (Yellowstone River at Forsyth, Mont.) for $A$, unregulated and $B$, regulated streamflow conditions, 1928-2002. 


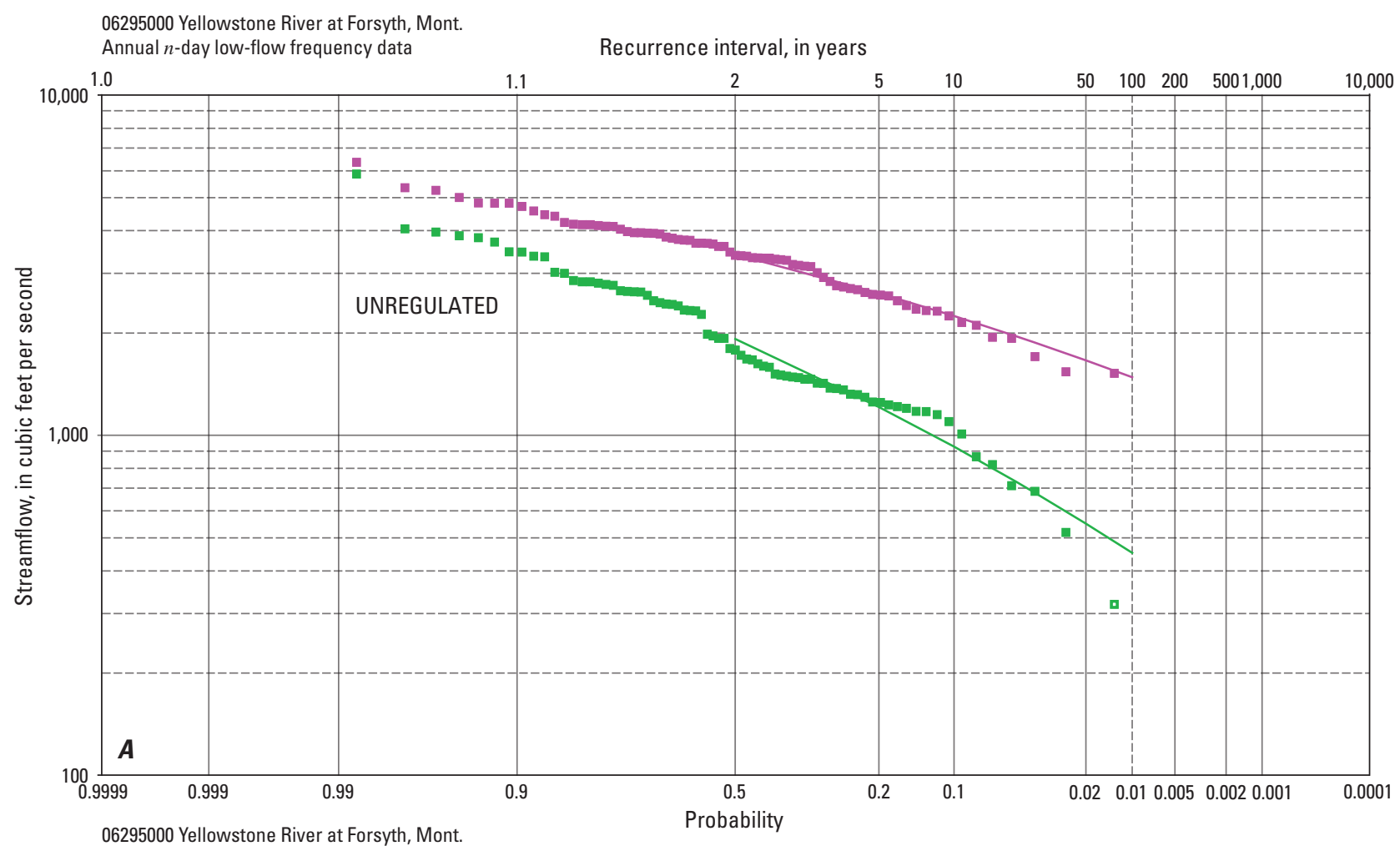

Annual n-day low-flow frequency data

Recurrence interval, in years

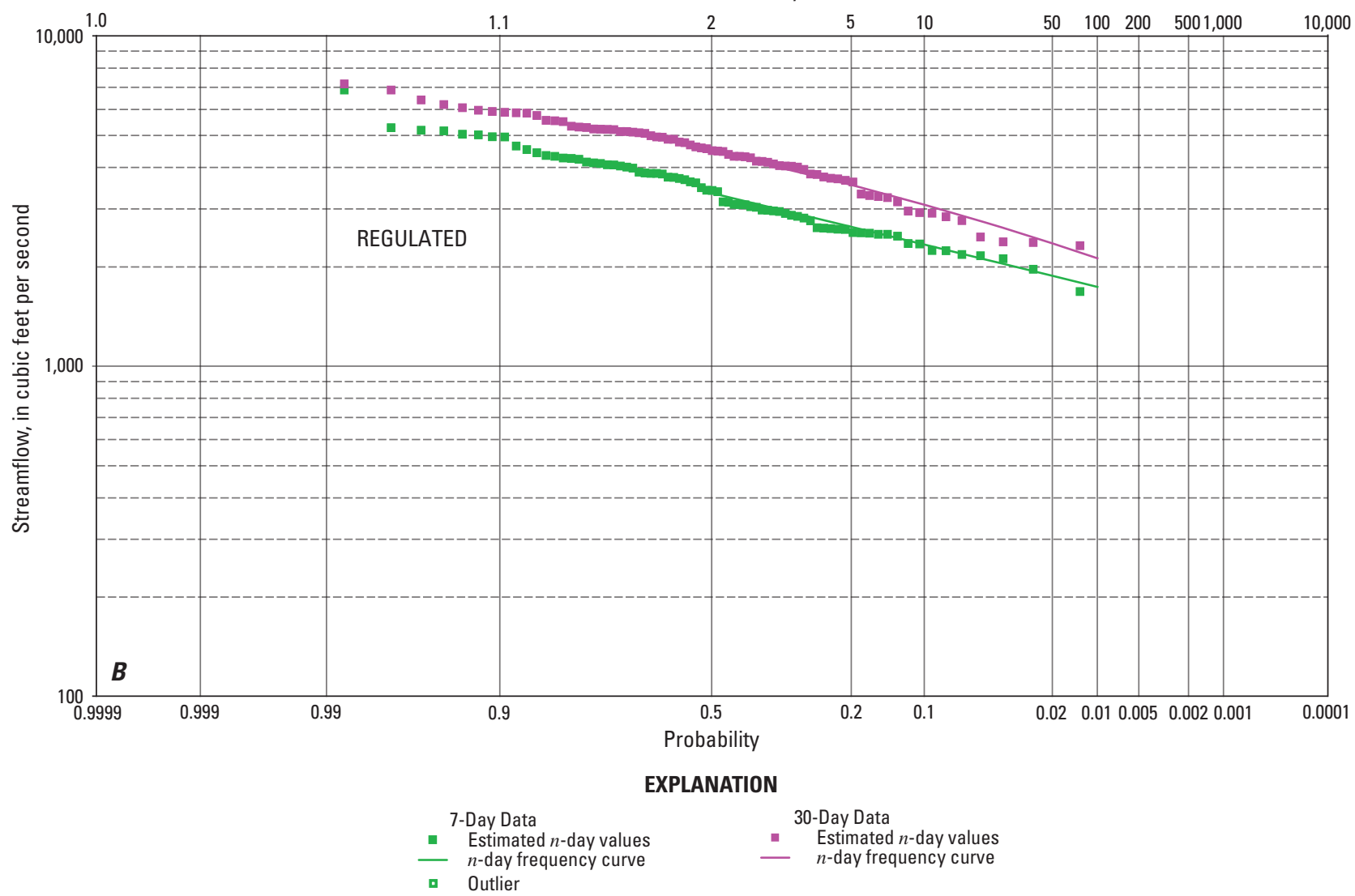

Figure 2-1-4. Annual $n$-day low-flow frequency data for streamflow-gaging station 06295000 (Yellowstone River at Forsyth, Mont.) for $A$, unregulated and $B$, regulated streamflow conditions, 1928-2002. 
06295000 Yellowstone River at Forsyth, Mont.

Winter (January-March) n-day low-flow frequency data Recurrence interval, in years

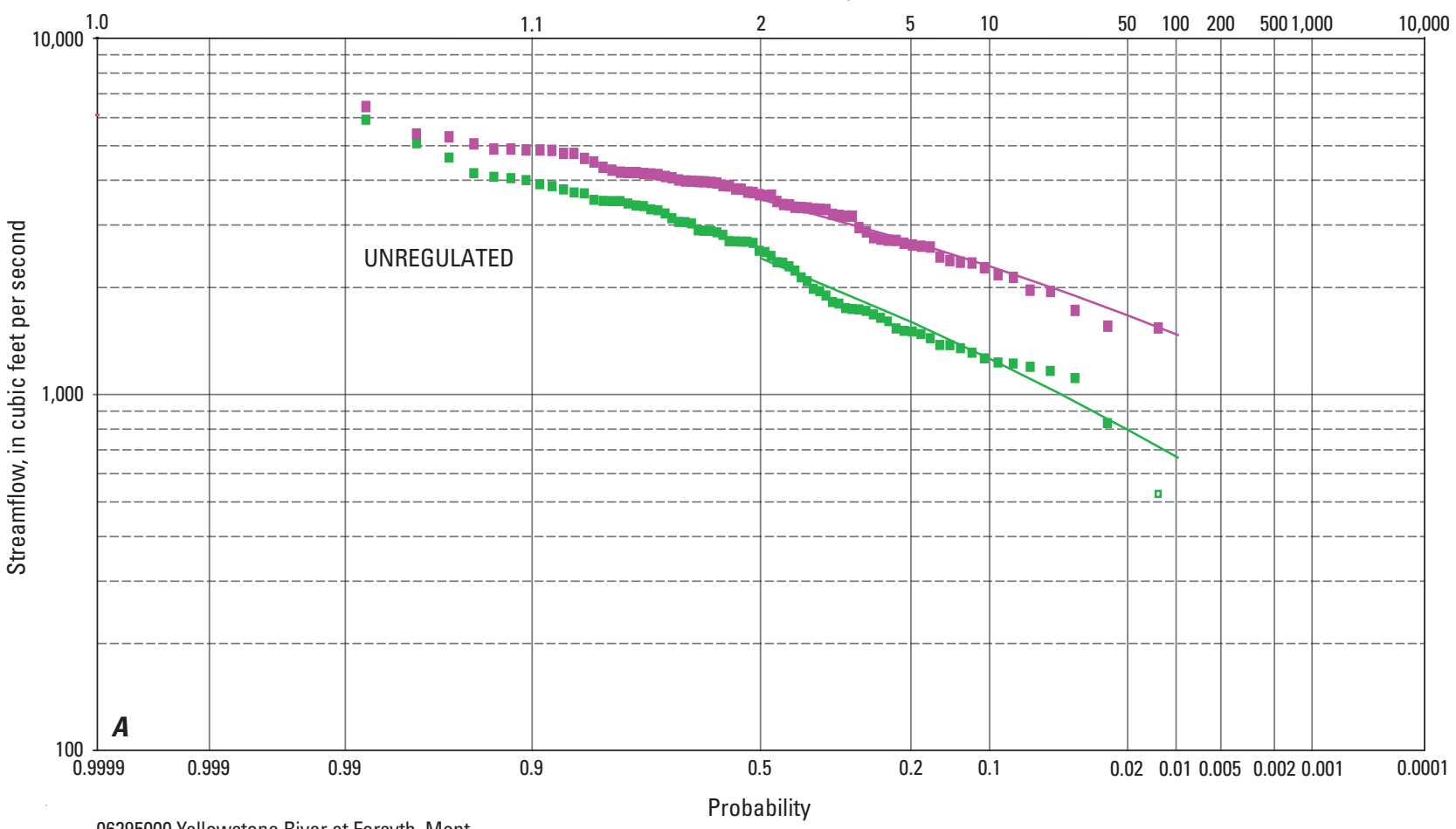

06295000 Yellowstone River at Forsyth, Mont.

Recurrence interval, in years

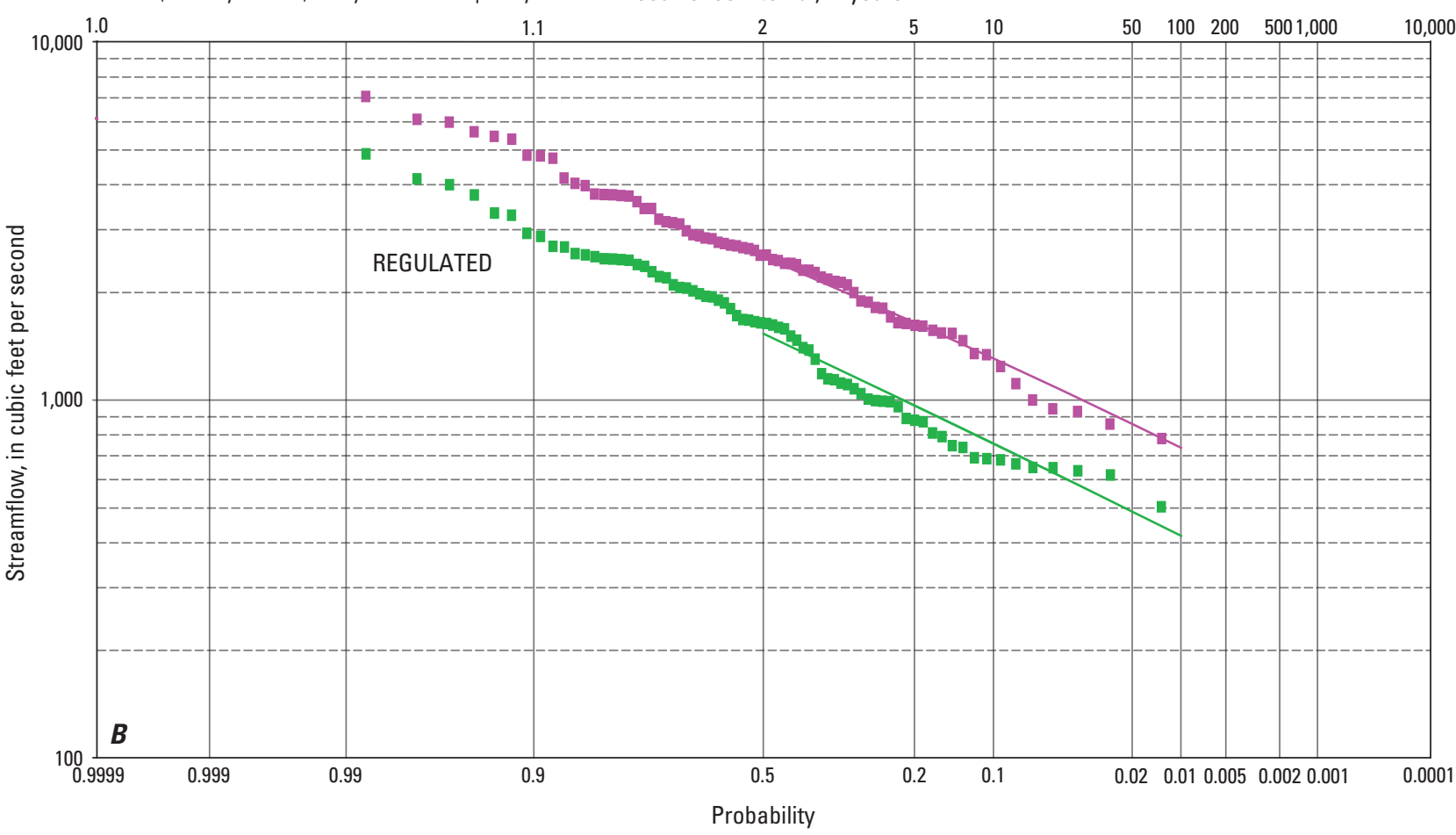

EXPLANATION

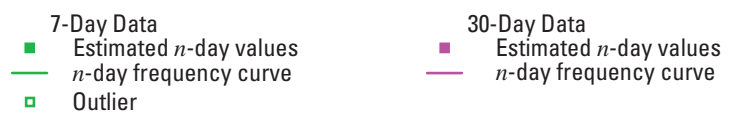

Figure 2-1-5. Winter (January-March) $n$-day low-flow frequency data for streamflow-gaging station 06295000 (Yellowstone River at Forsyth, Mont.) for $A$, unregulated and $B$, regulated streamflow conditions, 1928-2002. 

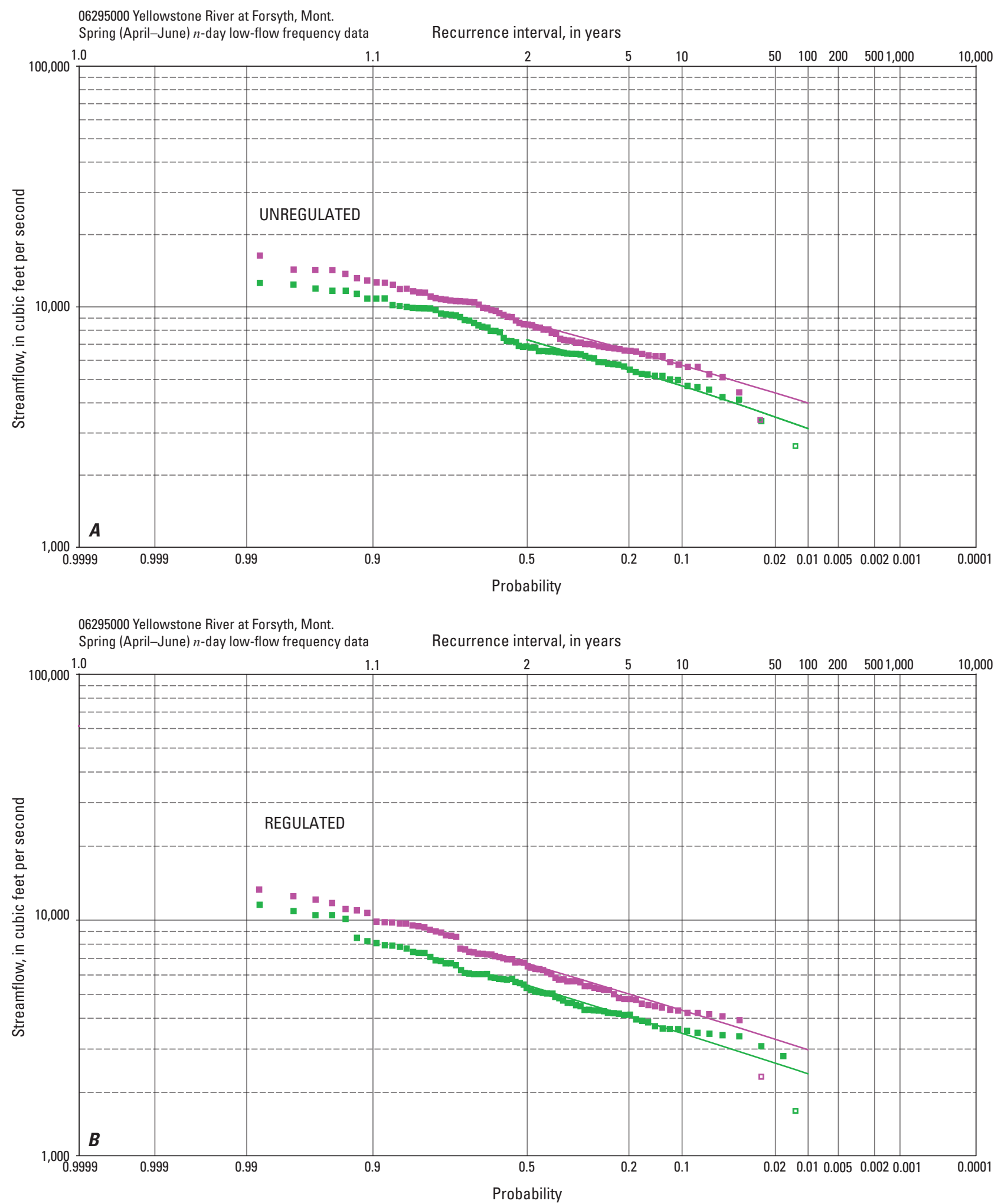

EXPLANATION

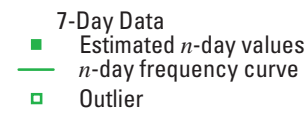

30-Day Data
$\quad$ Estimated $n$-day values
$n$-day frequency curve
Outlier

Figure 2-1-6. Spring (April-June) $n$-day low-flow frequency data for streamflow-gaging station 06295000 (Yellowstone River at Forsyth, Mont.) for $A$, unregulated and $B$, regulated streamflow conditions, 1928-2002. 
06295000 Yellowstone River at Forsyth, Mont.

Summer (July-September) $n$-day low-flow frequency data Recurrence interval, in years

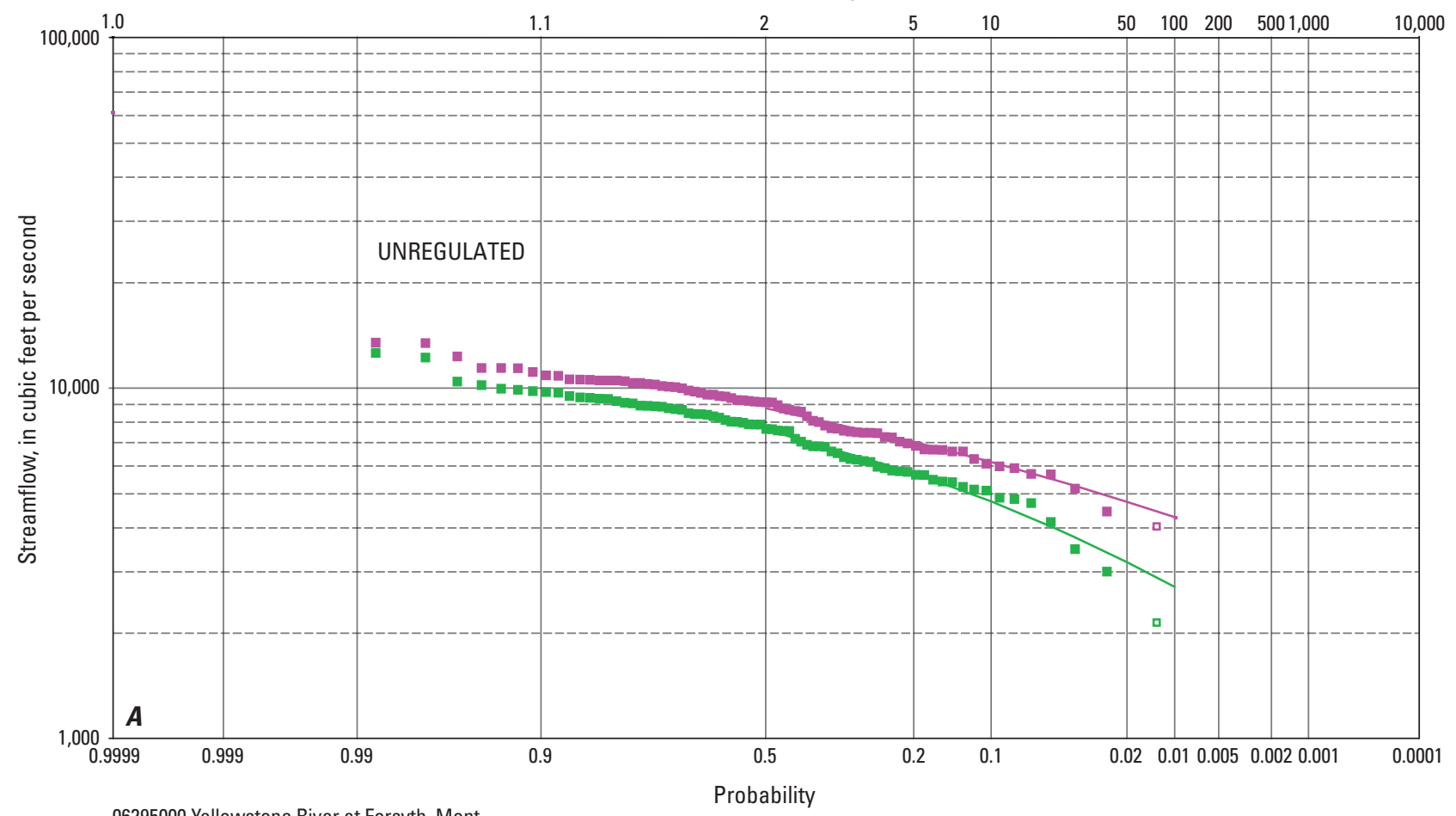

06295000 Yellowstone River at Forsyth, Mont

Summer (July-September) n-day low-flow frequency data Recurrence interval, in years

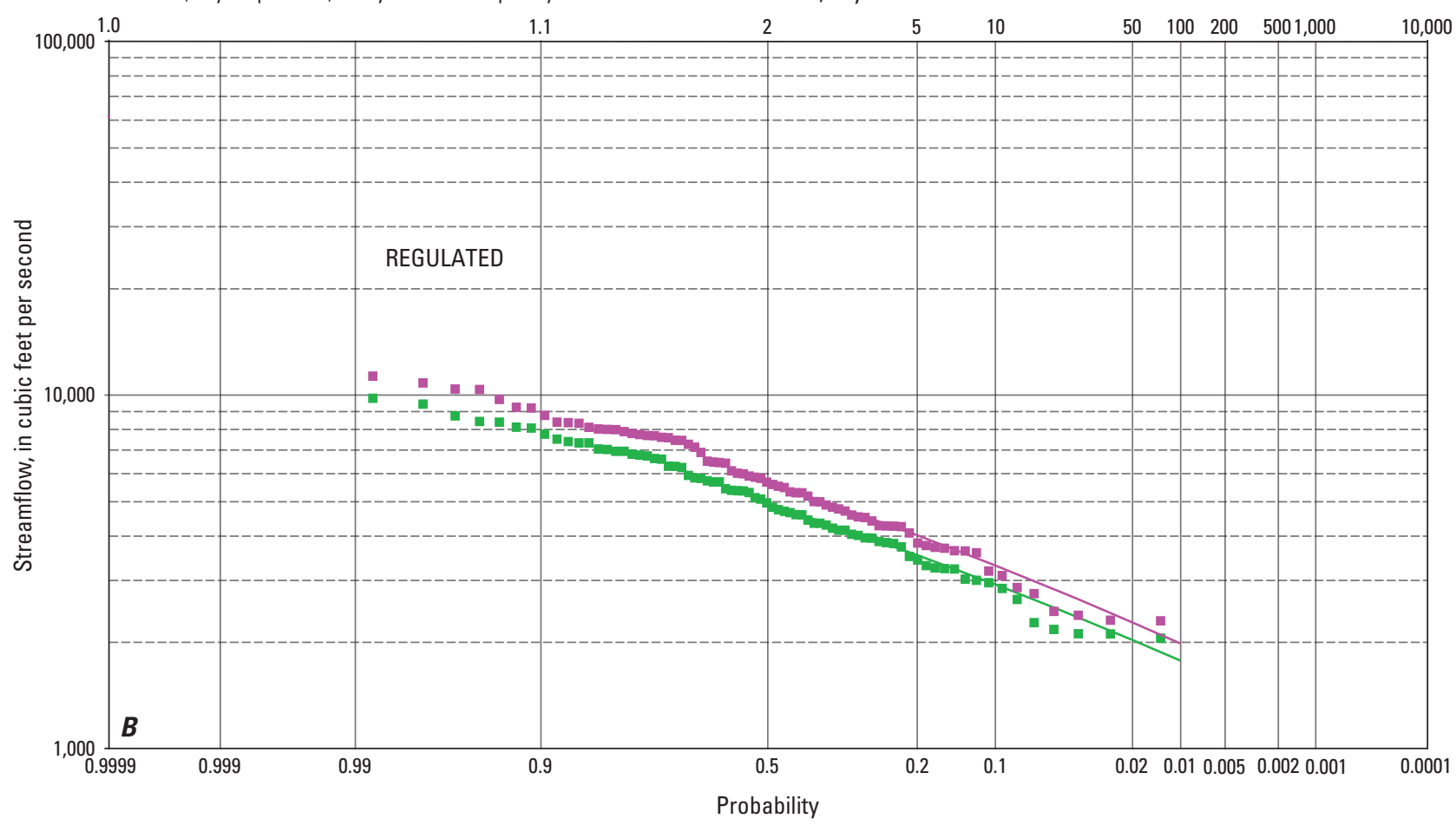

EXPLANATION

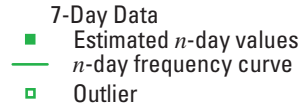

30-Day Data
Estimated $n$-day values
$n-\quad$-day frequency curve
Outlier

Figure 2-1-7. Summer (July-September) $n$-day low-flow frequency data for streamflow-gaging station 06295000 (Yellowstone River at Forsyth, Mont.) for $A$, unregulated and B, regulated streamflow conditions, 1928-2002. 


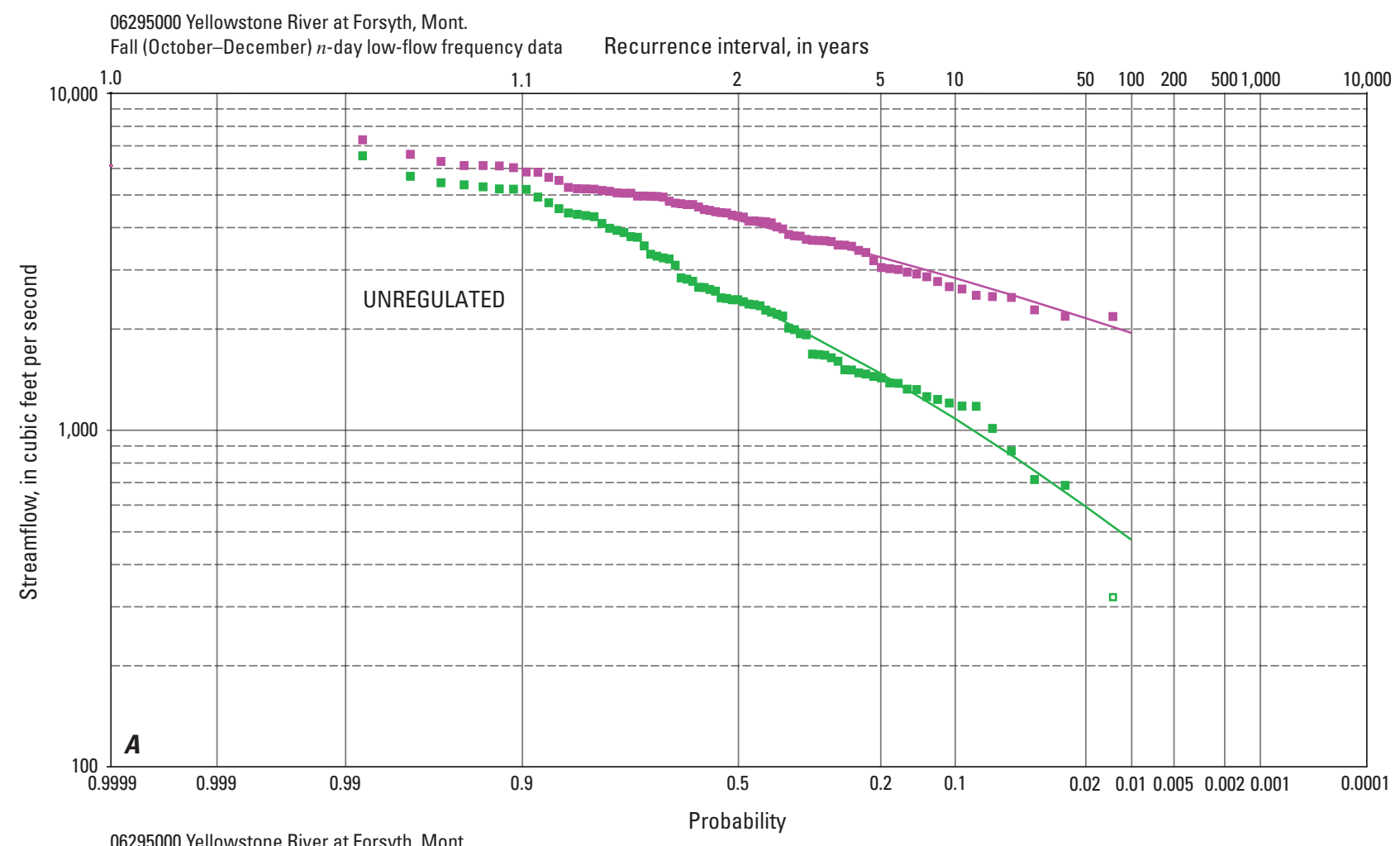

06295000 Yellowstone River at Forsyth, Mont.

Fall (October-December) $n$-day low-flow frequency data Recurrence interval, in years

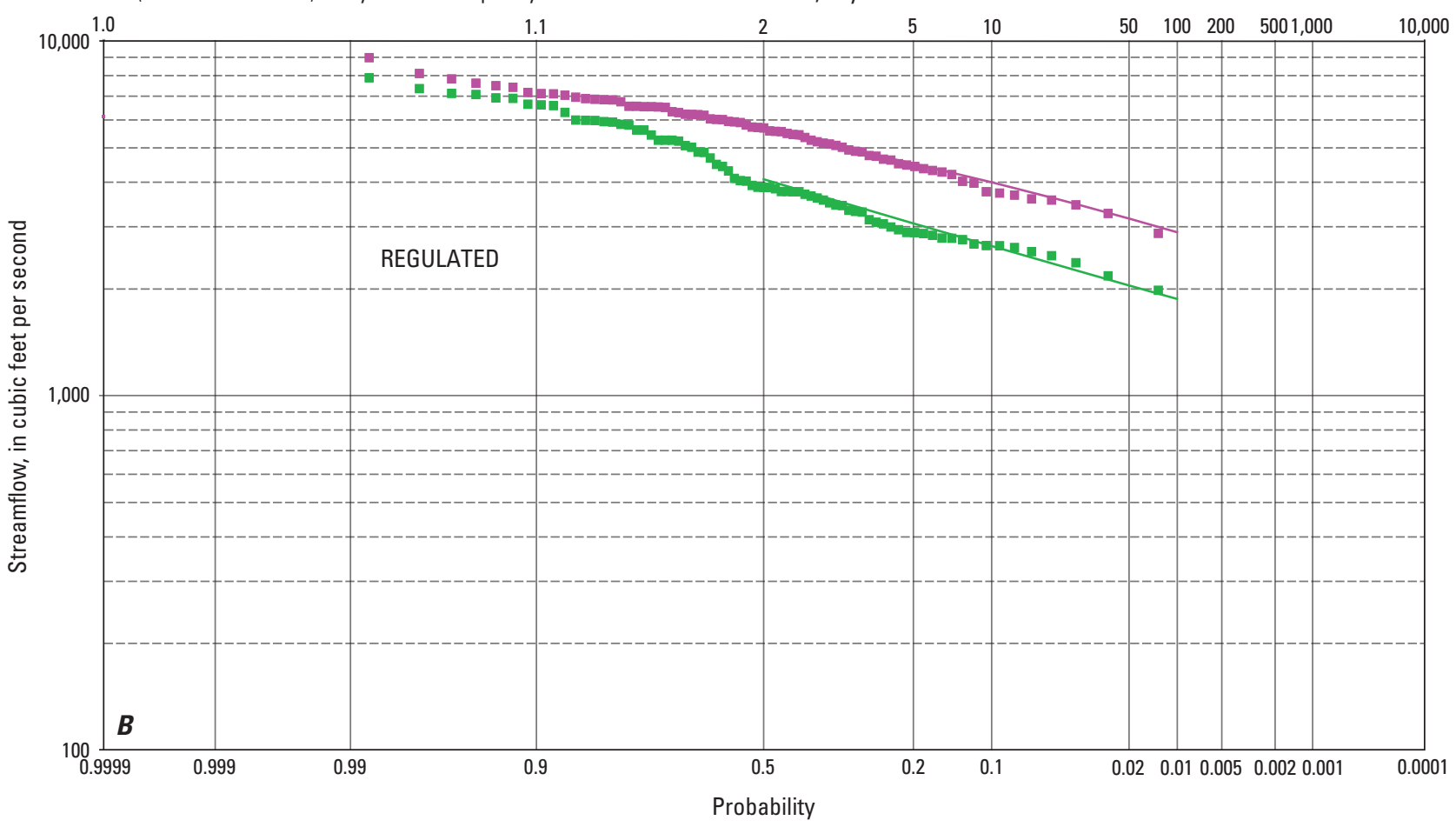

EXPLANATION

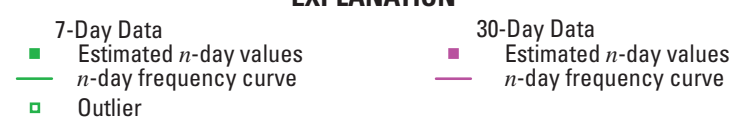

Figure 2-1-8. Fall (October-December) $n$-day low-flow frequency data for streamflow-gaging station 06295000 (Yellowstone River at Forsyth, Mont.) for $A$, unregulated and B, regulated streamflow conditions, 1928-2002. 

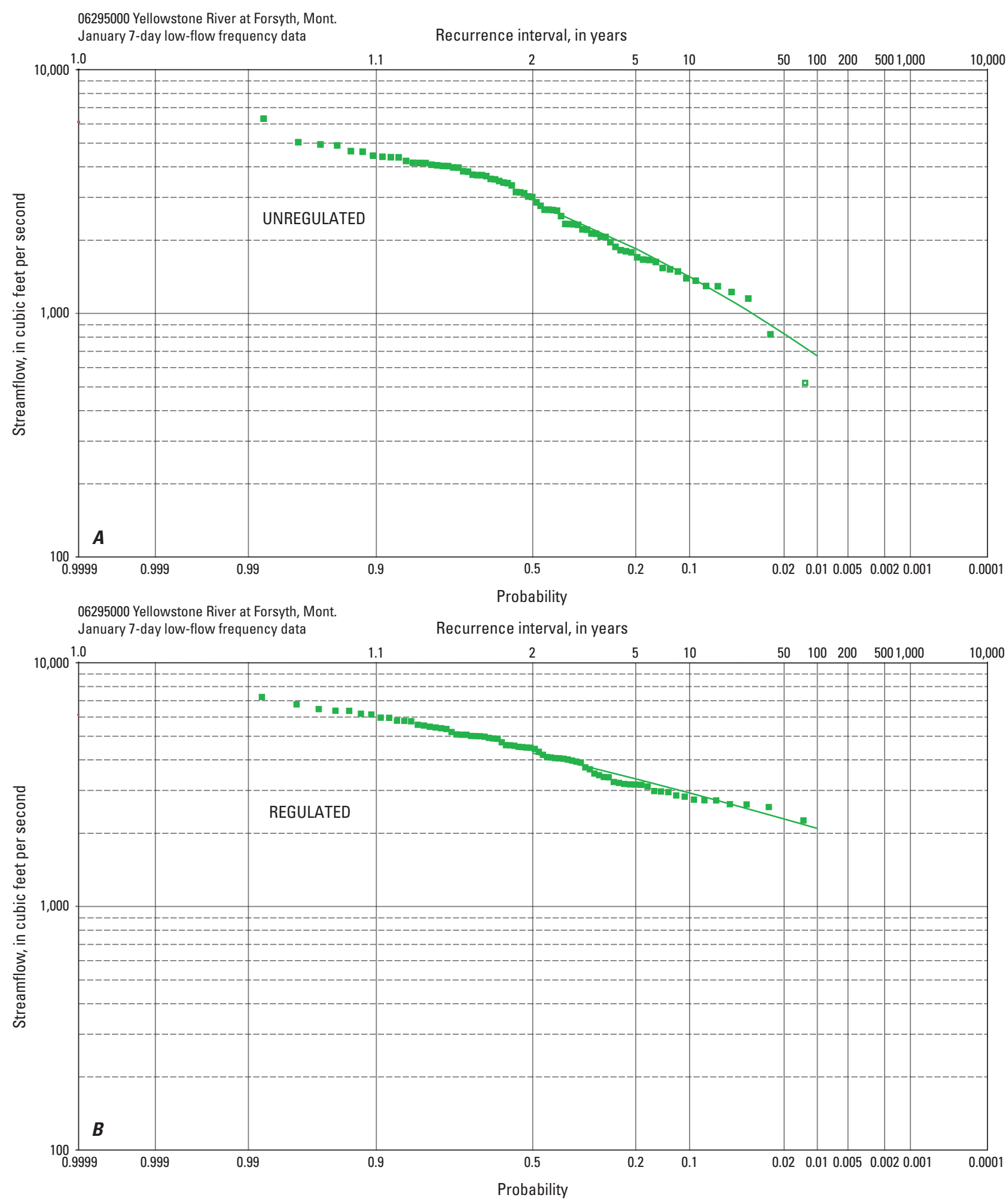

EXPLANATION

7-Day Data

- Estimated $n$-day values

- n-day frequency curve

- Outlier

Figure 2-1-9. January 7-day low-flow frequency data for streamflow-gaging station 06295000 (Yellowstone River at Forsyth, Mont.) for $A$, unregulated and $B$, regulated streamflow conditions, 1928-2002. 

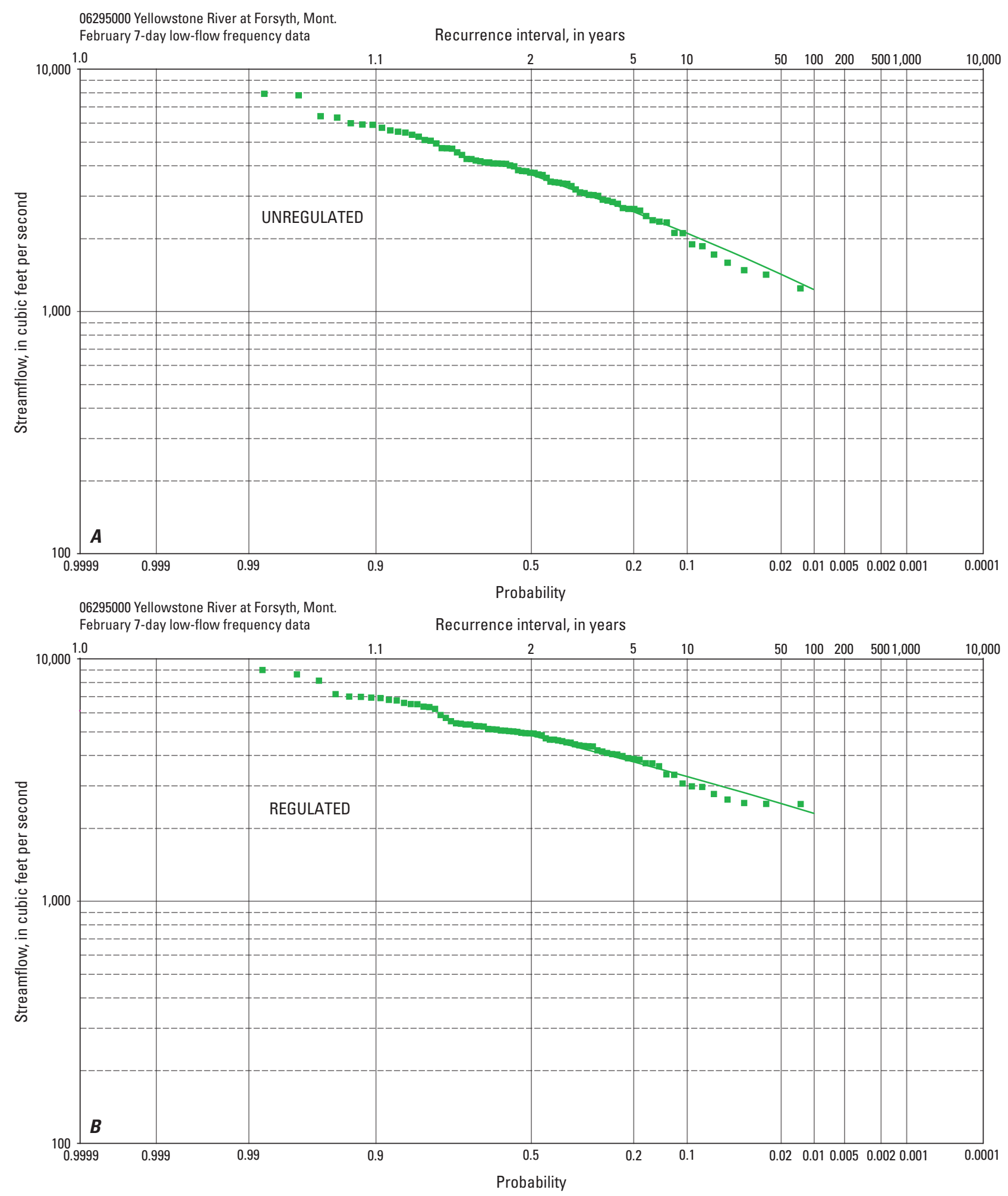

EXPLANATION

7-Day Data

- Estimated $n$-day values

$n$-day frequency curve

Figure 2-1-10. February 7-day low-flow frequency data for streamflow-gaging station 06295000 (Yellowstone River at Forsyth, Mont.) for $A$, unregulated and $B$, regulated streamflow conditions, 1928-2002. 

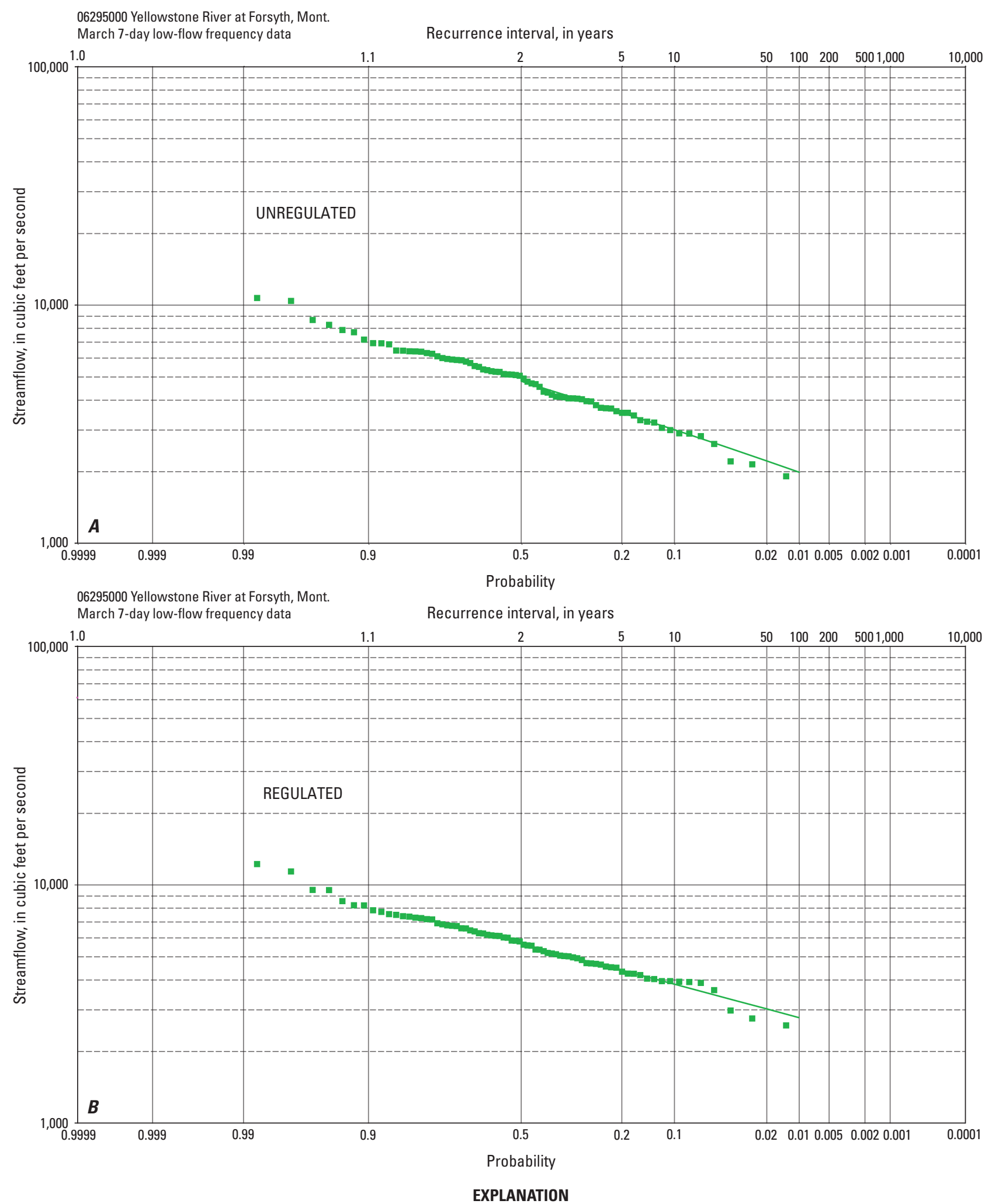

7-Day Data

- $\quad$ Estimated $n$-day values $n$-day frequency curve

Figure 2-1-11. March 7-day low-flow frequency data for streamflow-gaging station 06295000 (Yellowstone River at Forsyth, Mont.) for $A$, unregulated and $B$, regulated streamflow conditions, 1928-2002. 

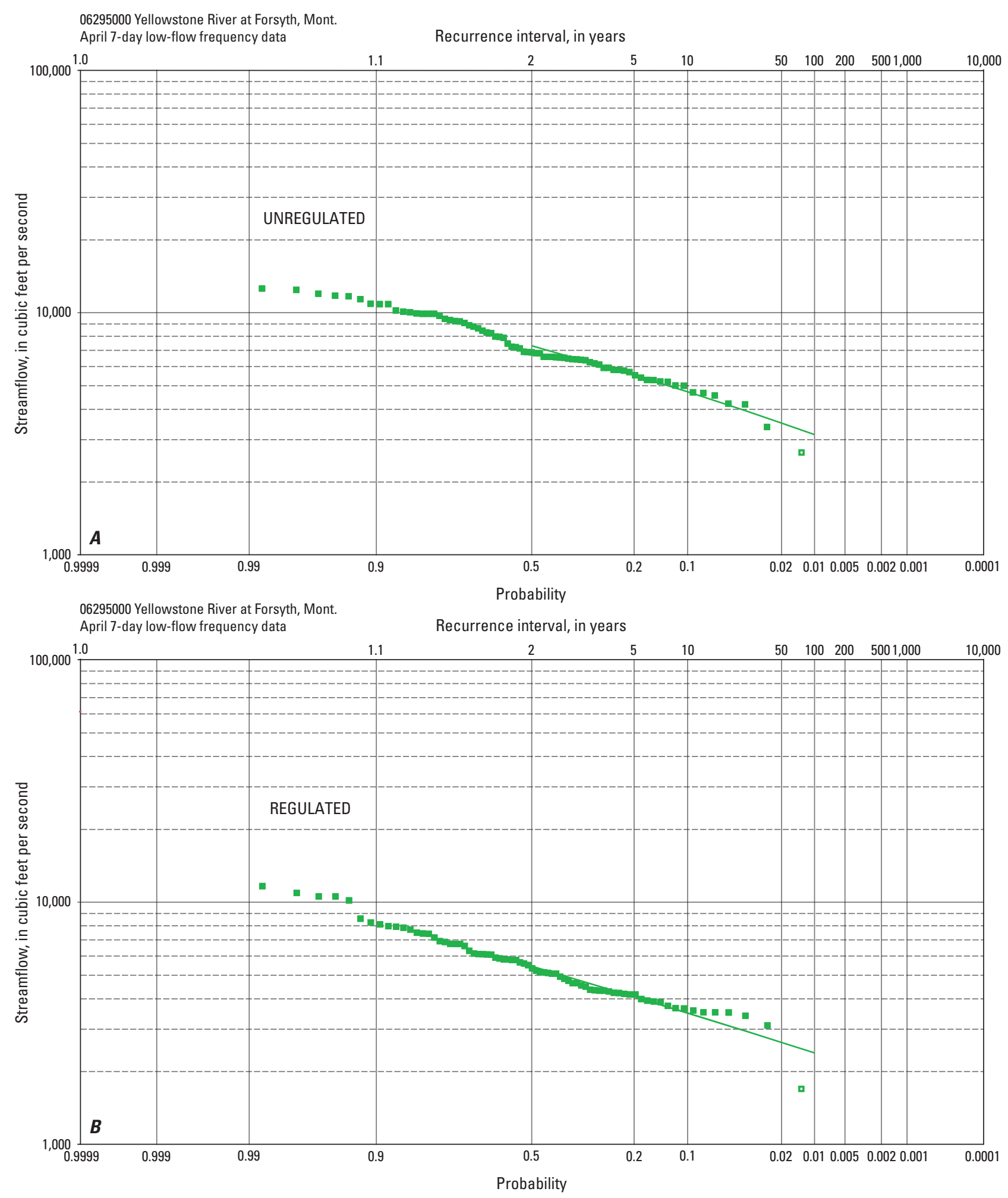

EXPLANATION

7-Day Data

- Estimated $n$-day values

- $n$-day frequency curve

口 Outlier

Figure 2-1-12. April 7-day low-flow frequency data for streamflow-gaging station 06295000 (Yellowstone River at Forsyth, Mont.) for $A$, unregulated and $B$, regulated streamflow conditions, 1928-2002. 

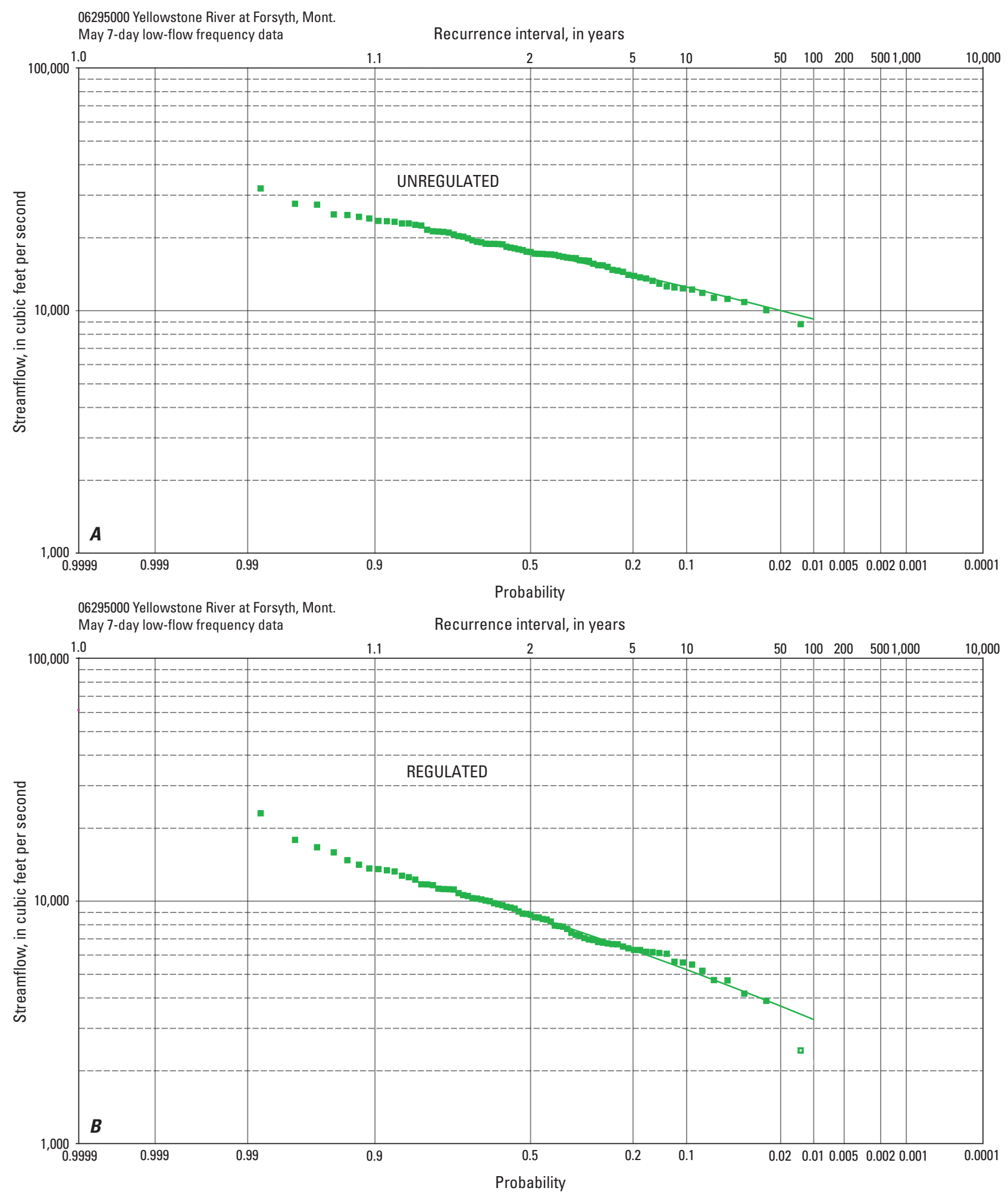

EXPLANATION

7-Day Data

- Estimated $n$-day values

- $n$-day frequency curve

- Outlier

Figure 2-1-13. May 7-day low-flow frequency data for streamflow-gaging station 06295000 (Yellowstone River at Forsyth, Mont.) for $A$, unregulated and $B$, regulated streamflow conditions, 1928-2002. 

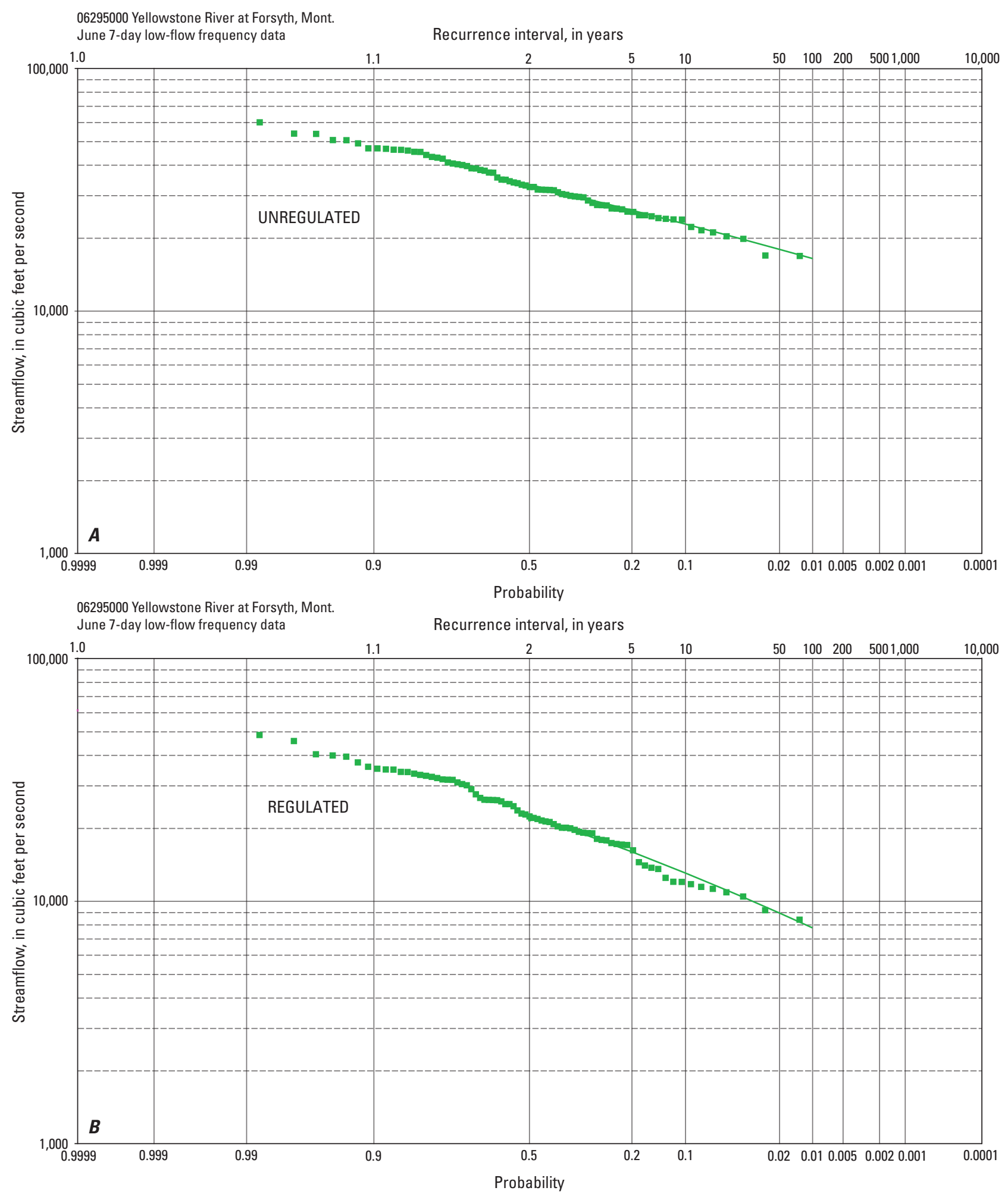

EXPLANATION

7-Day Data

- Estimated $n$-day values

$n$-day frequency curve

Figure 2-1-14. June 7-day low-flow frequency data for streamflow-gaging station 06295000 (Yellowstone River at Forsyth, Mont.) for $A$, unregulated and $B$, regulated streamflow conditions, 1928-2002. 

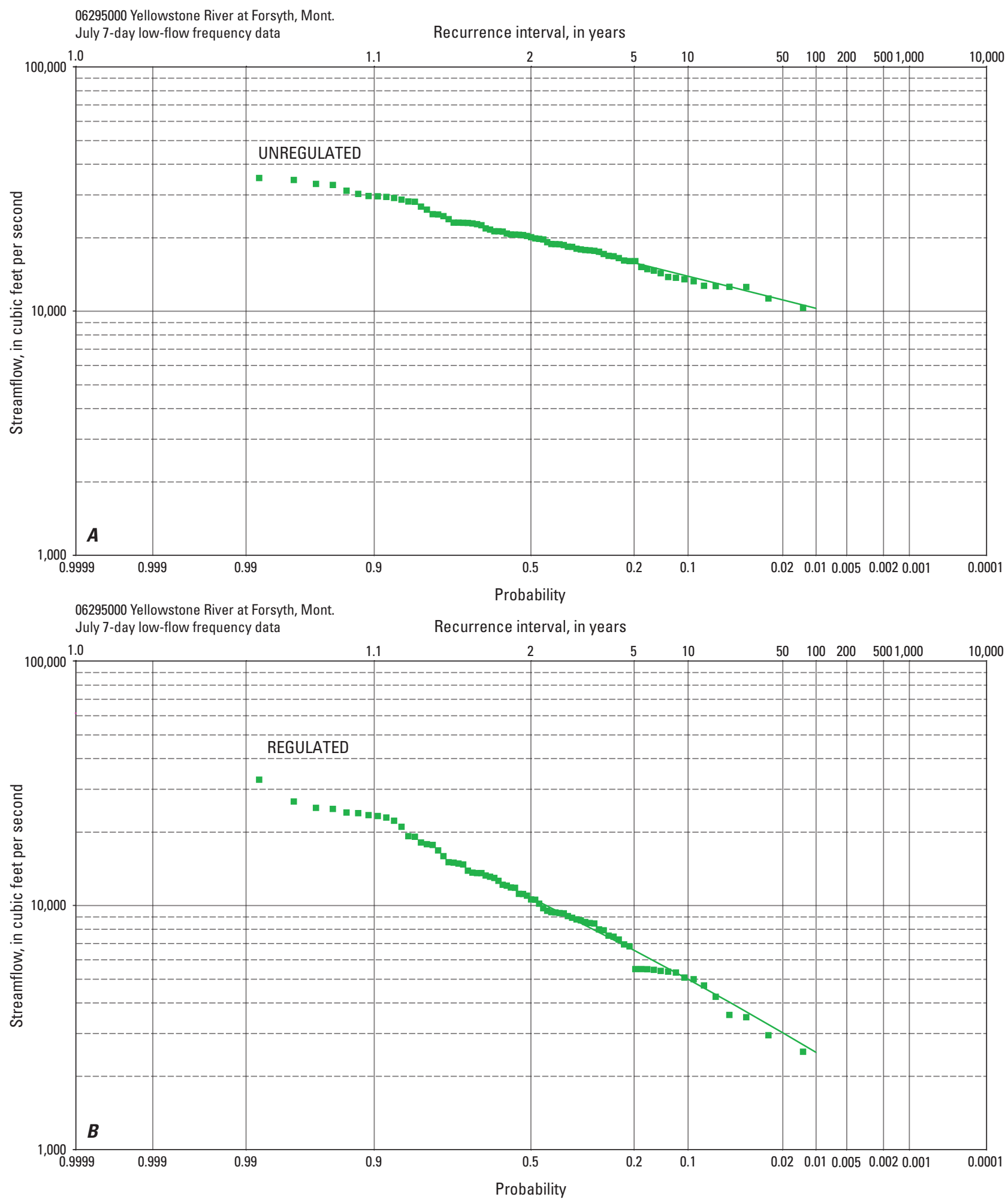

EXPLANATION

7-Day Data

- $\quad$ Estimated $n$-day values

$n$-day frequency curve

Figure 2-1-15. July 7-day low-flow frequency data for streamflow-gaging station 06295000 (Yellowstone River at Forsyth, Mont.) for $A$, unregulated and $B$, regulated streamflow conditions, 1928-2002. 


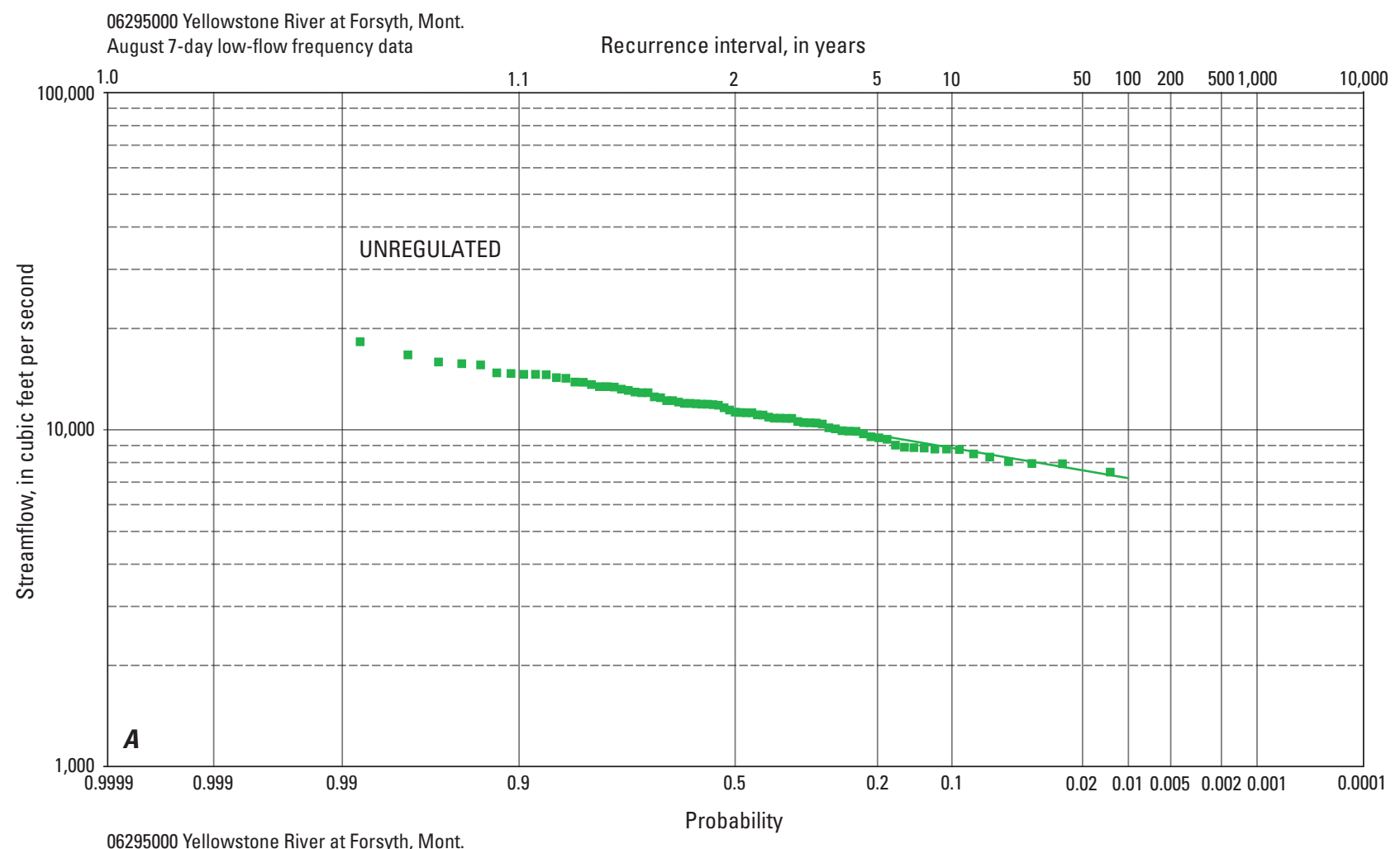

06295000 Yellowstone River at Forsyth, Mont.

Recurrence interval, in years

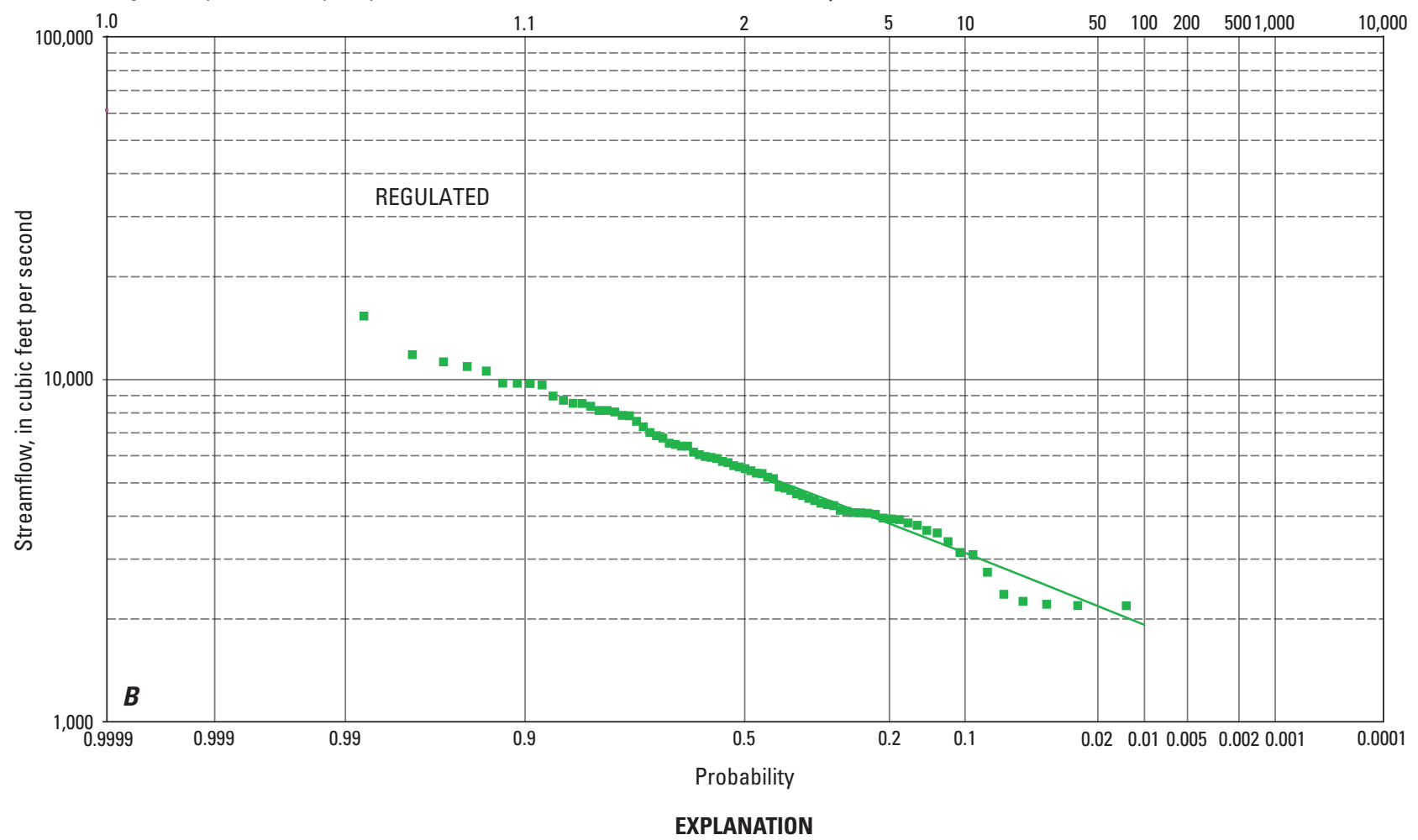

7-Day Data

- Estimated $n$-day values

- $n$-day frequency curve

Figure 2-1-16. August 7-day low-flow frequency data for streamflow-gaging station 06295000 (Yellowstone River at Forsyth, Mont.) for $A$, unregulated and $B$, regulated streamflow conditions, 1928-2002. 

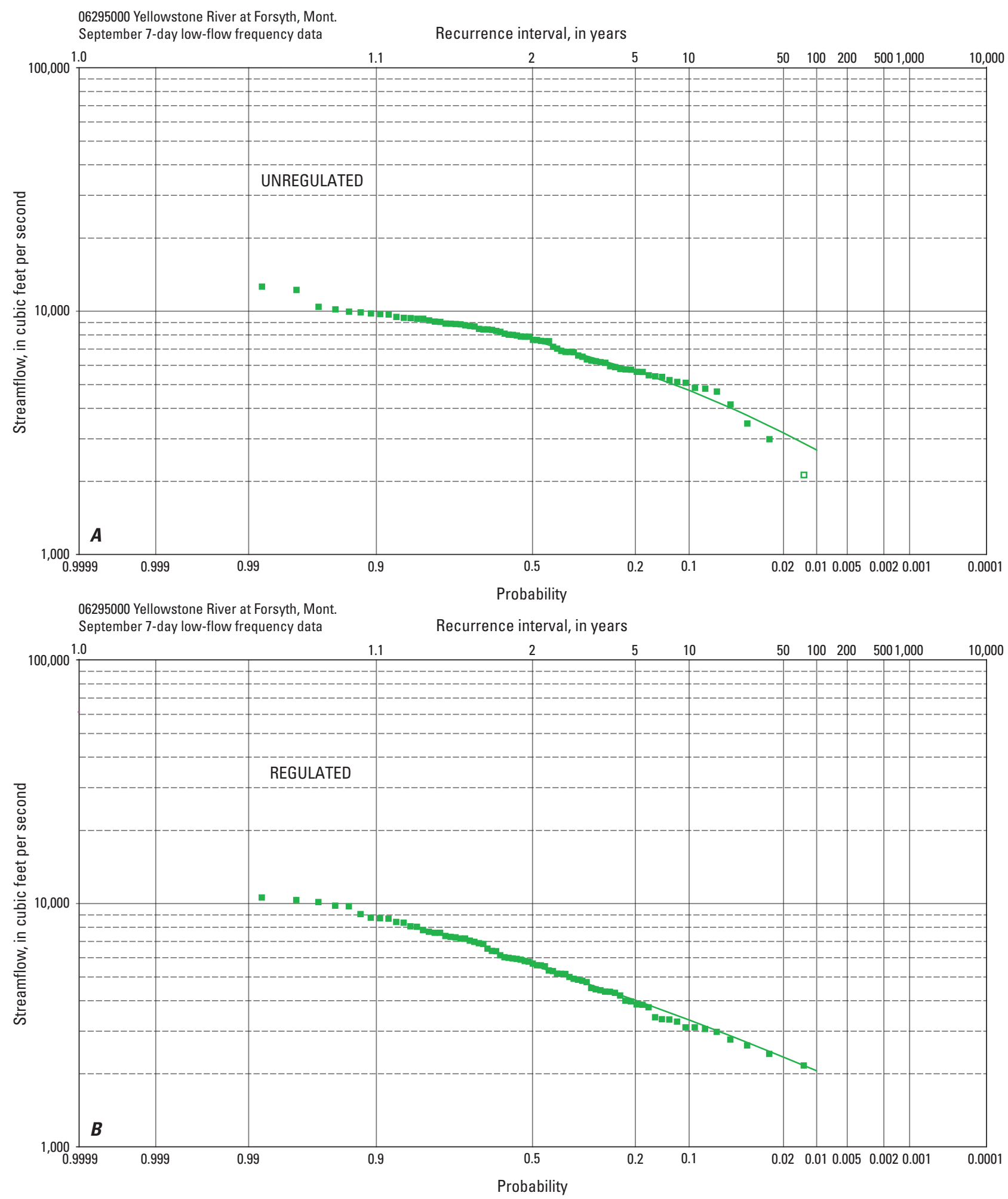

EXPLANATION

7-Day Data

- Estimated $n$-day values

- n-day frequency curve

Figure 2-1-17. September 7-day low-flow frequency data for streamflow-gaging station 06295000 (Yellowstone River at Forsyth, Mont.) for $A$, unregulated and $B$, regulated streamflow conditions, 1928-2002. 

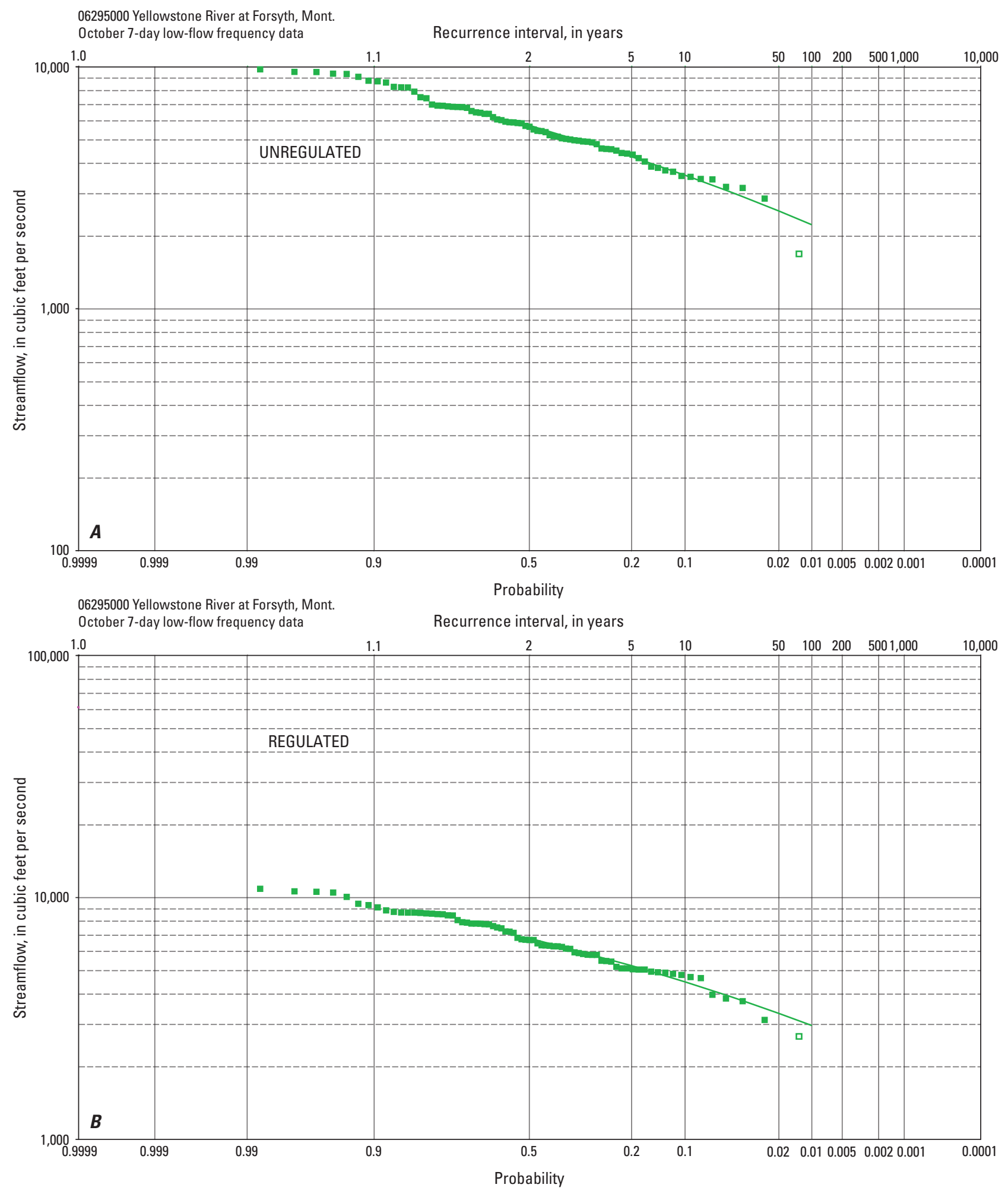

EXPLANATION

7-Day Data

- Estimated $n$-day values

- $n$-day frequency curve

Figure 2-1-18. October 7-day low-flow frequency data for streamflow-gaging station 06295000 (Yellowstone River at Forsyth, Mont.) for $A$, unregulated and $B$, regulated streamflow conditions, 1928-2002. 

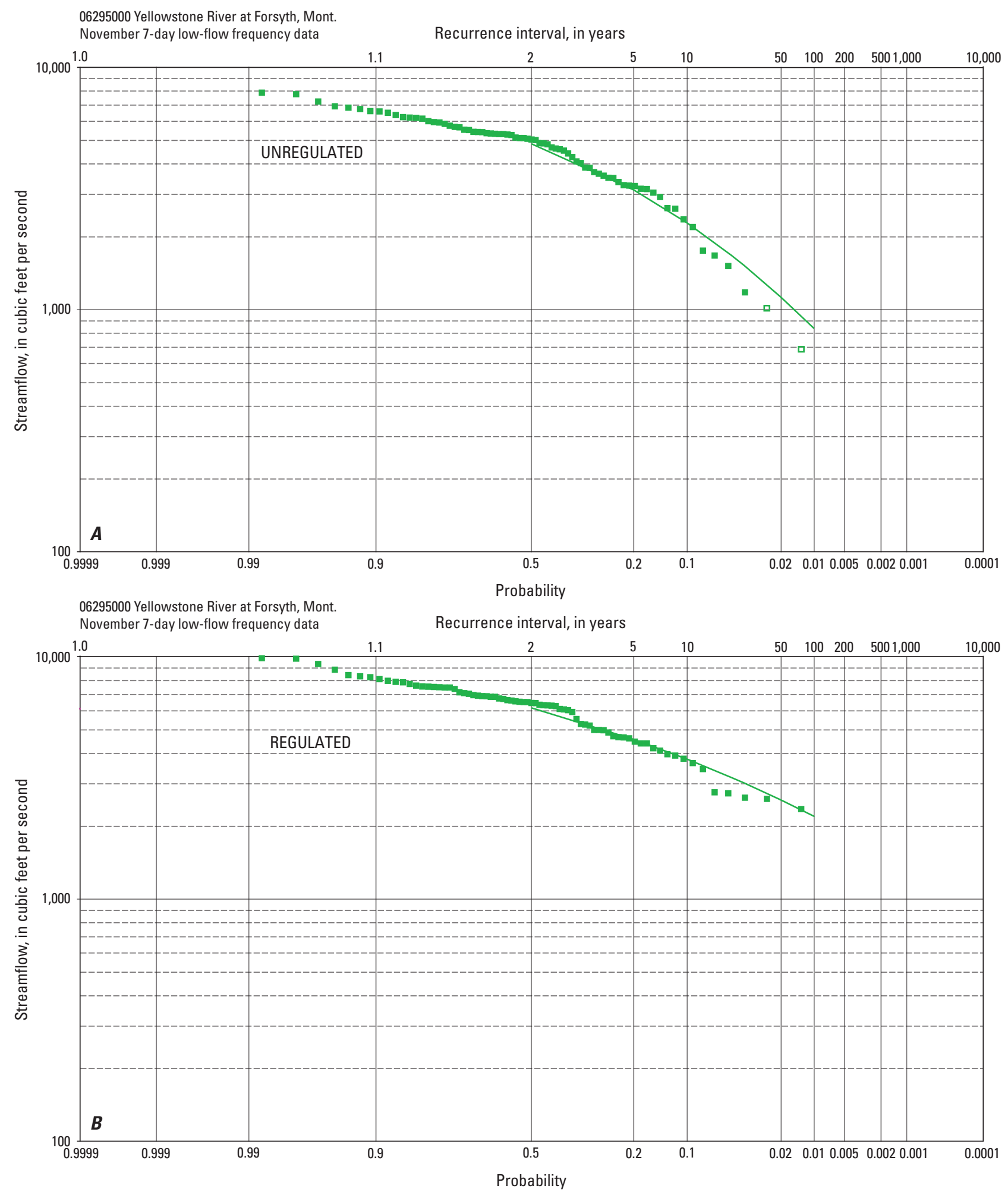

EXPLANATION

7-Day Data

- Estimated $n$-day values

- $n$-day frequency curve

口 Outlier

Figure 2-1-19. November 7-day low-flow frequency data for streamflow-gaging station 06295000 (Yellowstone River at Forsyth, Mont.) for $A$, unregulated and $B$, regulated streamflow conditions, 1928-2002. 


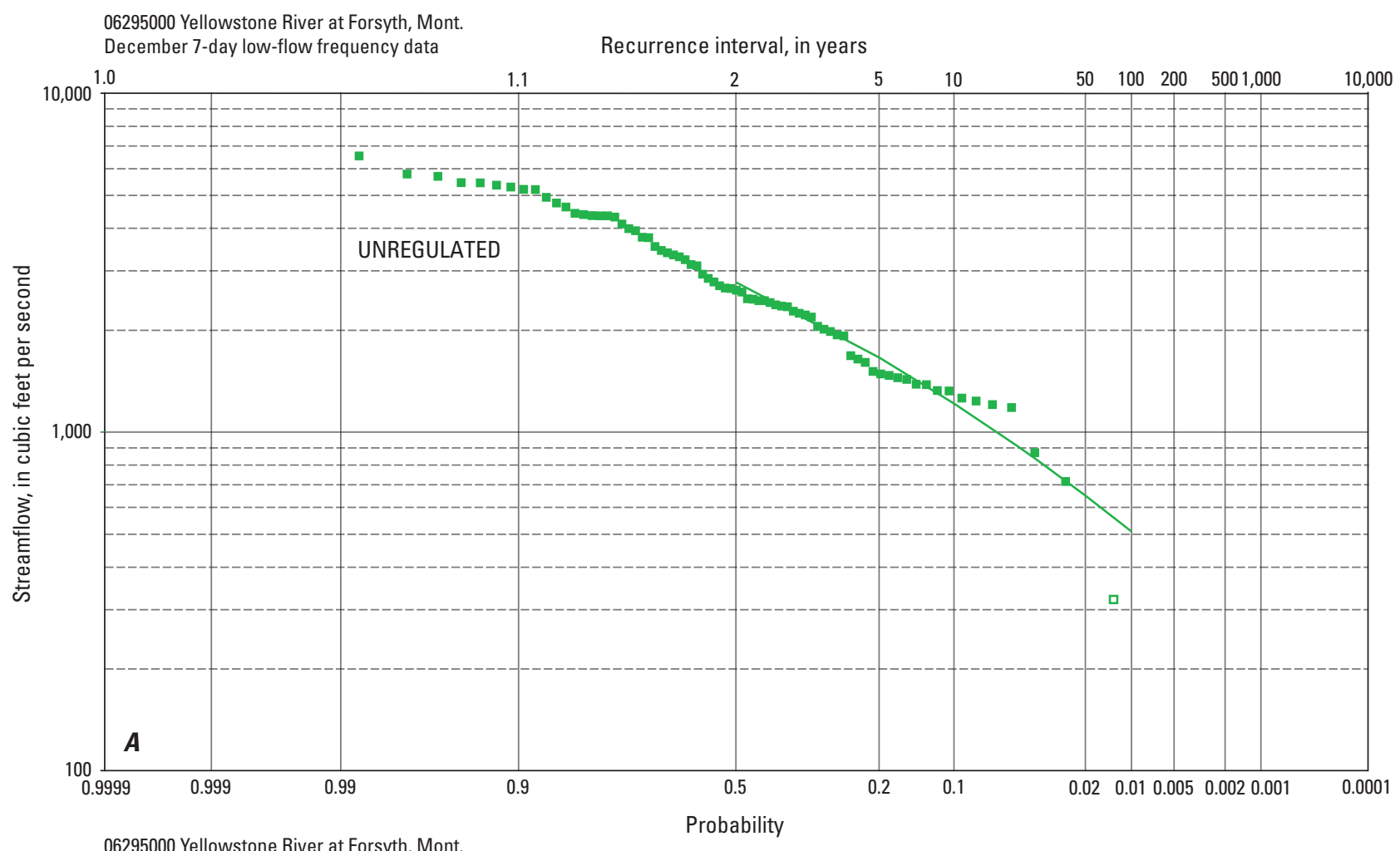

06295000 Yellowstone River at Forsyth, Mont December 7-day low-flow frequency data

Recurrence interval, in years

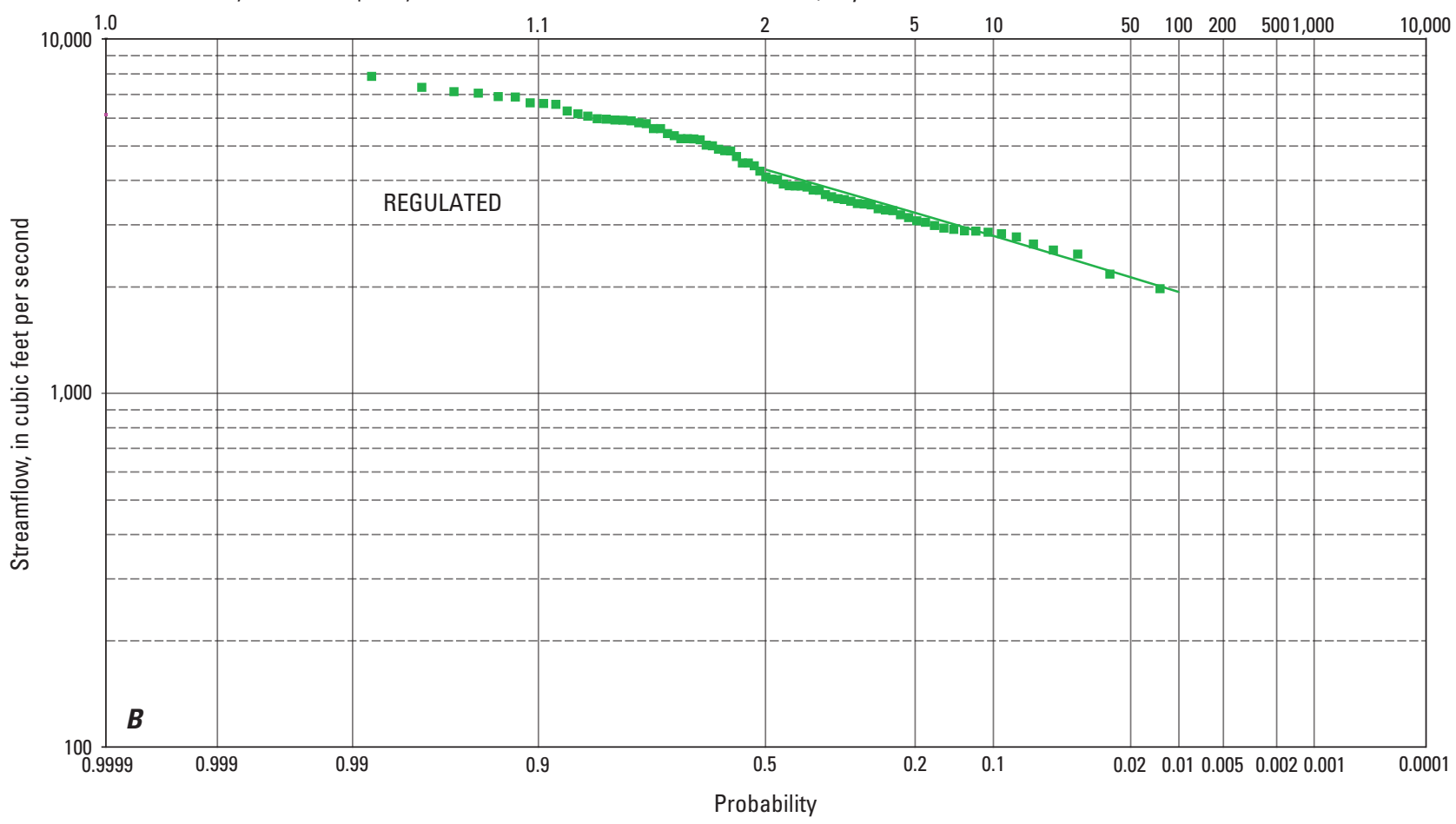

EXPLANATION

7-Day Data

- Estimated $n$-day values

- n-day frequency curve

․ Outlier

Figure 2-1-20. December 7-day low-flow frequency data for streamflow-gaging station 06295000 (Yellowstone River at Forsyth, Mont.) for $A$, unregulated and $B$, regulated streamflow conditions, 1928-2002. 
06295000 Yellowstone River at Forsyth, Mont.

Annual flow-duration data for unregulated and regulated streamflow conditions

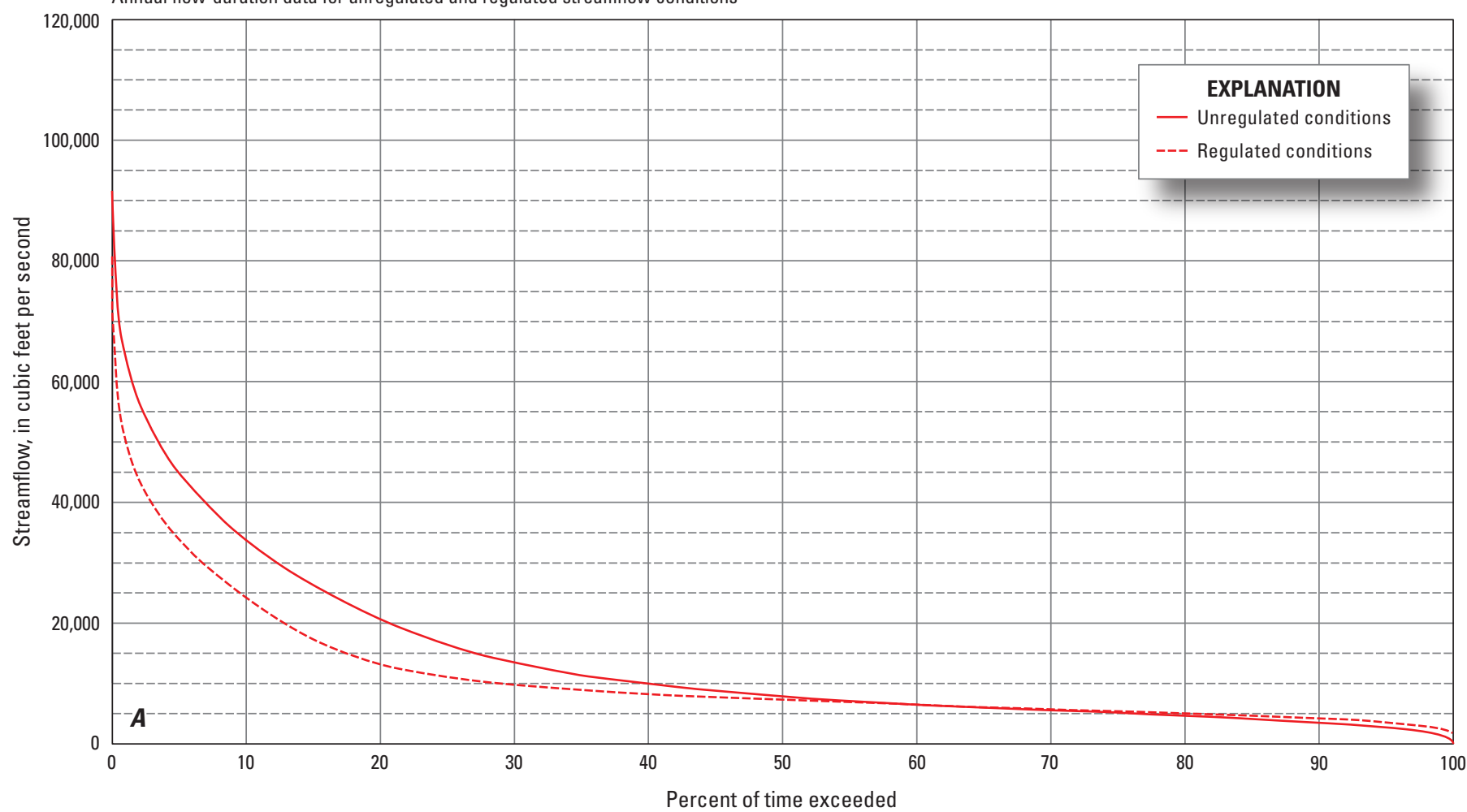

06295000 Yellowstone River at Forsyth, Mont.

Seasonal flow-duration data for unregulated and regulated streamflow conditions

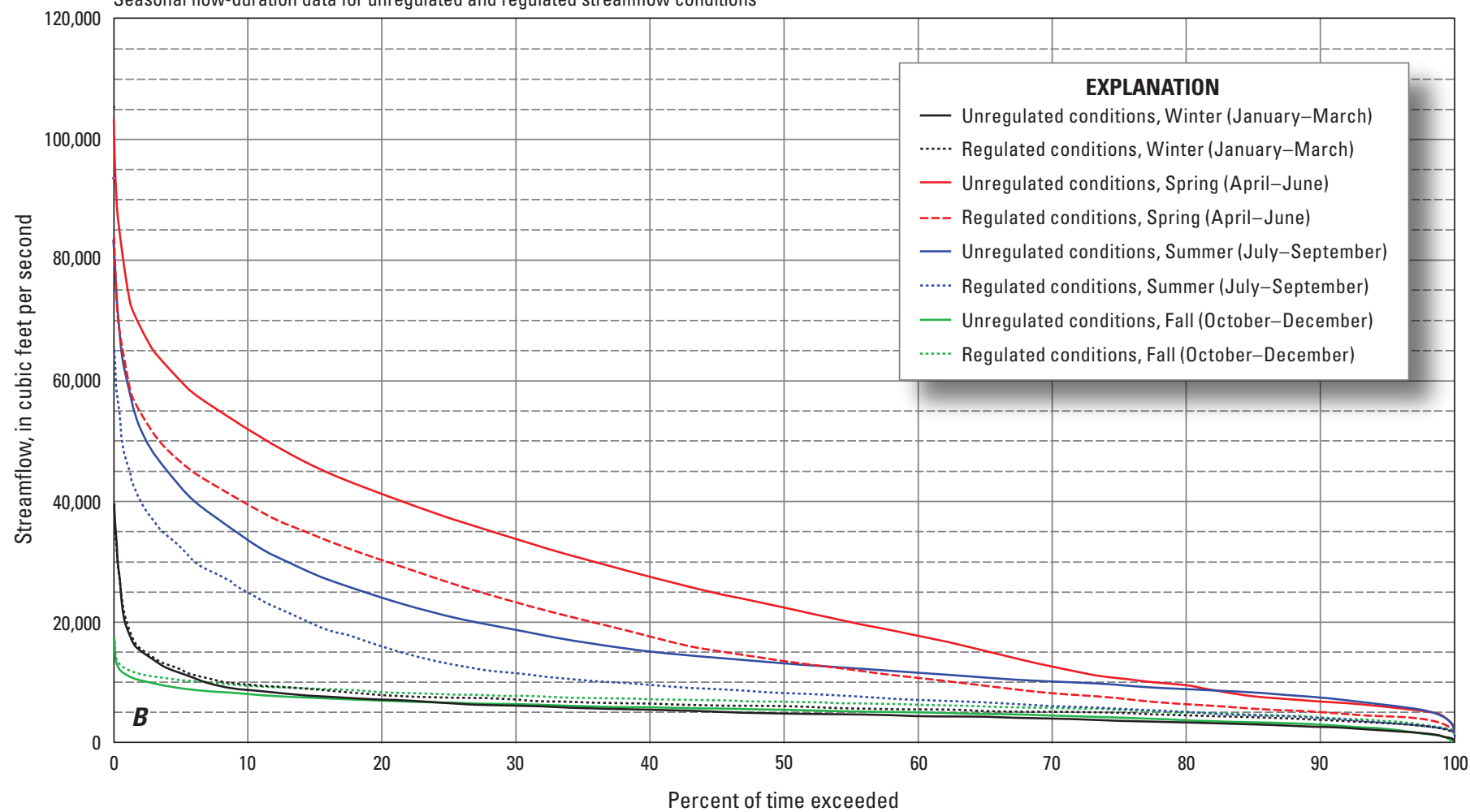

Figure 2-1-21. A, Annual and B, seasonal flow-duration data for streamflow-gaging station 06295000 (Yellowstone River at Forsyth, Mont.) for unregulated and regulated streamflow conditions, 1928-2002. 


\section{Appendix 2-2. Statistics for Streamflow-Gaging Station 06309000 (Yellowstone River at Miles City, Mont.)}

Table 2-2-1. Annual $n$-day high-flow frequency data for streamflow-gaging station 06309000 (Yellowstone River at Miles City, Mont.) for unregulated and regulated streamflow conditions, 1928-2002.

[Abbreviations: $\mathrm{ft}^{3} / \mathrm{s}$, cubic feet per second. Symbol: \%, percent]

\begin{tabular}{|c|c|c|c|c|c|c|c|}
\hline \multicolumn{8}{|c|}{ Unregulated } \\
\hline \multirow{3}{*}{$\begin{array}{c}n, \text { period of } \\
\text { consecutive } \\
\text { days }\end{array}$} & \multicolumn{7}{|c|}{ Streamflow, in $\mathrm{ft}^{3} / \mathrm{s}$, for indicated recurrence interval, in years, and exceedance probability, in percent } \\
\hline & 2 & 5 & 10 & 20 & 25 & 50 & 100 \\
\hline & $50 \%$ & $20 \%$ & $10 \%$ & $5 \%$ & $4 \%$ & $2 \%$ & $1 \%$ \\
\hline 1 & 61,800 & 76,600 & 85,500 & 93,400 & 95,800 & 103,000 & 110,000 \\
\hline 3 & 59,900 & 74,600 & 83,300 & 91,100 & 93,500 & 101,000 & 107,000 \\
\hline 7 & 56,600 & 70,400 & 78,600 & 86,000 & 88,200 & 94,800 & 101,000 \\
\hline 15 & 52,300 & 64,800 & 72,300 & 79,000 & 81,000 & 87,000 & 92,800 \\
\hline 30 & 47,300 & 58,400 & 64,900 & 70,600 & 72,400 & 77,500 & 82,400 \\
\hline 60 & 40,000 & 48,600 & 53,600 & 58,000 & 59,300 & 63,200 & 66,800 \\
\hline 90 & 34,000 & 40,700 & 44,400 & 47,700 & 48,700 & 51,500 & 54,200 \\
\hline 120 & 29,200 & 34,600 & 37,700 & 40,300 & 41,100 & 43,400 & 45,500 \\
\hline 183 & 22,700 & 26,600 & 28,800 & 30,700 & 31,300 & 32,900 & 34,400 \\
\hline \multicolumn{8}{|c|}{ Regulated } \\
\hline \multirow{3}{*}{$\begin{array}{c}n, \text { period of } \\
\text { consecutive } \\
\text { days }\end{array}$} & \multicolumn{7}{|c|}{ Streamflow, in $\mathrm{ft}^{3} / \mathrm{s}$, for indicated recurrence interval, in years, and exceedance probability, in percent } \\
\hline & 2 & 5 & 10 & 20 & 25 & 50 & 100 \\
\hline & $50 \%$ & $20 \%$ & $10 \%$ & $5 \%$ & $4 \%$ & $2 \%$ & $1 \%$ \\
\hline 1 & 46,900 & 60,900 & 68,800 & 75,700 & 77,800 & 83,700 & 89,200 \\
\hline 3 & 44,900 & 58,700 & 66,700 & 73,600 & 75,700 & 81,800 & 87,400 \\
\hline 7 & 42,000 & 55,200 & 62,700 & 69,100 & 71,100 & 76,600 & 81,700 \\
\hline 15 & 38,600 & 50,600 & 57,400 & 63,200 & 64,900 & 69,900 & 74,400 \\
\hline 30 & 34,400 & 45,100 & 51,100 & 56,200 & 57,700 & 62,100 & 66,000 \\
\hline 60 & 28,000 & 36,900 & 42,100 & 46,600 & 47,900 & 51,800 & 55,400 \\
\hline 90 & 23,000 & 30,200 & 34,300 & 37,900 & 38,900 & 42,000 & 44,800 \\
\hline 120 & 19,500 & 25,300 & 28,600 & 31,400 & 32,300 & 34,700 & 37,000 \\
\hline 183 & 15,900 & 20,000 & 22,300 & 24,400 & 25,000 & 26,800 & 28,400 \\
\hline
\end{tabular}


Table 2-2-2. Annual, seasonal, and monthly $n$-day low-flow frequency data for streamflow-gaging station 06309000 (Yellowstone River at Miles City, Mont.) for unregulated and regulated conditions, 1928-2002.

[Abbreviations: $\mathrm{ft}^{3} / \mathrm{s}$, cubic feet per second. Symbol: \%, percent]

Unregulated

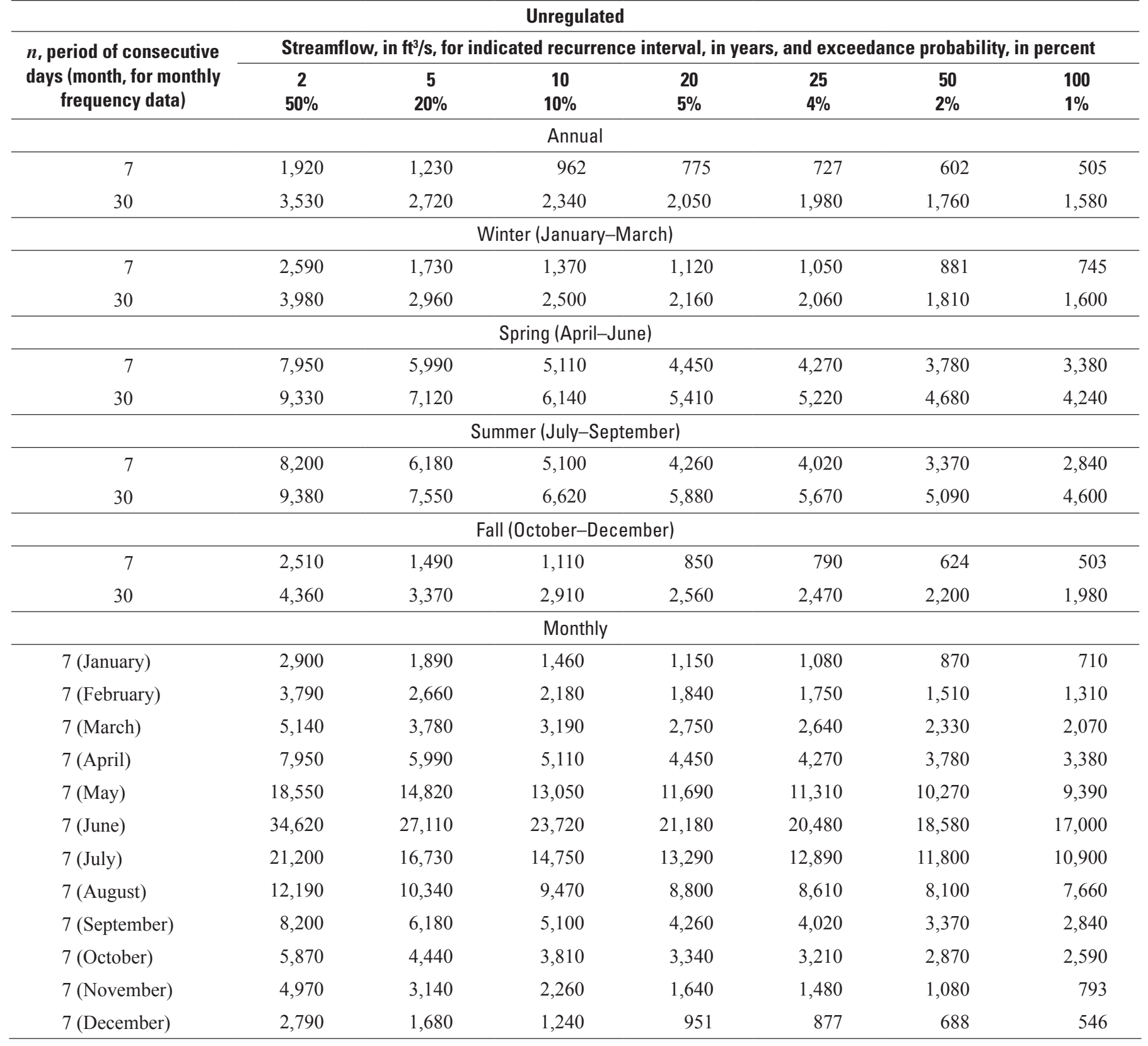


Table 2-2-2. Annual, seasonal, and monthly $n$-day low-flow frequency data for streamflow-gaging station 06309000 (Yellowstone River at Miles City, Mont.) for unregulated and regulated conditions, 1928-2002.-Continued

[Abbreviations: $\mathrm{ft}^{3} / \mathrm{s}$, cubic feet per second. Symbol: \%, percent]

\section{Regulated}

\begin{tabular}{|c|c|c|c|c|c|c|c|}
\hline \multirow{3}{*}{$\begin{array}{l}n \text {, period of consecutive } \\
\text { days (month, for monthly } \\
\text { frequency data) }\end{array}$} & \multicolumn{7}{|c|}{ Streamflow, in ft³/s, for indicated recurrence interval, in years, and exceedance probability, in percent } \\
\hline & 2 & 5 & 10 & 20 & 25 & 50 & 100 \\
\hline & $50 \%$ & $20 \%$ & $10 \%$ & $5 \%$ & $4 \%$ & $2 \%$ & $1 \%$ \\
\hline \multicolumn{8}{|c|}{ Annual } \\
\hline 7 & 3,390 & 2,710 & 2,420 & 2,210 & 2,150 & 2,000 & 1,880 \\
\hline 30 & 4,680 & 3,700 & 3,220 & 2,850 & 2,740 & 2,460 & 2,220 \\
\hline 7 & 3,990 & 3,170 & 2,820 & 2,560 & 2,490 & 2,300 & 2,140 \\
\hline 30 & 5,220 & 4,210 & 3,750 & 3,400 & 3,300 & 3,030 & 2,800 \\
\hline \multicolumn{8}{|c|}{ Spring (April-June) } \\
\hline 7 & 5,950 & 4,420 & 3,760 & 3,280 & 3,150 & 2,810 & 2,520 \\
\hline 30 & 6,150 & 4,350 & 3,580 & 3,020 & 2,870 & 2,470 & 2,160 \\
\hline \multicolumn{8}{|c|}{ Fall (October-December) } \\
\hline 7 & 4,140 & 3,120 & 2,690 & 2,380 & 2,300 & 2,080 & 1,900 \\
\hline 30 & 5,690 & 4,570 & 4,030 & 3,620 & 3,510 & 3,190 & 2,920 \\
\hline \multicolumn{8}{|c|}{ Monthly } \\
\hline 7 (January) & 4,330 & 3,400 & 2,990 & 2,680 & 2,590 & 2,360 & 2,170 \\
\hline 7 (February) & 5,000 & 3,880 & 3,390 & 3,030 & 2,930 & 2,660 & 2,430 \\
\hline 7 (March) & 6,020 & 4,630 & 4,010 & 3,560 & 3,430 & 3,090 & 2,810 \\
\hline 7 (April) & 5,980 & 4,440 & 3,780 & 3,300 & 3,170 & 2,820 & 2,540 \\
\hline 7 (October) & 7,060 & 5,530 & 4,810 & 4,260 & 4,110 & 3,700 & 3,350 \\
\hline 7 (November) & 6,460 & 4,750 & 3,900 & 3,250 & 3,070 & 2,590 & 2,200 \\
\hline 7 (December) & 4,380 & 3,290 & 2,830 & 2,490 & 2,400 & 2,160 & 1,960 \\
\hline
\end{tabular}


Table 2-2-3. Annual and seasonal flow-duration data for streamflow-gaging station 06309000 (Yellowstone River at Miles City, Mont.) for unregulated and regulated streamflow conditions, 1928-2002.

[Abbreviations: $\mathrm{ft}^{3} / \mathrm{s}$, cubic feet per second. Symbol: \%, percent]

\begin{tabular}{|c|c|c|c|c|c|c|c|c|c|c|c|c|c|c|c|c|c|c|c|}
\hline \multicolumn{20}{|c|}{ Streamflow, in $\mathrm{ft}^{3} / \mathrm{s}$, which was equaled or exceeded for indicated percent of time } \\
\hline $\begin{array}{c}\text { Streamflow } \\
\text { condition }\end{array}$ & $1 \%$ & $2 \%$ & $5 \%$ & $10 \%$ & $15 \%$ & $20 \%$ & $25 \%$ & $30 \%$ & $40 \%$ & $50 \%$ & $60 \%$ & $70 \%$ & $75 \%$ & $80 \%$ & $85 \%$ & $90 \%$ & $95 \%$ & $98 \%$ & $99 \%$ \\
\hline \multicolumn{20}{|c|}{ Annual } \\
\hline Unregulated & 66,100 & 58,800 & 46,700 & 35,100 & 27,300 & 21,600 & 17,400 & 14,300 & 10,600 & 8,300 & 6,870 & 5,860 & 5,420 & 4,910 & 4,330 & 3,670 & 2,870 & 1,960 & 1,540 \\
\hline Regulated & 51,600 & 45,300 & 34,900 & 24,800 & 17,800 & 13,800 & 11,600 & 10,230 & 8,640 & 7,640 & 6,880 & 6,110 & 5,710 & 5,290 & 4,860 & 4,370 & 3,740 & 3,010 & 2,670 \\
\hline \multicolumn{20}{|c|}{ Winter (January-March) } \\
\hline Unregulated & 21,700 & 16,600 & 12,400 & 9,430 & 8,290 & 7,540 & 6,960 & 6,470 & 5,730 & 5,170 & 4,680 & 4,130 & 3,820 & 3,500 & 3,150 & 2,710 & 2,080 & 1,600 & 1,320 \\
\hline Regulated & 21,500 & 17,100 & 13,100 & 10,400 & 9,250 & 8,430 & 7,910 & 7,500 & 6,830 & 6,240 & 5,800 & 5,250 & 4,990 & 4,690 & 4,400 & 4,000 & 3,330 & 2,890 & 2,620 \\
\hline \multicolumn{20}{|c|}{ Spring (April-June) } \\
\hline Unregulated & 77,600 & 71,000 & 62,000 & 53,800 & 47,500 & 42,800 & 38,600 & 35,000 & 28,600 & 23,300 & 18,600 & 13,400 & 11,500 & 10,200 & 8,350 & 7,410 & 6,430 & 5,470 & 4,880 \\
\hline Regulated & 62,000 & 55,500 & 47,800 & 40,600 & 35,400 & 31,000 & 27,200 & 23,800 & 17,800 & 13,900 & 11,200 & 8,640 & 7,790 & 6,860 & 6,220 & 5,470 & 4,640 & 4,070 & 3,630 \\
\hline \multicolumn{20}{|c|}{ Summer (July-September) } \\
\hline Unregulated & 63,000 & 54,500 & 44,200 & 35,400 & 29,400 & 25,400 & 22,000 & 19,600 & 16,100 & 14,000 & 12,300 & 10,800 & 10,200 & 9,550 & 8,880 & 8,050 & 6,730 & 5,670 & 4,980 \\
\hline Regulated & 48,600 & 41,200 & 33,300 & 25,700 & 20,400 & 16,400 & 13,700 & 12,000 & 9,950 & 8,550 & 7,460 & 6,390 & 5,840 & 5,310 & 4,760 & 4,200 & 3,530 & 2,820 & 2,570 \\
\hline \multicolumn{20}{|c|}{ Fall (October-December) } \\
\hline Unregulated & 11,700 & 10,800 & 9,390 & 8,460 & 7,790 & 7,300 & 6,940 & 6,650 & 6,120 & 5,740 & 5,300 & 4,670 & 4,320 & 3,930 & 3,540 & 3,040 & 2,340 & 1,400 & 1,110 \\
\hline Regulated & 12,600 & 11,900 & 10,800 & 9,950 & 9,380 & 8,850 & 8,410 & 8,090 & 7,560 & 7,100 & 6,640 & 6,050 & 5,650 & 5,260 & 4,840 & 4,350 & 3,750 & 2,890 & 2,590 \\
\hline
\end{tabular}


Table 2-2-4. Monthly and annual streamflow characteristics for streamflow-gaging station 06309000 (Yellowstone River at Miles City, Mont.) for unregulated and regulated streamflow conditions, 1928-2002.

[Abbreviations: $\mathrm{ft}^{3} / \mathrm{s}$, cubic feet per second]

Unregulated

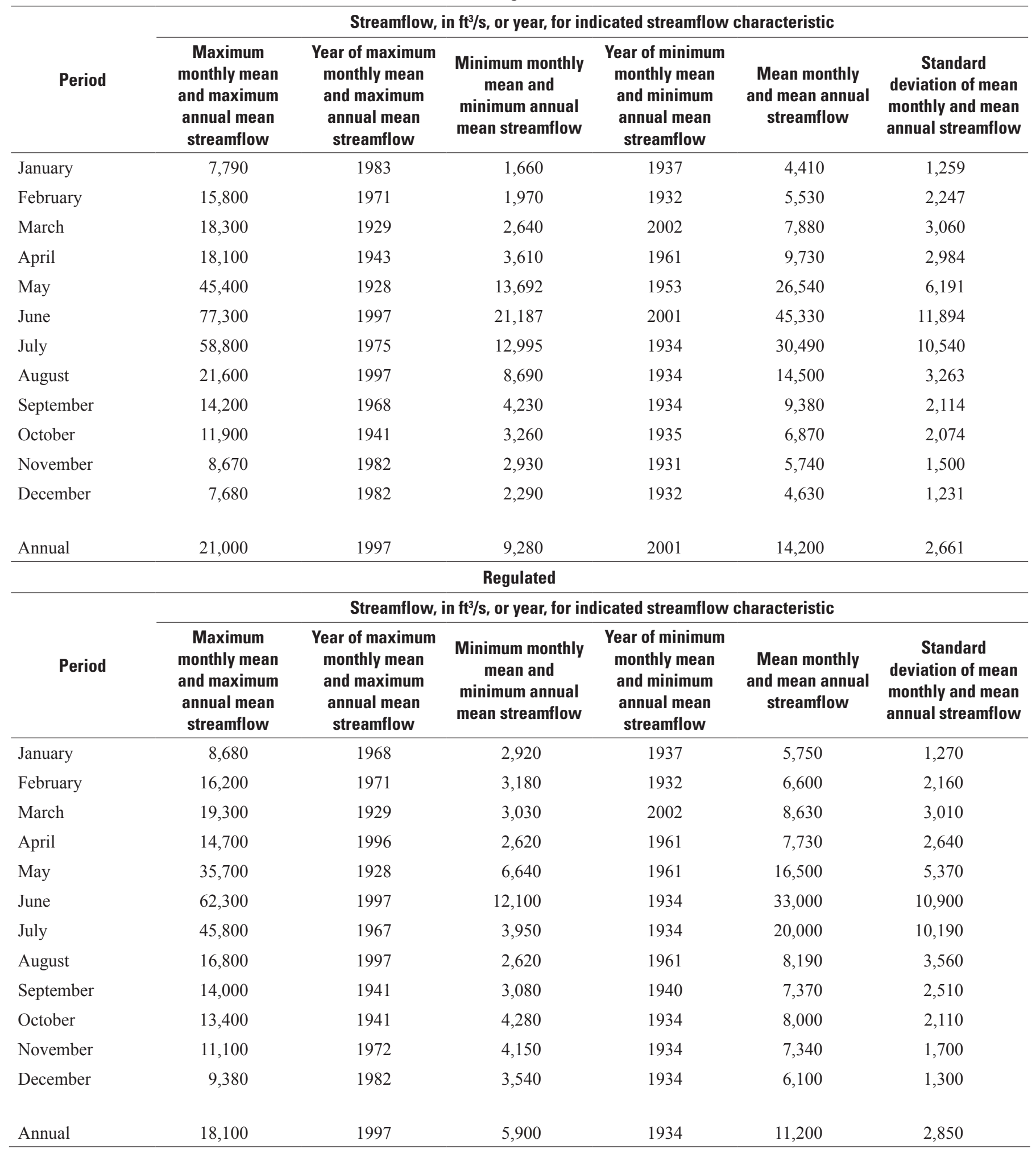




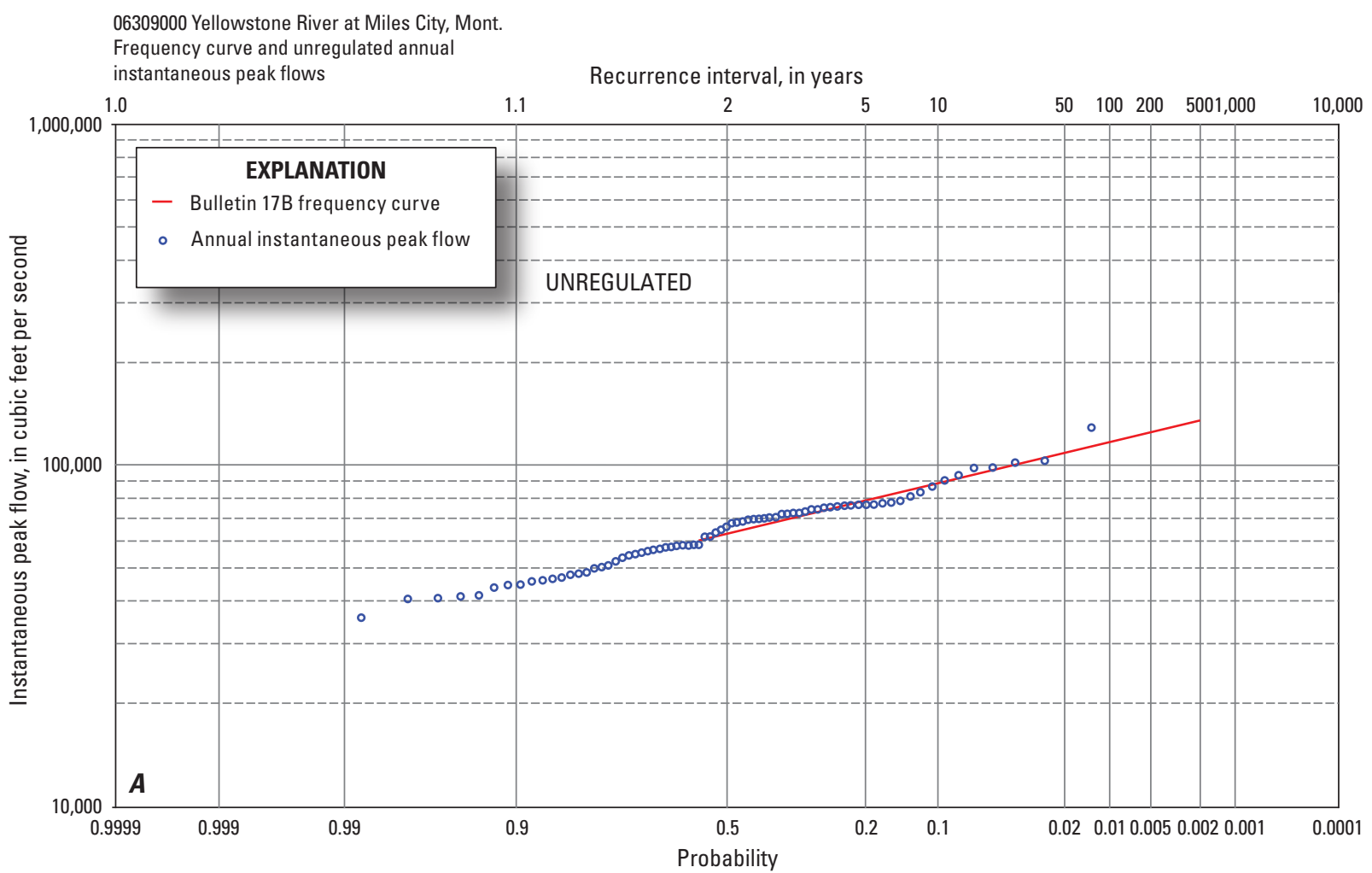

063090000 Yellowstone River at Miles City, Mont.

Time series of unregulated annual instantaneous peak flows

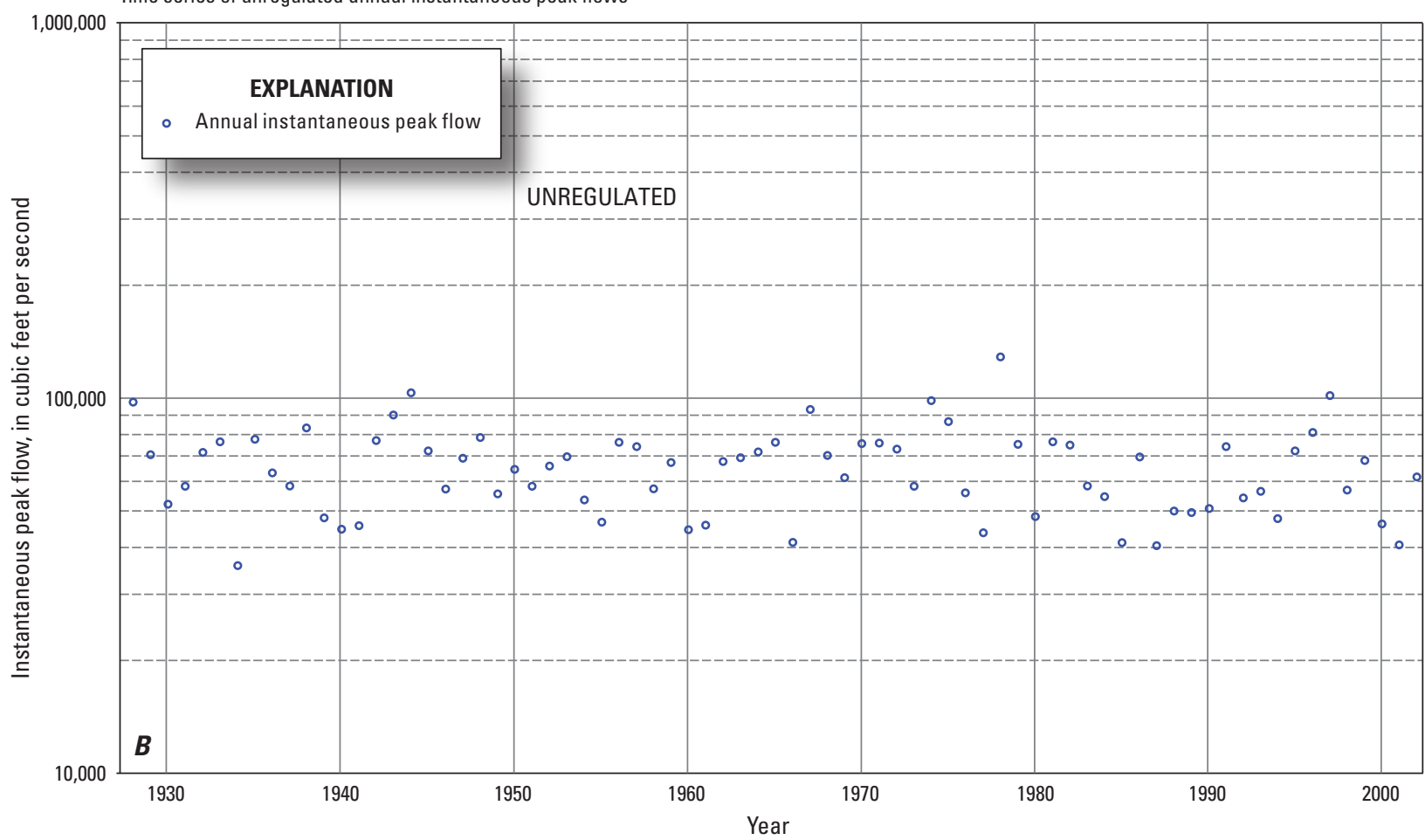

Figure 2-2-1. Annual instantaneous peak-flow data for streamflow-gaging station 06309000 (Yellowstone River at Miles City, Mont.) for unregulated streamflow conditions, 1928-2002. A, Frequency curve and unregulated annual instantaneous peak flows. B, Time series of unregulated annual instantaneous peak flows. [Bulletin 17B: U.S. Interagency Advisory Council on Water Data, 1982] 

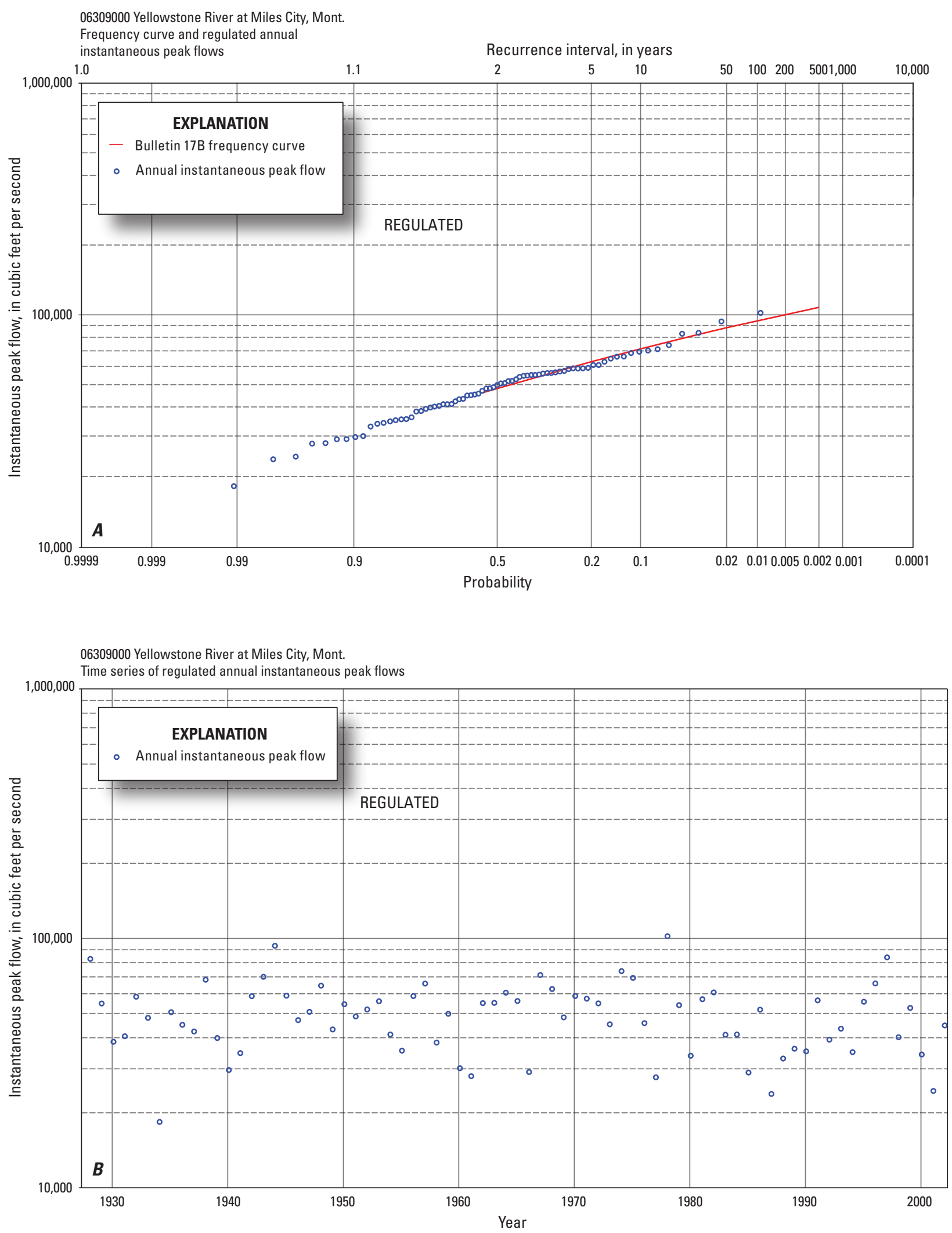

Figure 2-2-2. Annual instantaneous peak-flow data for streamflow-gaging station 06309000 (Yellowstone River at Miles City, Mont.) for regulated streamflow conditions, 1928-2002. A, Frequency curve and regulated annual instantaneous peak flows. $B$, Time series of regulated annual instantaneous peak flows. [Bulletin 17B: U.S. Interagency Advisory Council on Water Data, 1982] 


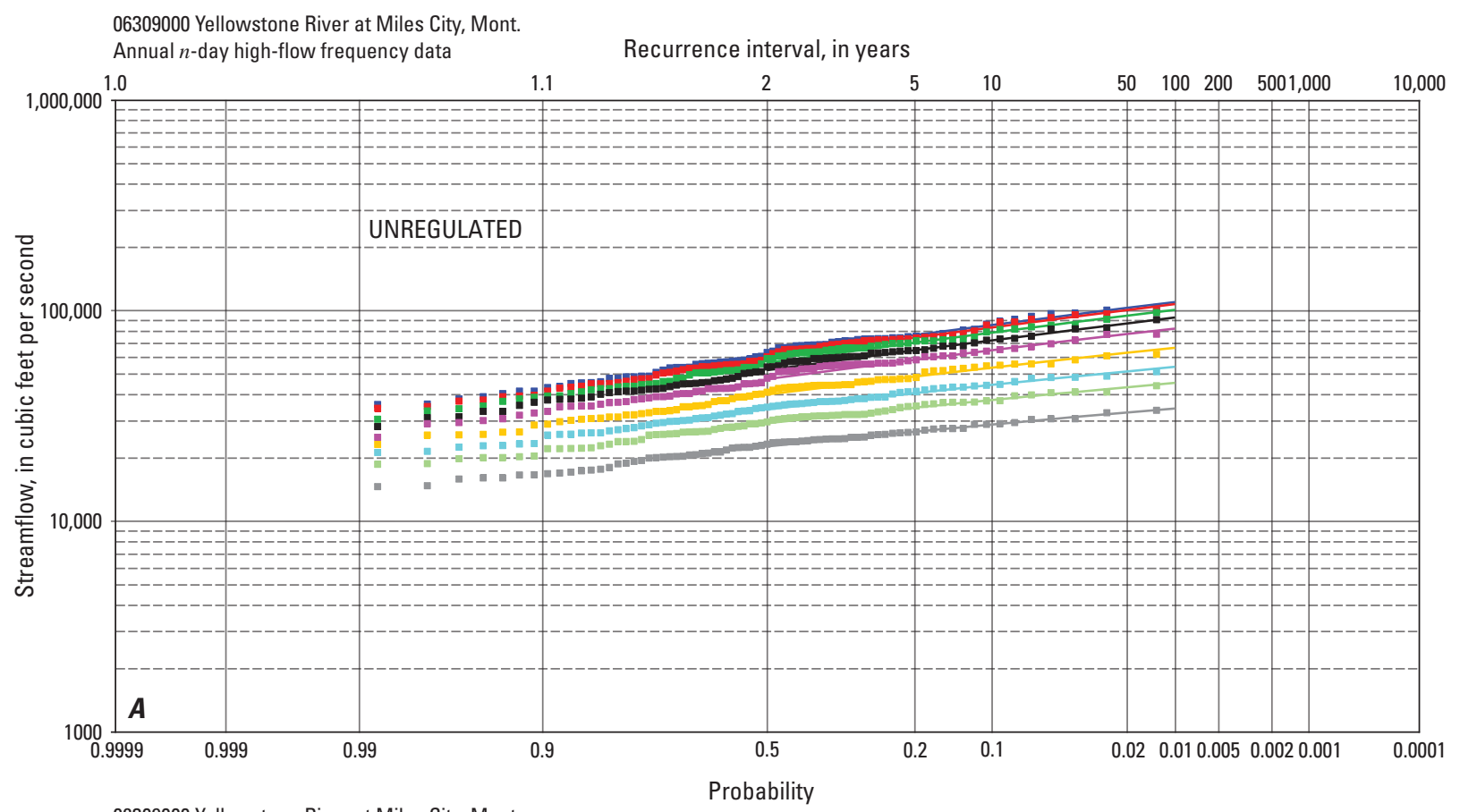

06309000 Yellowstone River at Miles City, Mont.

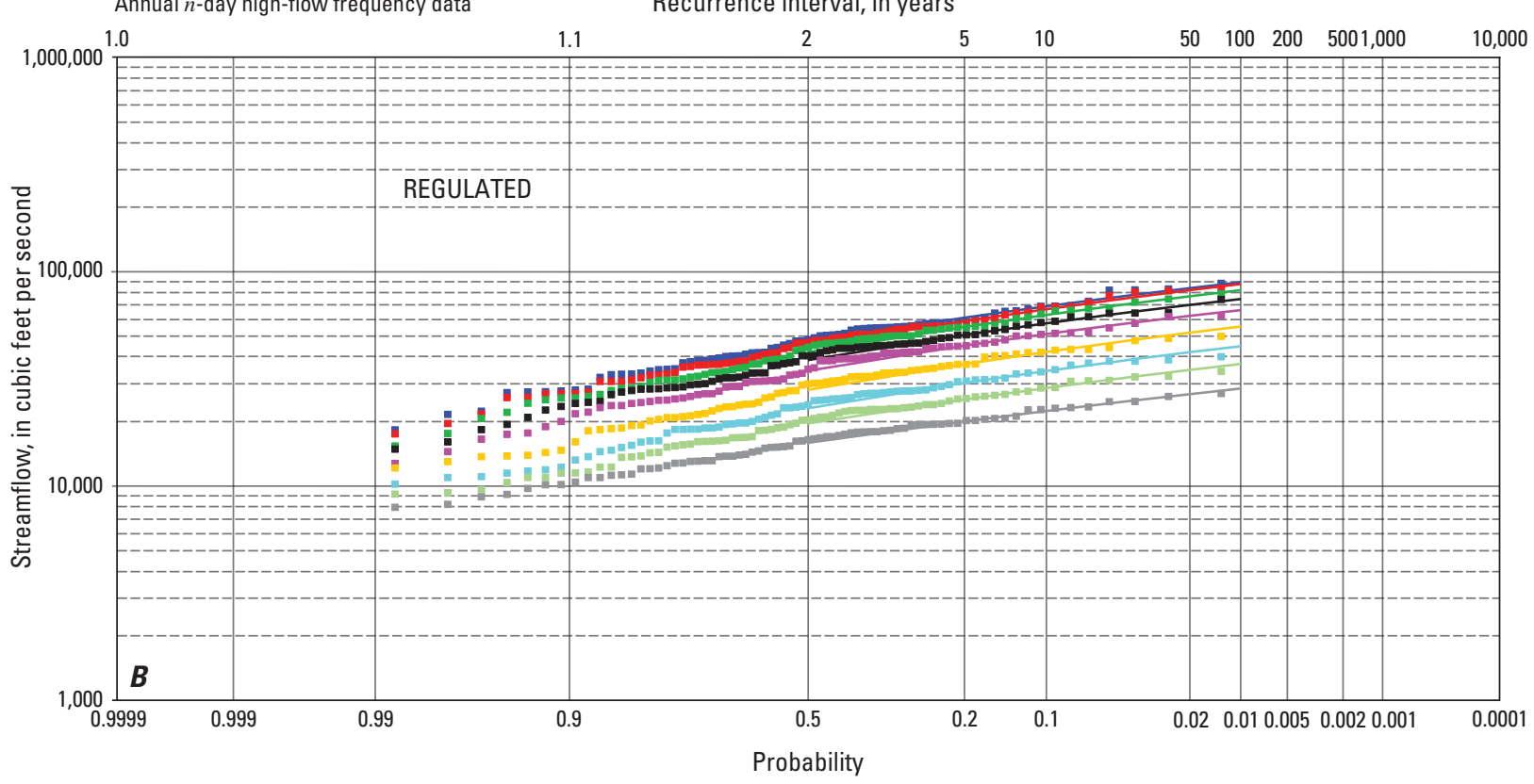

EXPLANATION

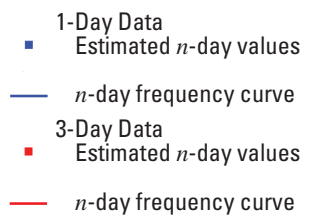

7-Day Data
Estimated $n$-day values
- $n$-day frequency curve
15-Day Data
Estimated $n$-day values
n-day frequency curve

30-Day Data
Estimated $n$-day values
$n$-day frequency curve
60-Day Data
Estimated $n$-day values
$n$-day frequency curve
90-Day Data
Estimated $n$-day values
n-day frequency curve
120-Day Data
Estimated $n$-day values
$n$-day frequency curve
183-Day Data
- Estimated $n$-day values
- n-day frequency curve

Figure 2-2-3. Annual $n$-day high-flow frequency data for streamflow-gaging station 06309000 (Yellowstone River at Miles City, Mont.) for $A$, unregulated and $B$, regulated streamflow conditions, 1928-2002. 

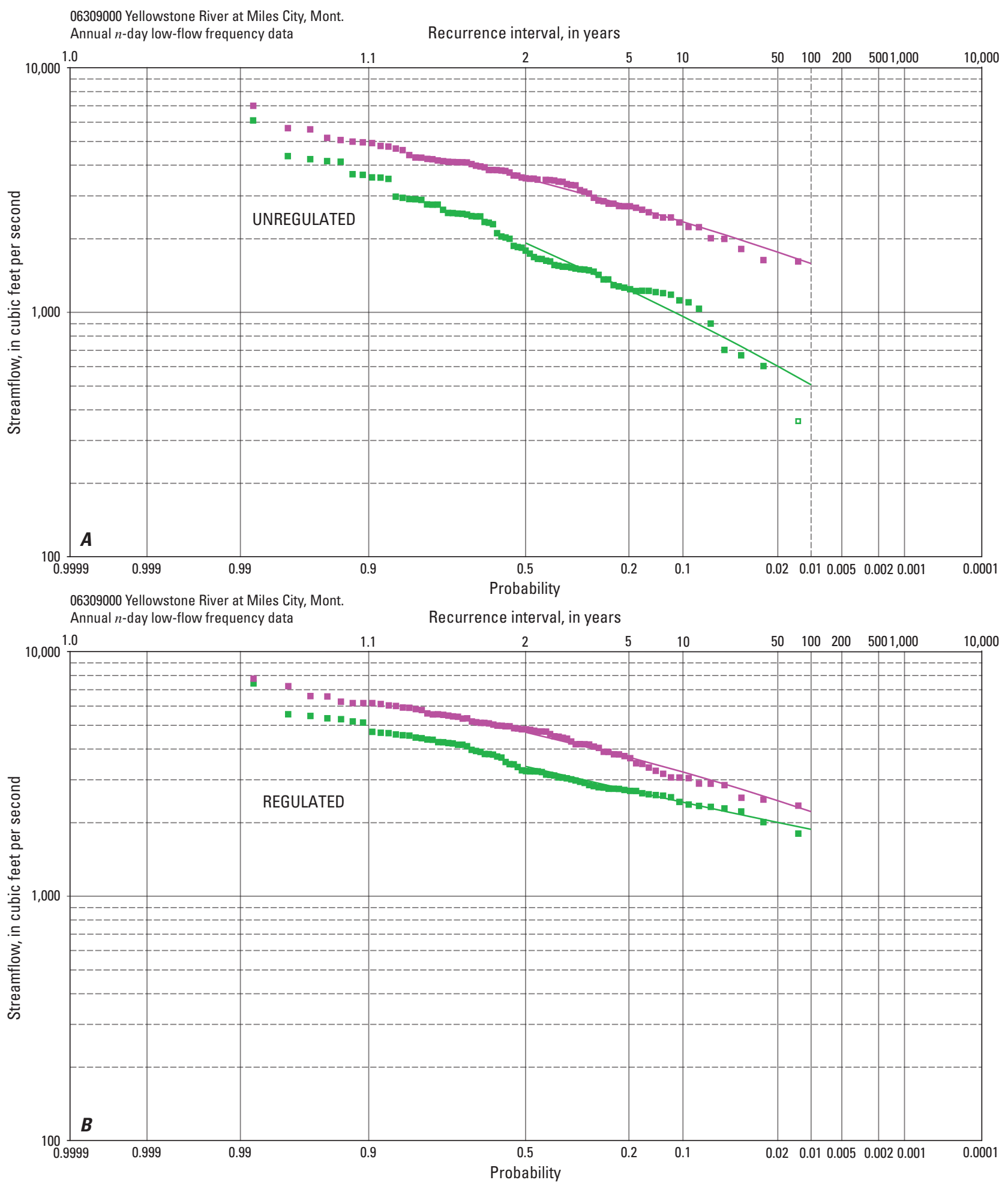

EXPLANATION

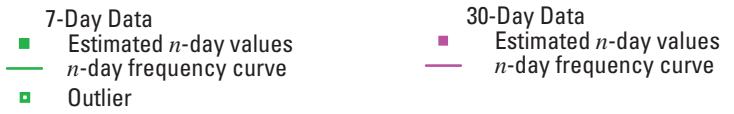

Figure 2-2-4. Annual $n$-day low-flow frequency data for streamflow-gaging station 06309000 (Yellowstone River at Miles City, Mont.) for $A$, unregulated and $B$, regulated streamflow conditions, 1928-2002. 
66309000 Yellowstone River at Miles City, Mont.

Winter (January-March) n-day low-flow frequency data Recurrence interval, in years

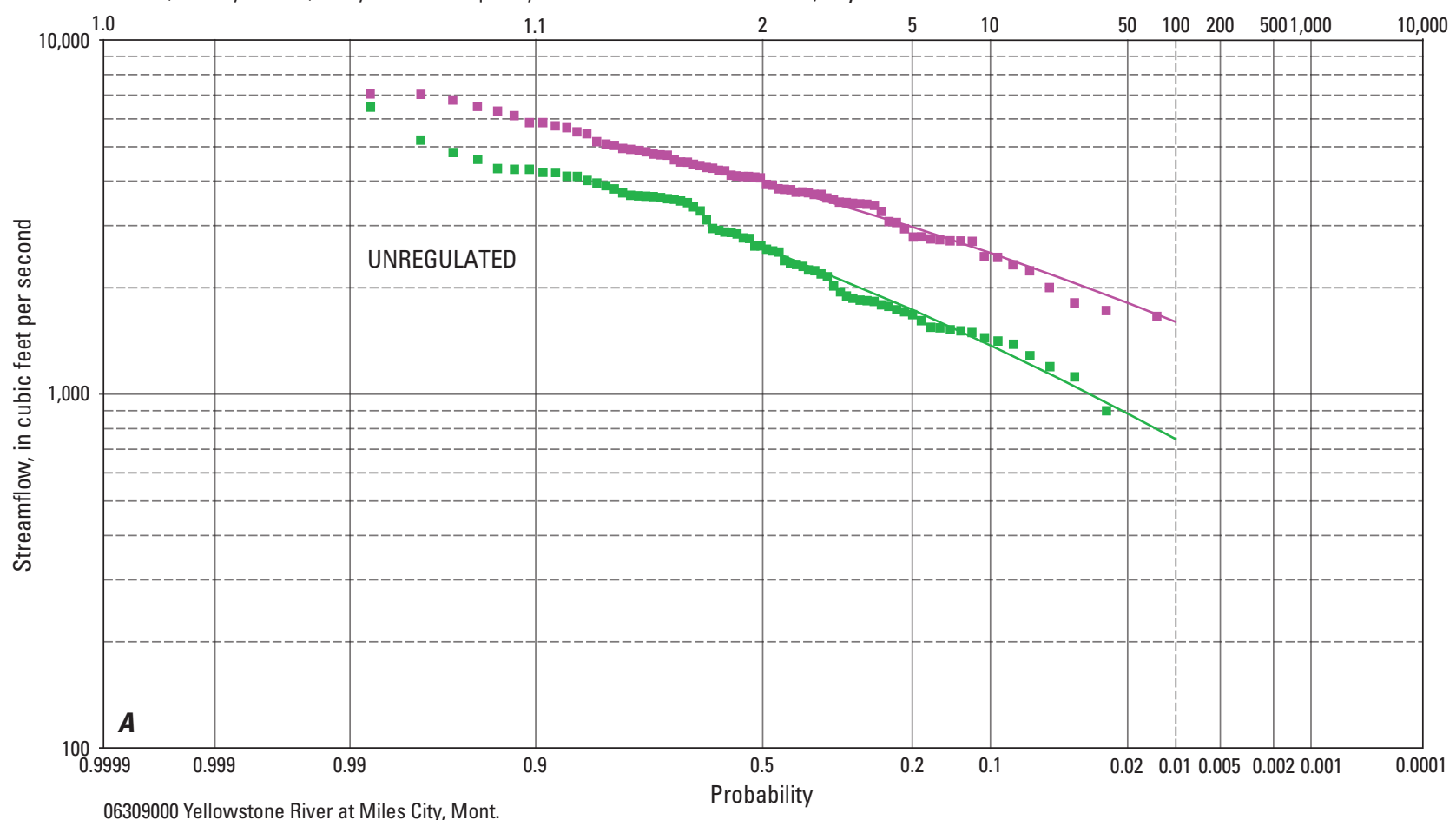

Winter (January-March) n-day low-flow frequency data Recurrence interval, in years

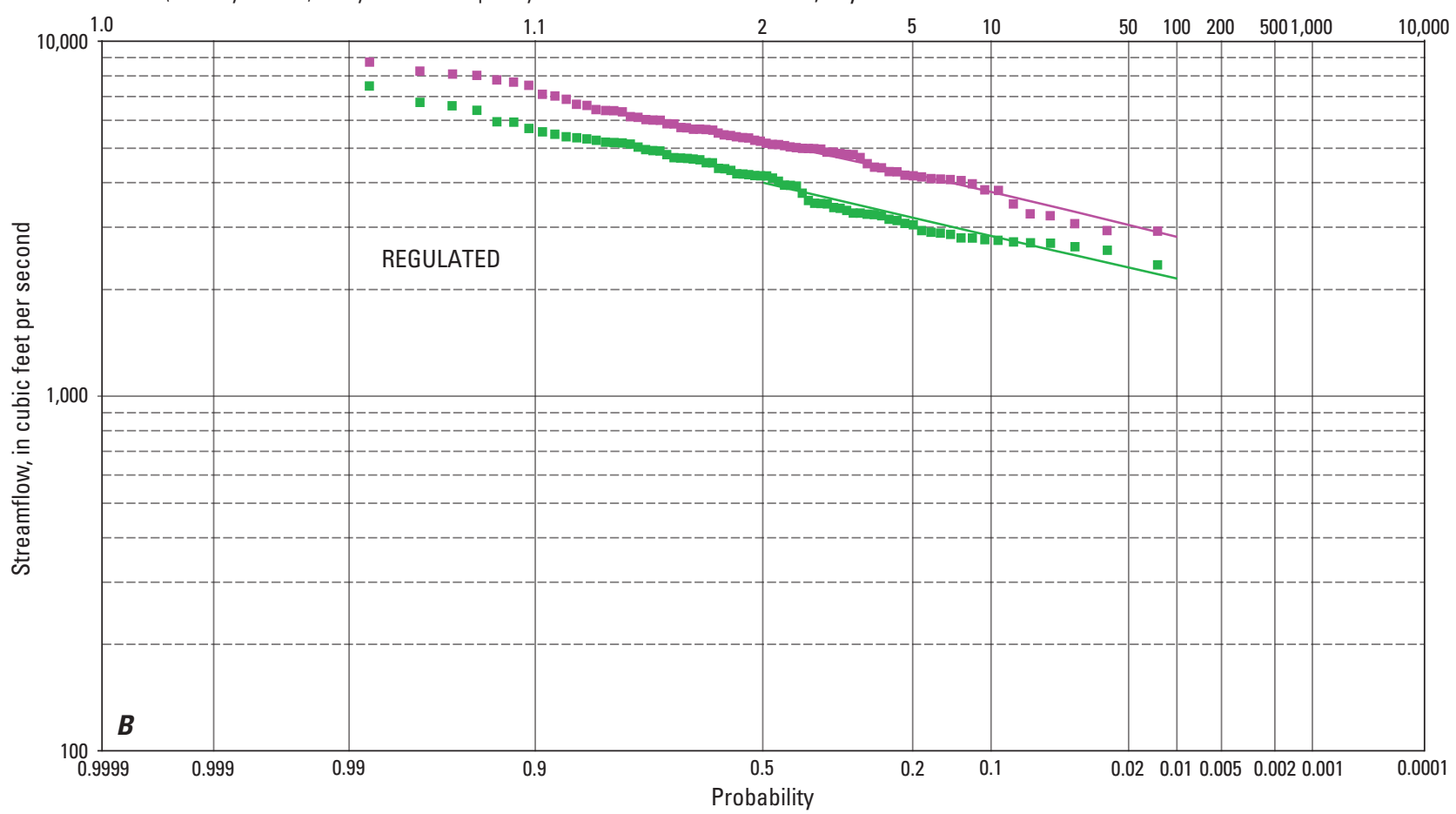

EXPLANATION

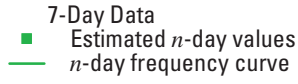

30-Day Data
Estimated $n$-day values
$n$-day frequency curve

Figure 2-2-5. Winter (January-March) n-day low-flow frequency data for streamflow-gaging station 06309000 (Yellowstone River at Miles City, Mont.) for $A$, unregulated and $B$, regulated streamflow conditions, 1928-2002. 

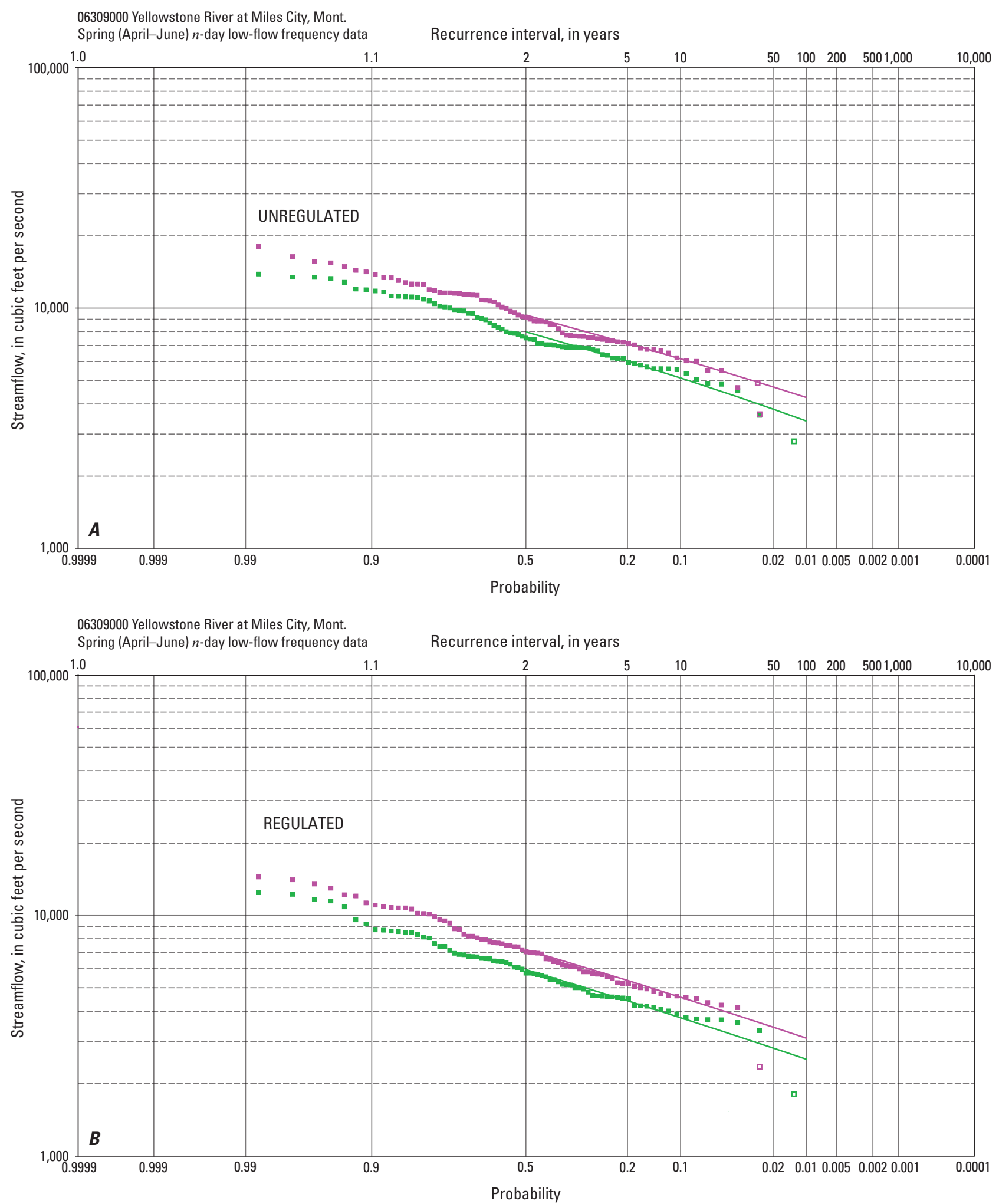

EXPLANATION

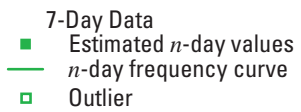

30-Day Data
Estimated $n$-day values
$n$-day frequency curve

Figure 2-2-6. Spring (April-June) $n$-day low-flow frequency data for streamflow-gaging station 06309000 (Yellowstone River at Miles City, Mont.) for $A$, unregulated and $B$, regulated streamflow conditions, 1928-2002. 
06309000 Yellowstone River at Miles City, Mont.

Summer (July-September) $n$-day low-flow frequency data Recurrence interval, in years

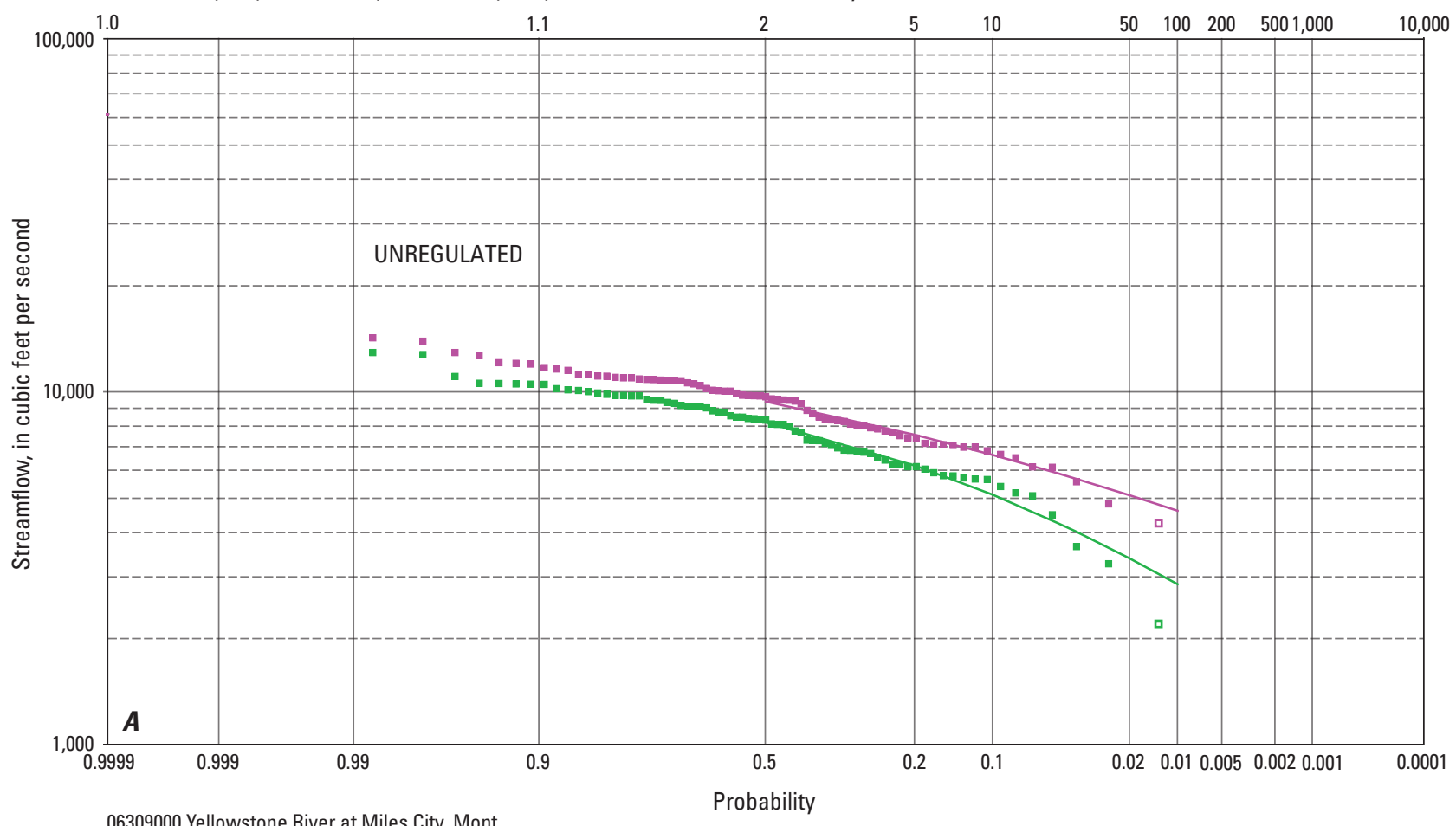

06309000 Yellowstone River at Miles City, Mont.

Recurrence interval, in years

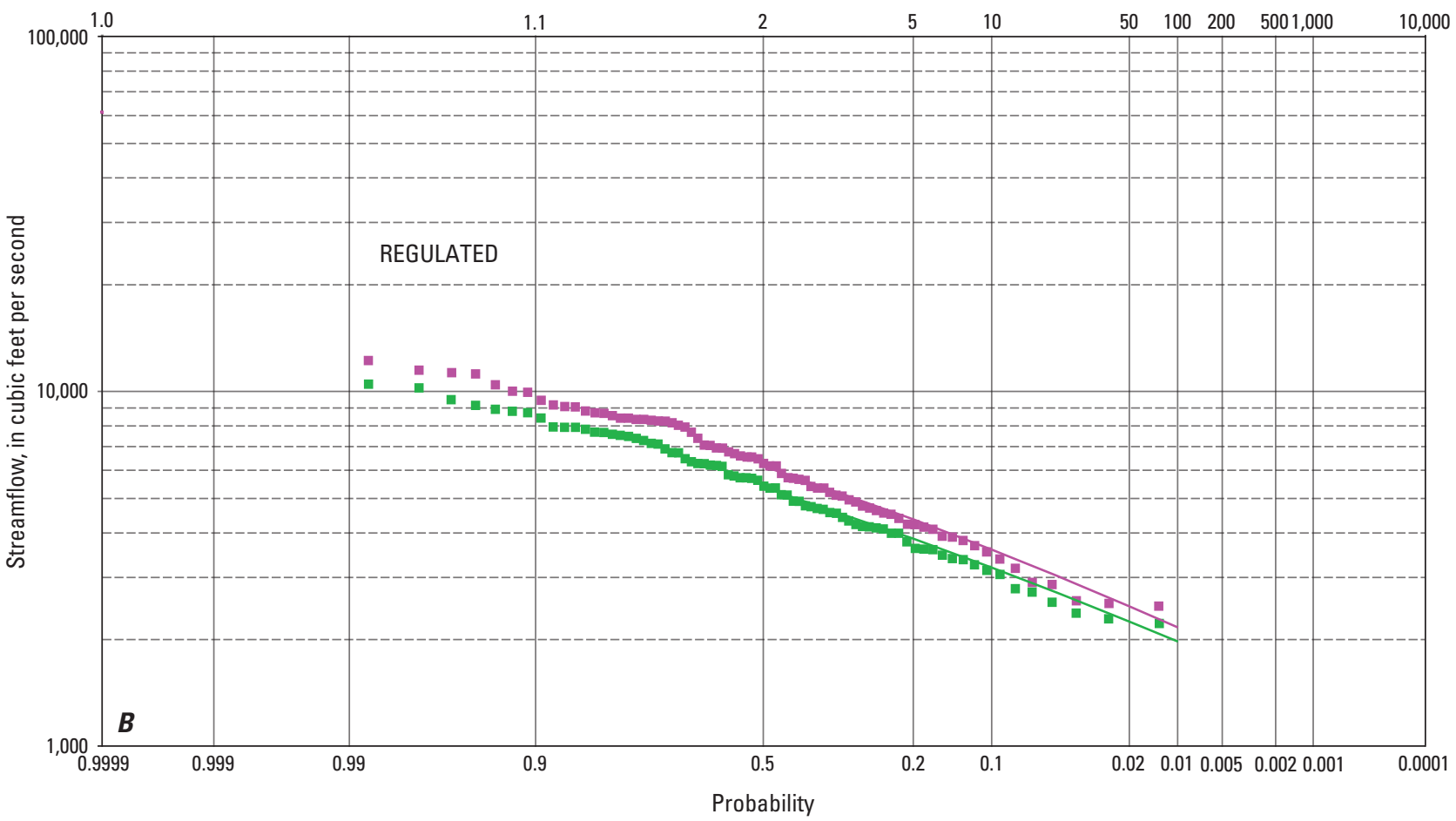

EXPLANATION

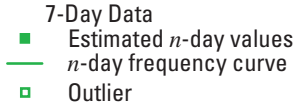

30-Day Data

- Estimated $n$-day values

- n-day frequency curve

Outlier

Figure 2-2-7. Summer (July-September) $n$-day low-flow frequency data for streamflow-gaging station 06309000 (Yellowstone River at Miles City, Mont.) for $A$, unregulated and $B$, regulated streamflow conditions, 1928-2002. 


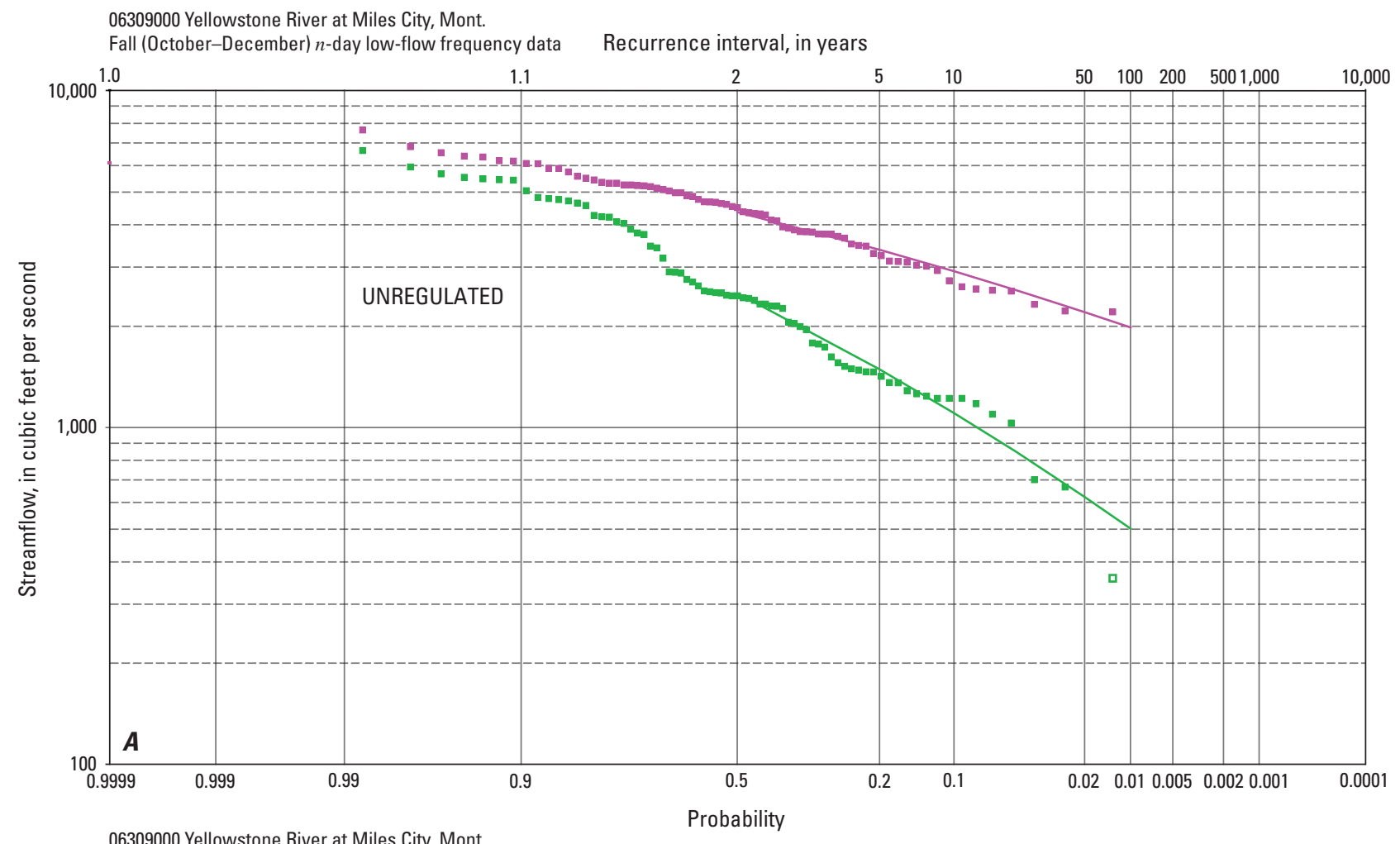

Fall (October-December) $n$-day low-flow frequency data Recurrence interval, in years

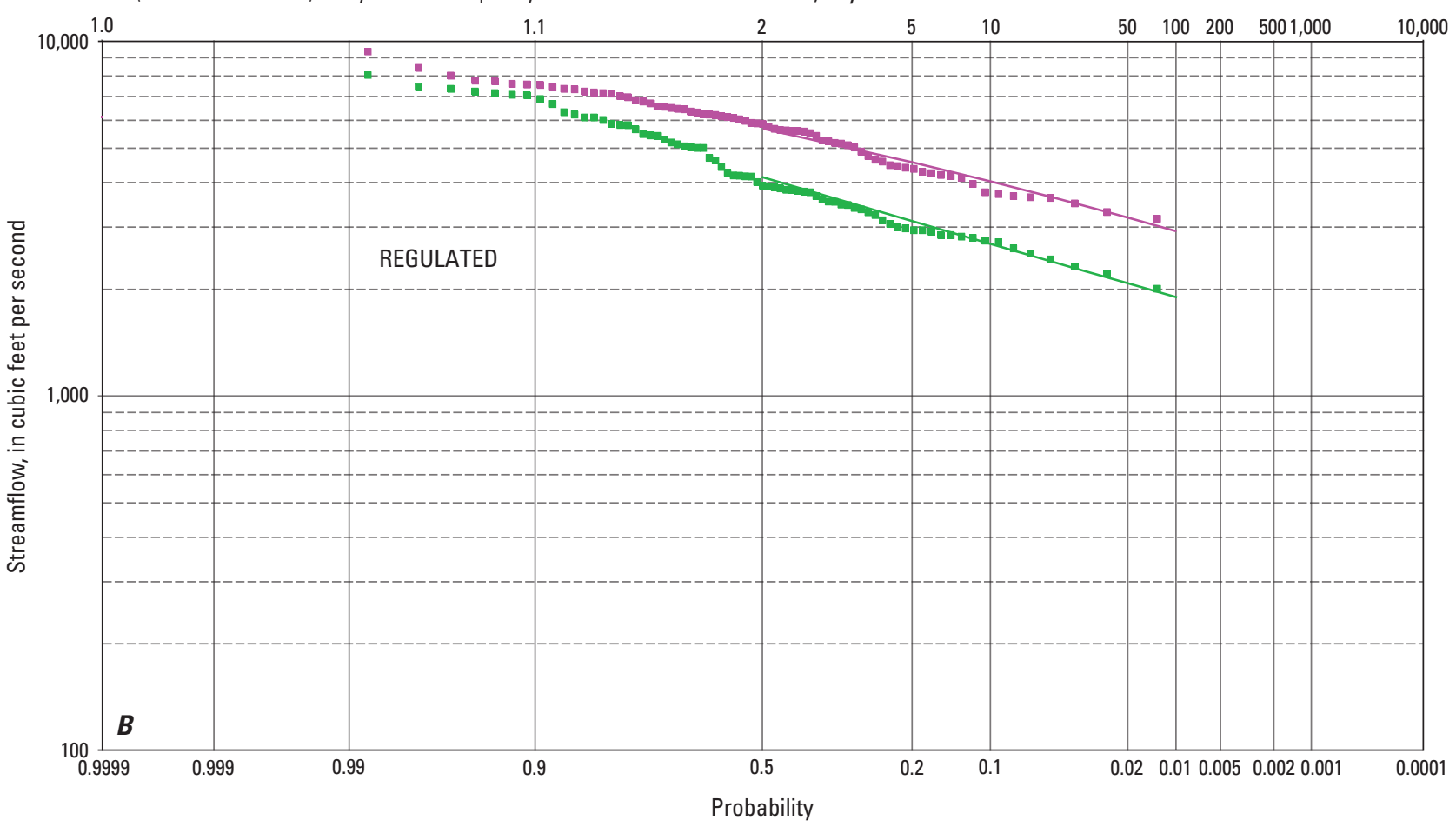

EXPLANATION

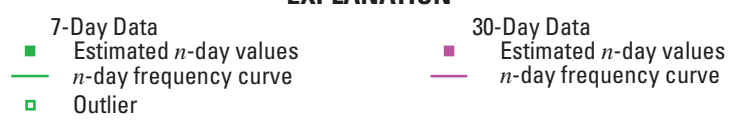

Figure 2-2-8. Fall (October-December) $n$-day low-flow frequency data for streamflow-gaging station 06309000 (Yellowstone River at Miles City, Mont.) for $A$, unregulated and $B$, regulated streamflow conditions, 1928-2002. 


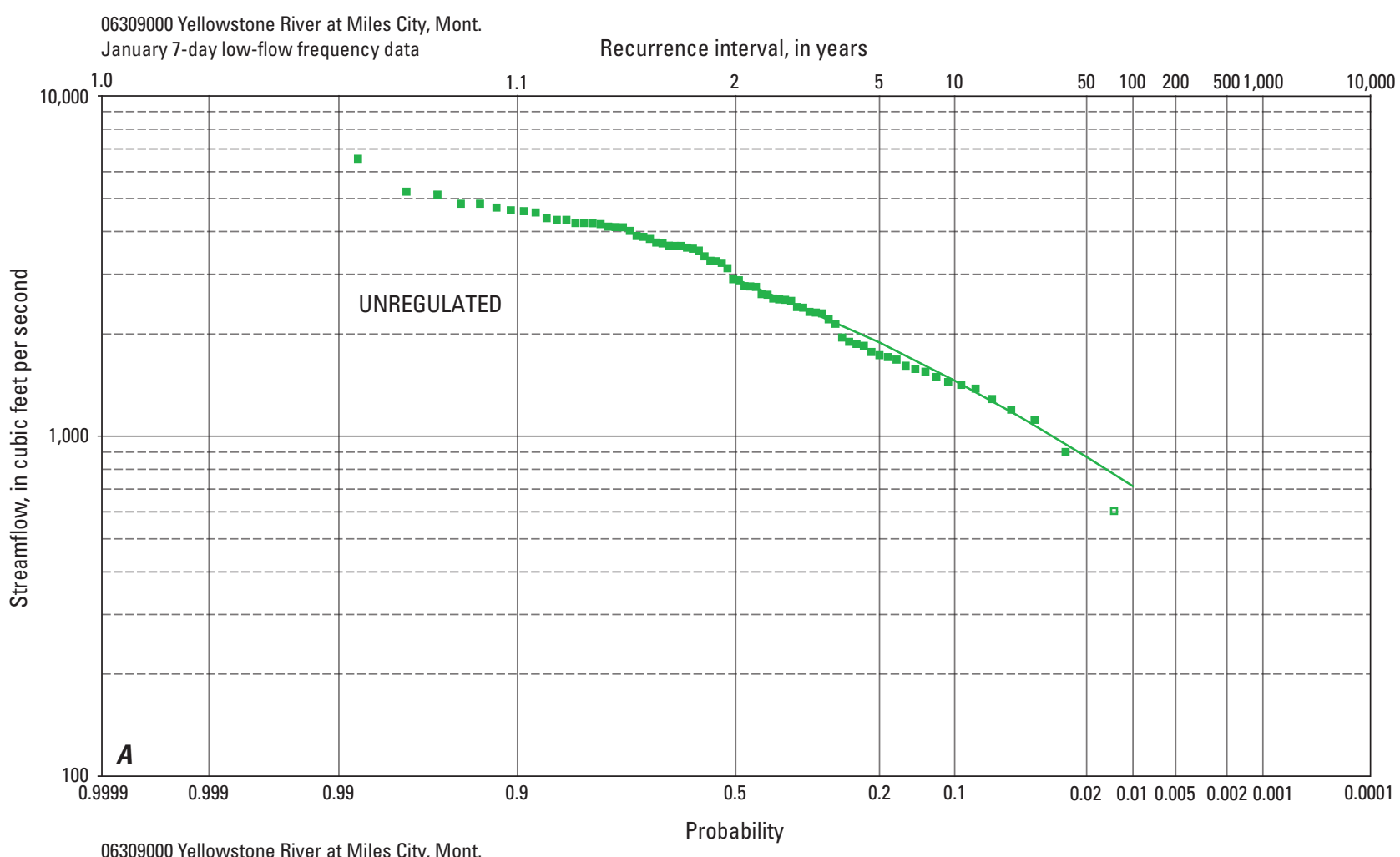

0630900 Yellowstone River at Miles City, Mont

Recurrence interval, in years

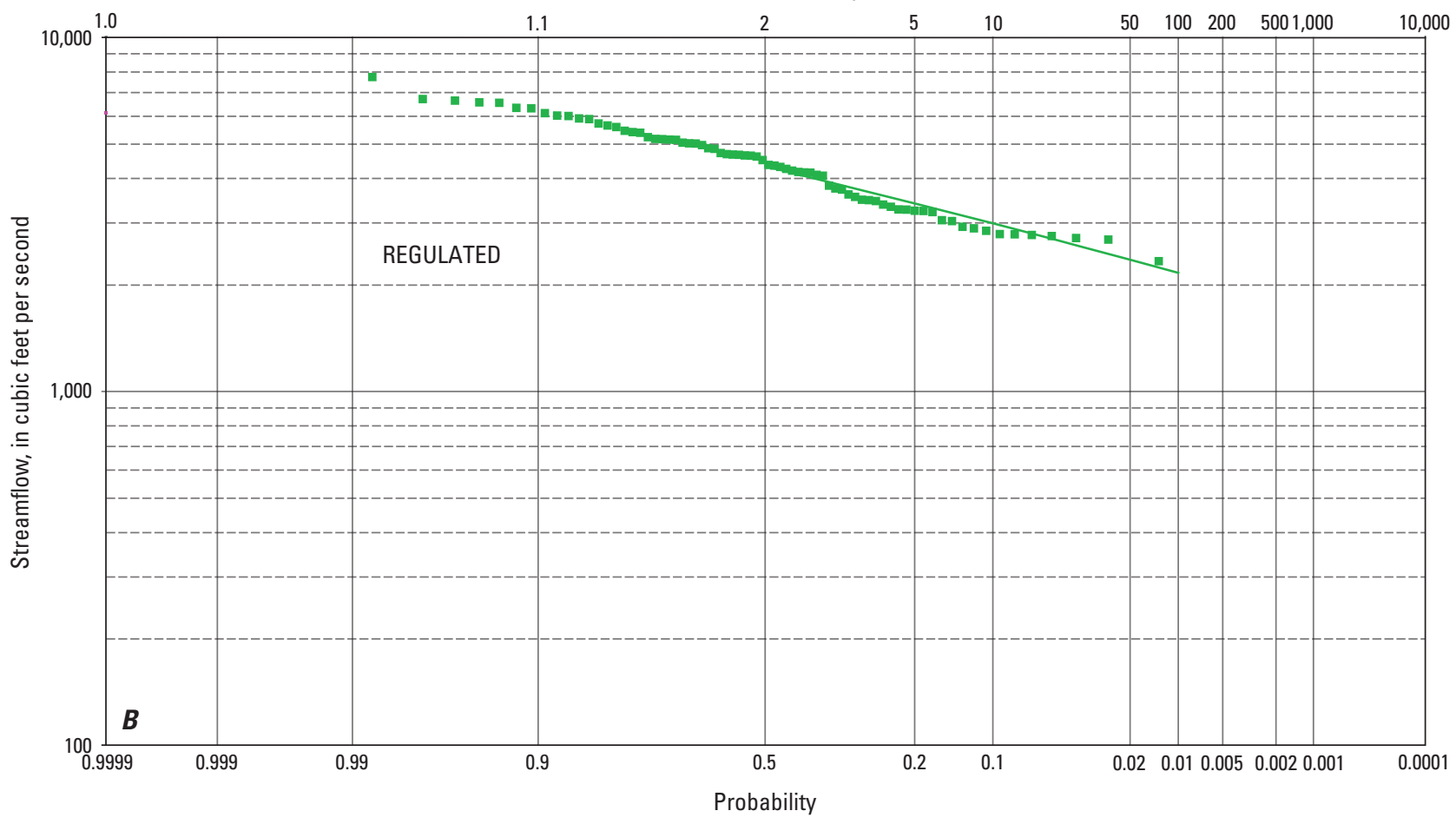

EXPLANATION

7-Day Data

- Estimated $n$-day values

- n-day frequency curve

- Outlier

Figure 2-2-9. January 7-day low-flow frequency data for streamflow-gaging station 06309000 (Yellowstone River at Miles City, Mont.) for $A$, unregulated and $B$, regulated streamflow conditions, 1928-2002. 


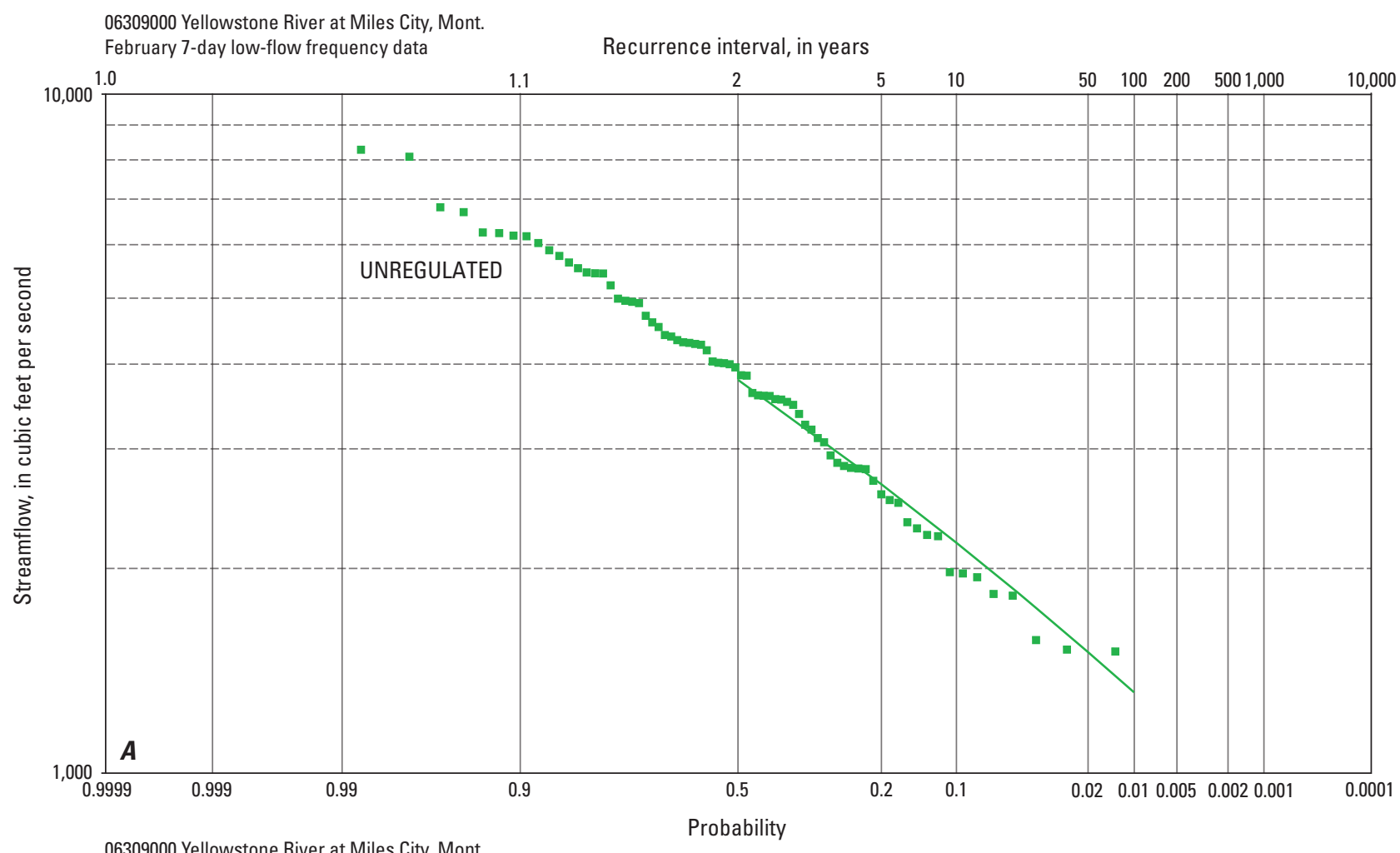

06309000 Yellowstone River at Miles City, Mont.

Recurrence interval, in years

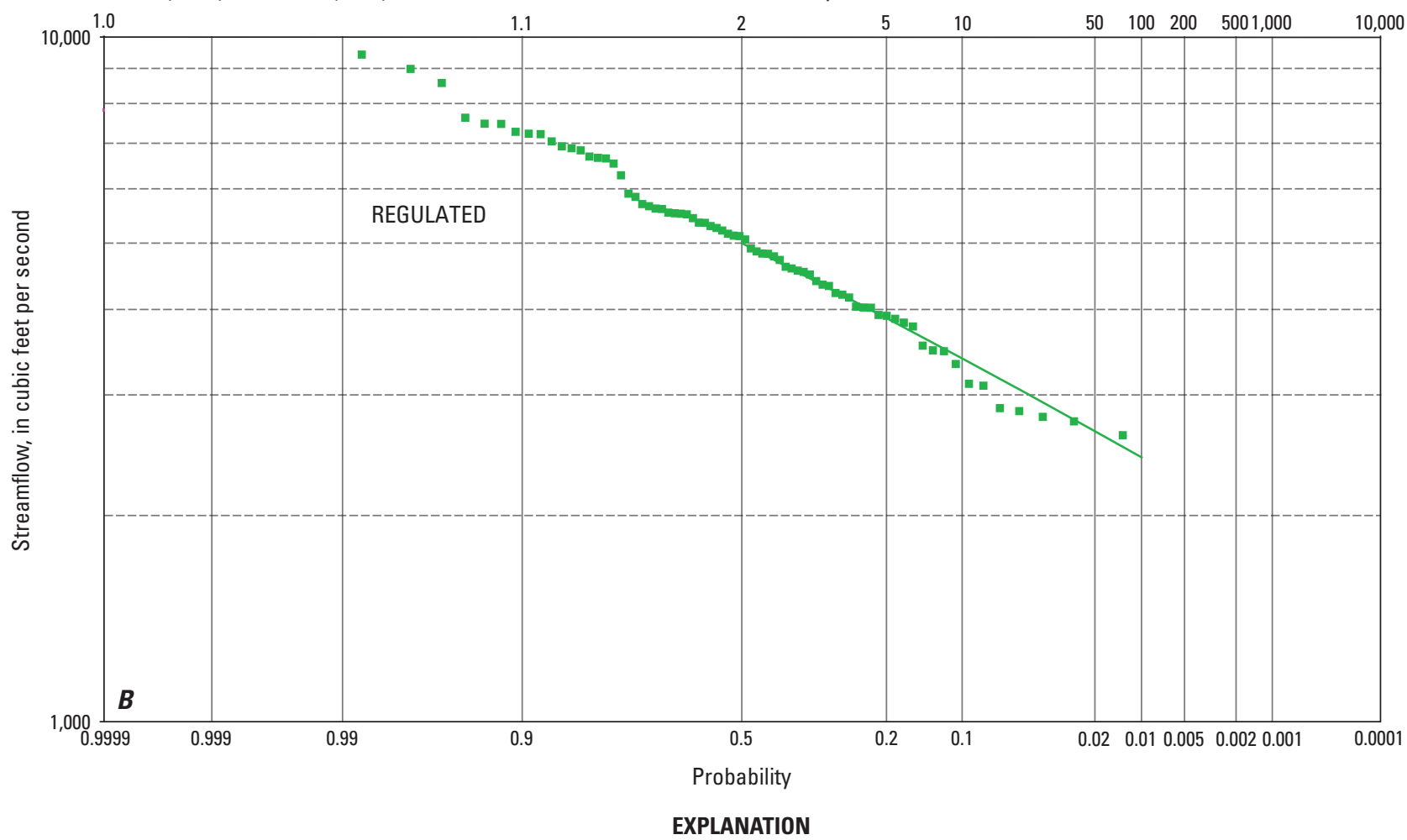

7-Day Data

- Estimated $n$-day values

$n$-day frequency curve

Figure 2-2-10. February 7-day low-flow frequency data for streamflow-gaging station 06309000 (Yellowstone River at Miles City, Mont.) for $A$, unregulated and $B$, regulated streamflow conditions, 1928-2002. 

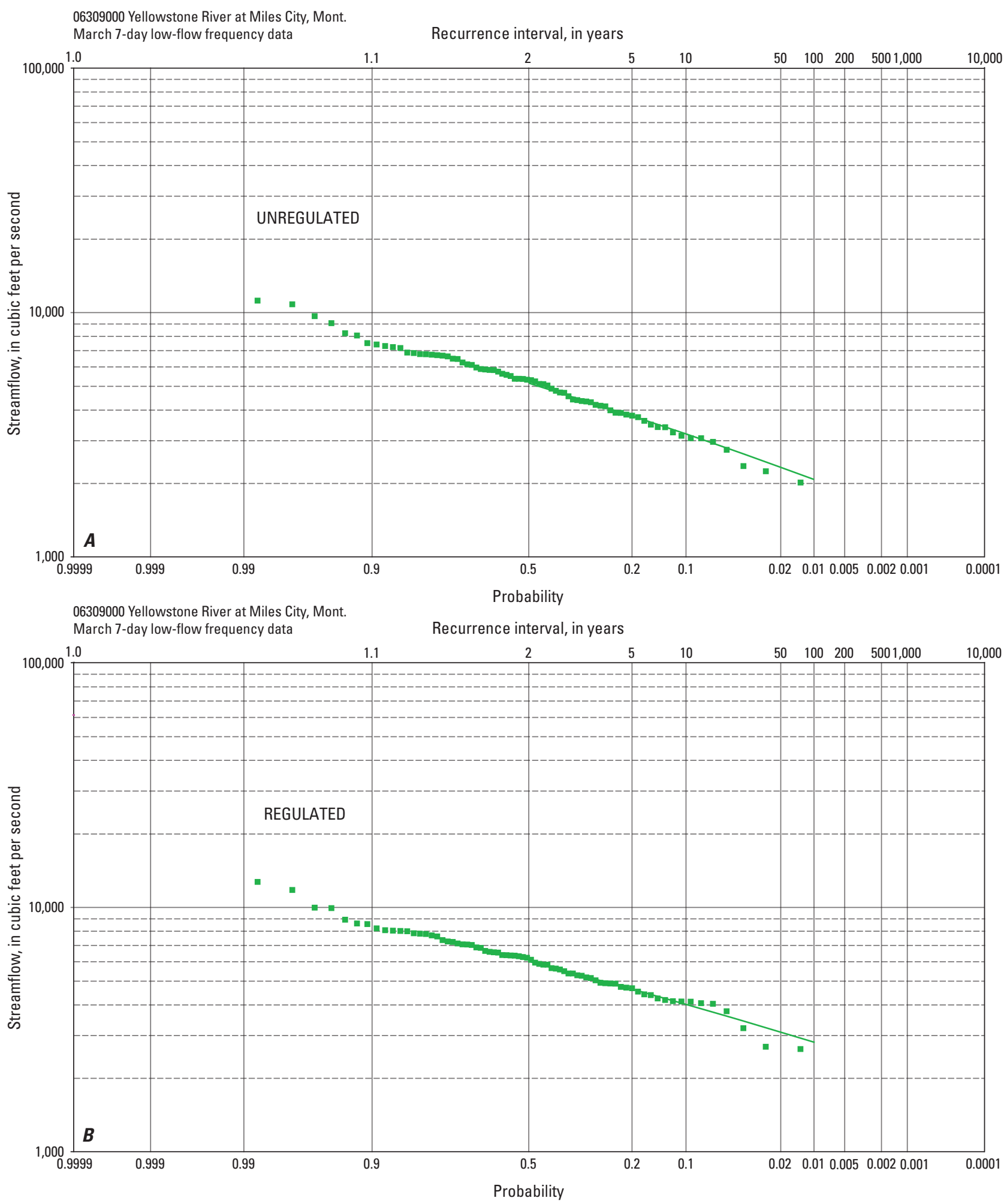

EXPLANATION

7-Day Data

- $\quad$ Estimated $n$-day values

- n-day frequency curve

Figure 2-2-11. March 7-day low-flow frequency data for streamflow-gaging station 06309000 (Yellowstone River at Miles City, Mont.) for $A$, unregulated and $B$, regulated streamflow conditions, 1928-2002. 

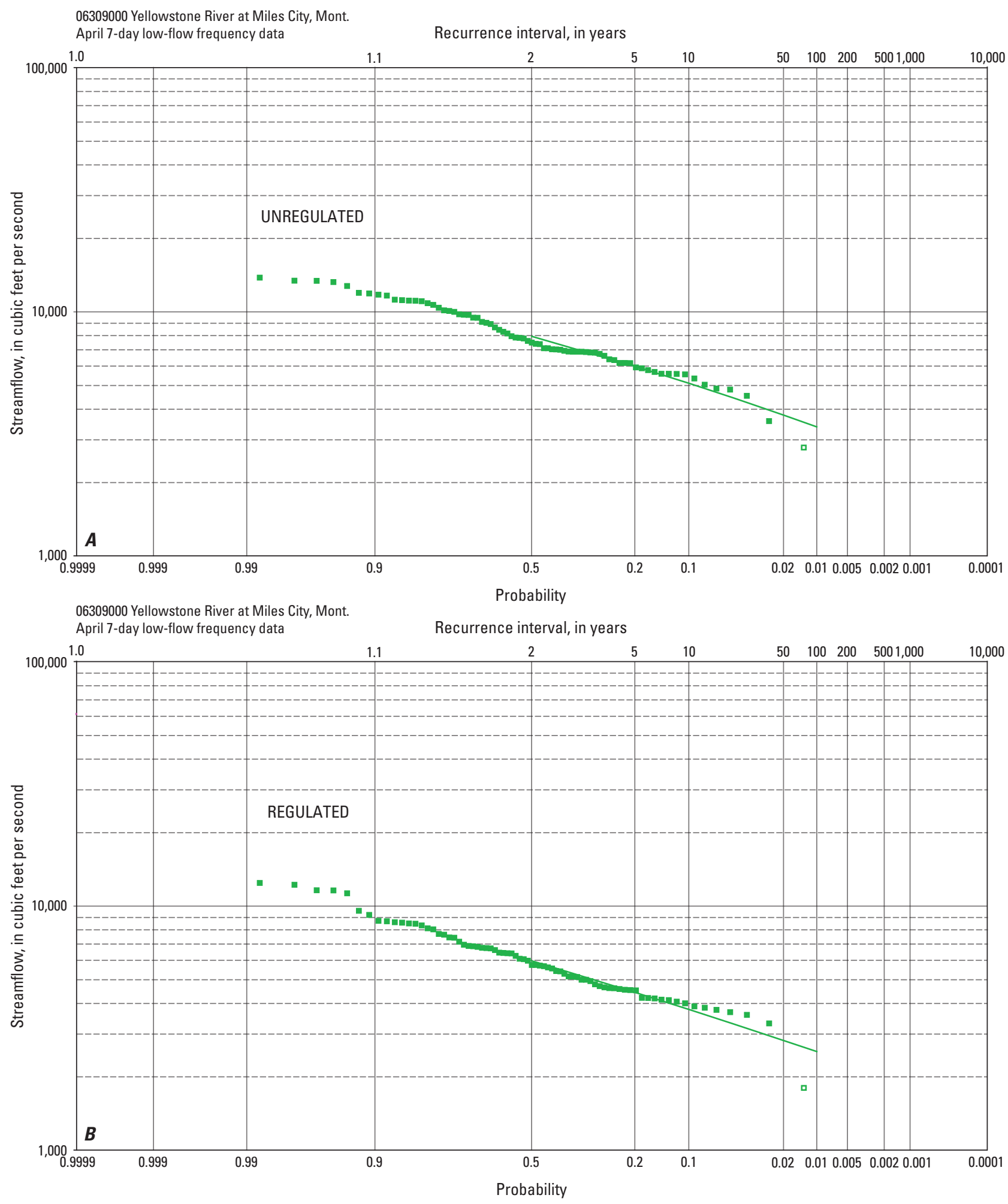

EXPLANATION

7-Day Data

- Estimated $n$-day values

- n-day frequency curve

Figure 2-2-12. April 7-day low-flow frequency data for streamflow-gaging station 06309000 (Yellowstone River at Miles City, Mont.) for $A$, unregulated and $B$, regulated streamflow conditions, 1928-2002. 


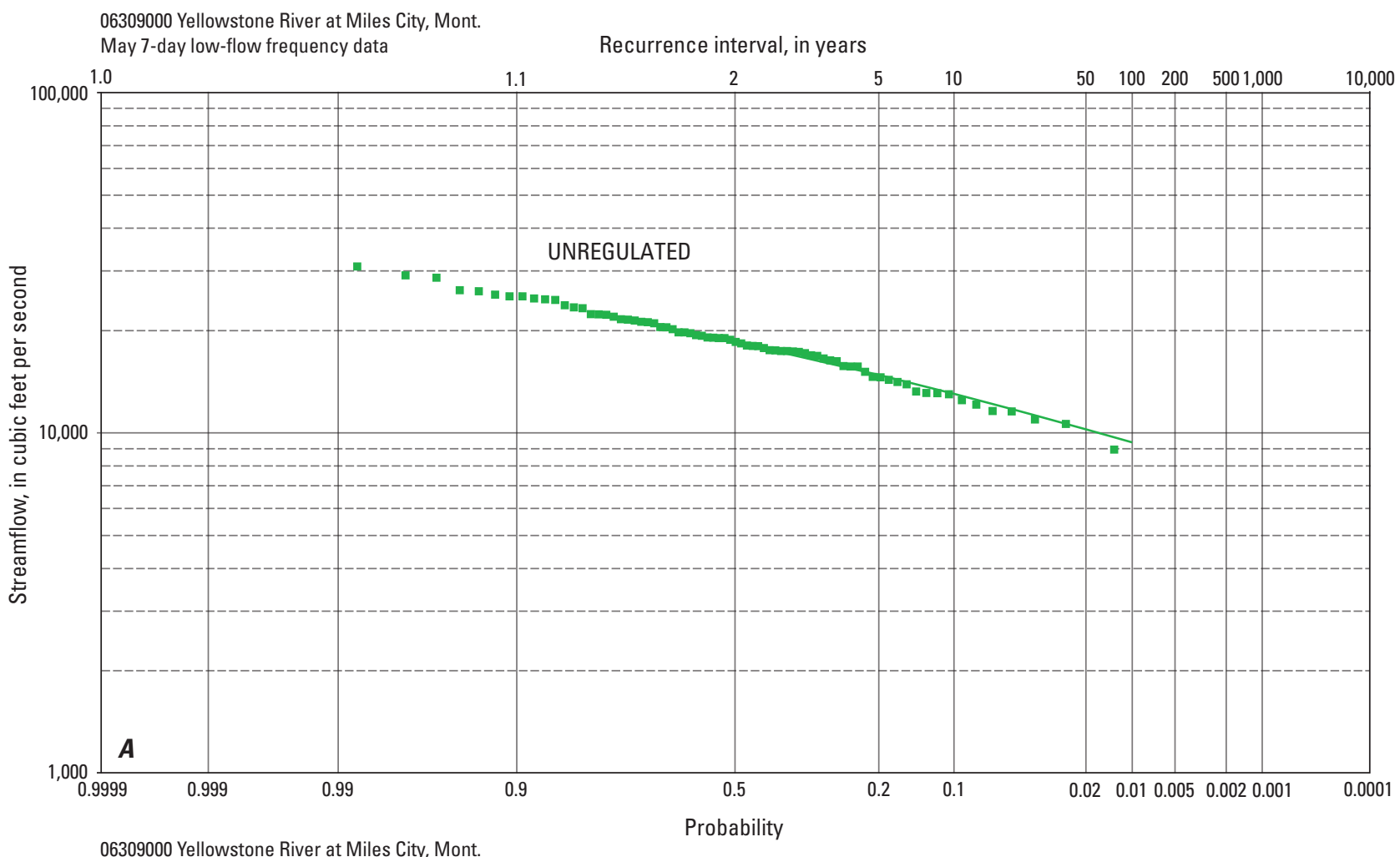

06309000 Yellowstone River at Miles City, Mont. May 7-day low-flow frequency data

Recurrence interval, in years

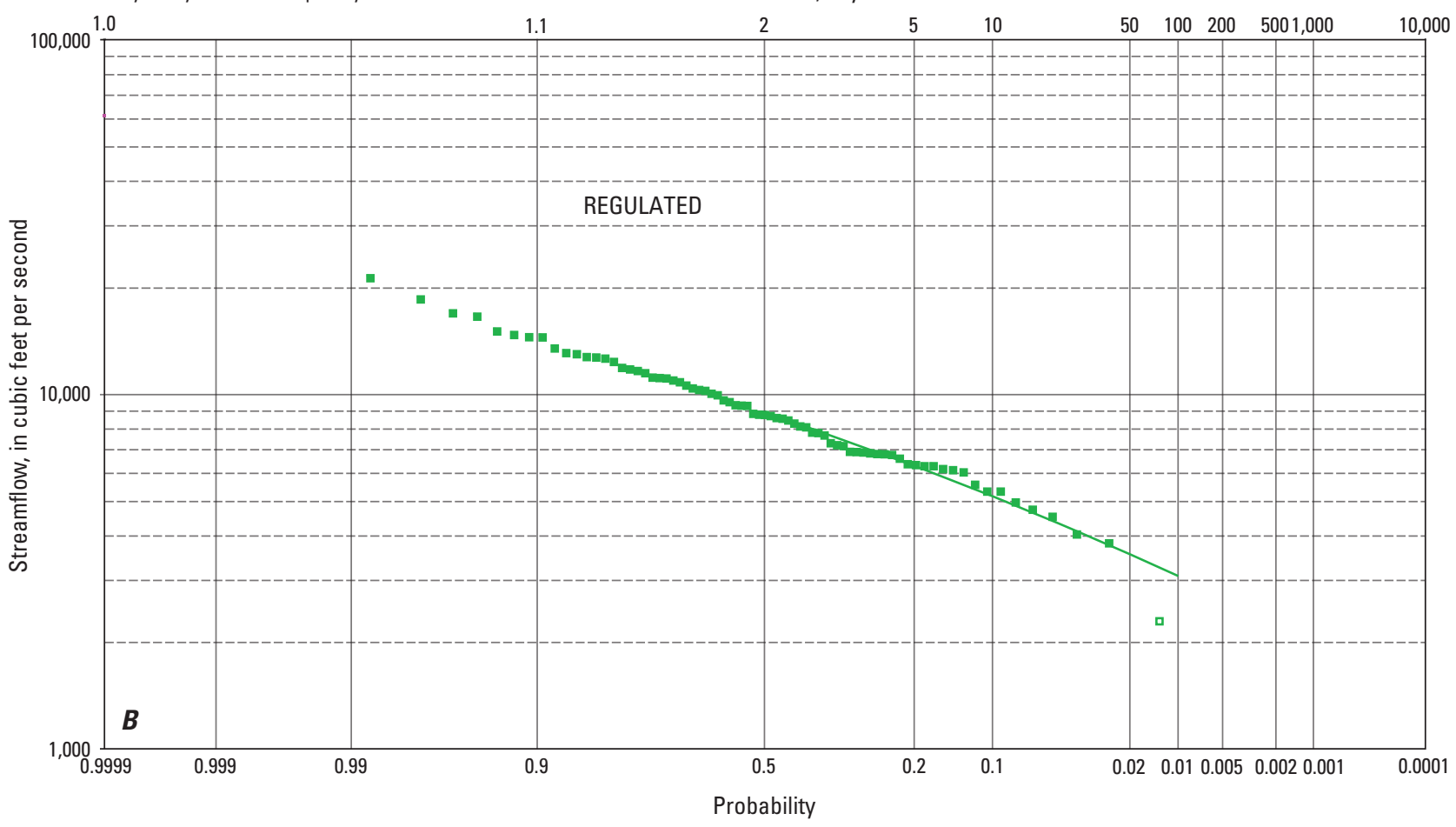

EXPLANATION

7-Day Data

- Estimated $n$-day values

- $n$-day frequency curve

- Outlier

Figure 2-2-13. May 7-day low-flow frequency data for streamflow-gaging station 06309000 (Yellowstone River at Miles City, Mont.) for $A$, unregulated and $B$, regulated streamflow conditions, 1928-2002. 

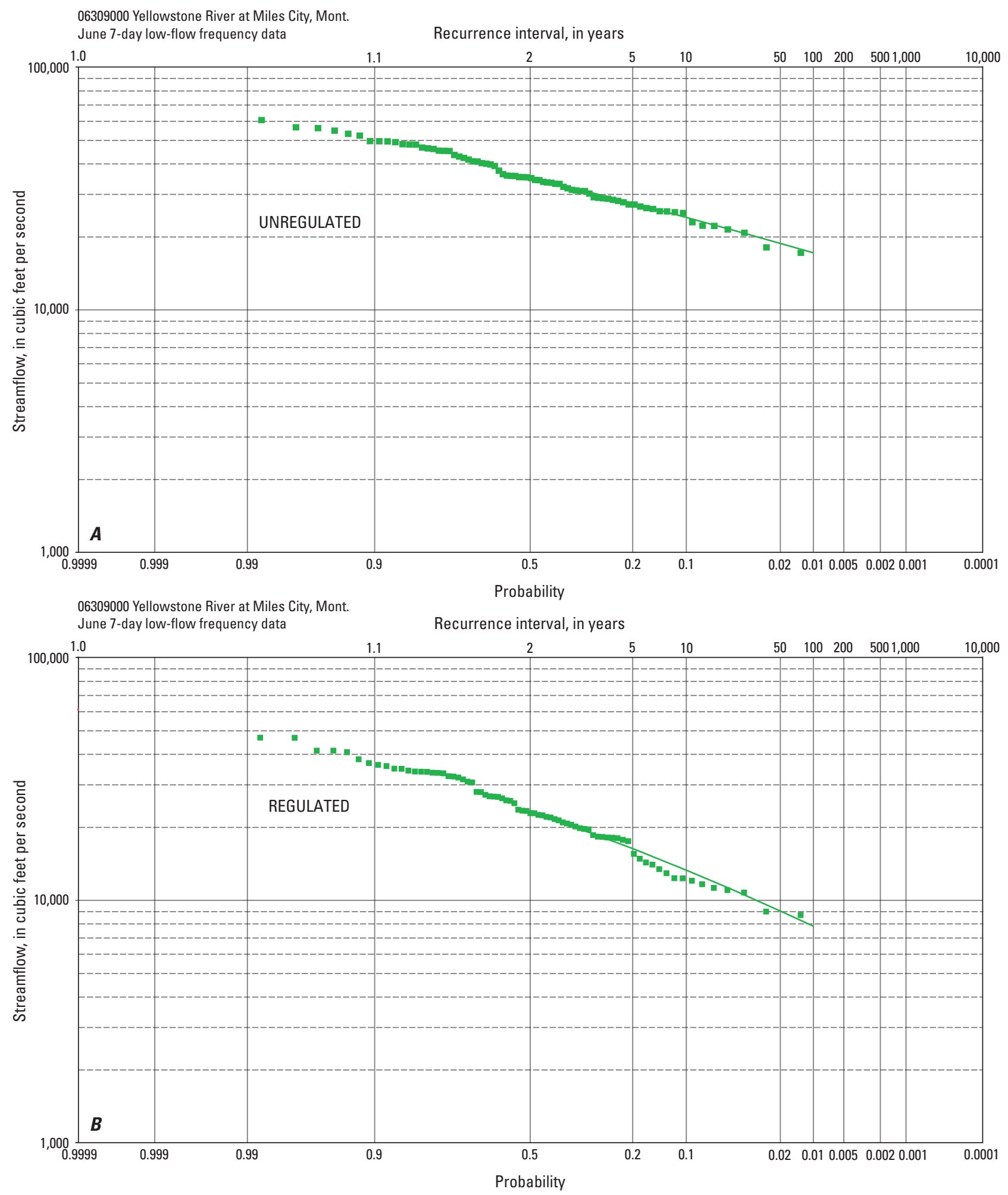

EXPLANATION

7-Day Data

- Estimated $n$-day values

- $n$-day frequency curve

Figure 2-2-14. June 7-day low-flow frequency data for streamflow-gaging station 06309000 (Yellowstone River at Miles City, Mont.) for $A$, unregulated and $B$, regulated streamflow conditions, 1928-2002. 

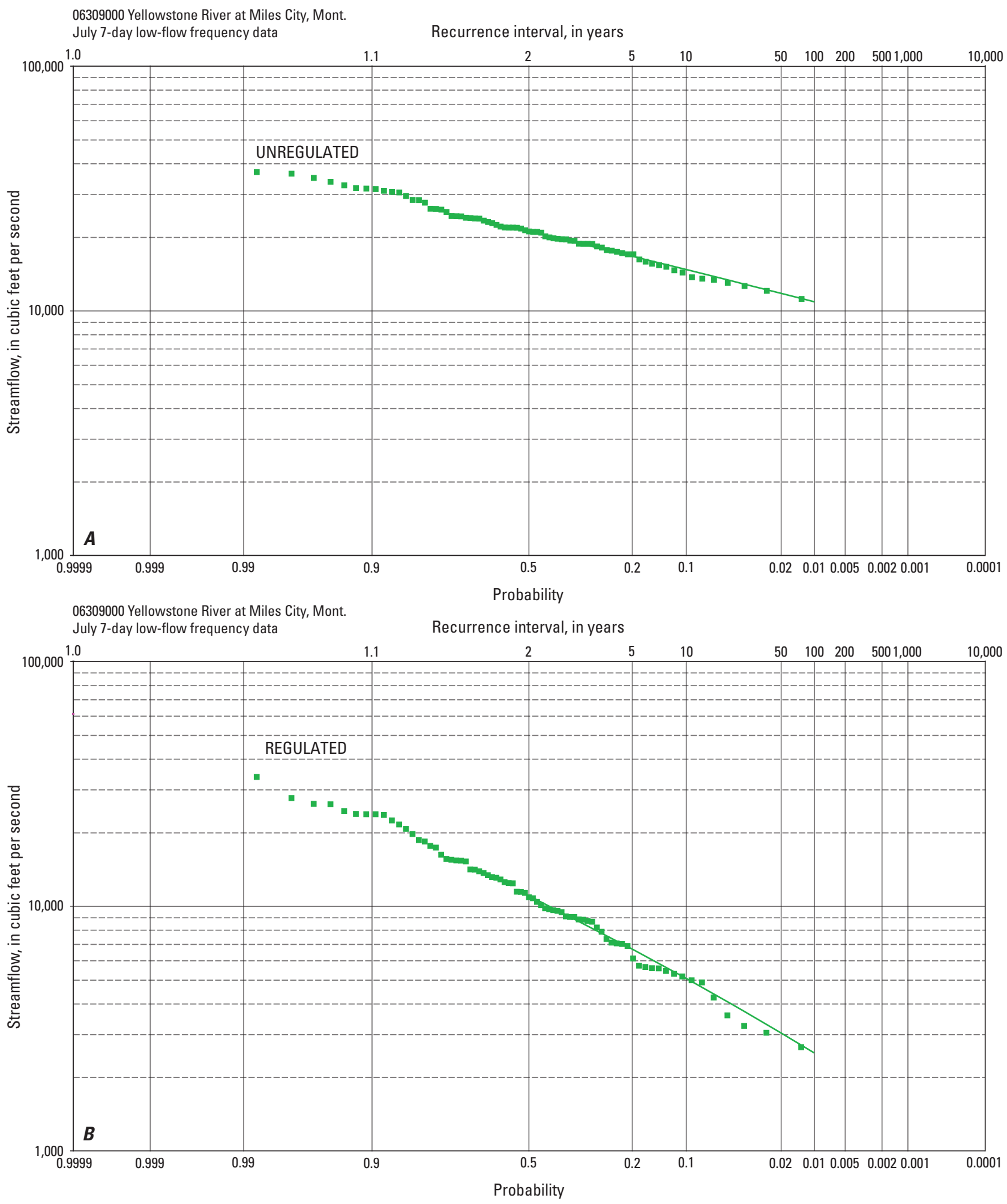

EXPLANATION

7-Day Data

- Estimated $n$-day values

- $n$-day frequency curve

Figure 2-2-15. July 7-day low-flow frequency data for streamflow-gaging station 06309000 (Yellowstone River at Miles City, Mont.) for $A$, unregulated and $B$, regulated streamflow conditions, 1928-2002. 


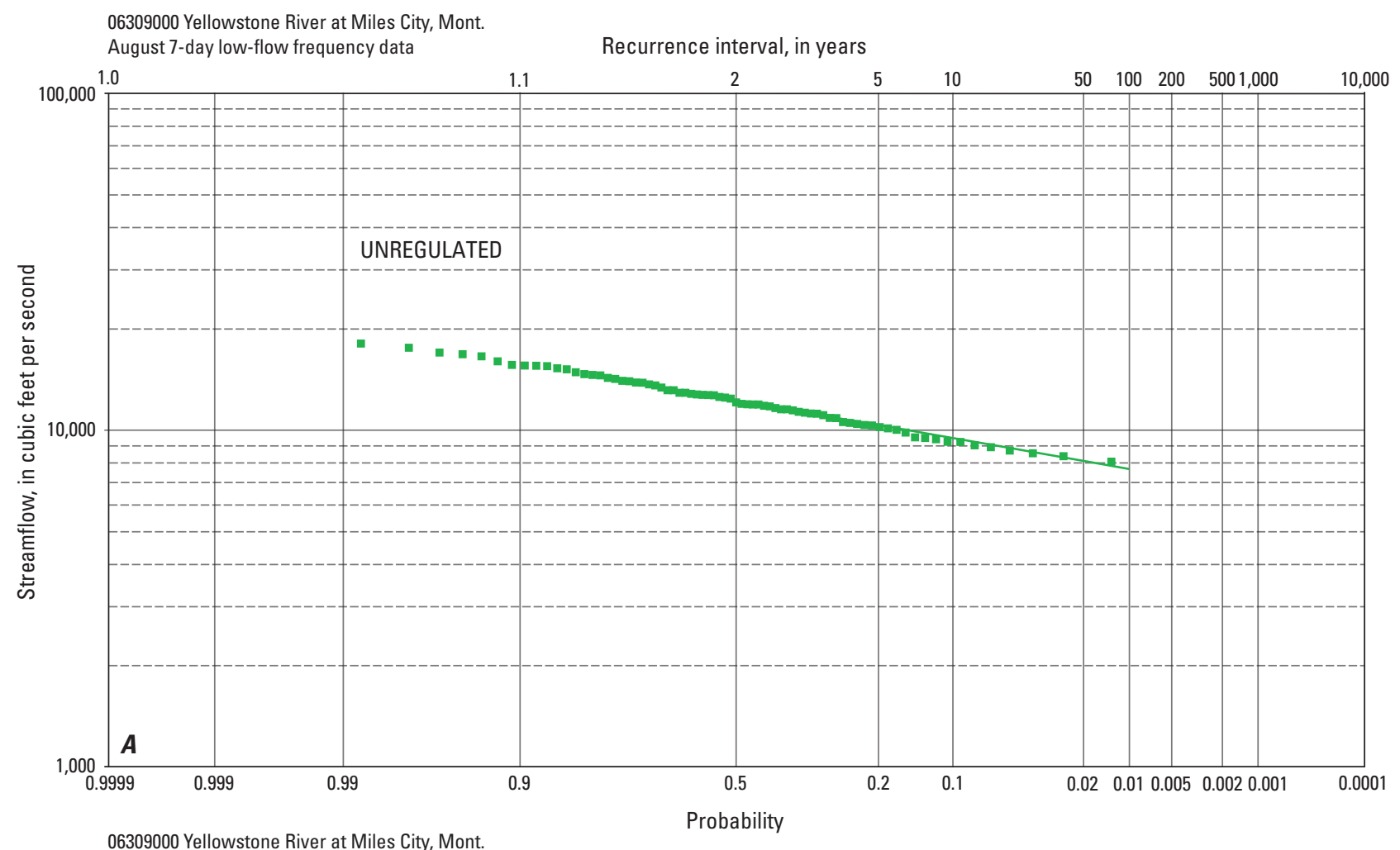

August 7-day low-flow frequency data

Recurrence interval, in years

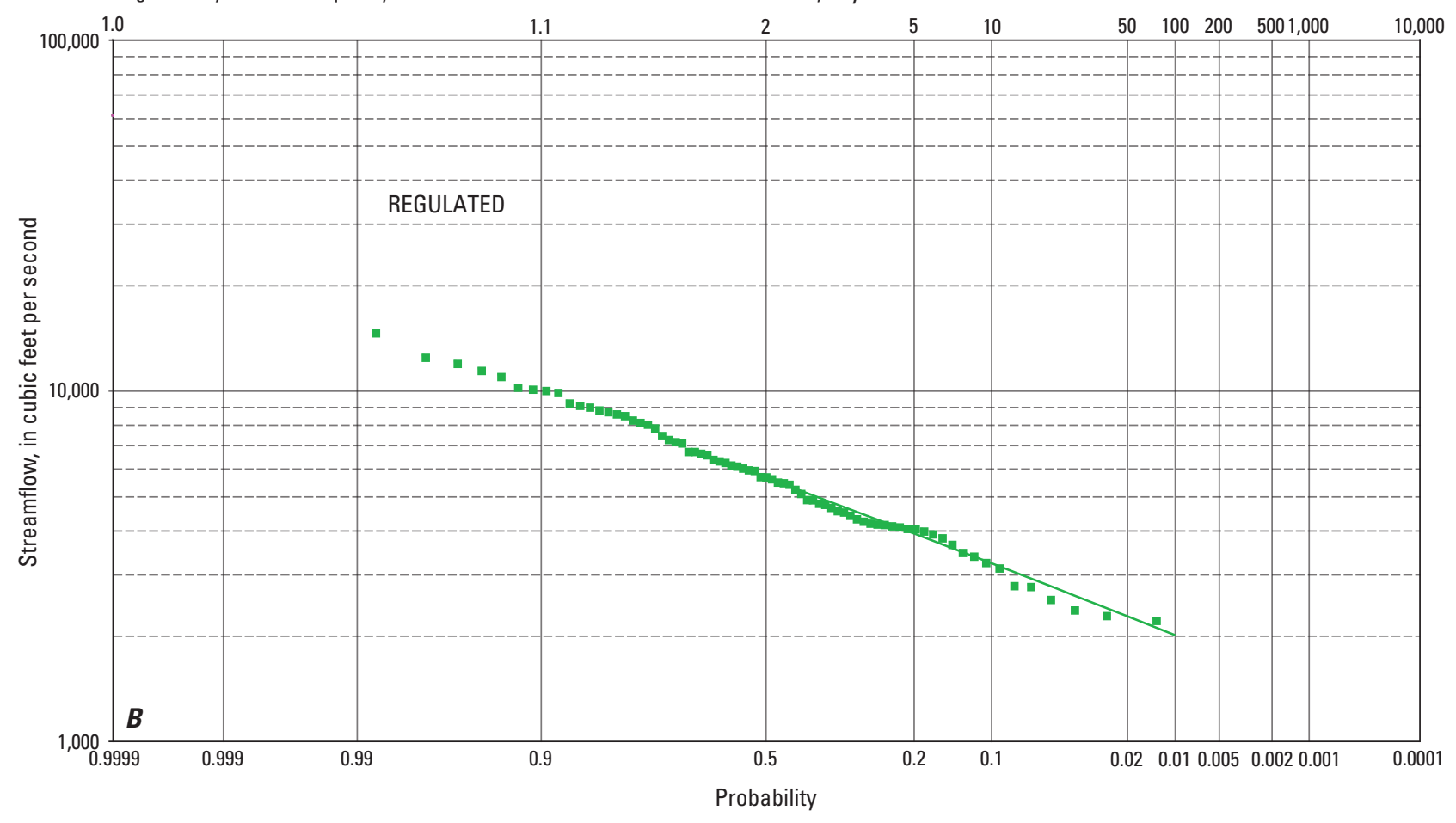

EXPLANATION

7-Day Data

- Estimated $n$-day values

- n-day frequency curve

Figure 2-2-16. August 7-day low-flow frequency data for streamflow-gaging station 06309000 (Yellowstone River at Miles City, Mont.) for $A$, unregulated and $B$, regulated streamflow conditions, 1928-2002. 

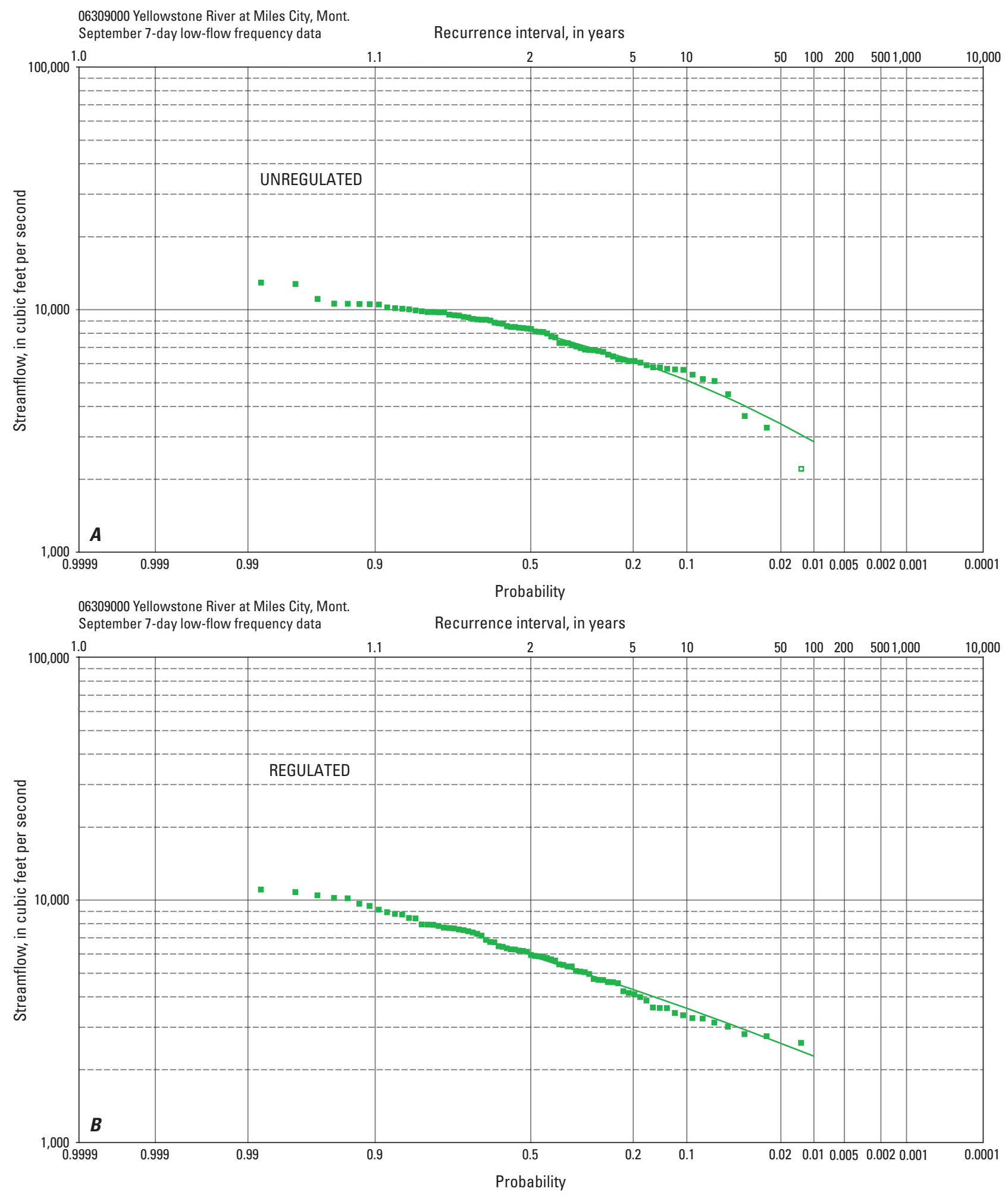

EXPLANATION

7-Day Data

- Estimated $n$-day values

- $n$-day frequency curve

ㅁ Outlier

Figure 2-2-17. September 7-day low-flow frequency data for streamflow-gaging station 06309000 (Yellowstone River at Miles City, Mont.) for $A$, unregulated and $B$, regulated streamflow conditions, 1928-2002. 


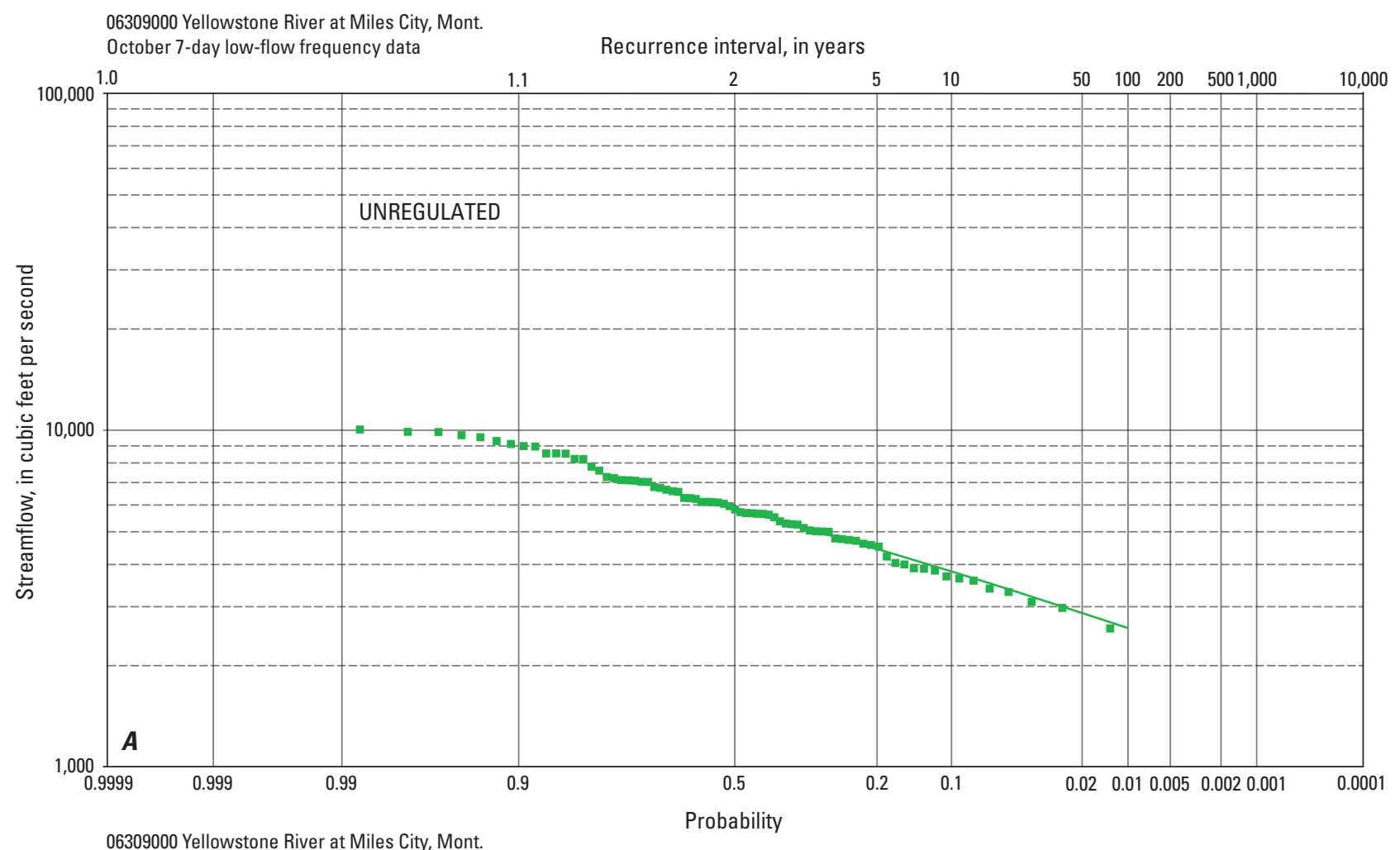

O

Recurrence interval, in years

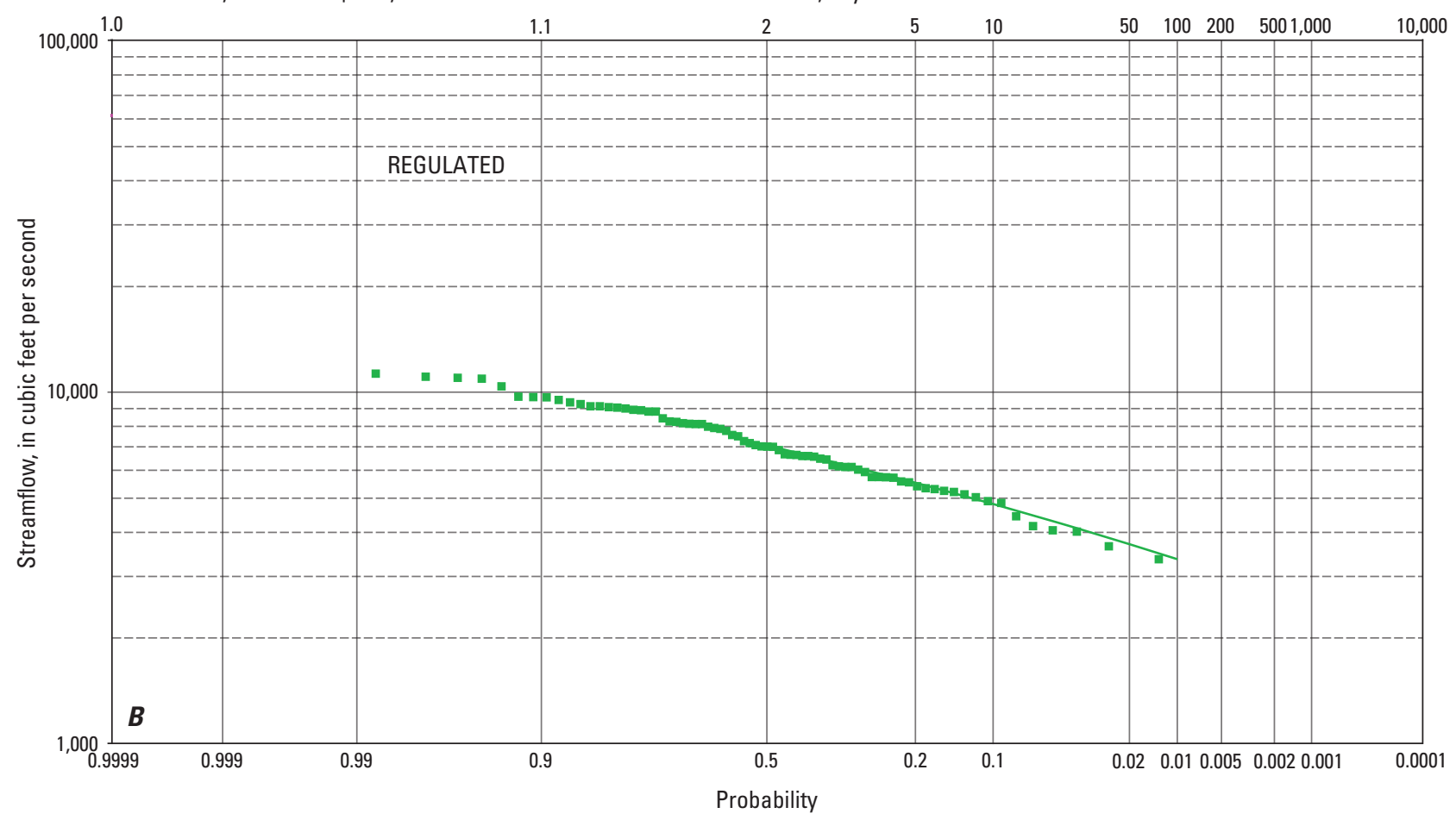

EXPLANATION

7-Day Data

- Estimated $n$-day values

- $n$-day frequency curve

Figure 2-2-18. October 7-day low-flow frequency data for streamflow-gaging station 06309000 (Yellowstone River at Miles City, Mont.) for $A$, unregulated and $B$, regulated streamflow conditions, 1928-2002. 

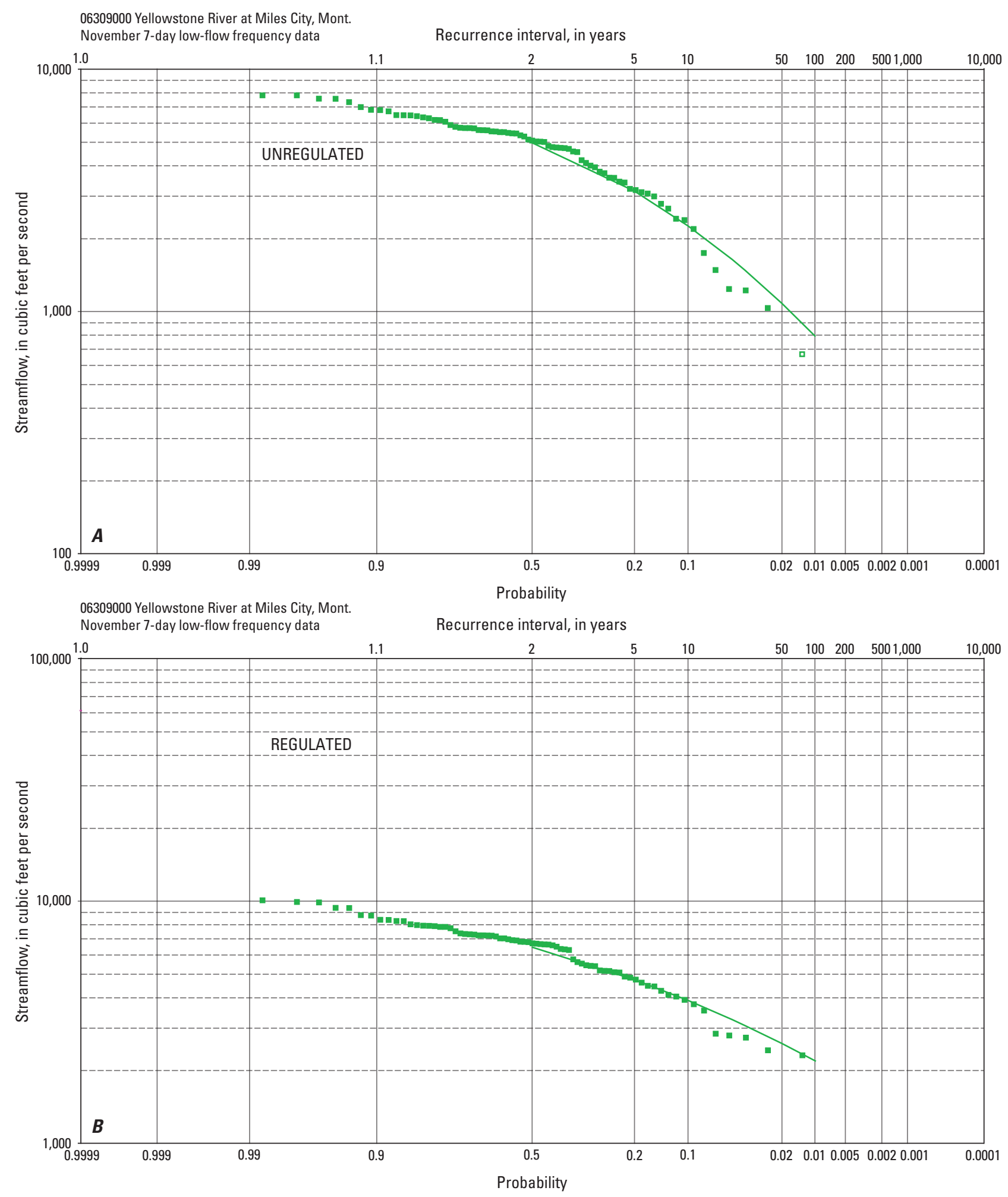

EXPLANATION

7-Day Data

- Estimated $n$-day values

- $n$-day frequency curve

․ Outlier

Figure 2-2-19. November 7-day low-flow frequency data for streamflow-gaging station 06309000 (Yellowstone River at Miles City, Mont.) for $A$, unregulated and $B$, regulated streamflow conditions, 1928-2002. 

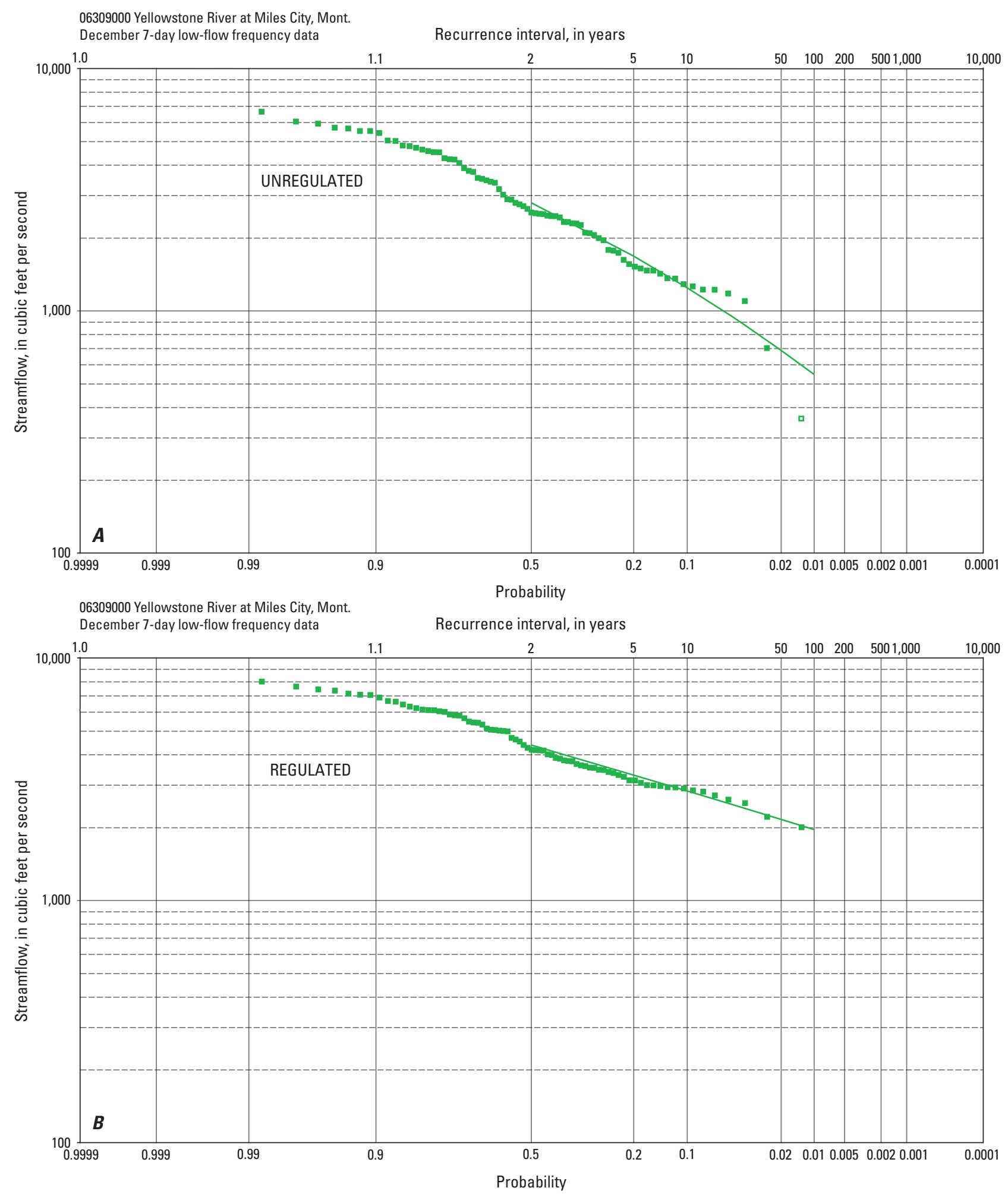

EXPLANATION

7-Day Data

- Estimated $n$-day values

- $n$-day frequency curve

․ Outlier

Figure 2-2-20. December 7-day low-flow frequency data for streamflow-gaging station 06309000 (Yellowstone River at Miles City, Mont.) for $A$, unregulated and $B$, regulated streamflow conditions, 1928-2002. 
06309000 Yellowstone River at Miles City, Mont.

Annual flow-duration data for unregulated and regulated streamflow conditions

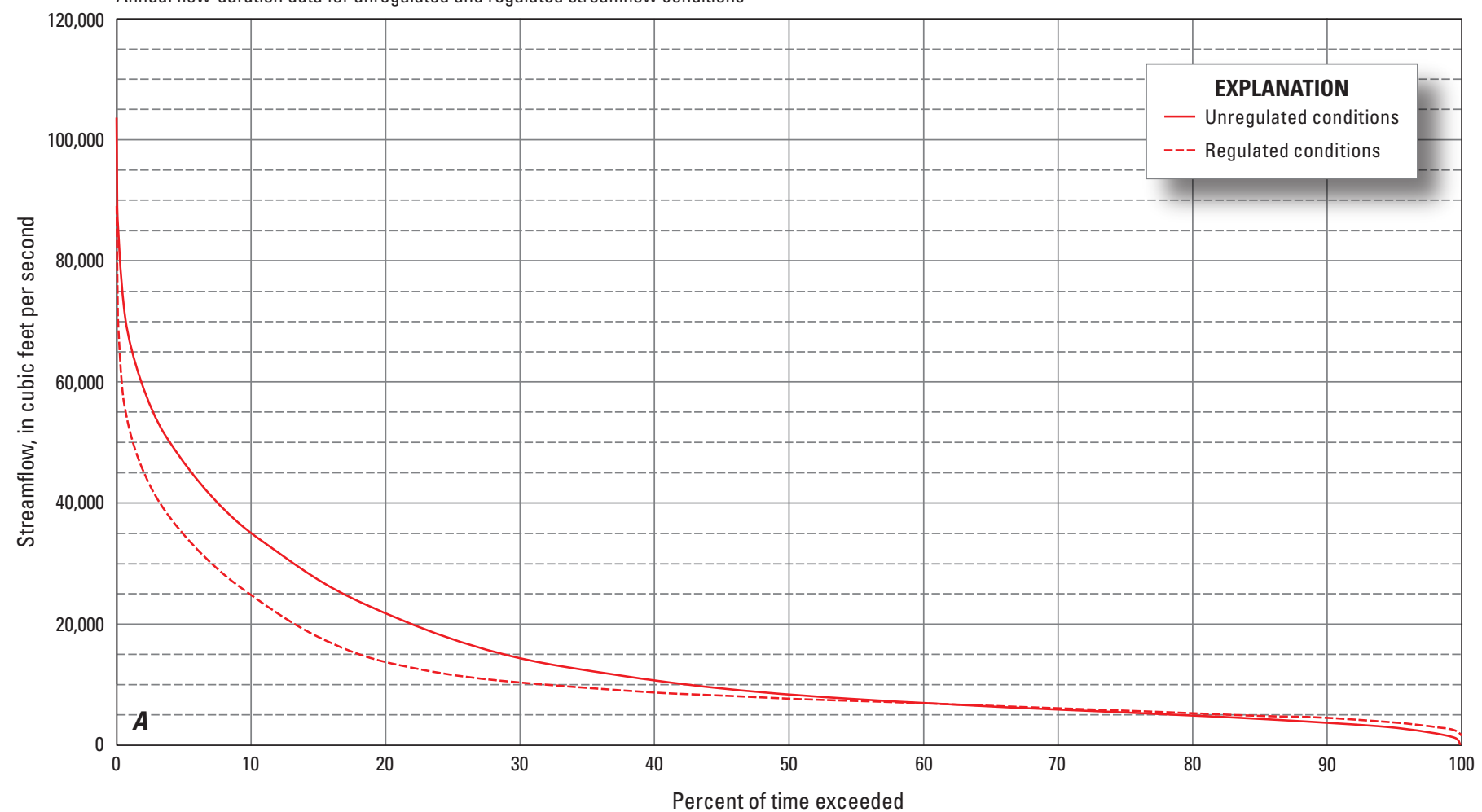

06309000 Yellowstone River at Miles City, Mont.

Seasonal flow-duration data for unregulated and regulated streamflow conditions

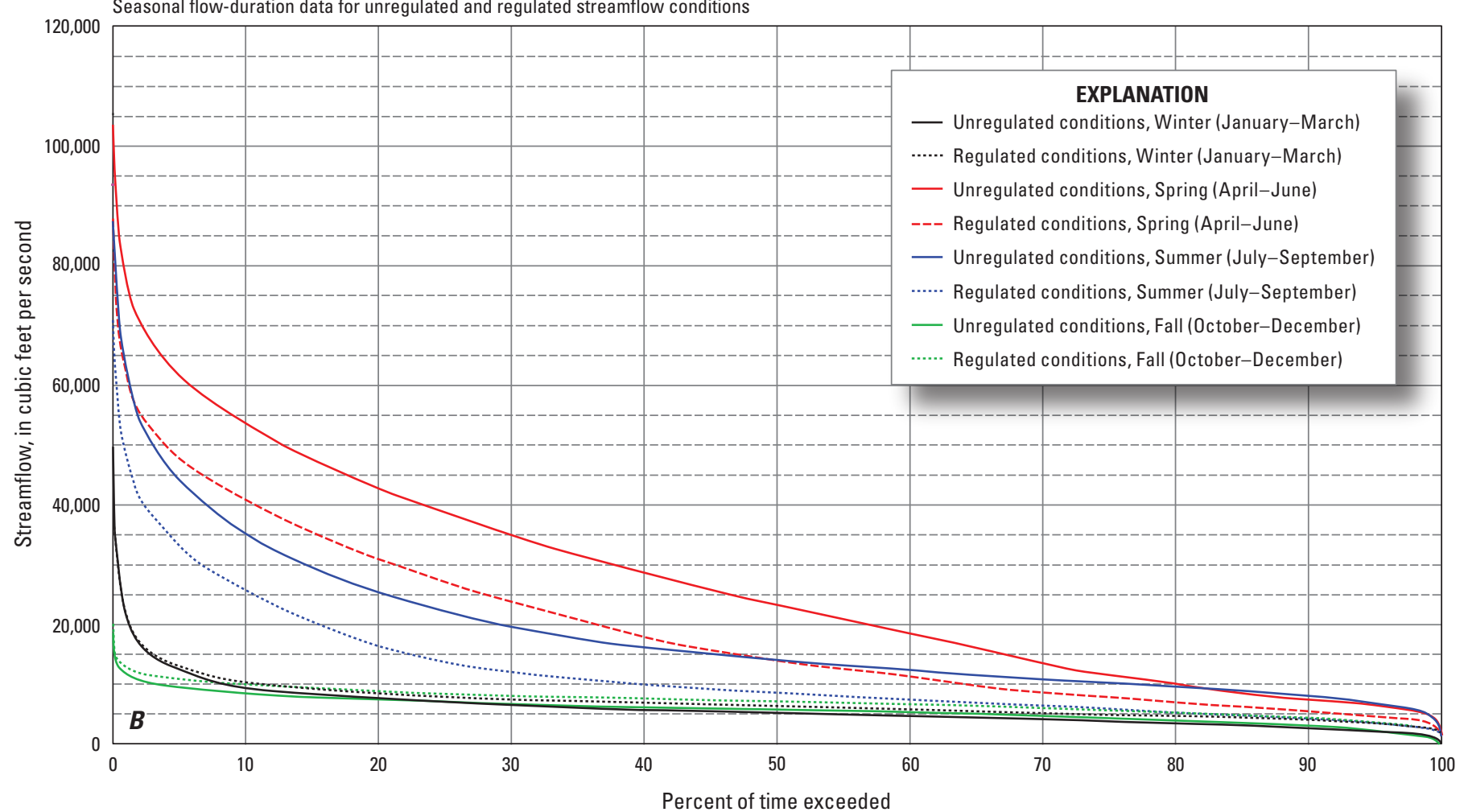

Figure 2-2-21. A, Annual and $B$, seasonal flow-duration data for streamflow-gaging station 06309000 (Yellowstone River at Miles City, Mont.) for unregulated and regulated streamflow conditions, 1928-2002. 


\section{Appendix 2-3. Statistics for Streamflow-Gaging Station 06327500 (Yellowstone River at Glendive, Mont.)}

Table 2-3-1. Annual $n$-day high-flow frequency data for streamflow-gaging station 06327500 (Yellowstone River at Glendive, Mont.) for unregulated and regulated streamflow conditions, 1928-2002.

[Abbreviations: $\mathrm{ft}^{3} / \mathrm{s}$, cubic feet per second. Symbol: \%, percent]

\begin{tabular}{|c|c|c|c|c|c|c|c|}
\hline \multicolumn{8}{|c|}{ Unregulated } \\
\hline \multirow{3}{*}{$\begin{array}{c}n \text {, period of } \\
\text { consecutive } \\
\text { days }\end{array}$} & \multicolumn{7}{|c|}{ Streamflow, in $\mathrm{ft}^{3} / \mathrm{s}$, for indicated recurrence interval, in years, and exceedance probability, in percent } \\
\hline & 2 & 5 & 10 & 20 & 25 & 50 & 100 \\
\hline & $50 \%$ & $20 \%$ & $10 \%$ & $5 \%$ & $4 \%$ & $2 \%$ & $1 \%$ \\
\hline 1 & 67,200 & 85,100 & 96,500 & 107,000 & 110,000 & 121,000 & 131,000 \\
\hline 3 & 64,800 & 80,900 & 90,700 & 99,600 & 102,000 & 110,000 & 118,000 \\
\hline 7 & 60,800 & 76,300 & 85,700 & 94,200 & 96,800 & 105,000 & 112,000 \\
\hline 15 & 56,000 & 69,900 & 78,200 & 85,800 & 88,100 & 95,000 & 102,000 \\
\hline 30 & 50,600 & 62,800 & 70,100 & 76,600 & 78,600 & 84,500 & 90,100 \\
\hline 60 & 42,700 & 52,100 & 57,600 & 62,500 & 64,000 & 68,400 & 72,600 \\
\hline 90 & 36,400 & 43,600 & 47,800 & 51,400 & 52,500 & 55,700 & 58,700 \\
\hline 120 & 31,300 & 37,100 & 40,500 & 43,400 & 44,300 & 46,800 & 49,200 \\
\hline 183 & 24,300 & 28,600 & 31,100 & 33,200 & 33,800 & 35,600 & 37,300 \\
\hline \multicolumn{8}{|c|}{ Regulated } \\
\hline \multirow{3}{*}{$\begin{array}{c}n, \text { period of } \\
\text { consecutive } \\
\text { days }\end{array}$} & \multicolumn{7}{|c|}{ Streamflow, in $\mathrm{ft}^{3} / \mathrm{s}$, for indicated recurrence interval, in years, and exceedance probability, in percent } \\
\hline & 2 & 5 & 10 & 20 & 25 & 50 & 100 \\
\hline & $50 \%$ & $20 \%$ & $10 \%$ & $5 \%$ & $4 \%$ & $2 \%$ & $1 \%$ \\
\hline 1 & 52,200 & 69,600 & 80,800 & 91,400 & 94,800 & 105,000 & 115,000 \\
\hline 3 & 49,900 & 65,100 & 74,300 & 82,400 & 84,900 & 92,200 & 99,100 \\
\hline 7 & 45,400 & 59,900 & 68,600 & 76,500 & 78,900 & 86,100 & 92,900 \\
\hline 15 & 41,400 & 54,900 & 62,700 & 69,300 & 71,300 & 77,000 & 82,200 \\
\hline 30 & 36,800 & 48,900 & 55,700 & 61,400 & 63,100 & 68,000 & 72,400 \\
\hline 60 & 29,700 & 39,600 & 45,300 & 50,300 & 51,900 & 56,300 & 60,300 \\
\hline 90 & 24,400 & 32,300 & 36,800 & 40,800 & 42,000 & 45,400 & 48,500 \\
\hline 120 & 20,900 & 27,100 & 30,600 & 33,700 & 34,600 & 37,200 & 39,600 \\
\hline 183 & 16,900 & 21,400 & 24,000 & 26,200 & 26,900 & 28,900 & 30,700 \\
\hline
\end{tabular}


Table 2-3-2. Annual, seasonal, and monthly $n$-day low-flow frequency data for streamflow-gaging station 06327500 (Yellowstone River at Glendive, Mont.) for unregulated and regulated steamflow conditions, 1928-2002.

[Abbreviations: $\mathrm{ft}^{3} / \mathrm{s}$, cubic feet per second. Symbol: \%, percent]

\begin{tabular}{|c|c|c|c|c|c|c|c|}
\hline \multicolumn{8}{|c|}{ Unregulated } \\
\hline \multirow{2}{*}{$\begin{array}{l}n \text {, period of consecutive } \\
\text { days (month, for monthly } \\
\text { frequency data) }\end{array}$} & \multicolumn{7}{|c|}{ Streamflow, in $\mathrm{ft}^{3} / \mathrm{s}$, for indicated recurrence interval, in years, and exceedance probability, in percent } \\
\hline & $\begin{array}{c}2 \\
50 \%\end{array}$ & $\begin{array}{c}5 \\
20 \%\end{array}$ & $\begin{array}{c}10 \\
10 \%\end{array}$ & $\begin{array}{l}20 \\
5 \%\end{array}$ & $\begin{array}{l}25 \\
4 \%\end{array}$ & $\begin{array}{c}50 \\
2 \%\end{array}$ & $\begin{array}{l}100 \\
1 \%\end{array}$ \\
\hline \multicolumn{8}{|c|}{ Annual } \\
\hline 7 & 1,820 & 936 & 567 & 343 & 292 & 177 & 107 \\
\hline \multicolumn{8}{|c|}{ Winter (January-March) } \\
\hline 7 & 2,390 & 1,560 & 1,230 & 1,010 & 949 & 798 & 681 \\
\hline 30 & 3,860 & 2,930 & 2,530 & 2,240 & 2,160 & 1,950 & 1,780 \\
\hline \multicolumn{8}{|c|}{ Spring (April-June) } \\
\hline 7 & 8,440 & 6,390 & 5,450 & 4,750 & 4,560 & 4,040 & 3,610 \\
\hline 7 & 9,050 & 6,450 & 4,790 & 3,490 & 3,140 & 2,250 & 1,600 \\
\hline 30 & 10,000 & 8,030 & 6,990 & 6,160 & 5,930 & 5,280 & 4,730 \\
\hline \multicolumn{8}{|c|}{ Fall (October-December) } \\
\hline 7 & 2,280 & 1,130 & 737 & 498 & 442 & 309 & 219 \\
\hline 30 & 4,460 & 3,350 & 2,830 & 2,440 & 2,330 & 2,040 & 1,800 \\
\hline \multicolumn{8}{|c|}{ Monthly } \\
\hline 7 (January) & 2,780 & 1,720 & 1,300 & 1,020 & 948 & 762 & 622 \\
\hline 7 (February) & 3,580 & 2,520 & 2,080 & 1,760 & 1,680 & 1,460 & 1,280 \\
\hline 7 (March) & 5,190 & 3,740 & 3,140 & 2,710 & 2,600 & 2,300 & 2,060 \\
\hline 7 (September) & 9,070 & 6,460 & 4,790 & 3,490 & 3,140 & 2,250 & 1,600 \\
\hline 7 (October) & 5,850 & 4,460 & 3,840 & 3,380 & 3,260 & 2,920 & 2,650 \\
\hline 7 (November) & 5,360 & 3,070 & 1,870 & 1,100 & 925 & 532 & 302 \\
\hline 7 (December) & 2,510 & 1,350 & 937 & 680 & 617 & 463 & 353 \\
\hline
\end{tabular}


Table 2-3-2. Annual, seasonal, and monthly n-day low-flow frequency data for streamflow-gaging station 06327500 (Yellowstone River at Glendive, Mont.) for unregulated and regulated steamflow conditions, 1928-2002.-Continued

[Abbreviations: $\mathrm{ft}^{3} / \mathrm{s}$, cubic feet per second. Symbol: \%, percent]

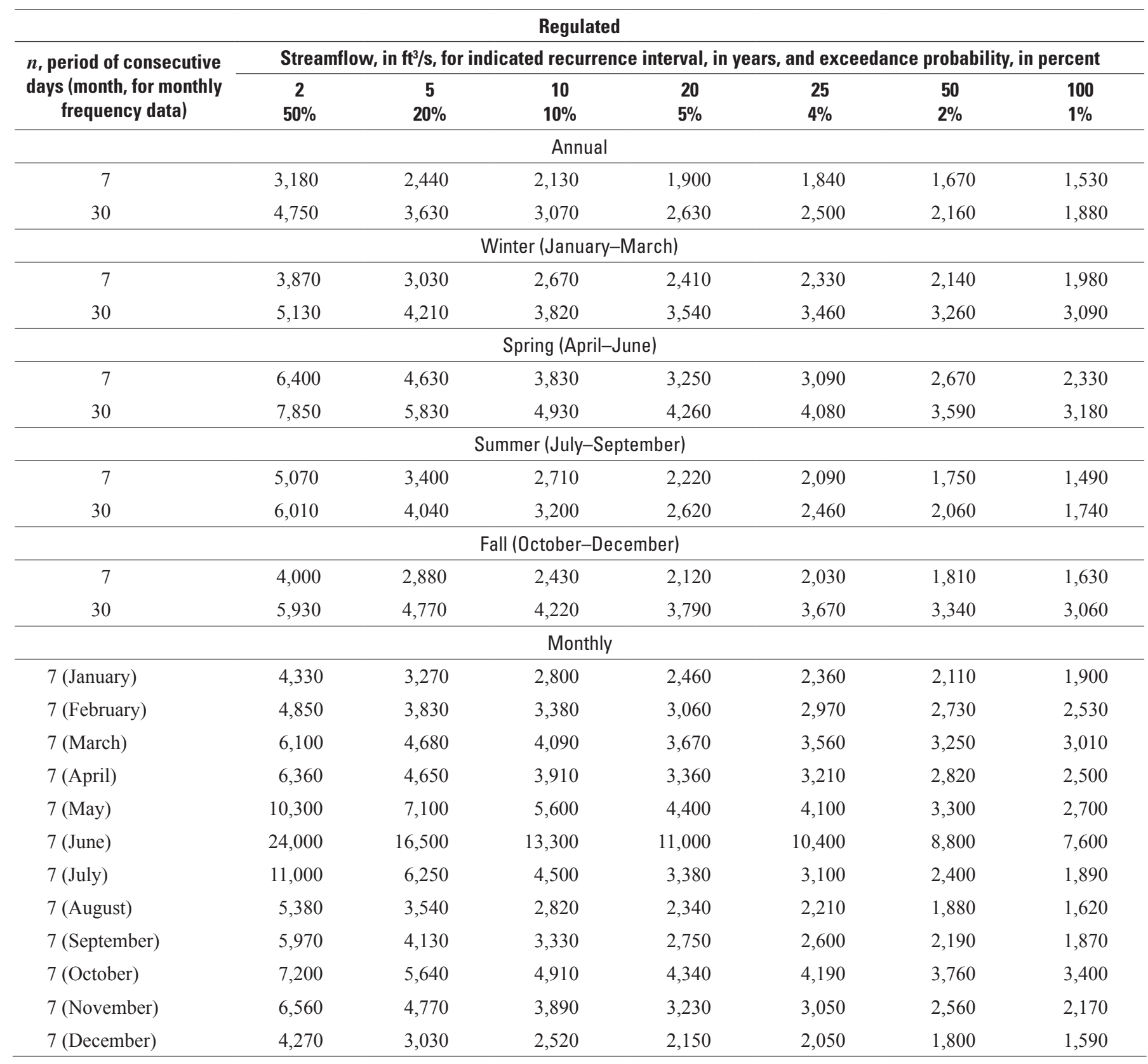


Table 2-3-3. Annual and seasonal flow-duration data for streamflow-gaging station 06327500 (Yellowstone River at Glendive, Mont.) for unregulated and regulated streamflow conditions, 1928-2002.

[Abbreviations: $\mathrm{ft}^{3} / \mathrm{s}$, cubic feet per second. Symbol: \%, percent]

\begin{tabular}{|c|c|c|c|c|c|c|c|c|c|c|c|c|c|c|c|c|c|c|c|}
\hline \multicolumn{20}{|c|}{ Streamflow, in $\mathrm{ft}^{3} / \mathrm{s}$, which was equaled or exceeded for indicated percent of time } \\
\hline $\begin{array}{c}\text { Streamflow } \\
\text { condition }\end{array}$ & $1 \%$ & $2 \%$ & $5 \%$ & $10 \%$ & $15 \%$ & $20 \%$ & $25 \%$ & $30 \%$ & $40 \%$ & $50 \%$ & $60 \%$ & $70 \%$ & $75 \%$ & $80 \%$ & $85 \%$ & $90 \%$ & $95 \%$ & $\mathbf{9 8} \%$ & $99 \%$ \\
\hline \multicolumn{20}{|c|}{ Annual } \\
\hline Unregulated & 72,000 & 64,200 & 49,900 & 37,500 & 29,400 & 23,400 & 19,000 & 15,500 & 11,400 & 8,920 & 7,240 & 6,110 & 5,620 & 5,050 & 4,400 & 3,730 & 2,820 & 1,870 & 1,290 \\
\hline Regulated & 56,800 & 49,200 & 37,200 & 26,300 & 19,000 & 14,800 & 12,300 & 10,900 & 9,170 & 8,020 & 7,210 & 6,380 & 5,940 & 5,450 & 4,980 & 4,450 & 3,650 & 2,850 & 2,450 \\
\hline \multicolumn{20}{|c|}{ Winter (January-March) } \\
\hline Unregulated & 27,600 & 21,100 & 14,500 & 10,900 & 9,310 & 8,320 & 7,430 & 6,820 & 5,940 & 5,330 & 4,740 & 4,140 & 3,830 & 3,530 & 3,190 & 2,730 & 2,110 & 1,410 & 1,090 \\
\hline Regulated & 28,000 & 21,900 & 15,100 & 11,600 & 10,300 & 9,300 & 8,440 & 7,850 & 7,090 & 6,500 & 5,920 & 5,320 & 5,060 & 4,800 & 4,420 & 3,980 & 3,430 & 2,810 & 2,520 \\
\hline \multicolumn{20}{|c|}{ Spring (April-June) } \\
\hline Unregulated & 85,700 & 76,600 & 67,500 & 57,700 & 50,900 & 45,400 & 40,900 & 37,100 & 30,600 & 25,200 & 20,400 & 14,400 & 12,400 & 10,700 & 9,200 & 7,980 & 6,910 & 5,940 & 5,290 \\
\hline Regulated & 69,300 & 60,700 & 52,100 & 43,800 & 37,600 & 32,700 & 28,500 & 25,000 & 18,800 & 15,000 & 12,100 & 9,280 & 8,320 & 7,490 & 6,820 & 6,020 & 5,050 & 4,180 & 3,570 \\
\hline \multicolumn{20}{|c|}{ Summer (July-September) } \\
\hline Unregulated & 69,100 & 60,300 & 47,200 & 37,700 & 31,400 & 27,000 & 23,400 & 20,800 & 17,300 & 14,900 & 13,100 & 11,500 & 10,800 & 10,100 & 9,440 & 8,520 & 6,990 & 5,850 & 4,530 \\
\hline Regulated & 53,700 & 46,100 & 35,200 & 27,300 & 21,600 & 17,100 & 14,300 & 12,600 & 10,400 & 8,930 & 7,640 & 6,490 & 5,970 & 5,350 & 4,760 & 4,140 & 3,210 & 2,560 & 2,140 \\
\hline \multicolumn{20}{|c|}{ Fall (October-December) } \\
\hline Unregulated & 11,800 & 11,000 & 9,770 & 8,770 & 8,080 & 7,610 & 7,250 & 6,950 & 6,380 & 5,960 & 5,500 & 4,830 & 4,440 & 4,010 & 3,640 & 3,080 & 2,030 & 1,170 & 689 \\
\hline Regulated & 12,900 & 12,200 & 11,200 & 10,300 & 9,730 & 9,250 & 8,820 & 8,480 & 7,920 & 7,450 & 6,950 & 6,280 & 5,890 & 5,440 & 4,960 & 4,470 & 3,580 & 2,810 & 2,330 \\
\hline
\end{tabular}


Table 2-3-4. Monthly and annual streamflow characteristics for streamflow-gaging station 06327500 (Yellowstone River at Glendive, Mont.) for unregulated and regulated streamflow conditions, 1928-2002.

[Abbreviations: $\mathrm{ft}^{3} / \mathrm{s}$, cubic feet per second]

\begin{tabular}{|c|c|c|c|c|c|c|}
\hline \multicolumn{7}{|c|}{ Unregulated } \\
\hline \multirow[b]{2}{*}{ Period } & \multicolumn{6}{|c|}{ Streamflow, in $\mathrm{ft}^{3} / \mathrm{s}$, or year, for indicated streamflow characteristic } \\
\hline & $\begin{array}{c}\text { Maximum } \\
\text { monthly mean and } \\
\text { maximum annual } \\
\text { mean streamflow }\end{array}$ & $\begin{array}{l}\text { Year of maximum } \\
\text { monthly mean and } \\
\text { maximum annual } \\
\text { mean streamflow }\end{array}$ & $\begin{array}{l}\text { Minimum monthly } \\
\text { mean and } \\
\text { minimum annual } \\
\text { mean streamflow }\end{array}$ & $\begin{array}{l}\text { Year of minimum } \\
\text { monthly mean and } \\
\text { minimum annual } \\
\text { mean streamflow }\end{array}$ & $\begin{array}{l}\text { Mean monthly } \\
\text { and mean annual } \\
\text { streamflow }\end{array}$ & $\begin{array}{c}\text { Standard } \\
\text { deviation of mean } \\
\text { monthly and mean } \\
\text { annual streamflow }\end{array}$ \\
\hline January & 8,410 & 1983 & 1,600 & 1940 & 4,580 & 1,430 \\
\hline March & 19,600 & 1929 & 2,750 & 2002 & 9,210 & 3,290 \\
\hline April & 19,300 & 1943 & 3,760 & 1961 & 10,530 & 3,090 \\
\hline May & 49,100 & 1928 & 15,050 & 1953 & 28,900 & 6,520 \\
\hline June & 84,000 & 1997 & 22,100 & 2001 & 48,300 & 13,100 \\
\hline October & 11,900 & 1982 & 3,510 & 1935 & 7,050 & 2,000 \\
\hline November & 8,800 & 1982 & 3,130 & 1931 & 5,920 & 1,470 \\
\hline December & 8,230 & 1982 & 2,160 & 1931 & 4,840 & 1,390 \\
\hline Annual & 22,400 & 1997 & 9,570 & 1934 & 15,200 & 2,850 \\
\hline \multicolumn{7}{|c|}{ Regulated } \\
\hline \multicolumn{7}{|c|}{ Streamflow, in $\mathrm{ft}^{3} / \mathrm{s}$, or year, for indicated streamflow characteristic } \\
\hline Period & $\begin{array}{c}\text { Maximum } \\
\text { monthly mean and } \\
\text { maximum annual } \\
\text { mean streamflow }\end{array}$ & $\begin{array}{l}\text { Year of maximum } \\
\text { monthly mean and } \\
\text { maximum annual } \\
\text { mean streamflow }\end{array}$ & $\begin{array}{l}\text { Minimum monthly } \\
\text { mean and } \\
\text { minimum annual } \\
\text { mean streamflow }\end{array}$ & $\begin{array}{l}\text { Year of minimum } \\
\text { monthly mean and } \\
\text { minimum annual } \\
\text { mean streamflow }\end{array}$ & $\begin{array}{l}\text { Mean monthly } \\
\text { and mean annual } \\
\text { streamflow }\end{array}$ & $\begin{array}{l}\text { Standard } \\
\text { deviation of mean } \\
\text { monthly and mean } \\
\text { annual streamflow }\end{array}$ \\
\hline June & 67,800 & 1997 & 12,000 & 1934 & 35,000 & 12,100 \\
\hline July & 49,000 & 1967 & 3,950 & 1934 & 21,100 & 11,110 \\
\hline August & 17,700 & 1997 & 2,560 & 1961 & 8,390 & 3,780 \\
\hline September & 15,000 & 1941 & 3,120 & 1934 & 7,810 & 2,700 \\
\hline October & 13,400 & 1941 & 4,610 & 1934 & 8,270 & 2,040 \\
\hline November & 11,200 & 1972 & 4,450 & 1934 & 7,610 & 1,670 \\
\hline December & 9,980 & 1982 & 3,510 & 2002 & 6,360 & 1,460 \\
\hline Annual & 19,300 & 1997 & 5,800 & 1934 & 11,900 & 3,060 \\
\hline
\end{tabular}




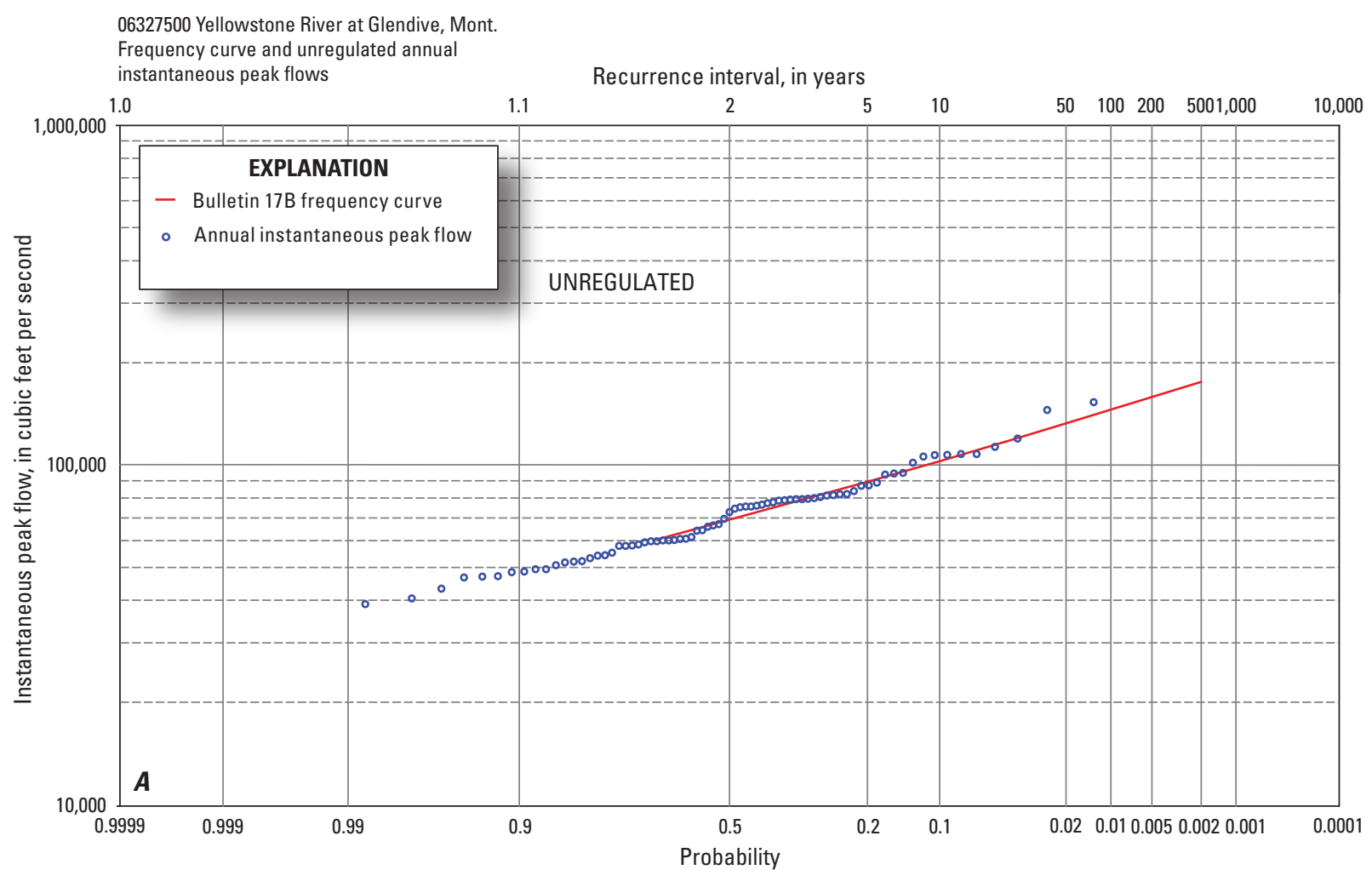

06327500 Yellowstone River at Glendive, Mont.

Time series of unregulated annual instantaneous peak flows

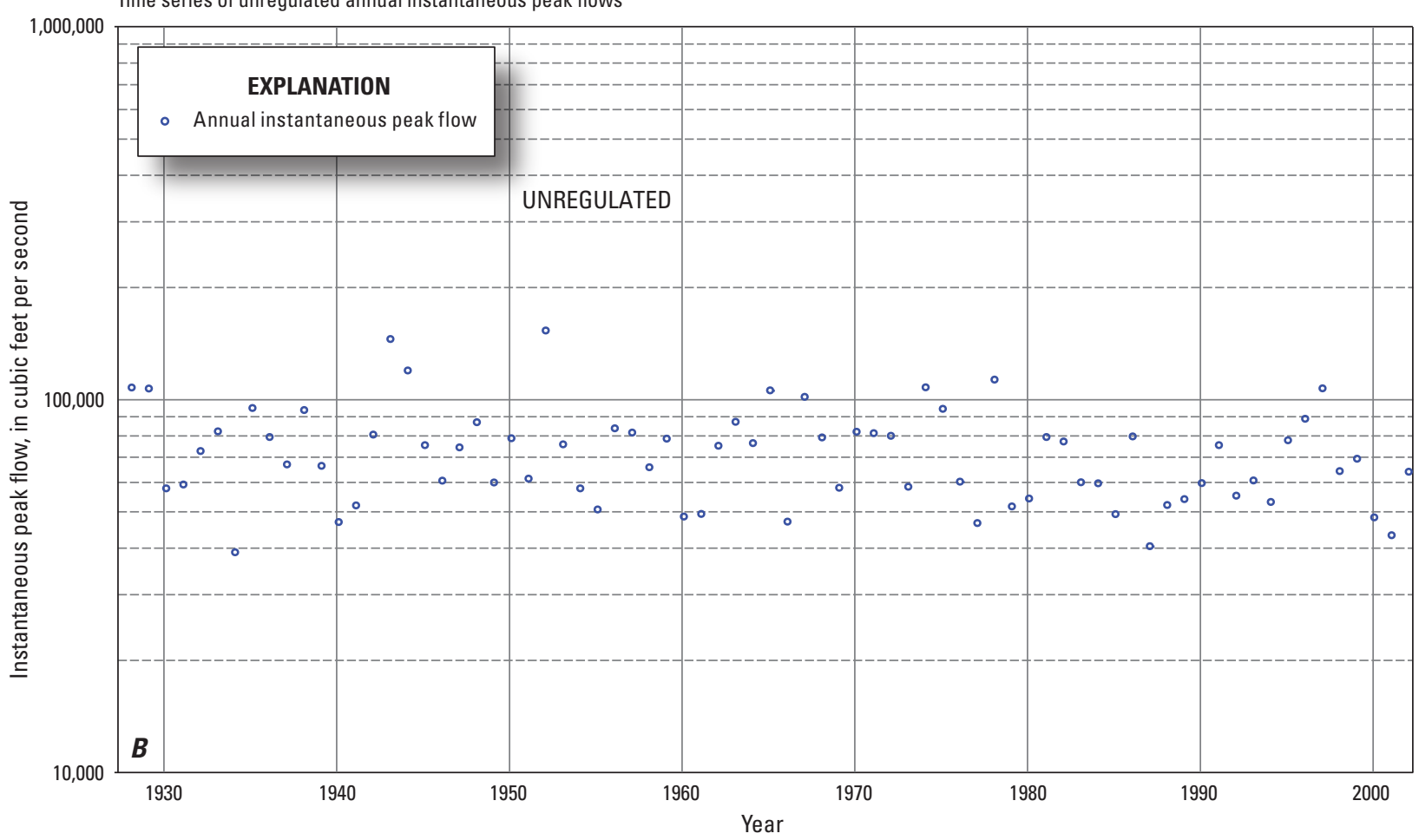

Figure 2-3-1. Annual instantaneous peak-flow data for streamflow-gaging station 06327500 (Yellowstone River at Glendive, Mont.) for unregulated streamflow conditions, 1928-2002. A, Frequency curve and unregulated annual instantaneous peak flows. $B$, Time series of unregulated annual instantaneous peak flows. [Bulletin 17B: U.S. Interagency Advisory Council on Water Data, 1982] 

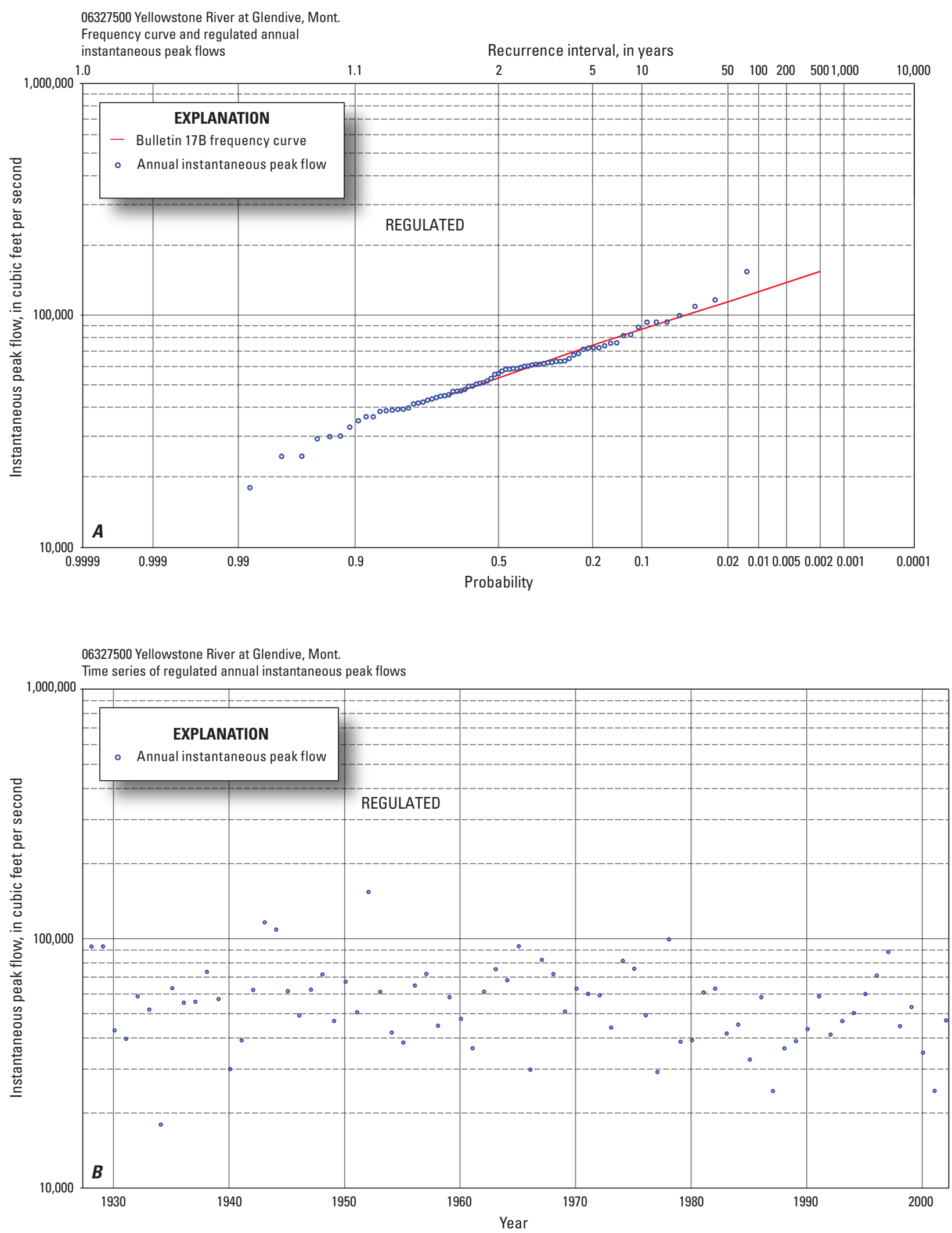

Figure 2-3-2. Annual instantaneous peak-flow data for streamflow-gaging station 06327500 (Yellowstone River at Glendive, Mont.) for regulated streamflow conditions, 1928-2002. A, Frequency curve and regulated annual instantaneous peak flows. $B$, Time series of regulated annual instantaneous peak flows. [Bulletin 17B: U.S. Interagency Advisory Council on Water Data, 1982] 


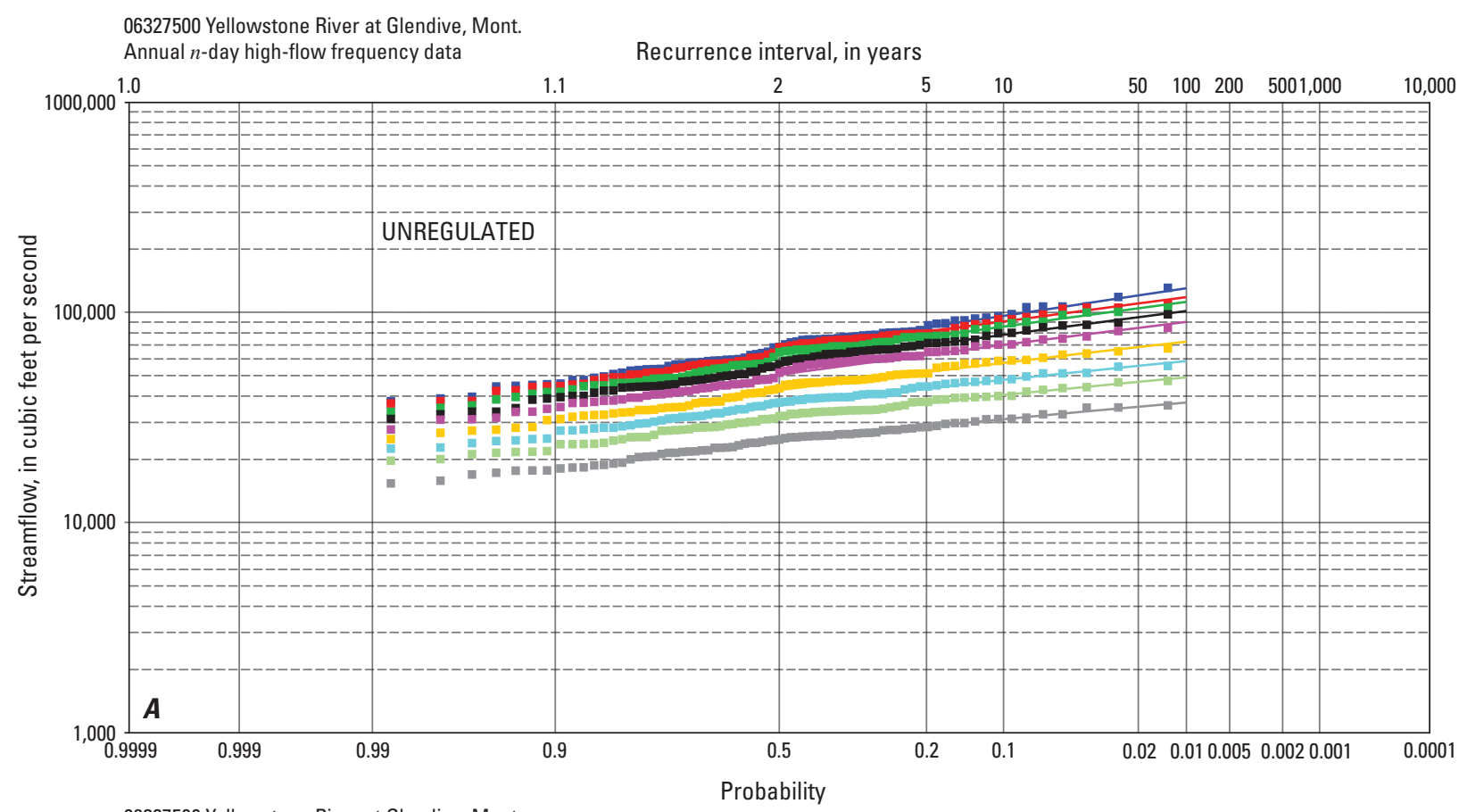

06327500 Yellowstone River at Glendive, Mont. Annual $n$-day high-flow frequency data Recurrence interval, in years

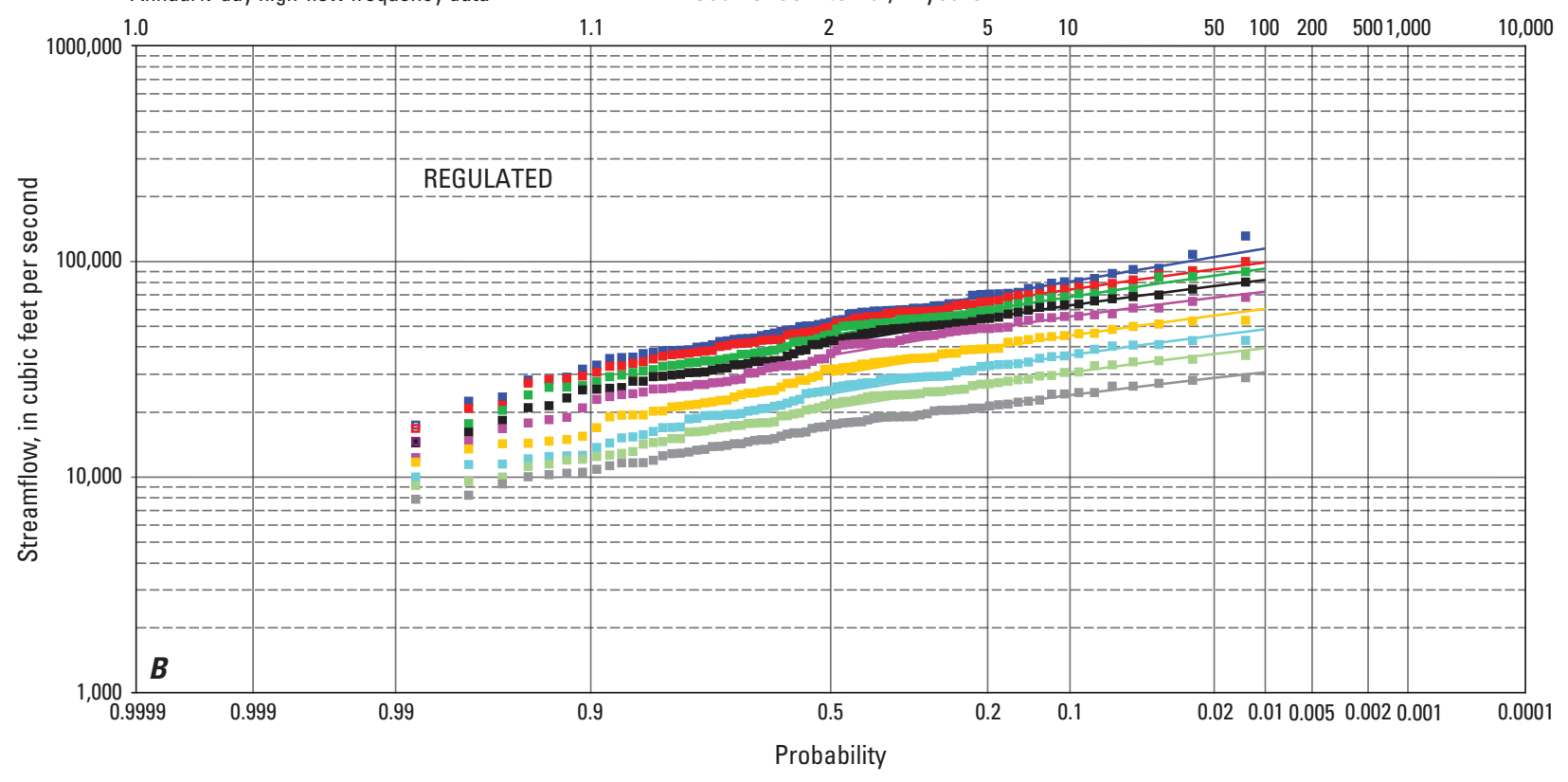

EXPLANATION

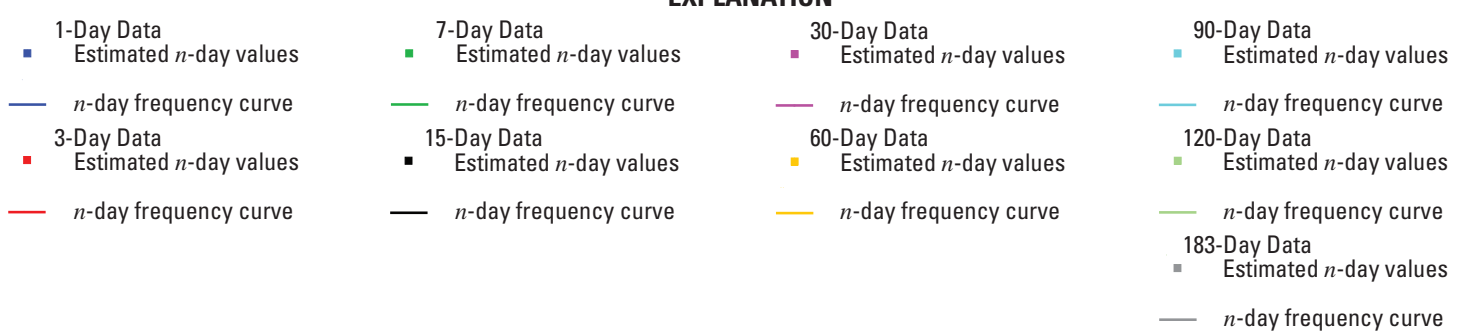

Figure 2-3-3. Annual $n$-day high-flow frequency data for streamflow-gaging station 06327500 (Yellowstone River at Glendive, Mont.) for $A$, unregulated and $B$, regulated streamflow conditions, 1928-2002. 

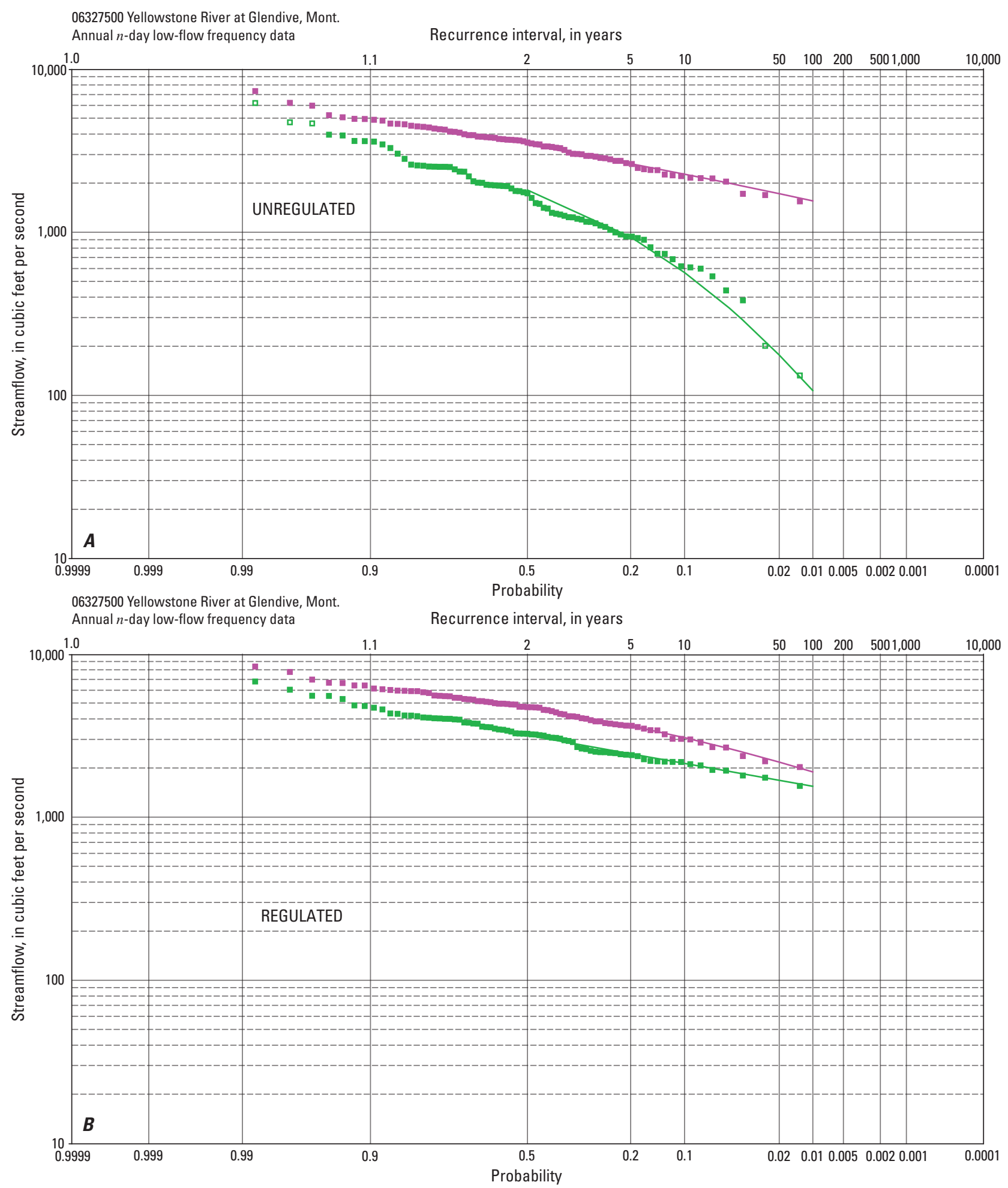

EXPLANATION

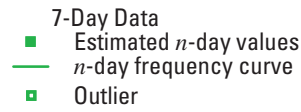

30-Day Data
Estimated $n$-day values
$n$-day frequency curve

Figure 2-3-4. Annual $n$-day low-flow frequency data for streamflow-gaging station 06327500 (Yellowstone River at Glendive, Mont.) for $A$, unregulated and $B$, regulated streamflow conditions, 1928-2002. 


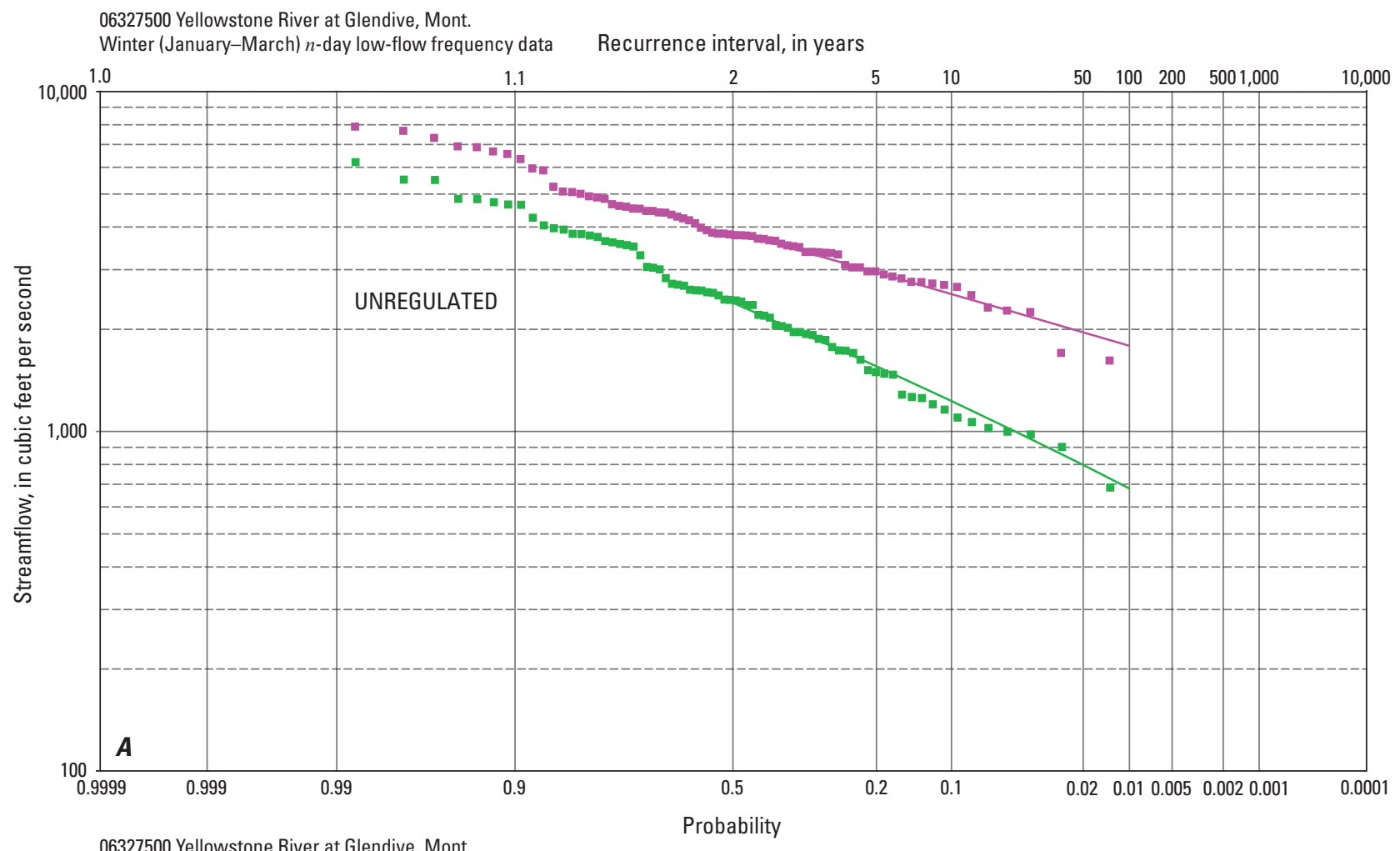

06327500 Yellowstone River at Glendive, Mont.

Winter (January-March) n-day low-flow frequency data Recurrence interval, in years

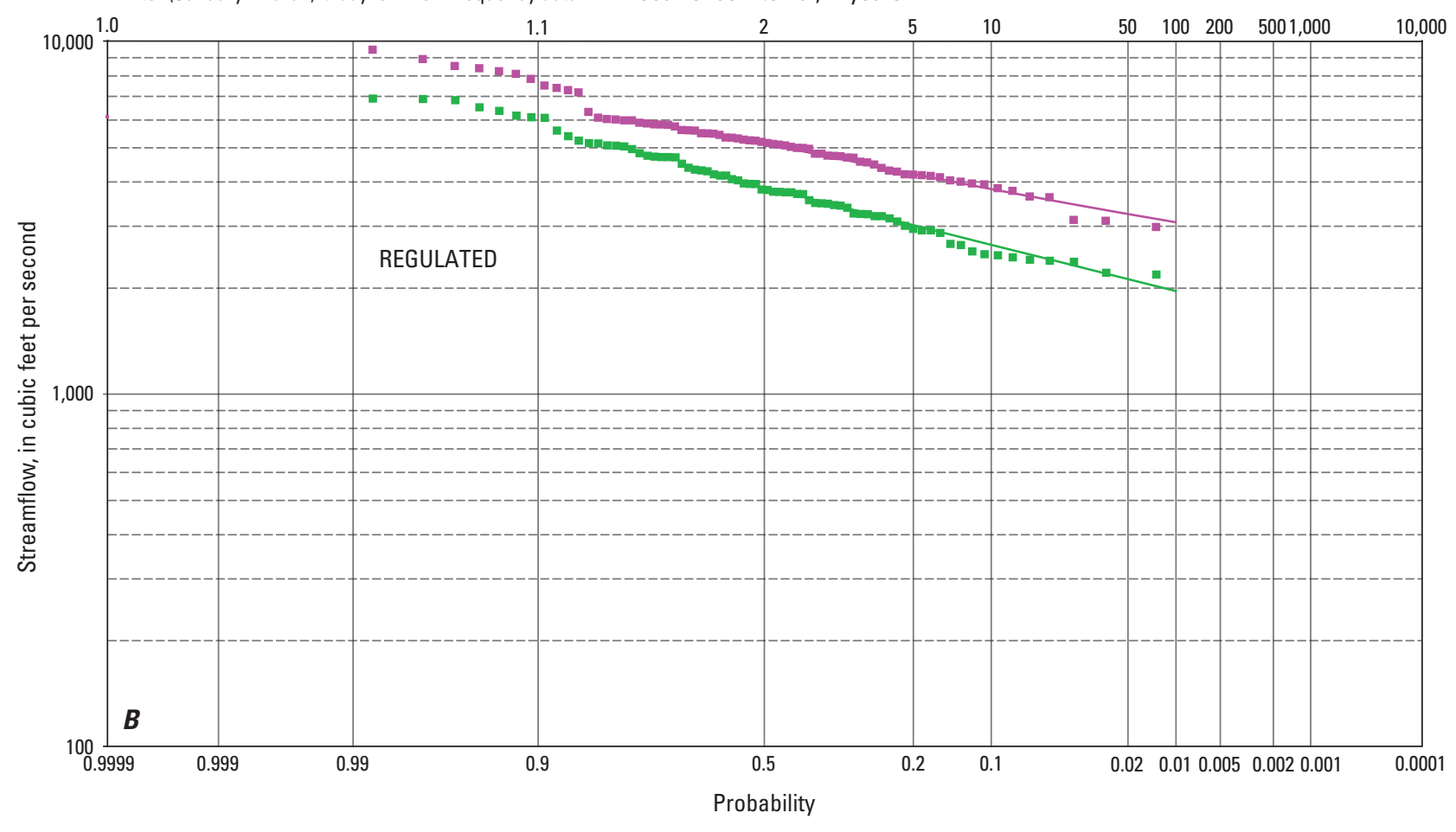

EXPLANATION

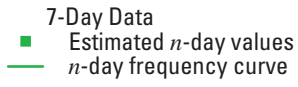

30-Day Data

- Estimated $n$-day values

- $n$-day frequency curve

Figure 2-3-5. Winter (January-March) $n$-day low-flow frequency data for streamflow-gaging station 06327500 (Yellowstone River at Glendive, Mont.) for $A$, unregulated and $B$, regulated streamflow conditions, 1928-2002. 

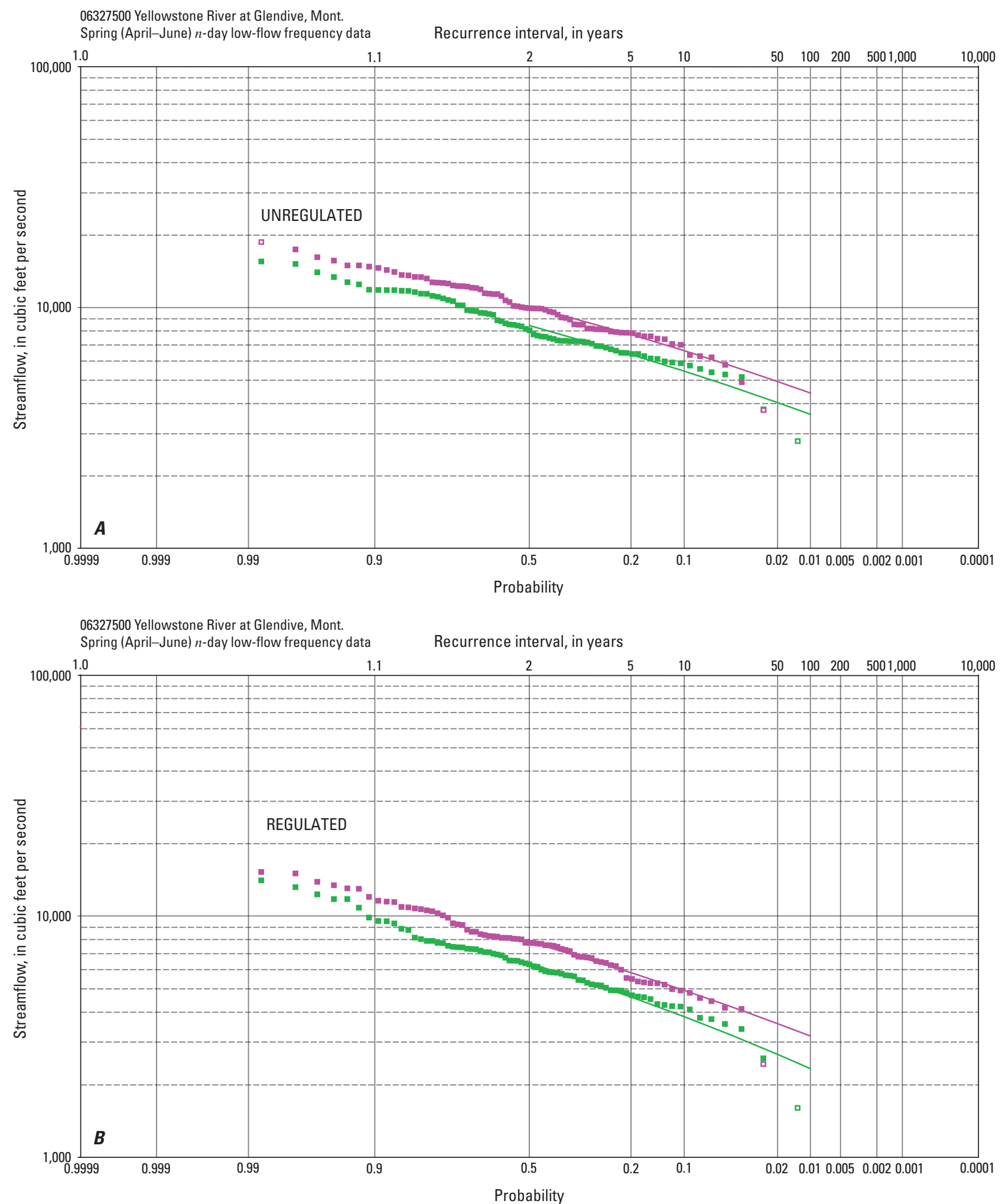

EXPLANATION

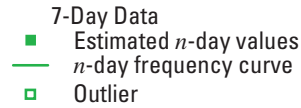

30-Day Data
Estimated $n$-day values
$n$-day frequency curve
Outlier

Figure 2-3-6. Spring (April-June) $n$-day low-frequency data for streamflow-gaging station 06327500 (Yellowstone River at Glendive, Mont.) for $A$, unregulated and $B$, regulated streamflow conditions, 1928-2002. 
06327500 Yellowstone River at Glendive, Mont.

Summer (July-September) $n$-day low-flow frequency data Recurrence interval, in years

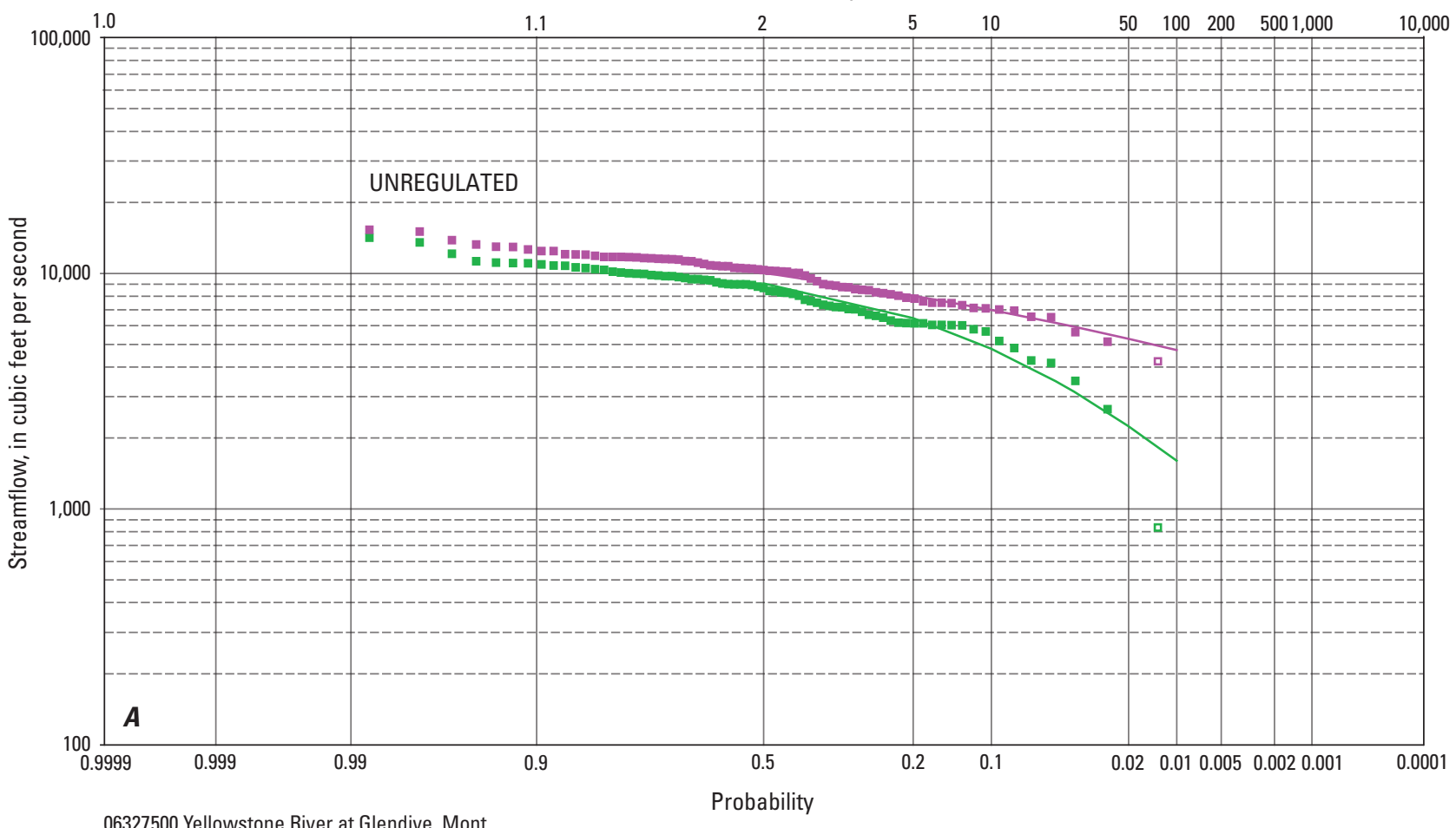

06327500 Yellowstone River at Glendive, Mont.

Recurrence interval, in years

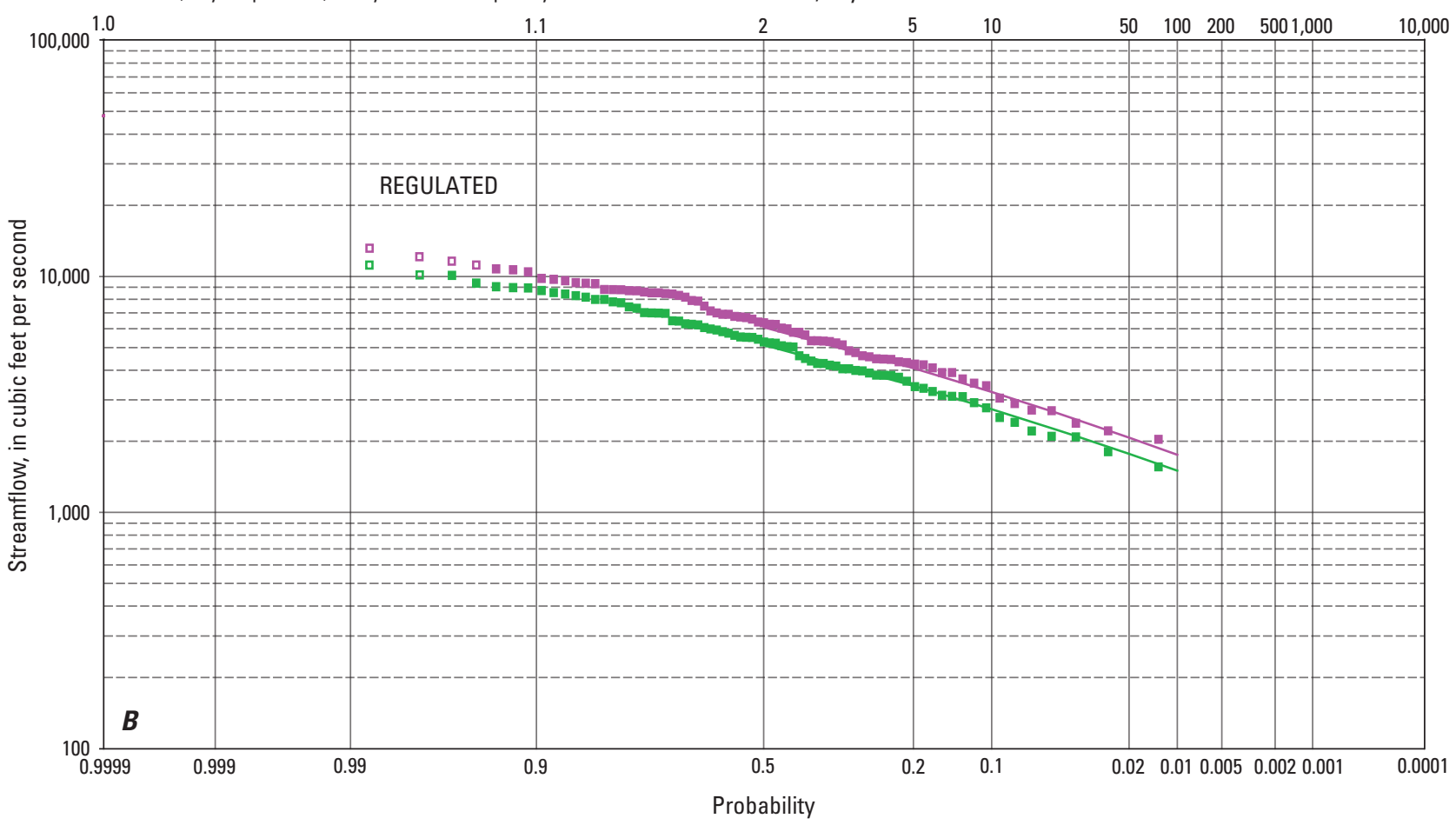

EXPLANATION

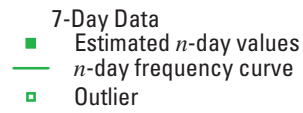

30-Day Data

- Estimated $n$-day values

- $n$-day frequency curve

- n-day frequency curve

Outlier

Figure 2-3-7. Summer (July-September) $n$-day low-frequency data for streamflow-gaging station 06327500 (Yellowstone River at Glendive, Mont.) for $A$, unregulated and $B$, regulated streamflow conditions, 1928-2002. 


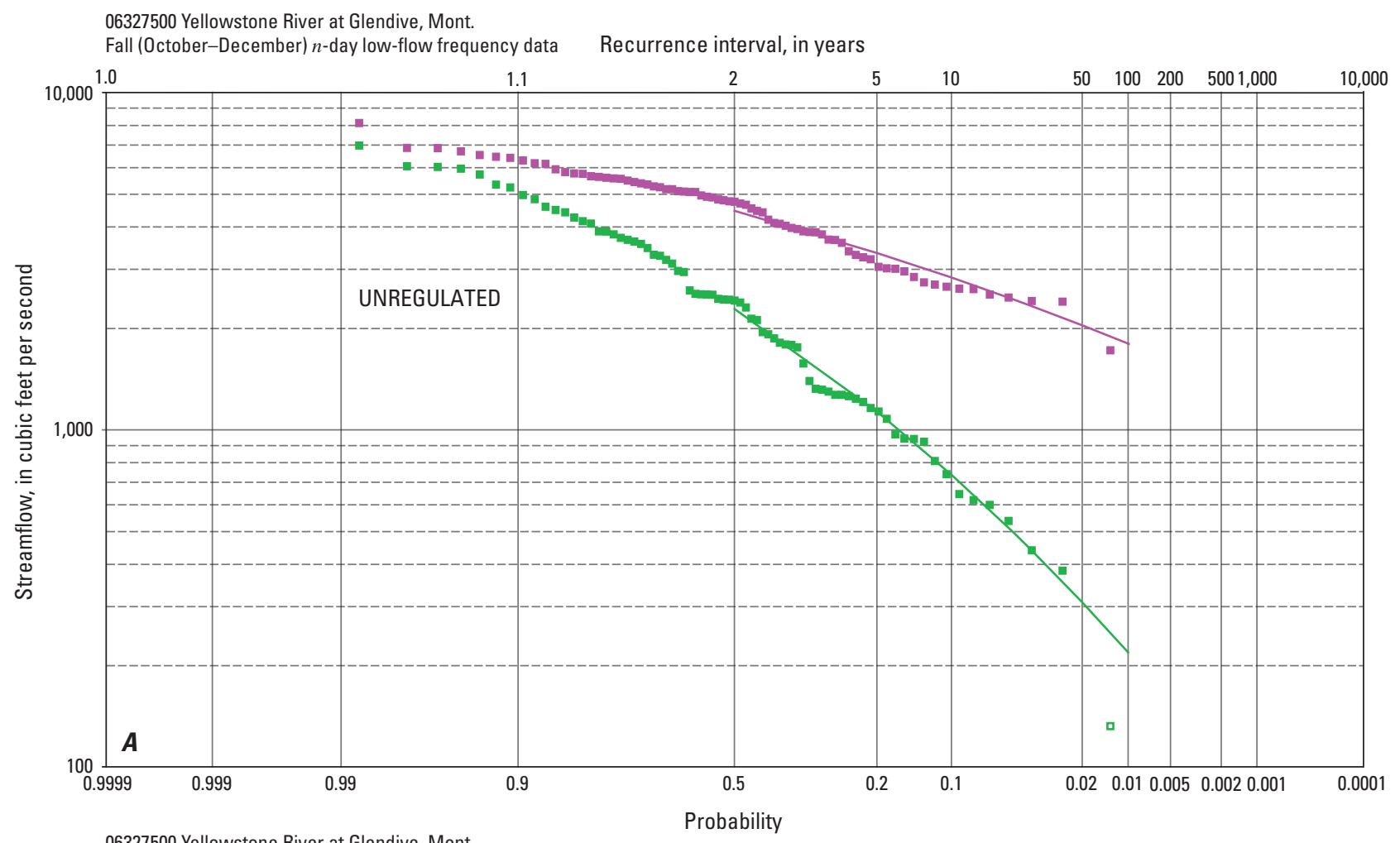

06327500 Yellowstone River at Glendive, Mont.

Recurrence interval, in years

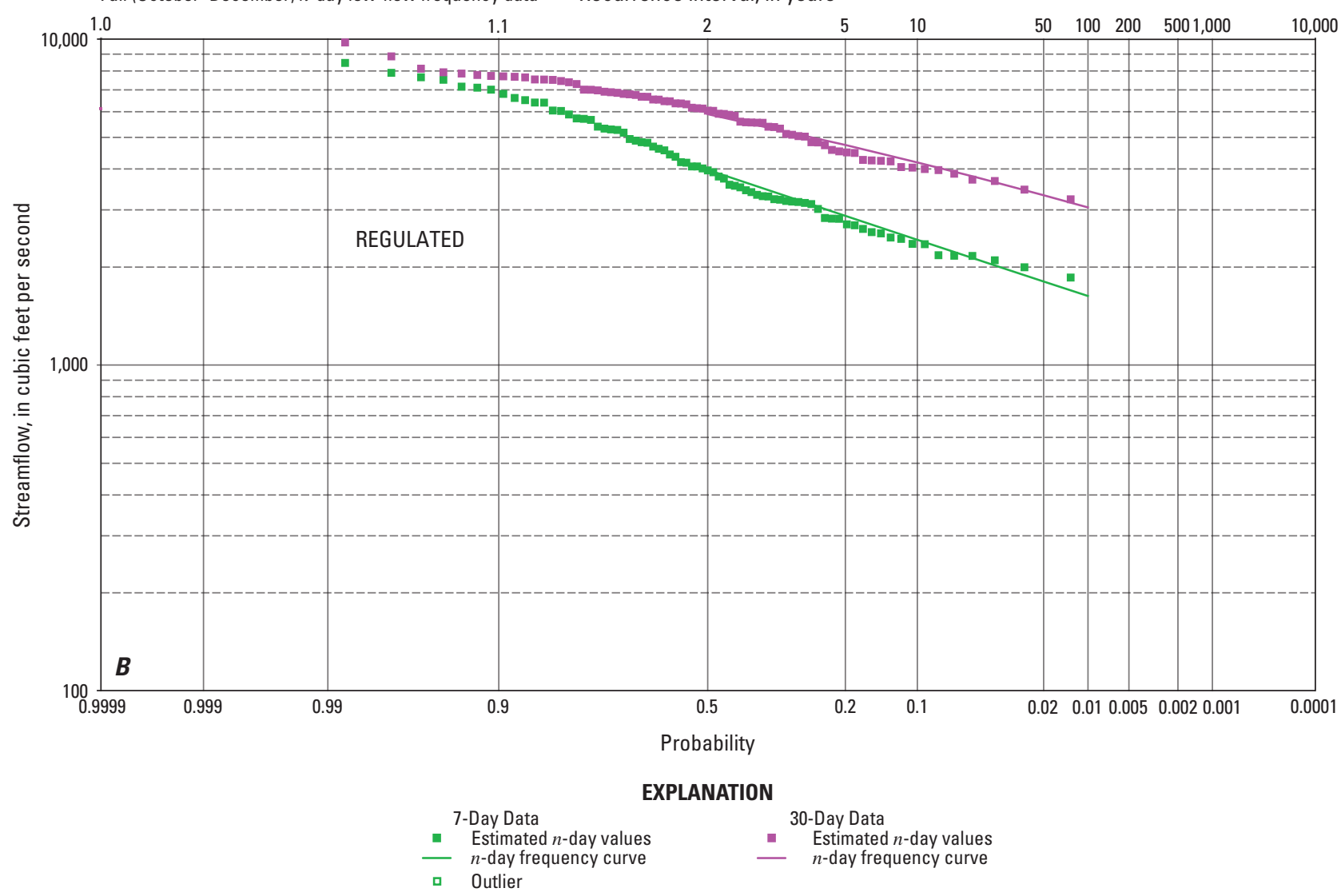

Figure 2-3-8. Fall (October-December) $n$-day low-flow frequency data for streamflow-gaging station 06327500 (Yellowstone River at Glendive, Mont.) for $A$, unregulated and $B$, regulated streamflow conditions, 1928-2002. 

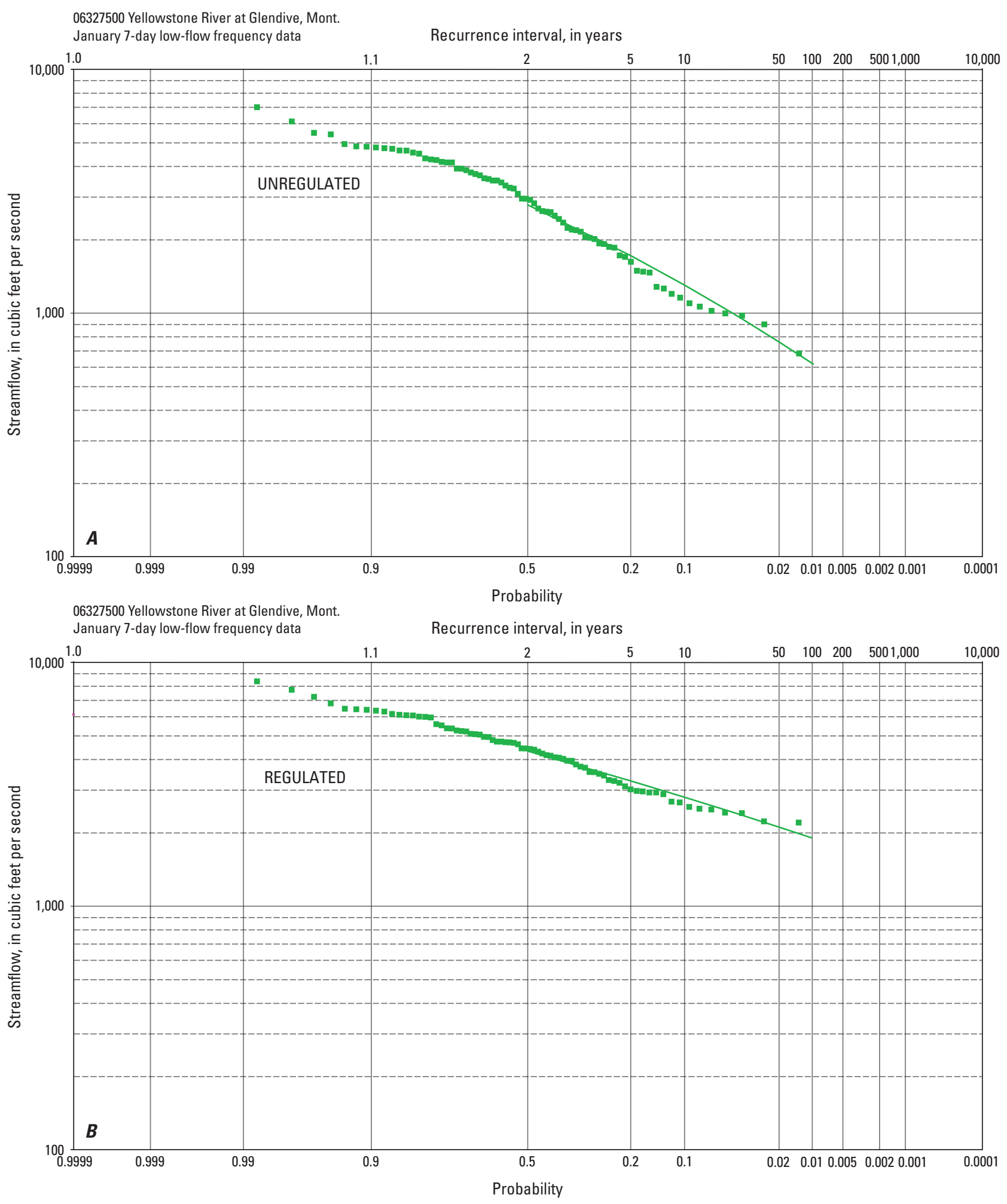

EXPLANATION

7-Day Data

- Estimated $n$-day values

- $n$-day frequency curve

Figure 2-3-9. January 7-day low-flow frequency data for streamflow-gaging station 06327500 (Yellowstone River at Glendive, Mont.) for $A$, unregulated and $B$, regulated streamflow conditions, 1928-2002. 

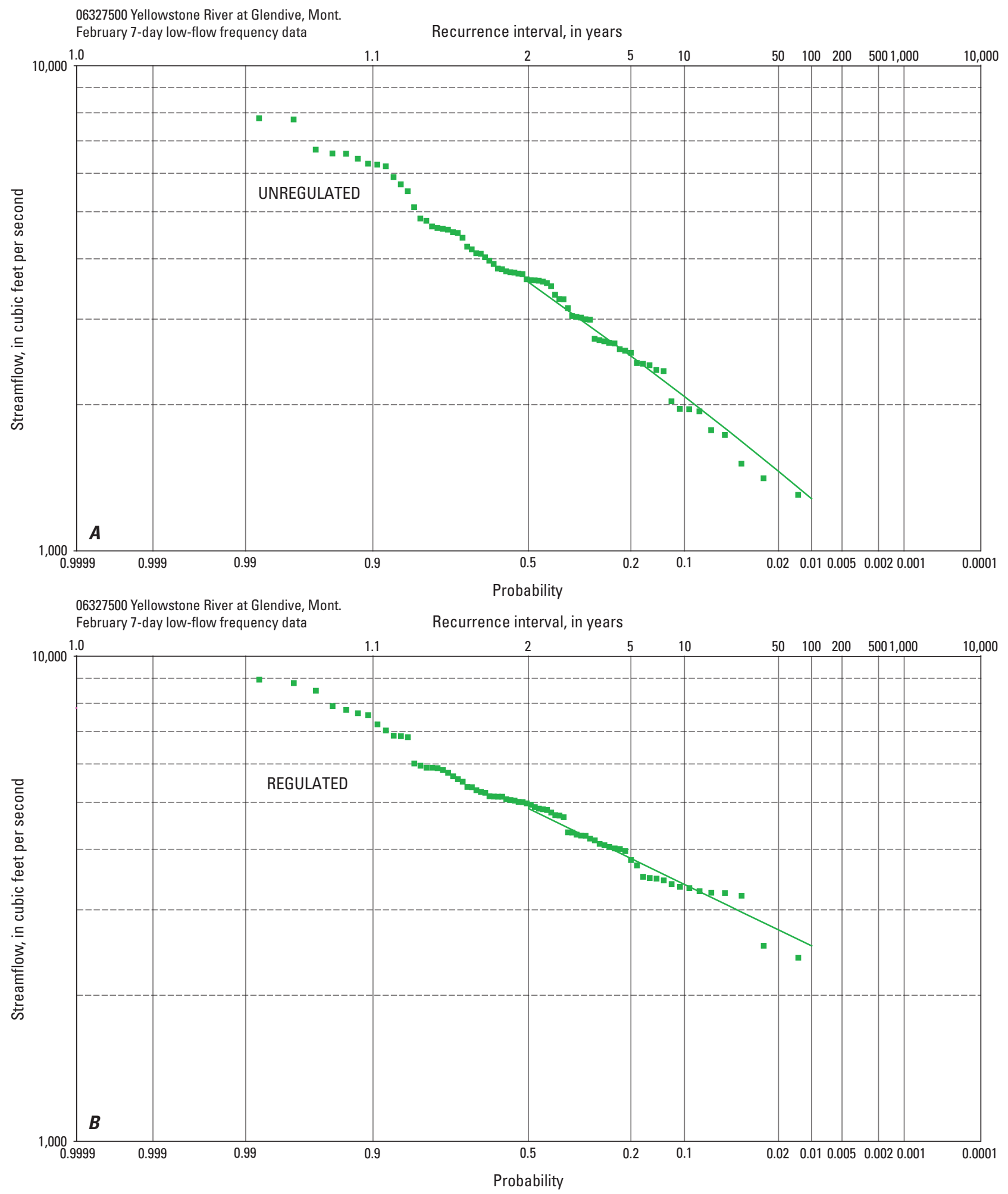

EXPLANATION

7-Day Data

- $\quad$ Estimated $n$-day values $n$-day frequency curve

Figure 2-3-10. February 7-day low-flow frequency data for streamflow-gaging station 06327500 (Yellowstone River at Glendive, Mont.) for $A$, unregulated and $B$, regulated streamflow conditions, 1928-2002. 

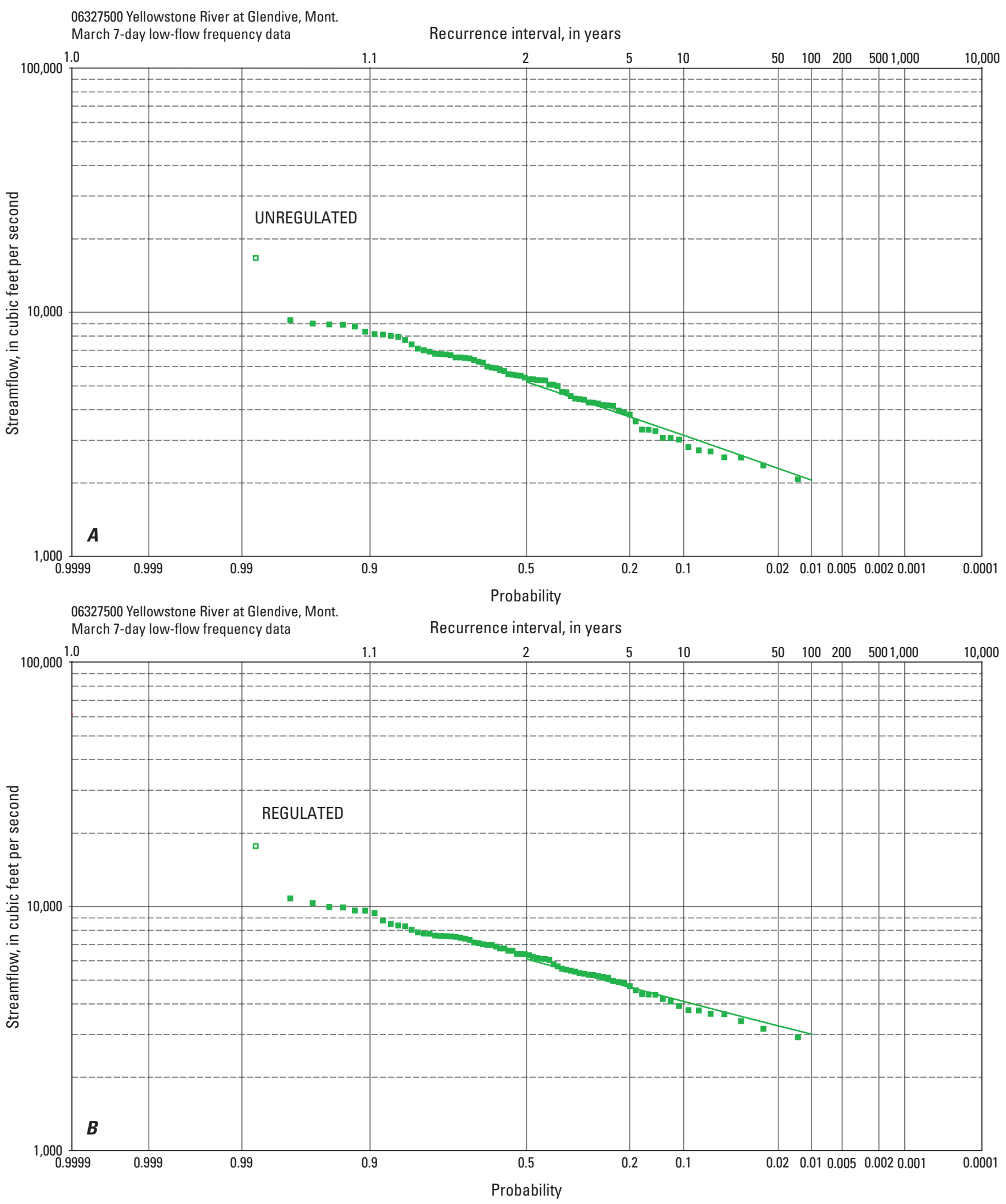

EXPLANATION

7-Day Data

- Estimated $n$-day values

- n-day frequency curve

Outlier

Figure 2-3-11. March 7-day low-flow frequency data for streamflow-gaging station 06327500 (Yellowstone River at Glendive, Mont.) for $A$, unregulated and $B$, regulated streamflow conditions, 1928-2002. 


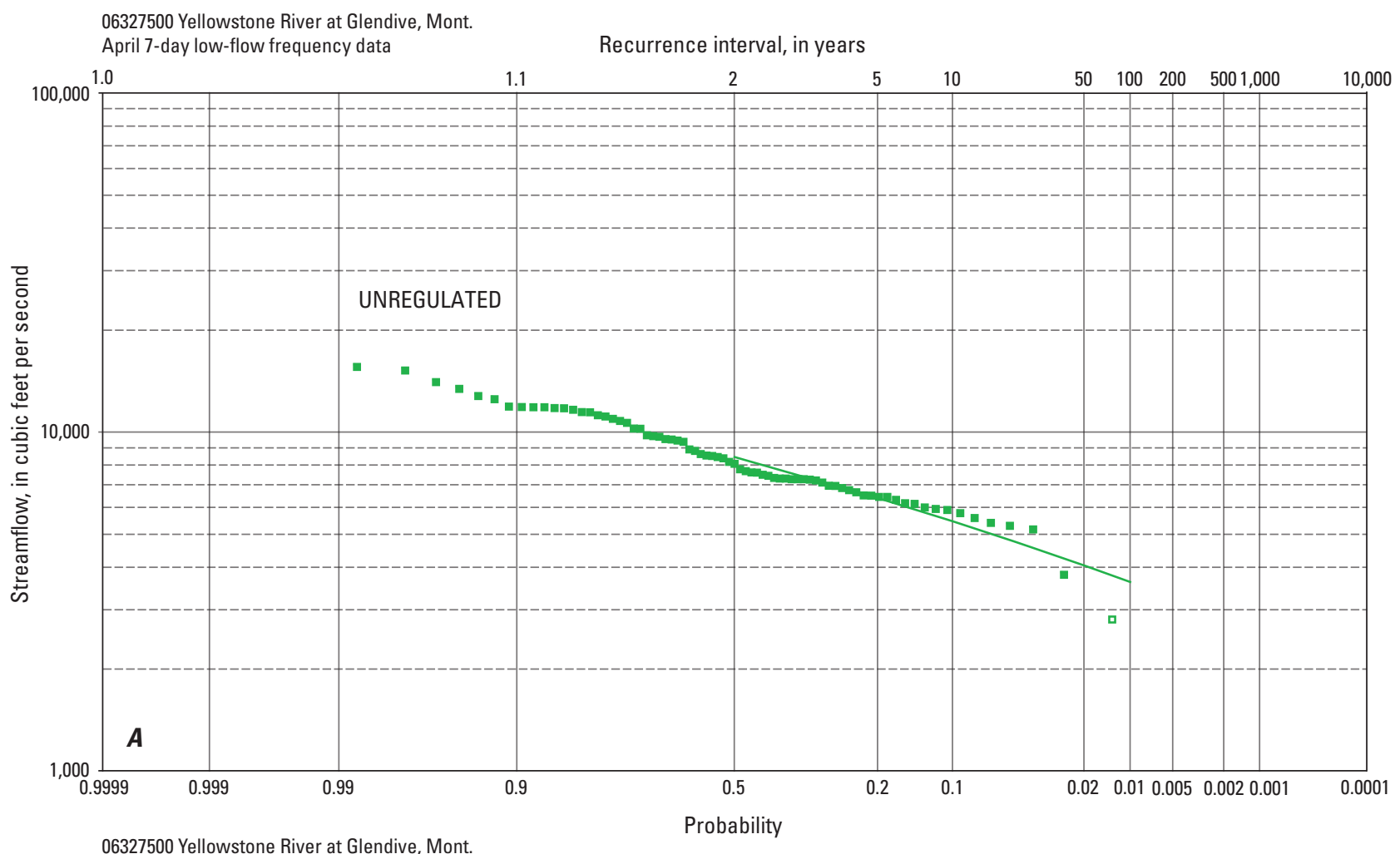

06327500 Yellowstone River at Glendive, Mont. April 7-day low-flow frequency data

Recurrence interval, in years

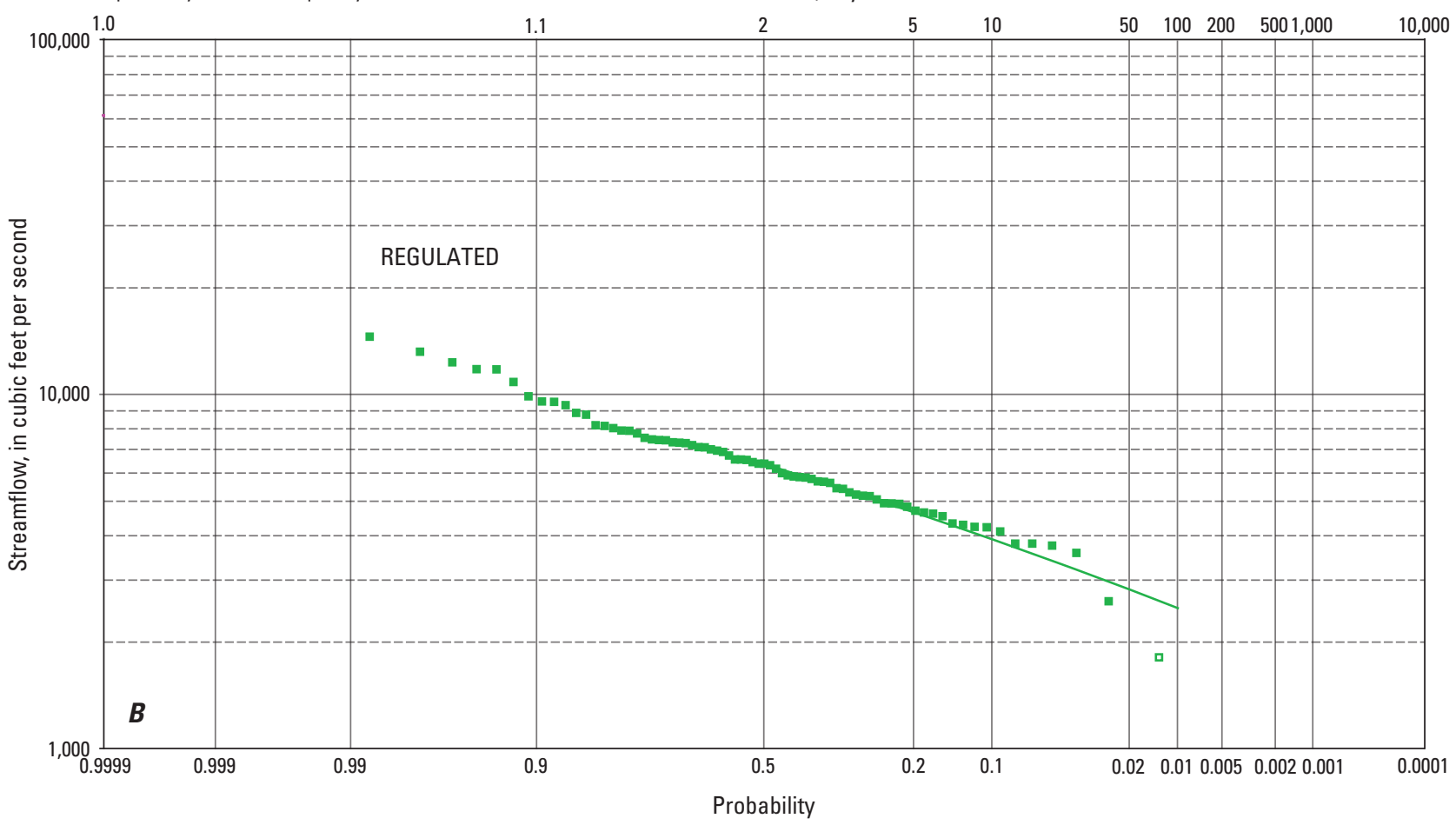

EXPLANATION

7-Day Data

- Estimated $n$-day values

n-day frequency curve

口 Outlier

Figure 2-3-12. April 7-day low-flow frequency data for streamflow-gaging station 06327500 (Yellowstone River at Glendive, Mont.) for $A$, unregulated and $B$, regulated streamflow conditions, 1928-2002. 


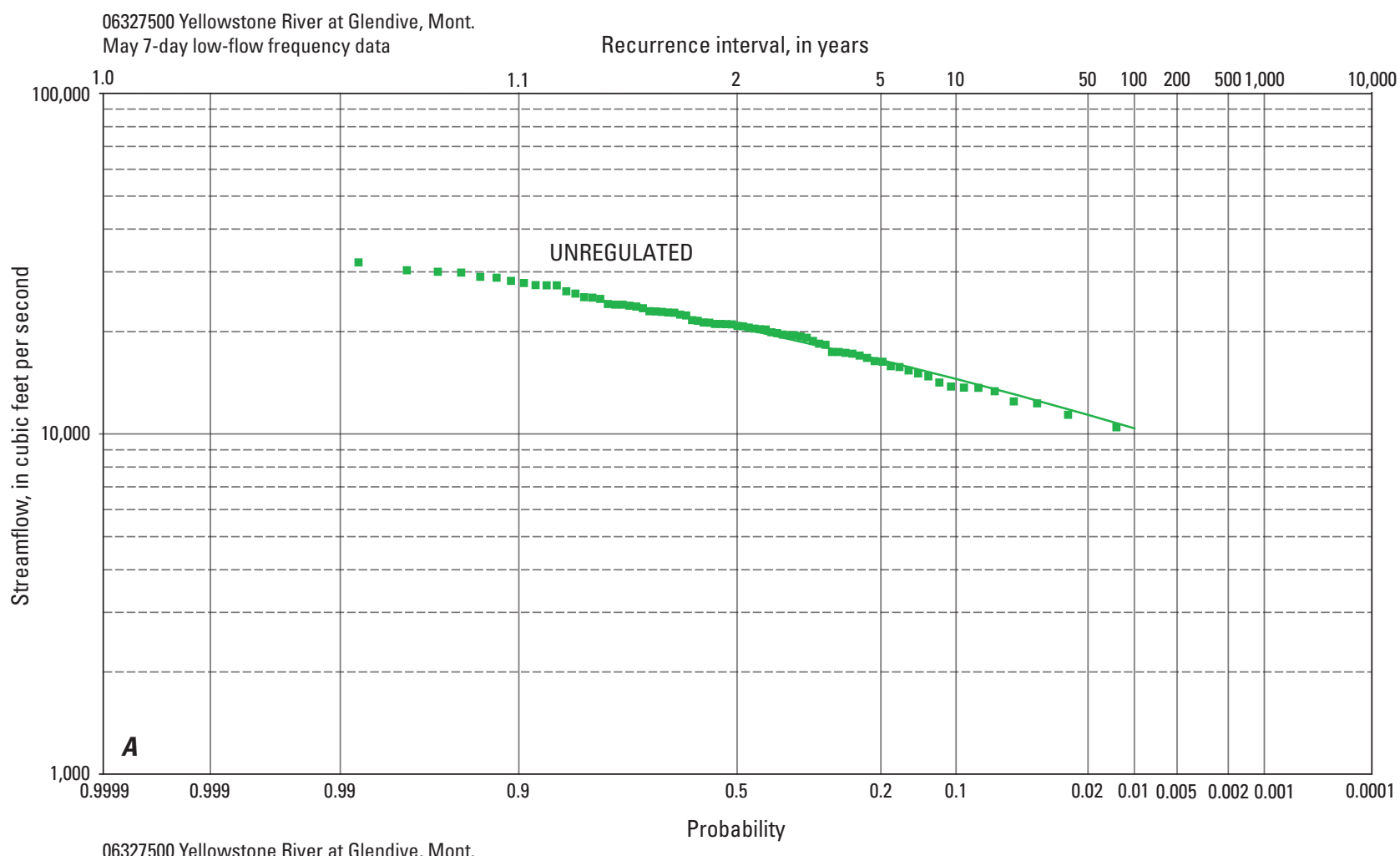

06327500 Yellowstone River at Glendive, Mont May 7-day low-flow frequency data

Recurrence interval, in years

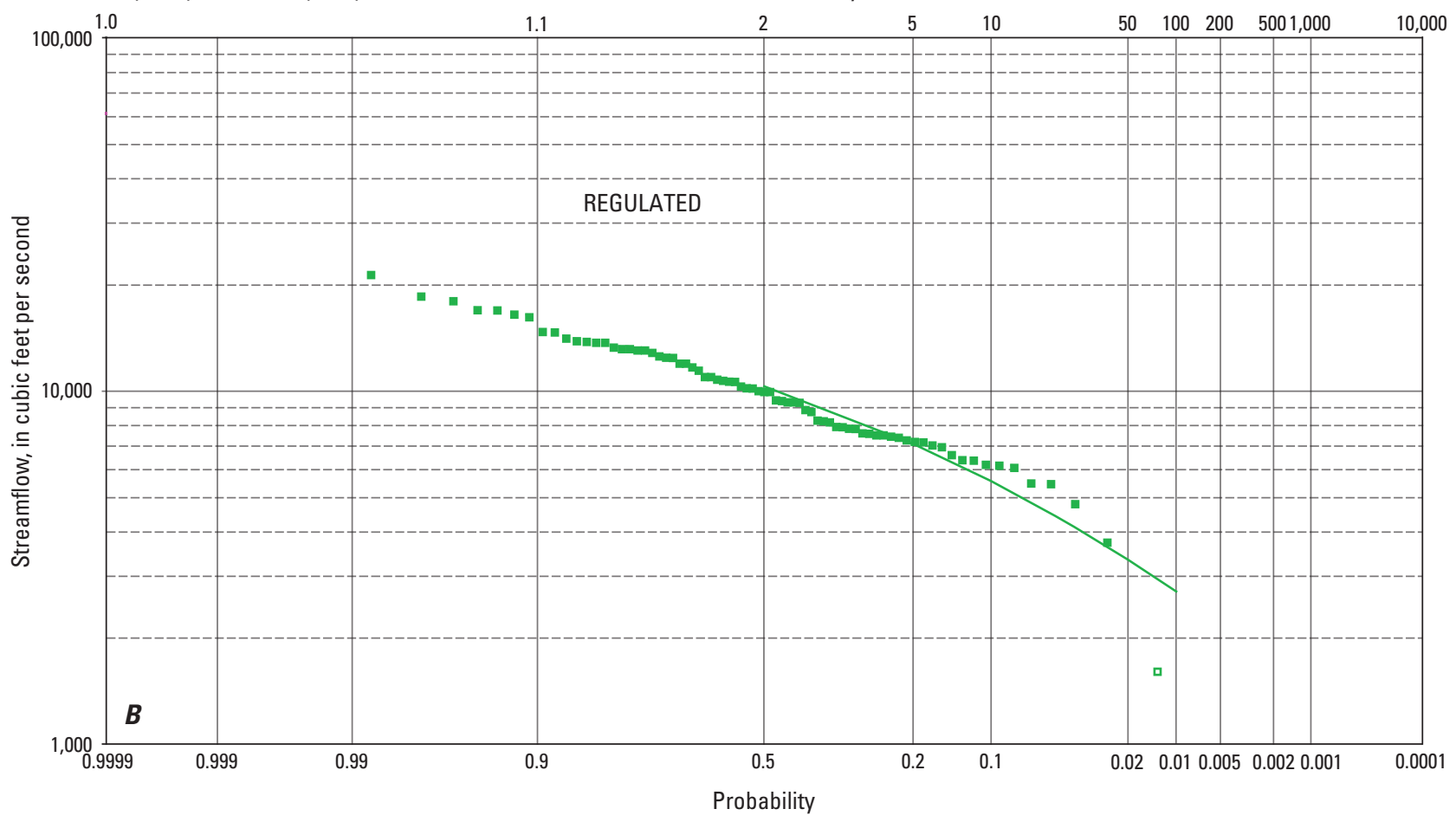

EXPLANATION

7-Day Data

- Estimated $n$-day values

- n-day frequency curve

- Outlier

Figure 2-3-13. May 7-day low-flow frequency data for streamflow-gaging station 06327500 (Yellowstone River at Glendive, Mont.) for $A$, unregulated and $B$, regulated streamflow conditions, 1928-2002. 

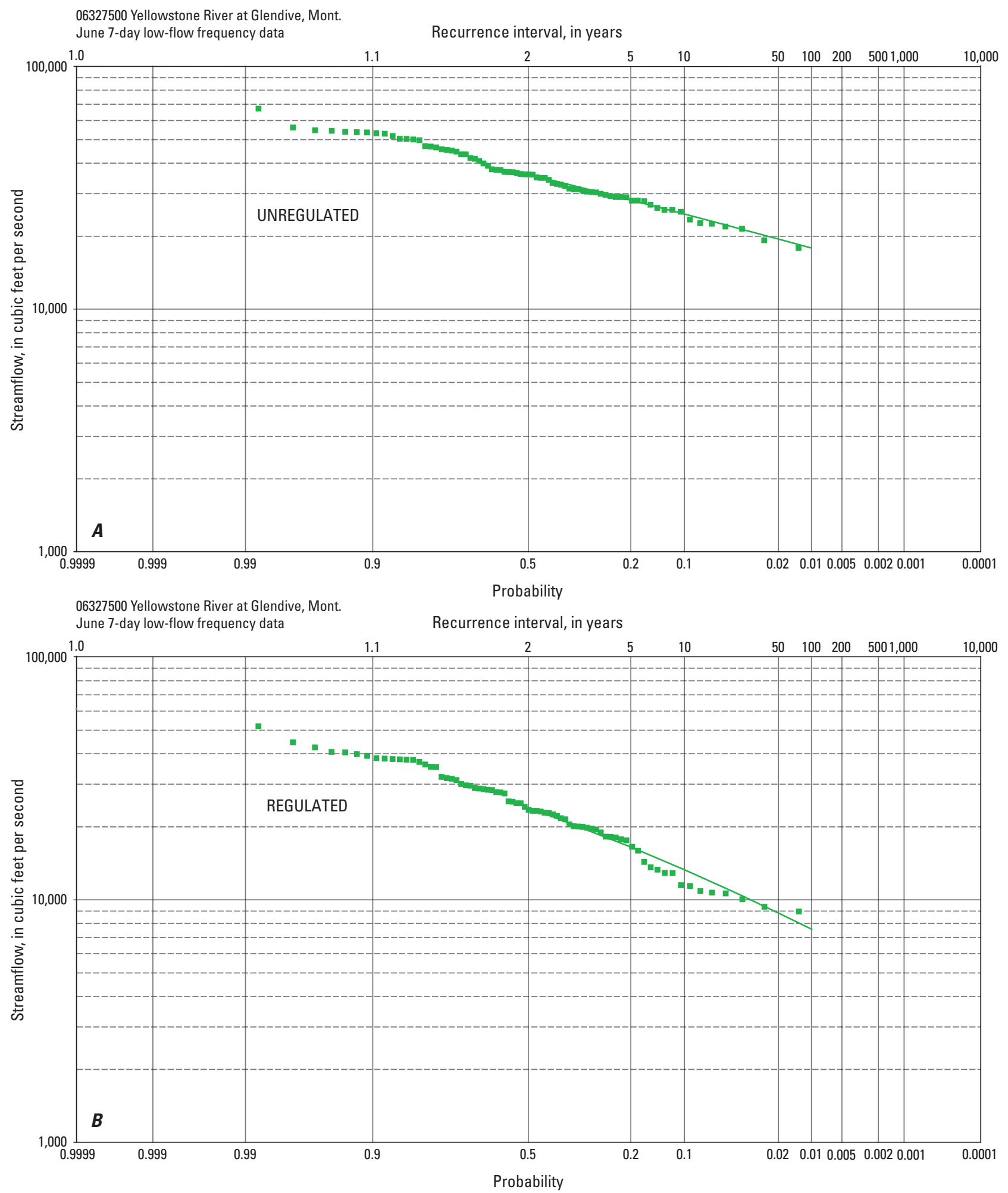

EXPLANATION

7-Day Data

- $\quad$ Estimated $n$-day values

- n-day frequency curve

Figure 2-3-14. June 7-day low-flow frequency data for streamflow-gaging station 06327500 (Yellowstone River at Glendive, Mont.) for $A$, unregulated and $B$, regulated streamflow conditions, 1928-2002. 

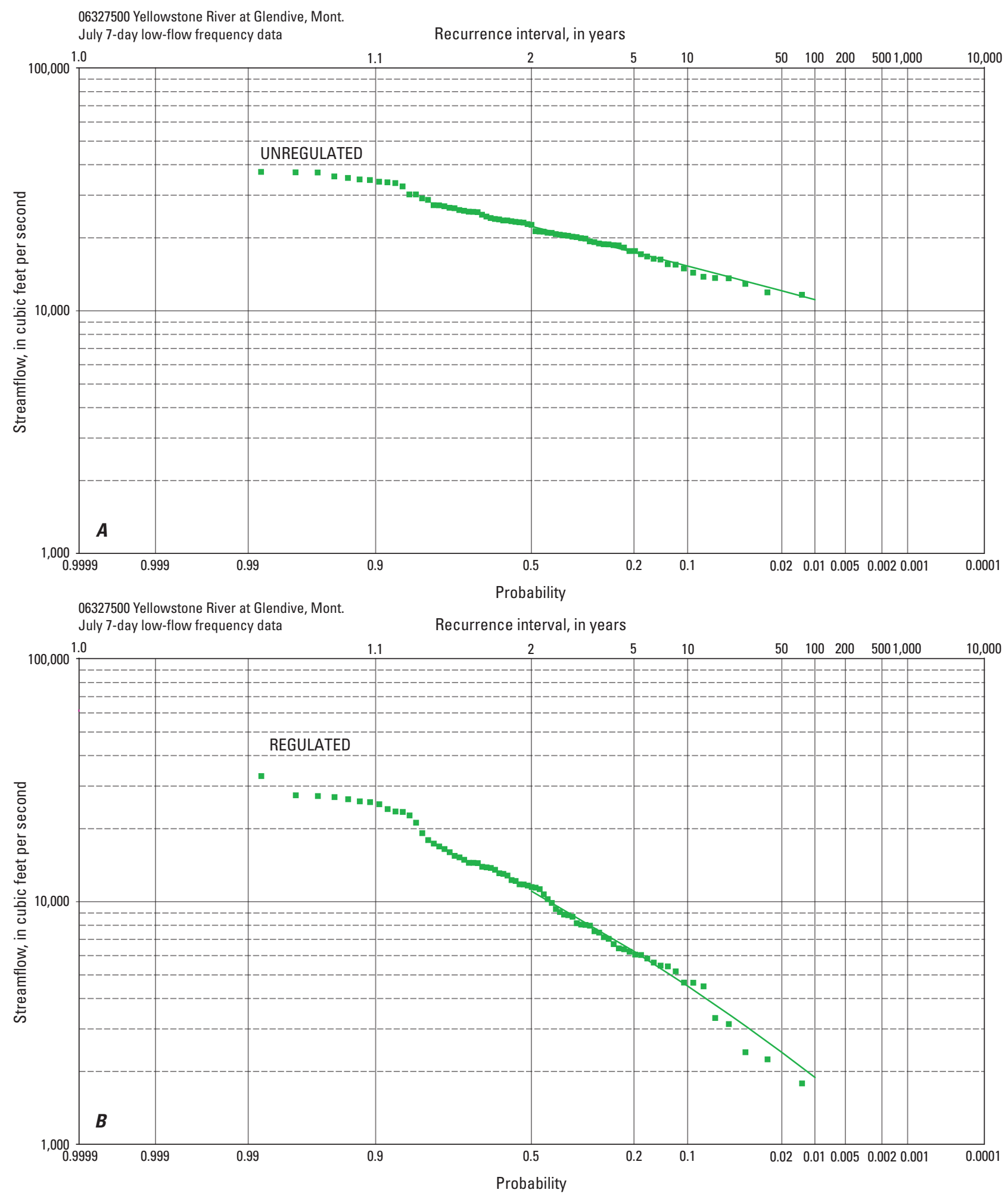

EXPLANATION

7-Day Data

- $\quad$ Estimated $n$-day values

- n-day frequency curve

Figure 2-3-15. July 7-day low flow frequency data for streamflow-gaging station 06327500 (Yellowstone River at Glendive, Mont.) for $A$, unregulated and $B$, regulated streamflow conditions, 1928-2002. 

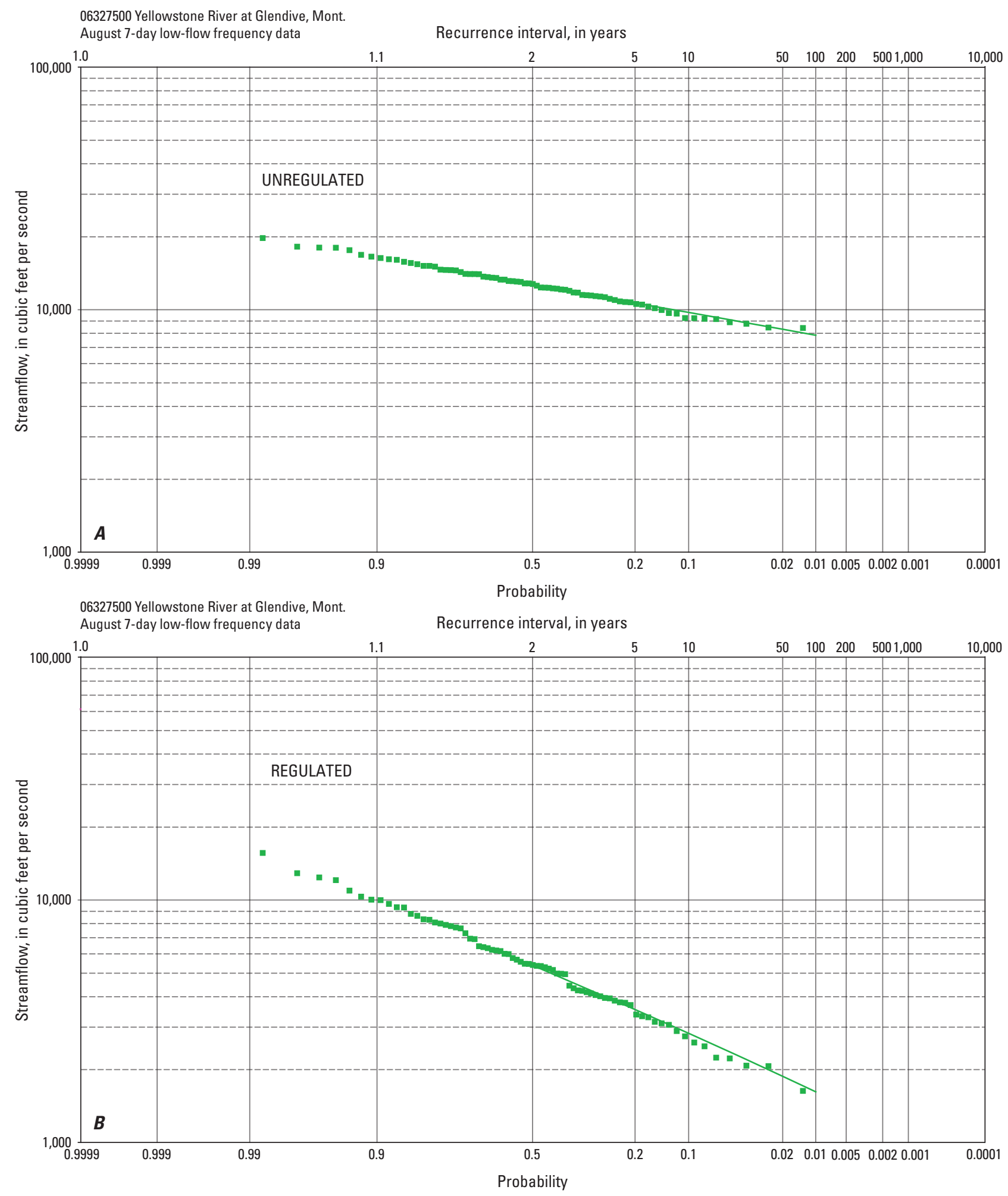

EXPLANATION

7-Day Data

- Estimated $n$-day values

- $n$-day frequency curve

Figure 2-3-16. August 7-day low-flow frequency data for streamflow-gaging station 06327500 (Yellowstone River at Glendive, Mont.) for $A$, unregulated and $B$, regulated streamflow conditions, 1928-2002. 


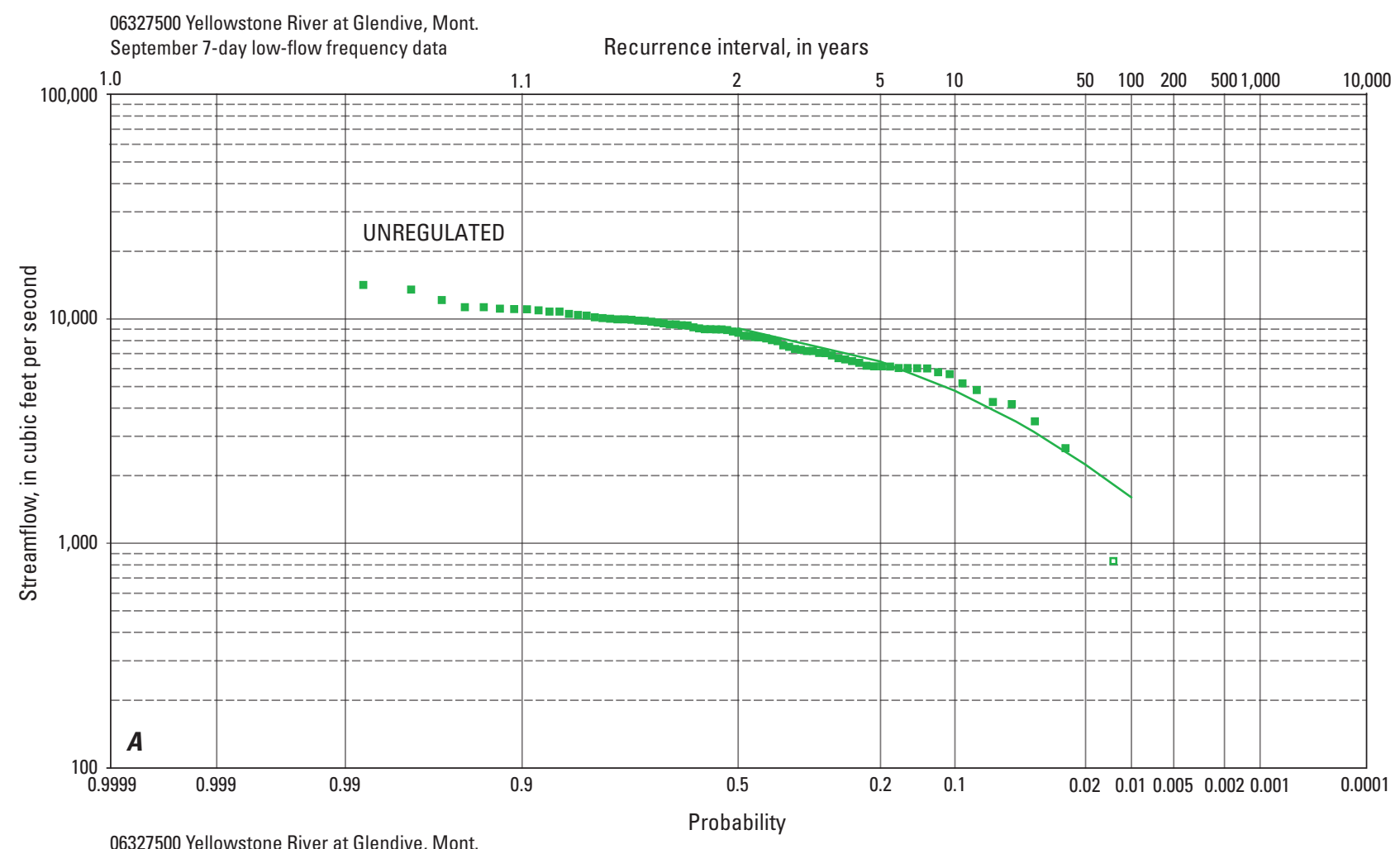

06327500 Yellowstone River at Glendive, Mont. September 7-day low-flow frequency data

Recurrence interval, in years

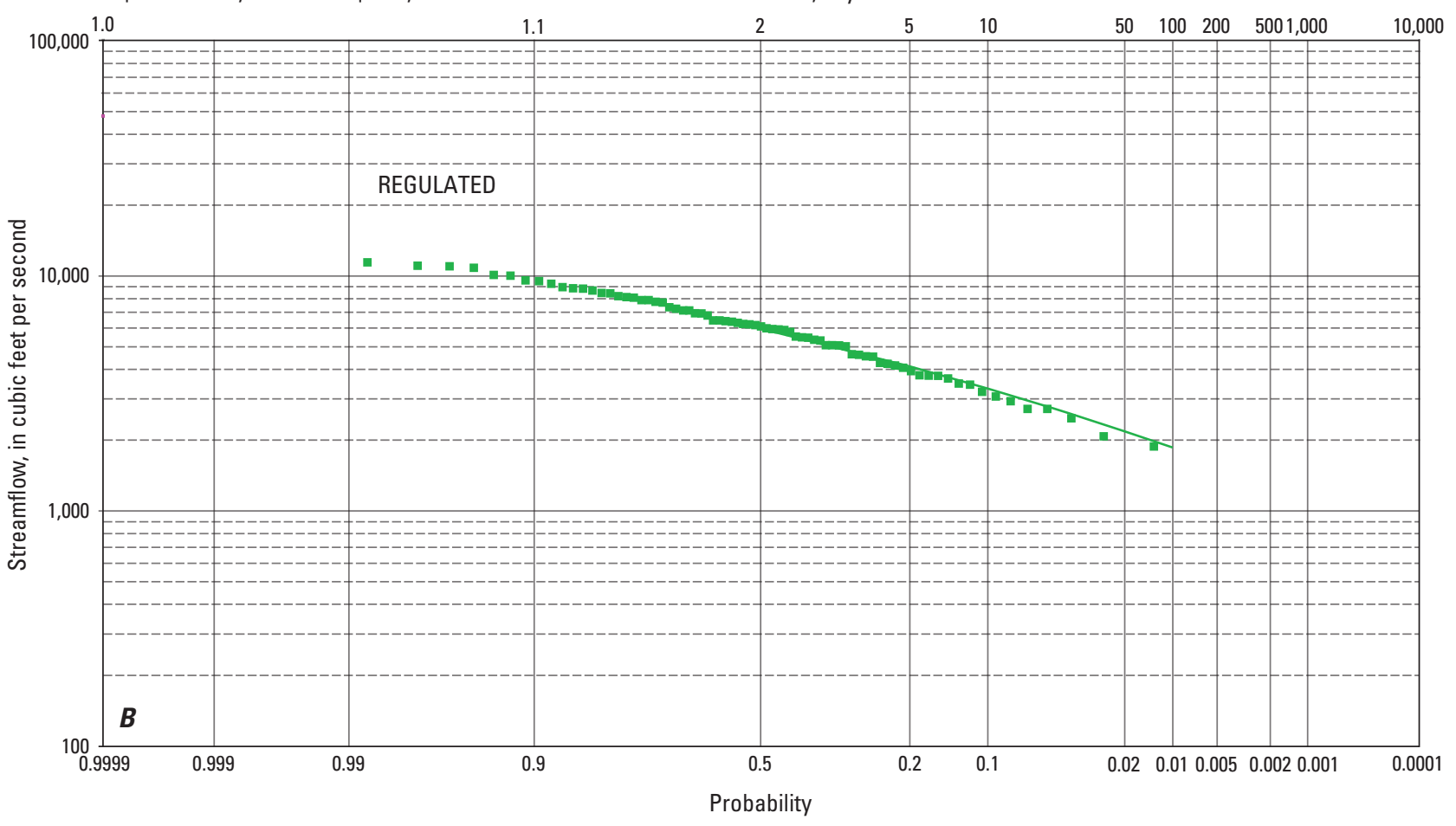

EXPLANATION

7-Day Data

- Estimated $n$-day values

- n-day frequency curve

Figure 2-3-17. September 7-day low-flow frequency data for streamflow-gaging station 06327500 (Yellowstone River at Glendive, Mont.) for $A$, unregulated and $B$, regulated streamflow conditions, 1928-2002. 

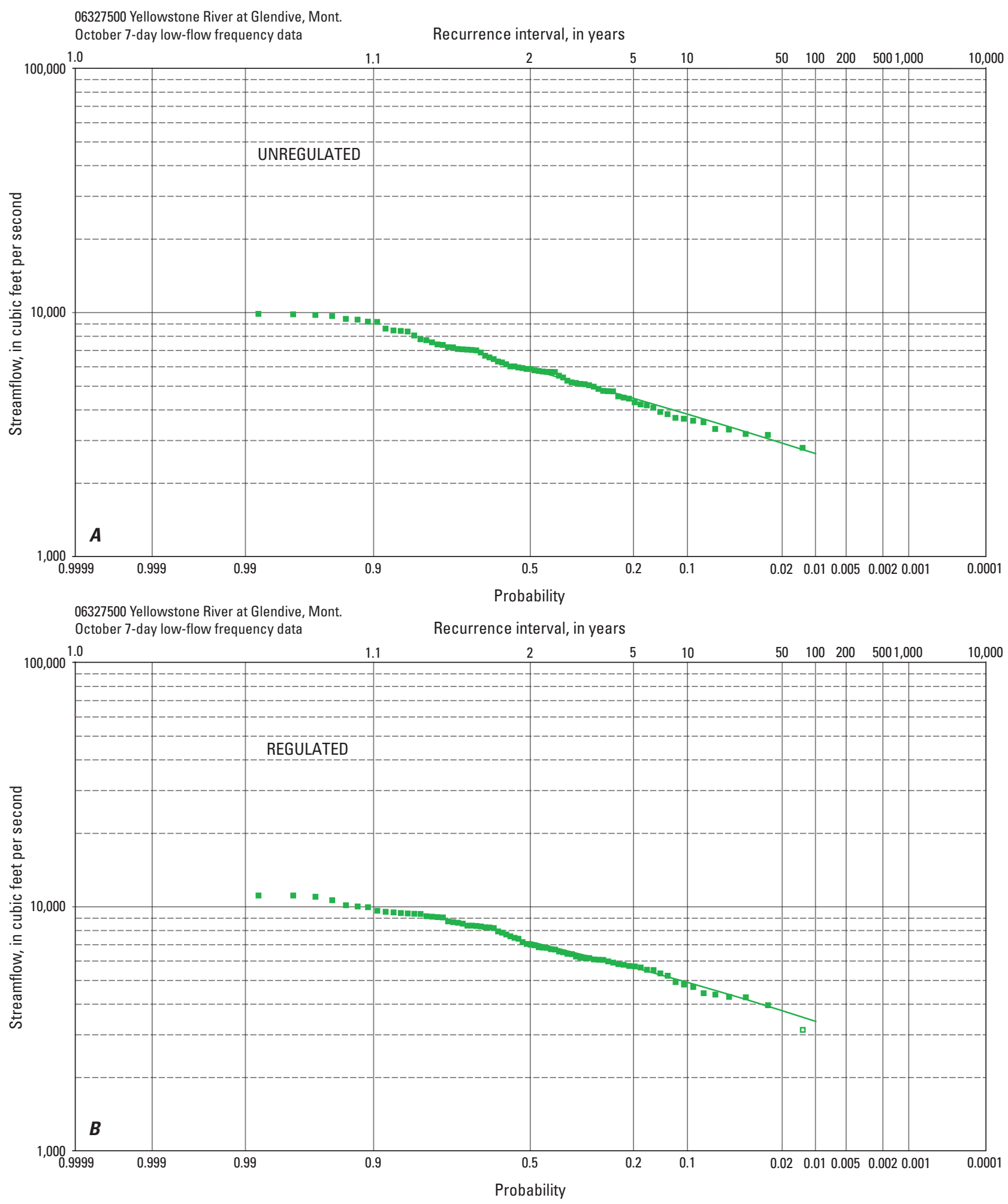

EXPLANATION

7-Day Data

- Estimated $n$-day values

- n-day frequency curve

Figure 2-3-18. October 7-day low-flow frequency data for streamflow-gaging station 06327500 (Yellowstone River at Glendive, Mont.) for $A$, unregulated and $B$, regulated streamflow conditions, 1928-2002. 


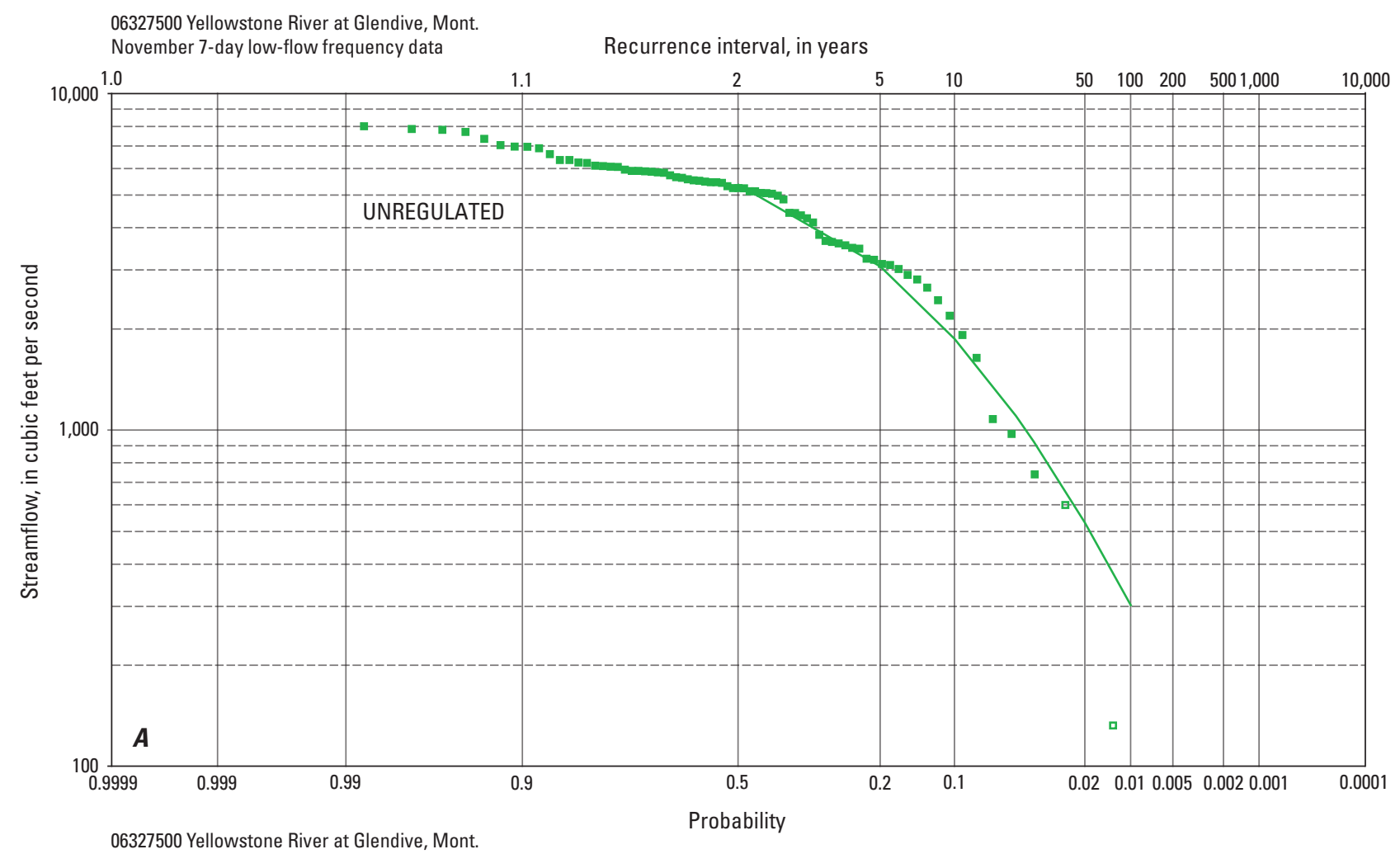

O6327500 Yellowstone River at Glendive, Mont.

Recurrence interval, in years

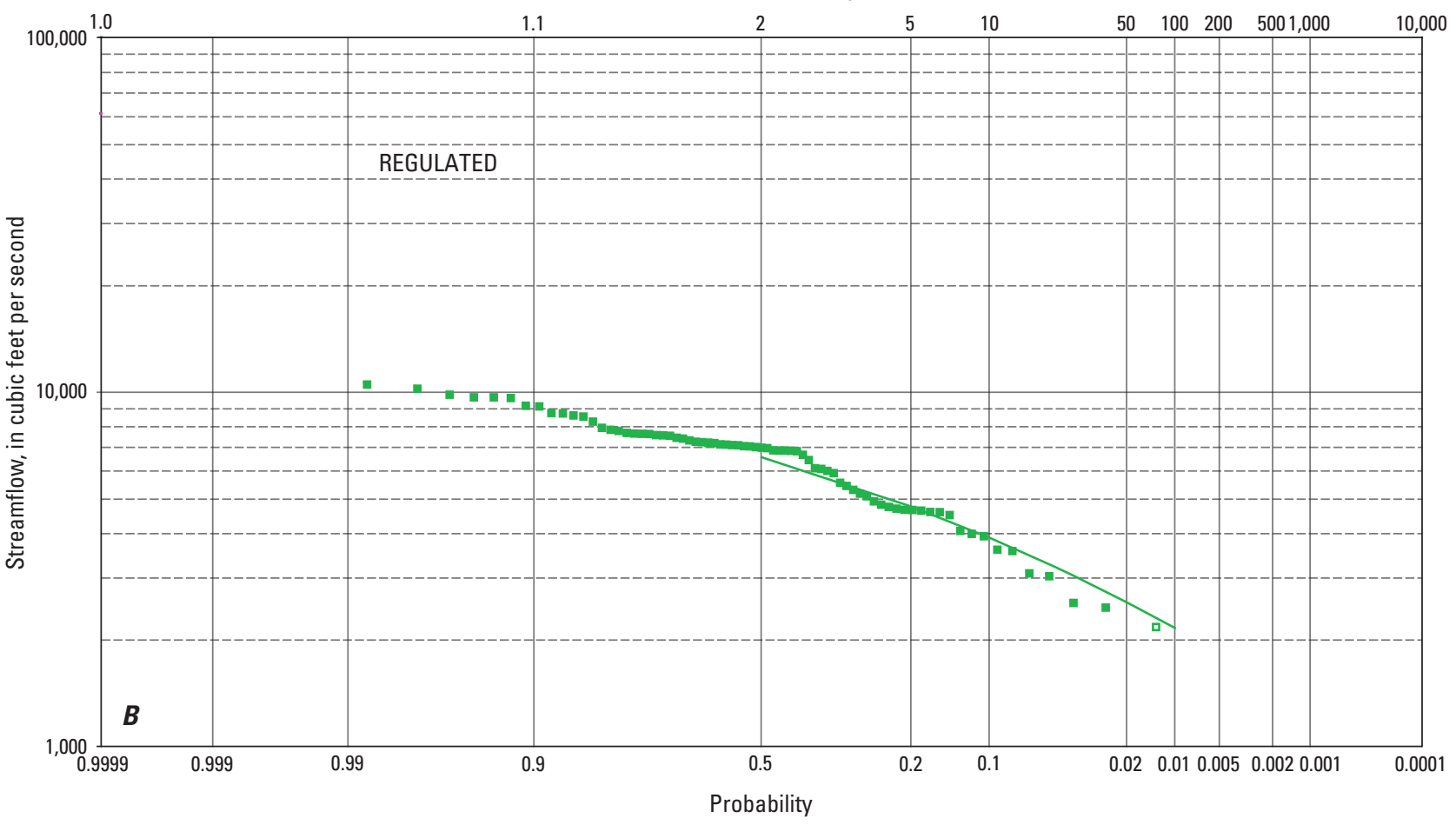

EXPLANATION

7-Day Data

- Estimated $n$-day values

- $n$-day frequency curve

口 Outlier

Figure 2-3-19. November 7-day low-flow frequency data for streamflow-gaging station 06327500 (Yellowstone River at Glendive, Mont.) for $A$, unregulated and $B$, regulated streamflow conditions, 1928-2002. 

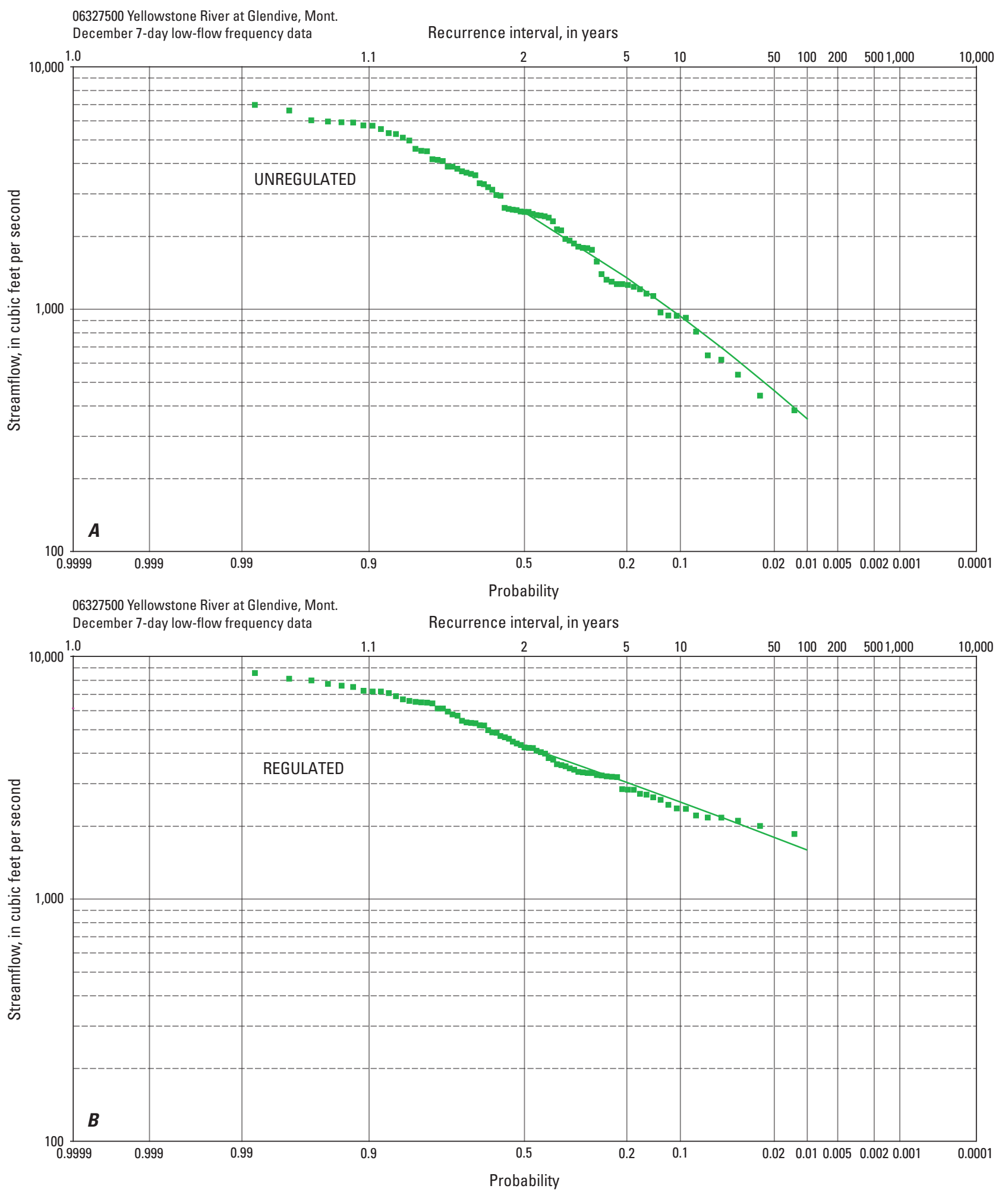

EXPLANATION

7-Day Data

- Estimated $n$-day values

- $n$-day frequency curve

Figure 2-3-20. December 7-day low-flow frequency data for streamflow-gaging station 06327500 (Yellowstone River at Glendive, Mont.) for $A$, unregulated and $B$, regulated streamflow conditions, 1928-2002. 
06327500 Yellowstone River at Glendive, Mont

Annual flow-duration data for unregulated and regulated streamflow conditions

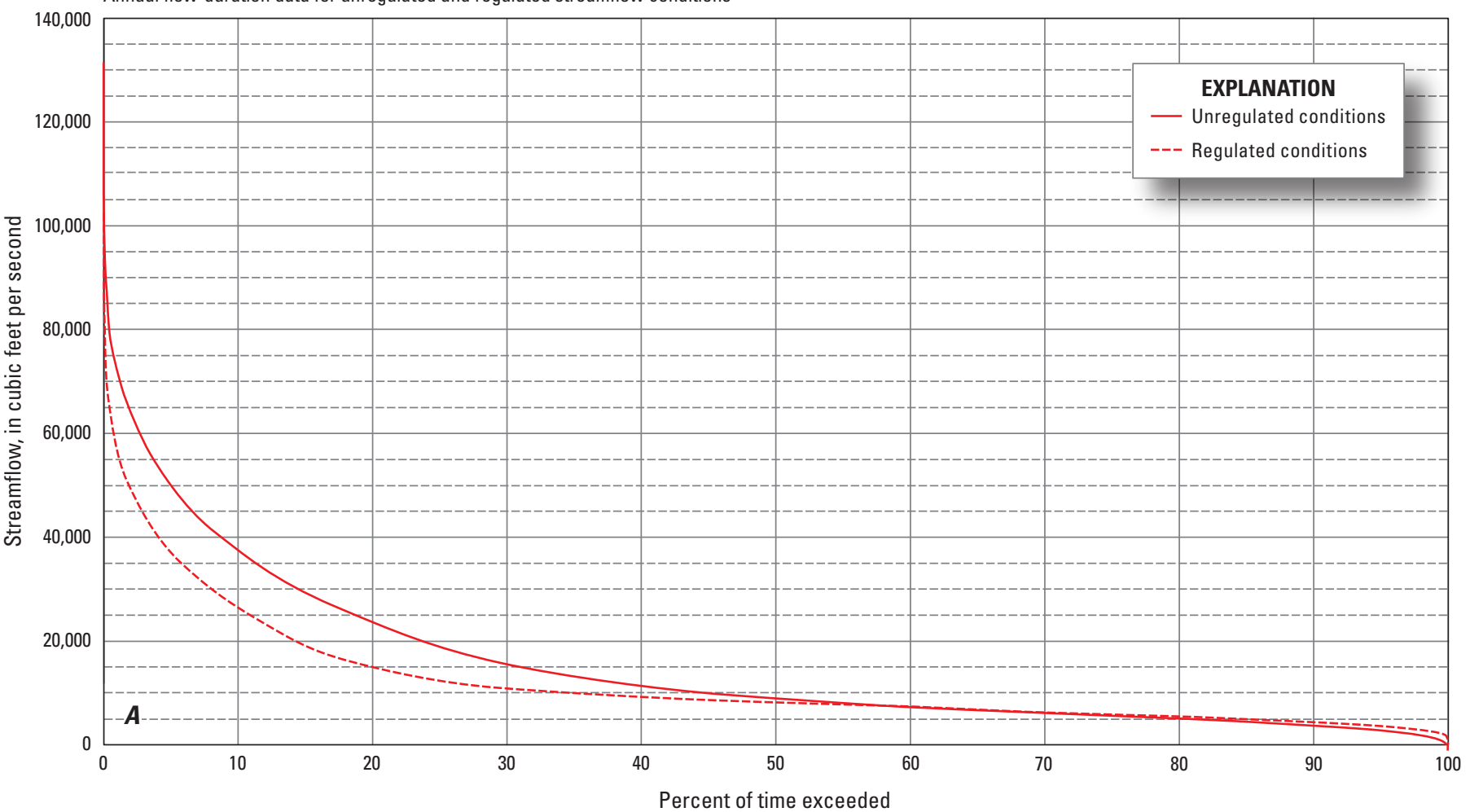

06327500 Yellowstone River at Glendive, Mont.

Annual flow-duration data for unregulated and regulated streamflow conditions

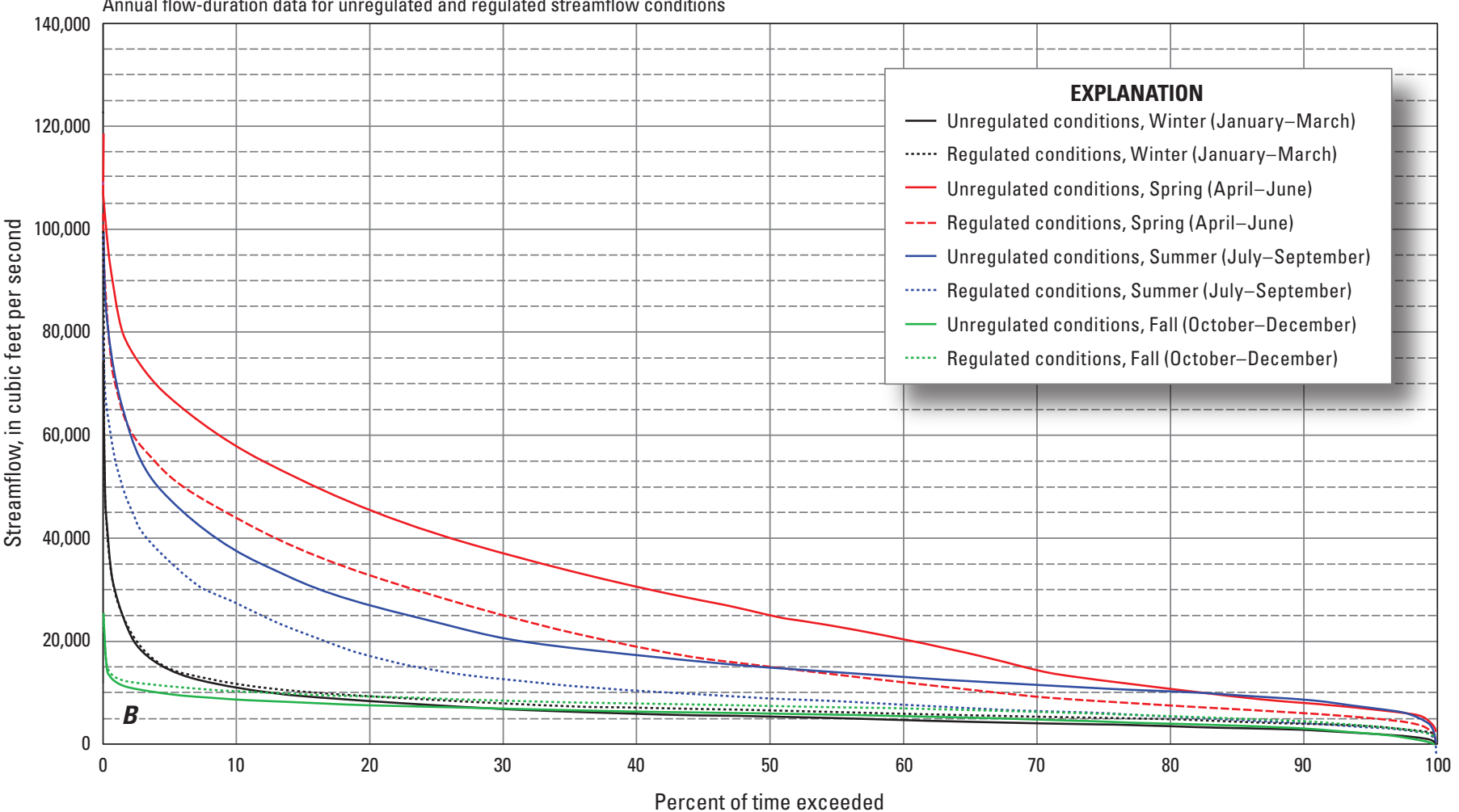

Figure 2-3-21. A, Annual and B, seasonal flow-duration data for streamflow-gaging station 06327500 (Yellowstone River at Glendive, Mont.) for unregulated and regulated streamflow conditions, 1928-2002. 


\section{Appendix 2-4. Statistics for Streamflow-Gaging Station 06329500 (Yellowstone River at Sidney, Mont.)}

Table 2-4-1. Annual $n$-day high-flow frequency data for streamflow-gaging station 06329500 (Yellowstone River at Sidney, Mont.) for unregulated and regulated streamflow conditions, 1928-2002.

[Abbreviations: $\mathrm{ft}^{3} / \mathrm{s}$, cubic feet per second. Symbol: \%, percent]

\begin{tabular}{|c|c|c|c|c|c|c|c|}
\hline \multicolumn{8}{|c|}{ Unregulated } \\
\hline \multirow{2}{*}{$\begin{array}{c}n, \text { period of } \\
\text { consecutive } \\
\text { days }\end{array}$} & \multicolumn{7}{|c|}{ Streamflow, in $\mathrm{ft}^{3} / \mathrm{s}$, for indicated recurrence interval, in years, and exceedance probability, in percent } \\
\hline & $\begin{array}{c}2 \\
50 \%\end{array}$ & $\begin{array}{c}5 \\
20 \%\end{array}$ & $\begin{array}{c}10 \\
10 \%\end{array}$ & $\begin{array}{l}20 \\
5 \%\end{array}$ & $\begin{array}{l}25 \\
4 \%\end{array}$ & $\begin{array}{c}50 \\
2 \%\end{array}$ & $\begin{array}{l}100 \\
1 \%\end{array}$ \\
\hline 1 & 67,700 & 86,200 & 97,400 & 108,000 & 111,000 & 120,000 & 129,000 \\
\hline 3 & 65,000 & 82,200 & 92,500 & 102,000 & 105,000 & 113,000 & 121,000 \\
\hline 7 & 60,500 & 76,600 & 86,200 & 94,800 & 97,400 & 105,000 & 113,000 \\
\hline 15 & 55,700 & 70,000 & 78,500 & 86,000 & 88,300 & 95,000 & 102,000 \\
\hline 30 & 50,300 & 62,900 & 70,400 & 77,000 & 79,000 & 85,000 & 90,700 \\
\hline 60 & 42,200 & 52,000 & 57,800 & 62,900 & 64,500 & 69,100 & 73,500 \\
\hline 90 & 35,900 & 43,400 & 47,800 & 51,600 & 52,700 & 56,100 & 59,200 \\
\hline 120 & 30,900 & 37,000 & 40,500 & 43,600 & 44,500 & 47,200 & 49,700 \\
\hline 183 & 24,200 & 28,800 & 31,400 & 33,700 & 34,400 & 36,400 & 38,300 \\
\hline \multicolumn{8}{|c|}{ Regulated } \\
\hline \multirow{2}{*}{$\begin{array}{l}n, \text { period of } \\
\text { consecutive } \\
\text { days }\end{array}$} & \multicolumn{7}{|c|}{ Streamflow, in $\mathrm{ft}^{3} / \mathrm{s}$, for indicated recurrence interval, in years, and exceedance probability, in percent } \\
\hline & $\begin{array}{c}2 \\
50 \%\end{array}$ & $\begin{array}{c}5 \\
20 \%\end{array}$ & $\begin{array}{c}10 \\
10 \%\end{array}$ & $\begin{array}{l}20 \\
5 \%\end{array}$ & $\begin{array}{l}25 \\
4 \%\end{array}$ & $\begin{array}{l}50 \\
2 \%\end{array}$ & $\begin{array}{l}100 \\
1 \%\end{array}$ \\
\hline 1 & 52,600 & 71,500 & 83,500 & 91,700 & 98,300 & 109,000 & 119,000 \\
\hline 3 & 50,000 & 67,000 & 77,400 & 86,900 & 89,800 & 98,400 & 107,000 \\
\hline 7 & 45,500 & 60,300 & 69,200 & 77,000 & 79,400 & 86,500 & 93,100 \\
\hline 15 & 40,700 & 54,100 & 62,200 & 69,300 & 71,500 & 77,900 & 84,000 \\
\hline 30 & 35,900 & 48,500 & 55,700 & 61,900 & 63,700 & 68,900 & 73,700 \\
\hline 60 & 28,700 & 39,100 & 45,200 & 50,500 & 51,100 & 56,800 & 61,200 \\
\hline 90 & 23,600 & 31,800 & 36,500 & 40,700 & 42,000 & 45,700 & 49,000 \\
\hline 120 & 20,400 & 26,900 & 30,600 & 33,900 & 34,800 & 37,600 & 40,200 \\
\hline 183 & 16,500 & 21,300 & 24,000 & 26,700 & 27,500 & 29,700 & 31,900 \\
\hline
\end{tabular}


Table 2-4-2. Annual, seasonal, and monthly $n$-day low-flow frequency data for streamflow-gaging station 06329500 (Yellowstone River at Sidney, Mont.) for unregulated and regulated steamflow conditions, 1928-2002.

[Abbreviations: $\mathrm{ft}^{3} / \mathrm{s}$, cubic feet per second. Symbol: \%, percent]

\begin{tabular}{|c|c|c|c|c|c|c|c|}
\hline \multicolumn{8}{|c|}{ Unregulated } \\
\hline \multirow{2}{*}{$\begin{array}{l}n \text {, period of consecutive } \\
\text { days (month, for monthly } \\
\text { frequency data) }\end{array}$} & \multicolumn{7}{|c|}{ Streamflow, in $\mathrm{ft}^{3} / \mathrm{s}$, for indicated recurrence interval, in years, and exceedance probability, in percent } \\
\hline & $\begin{array}{c}2 \\
50 \%\end{array}$ & $\begin{array}{c}5 \\
20 \%\end{array}$ & $\begin{array}{c}10 \\
10 \%\end{array}$ & $\begin{array}{l}20 \\
5 \%\end{array}$ & $\begin{array}{l}25 \\
4 \%\end{array}$ & $\begin{array}{l}50 \\
2 \%\end{array}$ & $\begin{array}{l}100 \\
1 \%\end{array}$ \\
\hline \multicolumn{8}{|c|}{ Annual } \\
\hline 7 & 1,750 & 773 & 435 & 249 & 208 & 121 & 71 \\
\hline \multicolumn{8}{|c|}{ Winter (January-March) } \\
\hline 7 & 2,620 & 1,620 & 1,210 & 940 & 864 & 682 & 545 \\
\hline 30 & 4,110 & 3,040 & 2,560 & 2,210 & 2,120 & 1,860 & 1,650 \\
\hline \multicolumn{8}{|c|}{ Spring (April-June) } \\
\hline 7 & 8,570 & 5,910 & 4,190 & 2,890 & 2,550 & 1,720 & 1,150 \\
\hline 30 & 9,200 & 7,180 & 6,170 & 5,400 & 5,180 & 4,590 & 4,100 \\
\hline \multicolumn{8}{|c|}{ Fall (October-December) } \\
\hline 7 & 2,320 & 970 & 527 & 291 & 241 & 135 & 76 \\
\hline 30 & 4,280 & 3,170 & 2,670 & 2,290 & 2,190 & 1,910 & 1,680 \\
\hline \multicolumn{8}{|c|}{ Monthly } \\
\hline 7 (January) & 2,910 & 1,750 & 1,280 & 959 & 878 & 672 & 524 \\
\hline 7 (February) & 3,950 & 2,710 & 2,190 & 1,820 & 1,720 & 1,460 & 1,260 \\
\hline 7 (March) & 5,560 & 4,020 & 3,400 & 2,970 & 2,850 & 2,540 & 2,300 \\
\hline 7 (September) & 8,580 & 5,900 & 4,180 & 2,880 & 2,550 & 1,720 & 1,150 \\
\hline 7 (October) & 5,790 & 4,260 & 3,590 & 3,110 & 2,980 & 2,630 & 2,340 \\
\hline 7 (November) & 5,550 & 2,940 & 1,500 & 707 & 547 & 240 & 101 \\
\hline 7 (December) & 2,440 & 1,210 & 784 & 530 & 471 & 329 & 234 \\
\hline
\end{tabular}


Table 2-4-2. Annual, seasonal, and monthly $n$-day low-flow frequency data for streamflow-gaging station 06329500 (Yellowstone River at Sidney, Mont.) for unregulated and regulated steamflow conditions, 1928-2002.-Continued

[Abbreviations: $\mathrm{ft}^{3} / \mathrm{s}$, cubic feet per second. Symbol: \%, percent]

\section{Regulated}

\begin{tabular}{|c|c|c|c|c|c|c|c|}
\hline \multirow{2}{*}{$\begin{array}{l}n \text {, period of consecutive } \\
\text { days (month, for monthly } \\
\text { frequency data) }\end{array}$} & \multicolumn{7}{|c|}{ Streamflow, in $\mathrm{ft}^{3} / \mathrm{s}$, for indicated recurrence interval, in years, and exceedance probability, in percent } \\
\hline & $\begin{array}{c}2 \\
50 \%\end{array}$ & $\begin{array}{c}5 \\
20 \%\end{array}$ & $\begin{array}{c}10 \\
10 \%\end{array}$ & $\begin{array}{l}20 \\
5 \%\end{array}$ & $\begin{array}{l}25 \\
4 \%\end{array}$ & $\begin{array}{l}50 \\
2 \%\end{array}$ & $\begin{array}{l}100 \\
1 \%\end{array}$ \\
\hline \multicolumn{8}{|c|}{ Annual } \\
\hline 7 & 3,120 & 2,190 & 1,780 & 1,480 & 1,400 & 1,200 & 1,030 \\
\hline 30 & 4,600 & 3,200 & 2,530 & 2,030 & 1,900 & 1,540 & 1,260 \\
\hline 30 & 5,440 & 4,390 & 3,920 & 3,560 & 3,470 & 3,200 & 2,980 \\
\hline \multicolumn{8}{|c|}{ Spring (April-June) } \\
\hline 7 & 7,000 & 4,850 & 3,780 & 2,980 & 2,760 & 2,200 & 1,760 \\
\hline 30 & 8,070 & 5,820 & 4,810 & 4,070 & 3,870 & 3,330 & 2,890 \\
\hline 30 & 5,280 & 3,230 & 2,400 & 1,840 & 1,700 & 1,340 & 1,060 \\
\hline \multicolumn{8}{|c|}{ Fall (October-December) } \\
\hline 7 & 3,900 & 2,770 & 2,310 & 1,990 & 1,900 & 1,680 & 1,500 \\
\hline 30 & 5,640 & 4,400 & 3,820 & 3,380 & 3,260 & 2,920 & 2,640 \\
\hline \multicolumn{8}{|c|}{ Monthly } \\
\hline 7 (January) & 4,420 & 3,330 & 2,850 & 2,490 & 2,390 & 2,130 & 1,910 \\
\hline 7 (February) & 5,250 & 4,030 & 3,490 & 3,090 & 2,980 & 2,680 & 2,430 \\
\hline 7 (March) & 6,480 & 4,950 & 4,330 & 3,890 & 3,770 & 3,460 & 3,210 \\
\hline 7 (April) & 6,730 & 4,950 & 4,180 & 3,620 & 3,460 & 3,050 & 2,720 \\
\hline 7 (October) & 7,180 & 5,450 & 4,650 & 4,050 & 3,880 & 3,430 & 3,060 \\
\hline 7 (November) & 6,550 & 4,590 & 3,650 & 2,950 & 2,760 & 2,260 & 1,860 \\
\hline 7 (December) & 4,220 & 2,960 & 2,430 & 2,060 & 1,960 & 1,700 & 1,490 \\
\hline
\end{tabular}


Table 2-4-3. Annual and seasonal flow-duration data for streamflow-gaging station 06329500 (Yellowstone River near Sidney, Mont.) for unregulated and regulated streamflow conditions, 1928-2002.

[Abbreviations: $\mathrm{ft}^{3} / \mathrm{s}$, cubic feet per second. Symbol: \%, percent]

\begin{tabular}{|c|c|c|c|c|c|c|c|c|c|c|c|c|c|c|c|c|c|c|c|}
\hline \multicolumn{20}{|c|}{ Streamflow, in $\mathrm{ft}^{3} / \mathrm{s}$, which was equaled or exceeded for indicated percent of time } \\
\hline $\begin{array}{c}\text { Streamflow } \\
\text { condition }\end{array}$ & $1 \%$ & $2 \%$ & $5 \%$ & $10 \%$ & $15 \%$ & $20 \%$ & $25 \%$ & $30 \%$ & $40 \%$ & $50 \%$ & $60 \%$ & $70 \%$ & $75 \%$ & $80 \%$ & $85 \%$ & $90 \%$ & $95 \%$ & $98 \%$ & $99 \%$ \\
\hline \multicolumn{20}{|c|}{ Annual } \\
\hline Unregulated & 72,800 & 64,700 & 49,700 & 37,200 & 29,200 & 23,300 & 19,000 & 15,600 & 11,300 & 8,810 & 7,300 & 6,090 & 5,610 & 5,040 & 4,420 & 3,740 & 2,830 & 1,810 & 1,240 \\
\hline Regulated & 56,800 & 49,500 & 36,900 & 25,800 & 18,700 & 14,500 & 12,200 & 10,700 & 9,030 & 7,990 & 7,070 & 6,210 & 5,780 & 5,350 & 4,880 & 4,270 & 3,440 & 2,520 & 2,060 \\
\hline \multicolumn{20}{|c|}{ Winter (January-March) } \\
\hline Unregulated & 36,200 & 24,500 & 16,500 & 11,600 & 9,700 & 8,600 & 7,850 & 7,260 & 6,280 & 5,640 & 4,970 & 4,360 & 4,010 & 3,670 & 3,300 & 2,800 & 2,150 & 1,470 & 1,170 \\
\hline Regulated & 35,300 & 25,000 & 17,000 & 12,400 & 10,500 & 9,500 & 8,800 & 8,250 & 7,500 & 6,810 & 6,130 & 5,560 & 5,250 & 4,970 & 4,560 & 4,120 & 3,510 & 2,830 & 2,560 \\
\hline \multicolumn{20}{|c|}{ Spring (April-June) } \\
\hline Unregulated & 83,800 & 76,900 & 67,400 & 57,600 & 50,100 & 44,600 & 40,100 & 36,200 & 29,800 & 24,600 & 20,000 & 15,200 & 12,900 & 11,000 & 9,430 & 8,280 & 7,250 & 6,030 & 5,400 \\
\hline Regulated & 66,600 & 60,500 & 52,000 & 43,500 & 36,800 & 31,600 & 27,500 & 23,800 & 18,000 & 14,300 & 11,500 & 9,110 & 8,230 & 7,500 & 6,640 & 5,860 & 5,220 & 4,530 & 3,620 \\
\hline \multicolumn{20}{|c|}{ Summer (July-September) } \\
\hline Unregulated & 71,400 & 61,400 & 47,800 & 37,900 & 31,500 & 27,000 & 23,500 & 20,700 & 17,000 & 14,600 & 12,600 & 11,000 & 10,300 & 9,500 & 8,590 & 7,780 & 6,340 & 5,240 & 3,960 \\
\hline Regulated & 55,500 & 46,200 & 35,300 & 26,900 & 21,100 & 16,600 & 13,700 & 12,000 & 9,700 & 8,230 & 6,860 & 5,680 & 5,150 & 4,600 & 4,010 & 3,460 & 2,550 & 1,940 & 1,550 \\
\hline \multicolumn{20}{|c|}{ Fall (October-December) } \\
\hline Unregulated & 12,200 & 11,300 & 9,950 & 8,810 & 8,090 & 7,590 & 7,200 & 6,870 & 6,280 & 5,800 & 5,270 & 4,590 & 4,230 & 3,870 & 3,490 & 2,950 & 1,920 & 950 & 492 \\
\hline Regulated & 13,700 & 12,500 & 11,300 & 10,400 & 9,740 & 9,230 & 8,840 & 8,510 & 7,890 & 7,300 & 6,730 & 6,050 & 5,660 & 5,300 & 4,850 & 4,320 & 3,490 & 2,610 & 2,200 \\
\hline
\end{tabular}


Table 2-4-4. Monthly and annual streamflow characteristics for streamflow-gaging station 06329500 (Yellowstone River near Sidney, Mont.) for unregulated and regulated streamflow conditions, 1928-2002.

[Abbreviations: $\mathrm{ft}^{3} / \mathrm{s}$, cubic feet per second]

\section{Unregulated}

\begin{tabular}{|c|c|c|c|c|c|c|}
\hline \multicolumn{7}{|c|}{ Unregulated } \\
\hline \multirow[b]{2}{*}{ Period } & \multicolumn{6}{|c|}{ Streamflow, in $\mathrm{ft}^{3} / \mathrm{s}$, or year, for indicated streamflow characteristic } \\
\hline & $\begin{array}{l}\text { Maximum } \\
\text { monthly mean } \\
\text { and maximum } \\
\text { annual mean } \\
\text { streamflow }\end{array}$ & $\begin{array}{l}\text { Year of maximum } \\
\text { monthly mean } \\
\text { and maximum } \\
\text { annual mean } \\
\text { streamflow }\end{array}$ & $\begin{array}{l}\text { Minimum monthly } \\
\text { mean and mini- } \\
\text { mum annual mean } \\
\text { streamflow }\end{array}$ & $\begin{array}{l}\text { Year of minimum } \\
\text { monthly mean and } \\
\text { minimum annual } \\
\text { mean streamflow }\end{array}$ & $\begin{array}{l}\text { Mean monthly } \\
\text { and mean annual } \\
\text { streamflow }\end{array}$ & $\begin{array}{c}\text { Standard } \\
\text { deviation of mean } \\
\text { monthly and mean } \\
\text { annual streamflow }\end{array}$ \\
\hline February & 17,300 & 1971 & 2,320 & 1936 & 6,100 & 2,780 \\
\hline March & 25,800 & 1972 & 2,810 & 2002 & 10,220 & 4,760 \\
\hline April & 27,500 & 1952 & 3,750 & 1961 & 11,210 & 4,020 \\
\hline May & 46,600 & 1928 & 14,440 & 1953 & 27,700 & 6,580 \\
\hline September & 15,600 & 1997 & 3,810 & 1934 & 9,350 & 2,480 \\
\hline October & 13,400 & 1971 & 3,230 & 2001 & 7,040 & 2,340 \\
\hline November & 9,000 & 1968 & 2,780 & 1931 & 5,820 & 1,650 \\
\hline December & 8,050 & 1975 & 2,170 & 1960 & 4,660 & 1,350 \\
\hline Annual & 23,200 & 1997 & 9,410 & 1934 & 15,200 & 3,060 \\
\hline \multicolumn{7}{|c|}{ Regulated } \\
\hline & \multicolumn{6}{|c|}{ Streamflow, in $\mathrm{ft}^{3} / \mathrm{s}$, or year, for indicated streamflow characteristic } \\
\hline Period & $\begin{array}{l}\text { Maximum } \\
\text { monthly mean } \\
\text { and maximum } \\
\text { annual mean } \\
\text { streamflow }\end{array}$ & $\begin{array}{l}\text { Year of maximum } \\
\text { monthly mean } \\
\text { and maximum } \\
\text { annual mean } \\
\text { streamflow }\end{array}$ & $\begin{array}{l}\text { Minimum monthly } \\
\text { mean and mini- } \\
\text { mum annual mean } \\
\text { streamflow }\end{array}$ & $\begin{array}{l}\text { Year of minimum } \\
\text { monthly mean and } \\
\text { minimum annual } \\
\text { mean streamflow }\end{array}$ & $\begin{array}{l}\text { Mean monthly } \\
\text { and mean annual } \\
\text { streamflow }\end{array}$ & $\begin{array}{c}\text { Standard } \\
\text { deviation of mean } \\
\text { monthly and mean } \\
\text { annual streamflow }\end{array}$ \\
\hline March & 25,700 & 1972 & 3,240 & 2002 & 11,010 & 4,730 \\
\hline April & 22,100 & 1952 & 2,700 & 1961 & 9,050 & 3,570 \\
\hline May & 35,600 & 1928 & 4,600 & 1961 & 16,200 & 5,850 \\
\hline June & 65,800 & 1997 & 11,200 & 1934 & 34,500 & 12,300 \\
\hline July & 49,100 & 1967 & 3,460 & 1934 & 20,800 & 11,460 \\
\hline August & 18,500 & 1997 & 1,170 & 1988 & 7,680 & 3,850 \\
\hline September & 16,300 & 1941 & 2,460 & 1960 & 6,990 & 2,900 \\
\hline October & 15,700 & 1971 & 4,020 & 1960 & 8,300 & 2,400 \\
\hline November & 11,700 & 1972 & 4,020 & 1977 & 7,560 & 1,850 \\
\hline December & 9,670 & 1975 & 3,380 & 1960 & 6,220 & 1,410 \\
\hline Annual & 19,900 & 1997 & 5,480 & 1934 & 11,700 & 3,280 \\
\hline
\end{tabular}




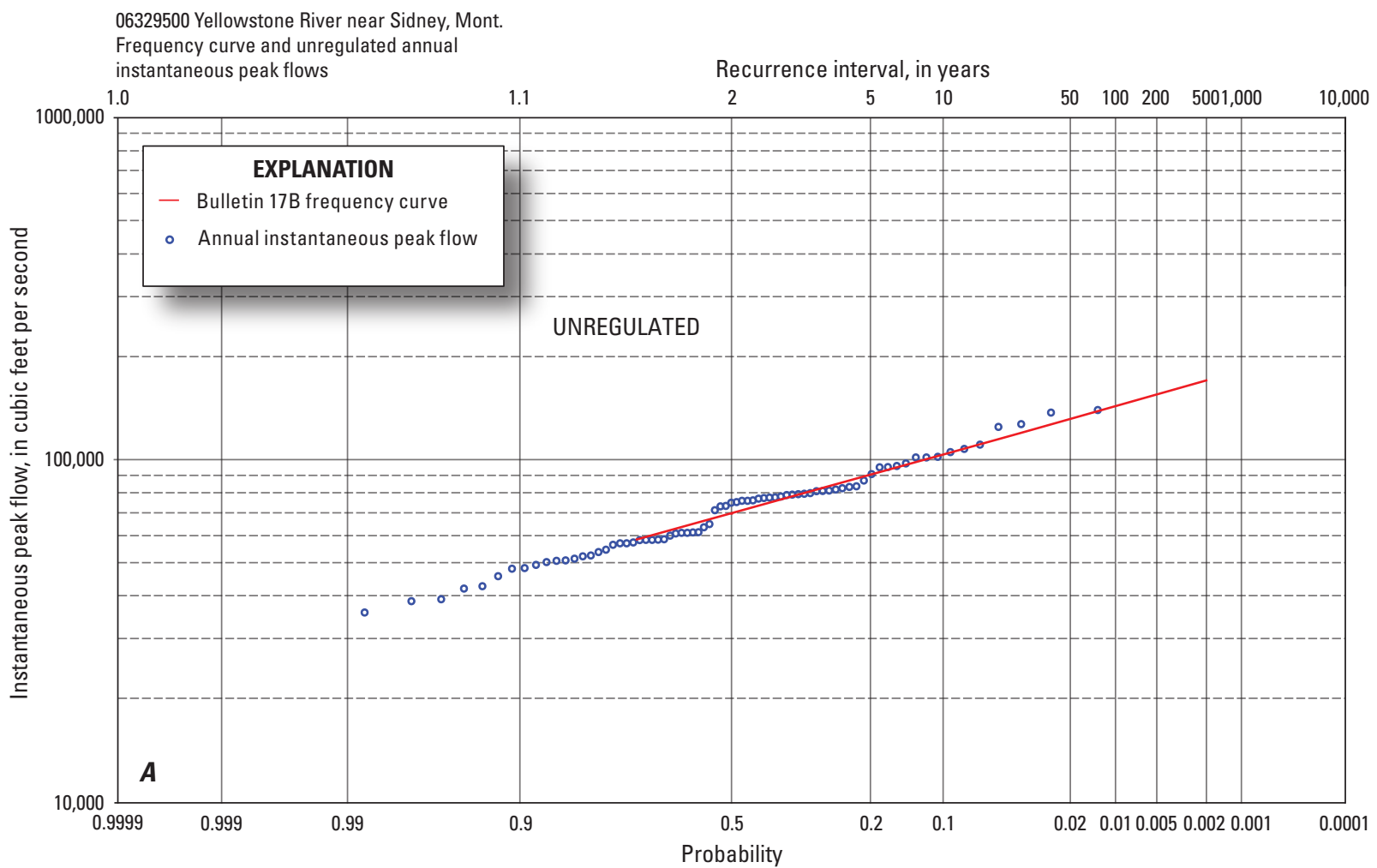

06329500 Yellowstone River near Sidney, Mont.

Time series of unregulated annual instantaneous peak flows

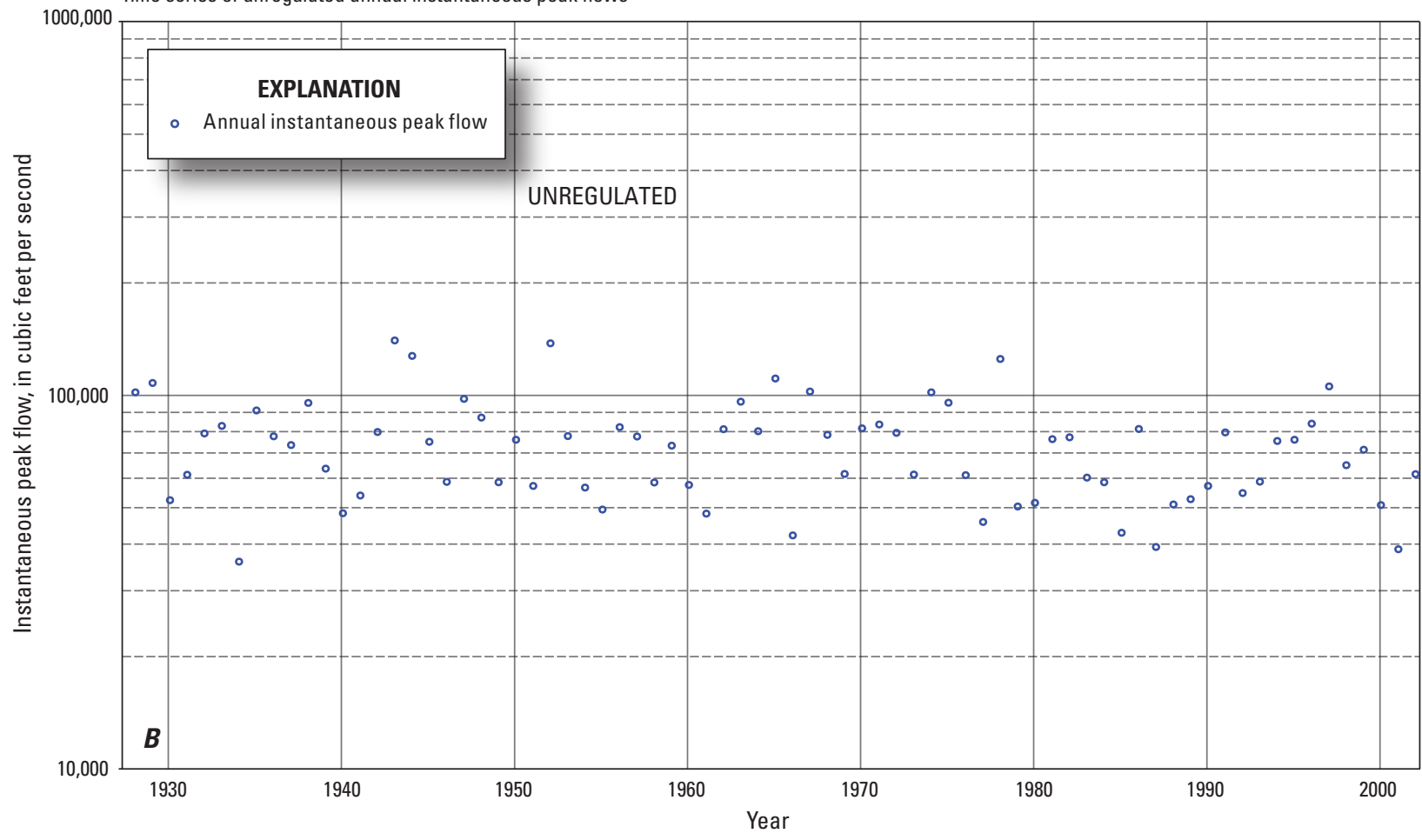

Figure 2-4-1. Annual instantaneous peak-flow data for streamflow-gaging station 06329500 (Yellowstone River at Sidney, Mont.) for unregulated streamflow conditions, 1928-2002. A, Frequency curve and unregulated annual instantaneous peak flows. $B$, Time series of regulated annual instantaneous peak flows. [Bulletin 17B: U.S. Interagency Advisory Council on Water Data, 1982] 


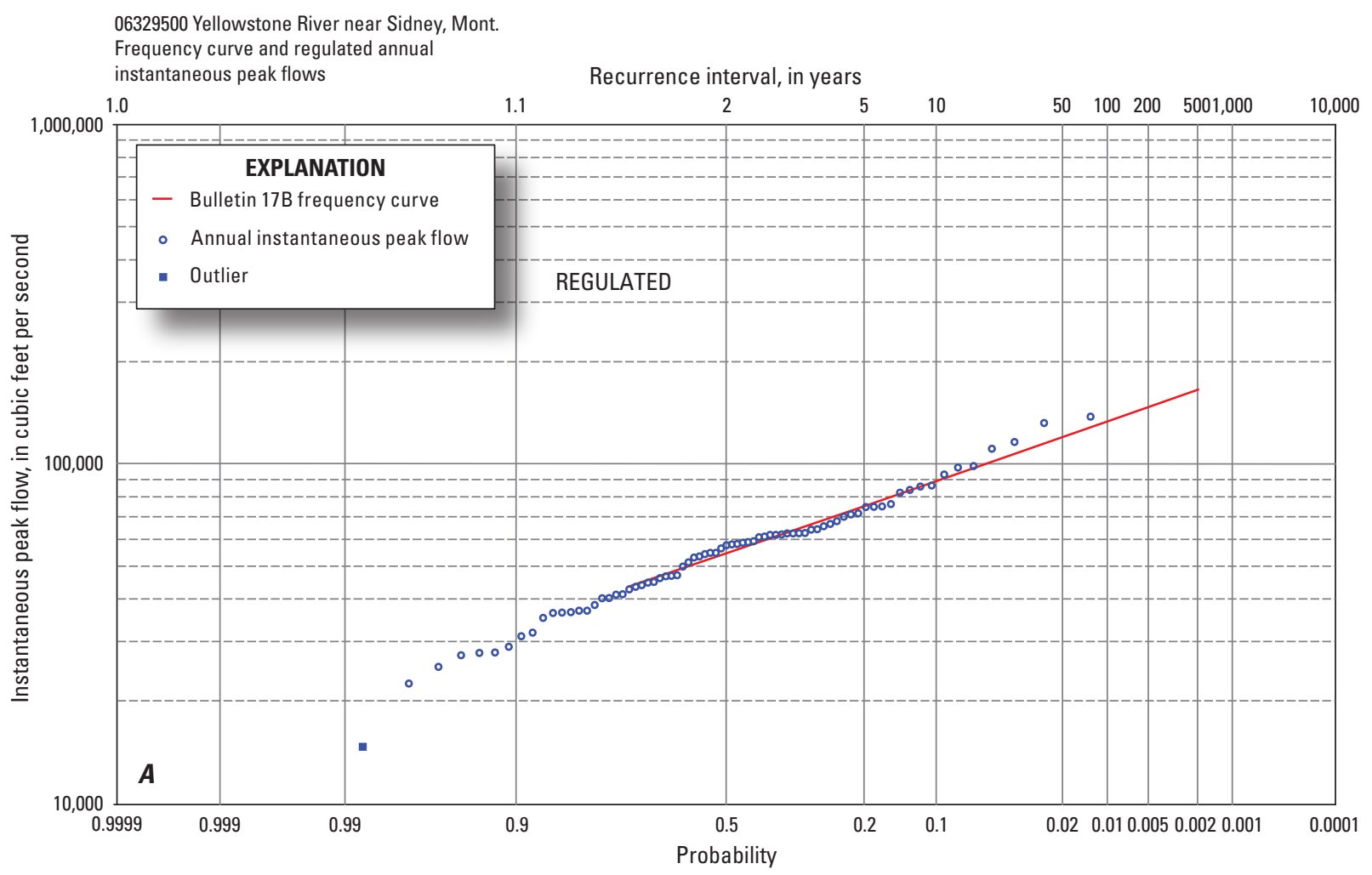

06329500 Yellowstone River near Sidney, Mont.

Time series of regulated annual instantaneous peak flows

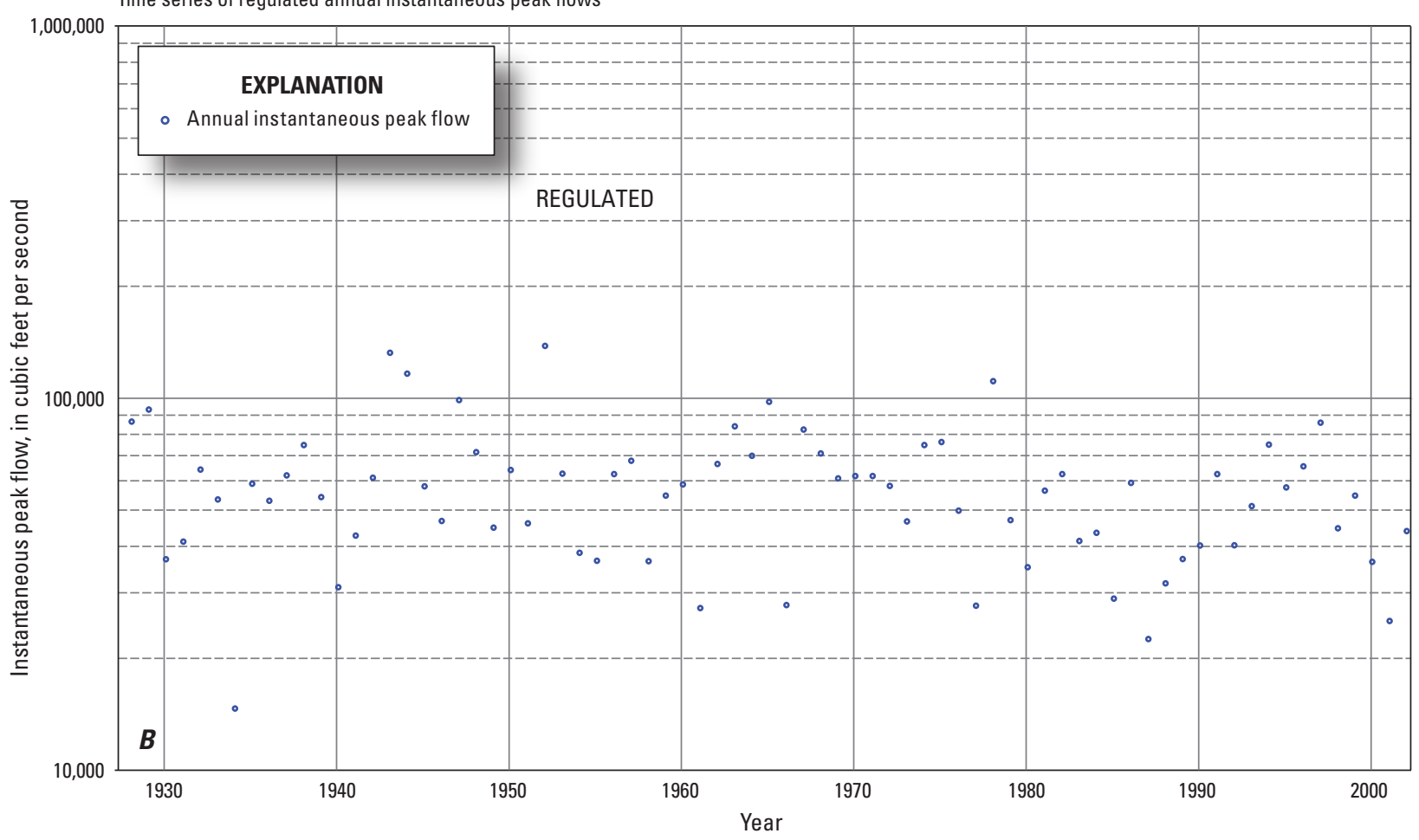

Figure 2-4-2. Annual instantaneous peak-flow data for streamflow-gaging station 06329500 (Yellowstone River at Sidney, Mont.) for unregulated streamflow conditions, 1928-2002. A, Frequency curve and unregulated annual instantaneous peak flows. $B$, Time series of regulated annual instantaneous peak flows. [Bulletin 17B: U.S. Interagency Advisory Council on Water Data, 1982] 


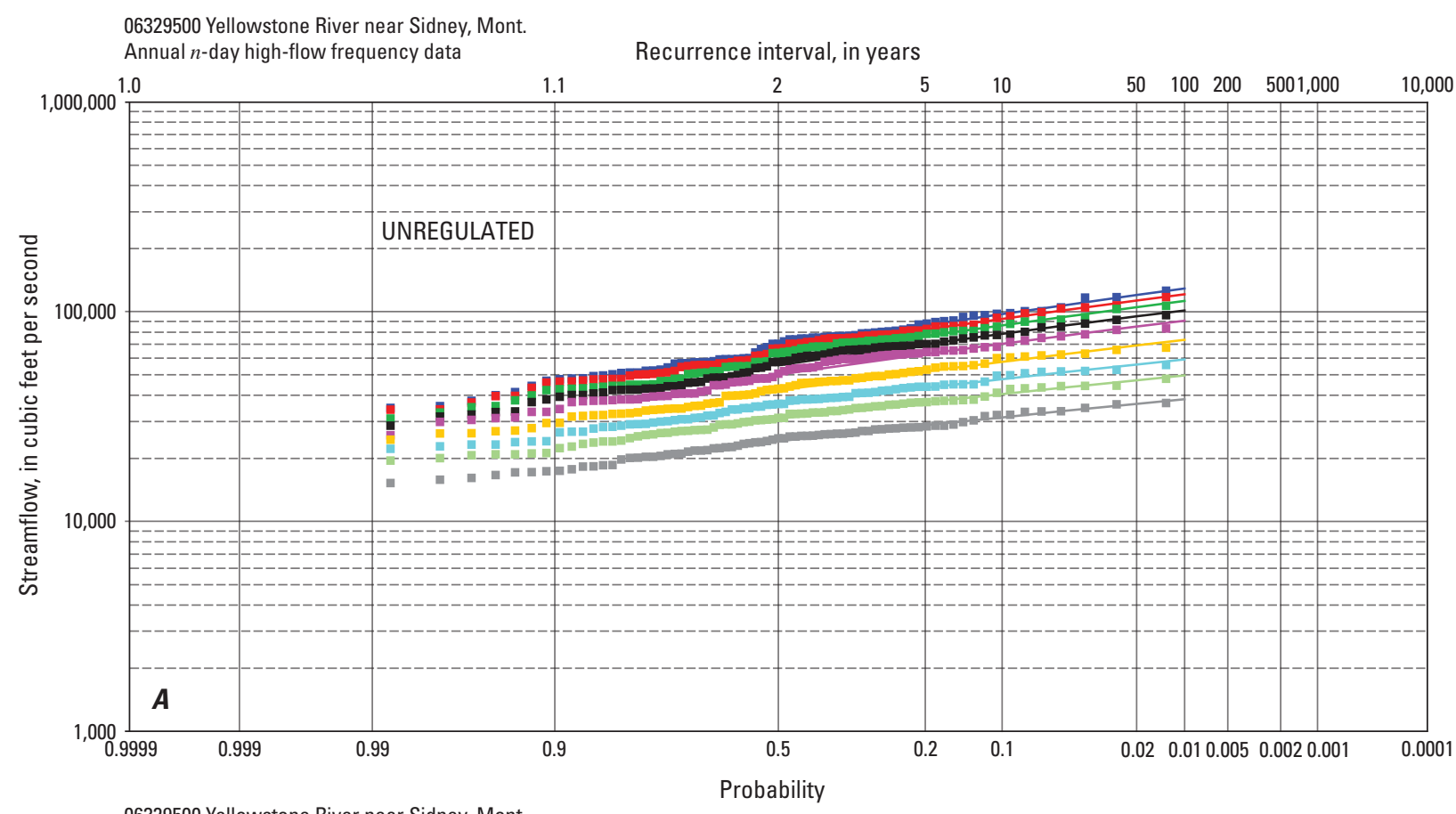

06329500 Yellowstone River near Sidney, Mont

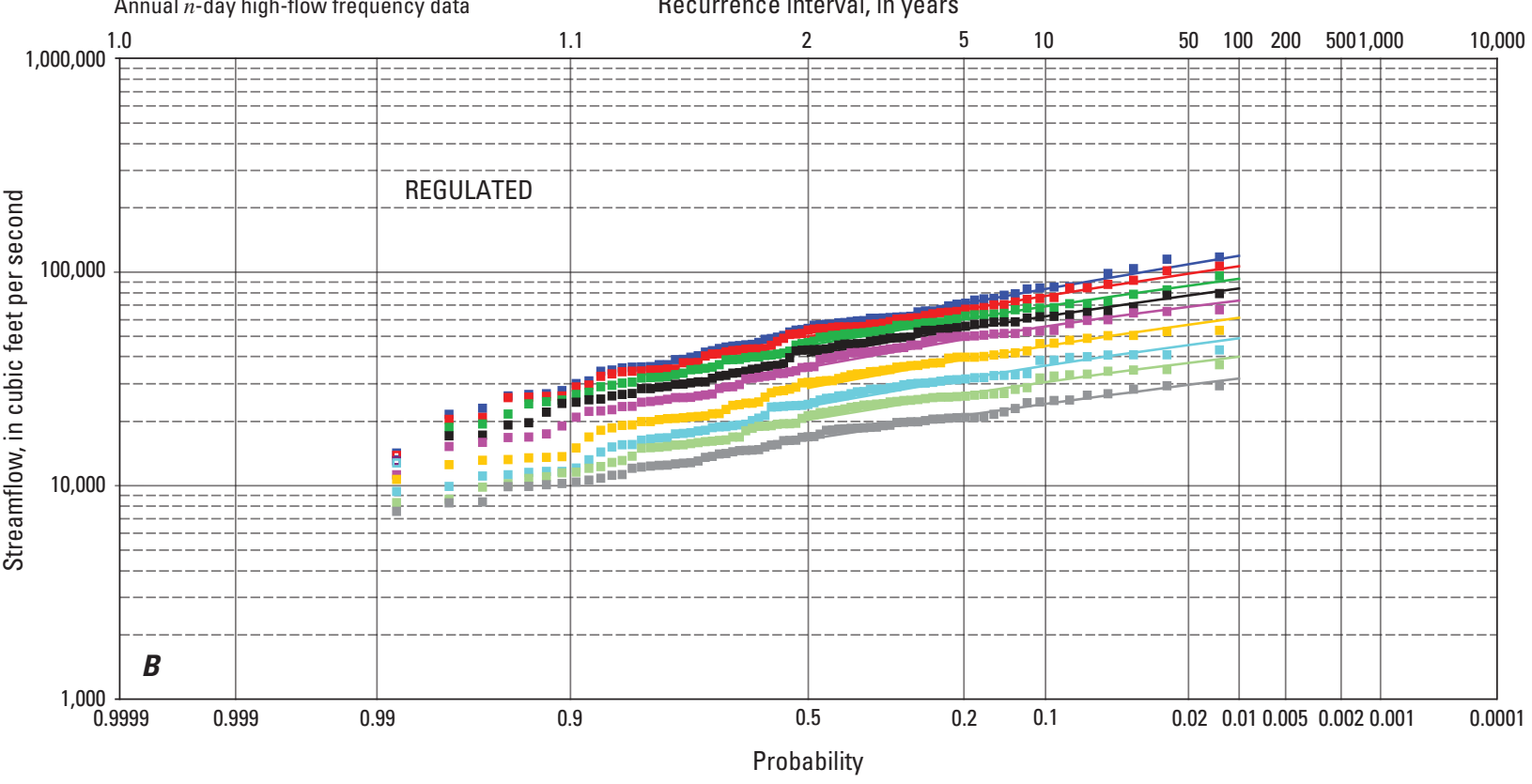

EXPLANATION
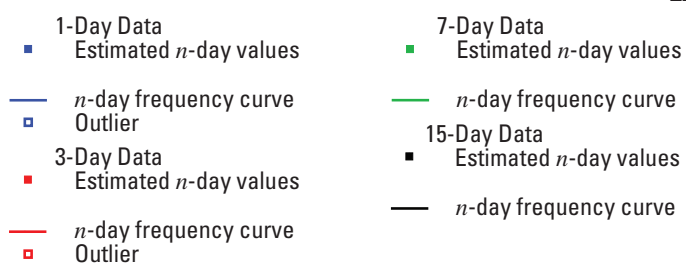

30-Day Data

- Estimated $n$-day values

- n-day frequency curve

- Outlier

60-Day Data

Estimated $n$-day values

- $n$-day frequency curve

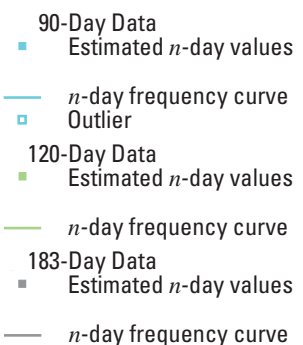

Figure 2-4-3. Annual $n$-day high-flow frequency data for streamflow-gaging station 06329500 (Yellowstone River at Sidney, Mont.) for $A$, unregulated and $B$, regulated streamflow conditions, 1928-2002. 

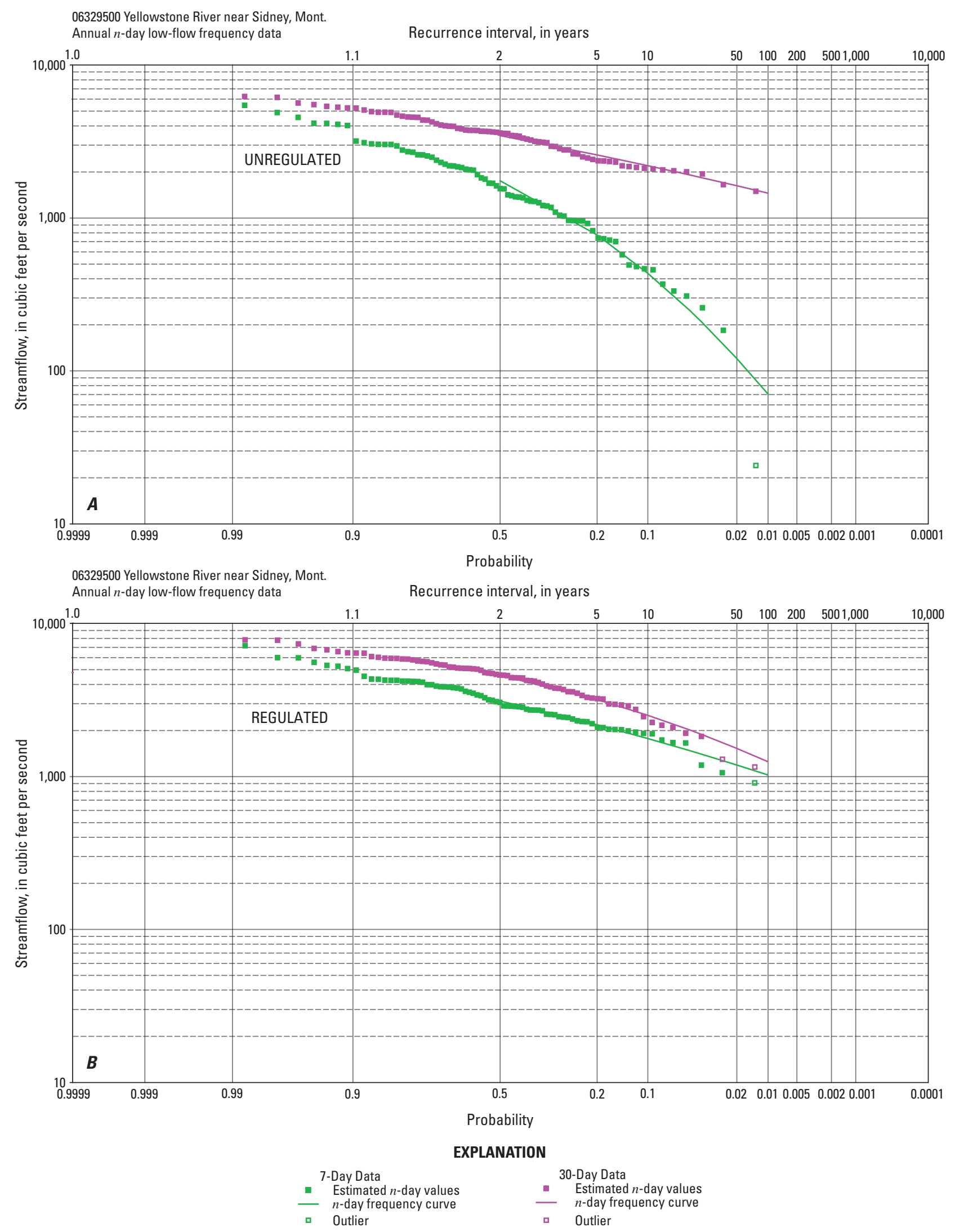

Figure 2-4-4. Annual $n$-day low-flow frequency data for streamflow-gaging station 06329500 (Yellowstone River at Sidney, Mont.) for $A$, unregulated and $B$, regulated streamflow conditions, 1928-2002. 
06329500 Yellowstone River near Sidney, Mont.

Winter (January-March) $n$-day low-flow frequency data Recurrence interval, in years

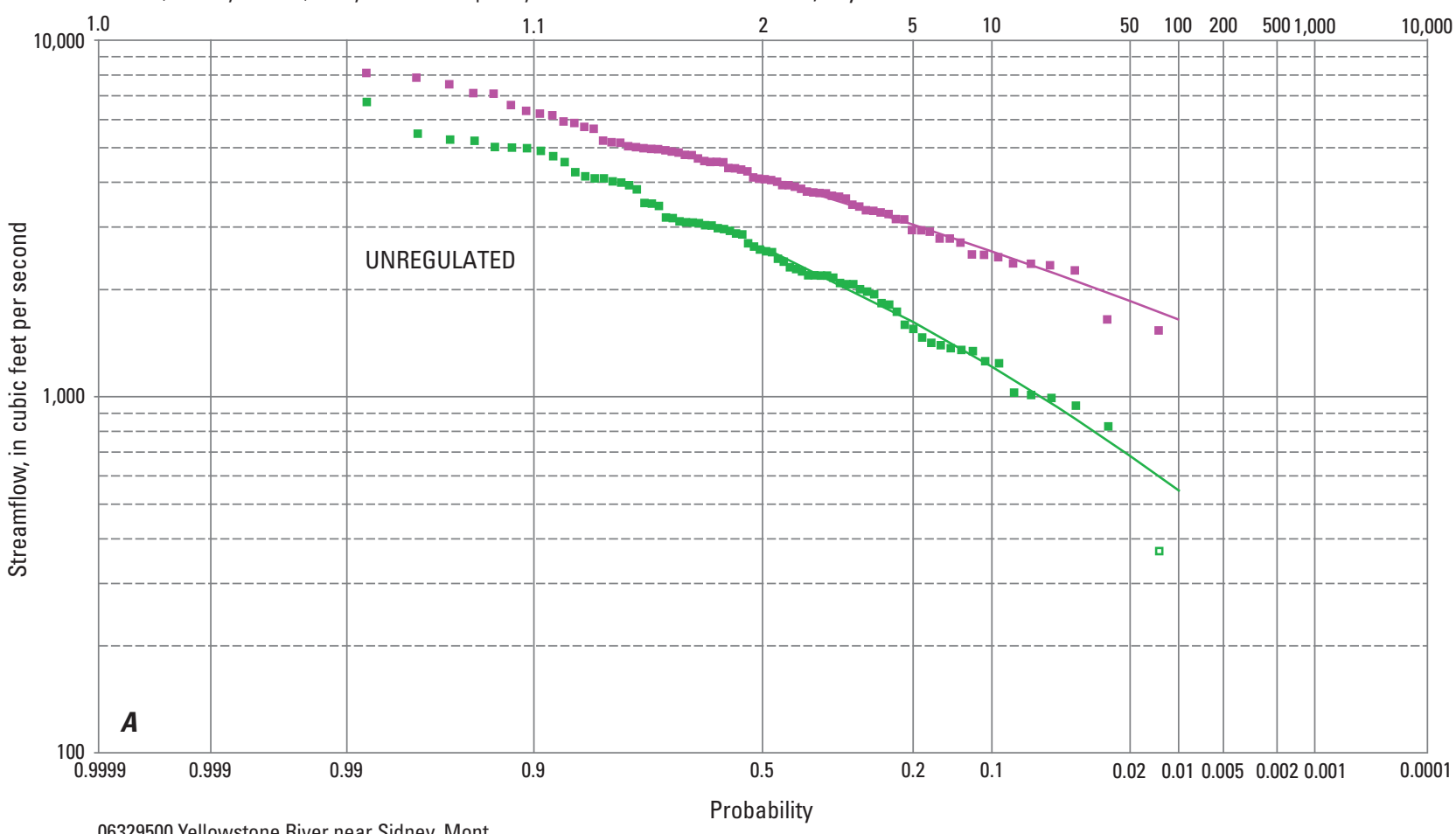

06329500 Yellowstone River near Sidney, Mont.

Recurrence interval, in years

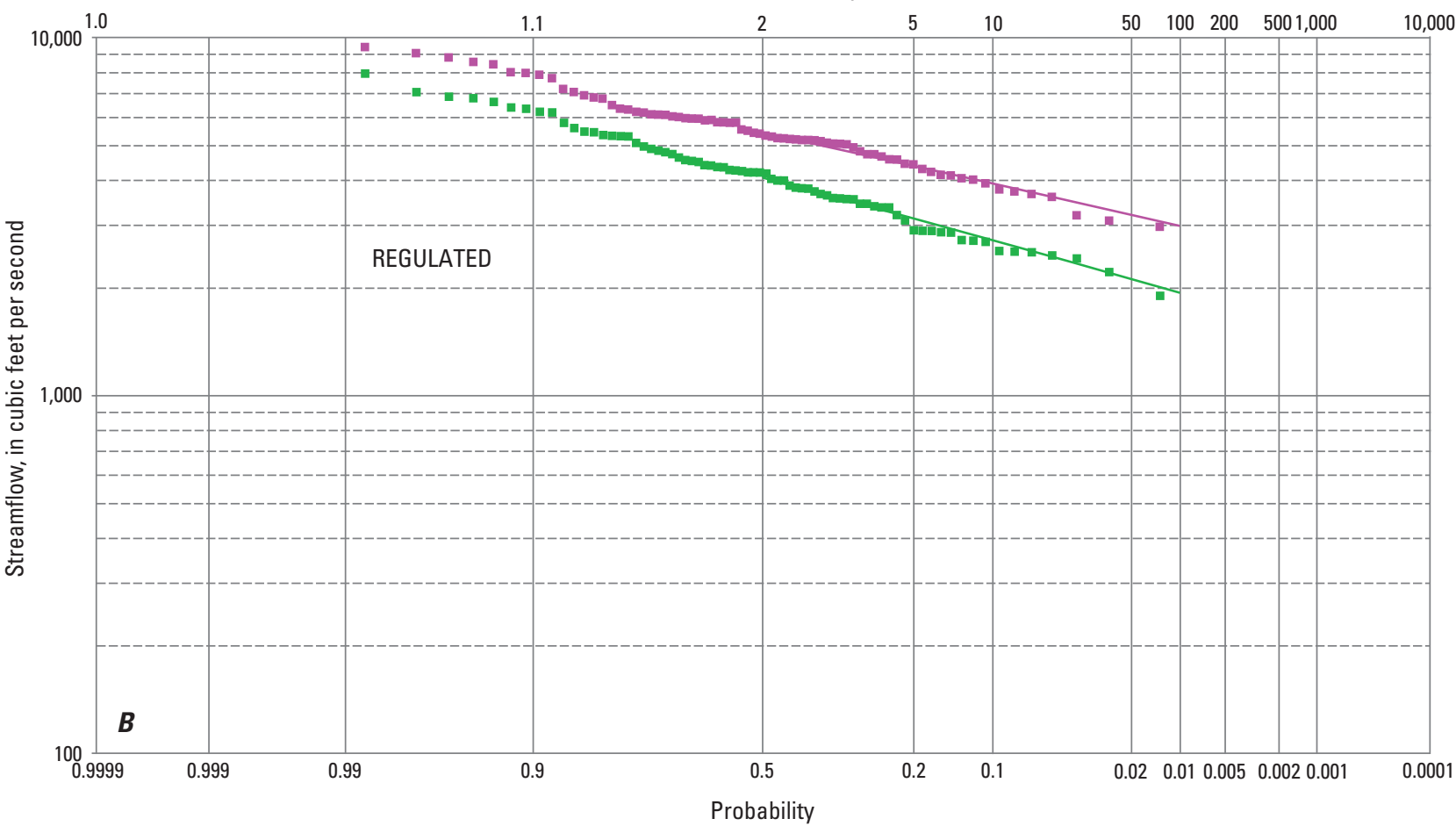

EXPLANATION

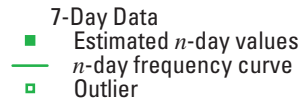

30-Day Data

- Estimated $n$-day values

$n$-day frequency curve $n$-day frequency curve

Figure 2-4-5. Winter (January-March) $n$-day low-flow frequency data for streamflow-gaging station 06329500 (Yellowstone River at Sidney, Mont.) for $A$, unregulated and $B$, regulated streamflow conditions, 1928-2002. 


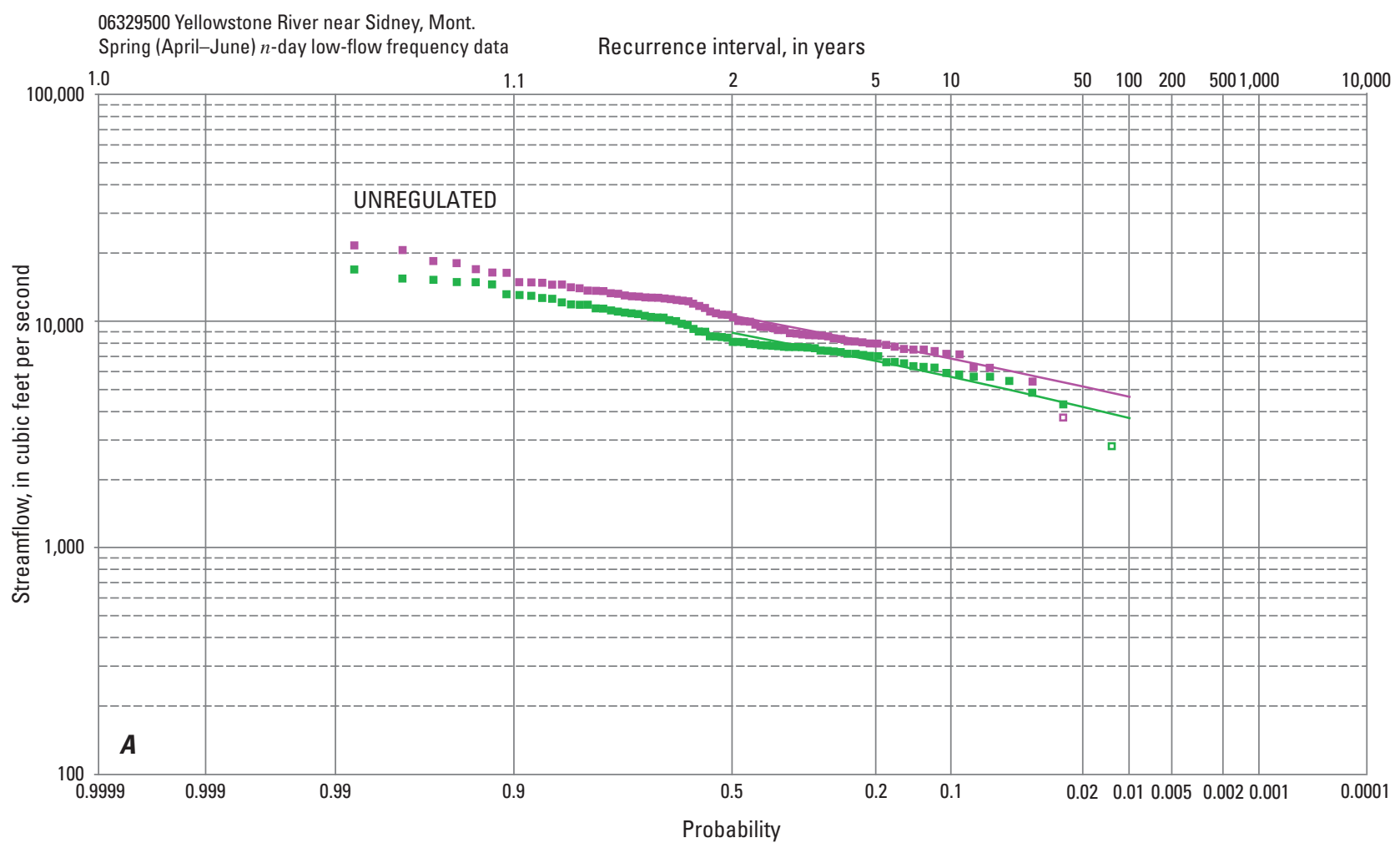

06329500 Yellowstone River near Sidney, Mont. Spring (April-June) $n$-day low-flow frequency data Recurrence interval, in years

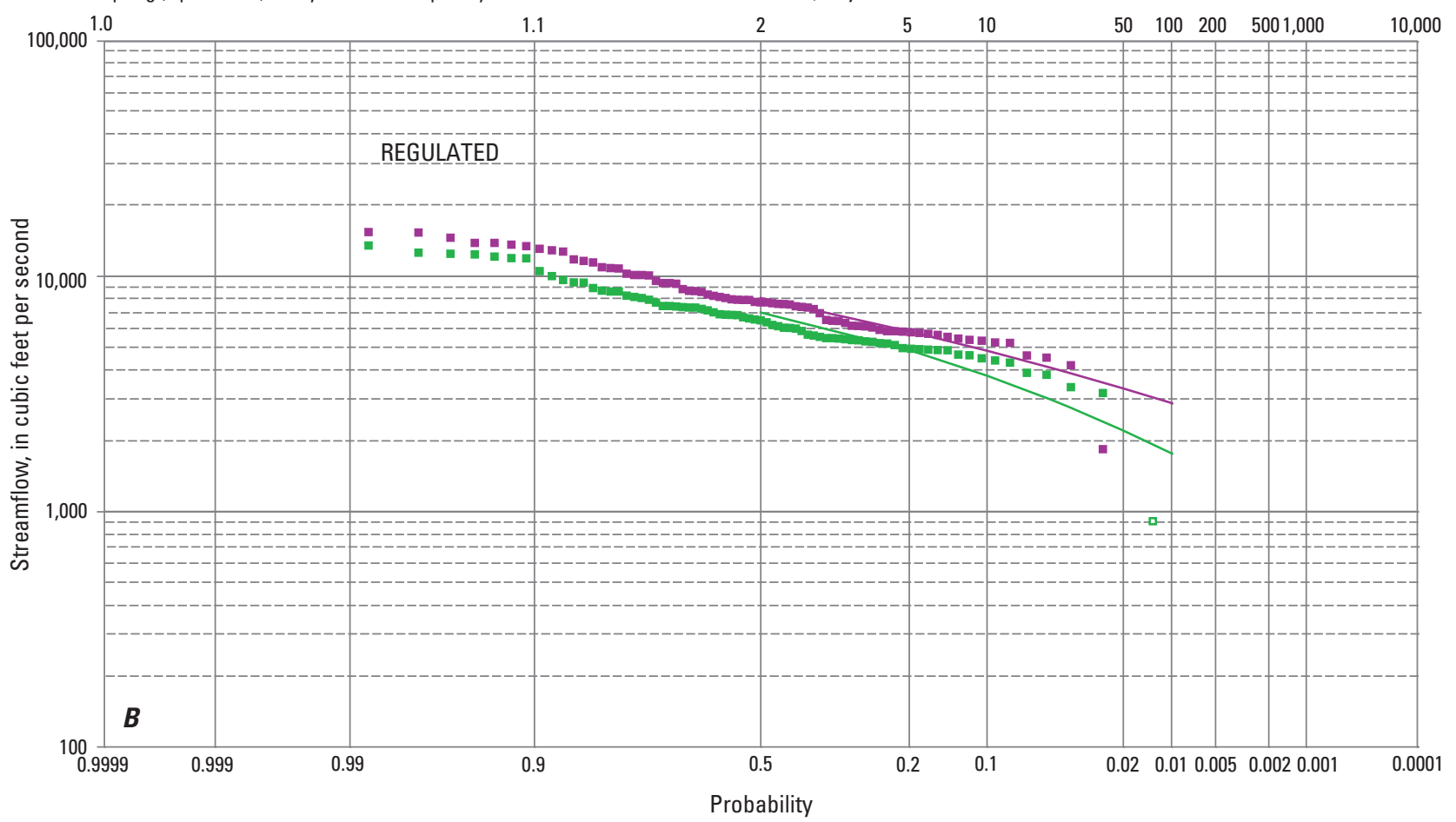

EXPLANATION

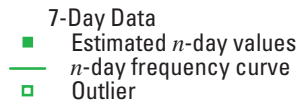

30-Day Data
Estimated $n$-day values
$n \quad \begin{aligned} & n \text {-day frequency curve } \\ & \text { Outlier }\end{aligned}$

Figure 2-4-6. Spring (April-June) n-day low-flow frequency data for streamflow-gaging station 06329500 (Yellowstone River at Sidney, Mont.) for $A$, unregulated and $B$, regulated streamflow conditions, 1928-2002. 
06329500 Yellowstone River near Sidney, Mont.

Summer (July-September) $n$-day low-flow frequency data Recurrence interval, in years

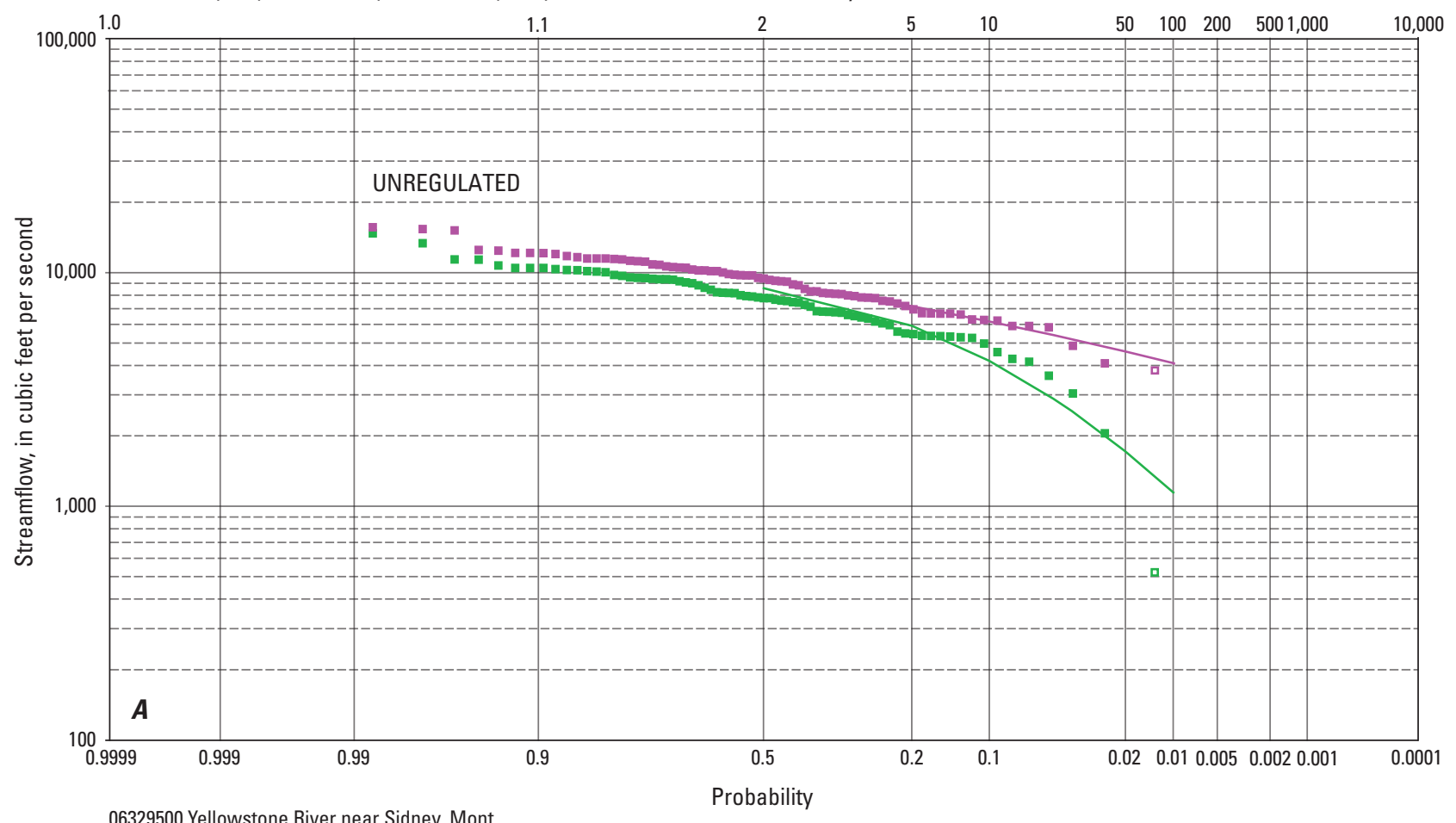

06329500 Yellowstone River near Sidney, Mont.

Summer (July-September) $n$-day low-flow frequency data Recurrence interval, in years

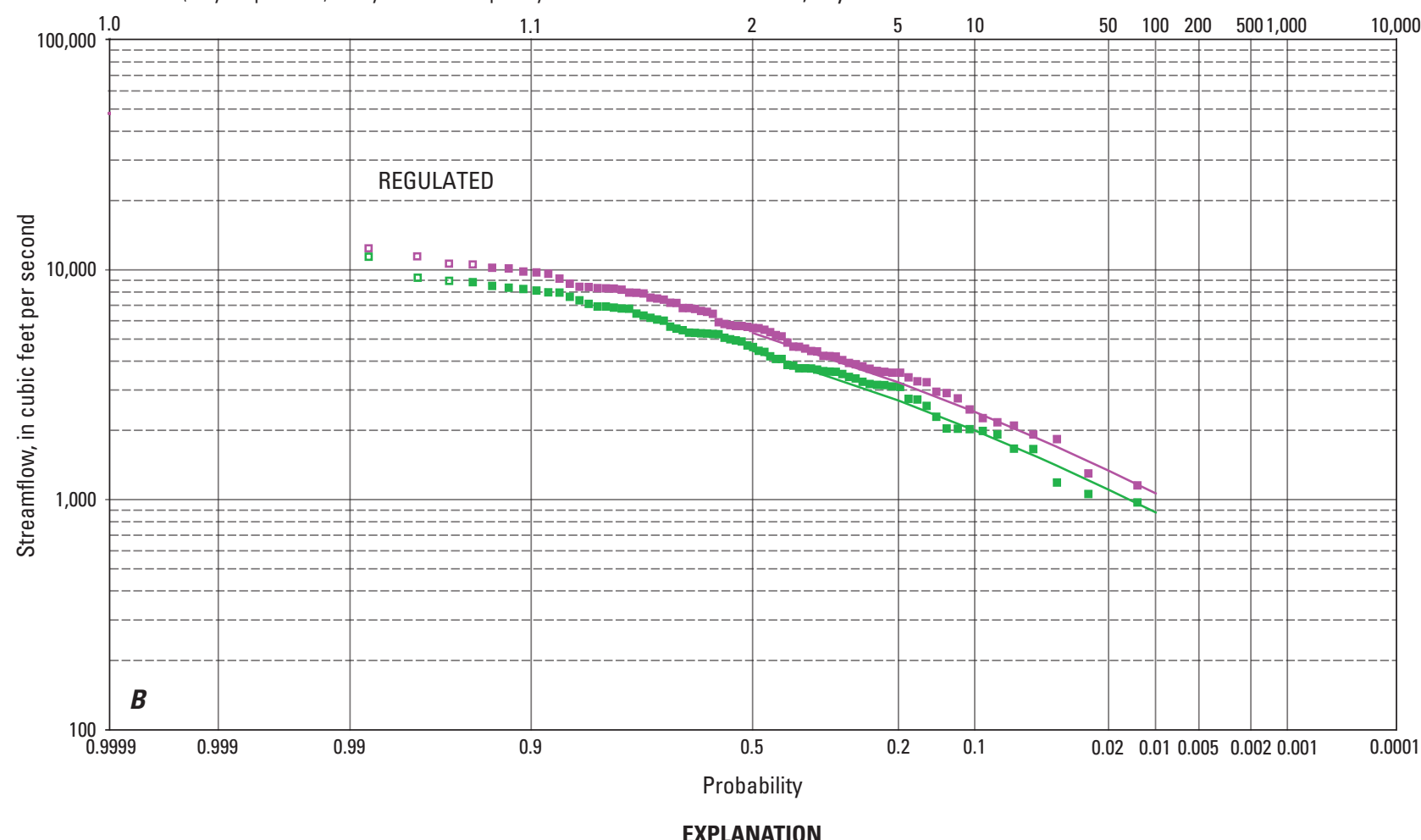

7-Day Data 30-Day Data

- Estimated $n$-day values (Weibull plotting positions) - Estimated $n$-day values (Weibull plotting positions)

- $n$-day frequency curve

- Outlier

- n-day frequency curve

․ Outlier

Figure 2-4-7. Summer (July-September) $n$-day low-flow frequency data for streamflow-gaging station 06329500 (Yellowstone River at Sidney, Mont.) for $A$, unregulated and $B$, regulated streamflow conditions, 1928-2002. 


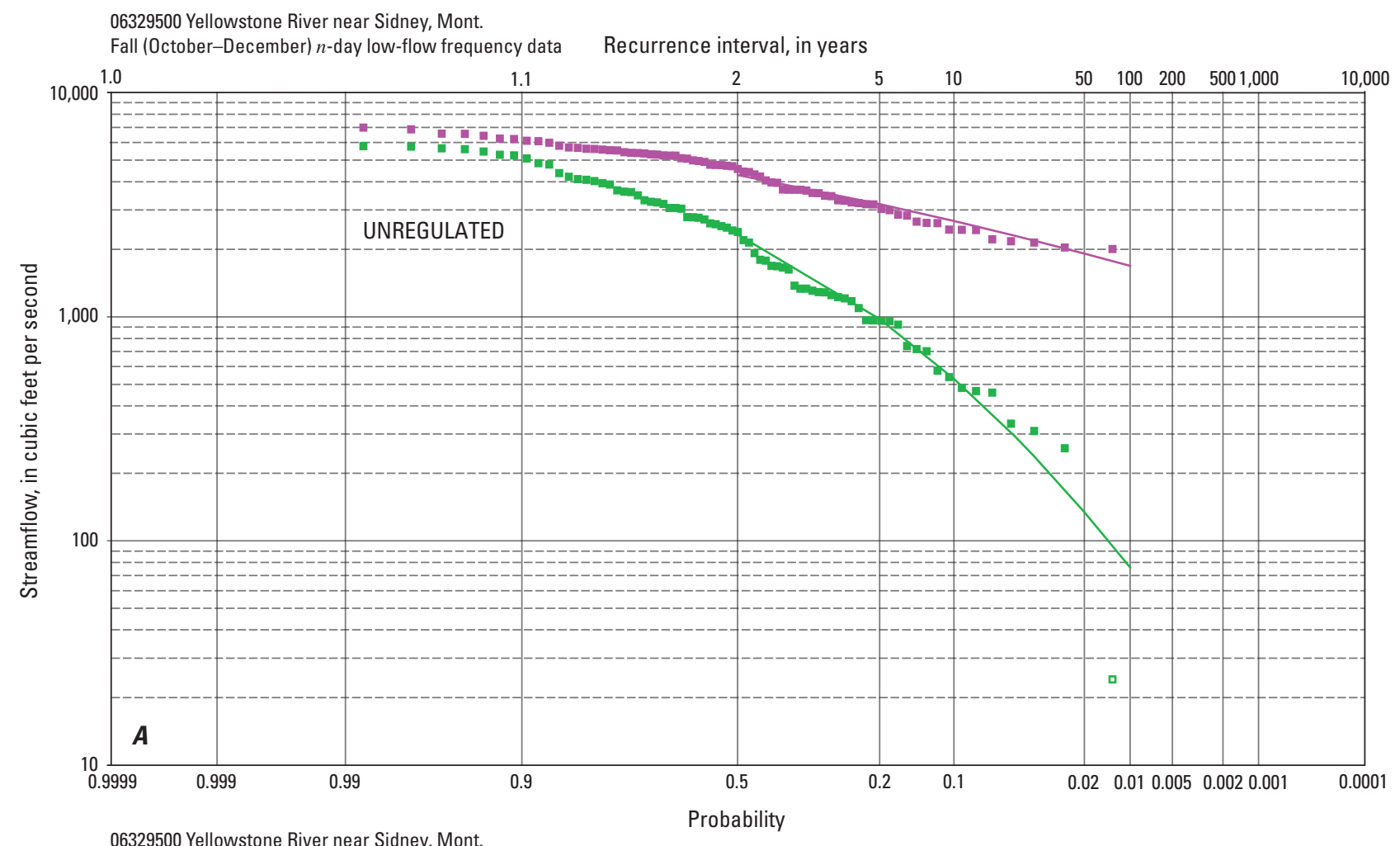

06329500 Yellowstone River near Sidney, Mont.

Fall (October-December) $n$-day low-flow frequency data Recurrence interval, in years

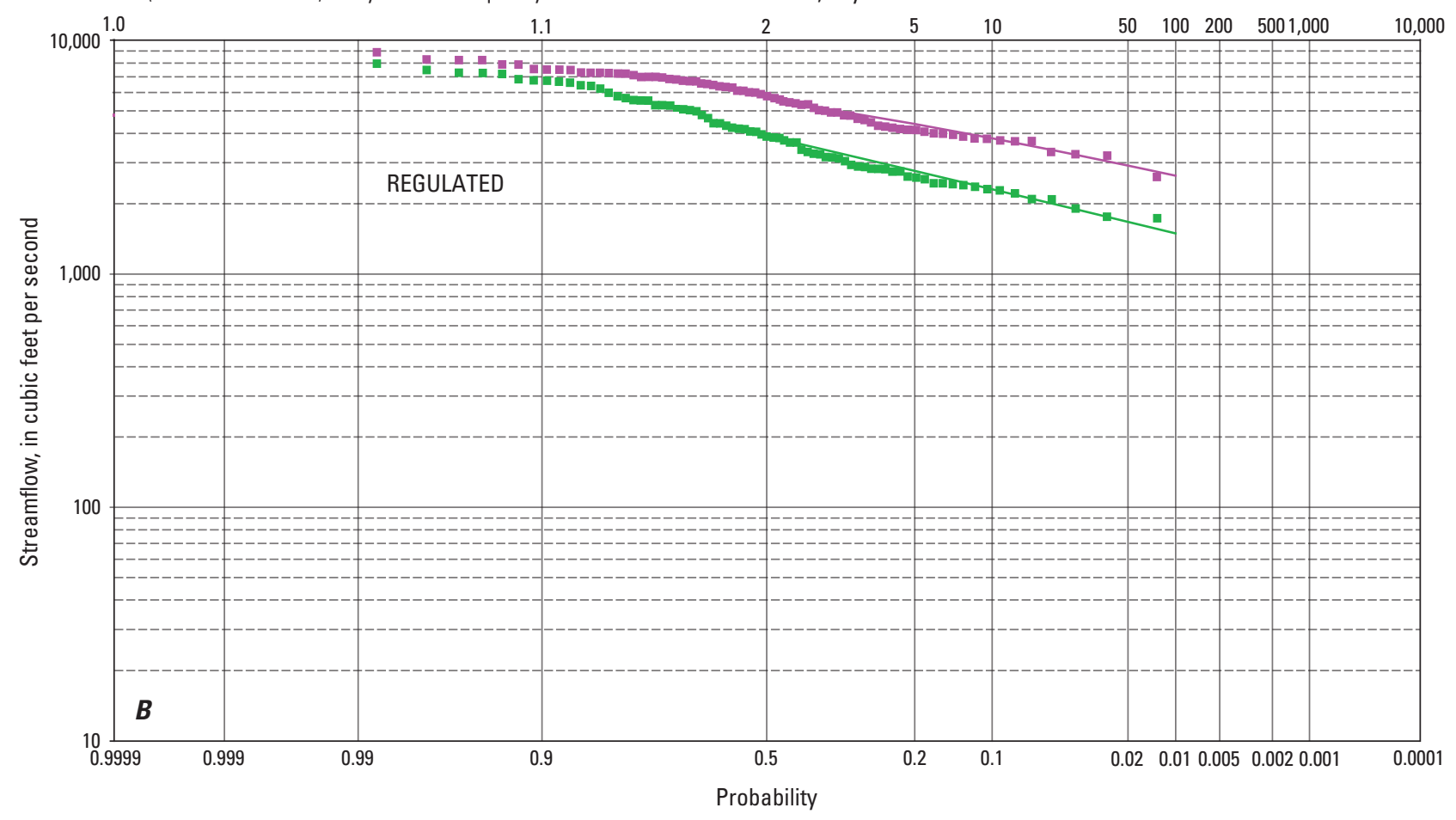

EXPLANATION

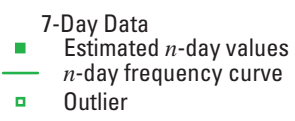

30-Day Data

- Estimated $n$-day values

- $n$-day frequency curve

- n-day frequency curve

Figure 2-4-8. Fall (October-December) $n$-day low-flow frequency data for streamflow-gaging station 06329500 (Yellowstone River at Sidney, Mont.) for $A$, unregulated and B, regulated streamflow conditions, 1928-2002. 

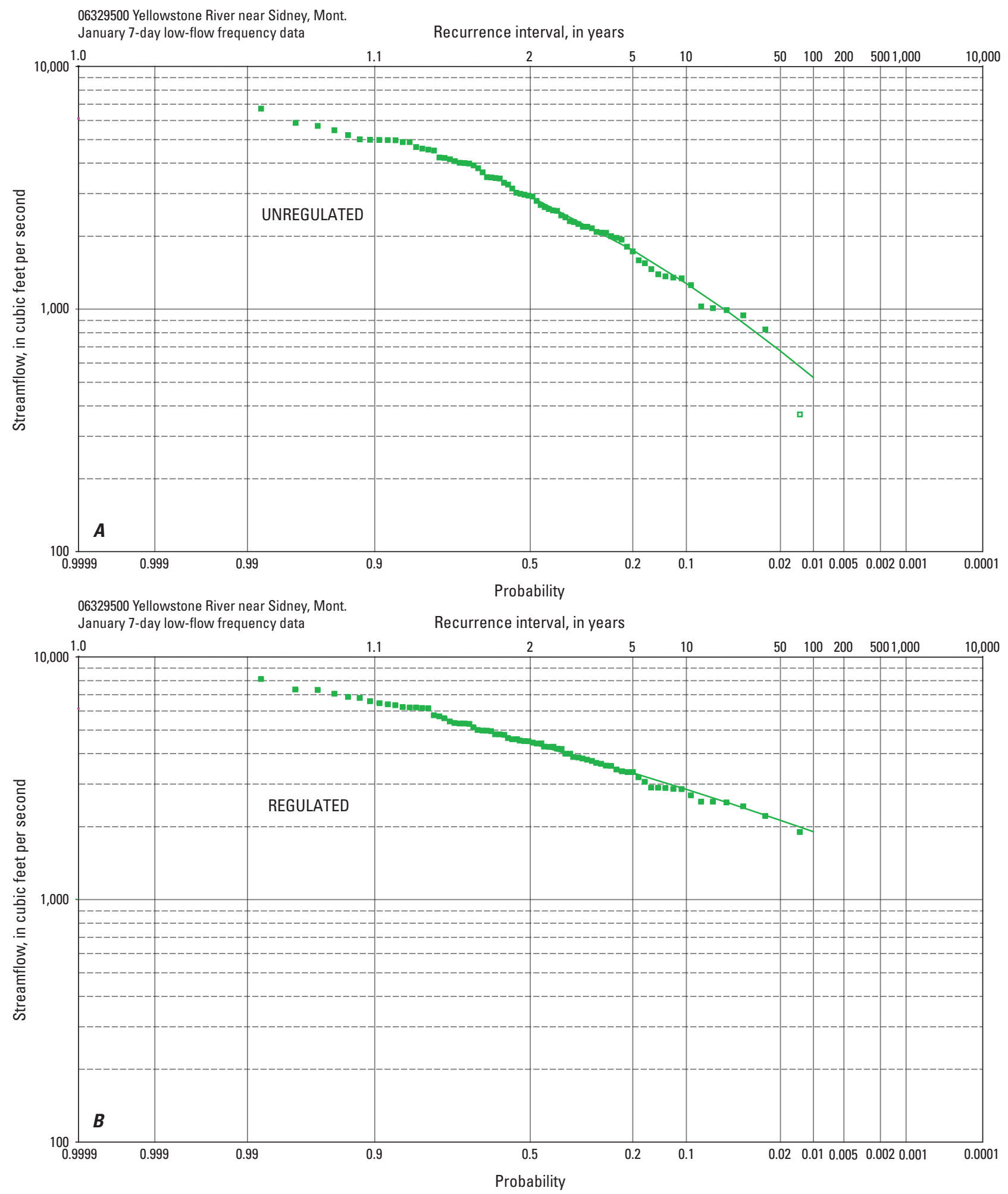

EXPLANATION

7-Day Data

- Estimated $n$-day values

- $n$-day frequency curve

- Outlier

Figure 2-4-9. January 7-day low-flow frequency data for streamflow-gaging station 06329500 (Yellowstone River at Sidney, Mont.) for $A$, unregulated and $B$, regulated streamflow conditions, 1928-2002. 


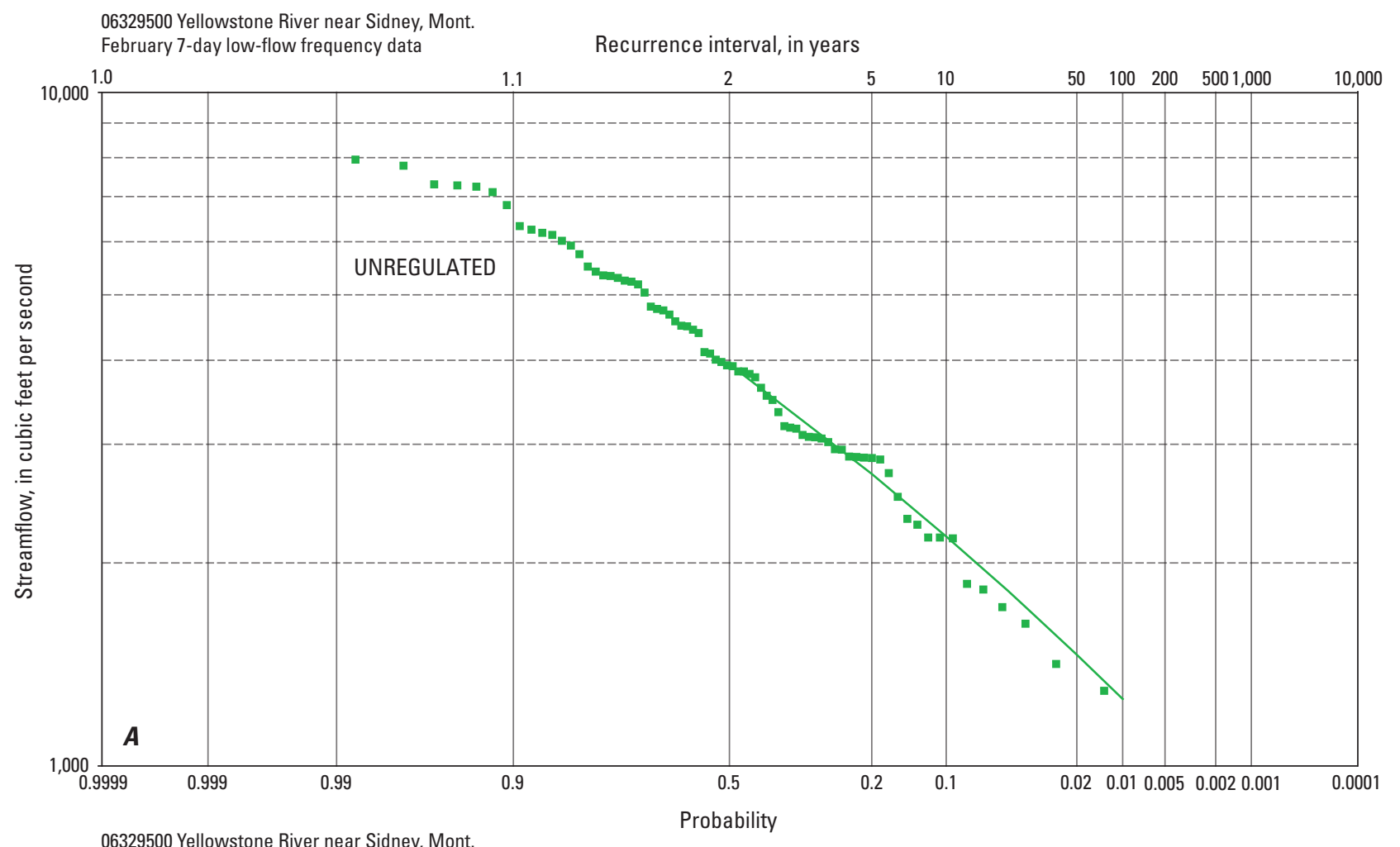

06329500 Yellowstone River near Sidney, Mont.

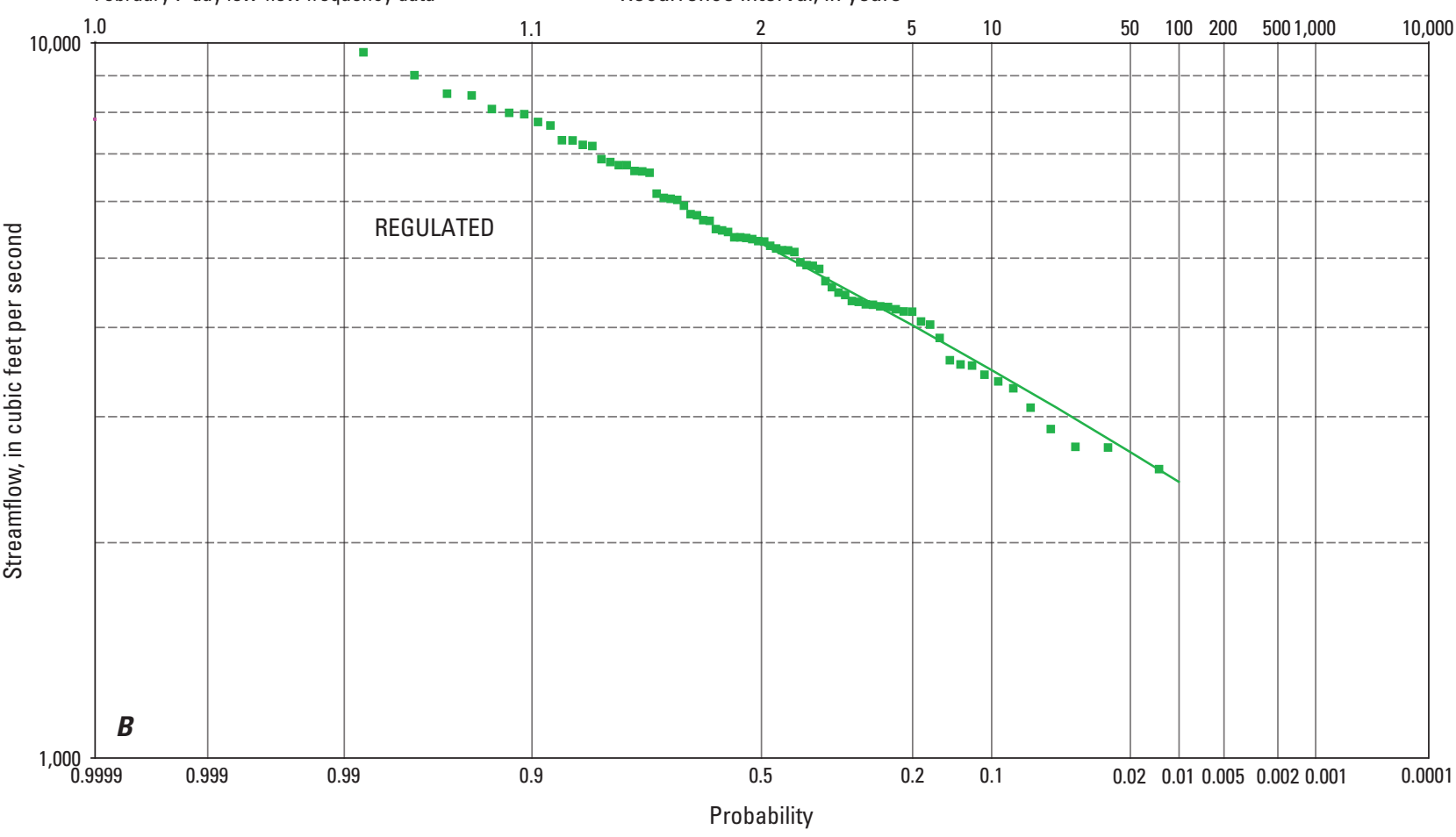

EXPLANATION

7-Day Data

- $\quad$ Estimated $n$-day values

- n-day frequency curve

Figure 2-4-10. February 7-day low-flow frequency data for streamflow-gaging station 06329500 (Yellowstone River at Sidney, Mont.) for $A$, unregulated and $B$, regulated streamflow conditions, 1928-2002. 

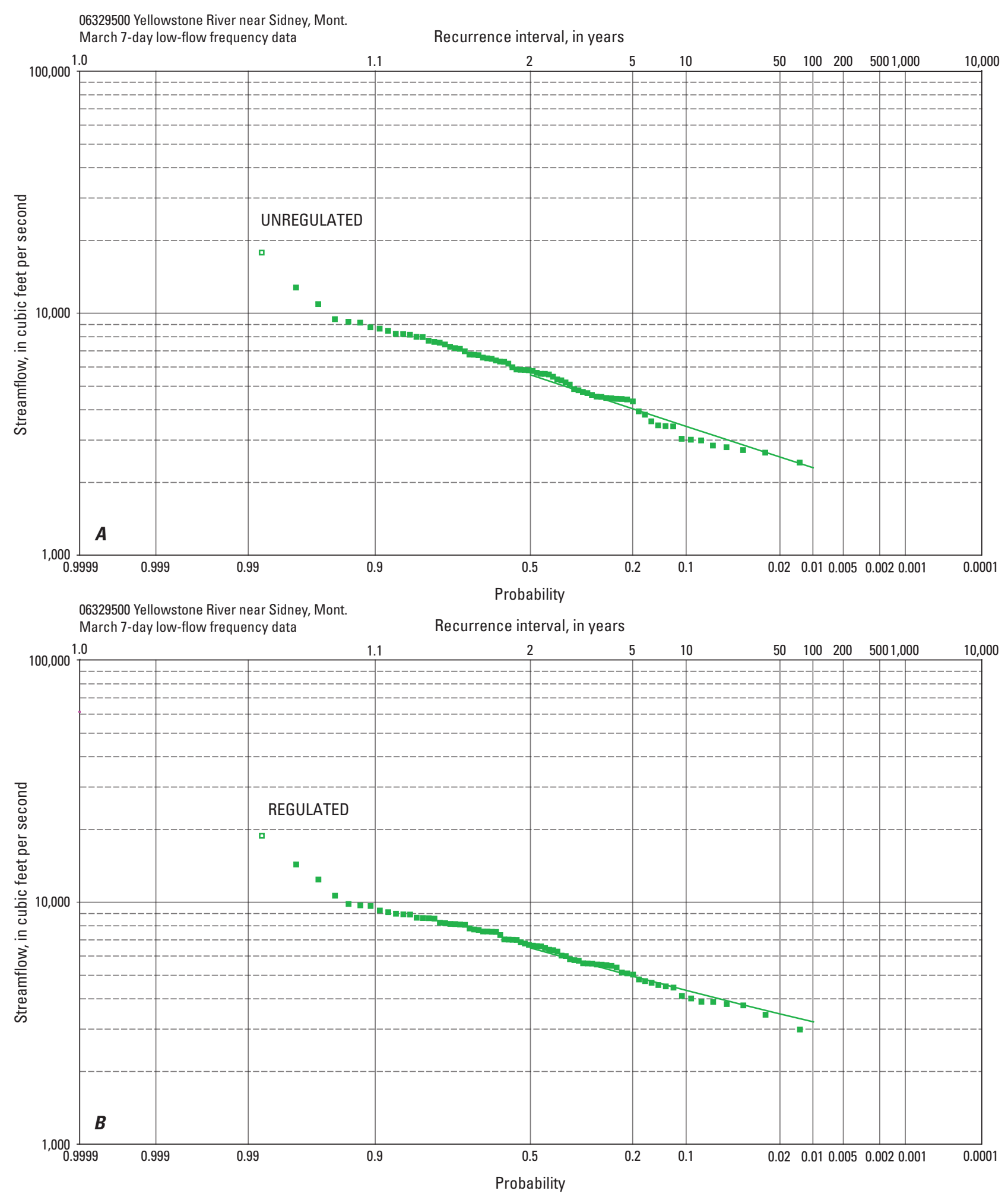

EXPLANATION

7-Day Data

- Estimated $n$-day values

- $n$-day frequency curve

Outlier

Figure 2-4-11. March 7-day low-flow frequency data for streamflow-gaging station 06329500 (Yellowstone River at Sidney, Mont.) for $A$, unregulated and $B$, regulated streamflow conditions, 1928-2002. 

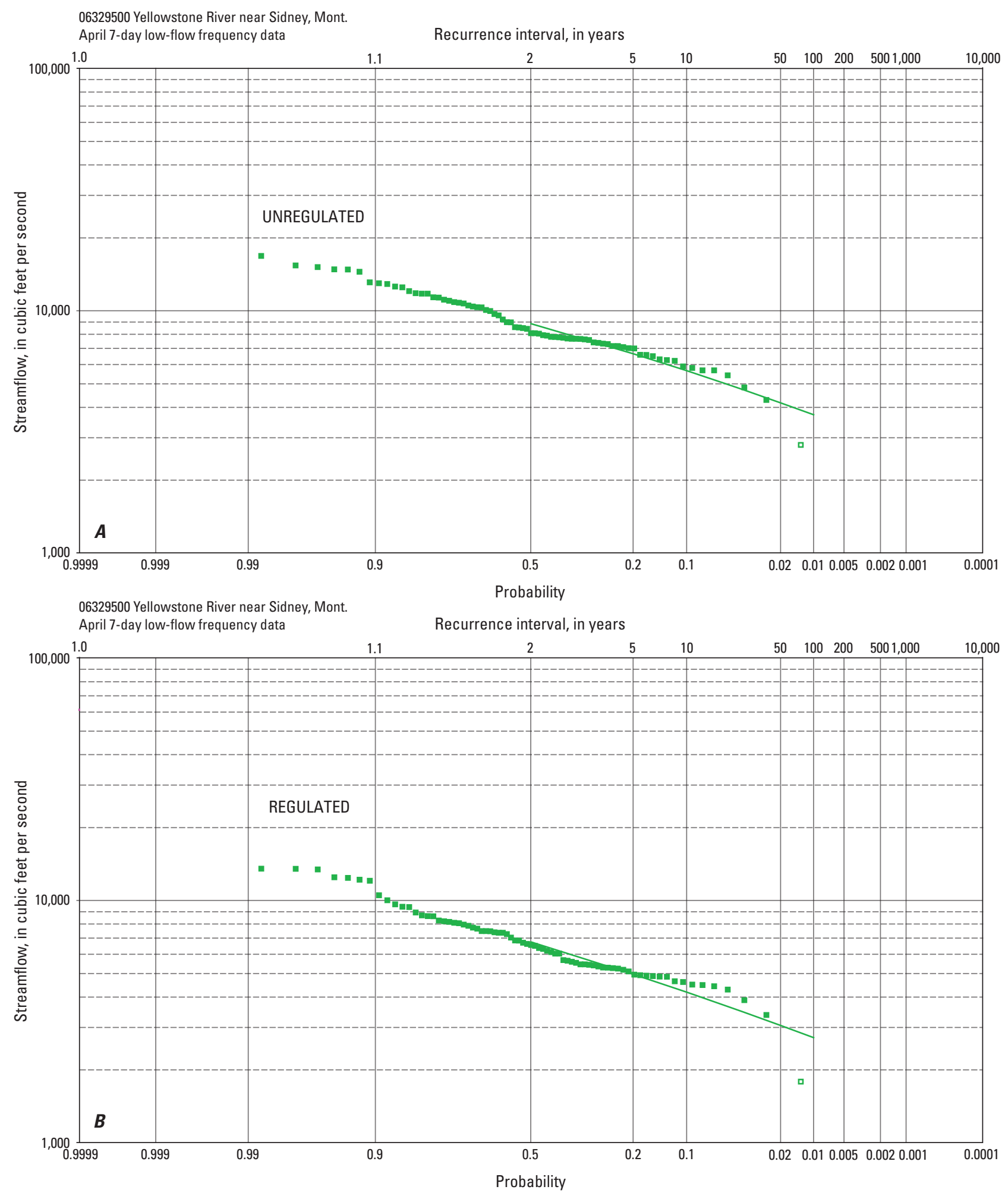

EXPLANATION

7-Day Data

- Estimated $n$-day values

- n-day frequency curve

- Outlier

Figure 2-4-12. April 7-day low-flow frequency data for streamflow-gaging station 06329500 (Yellowstone River at Sidney, Mont.) for $A$, unregulated and $B$, regulated streamflow conditions, 1928-2002. 

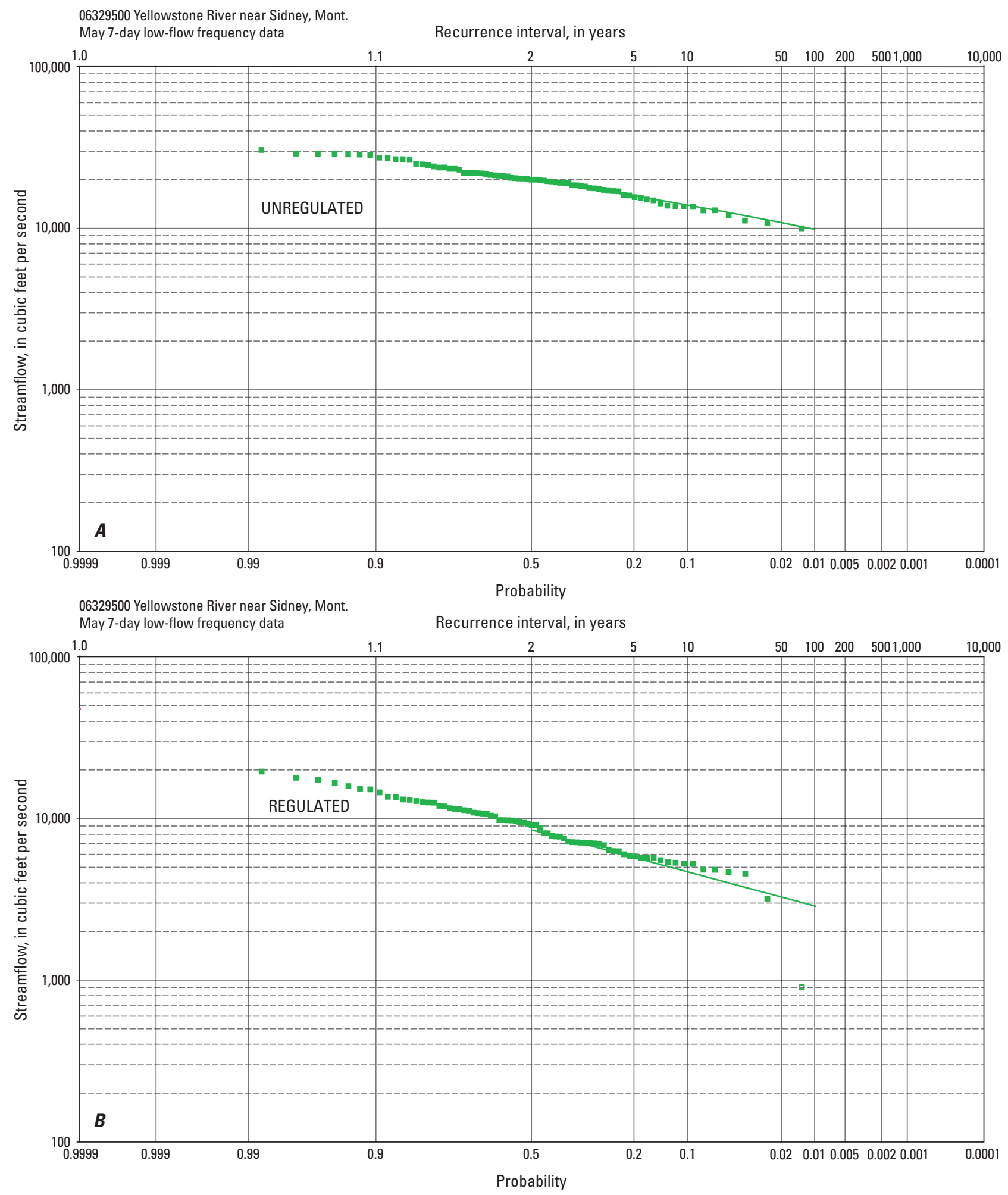

EXPLANATION

7-Day Data

- Estimated $n$-day values

n-day frequency curve

Figure 2-4-13. May 7-day low-flow frequency data for streamflow-gaging station 06329500 (Yellowstone River at Sidney, Mont.) for $A$, unregulated and $B$, regulated streamflow conditions, 1928-2002. 

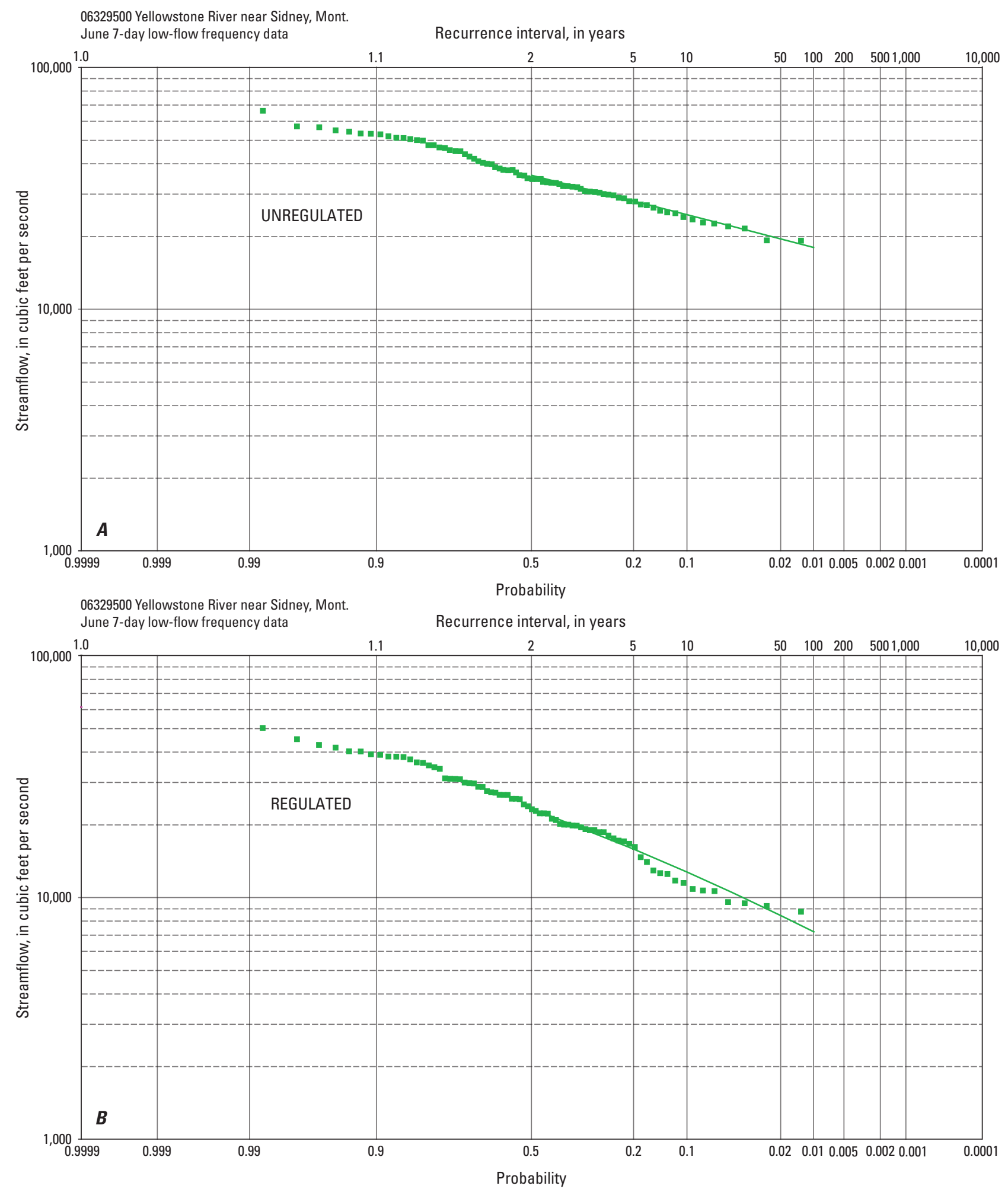

EXPLANATION

7-Day Data

- $\quad$ Estimated $n$-day values

- n-day frequency curve

Figure 2-4-14. June 7-day low-flow frequency data for streamflow-gaging station 06329500 (Yellowstone River at Sidney, Mont.) for $A$, unregulated and $B$, regulated streamflow conditions, 1928-2002. 


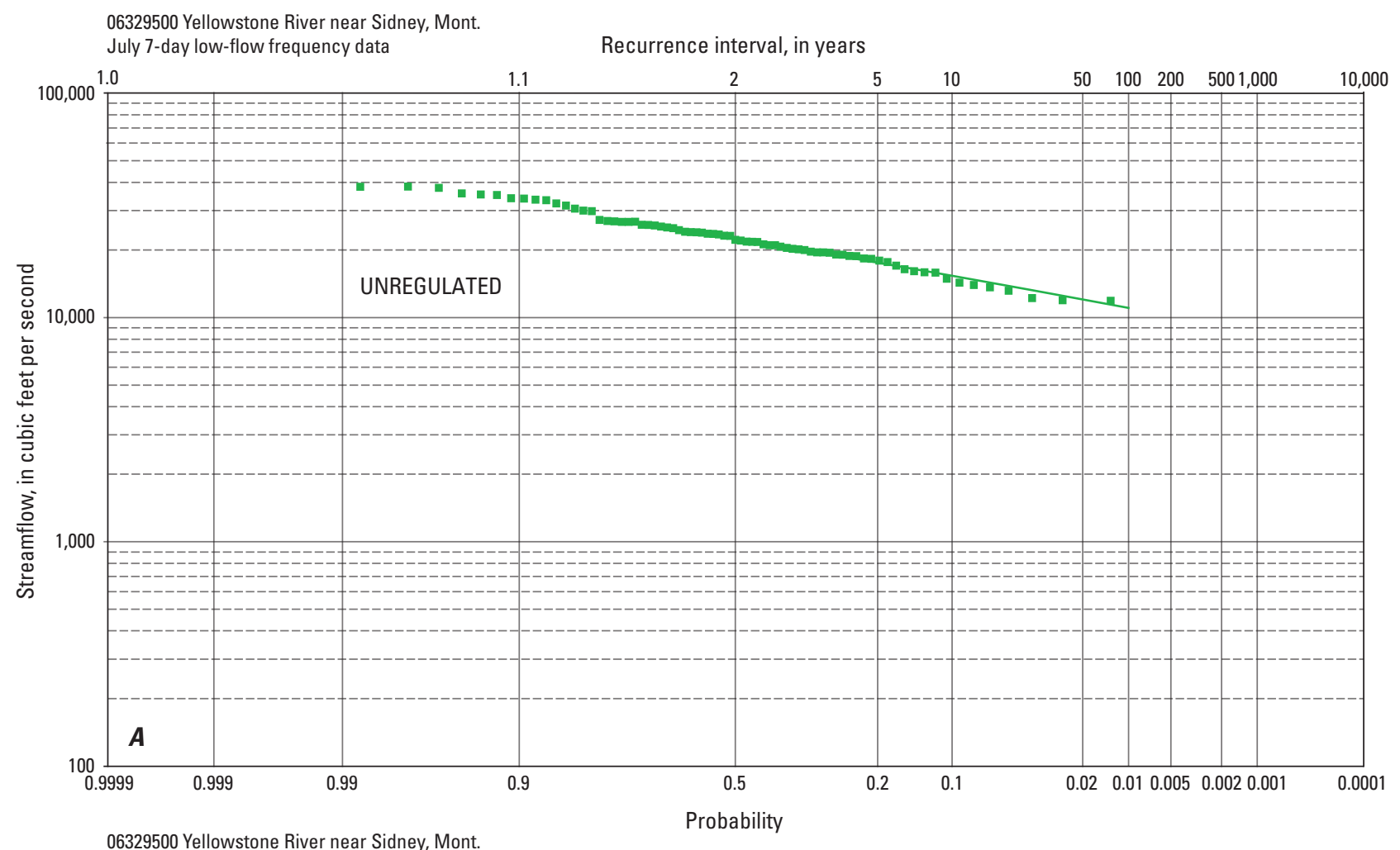

06329500 Yellowstone River near Sidney, Mont.

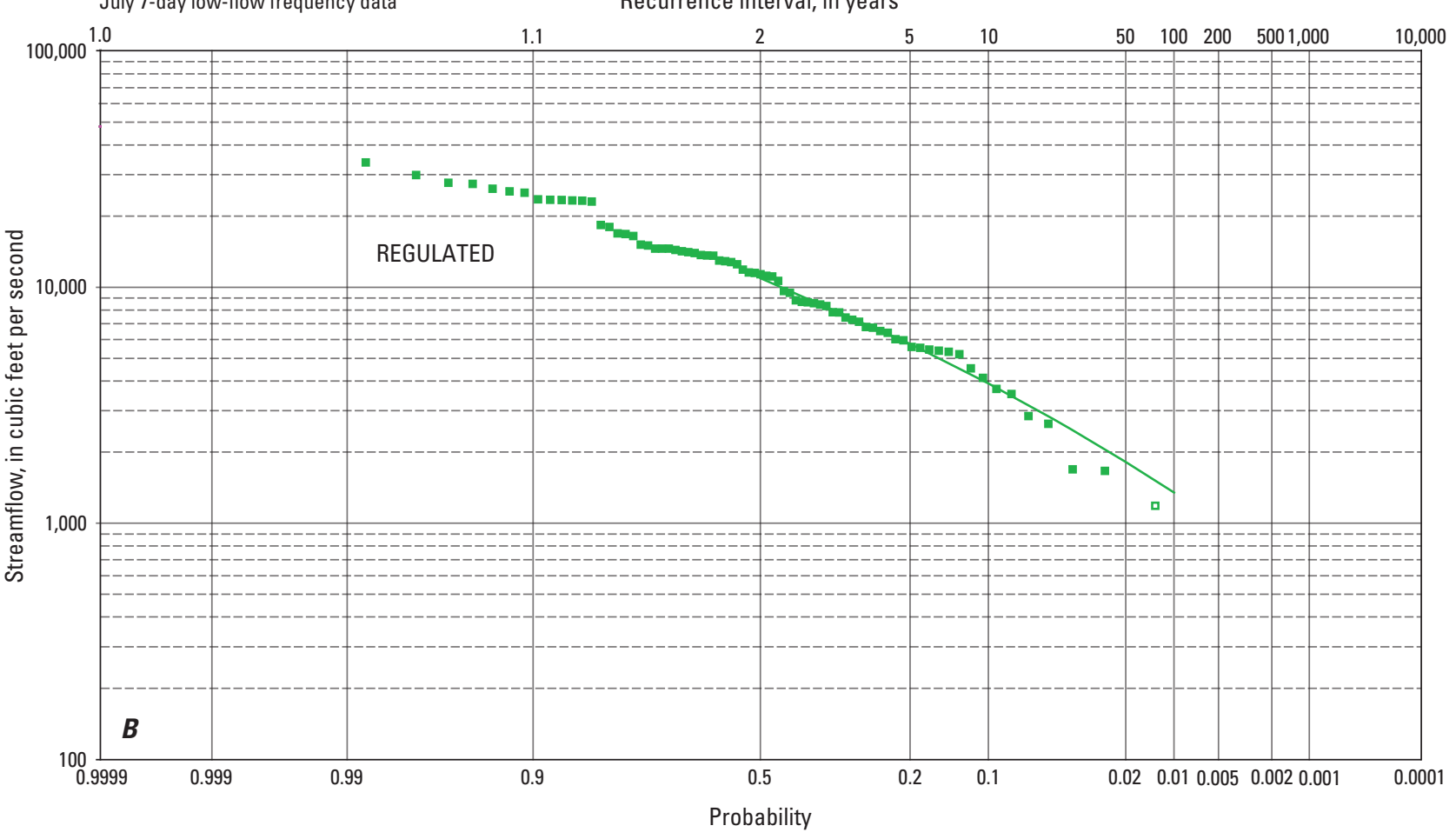

EXPLANATION

7-Day Data

- Estimated $n$-day values

- n-day frequency curve

Outlier

Figure 2-4-15. July 7-day low-flow frequency data for streamflow-gaging station 06329500 (Yellowstone River at Sidney, Mont.) for $A$, unregulated and $B$, regulated streamflow conditions, 1928-2002. 


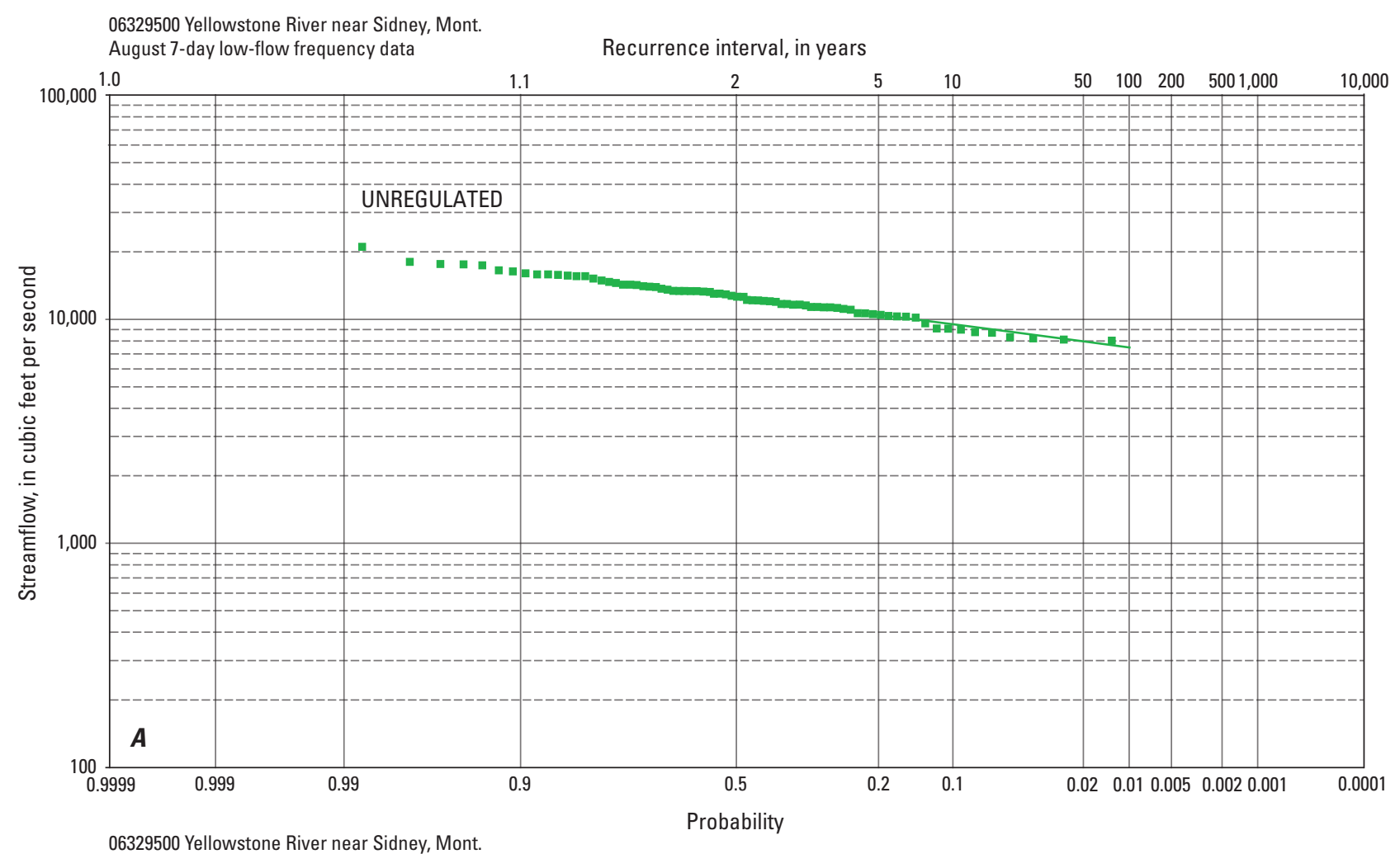

August 7-day low-flow frequency data, Mont.

Recurrence interval, in years

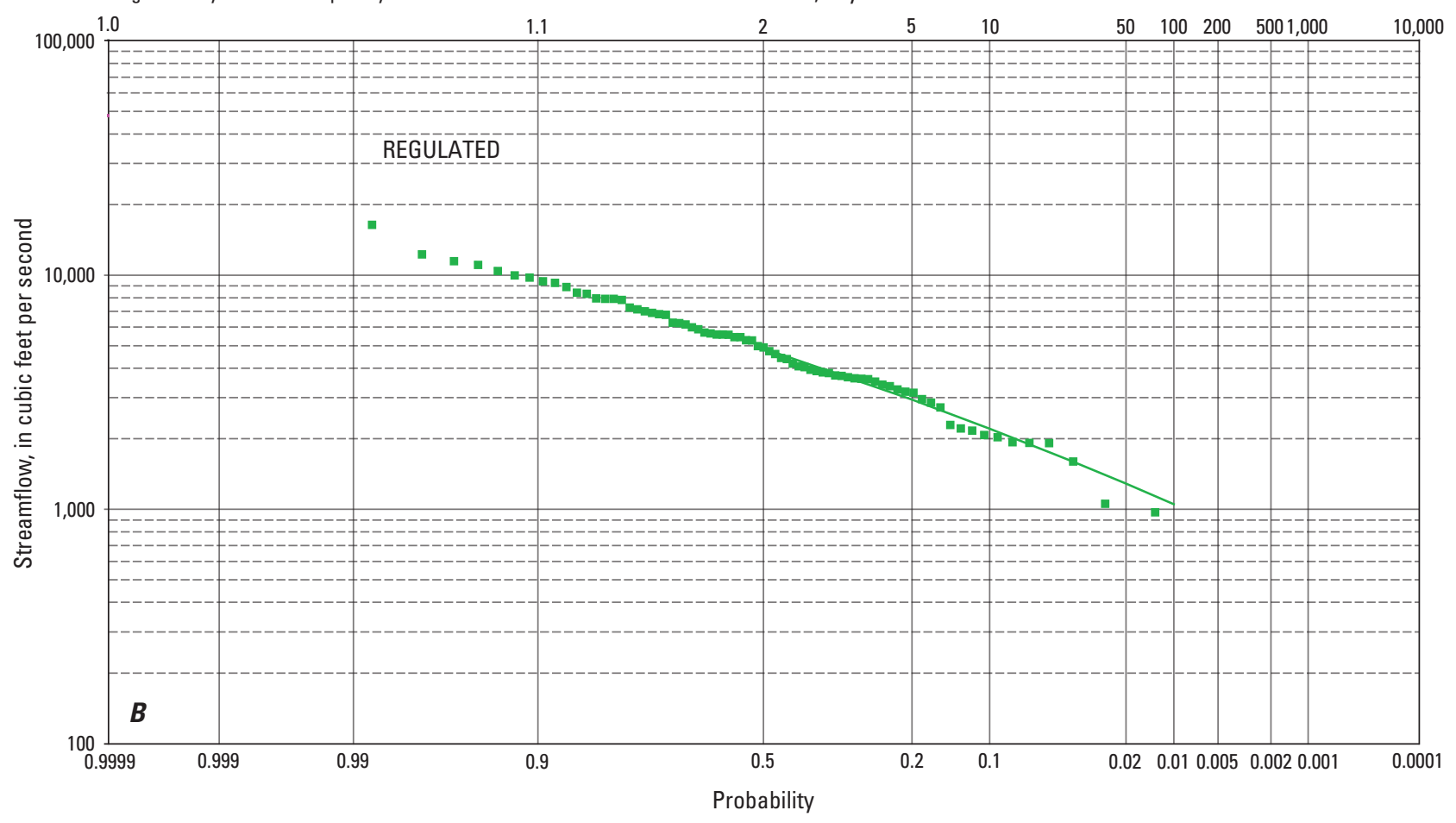

EXPLANATION

7-Day Data

- Estimated $n$-day values

$n$-day frequency curve

Figure 2-4-16. August 7-day low-flow frequency data for streamflow-gaging station 06329500 (Yellowstone River at Sidney, Mont.) for $A$, unregulated and $B$, regulated streamflow conditions, 1928-2002. 

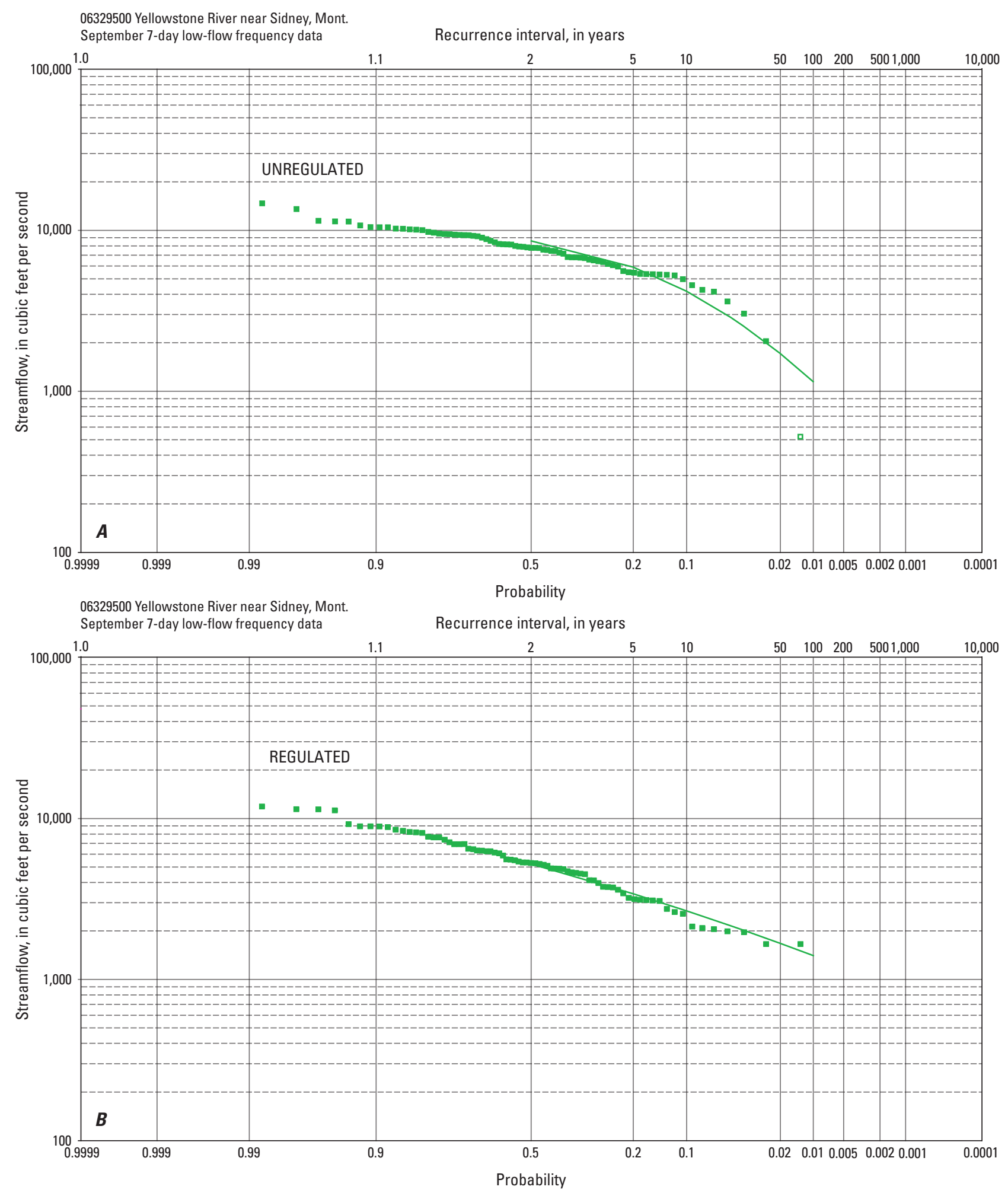

EXPLANATION

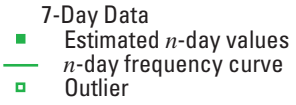

Figure 2-4-17. September 7-day low-flow frequency data for streamflow-gaging station 06329500 (Yellowstone River at Sidney, Mont.) for $A$, unregulated and $B$, regulated streamflow conditions, 1928-2002. 

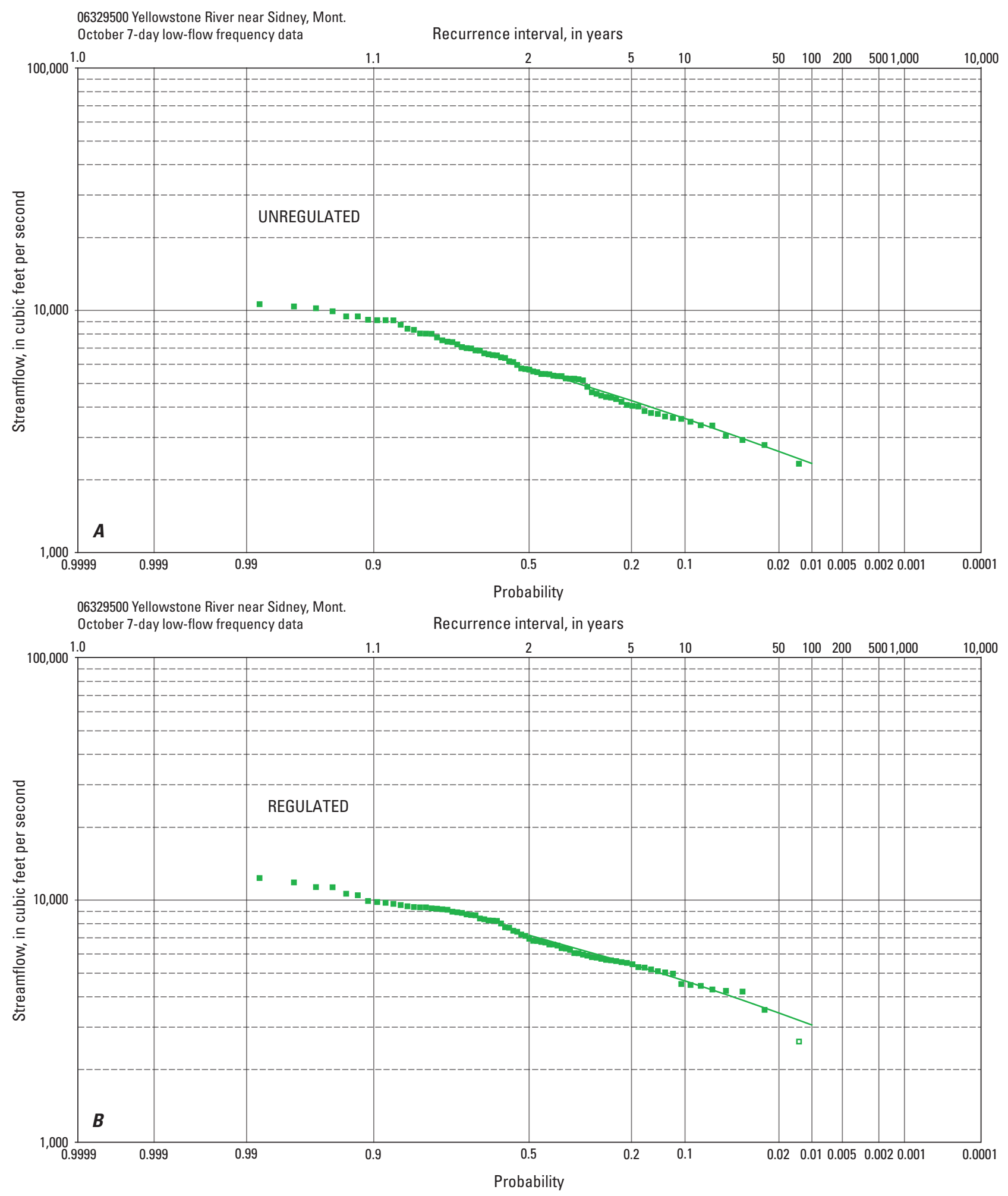

EXPLANATION

7-Day Data

- Estimated $n$-day values

- n-day frequency curve

a Outlier

Figure 2-4-18. October 7-day low-flow frequency data for streamflow-gaging station 06329500 (Yellowstone River at Sidney, Mont.) for $A$, unregulated and $B$, regulated streamflow conditions, 1928-2002. 


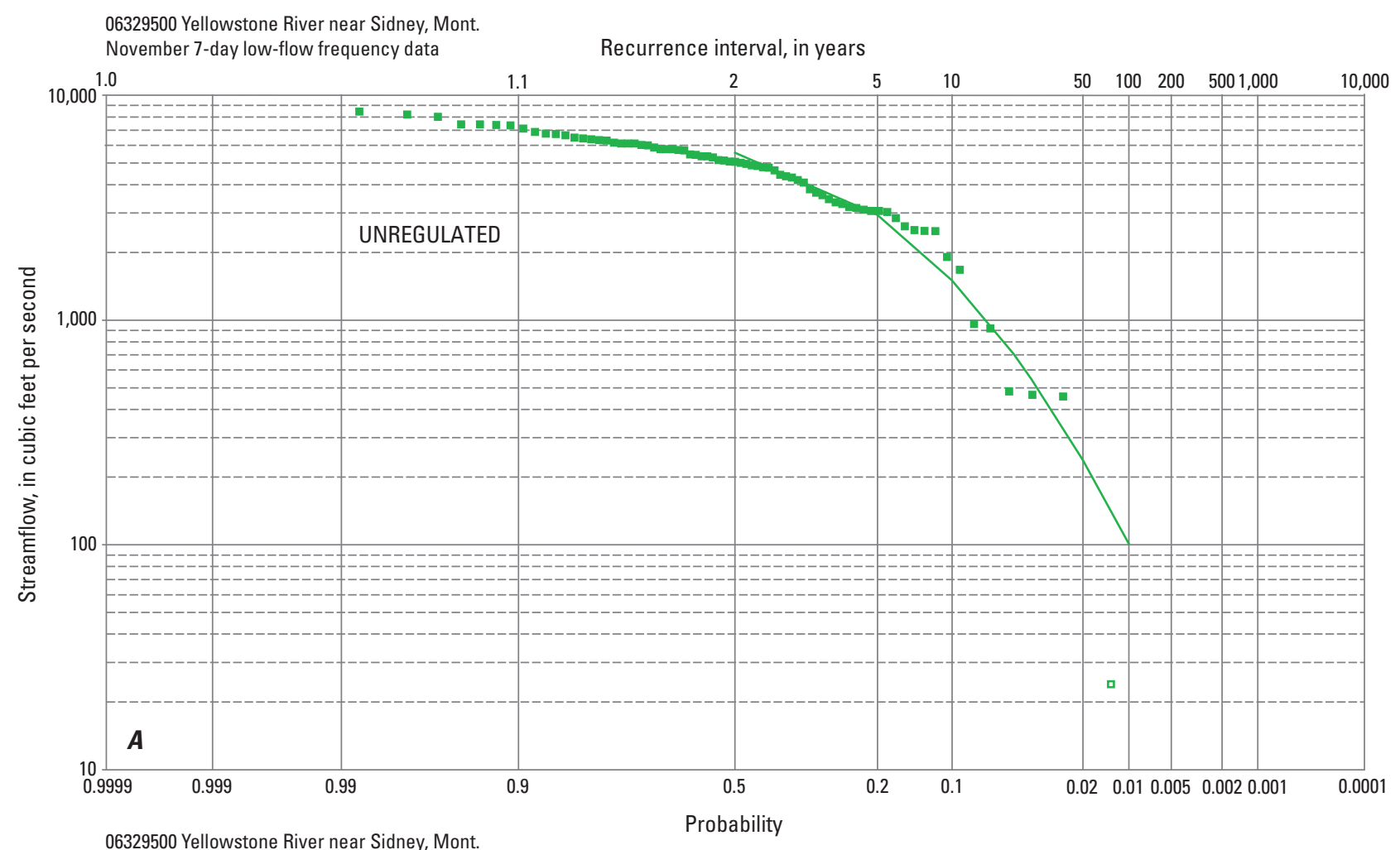

06329500 Yellowstone River near Sidney, Mont. November 7-day low-flow frequency data Recurrence interval, in years

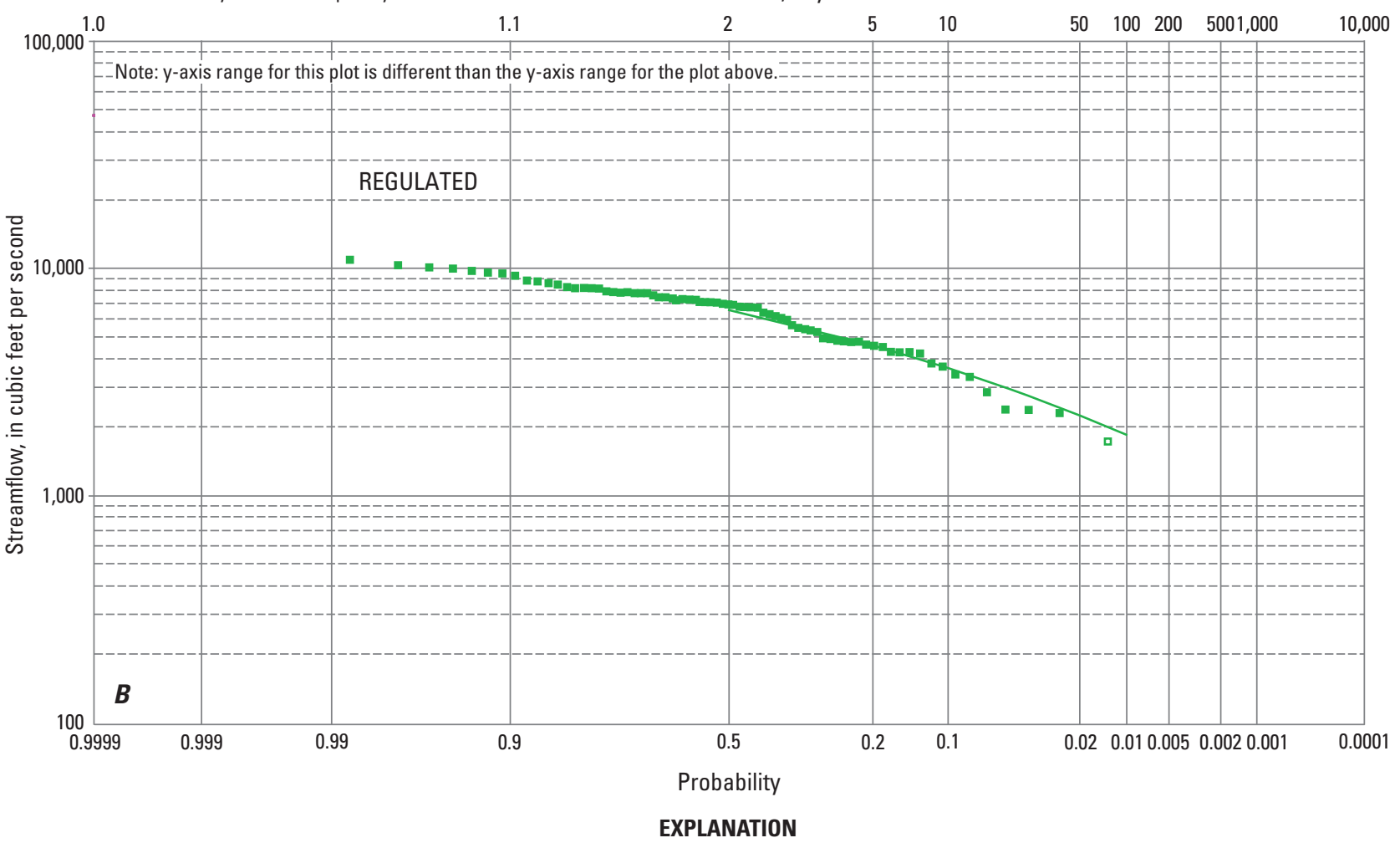

7-Day Data

- Estimated $n$-day values

- $n$-day frequency curve

Outlier

Figure 2-4-19. November 7-day low-flow frequency data for streamflow-gaging station 06329500 (Yellowstone River at Sidney, Mont.) for $A$, unregulated and $B$, regulated streamflow conditions, 1928-2002. 

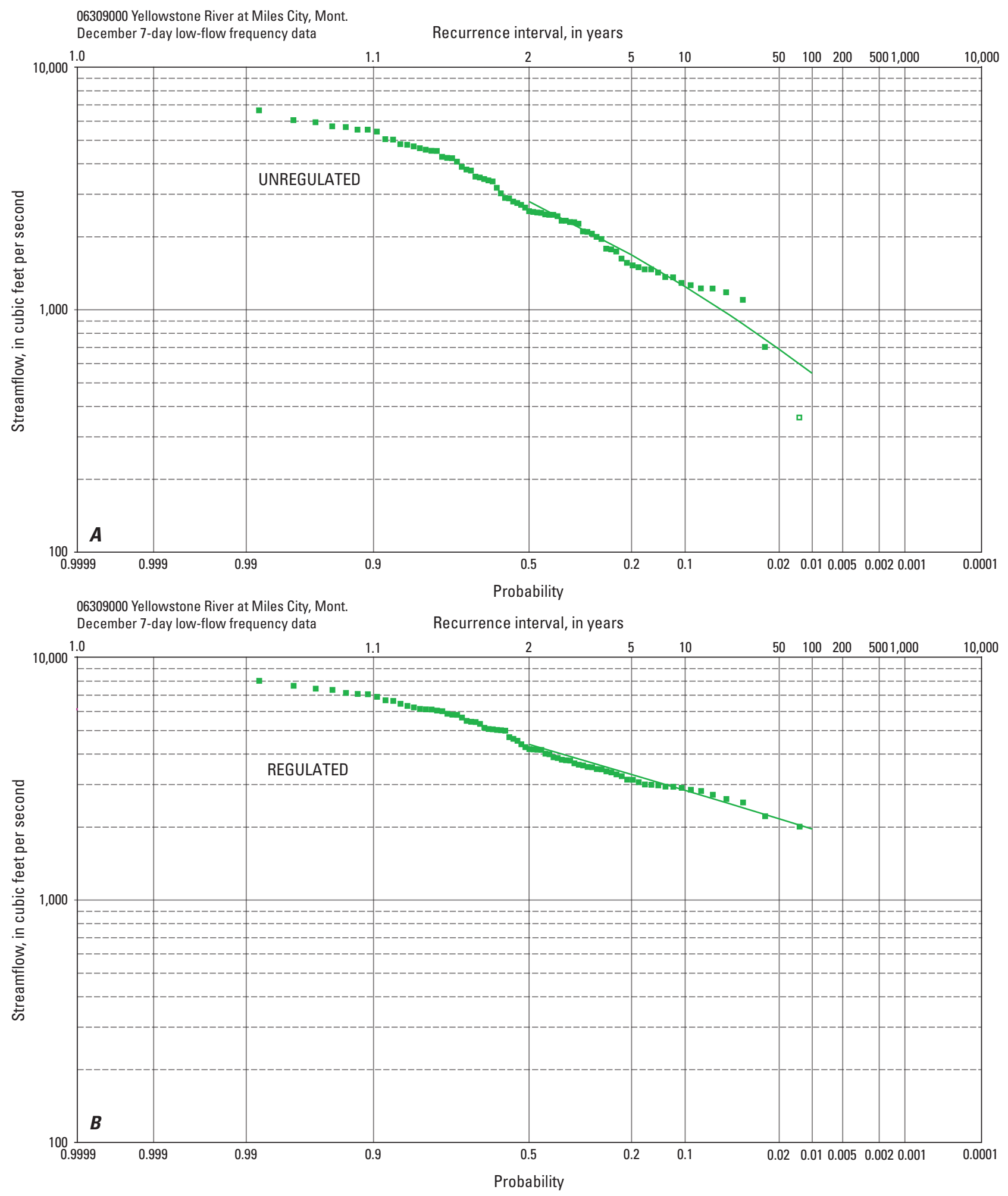

EXPLANATION

7-Day Data

- Estimated $n$-day values

- n-day frequency curve

Figure 2-4-20. December 7-day low-flow frequency data for streamflow-gaging station 06329500 (Yellowstone River at Sidney, Mont.) for $A$, unregulated and $B$, regulated streamflow conditions, 1928-2002. 
06309000 Yellowstone River at Miles City, Mont.

Annual flow-duration data for unregulated and regulated streamflow conditions

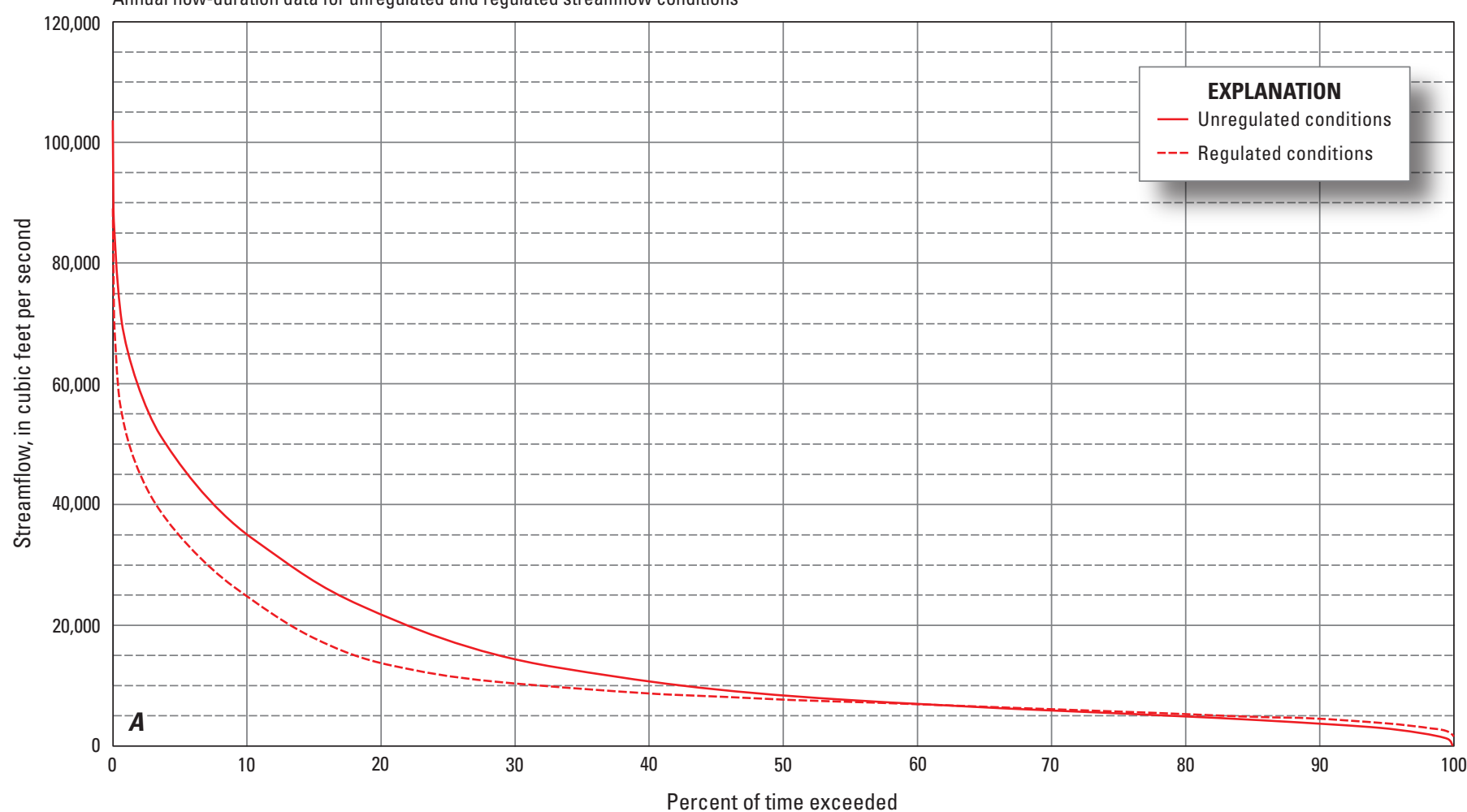

06309000 Yellowstone River at Miles City, Mont.

Seasonal flow-duration data for unregulated and regulated streamflow conditions

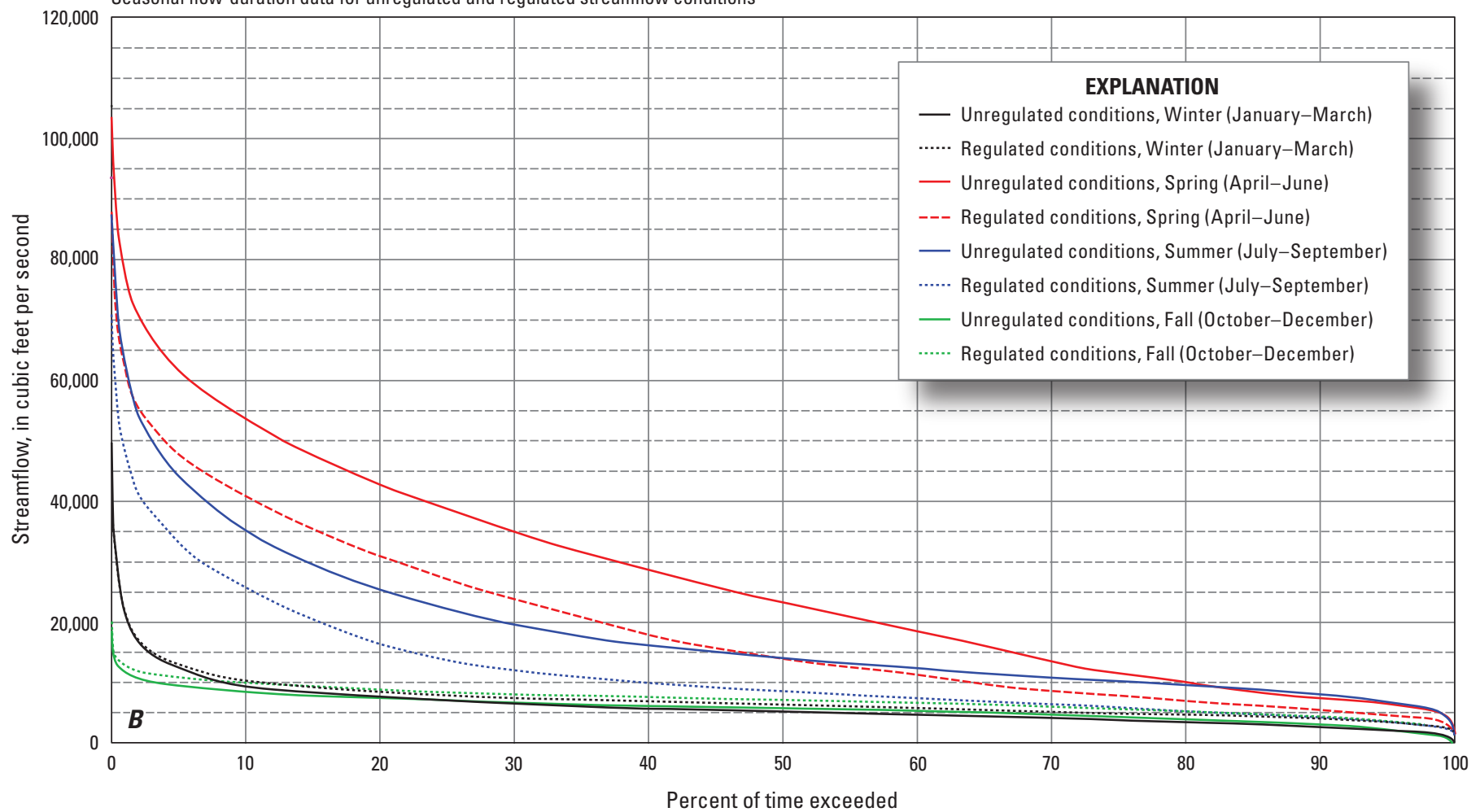

Figure 2-4-21. $A$, Annual and $B$, seasonal flow-duration data for streamflow-gaging station 06329500 (Yellowstone River at Sidney, Mont.) for unregulated and regulated streamflow conditions, 1928-2002. 


\section{Appendix 2-5. Statistics for Streamflow-Gaging Station 06308500 (Tongue River at Miles City, Mont.)}

Table 2-5-1. Annual $n$-day high-flow frequency data for streamflow-gaging station 06308500 (Tongue River at Miles City, Mont.) for unregulated and regulated streamflow conditions, 1928-2002.

[Abbreviations: $\mathrm{ft}^{3} / \mathrm{s}$, cubic feet per second. Symbol: \%, percent]

\begin{tabular}{|c|c|c|c|c|c|c|c|}
\hline \multicolumn{8}{|c|}{ Unregulated } \\
\hline \multirow{3}{*}{$\begin{array}{c}n, \text { period of } \\
\text { consecutive } \\
\text { days }\end{array}$} & \multicolumn{7}{|c|}{ Streamflow, in $\mathrm{ft}^{3} / \mathrm{s}$, for indicated recurrence interval, in years, and exceedance probability, in percent } \\
\hline & 2 & 5 & 10 & 20 & 25 & 50 & 100 \\
\hline & $50 \%$ & $20 \%$ & $10 \%$ & $5 \%$ & $4 \%$ & $2 \%$ & $1 \%$ \\
\hline 1 & 3,480 & 5,520 & 7,030 & 8,580 & 9,090 & 10,700 & 12,500 \\
\hline 3 & 3,150 & 4,870 & 6,080 & 7,270 & 7,660 & 8,880 & 10,100 \\
\hline 7 & 2,750 & 4,120 & 5,060 & 5,990 & 6,280 & 7,210 & 8,150 \\
\hline 15 & 2,370 & 3,440 & 4,170 & 4,870 & 5,100 & 5,800 & 6,510 \\
\hline 30 & 2,020 & 2,910 & 3,530 & 4,150 & 4,360 & 5,000 & 5,660 \\
\hline 60 & 1,640 & 2,300 & 2,750 & 3,210 & 3,360 & 3,830 & 4,310 \\
\hline 90 & 1,410 & 1,910 & 2,250 & 2,590 & 2,700 & 3,050 & 3,410 \\
\hline 120 & 1,250 & 1,660 & 1,930 & 2,190 & 2,280 & 2,550 & 2,820 \\
\hline 183 & 990 & 1,290 & 1,480 & 1,670 & 1,730 & 1,910 & 2,090 \\
\hline \multicolumn{8}{|c|}{ Regulated } \\
\hline \multirow{3}{*}{$\begin{array}{c}n, \text { period of } \\
\text { consecutive } \\
\text { days }\end{array}$} & \multicolumn{7}{|c|}{ Streamflow, in $\mathrm{ft}^{3} / \mathrm{s}$, for indicated recurrence interval, in years, and exceedance probability, in percent } \\
\hline & 2 & 5 & 10 & 20 & 25 & 50 & 100 \\
\hline & $50 \%$ & $20 \%$ & $10 \%$ & $5 \%$ & $4 \%$ & $2 \%$ & $1 \%$ \\
\hline 1 & 3,070 & 5,380 & 6,930 & 8,390 & 8,840 & 10,200 & 11,500 \\
\hline 3 & 2,760 & 4,730 & 5,910 & 6,930 & 7,220 & 8,060 & 8,790 \\
\hline 7 & 2,350 & 3,940 & 4,850 & 5,590 & 5,800 & 6,380 & 6,870 \\
\hline 15 & 1,950 & 3,200 & 3,920 & 4,500 & 4,660 & 5,110 & 5,480 \\
\hline 30 & 1,560 & 2,580 & 3,180 & 3,680 & 3,820 & 4,230 & 4,570 \\
\hline 60 & 1,150 & 1,890 & 2,340 & 2,730 & 2,840 & 3,160 & 3,440 \\
\hline 90 & 940 & 1,510 & 1,850 & 2,130 & 2,210 & 2,440 & 2,640 \\
\hline 120 & 830 & 1,300 & 1,560 & 1,790 & 1,850 & 2,030 & 2,190 \\
\hline 183 & 660 & 990 & 1,180 & 1,330 & 1,380 & 1,500 & 1,600 \\
\hline
\end{tabular}


Table 2-5-2. Annual, seasonal, and monthly $n$-day low-flow frequency data for streamflow-gaging station 06308500 (Tongue River at Miles City, Mont.) for unregulated and regulated steamflow conditions, 1928-2002.

[Abbreviations: $\mathrm{ft}^{3} / \mathrm{s}$, cubic feet per second. Symbol: \%, percent]

\begin{tabular}{|c|c|c|c|c|c|c|c|}
\hline \multicolumn{8}{|c|}{ Unregulated } \\
\hline \multirow{2}{*}{$\begin{array}{l}n \text {, period of consecutive } \\
\text { days (month, for monthly } \\
\text { frequency data) }\end{array}$} & \multicolumn{7}{|c|}{ Streamflow, in $\mathrm{ft}^{3} / \mathrm{s}$, for indicated recurrence interval, in years, and exceedance probability, in percent } \\
\hline & $\begin{array}{c}2 \\
50 \%\end{array}$ & $\begin{array}{c}5 \\
20 \%\end{array}$ & $\begin{array}{c}10 \\
10 \%\end{array}$ & $\begin{array}{l}20 \\
5 \%\end{array}$ & $\begin{array}{l}25 \\
4 \%\end{array}$ & $\begin{array}{l}50 \\
2 \%\end{array}$ & $\begin{array}{l}100 \\
1 \%\end{array}$ \\
\hline \multicolumn{8}{|c|}{ Annual } \\
\hline 7 & 48 & 10 & 2 & 1 & 0 & 0 & 0 \\
\hline \multicolumn{8}{|c|}{ Winter (January-March) } \\
\hline 7 & 87 & 47 & 32 & 23 & 20 & 14 & 10 \\
\hline 30 & 128 & 85 & 68 & 56 & 53 & 44 & 38 \\
\hline \multicolumn{8}{|c|}{ Spring (April-June) } \\
\hline 7 & 279 & 142 & 93 & 63 & 55 & 39 & 27 \\
\hline 7 & 281 & 184 & 136 & 98 & 87 & 56 & 29 \\
\hline 30 & 342 & 232 & 177 & 134 & 121 & 87 & 56 \\
\hline \multicolumn{8}{|c|}{ Fall (October-December) } \\
\hline 7 & 49 & 11 & 3 & 1 & 0 & 0 & 0 \\
\hline 30 & 81 & 22 & 6 & 2 & 1 & 0 & 0 \\
\hline \multicolumn{8}{|c|}{ Monthly } \\
\hline 7 (January) & 96 & 50 & 33 & 22 & 19 & 13 & 9 \\
\hline 7 (February) & 113 & 67 & 48 & 36 & 33 & 25 & 19 \\
\hline 7 (March) & 171 & 98 & 73 & 57 & 53 & 43 & 39 \\
\hline 7 (September) & 276 & 179 & 134 & 99 & 90 & 63 & 41 \\
\hline 7 (October) & 85 & 14 & 3 & 1 & 1 & 1 & 1 \\
\hline 7 (November) & 109 & 25 & 6 & 1 & 1 & 1 & 1 \\
\hline 7 (December) & 79 & 35 & 21 & 13 & 11 & 7 & 4 \\
\hline
\end{tabular}


Table 2-5-2. Annual, seasonal, and monthly $n$-day low-flow frequency data for streamflow-gaging station 06308500 (Tongue River at Miles City, Mont.) for unregulated and regulated steamflow conditions, 1928-2002.-Continued

[Abbreviations: $\mathrm{ft}^{3} / \mathrm{s}$, cubic feet per second. Symbol: \%, percent]

\section{Regulated}

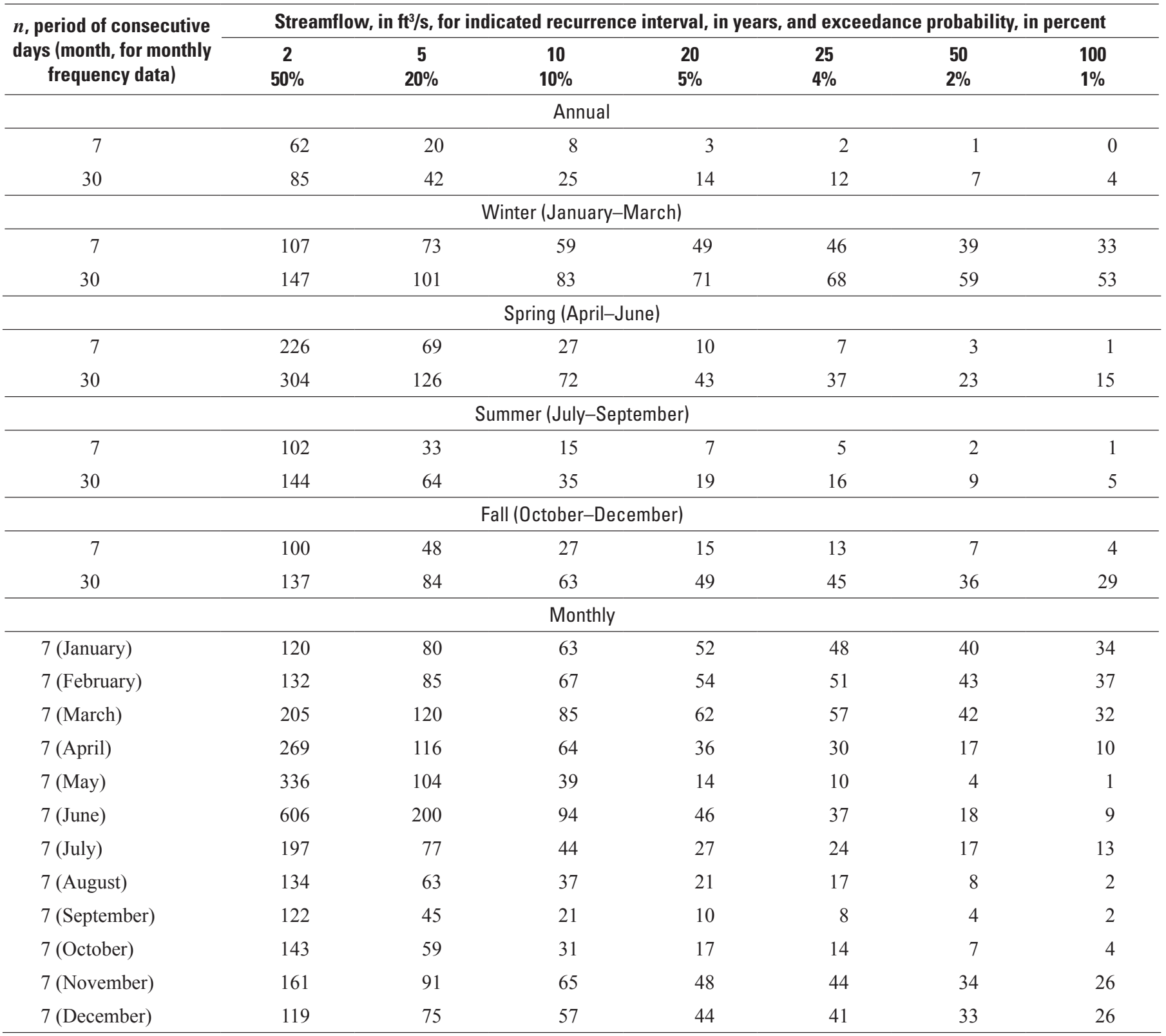


Table 2-5-3. Annual and seasonal flow-duration data for streamflow-gaging station 06308500 (Tongue River at Miles City, Mont.) for unregulated and regulated streamflow conditions, 1928-2002.

[Abbreviations: $\mathrm{ft}^{3} / \mathrm{s}$, cubic feet per second. Symbol: \%, percent]

\begin{tabular}{|c|c|c|c|c|c|c|c|c|c|c|c|c|c|c|c|c|c|}
\hline \multicolumn{18}{|c|}{ Streamflow, in $\mathrm{ft}^{3} / \mathrm{s}$, which was equaled or exceeded for indicated percent of time } \\
\hline $\begin{array}{c}\text { Streamflow } \\
\text { condition }\end{array}$ & $1 \%$ & $2 \%$ & $5 \%$ & $10 \%$ & $15 \%$ & $20 \%$ & $30 \%$ & $40 \%$ & $50 \%$ & $60 \%$ & $70 \%$ & $80 \%$ & $85 \%$ & $90 \%$ & $95 \%$ & $98 \%$ & $99 \%$ \\
\hline \multicolumn{18}{|c|}{ Annual } \\
\hline Unregulated & 3,880 & 3,040 & 2,100 & 1,450 & 1,120 & 922 & 667 & 487 & 339 & 241 & 181 & 135 & 110 & 80 & 41 & 13 & 0 \\
\hline Regulated & 3,480 & 2,580 & 1,620 & 1,010 & 699 & 549 & 379 & 288 & 233 & 198 & 161 & 124 & 103 & 78 & 52 & 27 & 16 \\
\hline \multicolumn{18}{|c|}{ Winter (January-March) } \\
\hline Unregulated & 2,790 & 1,720 & 930 & 546 & 428 & 342 & 255 & 208 & 180 & 155 & 133 & 111 & 95 & 80 & 61 & 42 & 33 \\
\hline Regulated & 2,800 & 1,740 & 944 & 559 & 440 & 360 & 270 & 226 & 199 & 173 & 151 & 129 & 114 & 99 & 80 & 61 & 52 \\
\hline \multicolumn{18}{|c|}{ Spring (April-June) } \\
\hline Unregulated & 4,730 & 4,250 & 3,230 & 2,590 & 2,140 & 1,900 & 1,470 & 1190 & 980 & 817 & 647 & 452 & 352 & 266 & 195 & 107 & 65 \\
\hline Regulated & 4,280 & 3,840 & 2,770 & 2,050 & 1,650 & 1,370 & 978 & 714 & 552 & 425 & 327 & 218 & 183 & 128 & 63 & 30 & 19 \\
\hline \multicolumn{18}{|c|}{ Summer (July-September) } \\
\hline Unregulated & 2,990 & 2,380 & 1,700 & 1,250 & 1,050 & 940 & 807 & 685 & 606 & 521 & 441 & 358 & 305 & 258 & 193 & 130 & 109 \\
\hline Regulated & 2,430 & 1,790 & 1,110 & 719 & 538 & 426 & 317 & 254 & 217 & 180 & 146 & 96 & 72 & 50 & 25 & 13 & 6 \\
\hline \multicolumn{18}{|c|}{ Fall (October-December) } \\
\hline Unregulated & 763 & 642 & 493 & 368 & 309 & 268 & 212 & 178 & 150 & 120 & 88 & 51 & 34 & 18 & 4 & 0 & 0 \\
\hline Regulated & 828 & 681 & 540 & 415 & 360 & 320 & 264 & 225 & 198 & 167 & 135 & 106 & 90 & 70 & 54 & 38 & 29 \\
\hline
\end{tabular}


Table 2-5-4. Monthly and annual streamflow characteristics for streamflow-gaging station 06308500 (Tongue River at Miles City, Mont.) for unregulated and regulated streamflow conditions, 1928-2002.

[Abbreviations: $\mathrm{ft}^{3} / \mathrm{s}$, cubic feet per second]

\section{Unregulated}

\begin{tabular}{|c|c|c|c|c|c|c|}
\hline \multirow[b]{2}{*}{ Period } & \multicolumn{6}{|c|}{ Streamflow, in $\mathrm{ft}^{3} / \mathrm{s}$, or year, for indicated streamflow characteristic } \\
\hline & $\begin{array}{l}\text { Maximum } \\
\text { monthly mean and } \\
\text { maximum annual } \\
\text { mean streamflow }\end{array}$ & $\begin{array}{l}\text { Year of maximum } \\
\text { monthly mean and } \\
\text { maximum annual } \\
\text { mean streamflow }\end{array}$ & $\begin{array}{l}\text { Minimum monthly } \\
\text { mean and } \\
\text { minimum annual } \\
\text { mean streamflow }\end{array}$ & $\begin{array}{l}\text { Year of minimum } \\
\text { monthly mean and } \\
\text { minimum annual } \\
\text { mean streamflow }\end{array}$ & $\begin{array}{l}\text { Mean monthly } \\
\text { and mean annual } \\
\text { streamflow }\end{array}$ & $\begin{array}{c}\text { Standard } \\
\text { deviation of mean } \\
\text { monthly and mean } \\
\text { annual streamflow }\end{array}$ \\
\hline January & 505 & 1999 & 27 & 1937 & 161 & 89 \\
\hline April & 1,760 & 1965 & 32 & 1961 & 489 & 317 \\
\hline May & 3,010 & 1928 & 435 & 1981 & 1,300 & 561 \\
\hline June & 5,390 & 1944 & 558 & 1998 & 1,970 & 954 \\
\hline July & 4,080 & 1937 & 494 & 1994 & 1,190 & 559 \\
\hline October & 1,000 & 1945 & 0 & 1935 & 194 & 177 \\
\hline November & 612 & 1929 & 1 & 1963 & 204 & 147 \\
\hline December & 387 & 1949 & 13 & 1937 & 146 & 79 \\
\hline Annual & 1,140 & 1978 & 255 & 2,002 & 612 & 184 \\
\hline \multicolumn{7}{|c|}{ Regulated } \\
\hline & \multicolumn{6}{|c|}{ Streamflow, in $\mathrm{ft}^{3} / \mathrm{s}$, or year, for indicated streamflow characteristic } \\
\hline Period & $\begin{array}{c}\text { Maximum } \\
\text { monthly mean and } \\
\text { maximum annual } \\
\text { mean streamflow }\end{array}$ & $\begin{array}{l}\text { Year of maximum } \\
\text { monthly mean and } \\
\text { maximum annual } \\
\text { mean streamflow }\end{array}$ & $\begin{array}{l}\text { Minimum monthly } \\
\text { mean and mini- } \\
\text { mum annual mean } \\
\text { streamflow }\end{array}$ & $\begin{array}{l}\text { Year of minimum } \\
\text { monthly mean and } \\
\text { minimum annual } \\
\text { mean streamflow }\end{array}$ & $\begin{array}{l}\text { Mean monthly } \\
\text { and mean annual } \\
\text { streamflow }\end{array}$ & $\begin{array}{c}\text { Standard } \\
\text { deviation of mean } \\
\text { monthly and mean } \\
\text { annual streamflow }\end{array}$ \\
\hline May & 2,980 & 1978 & 53 & 1961 & 771 & 596 \\
\hline June & 5,330 & 1944 & 42 & 2002 & 1,430 & 1,010 \\
\hline July & 3,590 & 1937 & 19 & 2002 & 593 & 564 \\
\hline August & 714 & 1975 & 0 & 1949 & 230 & 150 \\
\hline September & 610 & 1968 & 19 & 1960 & 205 & 133 \\
\hline October & 1,040 & 1945 & 44 & 1963 & 253 & 173 \\
\hline November & 662 & 1929 & 62 & 1988 & 259 & 146 \\
\hline December & 424 & 1949 & 46 & 1934 & 179 & 78 \\
\hline Annual & 1,010 & 1978 & 70 & 2002 & 441 & 197 \\
\hline
\end{tabular}



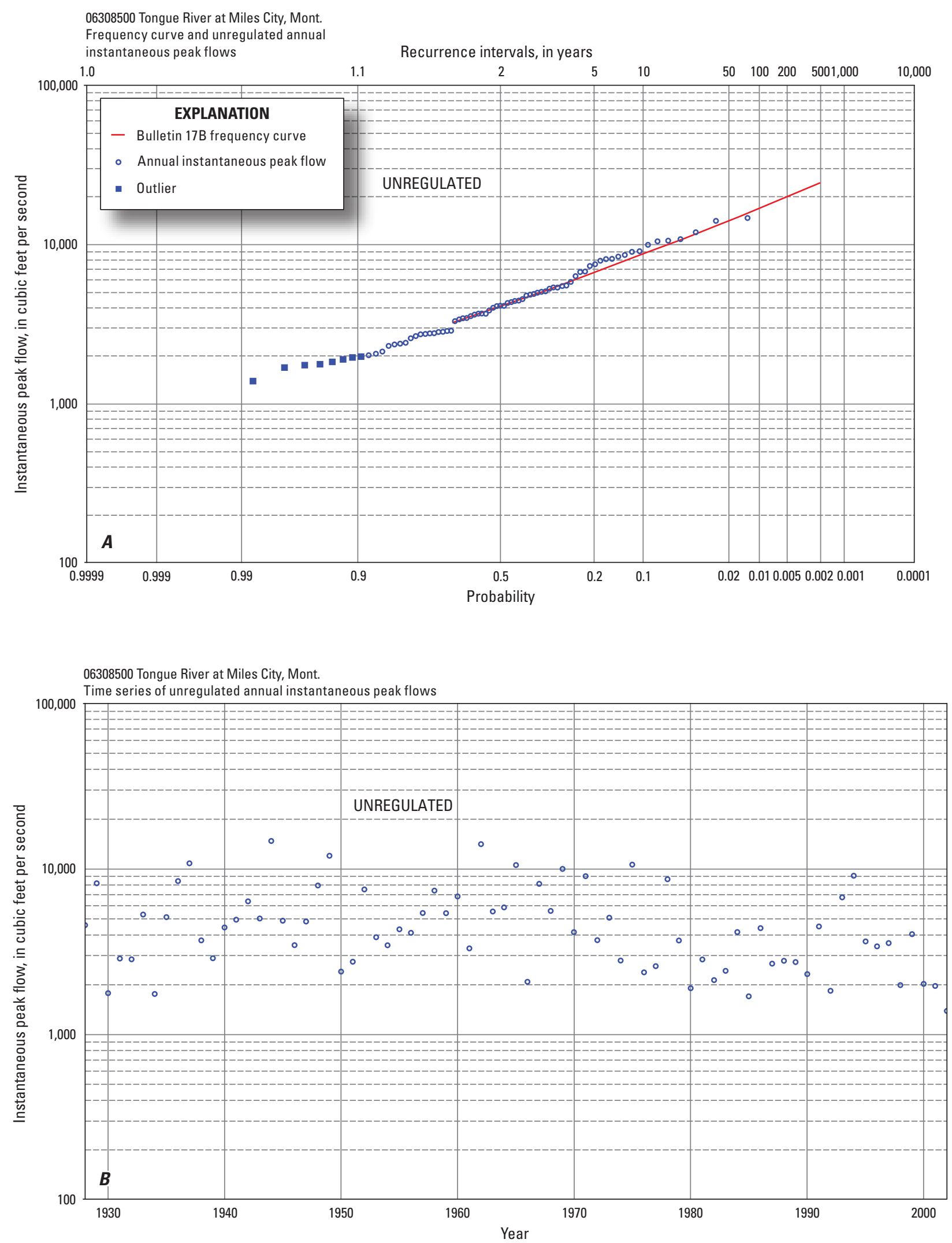

Figure 2-5-1. Annual instantaneous peak-flow data for streamflow-gaging station 06308500 (Tongue River at Miles City, Mont.) for unregulated streamflow conditions, 1928-2002. A, Frequency curve and unregulated annual instantaneous peak flows. $B$, Time series of unregulated annual instantaneous peak flows. [Bulletin 17B: U.S. Interagency Advisory Council on Water Data, 1982] 

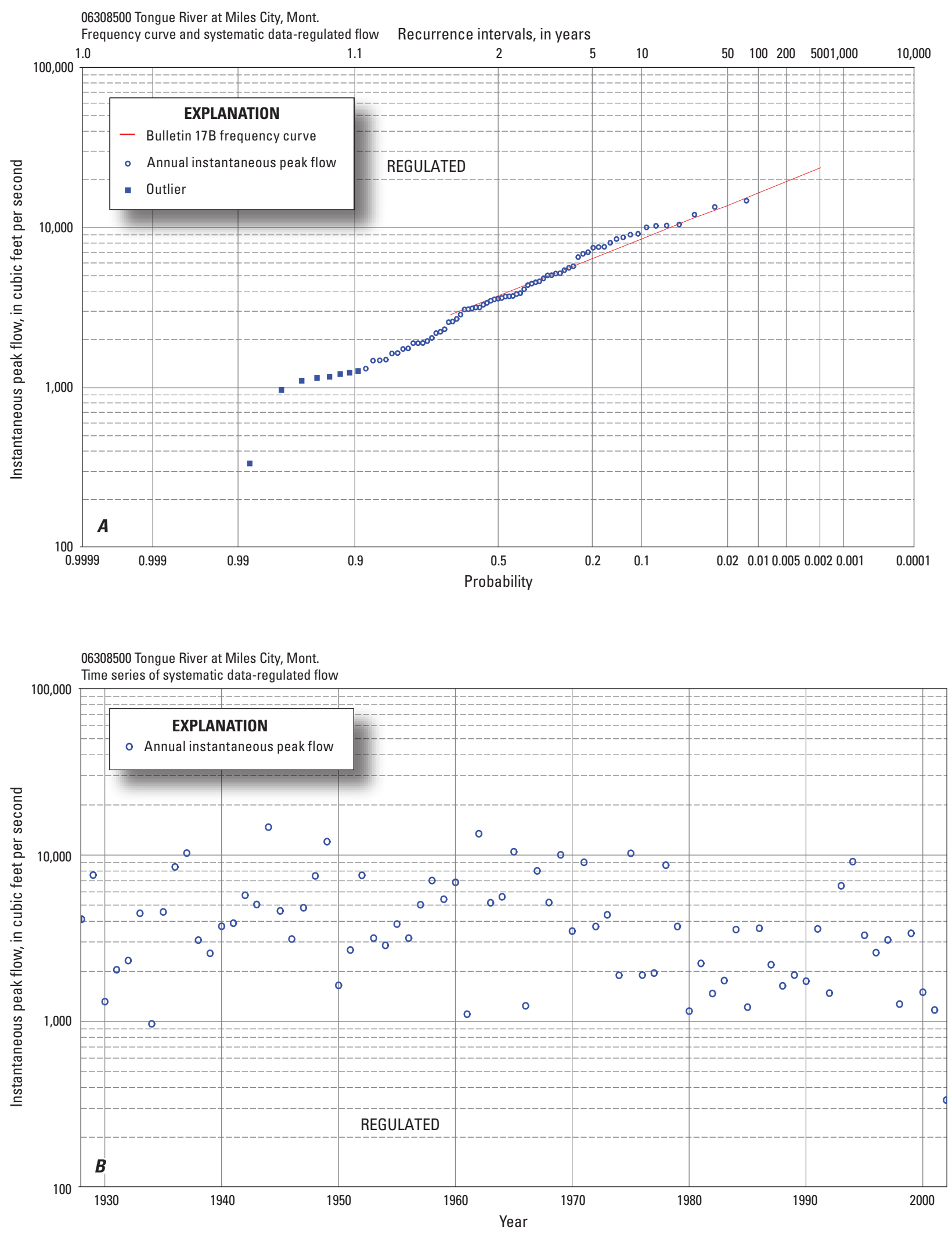

Figure 2-5-2. Annual instantaneous peak-flow data for streamflow-gaging station 06308500 (Tongue River at Miles City, Mont.) for unregulated streamflow conditions, 1928-2002. A, Frequency curve and regulated annual instantaneous peak flows. $B$, Time series of regulated annual instantaneous peak flows. [Bulletin 17B: U.S. Interagency Advisory Council on Water Data, 1982] 


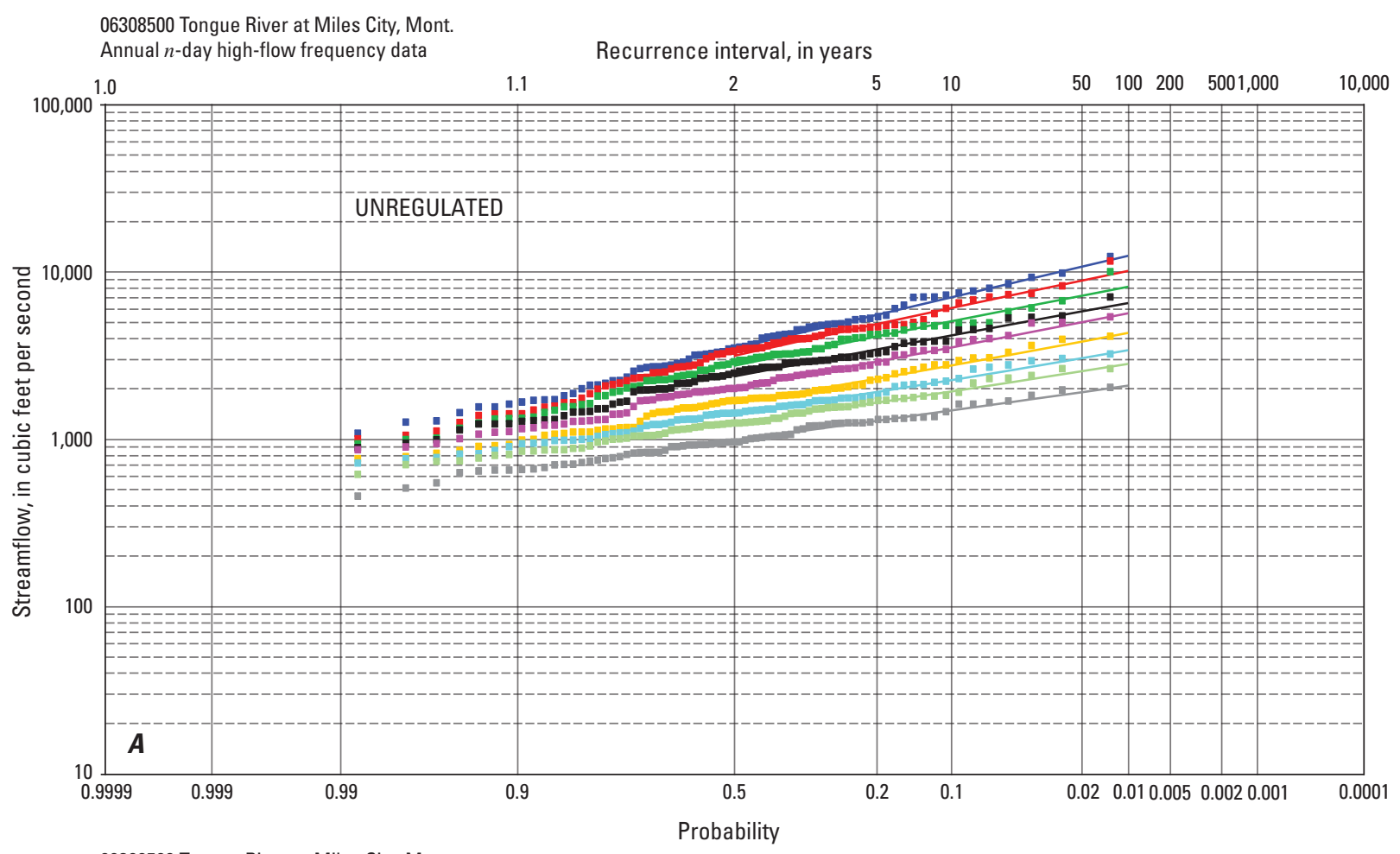

06308500 Tongue River at Miles City, Mont. Annual $n$-day high-flow frequency data

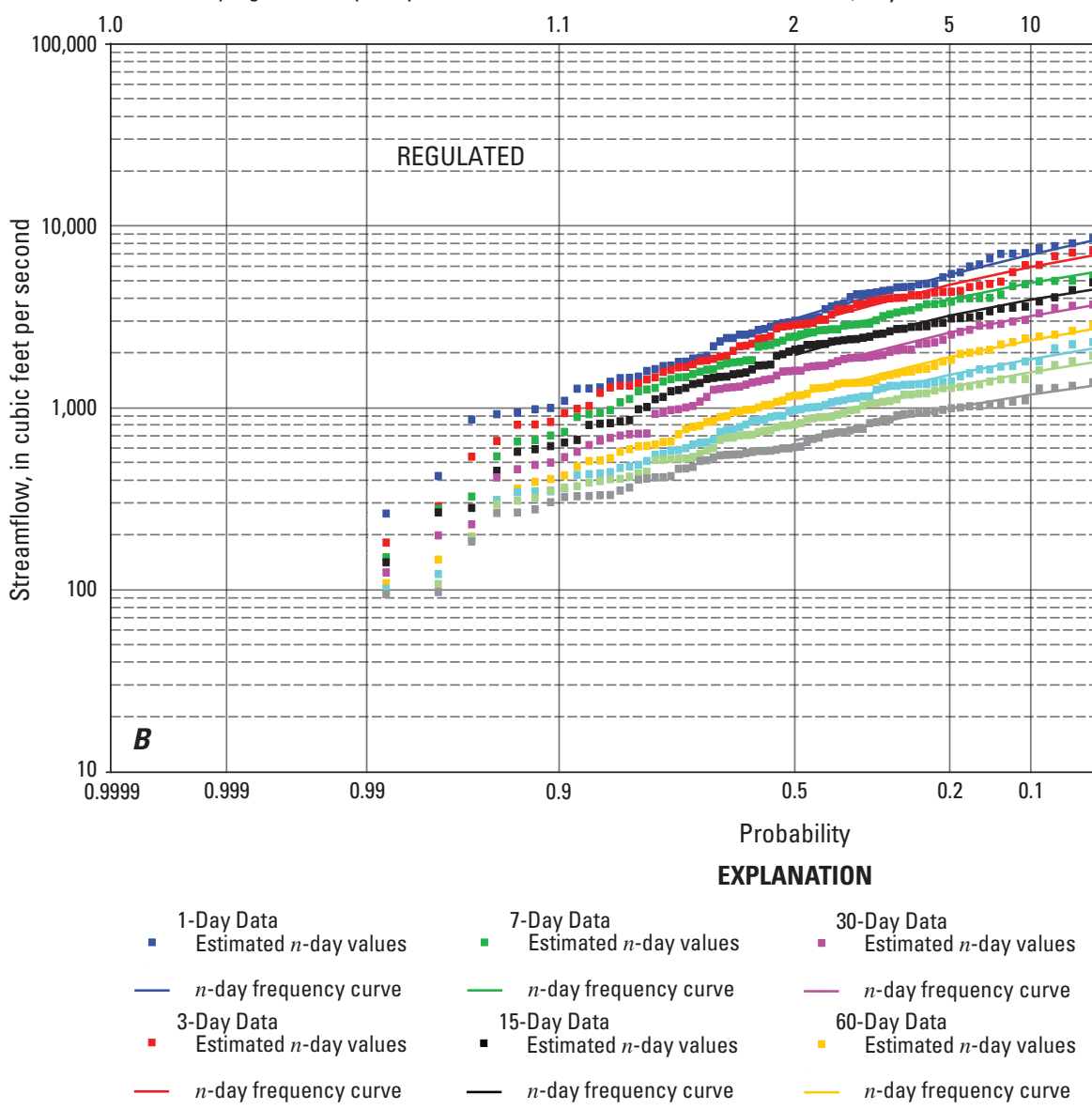

Figure 2-5-3. Annual $n$-day high-flow frequency data for streamflow-gaging station 06308500 (Tongue River at Miles City, Mont.) for $A$, unregulated and $B$, regulated streamflow conditions, 1928-2002. 


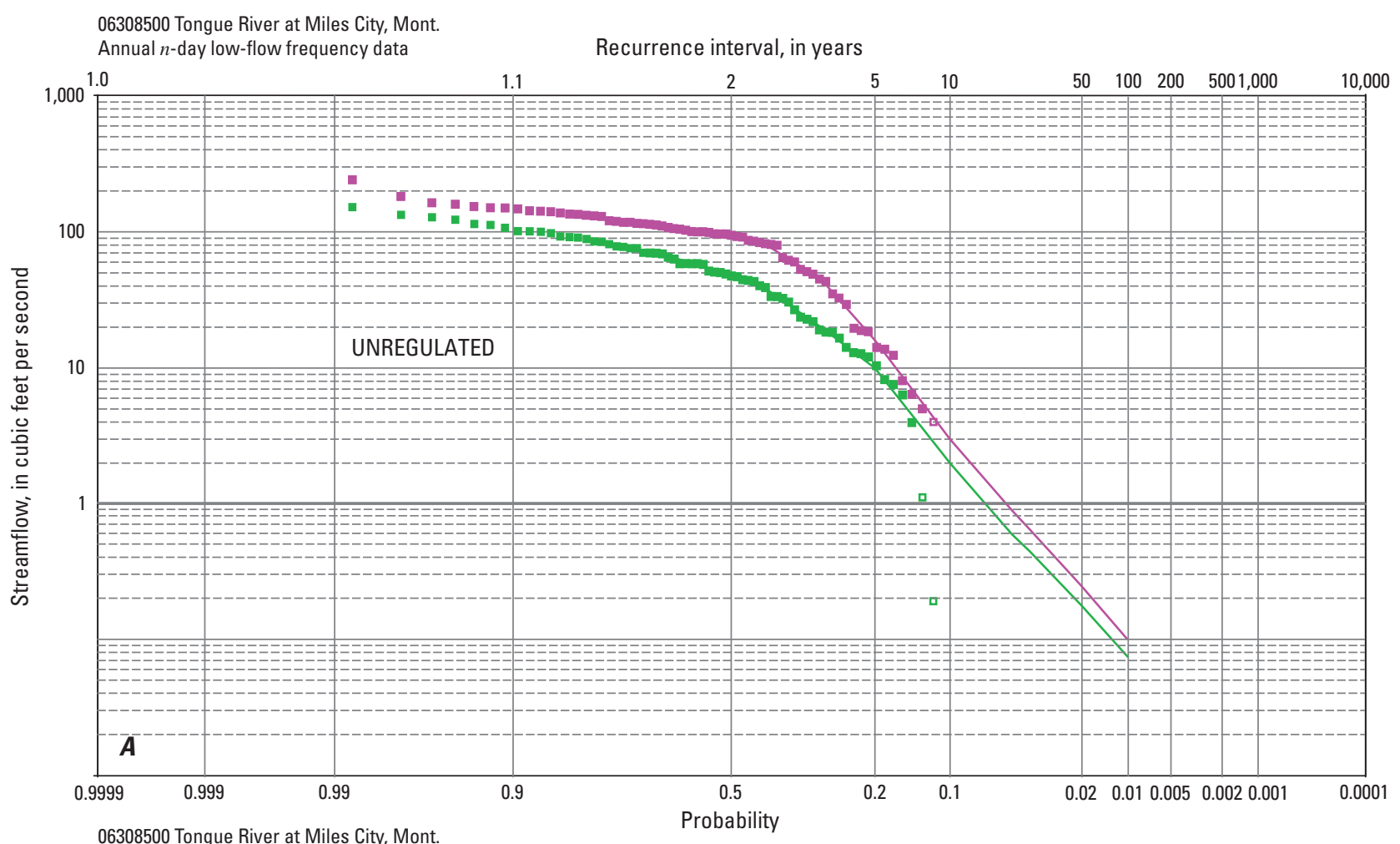

06308500 Tongue River at Miles City, Mont. Recurrence interval, in years

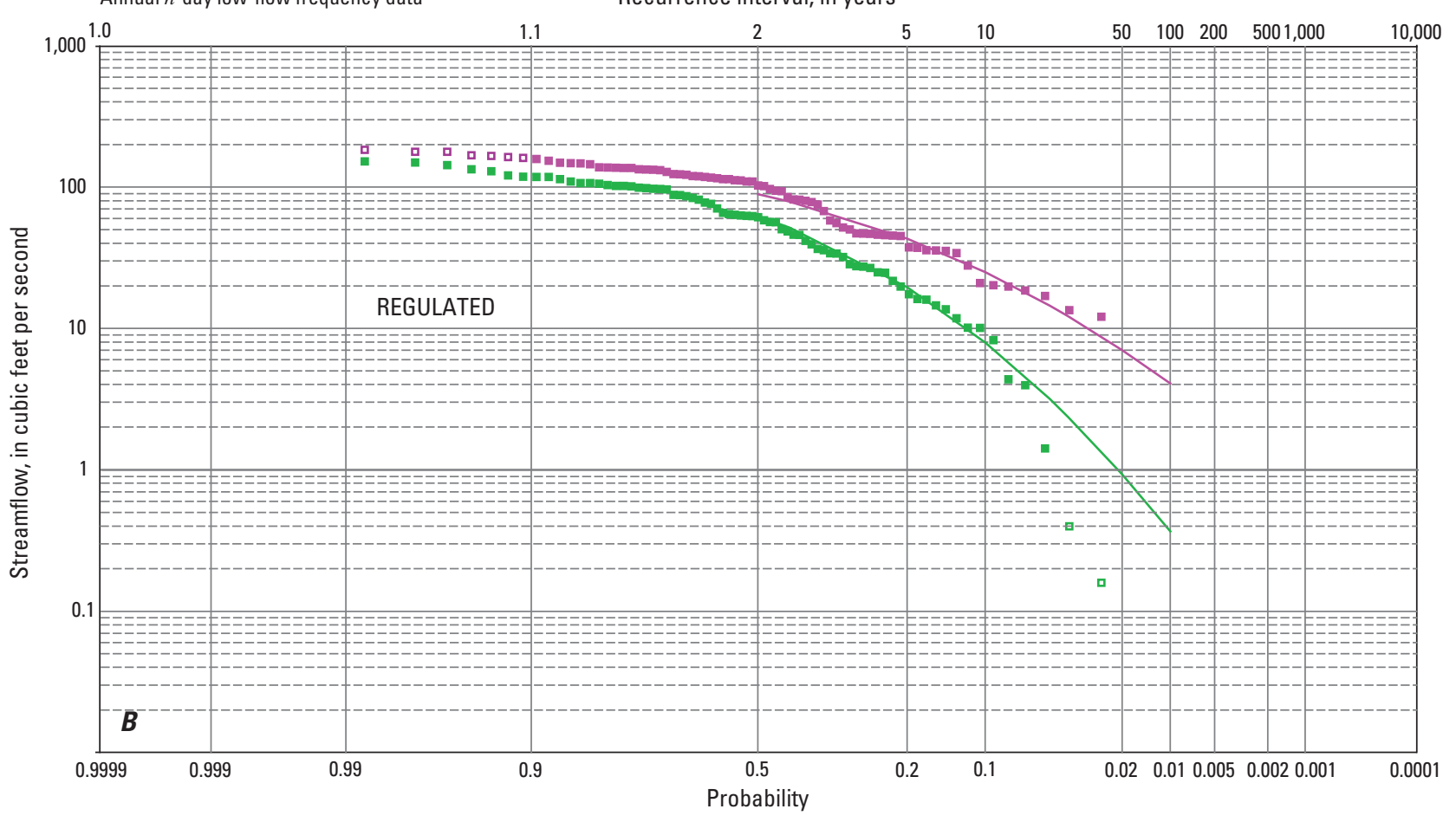

EXPLANATION

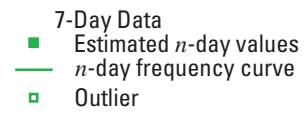

30-Day Data
$\quad$ Estimated $n$-day values
$-\quad n$-day frequency curve
$\quad$ Outlier

Figure 2-5-4. Annual $n$-day low-flow frequency data for streamflow-gaging station 06308500 (Tongue River at Miles City, Mont.) for $A$, unregulated and $B$, regulated streamflow conditions, 1928-2002. 


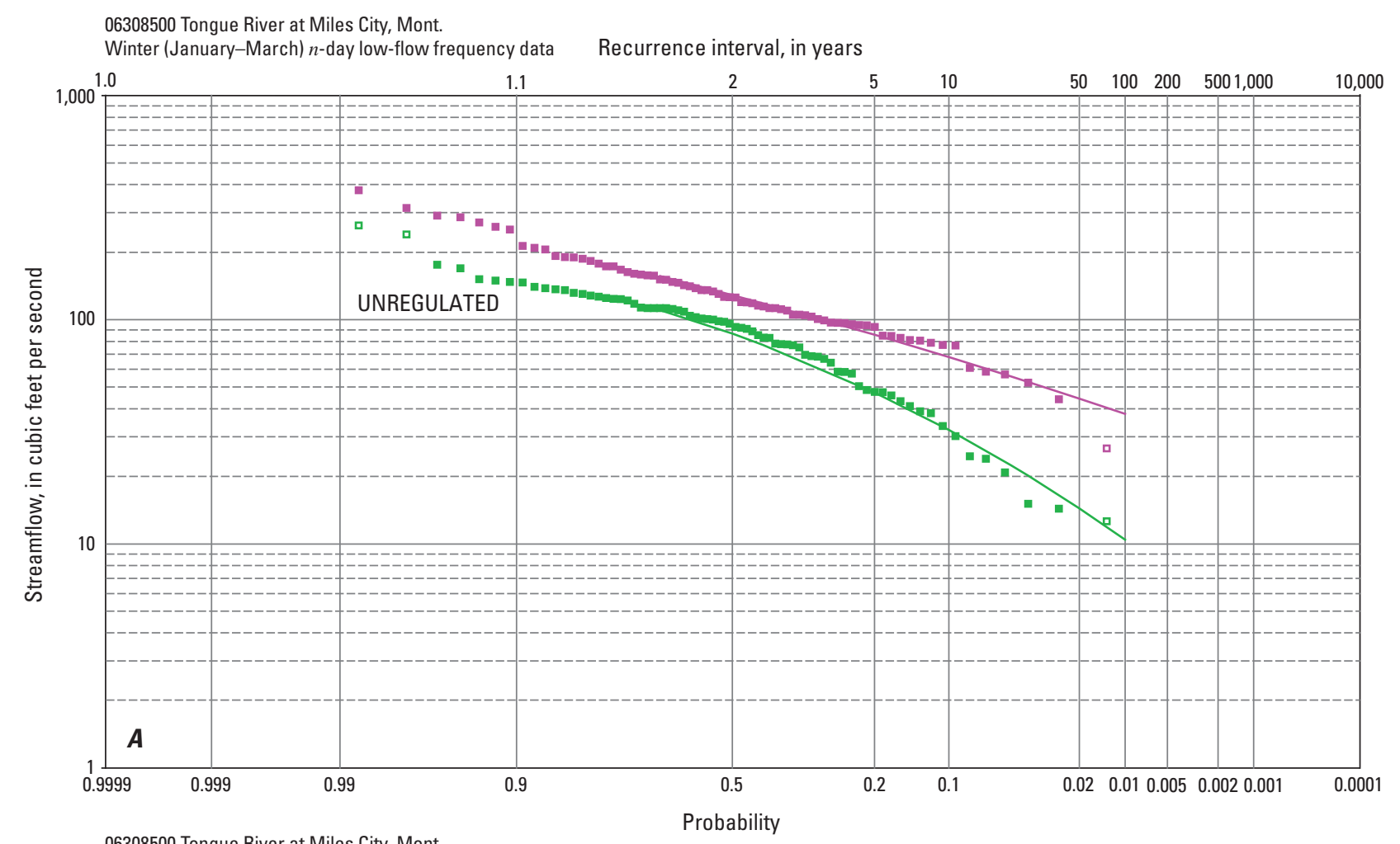

06308500 Tongue River at Miles City, Mont.

Recurrence interval, in years

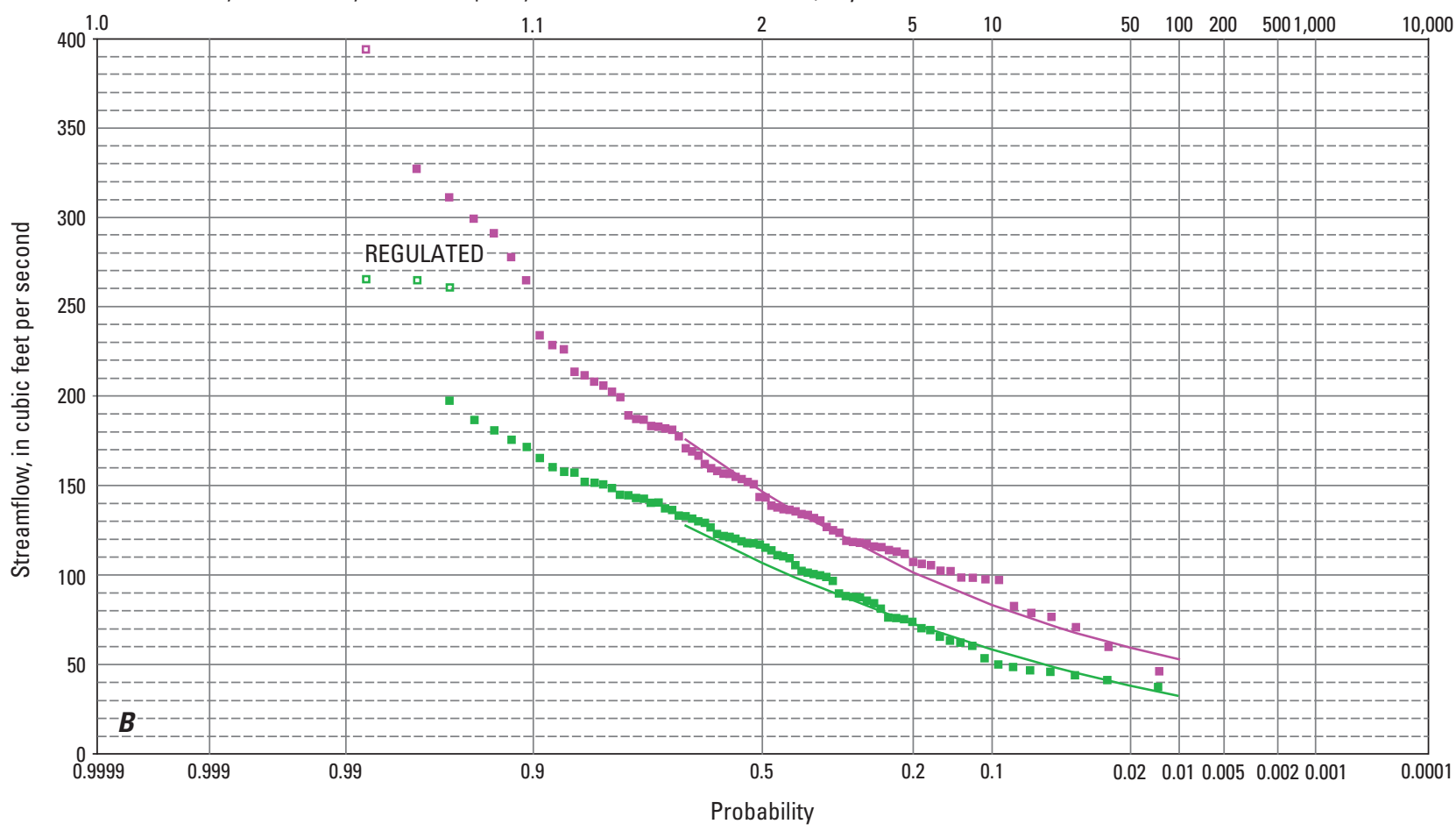

EXPLANATION

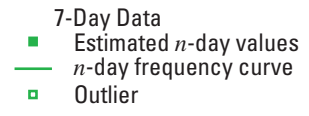

30-Day Data
Estimated $n$-day values
$n$-day frequency curve
$\quad$ Outlier

Figure 2-5-5. Winter (January-March) $n$-day low-flow frequency data for streamflow-gaging station 06308500 (Tongue River at Miles City, Mont.) for $A$, unregulated and $B$, regulated streamflow conditions, 1928-2002. 

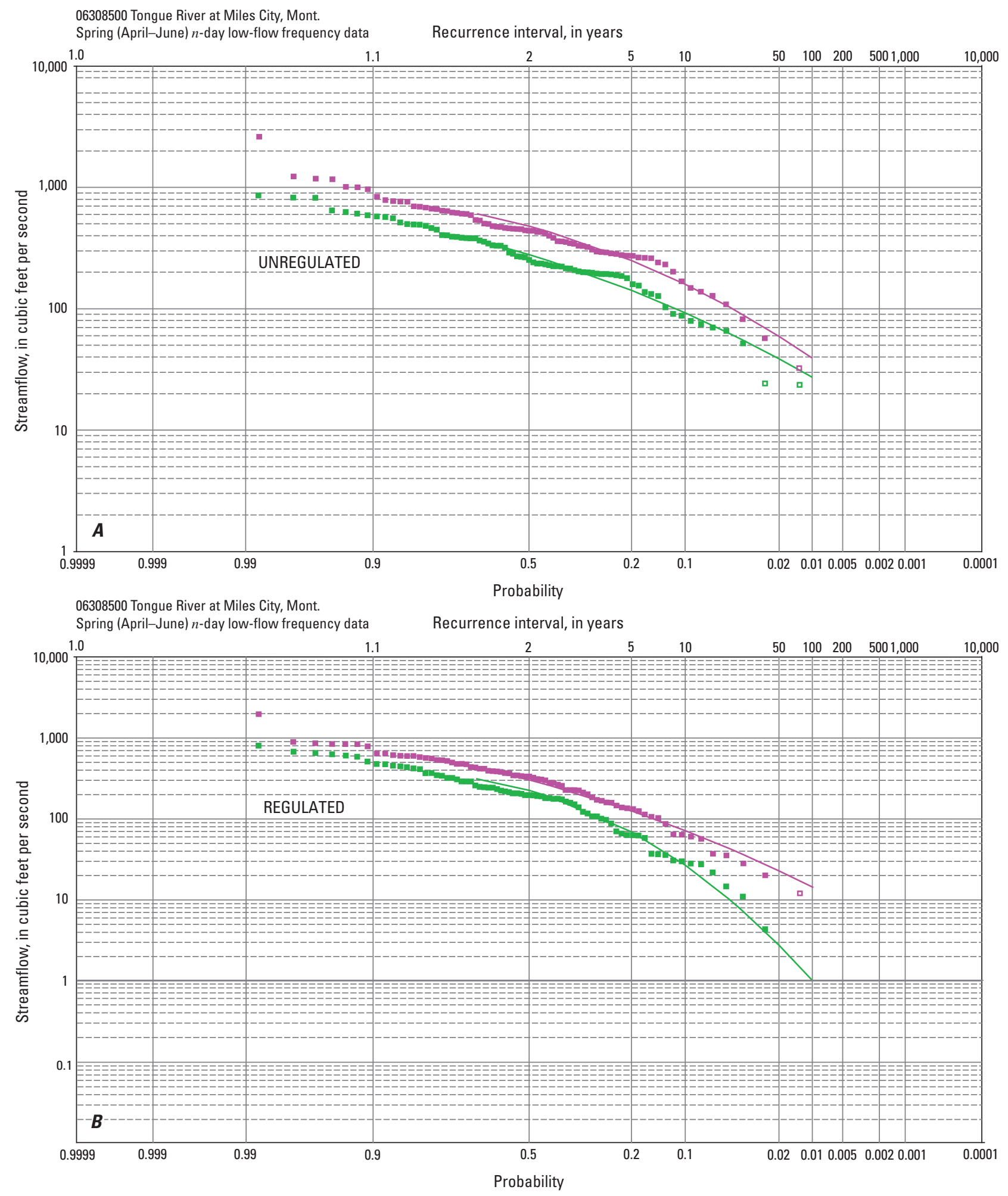

EXPLANATION

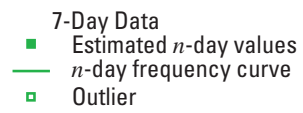

30-Day Data
Estimated $n$-day values
$n$-day frequency curve
Outlier

Figure 2-5-6. Spring (April-June) $n$-day low-flow frequency data for streamflow-gaging station 06308500 (Tongue River at Miles City, Mont.) for $A$, unregulated and $B$, regulated streamflow conditions, 1928-2002. 
O630850 Tongue River at Miles City, Mont.

Summer (July-September) n-day low-flow frequency data Recurrence interval, in years

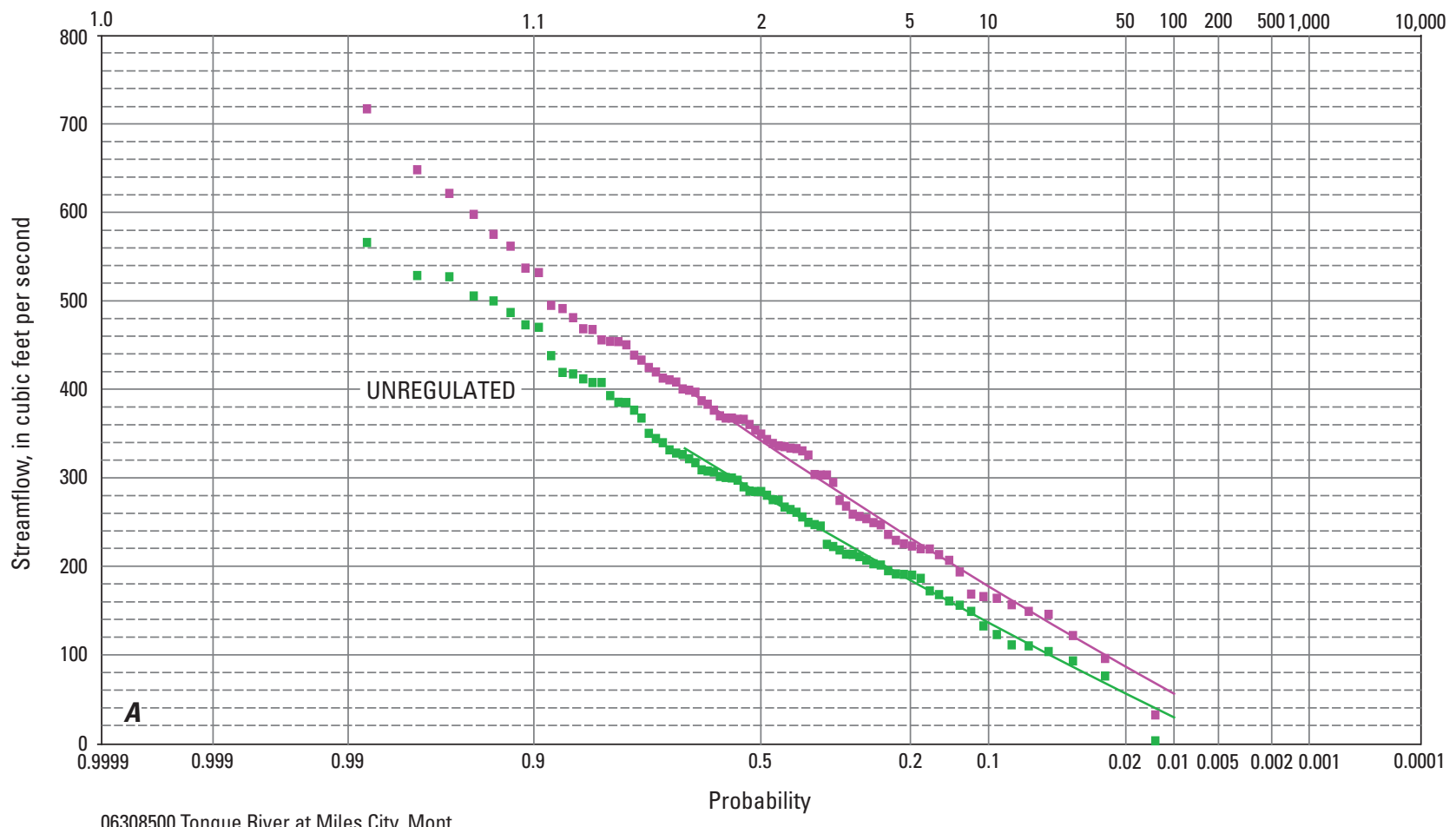

06308500 Tongue River at Miles City, Mont.

ce interval, in years

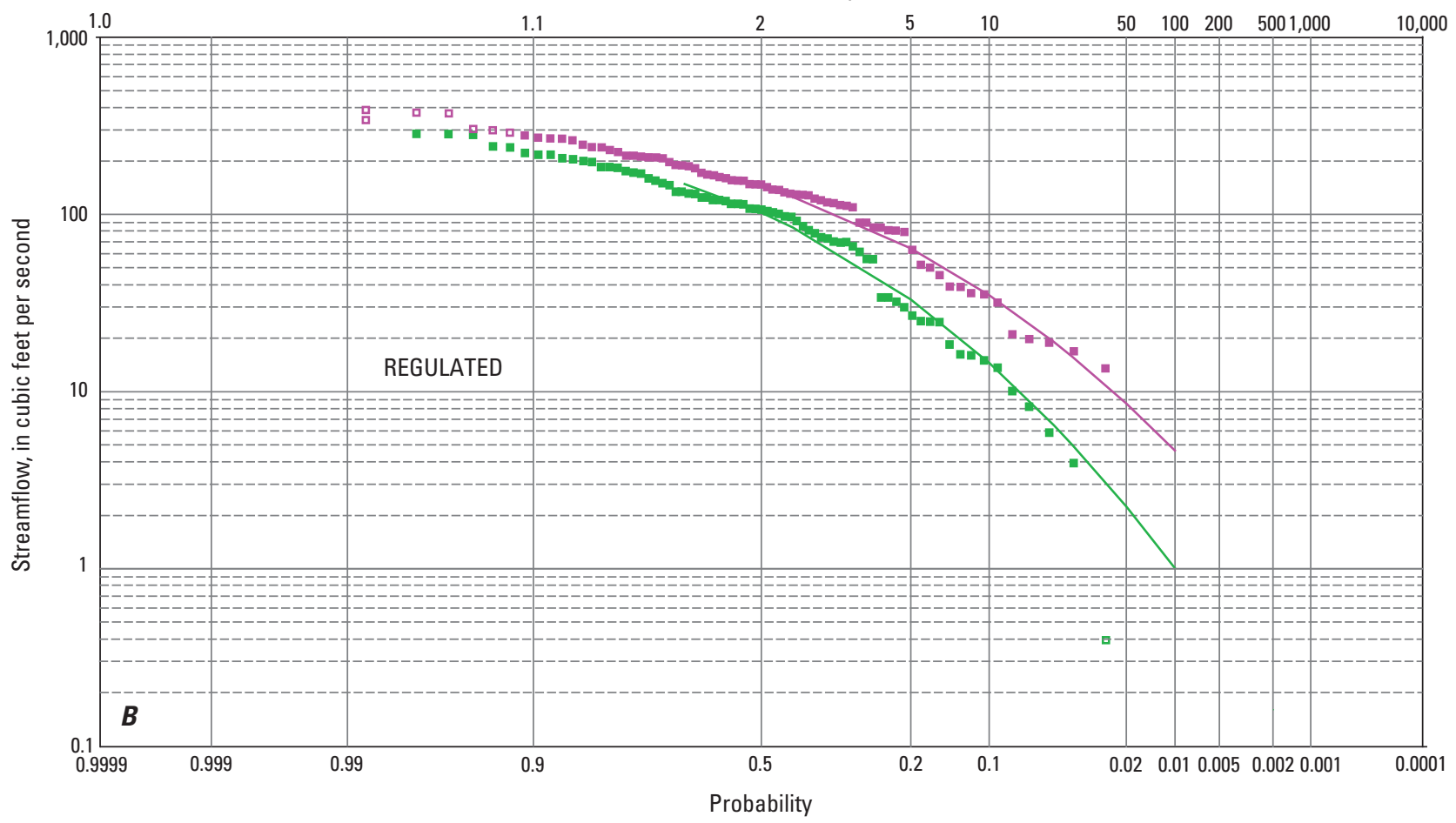

EXPLANATION

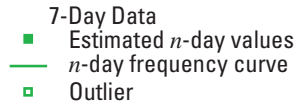

30-Day Data

- Estimated $n$-day values

$n$-day frequency curve

- Outlier

Figure 2-5-7. Summer (July-September) $n$-day low-flow frequency data for streamflow-gaging station 06308500 (Tongue River at Miles City, Mont.) for $A$, unregulated and $B$, regulated streamflow conditions, 1928-2002. 


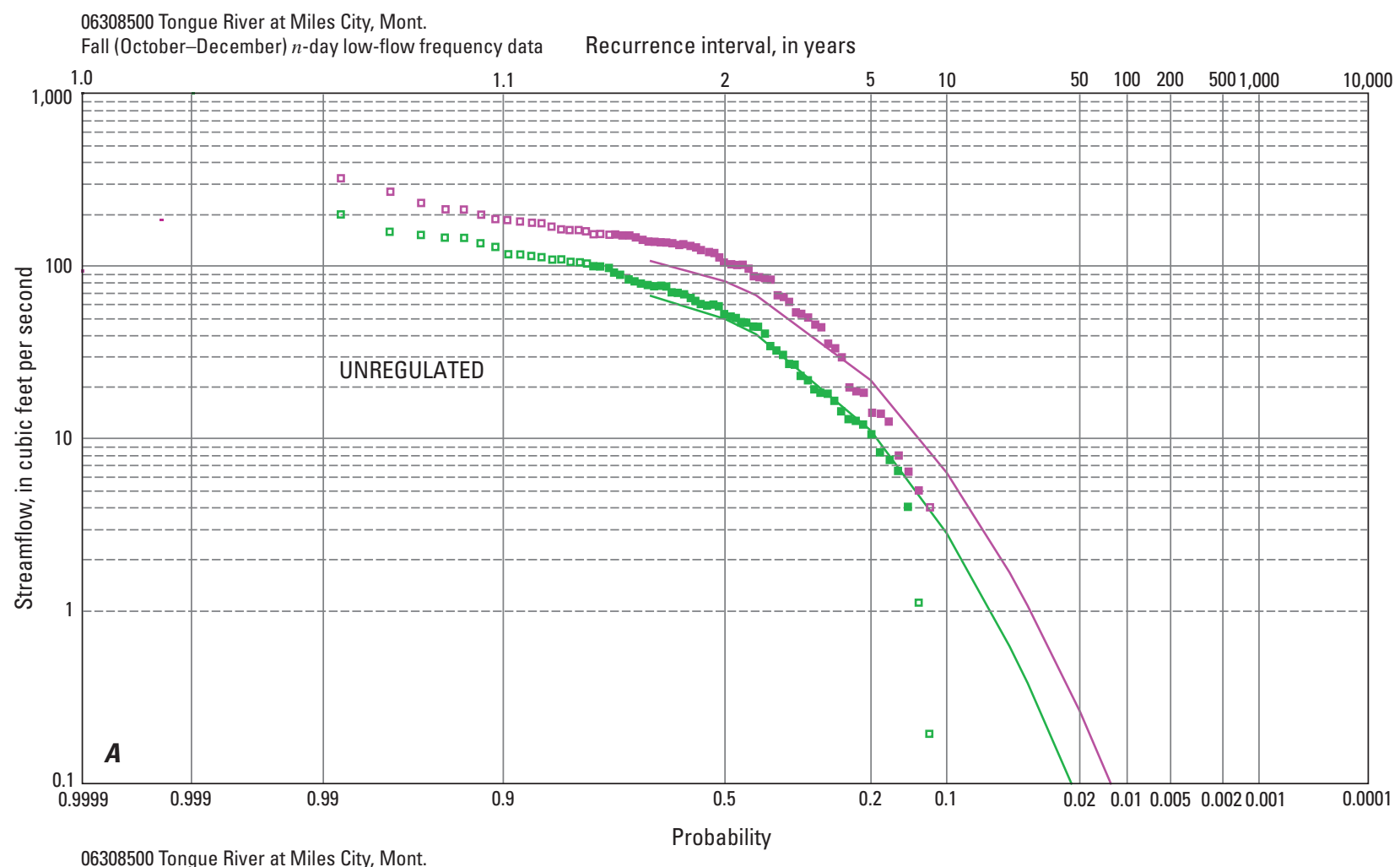

06308500 Tongue River at Miles City, Mont.

Fall (October-December) $n$-day low-flow frequency data Recurrence interval, in years

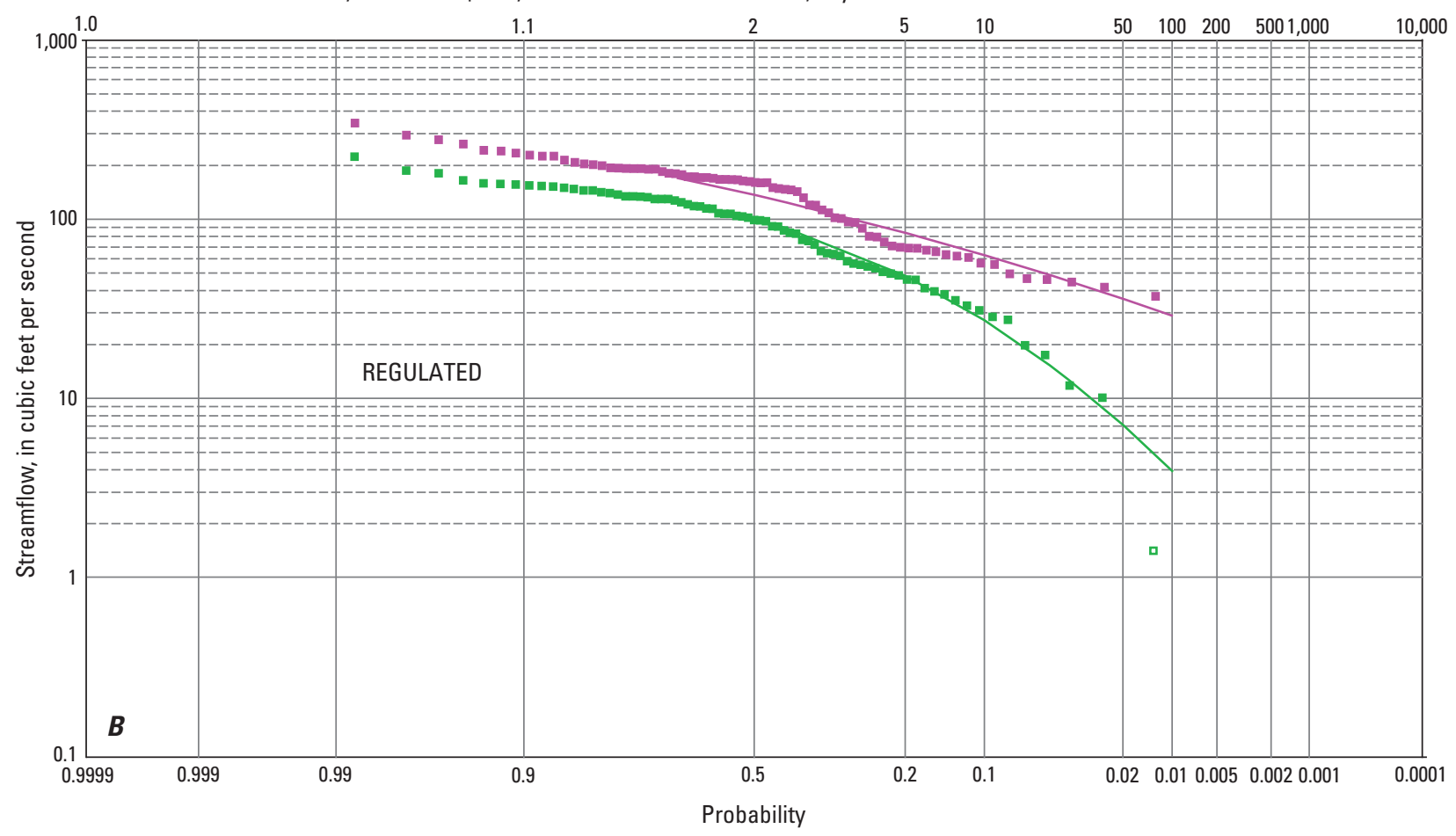

EXPLANATION

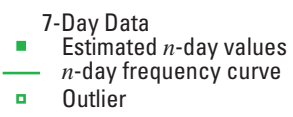

30-Day Data
Estimated $n$-day values
$n$-day frequency curve
$\quad$ Outlier

Figure 2-5-8. Fall (October-December) $n$-day low-flow frequency data for streamflow-gaging station 06308500 (Tongue River at Miles City, Mont.) for $A$, unregulated and $B$, regulated streamflow conditions, 1928-2002. 


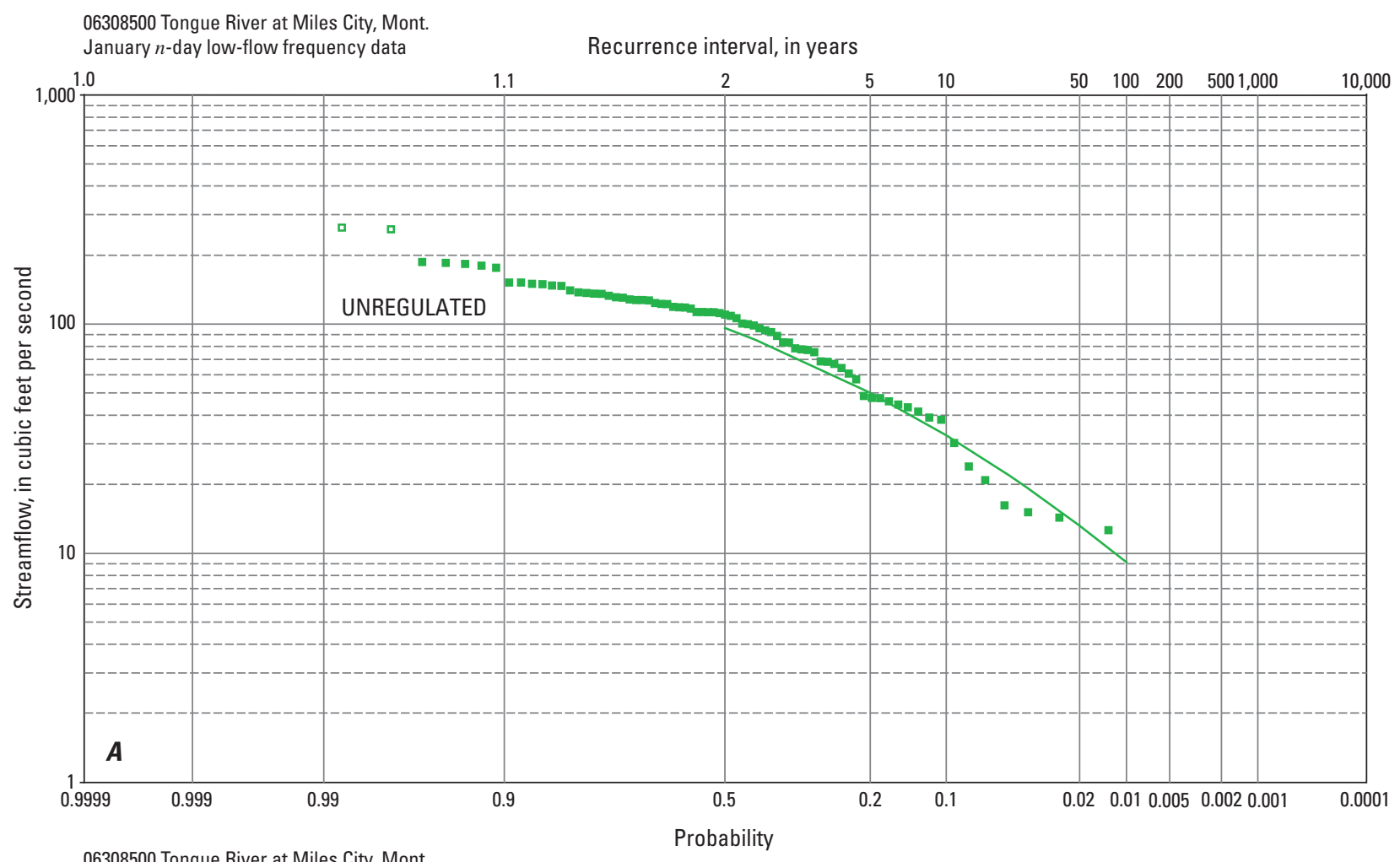

06308500 Tongue River at Miles City, Mont.

Recurrence interval, in years

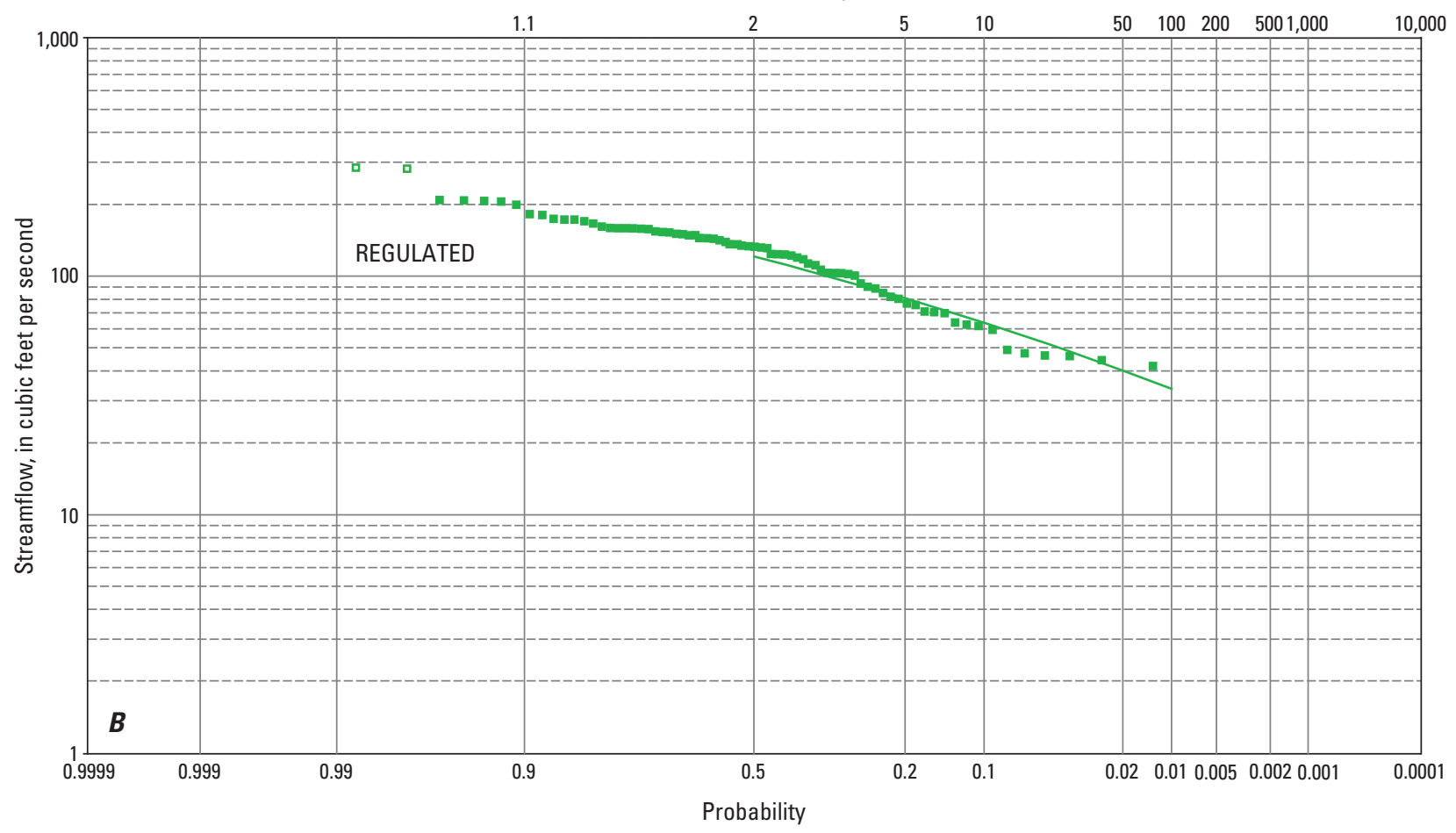

EXPLANATION

7-Day Data

- Estimated $n$-day values

$n$-day frequency curve

Outlier

Figure 2-5-9. January $n$-day low-flow frequency data for streamflow-gaging station 06308500 (Tongue River at Miles City, Mont.) for $A$, unregulated and $B$, regulated streamflow conditions, 1928-2002. 


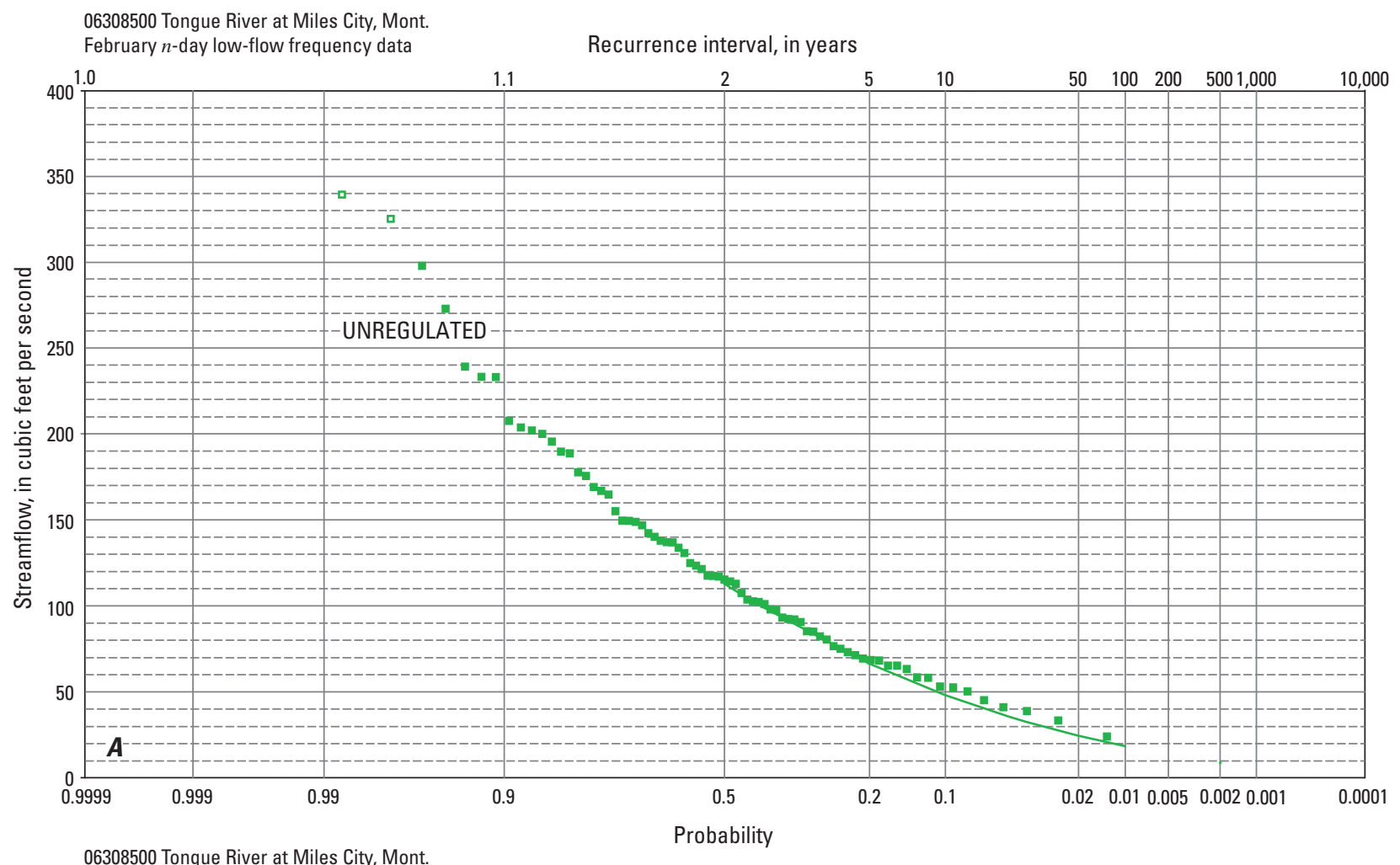

06308500 Tongue River at Miles City, Mont. February $n$-day low-flow frequency data

Recurrence interval, in years

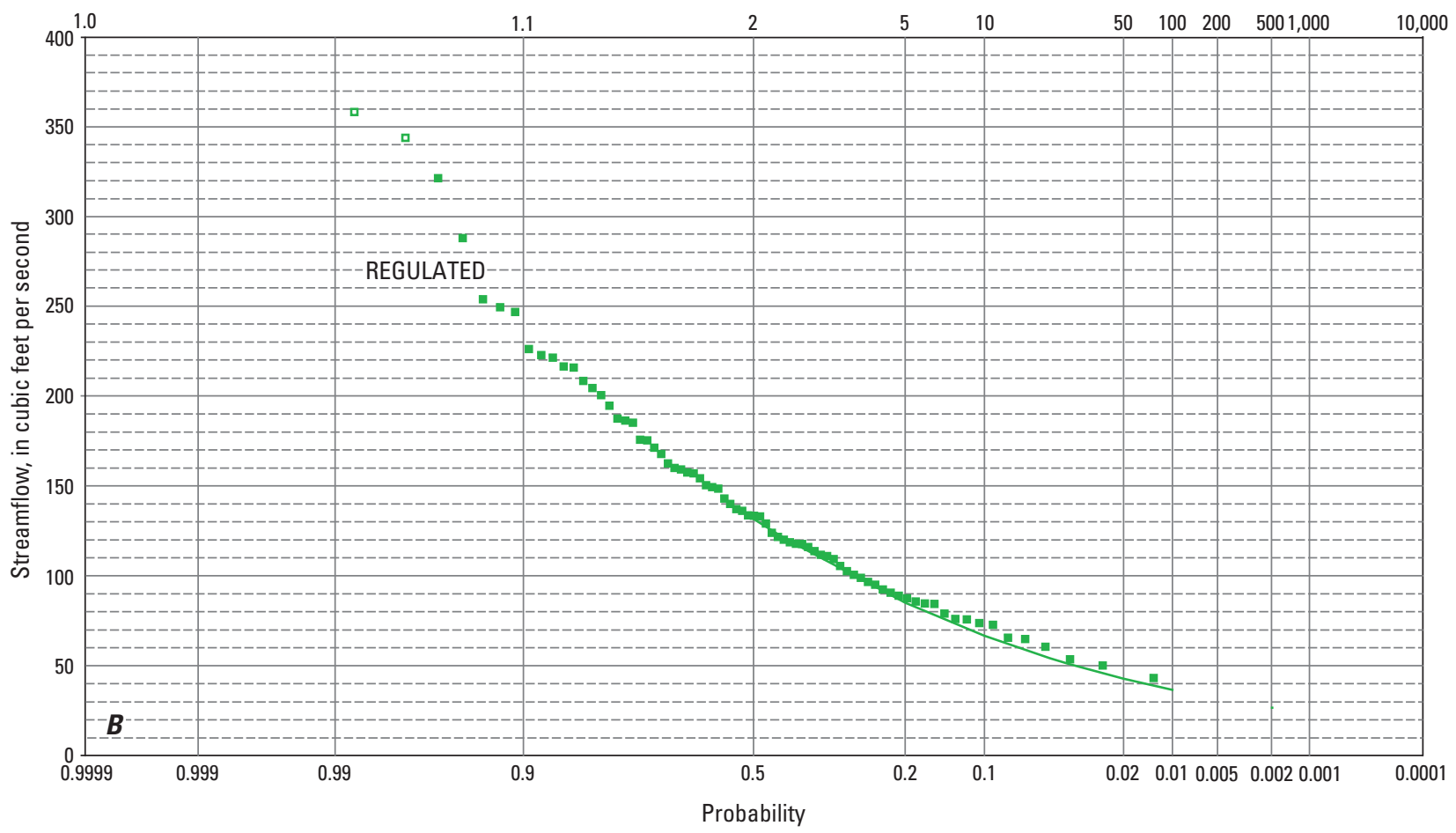

EXPLANATION

7-Day Data

- Estimated $n$-day values

- n-day frequency curve

- Outlier

Figure 2-5-10. February n-day low-flow frequency data for streamflow-gaging station 06308500 (Tongue River at Miles City, Mont.) for $A$, unregulated and $B$, regulated streamflow conditions, 1928-2002. 


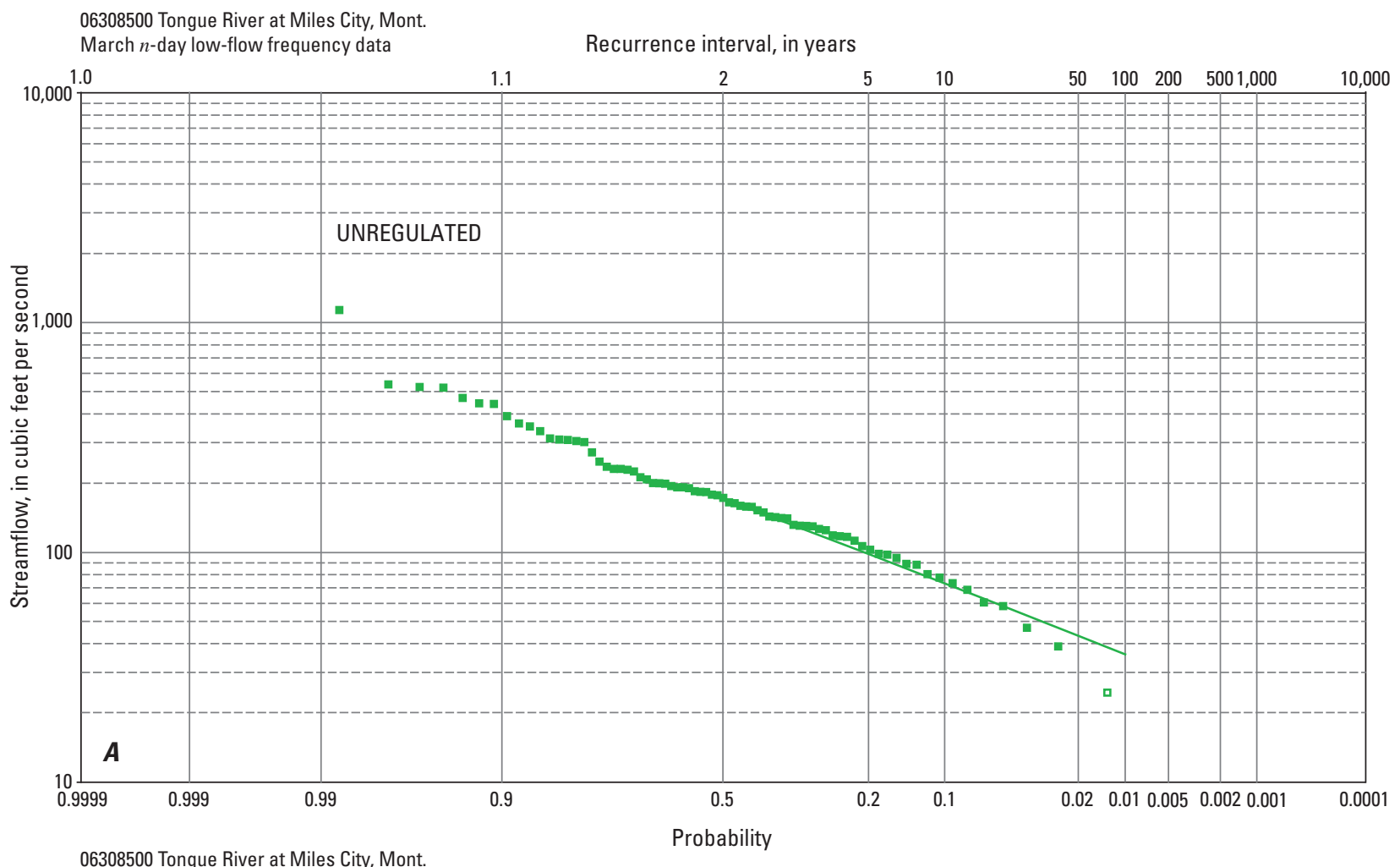

March $n$-day low-flow frequency data

Recurrence interval, in years

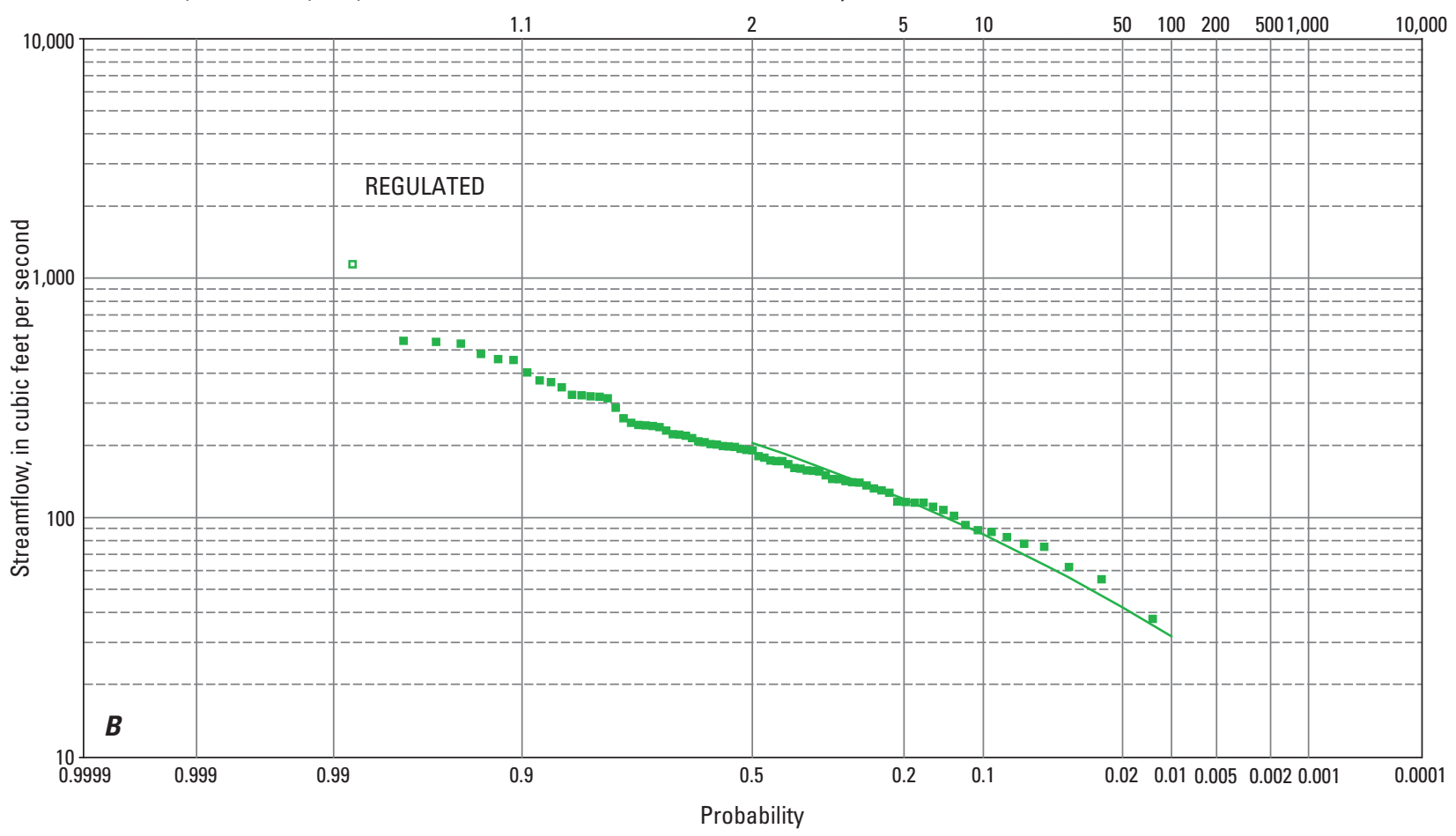

EXPLANATION

7-Day Data

- Estimated $n$-day values

- n-day frequency curve

- Outlier

Figure 2-5-11. March $n$-day low-flow frequency data for streamflow-gaging station 06308500 (Tongue River at Miles City, Mont.) for $A$, unregulated and $B$, regulated streamflow conditions, 1928-2002. 


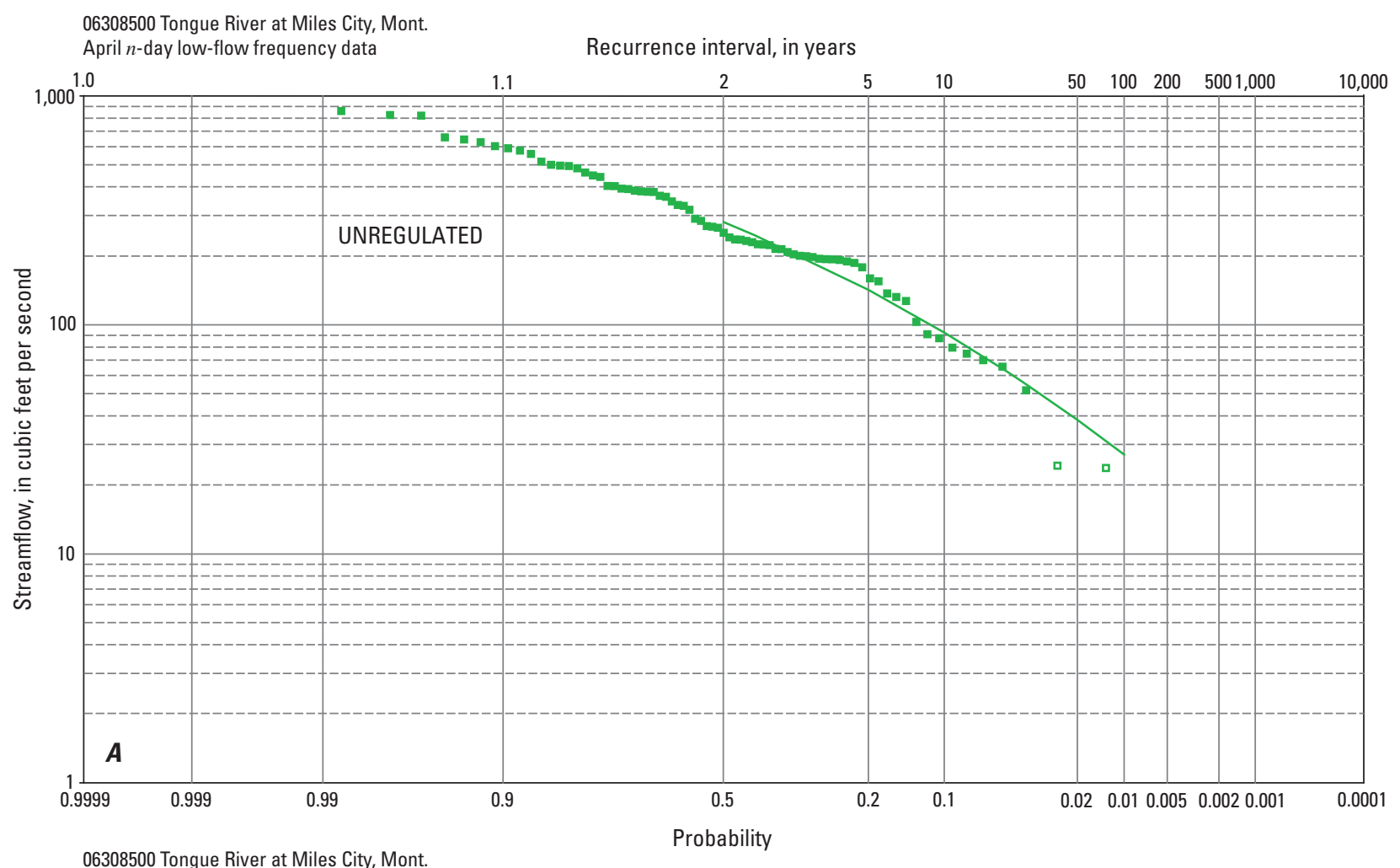

06308500 Tongue River at Miles City, Mont. April $n$-day low-flow frequency data

Recurrence interval, in years

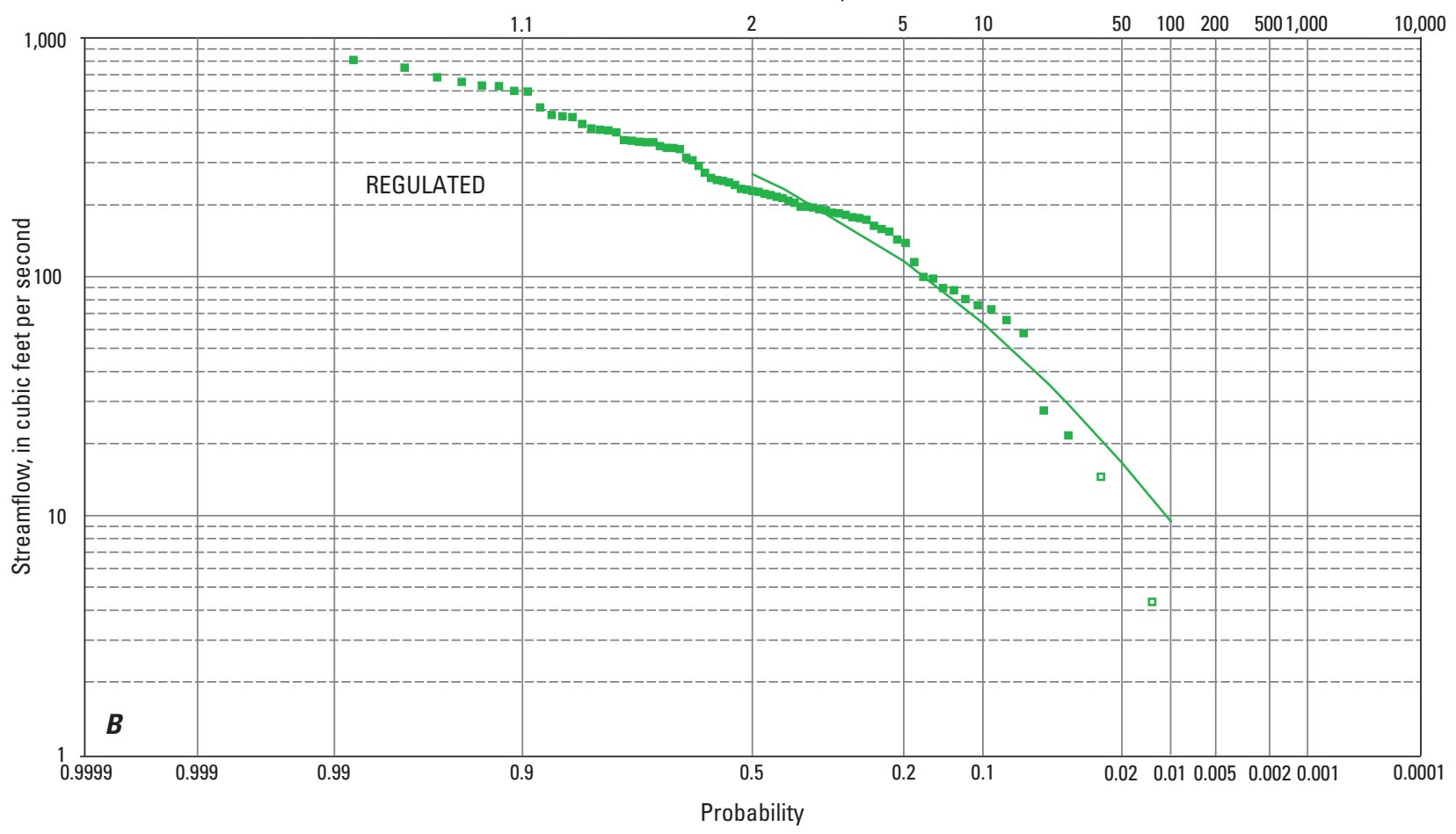

EXPLANATION

7-Day Data

- Estimated $n$-day values

$n$-day frequency curve

Outlier

Figure 2-5-12. April $n$-day low-flow frequency data for streamflow-gaging station 06308500 (Tongue River at Miles City, Mont.) for $A$, unregulated and $B$, regulated streamflow conditions, 1928-2002. 

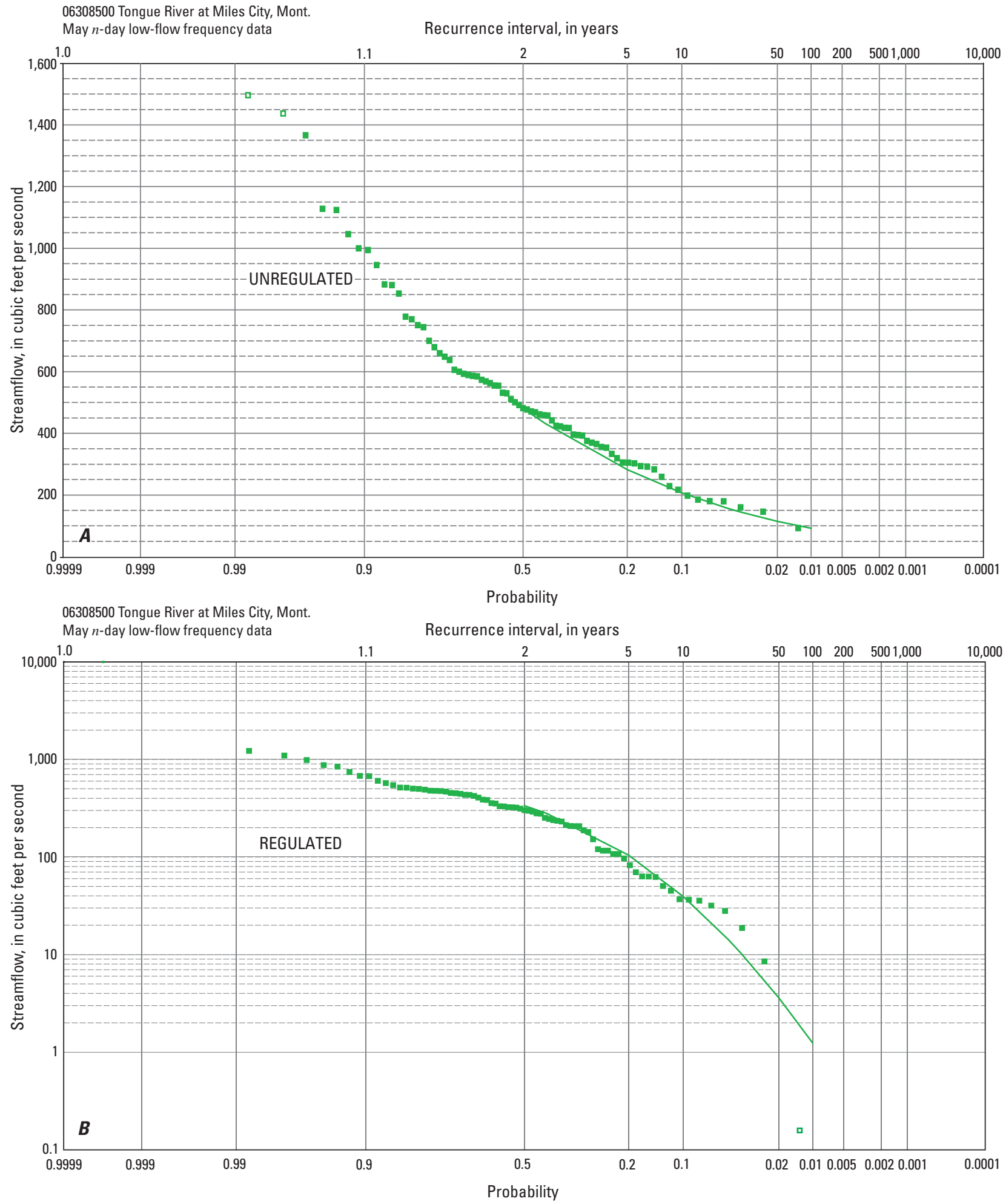

EXPLANATION

7-Day Data

- Estimated $n$-day values

- n-day frequency curve

Figure 2-5-13. May $n$-day low-flow frequency data for streamflow-gaging station 06308500 (Tongue River at Miles City, Mont.) for $A$, unregulated and $B$, regulated streamflow conditions, 1928-2002. 


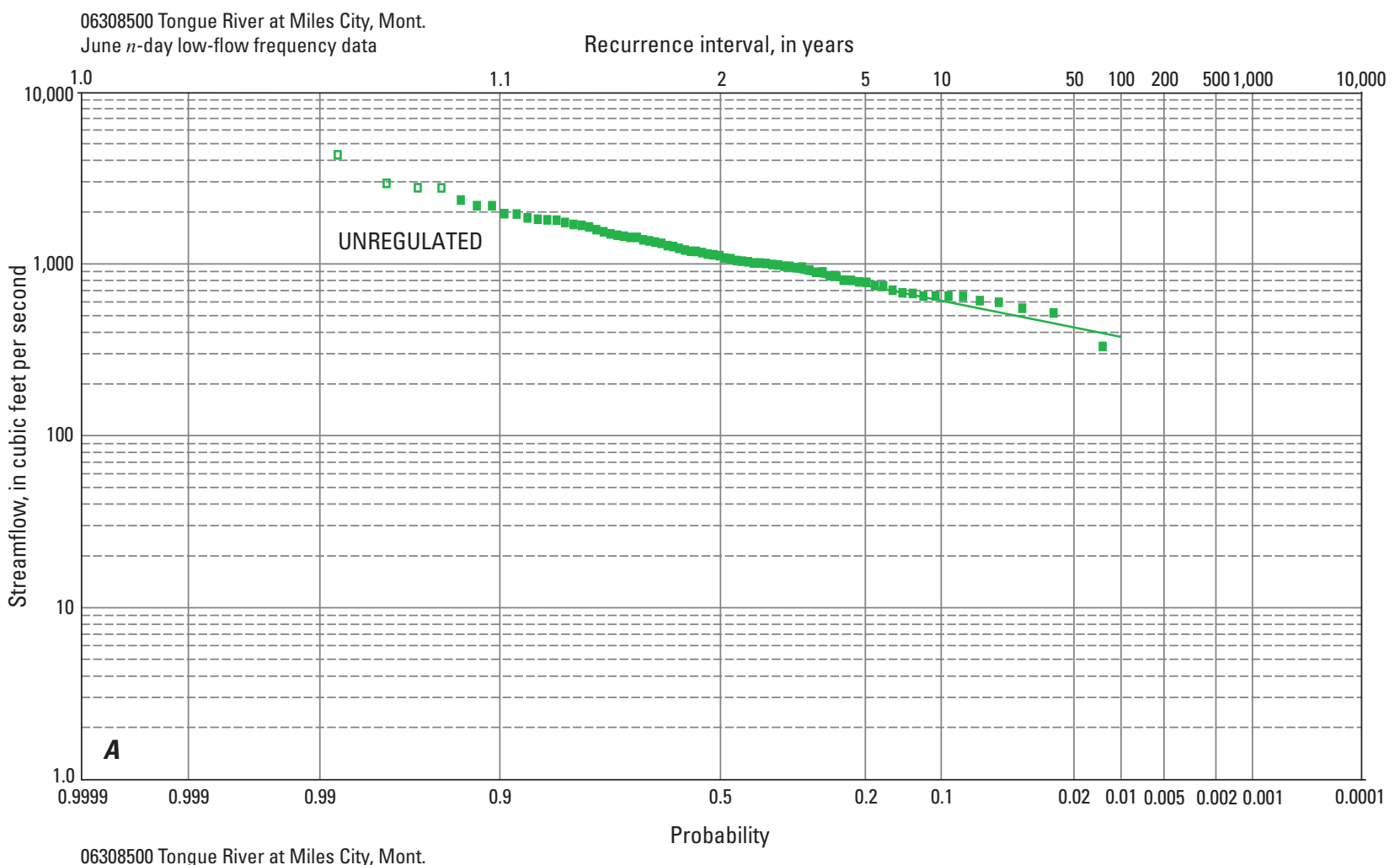

06308500 Tongue River at Miles City, Mont. June $n$-day low-flow frequency data

Recurrence interval, in years

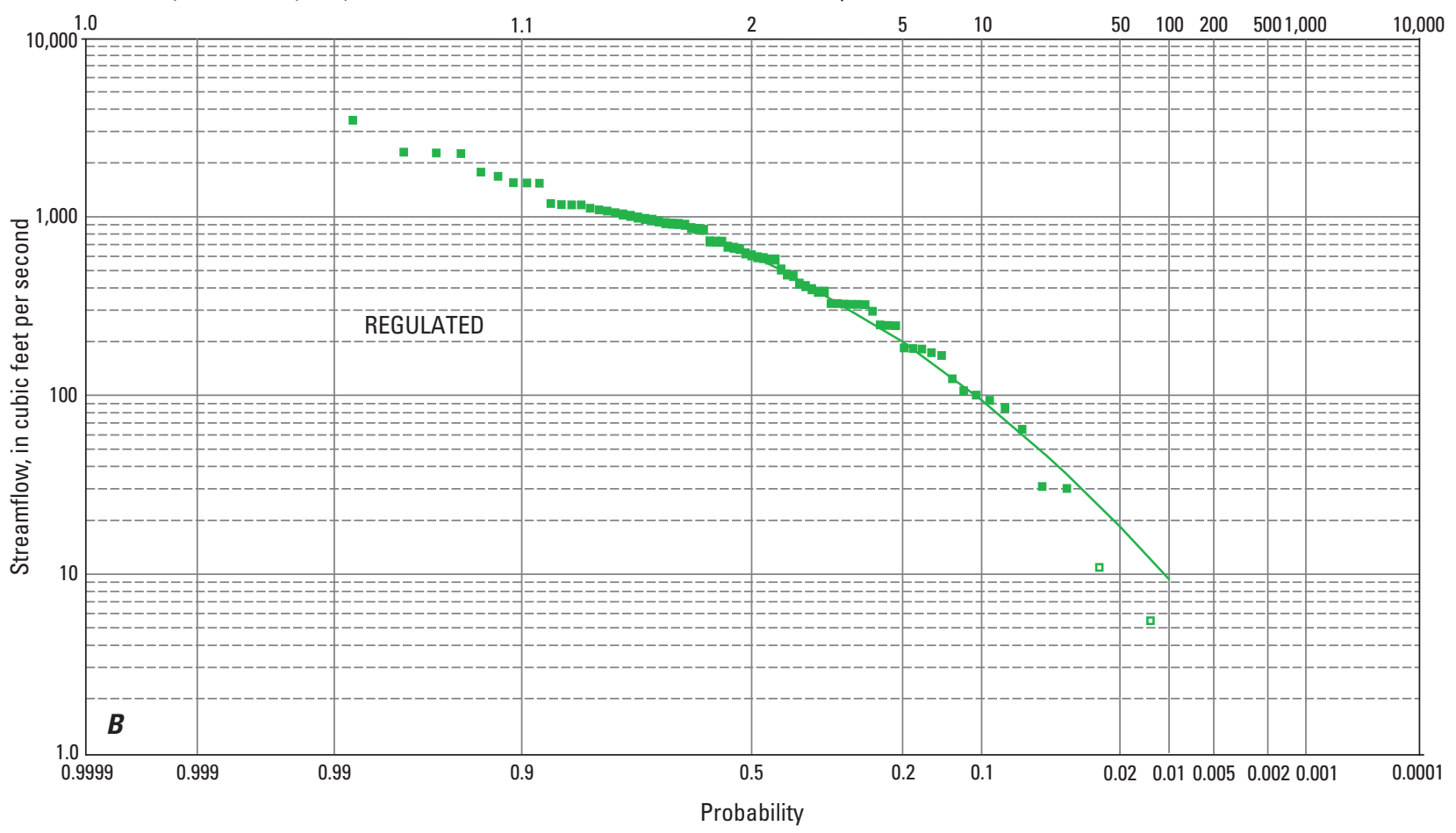

EXPLANATION

7-Day Data

- Estimated $n$-day values

- $n$-day frequency curve

- Outlier

Figure 2-5-14. June $n$-day low-flow frequency data for streamflow-gaging station 06308500 (Tongue River at Miles City, Mont.) for $A$, unregulated and $B$, regulated streamflow conditions, 1928-2002. 

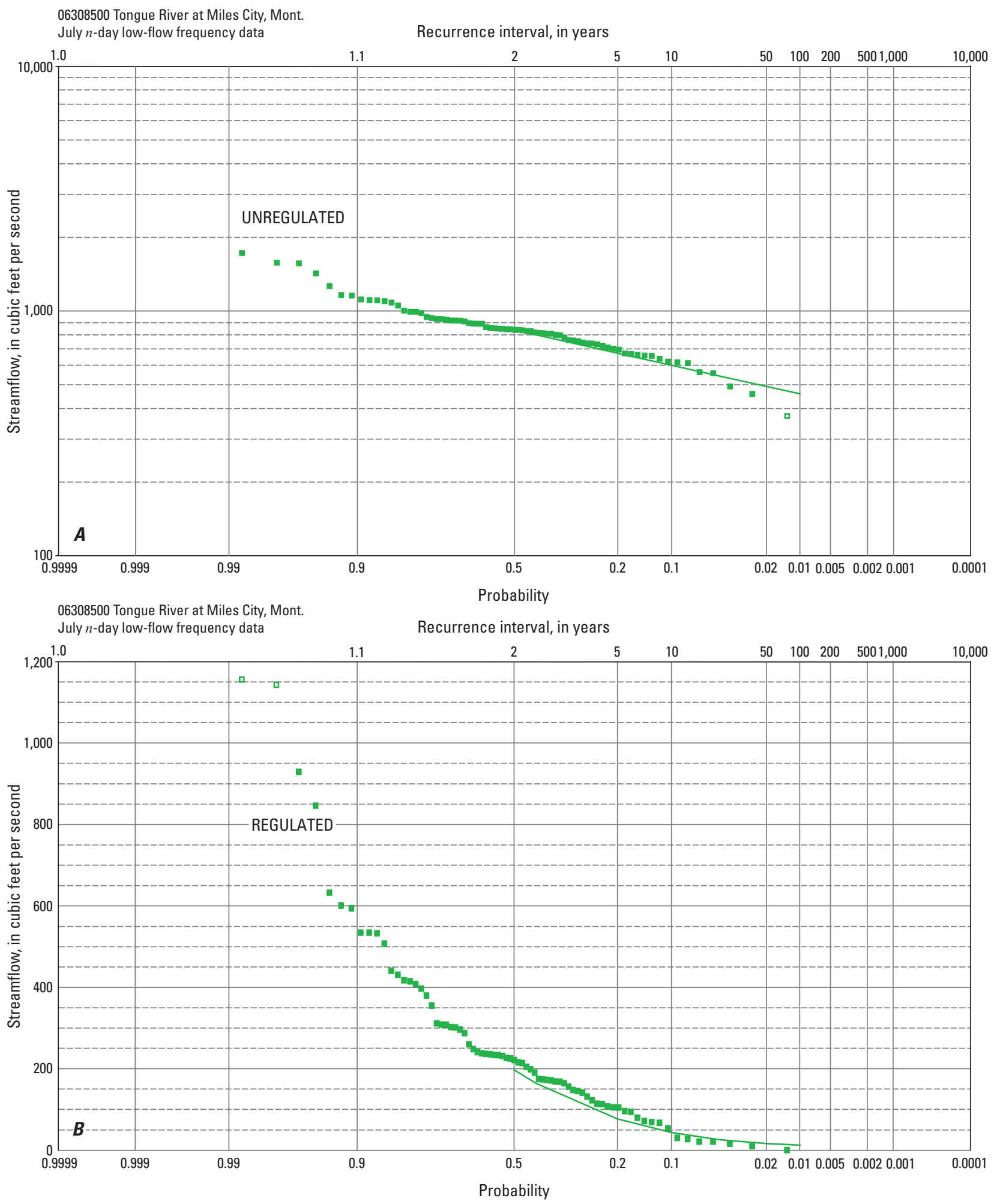

EXPLANATION

7-Day Data

- Estimated $n$-day values

- $n$-day frequency curve

Outlier

Figure 2-5-15. July $n$-day low-flow frequency data for streamflow-gaging station 06308500 (Tongue River at Miles City, Mont.) for $A$, unregulated and $B$, regulated streamflow conditions, 1928-2002. 

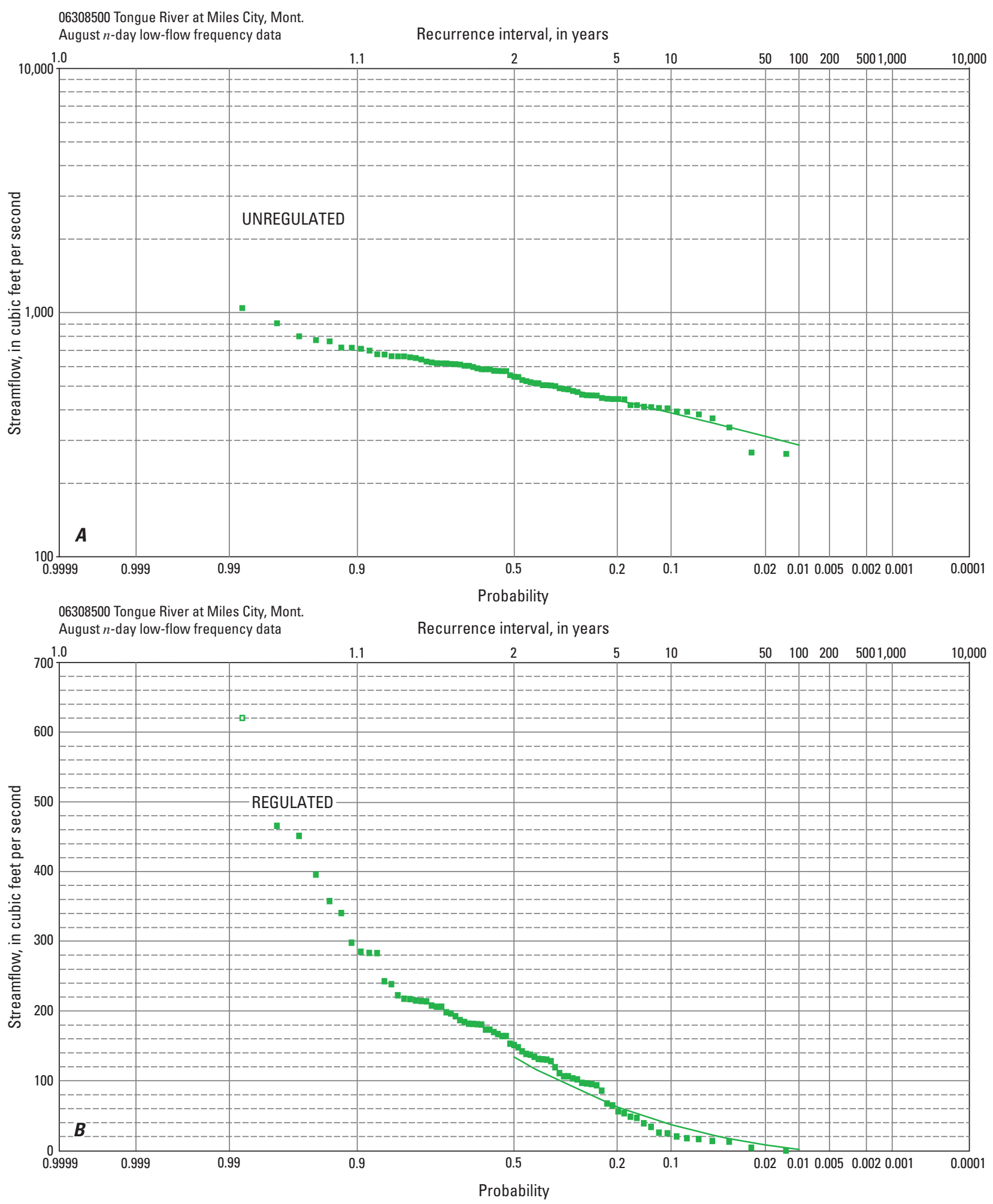

EXPLANATION

7-Day Data

- Estimated $n$-day values

- n-day frequency curve

Outlier

Figure 2-5-16. August $n$-day low-flow frequency data for streamflow-gaging station 06308500 (Tongue River at Miles City, Mont.) for $A$, unregulated and $B$, regulated streamflow conditions, 1928-2002. 


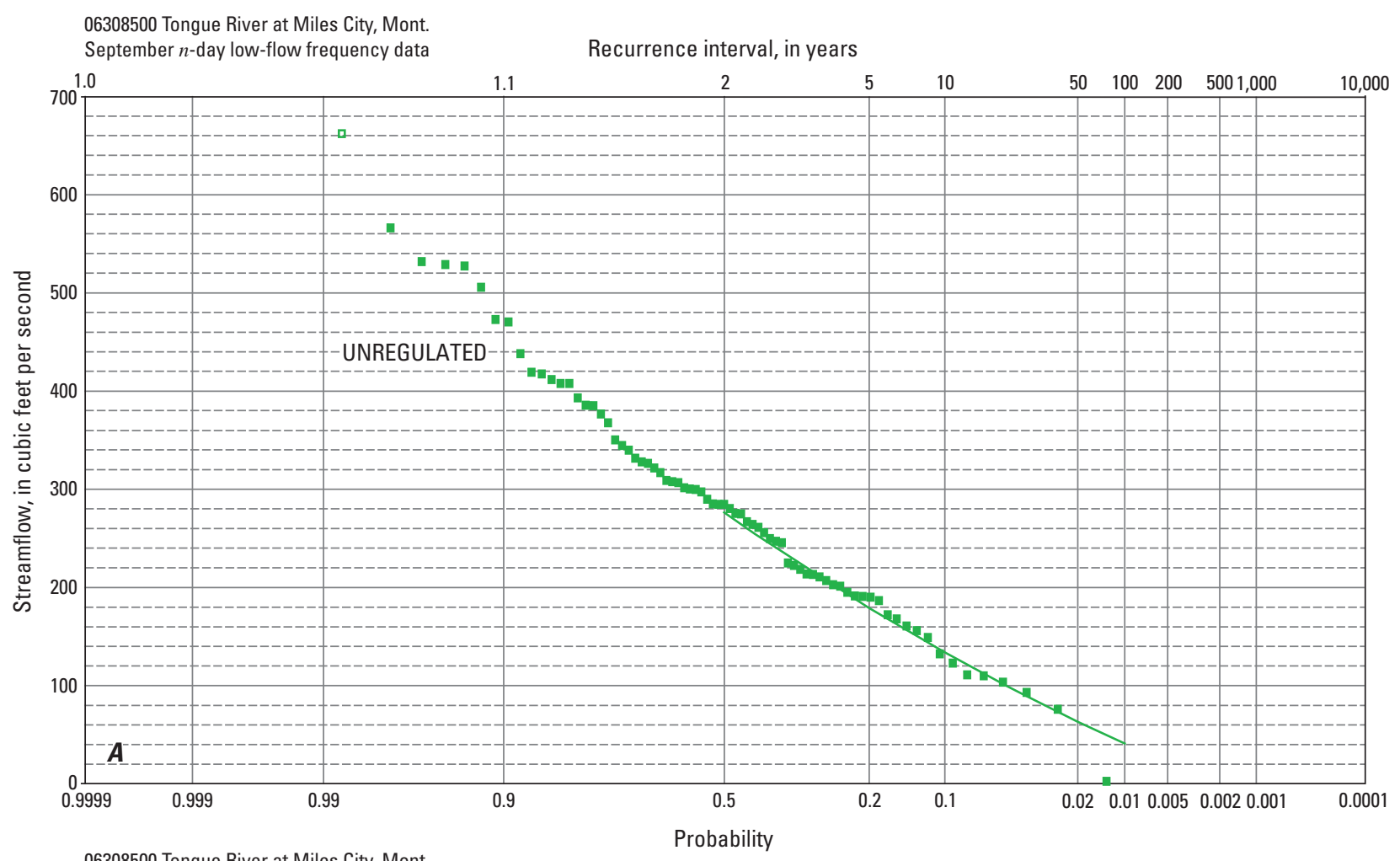

O6308500 Tongue River at Miles City, Mont.

Recurrence interval, in years

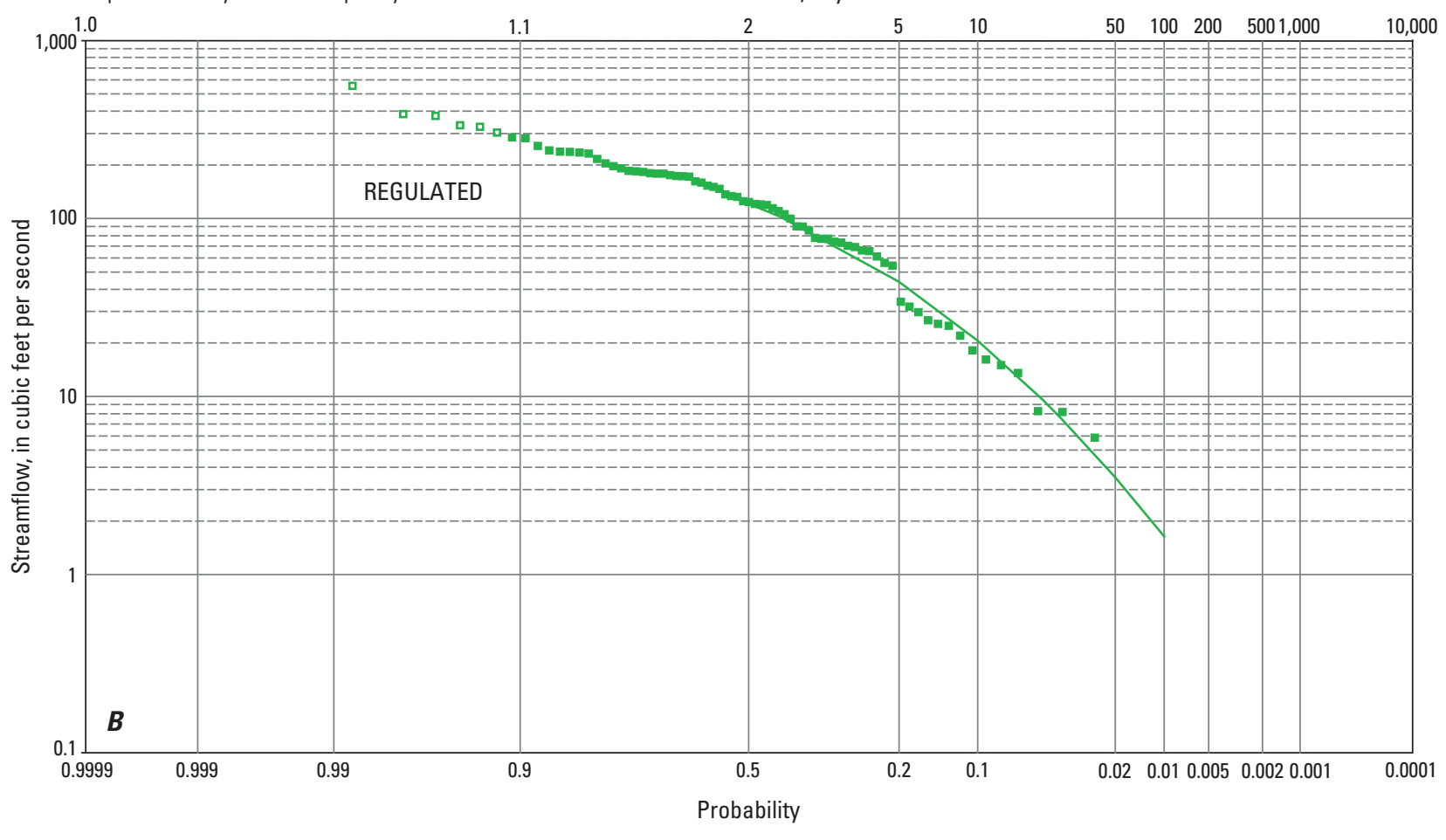

EXPLANATION

7-Day Data

- Estimated $n$-day values

- $n$-day frequency curve

口 Outlier

Figure 2-5-17. September $n$-day low-flow frequency data for streamflow-gaging station 06308500 (Tongue River at Miles City, Mont.) for $A$, unregulated and $B$, regulated streamflow conditions, 1928-2002. 


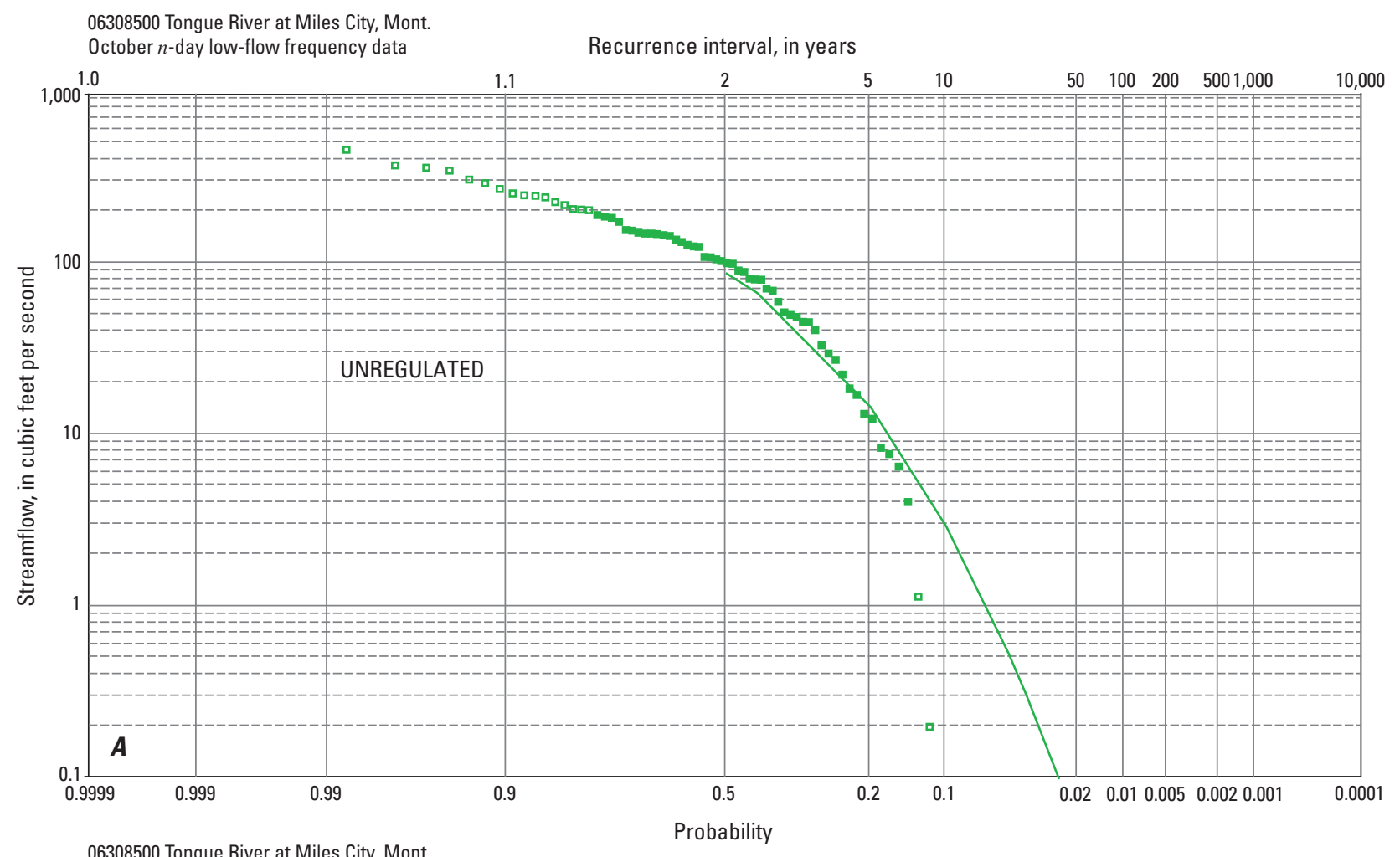

06308500 Tongue River at Miles City, Mont.

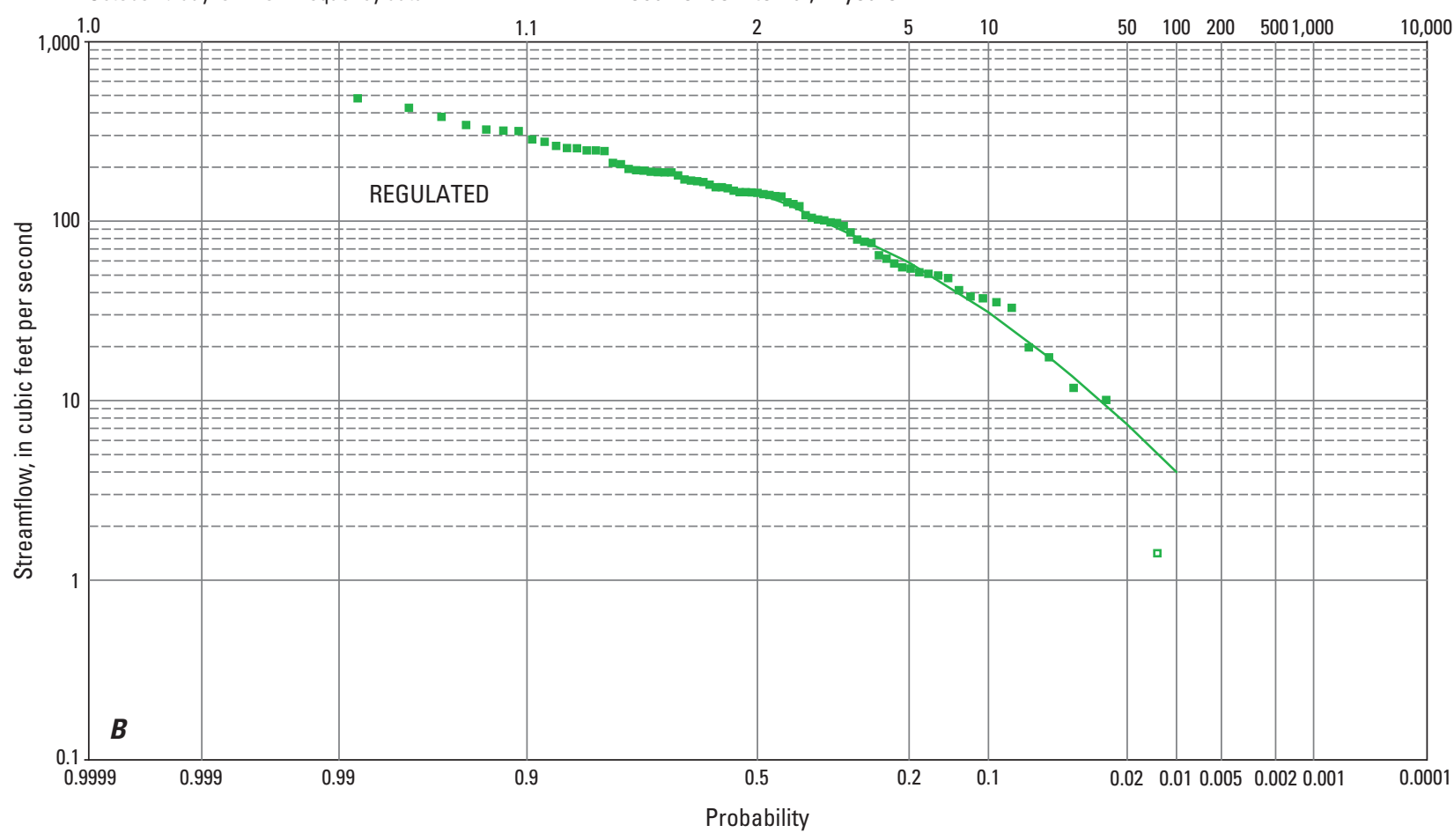

EXPLANATION

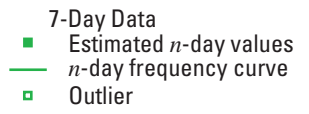

Figure 2-5-18. October $n$-day low-flow frequency data for streamflow-gaging station 06308500 (Tongue River at Miles City, Mont.) for $A$, unregulated and $B$, regulated streamflow conditions, 1928-2002. 


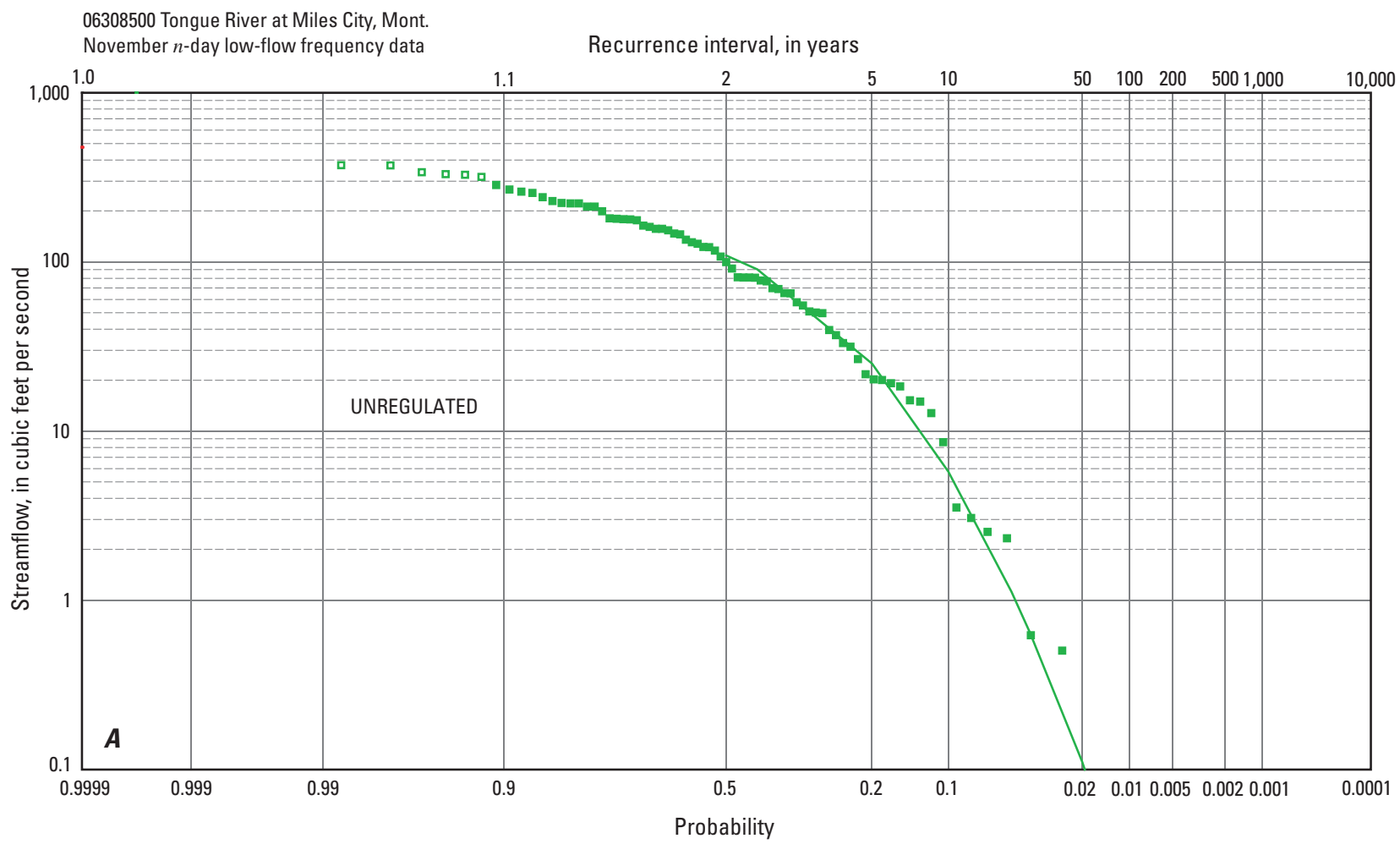

06308500 Tongue River at Miles City, Mont. November $n$-day low-flow frequency data

Recurrence interval, in years

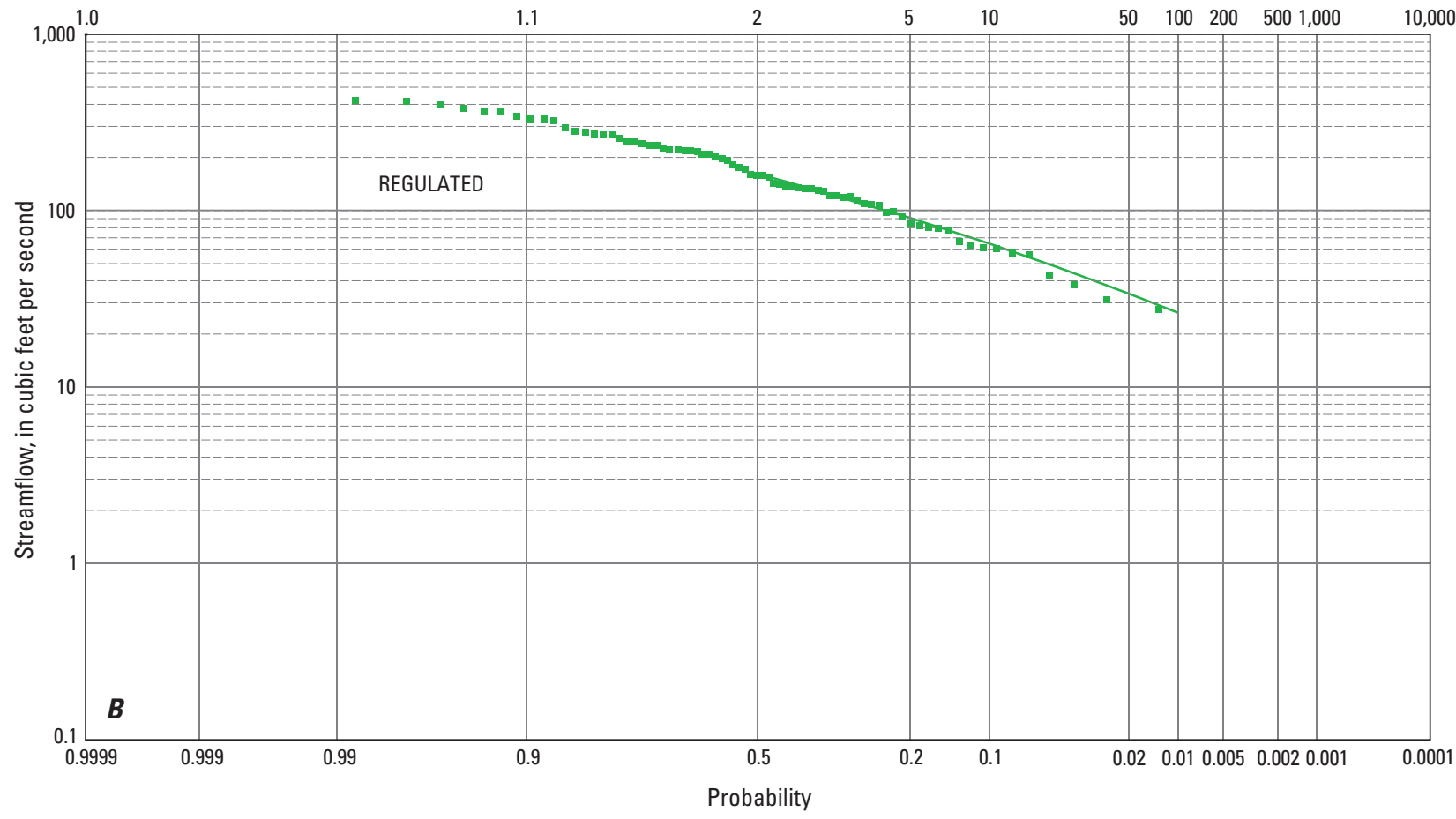

EXPLANATION

7-Day Data

- Estimated $n$-day values

- $n$-day frequency curve

- Outlier

Figure 2-5-19. November $n$-day low-flow frequency data for streamflow-gaging station 06308500 (Tongue River at Miles City, Mont.) for $A$, unregulated and $B$, regulated streamflow conditions, 1928-2002. 


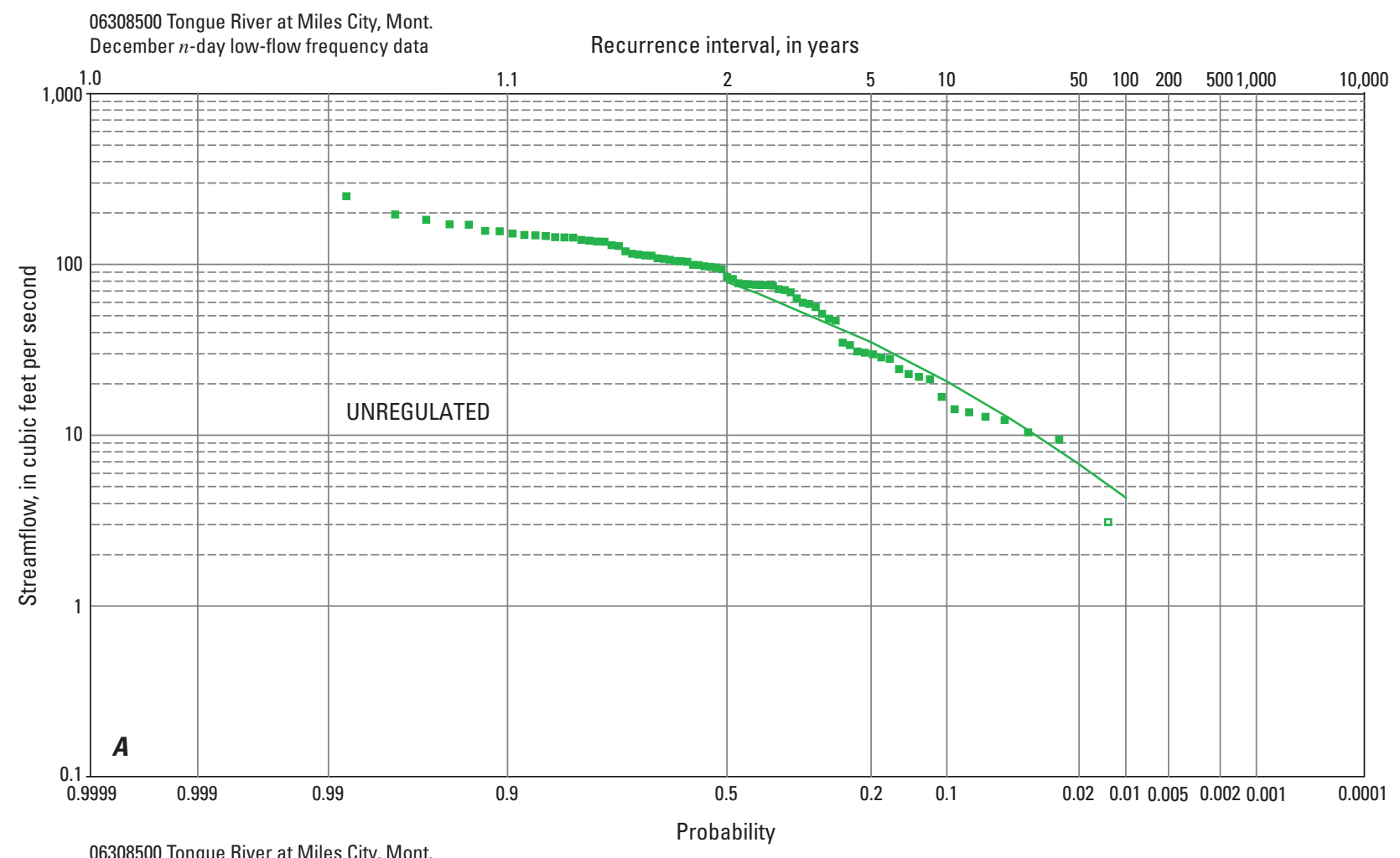

06308500 Tongue River at Miles City, Mont. December $n$-day low-flow frequency data

Recurrence interval, in years

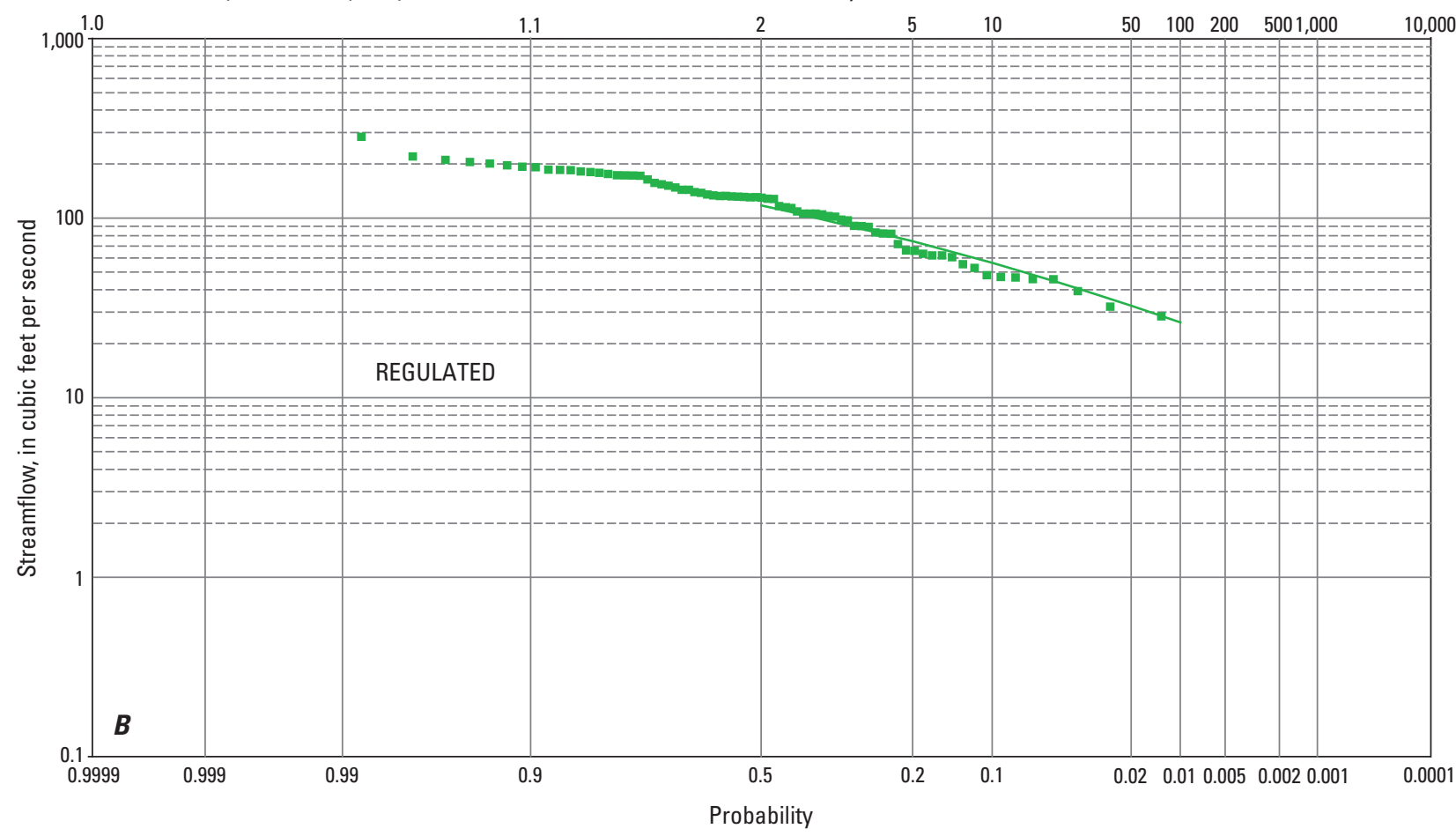

EXPLANATION

7-Day Data

- Estimated $n$-day values

- n-day frequency curve

Outlier

Figure 2-5-20. December $n$-day low-flow frequency data for streamflow-gaging station 06308500 (Tongue River at Miles City, Mont.) for $A$, unregulated and $B$, regulated streamflow conditions, 1928-2002. 
06308500 Tongue River at Miles City, Mont

Seasonal flow-duration data for unregulated and regulated streamflow conditions

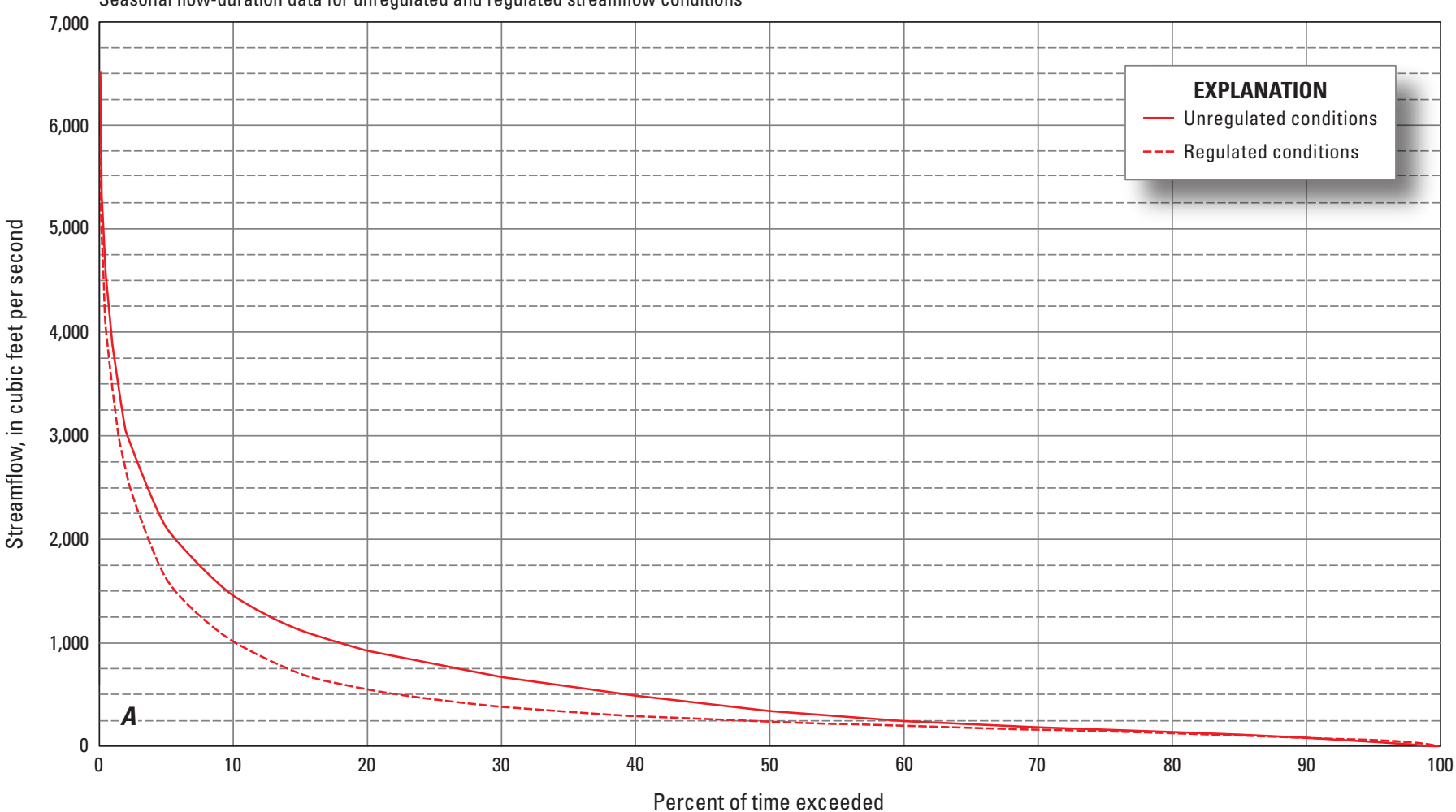

06308500 Tongue River at Miles City, Mont

Seasonal flow-duration data for unregulated and regulated streamflow conditions

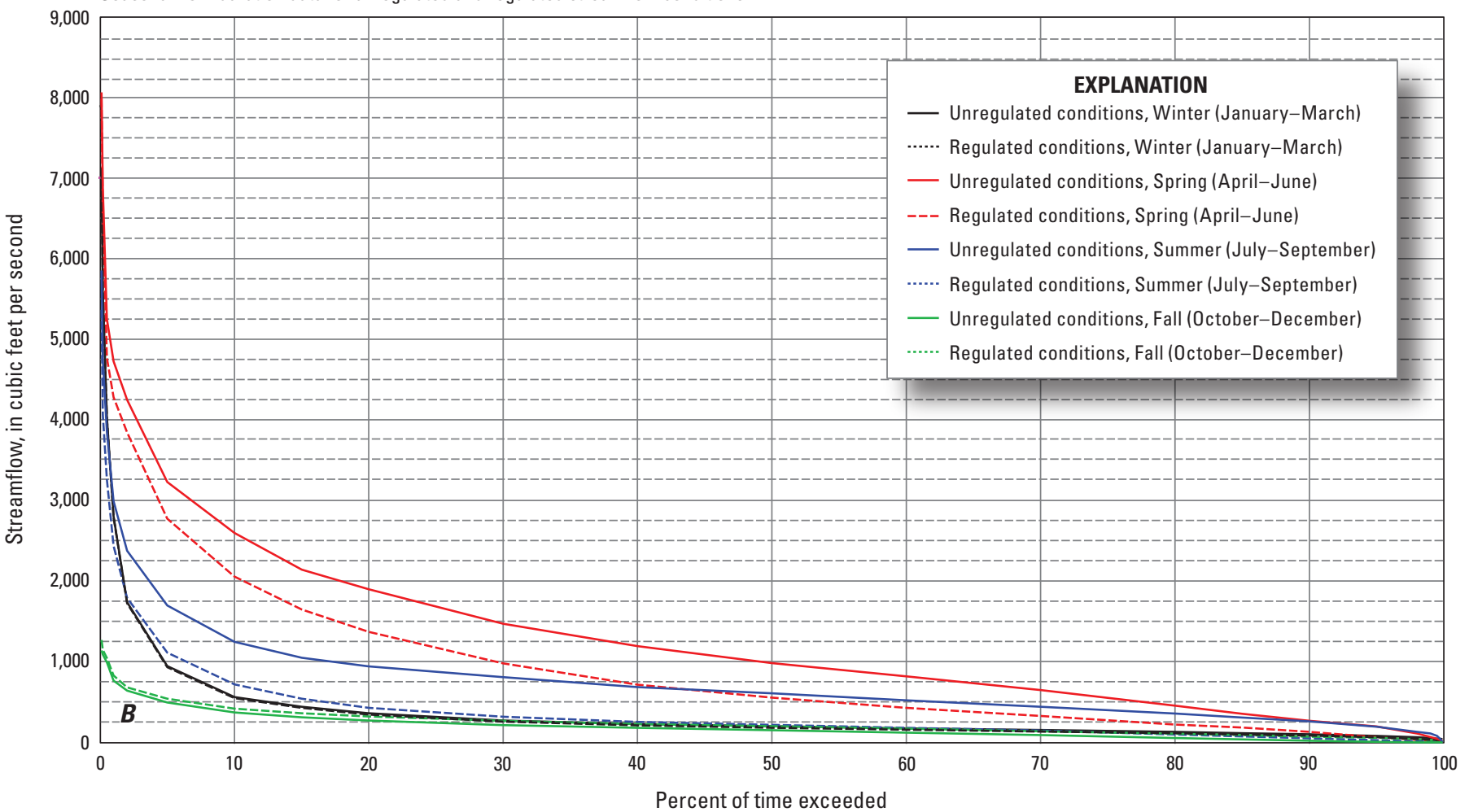

Figure 2-5-21. $\quad A$, Annual and $B$, seasonal flow-duration data for streamflow-gaging station 06308500 (Tongue River at Miles City, Mont.) for unregulated and regulated conditions, 1928-2002. 


\section{Appendix 2-6. Statistics for Streamflow-Gaging Station 06326500 (Powder River near Locate, Mont.)}

Table 2-6-1. Annual $n$-day high-flow frequency data for streamflow-gaging station 06326500 (Powder River near Locate, Mont.) for unregulated and regulated streamflow conditions, 1928-2002.

[Abbreviations: $\mathrm{ft}^{3} / \mathrm{s}$, cubic feet per second. Symbol: \%, percent]

\begin{tabular}{|c|c|c|c|c|c|c|c|}
\hline \multicolumn{8}{|c|}{ Unregulated } \\
\hline \multirow{3}{*}{$\begin{array}{c}n, \text { period of } \\
\text { consecutive } \\
\text { days }\end{array}$} & \multicolumn{7}{|c|}{ Streamflow, in $\mathrm{ft}^{3} / \mathrm{s}$, for indicated recurrence interval, in years, and exceedance probability, in percent } \\
\hline & 2 & 5 & 10 & 20 & 25 & 50 & 100 \\
\hline & $50 \%$ & $20 \%$ & $10 \%$ & $5 \%$ & $4 \%$ & $2 \%$ & $1 \%$ \\
\hline 1 & 6,100 & 11,400 & 15,900 & 21,100 & 23,000 & 29,300 & 36,600 \\
\hline 3 & 5,110 & 9,470 & 13,300 & 17,700 & 19,200 & 24,500 & 30,700 \\
\hline 7 & 4,030 & 7,200 & 9,850 & 12,800 & 13,800 & 17,300 & 21,200 \\
\hline 15 & 3,200 & 5,230 & 6,800 & 8,450 & 9,010 & 10,800 & 12,800 \\
\hline 30 & 2,570 & 3,950 & 4,970 & 6,020 & 6,360 & 7,480 & 8,660 \\
\hline 60 & 2,030 & 2,990 & 3,670 & 4,350 & 4,580 & 5,290 & 6,040 \\
\hline 90 & 1,750 & 2,480 & 2,990 & 3,490 & 3,660 & 4,170 & 4,710 \\
\hline 120 & 1,550 & 2,190 & 2,650 & 3,110 & 3,260 & 3,740 & 4,230 \\
\hline 183 & 1,250 & 1,730 & 2,070 & 2,390 & 2,500 & 2,830 & 3,180 \\
\hline \multicolumn{8}{|c|}{ Regulated } \\
\hline \multirow{3}{*}{$\begin{array}{c}n, \text { period of } \\
\text { consecutive } \\
\text { days }\end{array}$} & \multicolumn{7}{|c|}{ Streamflow, in $\mathrm{ft}^{3} / \mathrm{s}$, for indicated recurrence interval, in years, and exceedance probability, in percent } \\
\hline & 2 & 5 & 10 & 20 & 25 & 50 & 100 \\
\hline & $50 \%$ & $20 \%$ & $10 \%$ & $5 \%$ & $4 \%$ & $2 \%$ & $1 \%$ \\
\hline 1 & 6,090 & 11,300 & 15,600 & 20,400 & 22,100 & 27,800 & 34,100 \\
\hline 3 & 5,010 & 9,400 & 13,100 & 17,100 & 18,500 & 23,200 & 28,300 \\
\hline 7 & 3,840 & 7,030 & 9,630 & 12,500 & 13,400 & 16,600 & 20,200 \\
\hline 15 & 2,930 & 4,960 & 6,500 & 8,110 & 8,640 & 10,400 & 12,200 \\
\hline 30 & 2,280 & 3,630 & 4,620 & 5,640 & 5,980 & 7,050 & 8,190 \\
\hline 60 & 1,600 & 2,700 & 3,430 & 4,120 & 4,340 & 4,990 & 5,610 \\
\hline 90 & 1,330 & 2,170 & 2,710 & 3,200 & 3,360 & 3,800 & 4,230 \\
\hline 120 & 1,180 & 1,900 & 2,370 & 2,810 & 2,940 & 3,350 & 3,730 \\
\hline 183 & 923 & 1,450 & 1,790 & 2,100 & 2,190 & 2,470 & 2,730 \\
\hline
\end{tabular}


Table 2-6-2. Annual, seasonal, and monthly $n$-day low-flow frequency data for streamflow-gaging station 06326500 (Powder River near Locate, Mont.) for unregulated and regulated steamflow conditions, 1928-2002.

[Abbreviations: $\mathrm{ft}^{3} / \mathrm{s}$, cubic feet per second. Symbol: \%, percent]

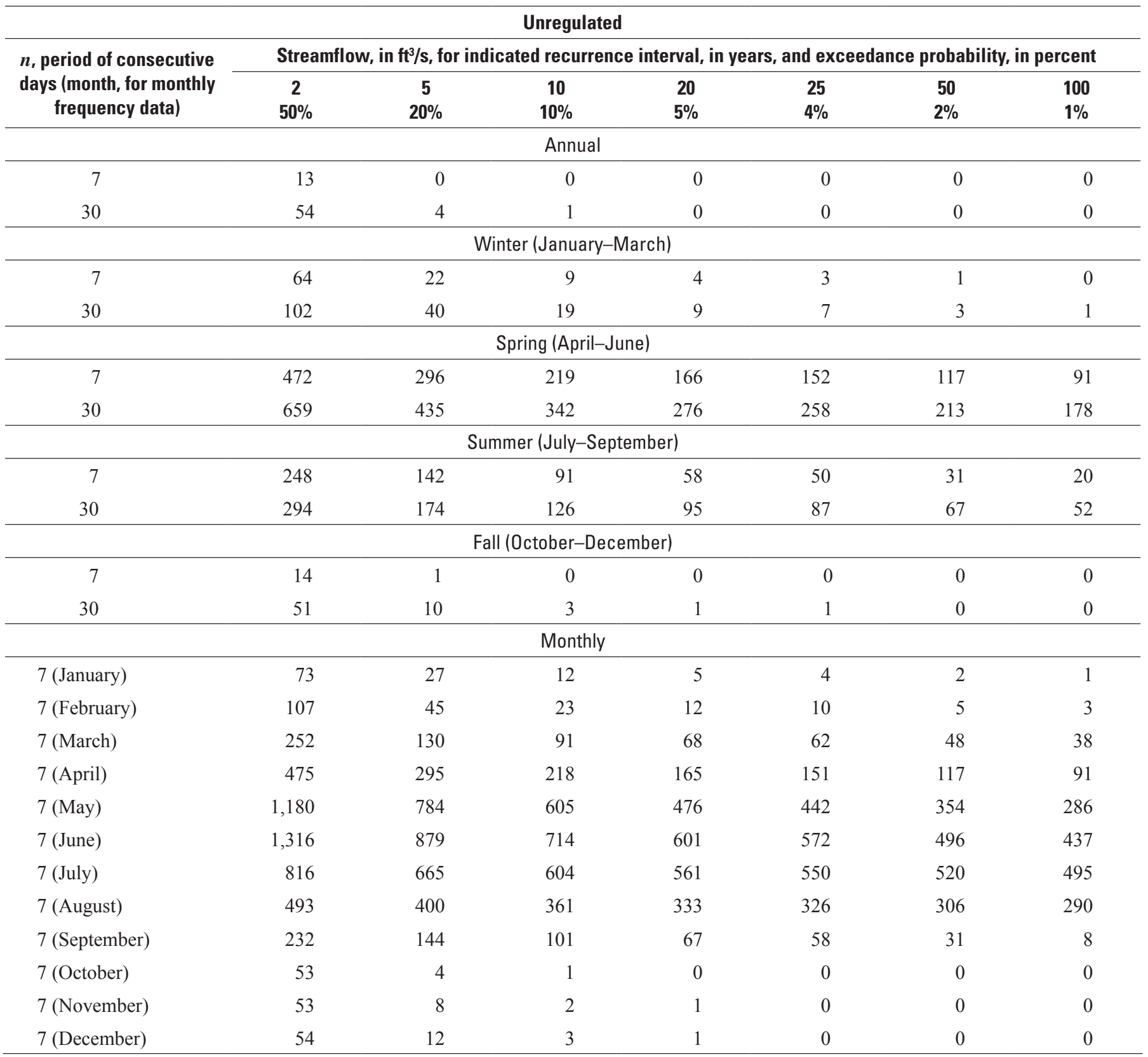


Table 2-6-2. Annual, seasonal, and monthly $n$-day low-flow frequency data for streamflow-gaging station 06326500 (Powder River near Locate, Mont.) for unregulated and regulated steamflow conditions, 1928-2002.-Continued

[Abbreviations: $\mathrm{ft}^{3} / \mathrm{s}$, cubic feet per second. Symbol: \%, percent]

\section{Regulated}

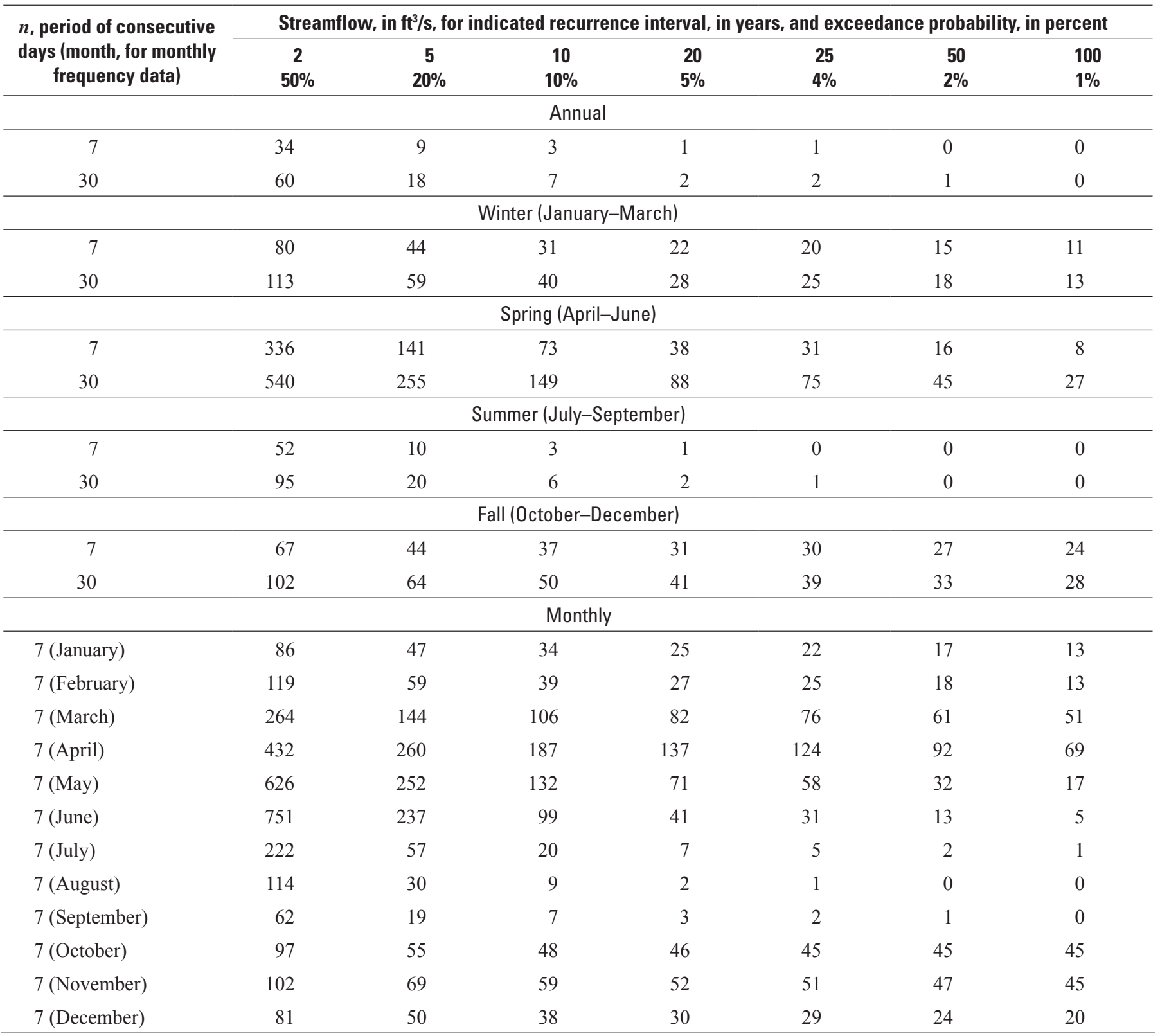


Table 2-6-3. Annual and seasonal flow-duration data for streamflow-gaging station 06326500 (Powder River near Locate, Mont.) for unregulated and regulated conditions, 1928-2002.

[Abbreviations: $\mathrm{ft}^{3} / \mathrm{s}$, cubic feet per second. Symbol: \%, percent]

\begin{tabular}{|c|c|c|c|c|c|c|c|c|c|c|c|c|c|c|c|c|c|c|c|}
\hline \multicolumn{20}{|c|}{ Streamflow, in $\mathrm{ft}^{3} / \mathrm{s}$, which was equaled or exceeded for indicated percent of time } \\
\hline $\begin{array}{c}\text { Streamflow } \\
\text { condition }\end{array}$ & $1.0 \%$ & $2.0 \%$ & $5.0 \%$ & $10 \%$ & $15 \%$ & $20 \%$ & $25 \%$ & $30 \%$ & $40 \%$ & $50 \%$ & $60 \%$ & $70 \%$ & $75 \%$ & $80 \%$ & $85 \%$ & $90 \%$ & $95 \%$ & $98 \%$ & $99 \%$ \\
\hline \multicolumn{20}{|c|}{ Annual } \\
\hline Unregulated & 5,850 & 4,230 & 2,610 & 1,800 & 1,380 & 1,120 & 922 & 786 & 565 & 385 & 253 & 163 & 127 & 99 & 71 & 42 & 3 & 0 & 0 \\
\hline Regulated & 5,510 & 3,880 & 2,200 & 1,380 & 1,000 & 769 & 600 & 482 & 330 & 244 & 174 & 126 & 108 & 89 & 70 & 55 & 31 & 14 & 1 \\
\hline \multicolumn{20}{|c|}{ Winter (January-March) } \\
\hline Unregulated & 7,930 & 4,990 & 2,050 & 1,090 & 780 & 590 & 462 & 367 & 237 & 176 & 132 & 102 & 91 & 75 & 60 & 40 & 10 & 0 & 0 \\
\hline Regulated & 7,940 & 5,000 & 2,060 & 1,100 & 799 & 600 & 477 & 380 & 251 & 193 & 150 & 121 & 110 & 96 & 80 & 59 & 30 & 20 & 17 \\
\hline \multicolumn{20}{|c|}{ Spring (April-June) } \\
\hline Unregulated & 7,350 & 5,930 & 4,250 & 3,060 & 2,530 & 2,220 & 1,937 & 1,709 & 1,400 & 1,184 & 994 & 804 & 721 & 640 & 534 & 432 & 341 & 253 & 214 \\
\hline Regulated & 6,940 & 5,490 & 3,840 & 2,590 & 2,040 & 1,700 & 1,430 & 1,240 & 966 & 766 & 607 & 479 & 425 & 367 & 306 & 246 & 149 & 80 & 49 \\
\hline \multicolumn{20}{|c|}{ Summer (July-September) } \\
\hline Unregulated & 3,370 & 2,720 & 1,950 & 1,460 & 1,170 & 1,000 & 901 & 822 & 701 & 591 & 507 & 407 & 359 & 297 & 258 & 206 & 152 & 92 & 69 \\
\hline Regulated & 2,850 & 2,230 & 1,430 & 959 & 689 & 503 & 403 & 332 & 246 & 179 & 125 & 81 & 65 & 53 & 38 & 21 & 7 & 0 & 0 \\
\hline \multicolumn{20}{|c|}{ Fall (October-December) } \\
\hline Unregulated & 867 & 621 & 427 & 315 & 271 & 241 & 211 & 184 & 136 & 101 & 70 & 46 & 31 & 17 & 1 & 0 & 0 & 0 & 0 \\
\hline Regulated & 930 & 681 & 482 & 372 & 322 & 288 & 259 & 234 & 182 & 146 & 115 & 92 & 81 & 72 & 62 & 57 & 44 & 33 & 31 \\
\hline
\end{tabular}


Table 2-6-4. Monthly and annual streamflow characteristics for streamflow-gaging station 06326500 (Powder River near Locate, Mont.) for unregulated and regulated streamflow conditions, 1928-2002.

[Abbreviations: $\mathrm{ft}^{3} / \mathrm{s}$, cubic feet per second]

\section{Unregulated}

\begin{tabular}{|c|c|c|c|c|c|c|}
\hline Period & \multicolumn{6}{|c|}{ Streamflow, in $\mathrm{ft}^{3} / \mathrm{s}$, or year, for indicated streamflow characteristic } \\
\hline January & 452 & 1981 & 0 & 1929 & 117 & 87 \\
\hline March & 4,970 & 1936 & 66 & 1950 & 1,200 & 1,120 \\
\hline April & 3,130 & 1965 & 129 & 1961 & 769 & 477 \\
\hline May & 6,580 & 1928 & 612 & 1935 & 1,790 & 1,060 \\
\hline June & 8,070 & 1944 & 674 & 1994 & 2,200 & 1,280 \\
\hline October & 860 & 1940 & 0 & 1935 & 186 & 208 \\
\hline November & 729 & 1998 & 0 & 1935 & 158 & 139 \\
\hline December & 378 & 1941 & 0 & 1960 & 111 & 81 \\
\hline Annual & 1,757 & 1944 & 314 & 1961 & 762 & 279 \\
\hline \multicolumn{7}{|c|}{ Regulated } \\
\hline & \multicolumn{6}{|c|}{ Streamflow, in $\mathrm{ft}^{3} / \mathrm{s}$, or year, for indicated streamflow characteristic } \\
\hline Period & $\begin{array}{l}\text { Maximum } \\
\text { monthly mean } \\
\text { and maximum } \\
\text { annual mean } \\
\text { streamflow }\end{array}$ & $\begin{array}{l}\text { Year of maximum } \\
\text { monthly mean } \\
\text { and maximum } \\
\text { annual mean } \\
\text { streamflow }\end{array}$ & $\begin{array}{l}\text { Minimum monthly } \\
\text { mean and } \\
\text { minimum annual } \\
\text { mean streamflow }\end{array}$ & $\begin{array}{l}\text { Year of minimum } \\
\text { monthly mean } \\
\text { and minimum } \\
\text { annual mean } \\
\text { streamflow }\end{array}$ & $\begin{array}{l}\text { Mean monthly } \\
\text { and mean annual } \\
\text { streamflow }\end{array}$ & $\begin{array}{c}\text { Standard } \\
\text { deviation of } \\
\text { mean monthly } \\
\text { and mean annual } \\
\text { steamflow }\end{array}$ \\
\hline April & 3,070 & 1965 & 109 & 1961 & 718 & 466 \\
\hline May & 6,130 & 1928 & 123 & 1992 & 1,260 & 1,110 \\
\hline June & 8,010 & 1944 & 48 & 2002 & 1,660 & 1,360 \\
\hline July & 4,340 & 1937 & 5 & 1988 & 691 & 669 \\
\hline August & 1,230 & 1941 & 0 & 1988 & 262 & 233 \\
\hline September & 1,061 & 1933 & 5 & 1988 & 194 & 214 \\
\hline October & 910 & 1940 & 50 & 1939 & 245 & 209 \\
\hline November & 786 & 1998 & 44 & 1934 & 214 & 137 \\
\hline December & 407 & 1941 & 31 & 1960 & 144 & 80 \\
\hline Annual & 1,617 & 1944 & 119 & 1961 & 590 & 291 \\
\hline
\end{tabular}



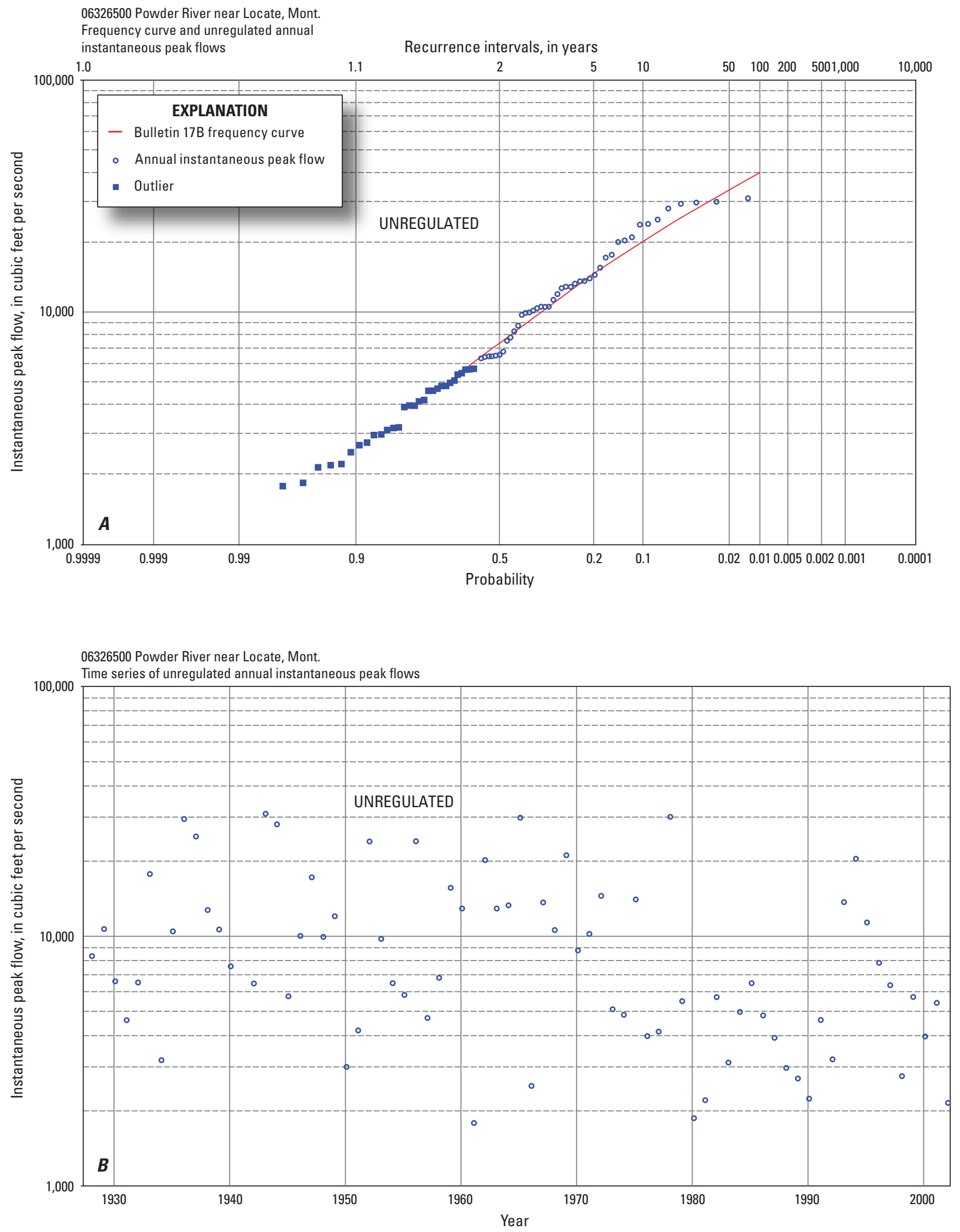

Figure 2-6-1. Annual instantaneous peak-flow data for streamflow-gaging station 06326500 (Powder River near Locate, Mont.) for unregulated conditions, 1928-2002. $A$, Frequency curve and unregulated annual instantaneous peak flows. $B$, Time series of unregulated annual instantaneous peak flows. [Bulletin 17B: U.S. Interagency Advisory Council on Water Data, 1982] 

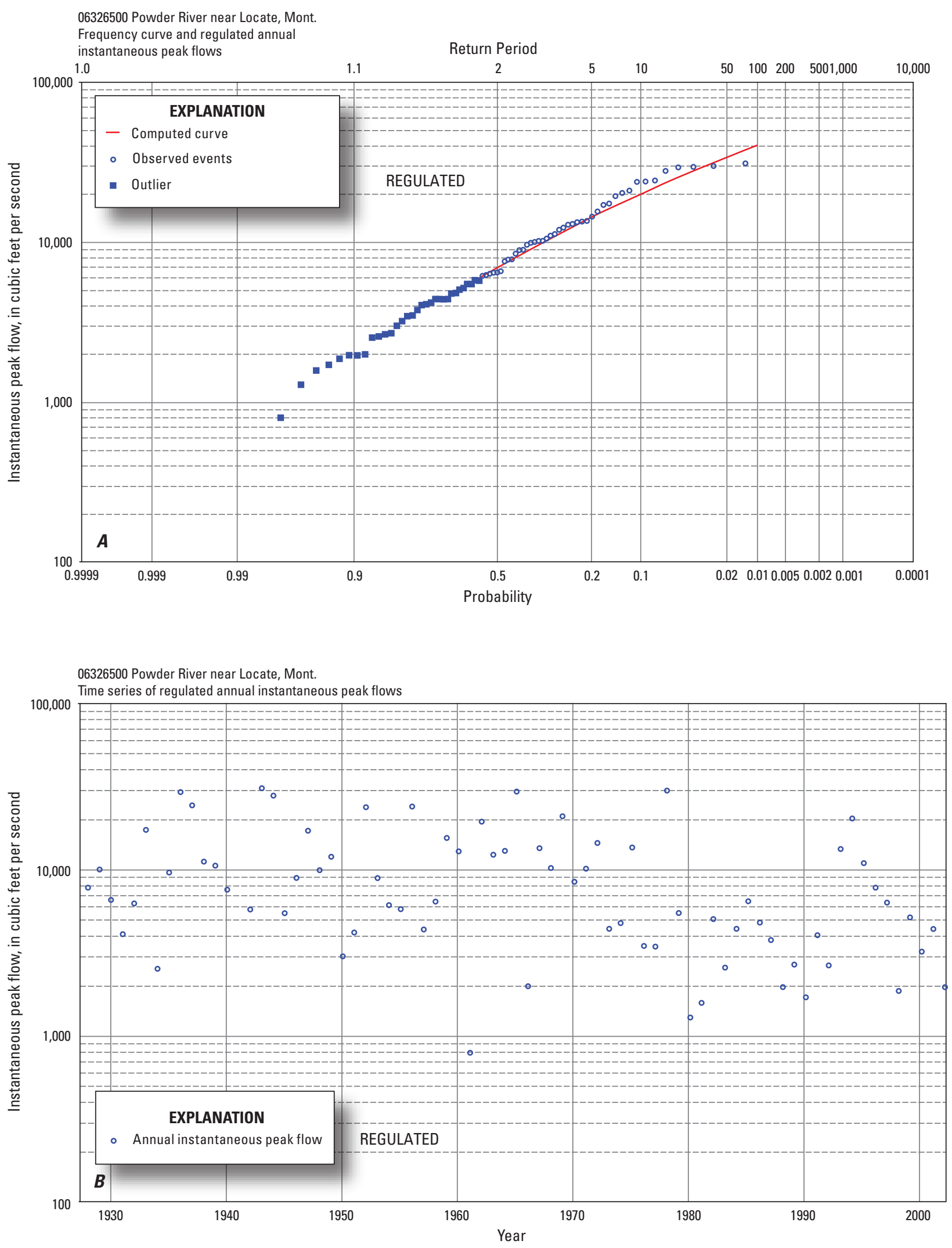

Figure 2-6-2. Annual instantaneous peak-flow data for streamflow-gaging station 06326500 (Powder River near Locate, Mont.) for regulated conditions, 1928-2002. A, Frequency curve and regulated annual instantaneous peak flows. $B$, Time series of regulated annual instantaneous peak flows. [Bulletin 17B: U.S. Interagency Advisory Council on Water Data, 1982] 


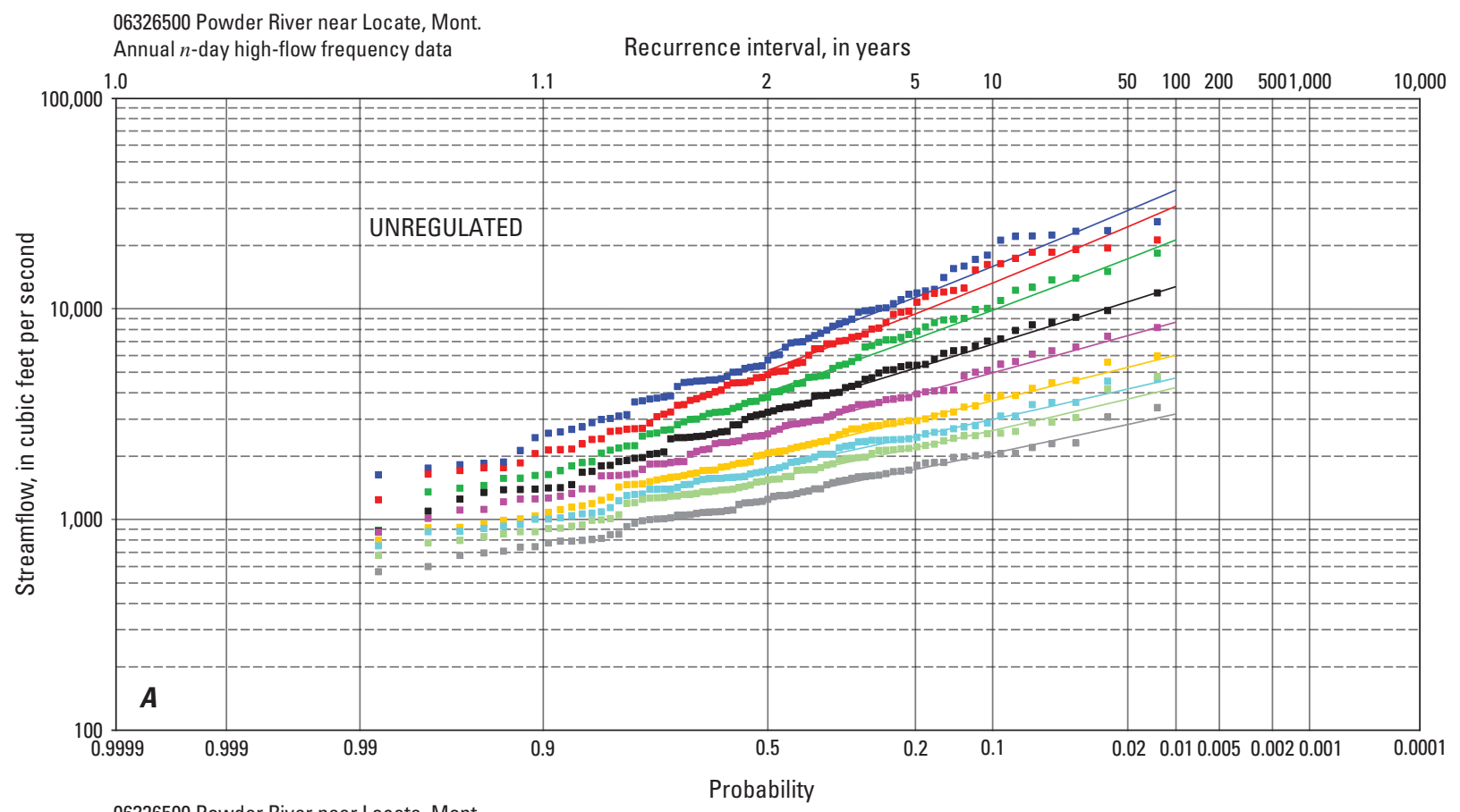

06326500 Powder River near Locate, Mont.

Recurrence interval, in years

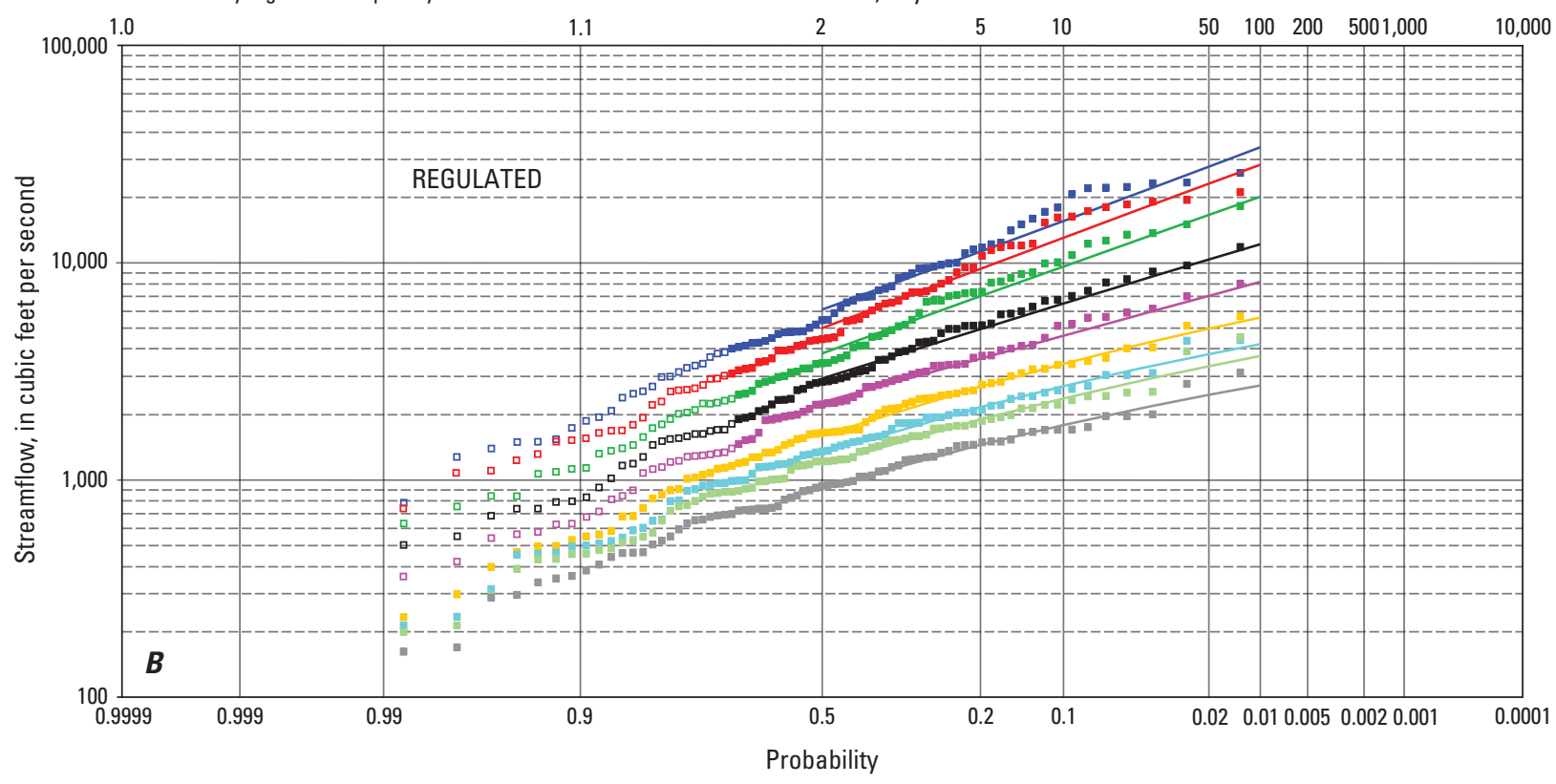

EXPLANATION
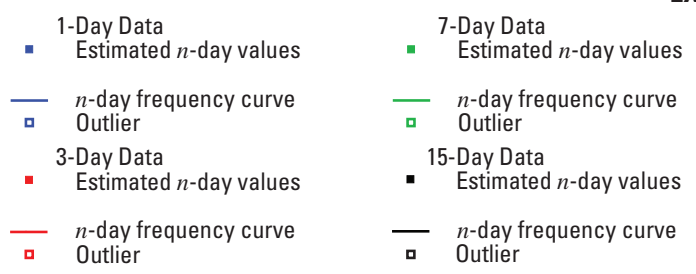

\begin{tabular}{c} 
30-Day Data \\
Estimated $n$-day values \\
\hline - $\quad$-day frequency curve \\
Outlier \\
60-Day Data \\
Estimated $n$-day values \\
$n$-day frequency curve
\end{tabular}

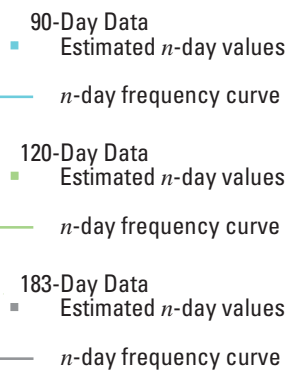

Figure 2-6-3. Annual $n$-day high-flow frequency data for streamflow-gaging station 06326500 (Powder River near Locate, Mont.) for $A$, unregulated and $B$, regulated conditions, 1928-2002. 

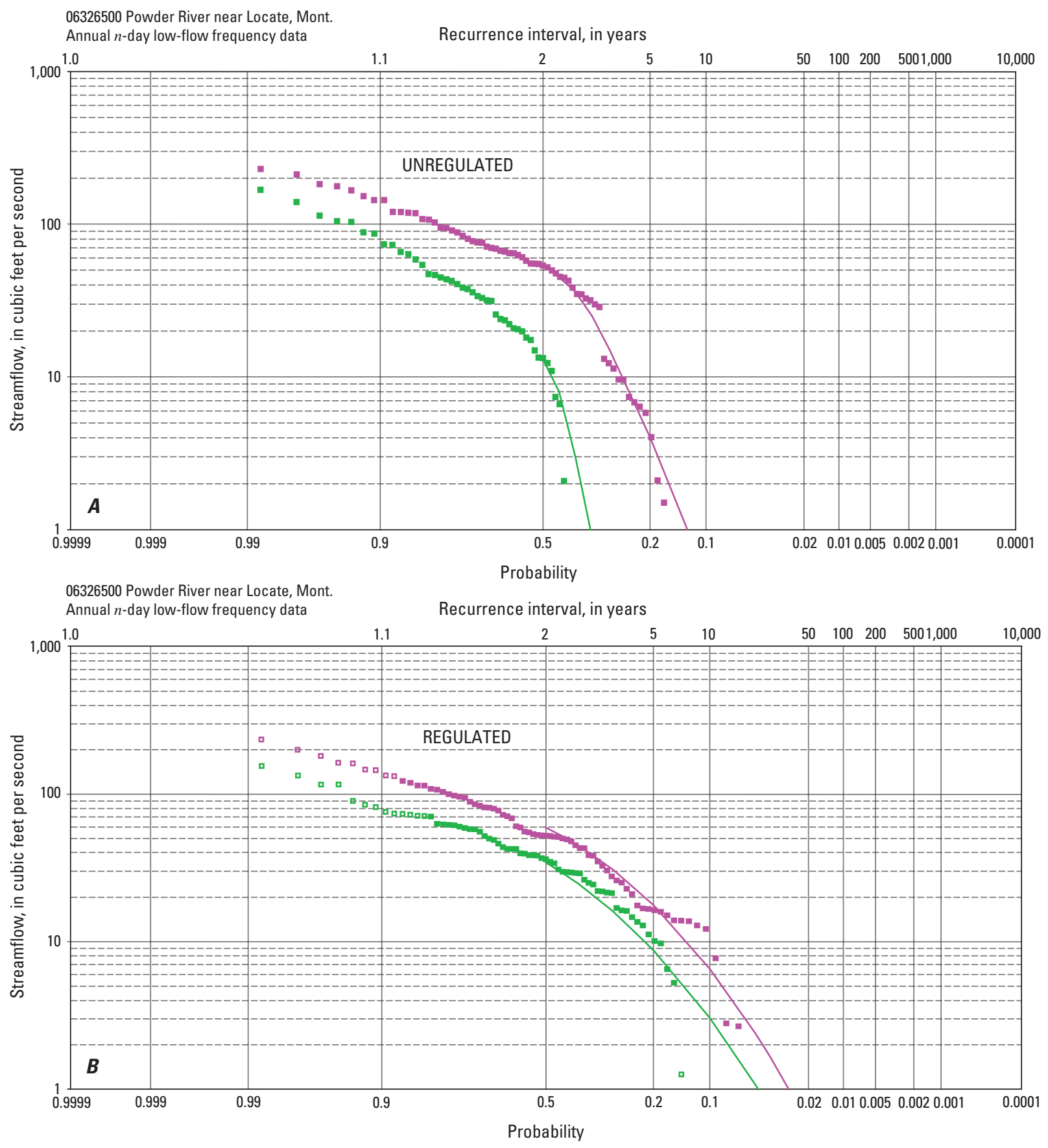

EXPLANATION
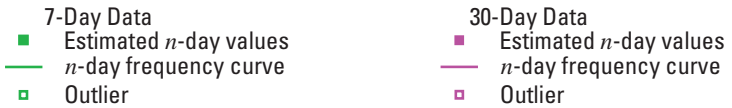

Figure 2-6-4. Annual $n$-day low-flow frequency data for streamflow-gaging station 06326500 (Powder River near Locate, Mont.) for $A$, unregulated and $B$, regulated conditions, 1928-2002. 
06326500 Powder River near Locate, Mont

Winter (January-March) $n$-day low-flow frequency data Recurrence interval, in years

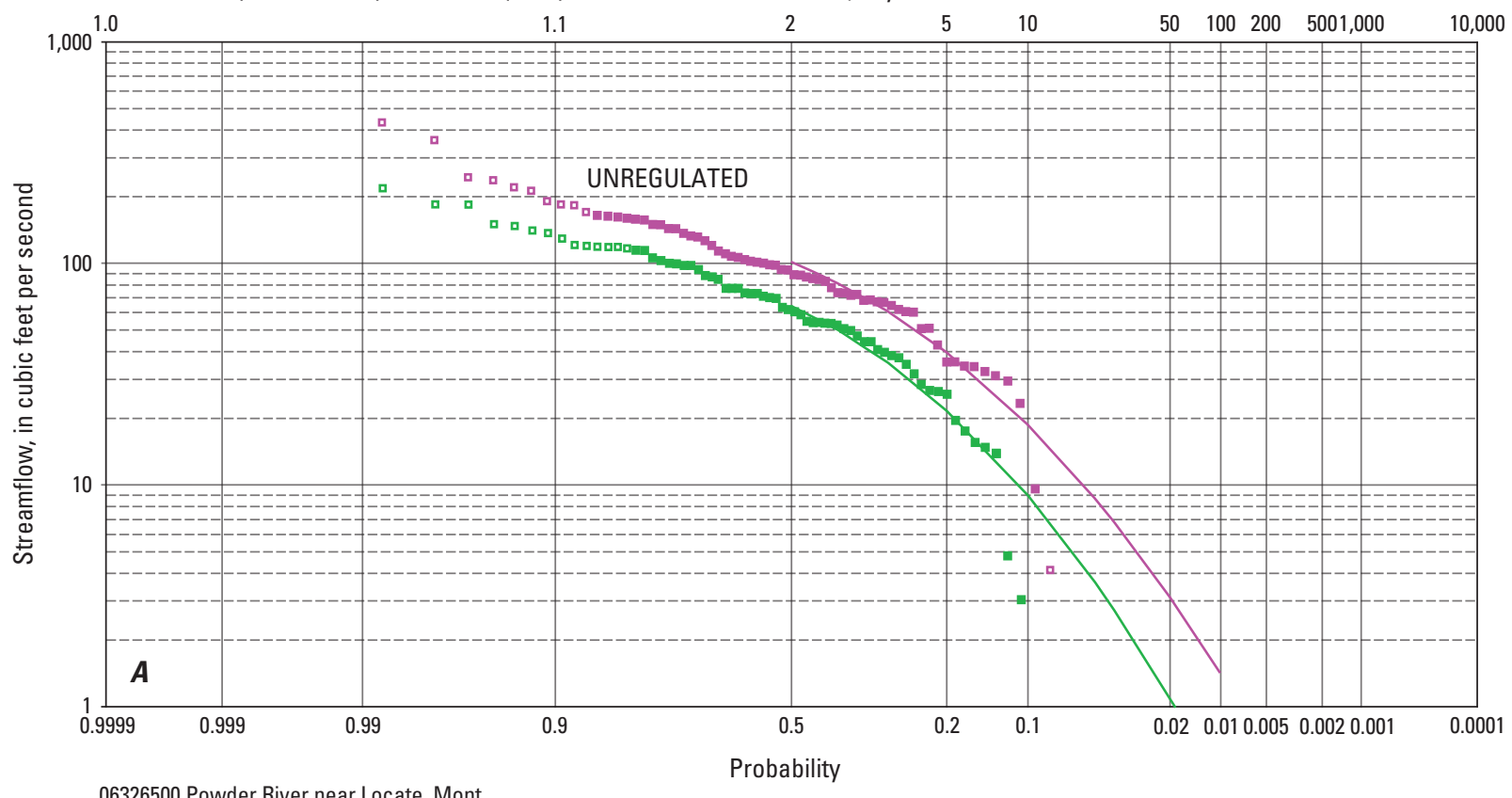

06326500 Powder River near Locate, Mont

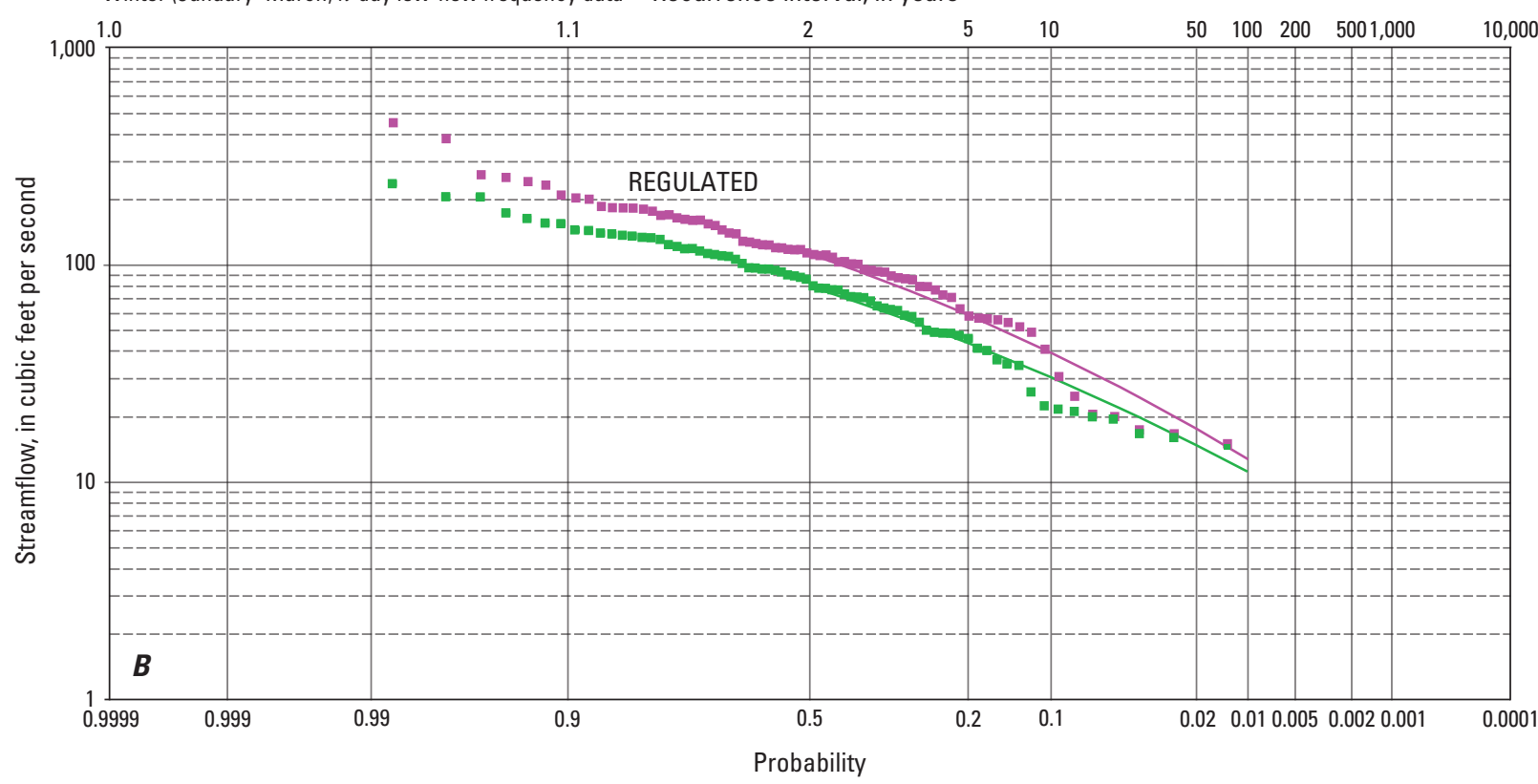

EXPLANATION

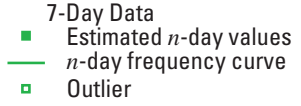

30-Day Data
Estimated $n$-day values
$n$-day frequency curve
Outlier

Figure 2-6-5. Winter (January-March) $n$-day low-flow frequency data for streamflow-gaging station 06326500 (Powder River near Locate, Mont.) for $A$, unregulated and $B$, regulated conditions, 1928-2002. 


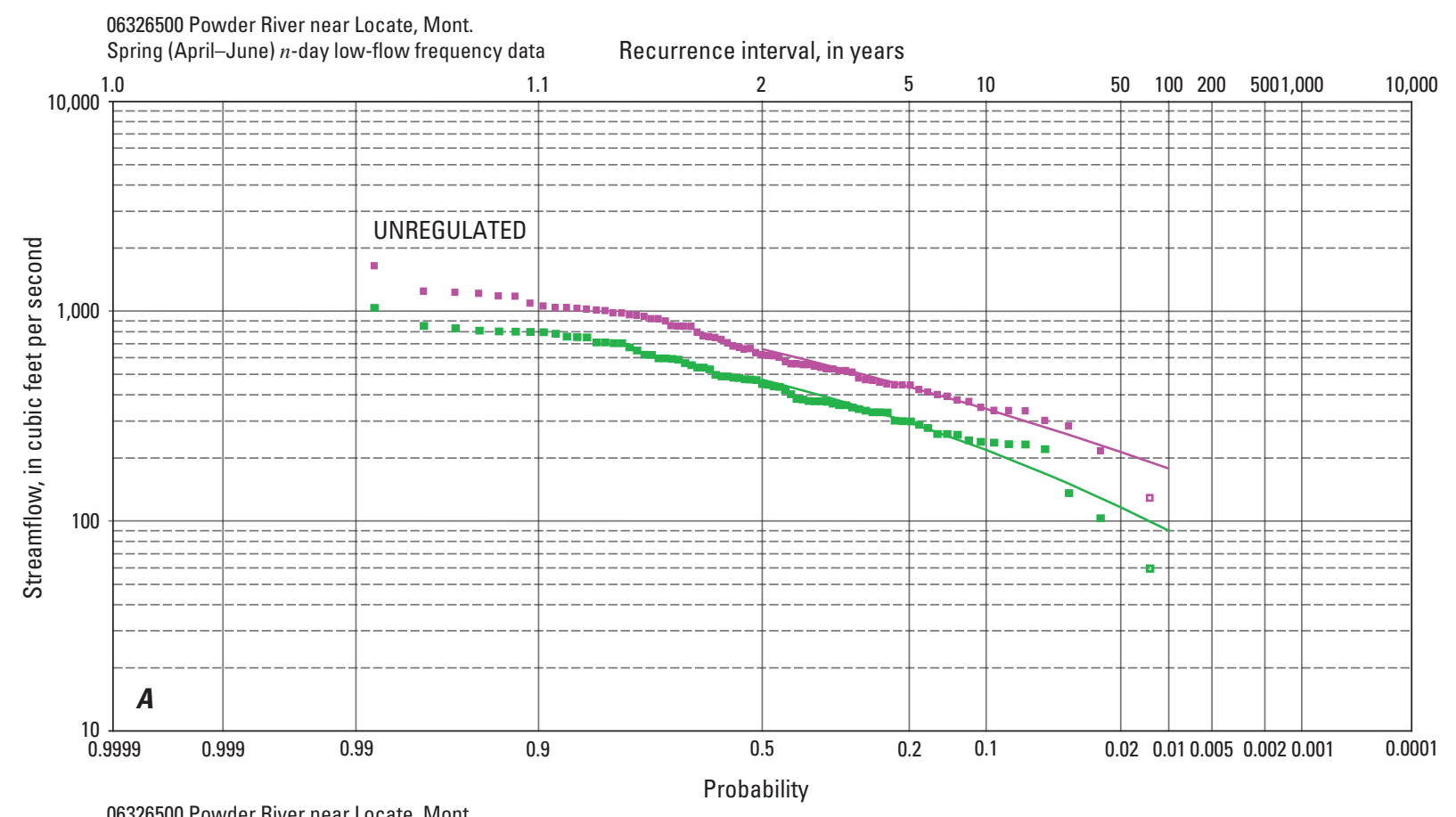

06326500 Powder River near Locate, Mont.

Spring (April-June) $n$-day low-flow frequency data Recurrence interval, in years

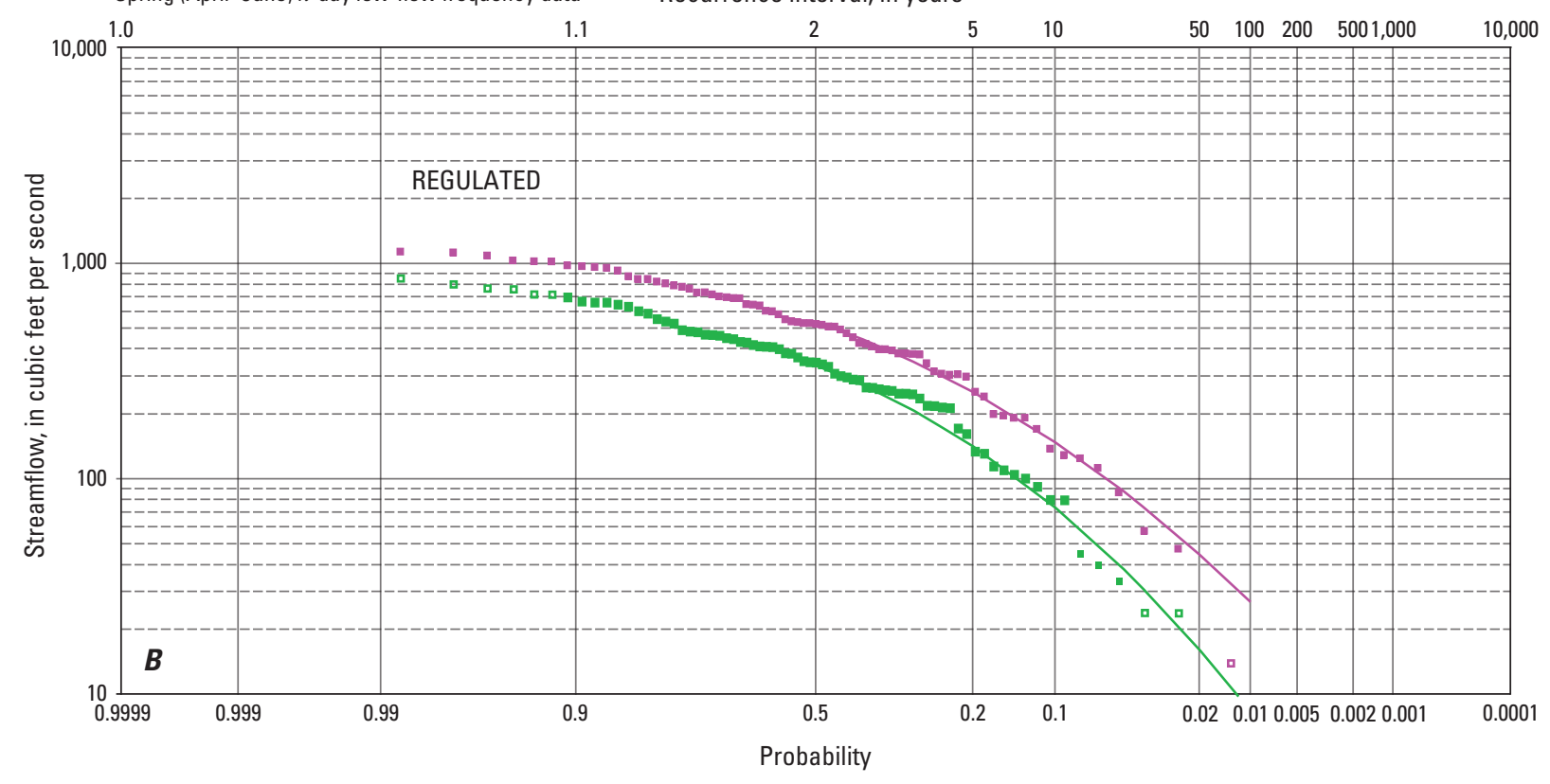

EXPLANATION
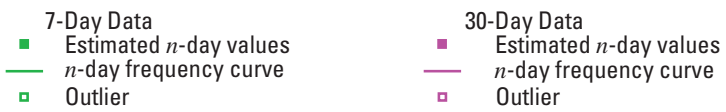

Figure 2-6-6. Spring (April-June) n-day low-flow frequency data for streamflow-gaging station 06326500 (Powder River near Locate, Mont.) for $A$, unregulated and $B$, regulated conditions, 1928-2002. 

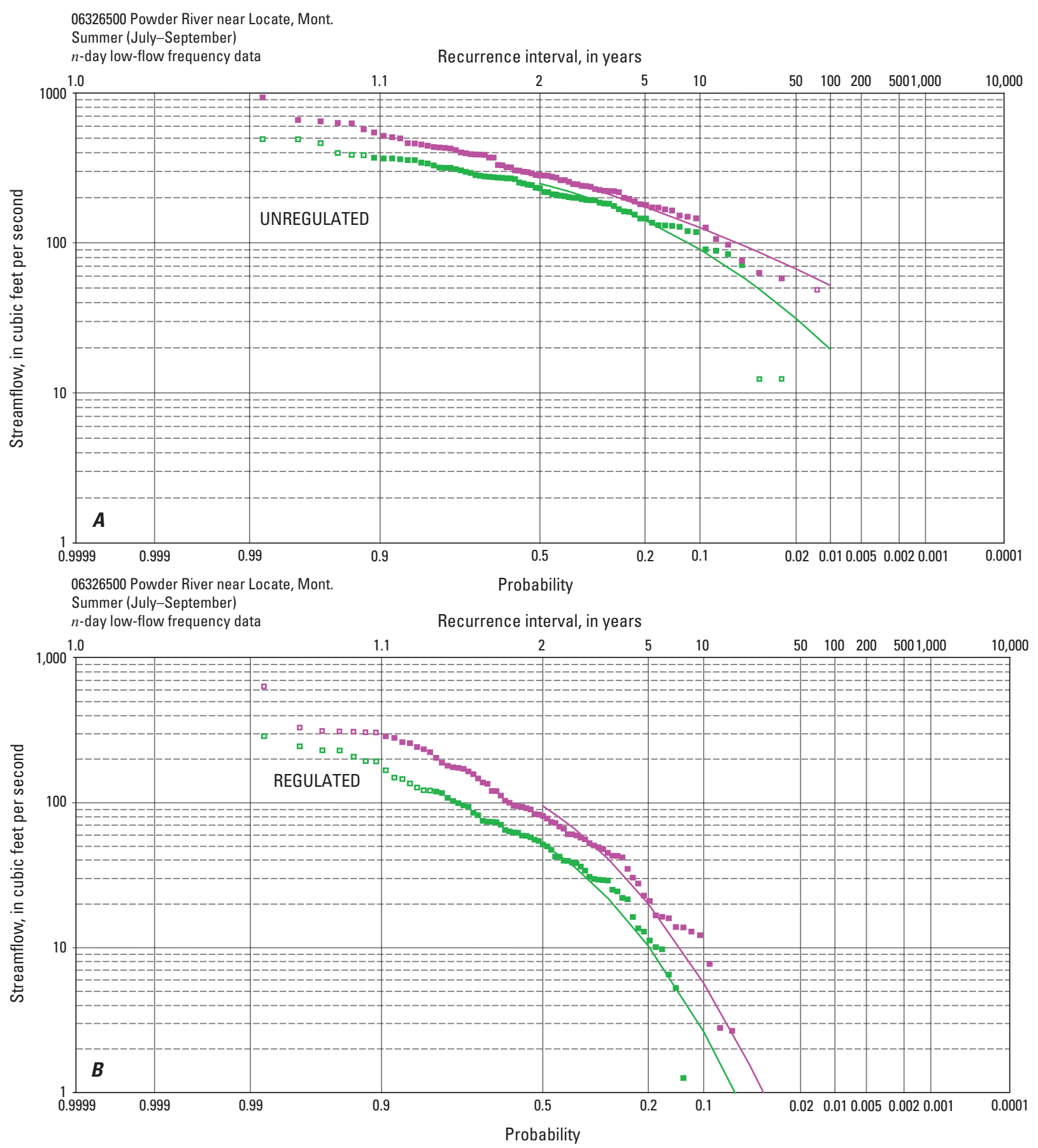

EXPLANATION

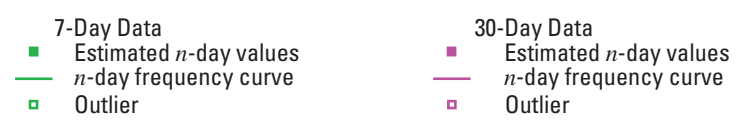

Figure 2-6-7. Summer (July-September) $n$-day low-flow frequency data for streamflow-gaging station 06326500 (Powder River near Locate, Mont.) for $A$, unregulated and $B$, regulated and regulated conditions, 1928-2002. 


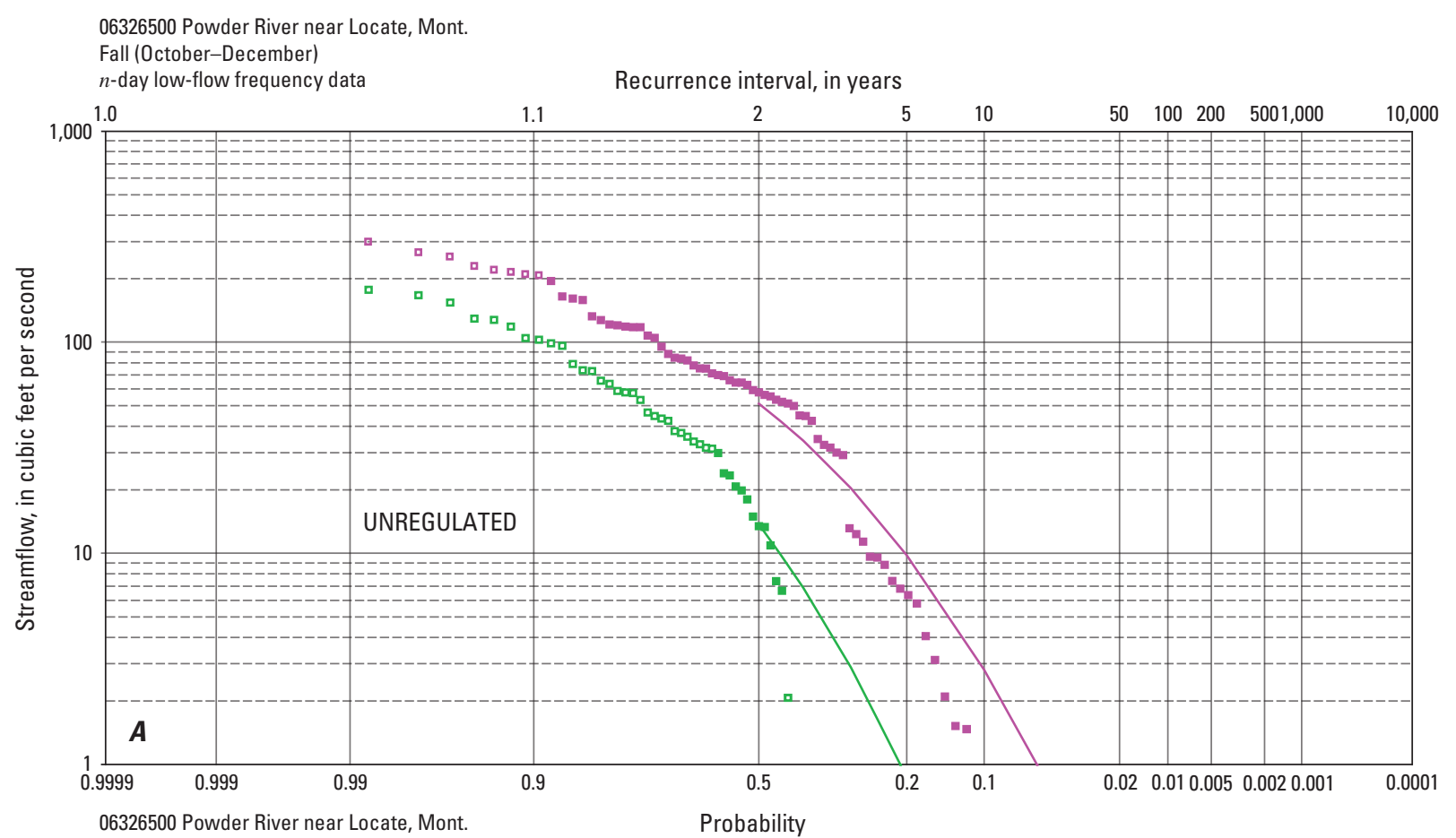

Fall (October-December)

$n$-day low-flow frequency data Recurrence interval, in years

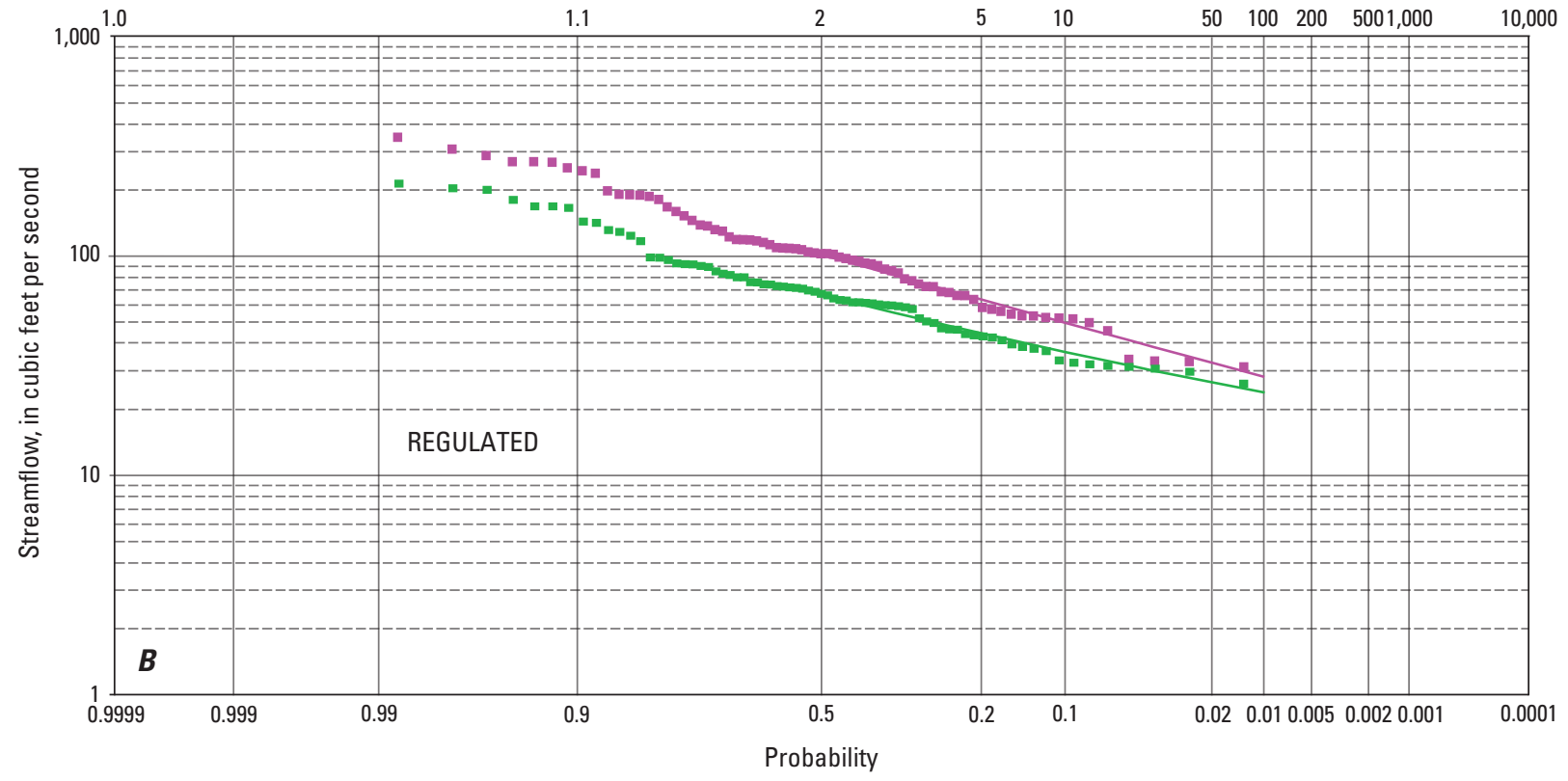

EXPLANATION

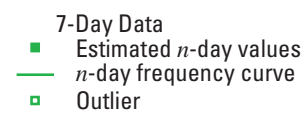

30-Day Data

- Estimated $n$-day values

- n-day frequency curve

- n-day frequency curve

Figure 2-6-8. Fall (October-December) $n$-day low-flow frequency data for streamflow-gaging station 06326500 (Powder River near Locate, Mont.) for $A$, unregulated and $B$, regulated conditions, 1928-2002. 


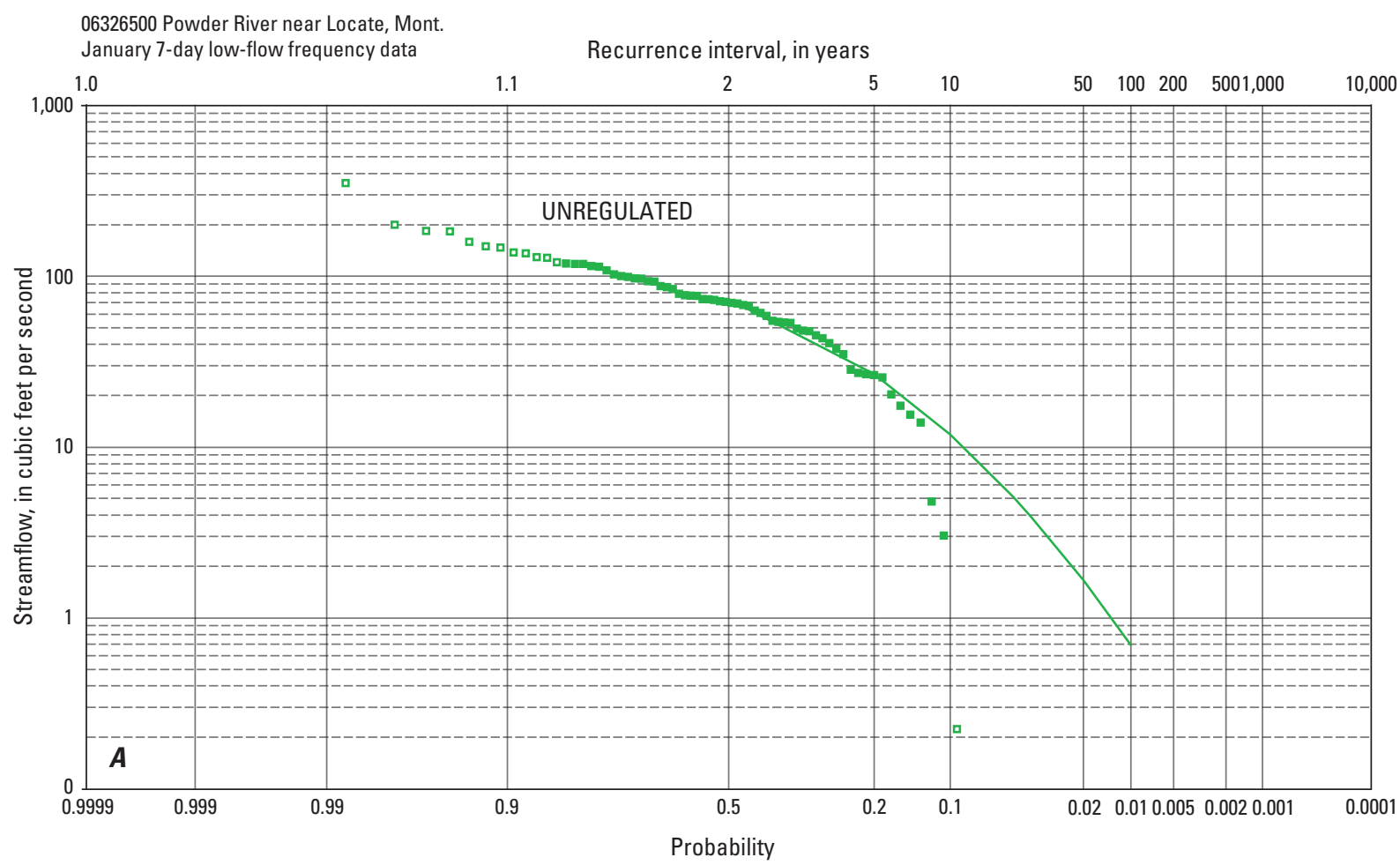

06326500 Powder River near Locate, Mont January 7-day low-flow frequency data

Recurrence interval, in years

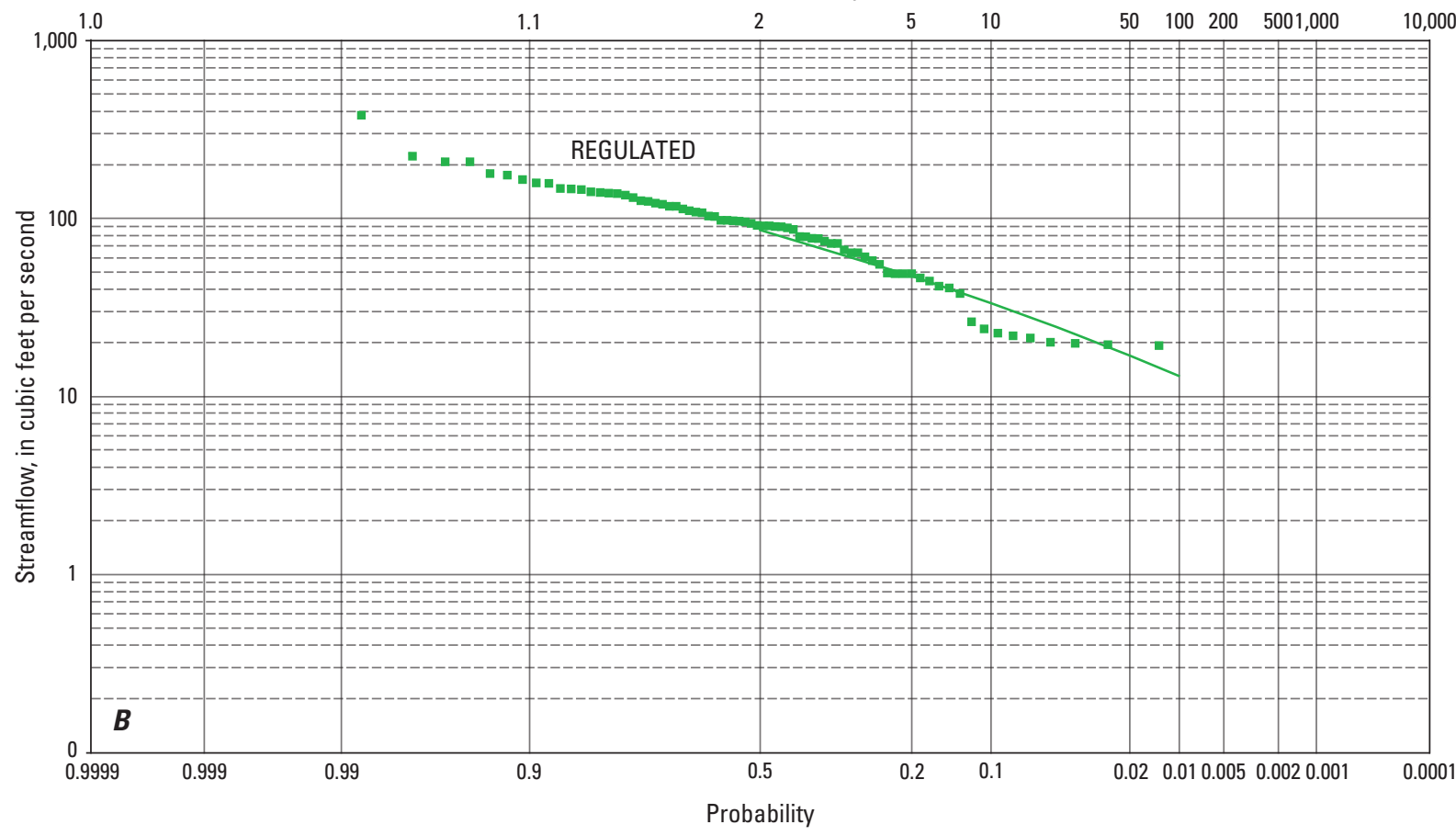

EXPLANATION

7-Day Data

- Estimated $n$-day values

- $n$-day frequency curve

口 Outlier

Figure 2-6-9. January 7-day low-flow frequency data for streamflow-gaging station 06326500 (Powder River near Locate, Mont.) for $A$, unregulated and $B$, regulated conditions, 1928-2002. 

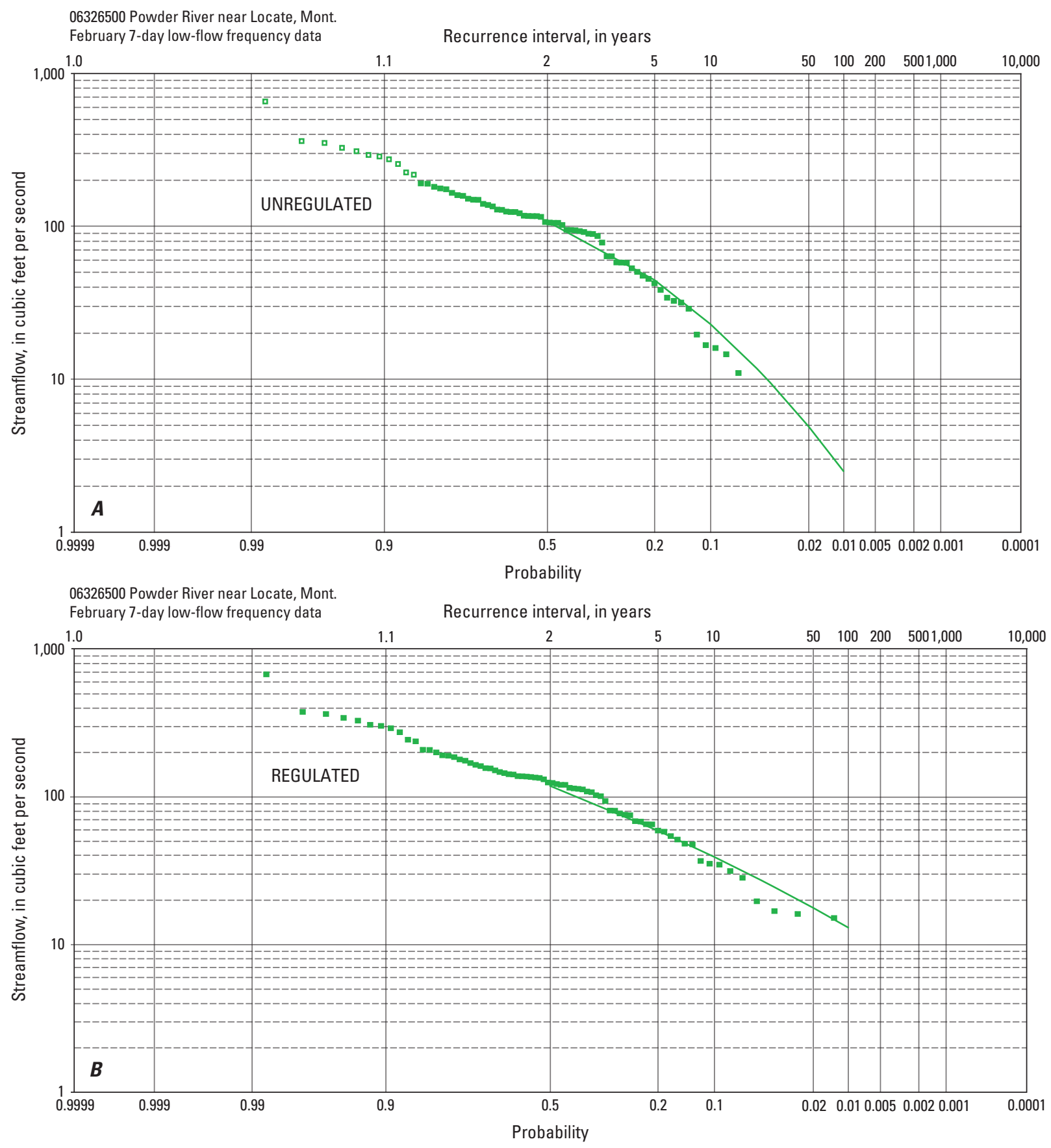

EXPLANATION

7-Day Data

- Estimated $n$-day values

$n$-day frequency curve

- Outlier

Figure 2-6-10. February 7-day low-flow frequency data for streamflow-gaging station 06326500 (Powder River near Locate, Mont.) for $A$, unregulated and $B$, regulated conditions, 1928-2002. 

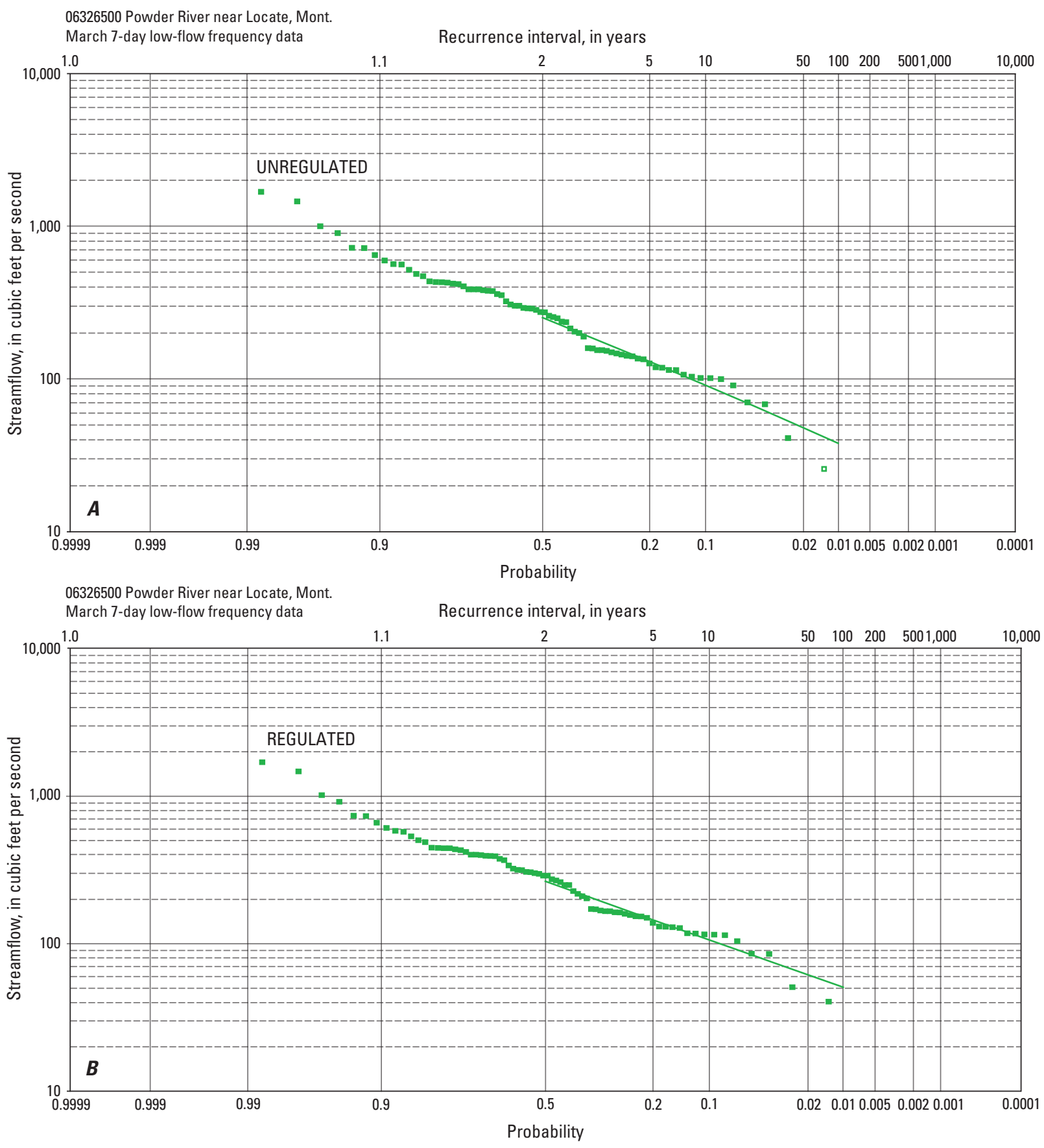

EXPLANATION

7-Day Data

- Estimated $n$-day values

$n$-day frequency curve

口 Outlier

Figure 2-6-11. March 7-day low-flow frequency data for streamflow-gaging station 06326500 (Powder River near Locate, Mont.) for $A$, unregulated and $B$, regulated conditions, 1928-2002. 

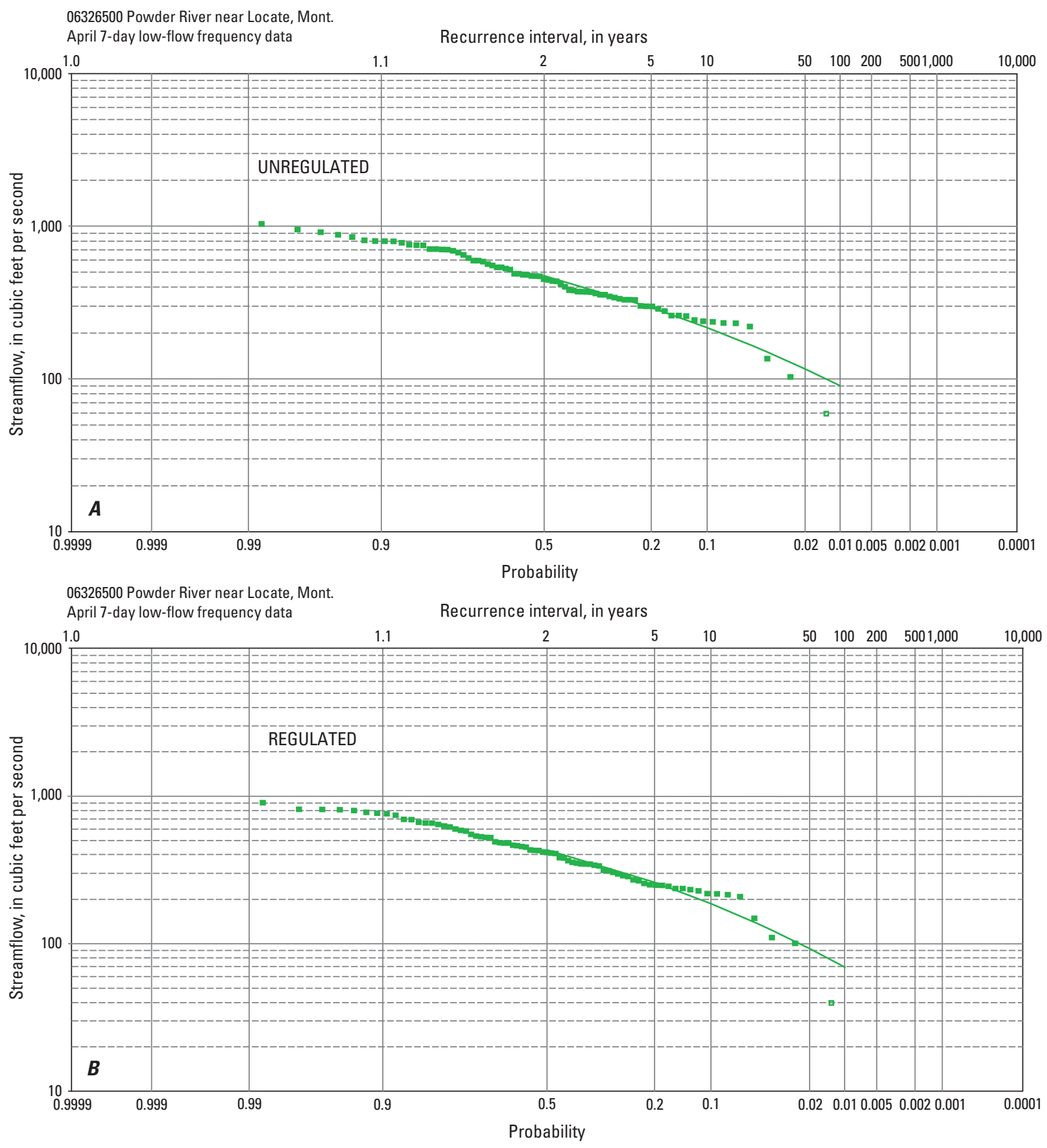

EXPLANATION

7-Day Data

- Estimated $n$-day values

n-day frequency curve

- Outlier

Figure 2-6-12. April 7-day low-flow frequency data for streamflow-gaging station 06326500 (Powder River near Locate, Mont.) for $A$, unregulated and $B$, regulated conditions, 1928-2002. 

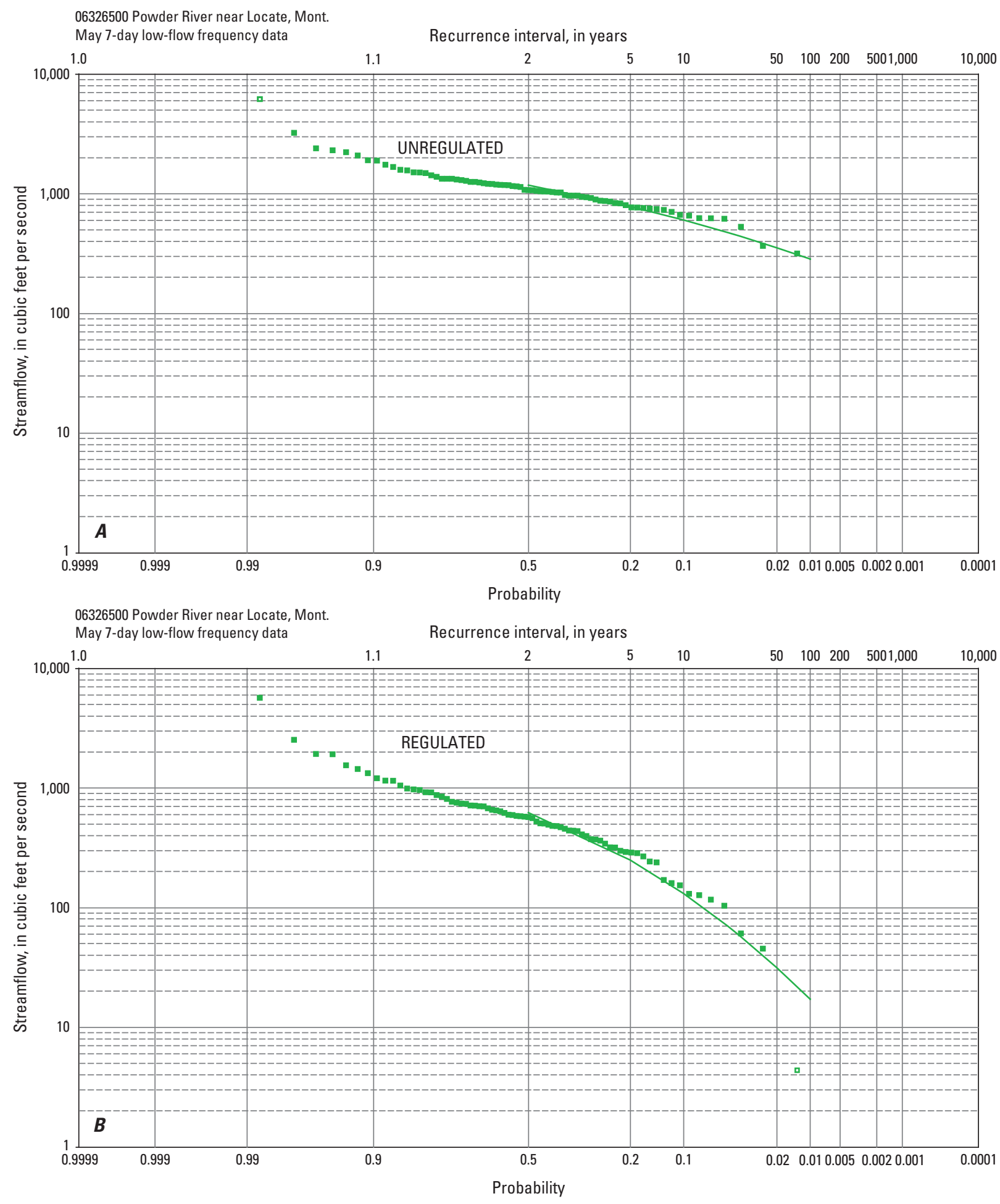

EXPLANATION

7-Day Data

- Estimated $n$-day values

- n-day frequency curve

- Outlier

Figure 2-6-13. May 7-day low-flow frequency data for streamflow-gaging station 06326500 (Powder River near Locate, Mont.) for $A$, unregulated and $B$, regulated conditions, 1928-2002. 

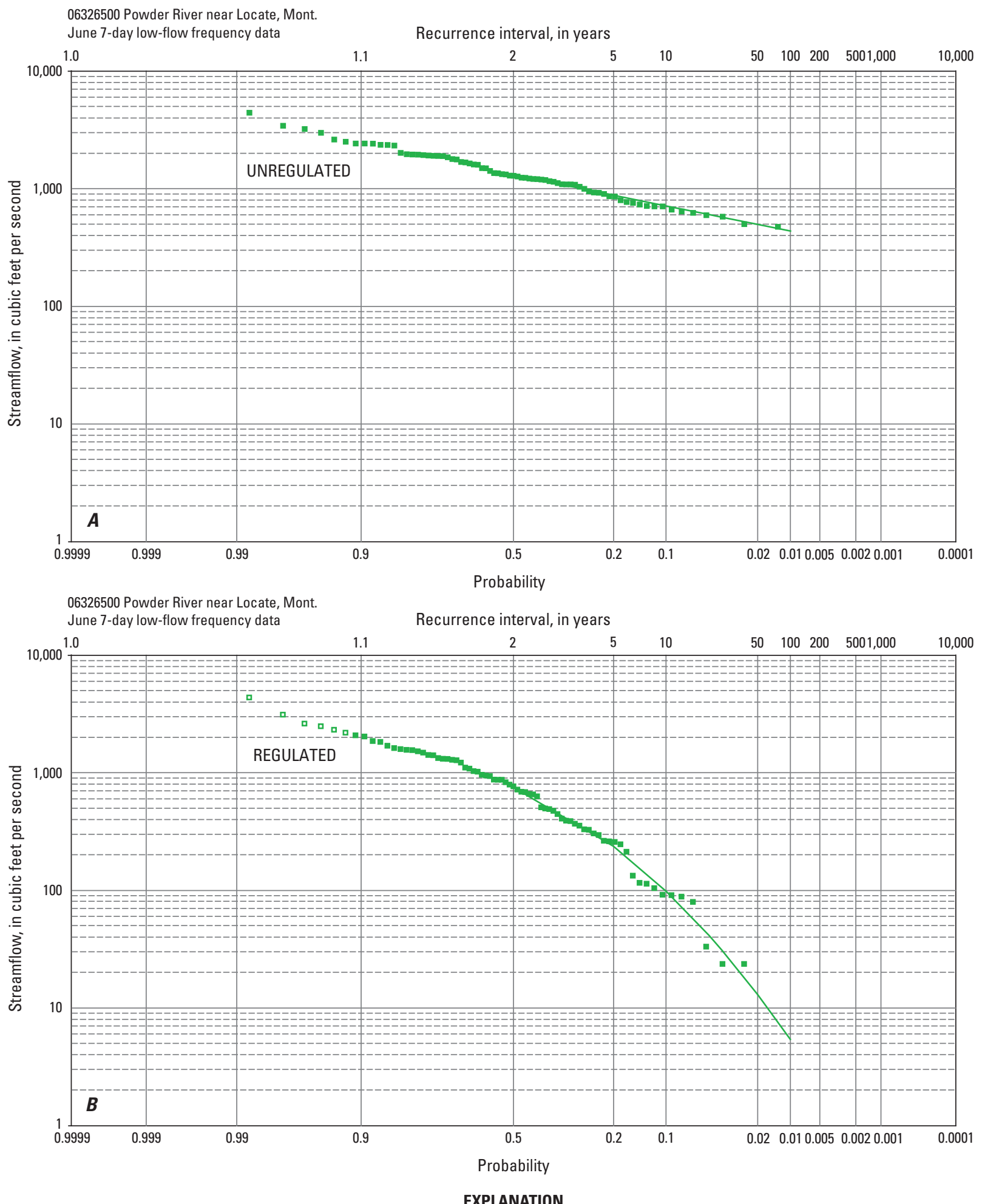

EXPLANATION

7-Day Data

- Estimated $n$-day values

- n-day frequency curve

- Outlier

Figure 2-6-14. June 7-day low-flow frequency data for streamflow-gaging station 06326500 (Powder River near Locate, Mont.) for $A$, unregulated and $B$, regulated conditions, 1928-2002. 

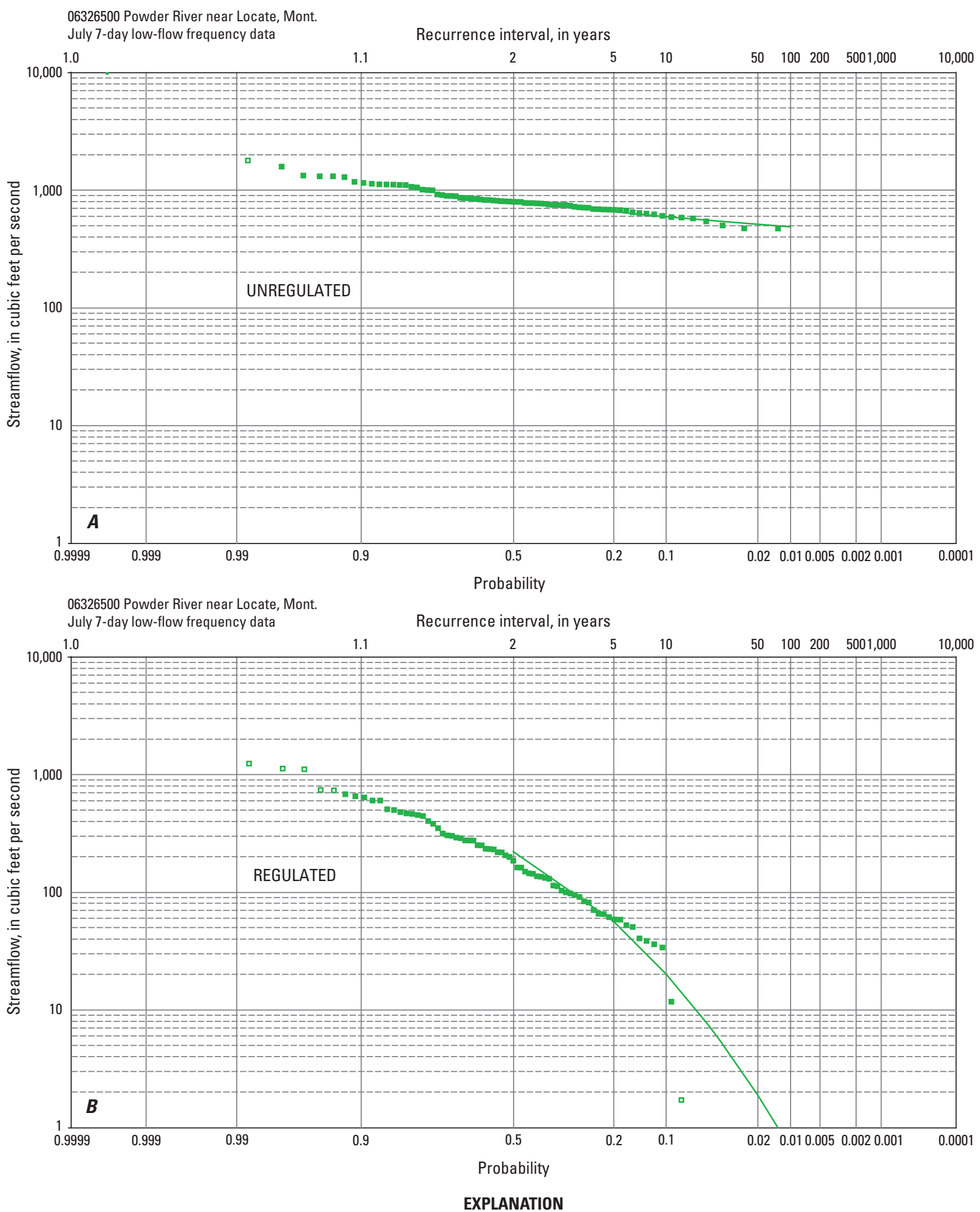

EXPLANATION

7-Day Data

- Estimated $n$-day values

- $n$-day frequency curve

- Outlier

Figure 2-6-15. July 7-day low-flow frequency data for streamflow-gaging station 06326500 (Powder River near Locate, Mont.) for $A$, unregulated and $B$, regulated conditions, 1928-2002. 

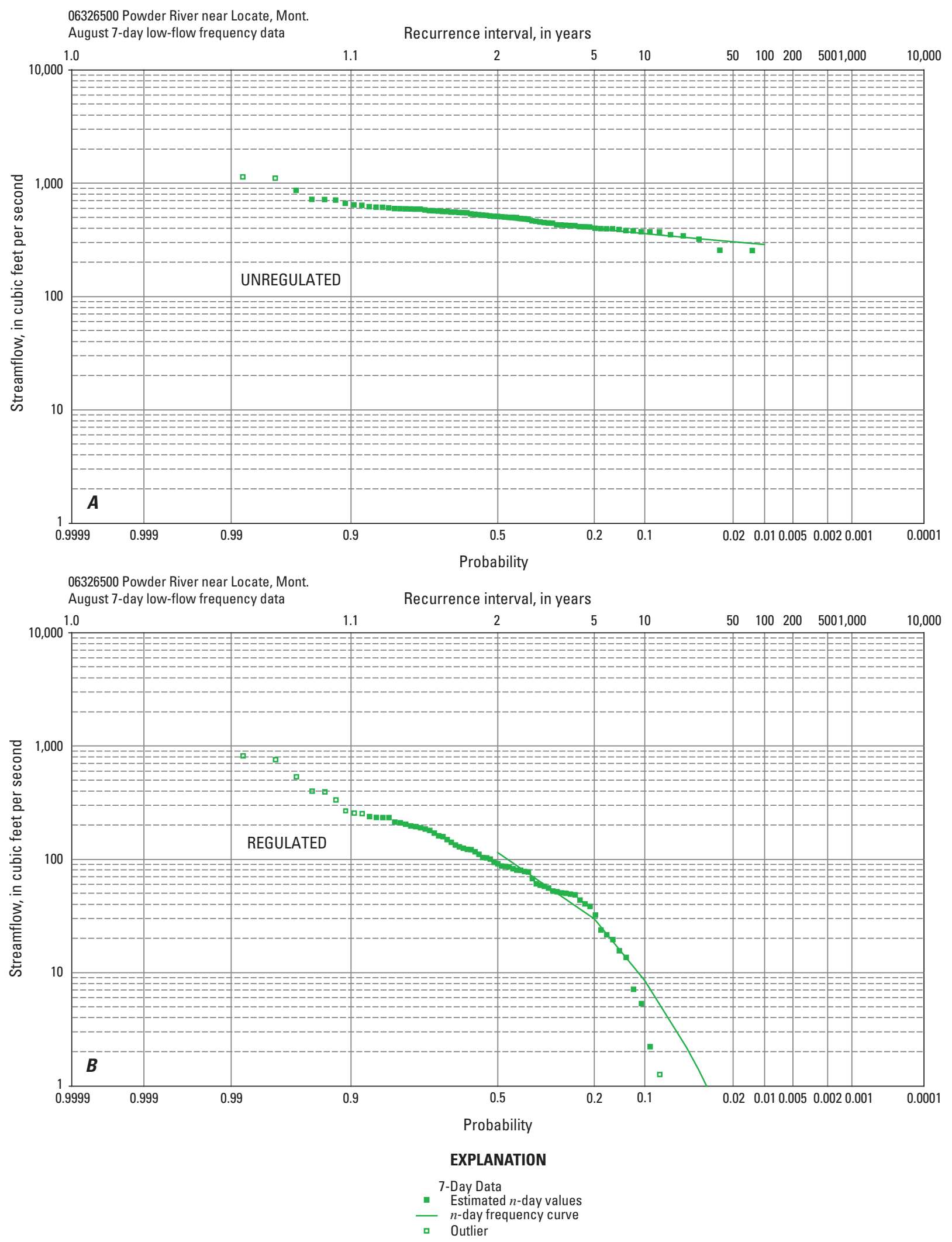

Figure 2-6-16. August 7-day low-flow frequency data for streamflow-gaging station 06326500 (Powder River near Locate, Mont.) for $A$, unregulated and $B$, regulated conditions, 1928-2002. 

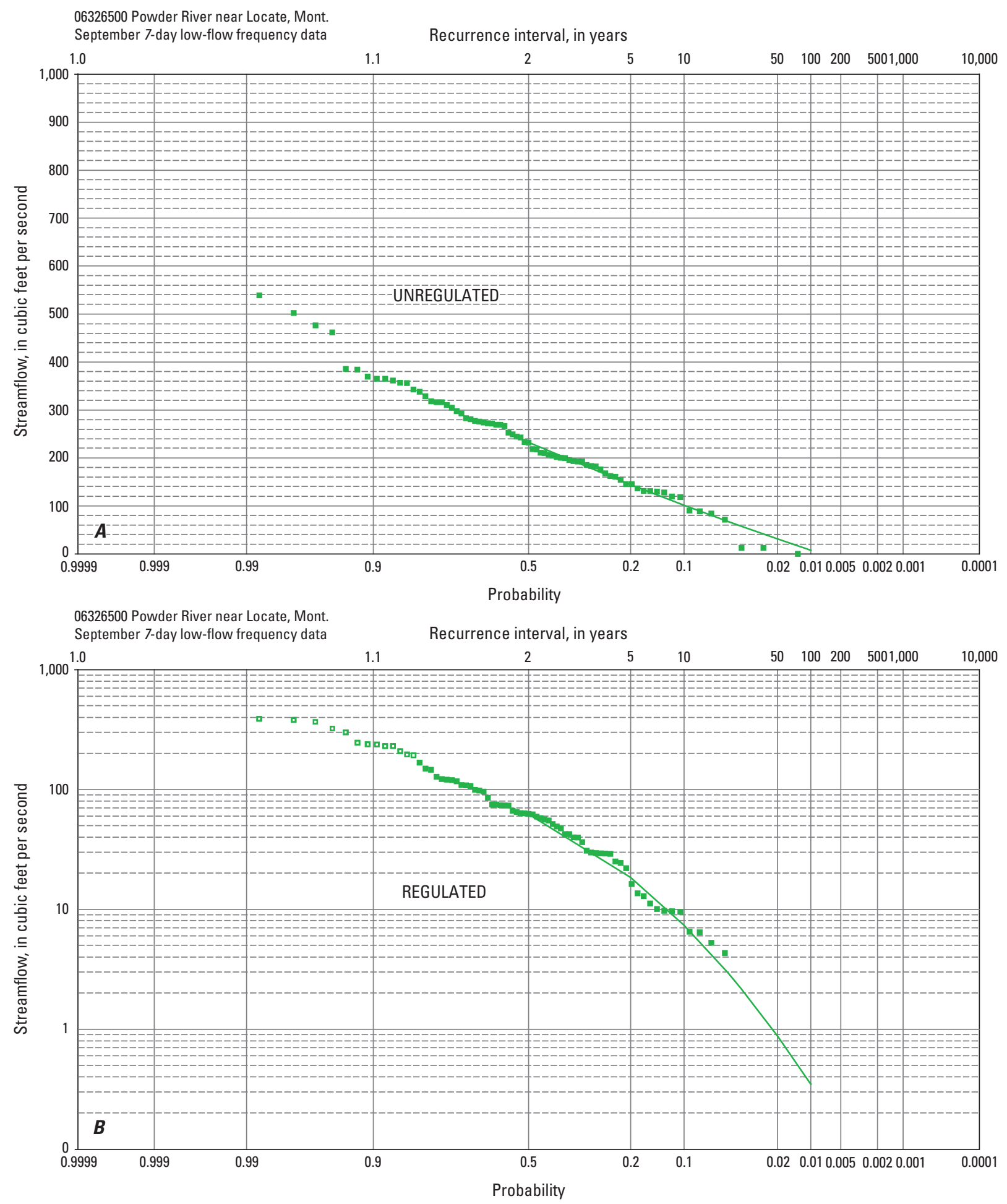

EXPLANATION

7-Day Data

- Estimated $n$-day values

- $n$-day frequency curve

Dutlier

Figure 2-6-17. September 7-day low-flow frequency data for streamflow-gaging station 06326500 (Powder River near Locate, Mont.) for $A$, unregulated and $B$, regulated conditions, 1928-2002. 


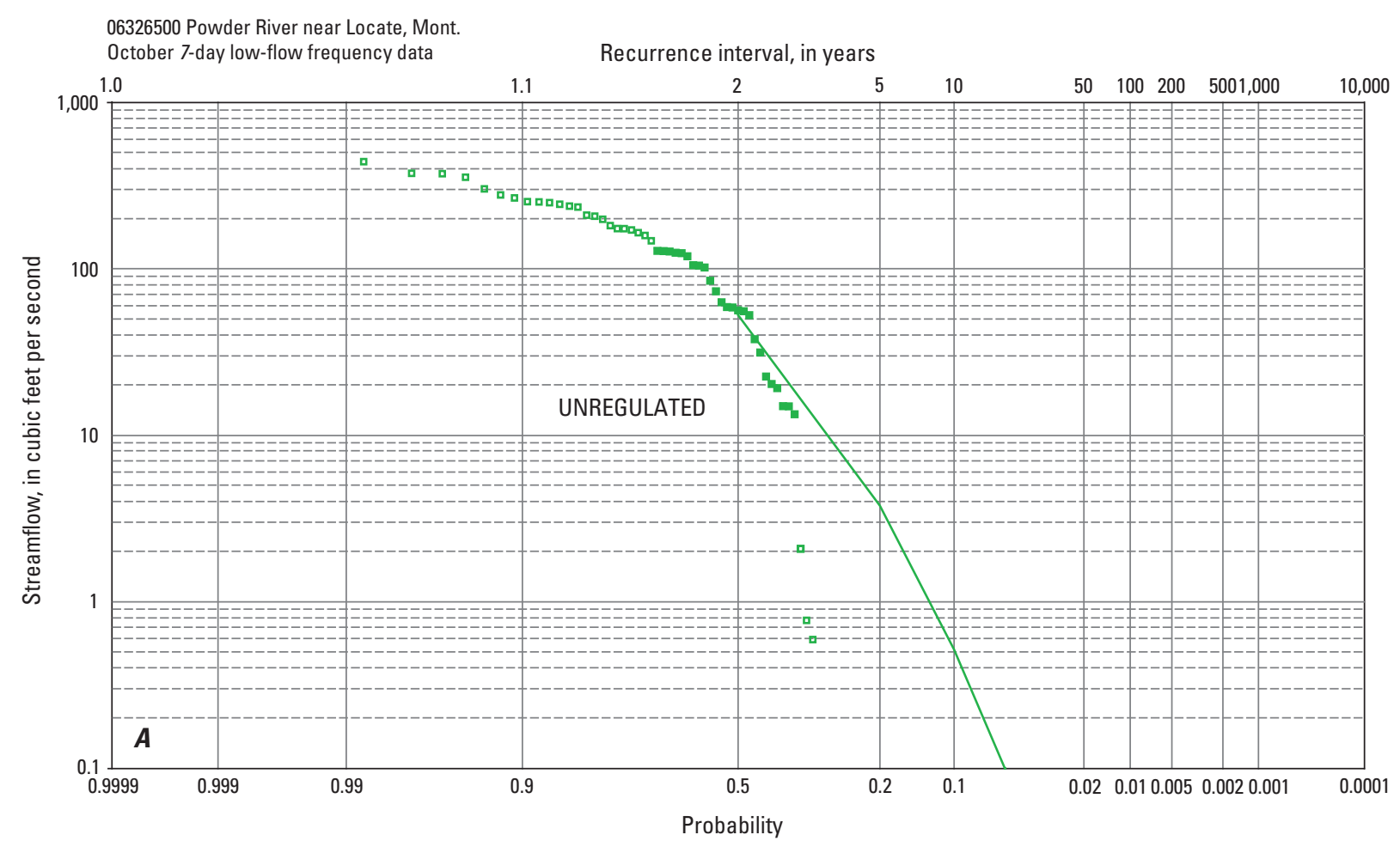

06326500 Powder River near Locate, Mont. October 7-day low-flow frequency data

Recurrence interval, in years

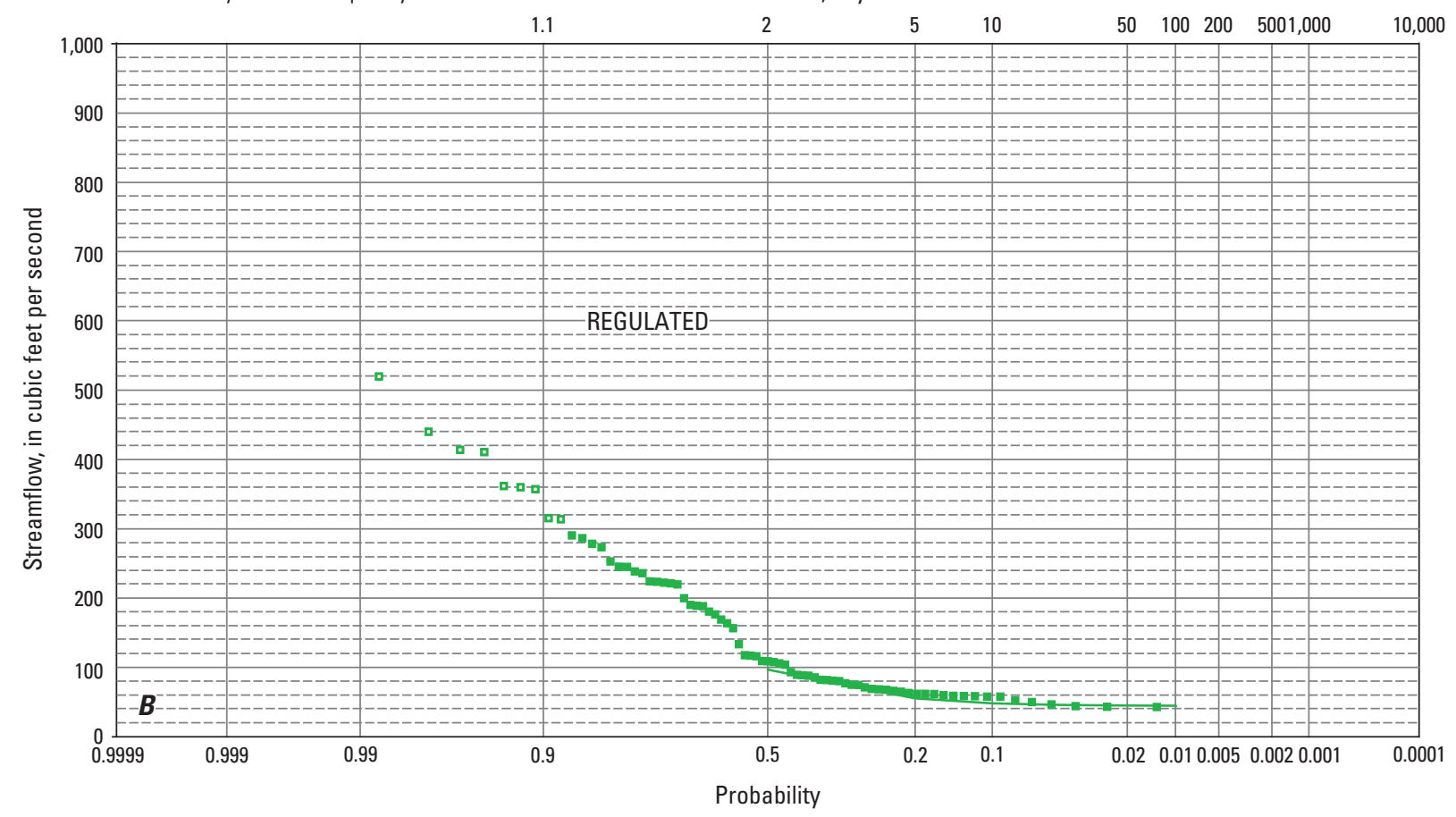

EXPLANATION

7-Day Data

- Estimated $n$-day values

- n-day frequency curve

- Outlier

Figure 2-6-18. October 7-day low-flow frequency data for streamflow-gaging station 06326500 (Powder River near Locate, Mont.) for $A$, unregulated and $B$, regulated conditions, 1928-2002. 


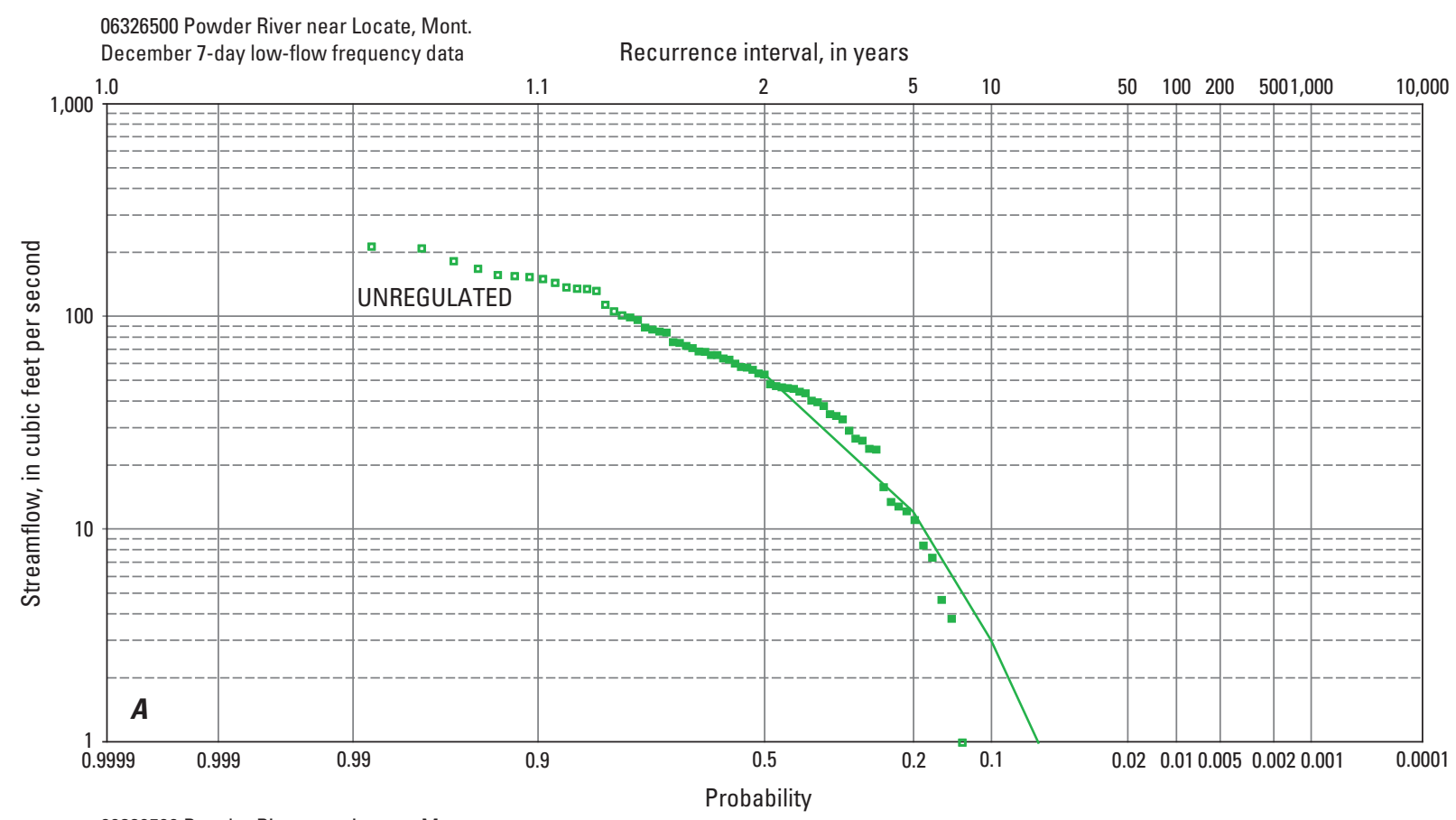

06326500 Powder River near Locate, Mont. December 7-day low-flow frequency data

Recurrence interval, in years

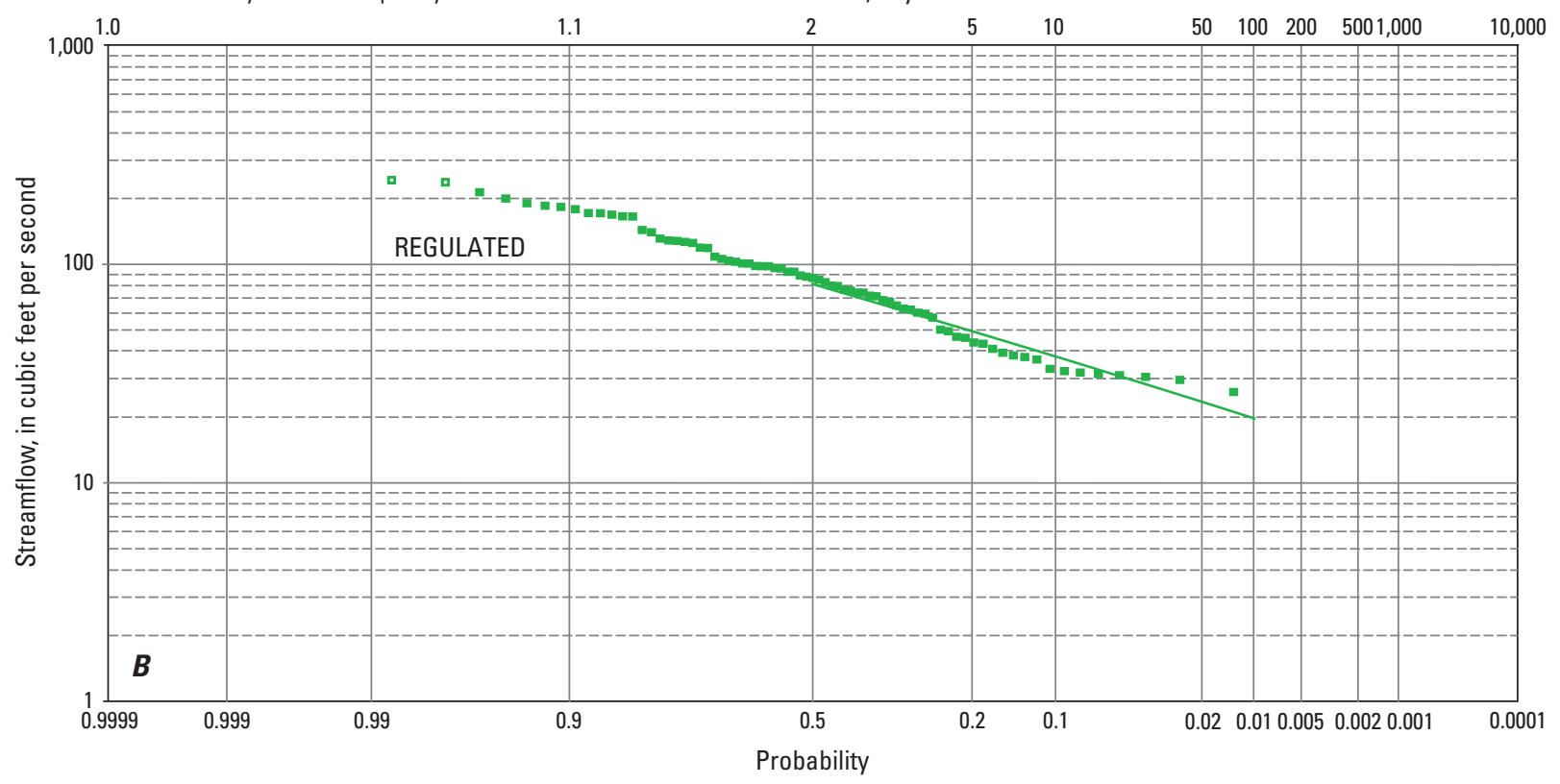

EXPLANATION

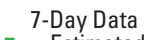

- Estimated $n$-day values

- n-day frequency curve

Outlier

Figure 2-6-19. Novmeber 7-day low-flow frequency data for streamflow-gaging station 06326500 (Powder River near Locate, Mont.) for $A$, unregulated and $B$, regulated conditions, 1928-2002. 

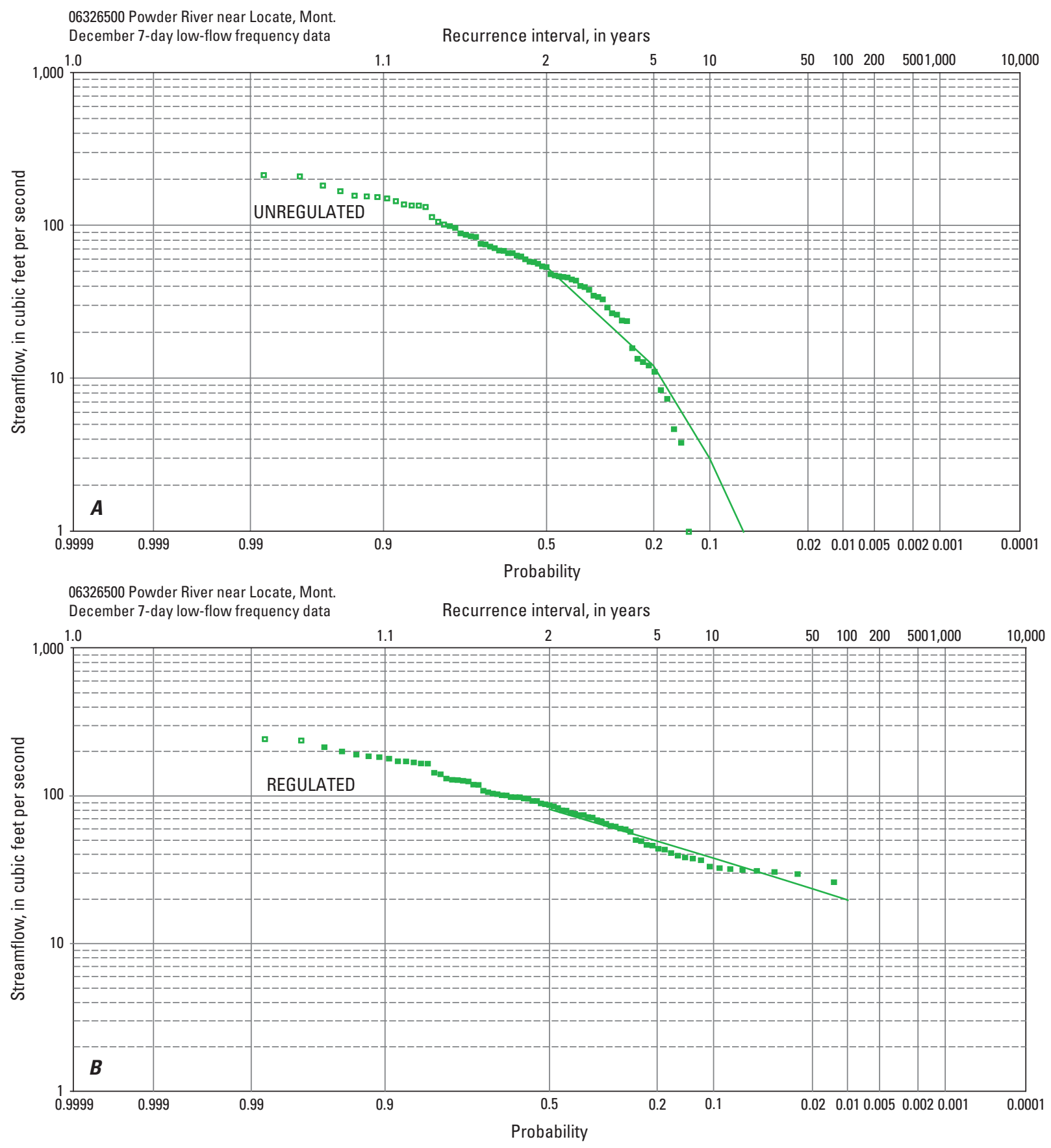

EXPLANATION

7-Day Data

- Estimated $n$-day values

- $n$-day frequency curve

Outlier

Figure 2-6-20. December 7-day low-flow frequency data for streamflow-gaging station 06326500 (Powder River near Locate, Mont.) for $A$, unregulated and $B$, regulated conditions, 1928-2002. 
06326500 Powder River near Locate, Mont.

Annual flow-duration data for unregulated and regulated streamflow conditions

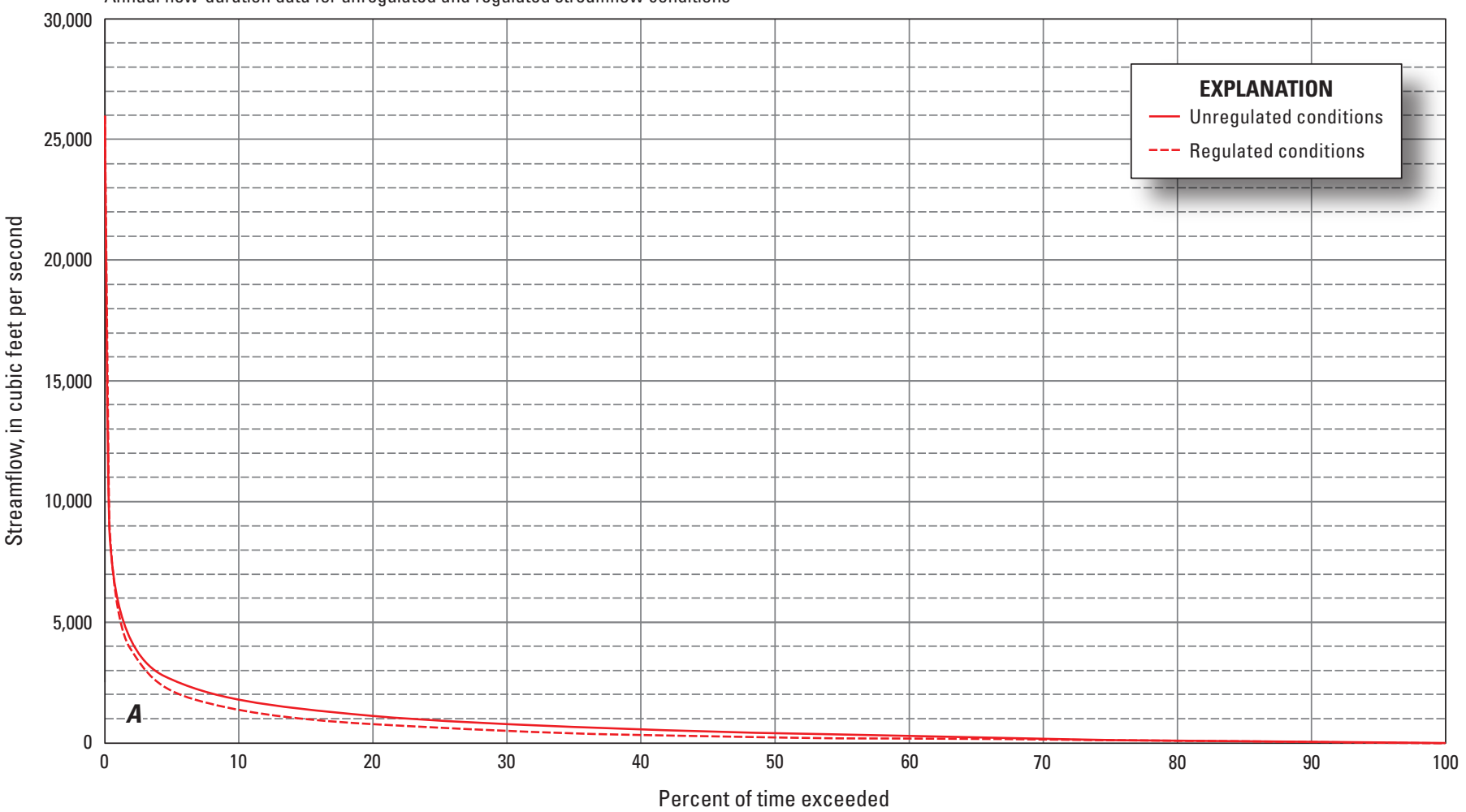

06326500 Powder River near Locate, Mont.

Seasonal flow-duration data for unregulated and regulated streamflow conditions

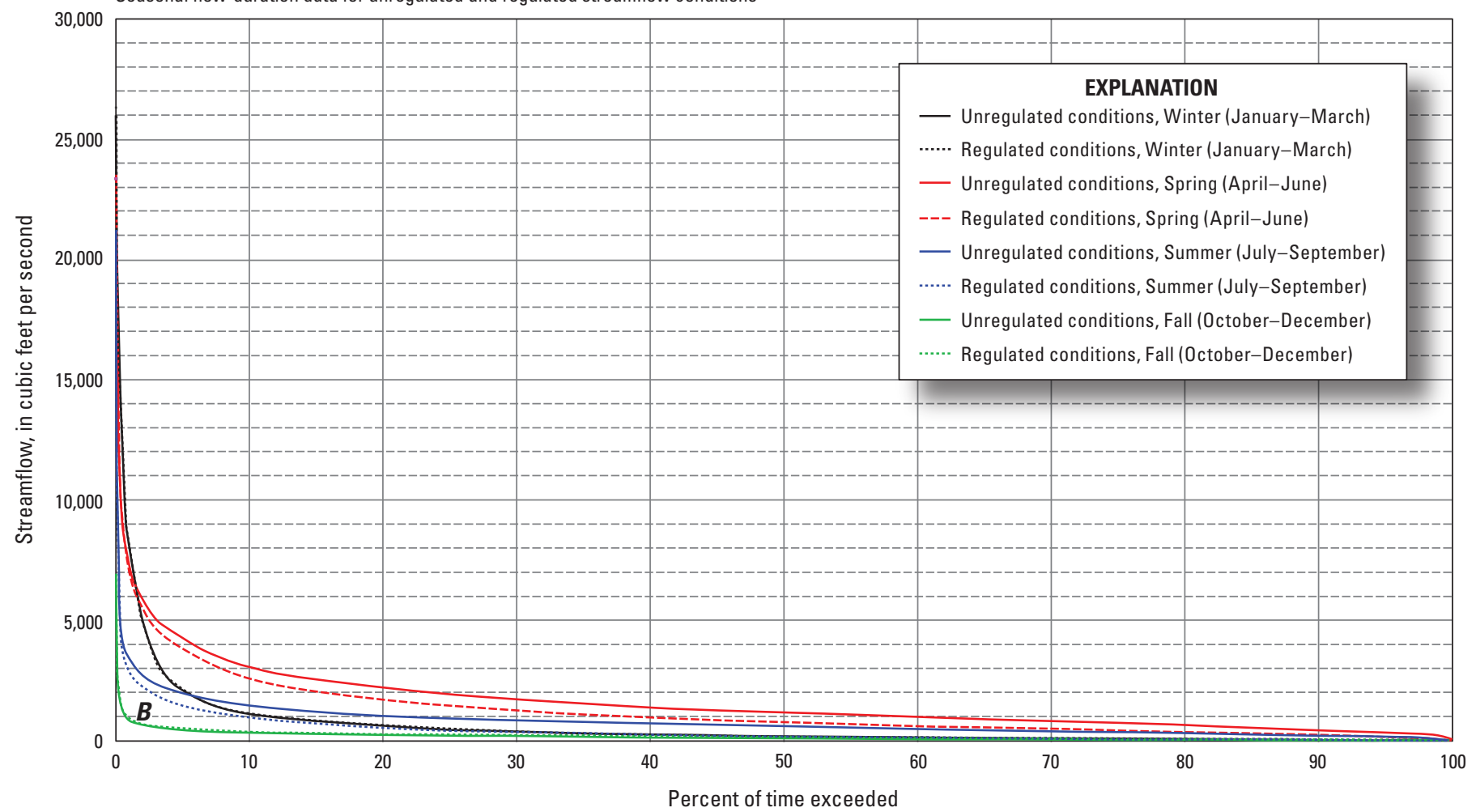

Figure 2-6-21. $\quad A$, Annual and $B$, seasonal flow-duration data for streamflow-gaging station 06326500 (Powder River near Locate, Mont.) for unregulated and regulated conditions, 1928-2002. 


\section{Appendix 3. Annual Instantaneous Peak-Flow Data at Selected Locations on the Yellowstone River, Mont., for Unregulated and Regulated Streamflow Conditions, 1928-2002}

Appendix 3 contains annual instantaneous peak-flow data at selected streamflow-gaging stations; these data also were interpolated for selected locations on the Yellowstone River, Mont., for unregulated and regulated streamflow conditions. The excel file is named sir2013-5173_APP_3 peakflow.xlsx. Locations of the sites are shown on figures 2 and 5 (main report). 


\section{Appendix 4. Annual $n$-day High-Flow Frequency Data at Selected Locations on the Yellowstone River, Mont., for Unregulated and Regulated Streamflow Conditions, 1928-2002}

Appendix 4 contains annual $n$-day high-flow frequency data at selected streamflow-gaging stations; these data also were interpolated for selected locations on the Yellowstone River, for unregulated and regulated streamflow conditions. The excel file is named sir2013-5173_APP_4_highflowfreq. $x l s x$. Locations of the sites are shown on figures 2 and 5 (main report). 


\section{Appendix 5. Annual $n$-day Low-Flow Frequency Data at Selected Locations on the Yellowstone River, Mont., for Unregulated and Regulated Streamflow Conditions, 1928-2002}

Appendix 5 contains annual $n$-day low-flow frequency data at selected streamflow-gaging stations; these data also were interpolated for selected locations on the Yellowstone River, Mont., for unregulated and regulated streamflow conditions. The excel file is named sir2013-5173_APP_5_ lowflowfreq.xlsx. Locations of the sites are shown on figures 2 and 5 (main report). 


\section{Appendix 6. Annual and Seasonal Flow-Duration Data at Selected Locations on the Yellowstone River, Mont., for Unregulated and Regulated Streamflow Conditions, 1928-2002}

Appendix 6 contains annual and seasonal flow-duration data at selected streamflow-gaging stations; these data also were interpolated for selected locations on the Yellowstone River, Mont., for unregulated and regulated streamflow conditions, 1928-2002. The excel file is named sir20135173_APP_6_Flowduration.xlsx. Locations of the sites are shown on figures 2 and 5 (main report). 


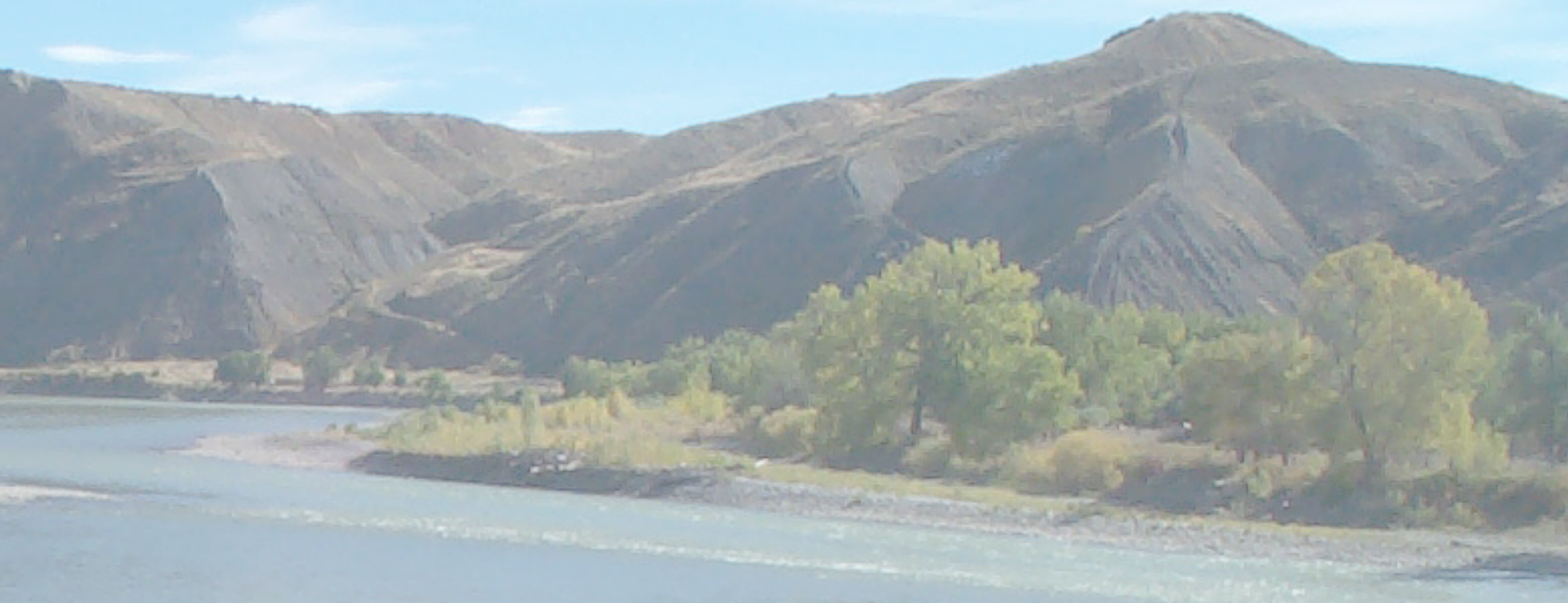

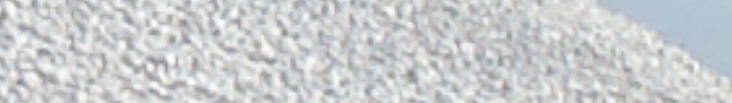

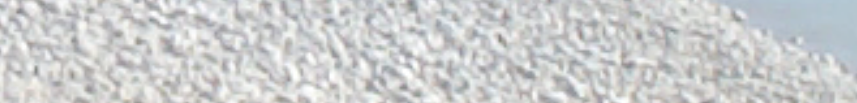

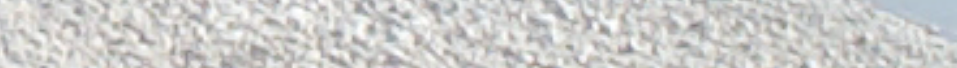

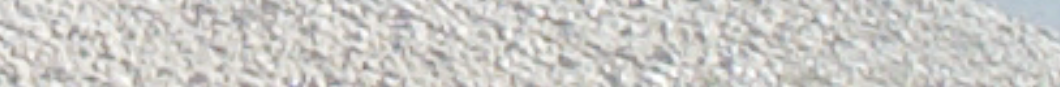

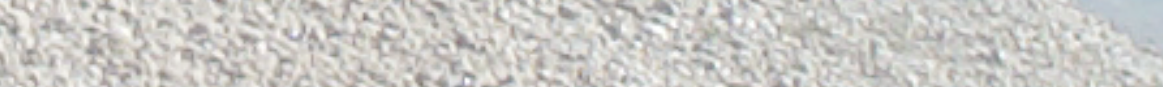

Fins

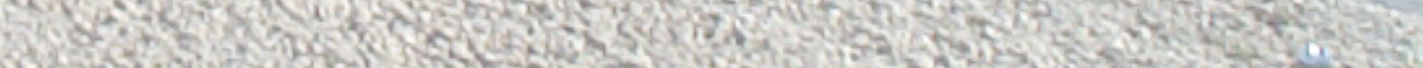

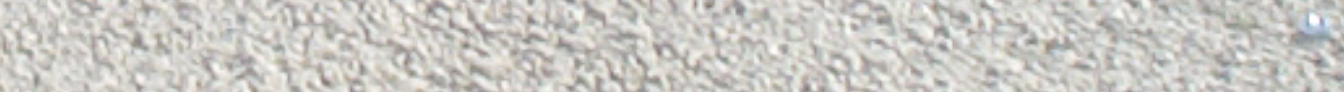

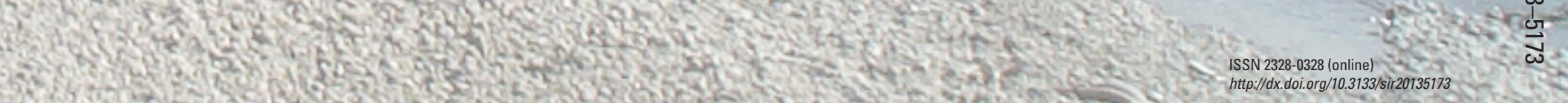
7.2.

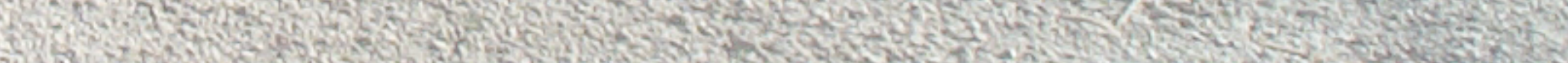
If 